Antonio Reguete Monteiro de Souza

\title{
O papel do Estado na construção da Assistência através da ação da polícia do Rio de Janeiro:
} 1870-1930.

Tese de Doutorado

Tese apresentada ao Programa de Pós-Graduação em Serviço Social da PUC-Rio como requisito parcial para obtenção do grau de Doutor em Serviço Social.

Orientador: Prof. Rafael Soares Gonçalves

VOLUME I 


\section{Antonio Reguete Monteiro de Souza}

\section{O papel do Estado na construção da Assistência através da ação da polícia do Rio de Janeiro:}

1870-1930.

Tese apresentada como requisito parcial para obtenção do grau de Doutor pelo Programa de Pós-Graduação em Serviço Social do Departamento de Serviço Social do Centro de Ciências Sociais da PUC-Rio. Aprovada pela Comissão Examinadora abaixo assinada.

Prof. Rafael Soares Gonçalves

Orientador

Departamento de Serviço Social - PUC-Rio

Profa. Gisele Porto Sanglard FIOCRUZ

Profa. Inez Terezinha Stampa

PUC-Rio

Mario Sérgio Ignácio Brum

UERJ

Prof. Marcio Eduardo Brotto

PUC-Rio

Profa. Mônica Herz

Vice-Decana de Pós-Graduação do Centro de Ciências Sociais - PUC-Rio 
Todos os direitos reservados. É proibida a reprodução total ou parcial do trabalho sem autorização da universidade, do autor e do orientador.

\section{Antonio Reguete Monteiro de Souza}

Graduou-se em Psicologia em 1994 pela Universidade Gama Filho. Mestre em Serviço Social pela Pontifícia Universidade Católica - PUC-Rio, em 2010. Possui formação em Psicodrama, é ator com especialização em Teatro do Oprimido. Atua desde 1992 em organizações e movimentos sociais de direitos humanos, com atividades nas áreas da formação humana, coordenação de projetos sociais, garantia de direitos e assessoria em elaboração de políticas públicas. Inclui em sua trajetória profissional a experiência docente em cursos de formação para profissionais da saúde e da assistência social e o desenvolvimento de pesquisas nas temáticas Educação Popular, Movimentos Sociais, Organizações da Sociedade Civil, Políticas Públicas, Infância e Instituições. Tem como ênfase profissional a produção de conhecimentos sistematizados nas áreas da Educação Popular, Movimentos Sociais e população infanto-juvenil em "situação de rua". Atualmente é professor dos cursos de Psicologia, Serviço Social e Medicina da Universidade do Grande Rio UNIGRANRIO e consultor em desenvolvimento e avaliação de projetos sociais.

Ficha Catalográfica

Souza, Antonio Reguete Monteiro de

O papel do estado na construção da assistência através da ação da polícia do Rio de Janeiro : 1870-1930 / Antonio Reguete Monteiro de Souza ; orientador: Rafael Soares Gonçalves. - 2015.

2v. : il. ; $30 \mathrm{~cm}$

Tese (doutorado)-Pontifícia Universidade Católica do Rio de Janeiro, Departamento de Serviço Social, 2015. Inclui bibliografia.

1. Serviço social - Teses. 2. Assistência social. 3. Polícia. 4. Pobreza. 5. Questão social. 6. Trabalho. I. Gonçalves, Rafael Soares. II. Pontifícia Universidade Católica do Rio de Janeiro. Departamento de Serviço Social. III. Título. 


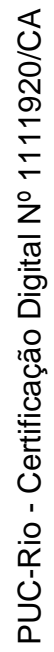

A Ana Paula, mulher amada e a meu filho, Antonio Caetano. 


\section{Agradecimentos}

Muitos foram os caminhos que aqui me trouxeram, a travessias só foi possível pelos encontros que inspiraram e informaram. Agradeço a todos(as) que estiveram direta e indiretamente presentes nesta construção, aos companheiros de Doutorado pela partilha de ideias e indagações, aos docentes que contribuíram na minha formação, em especial:

À Prof. Ana Maria Quiroga, que na primeira hora acreditou nas possiblidades das minhas hipóteses, encorajou a caminhada e orientou o percurso.

Ao Professor Antonio Edmilson Rodrigues, influência fundamental no meu modo de pensar o Brasil.

À Professora Irene Rizzini, que ainda no mestrado me mostrou os caminhos da pesquisa histórica.

Ao Prof. Rafael Soares Gonçalves, pelo acolhimento e apoio na orientação.

À Profa. Gisele Porto Sanglard, pelos subsídios e preciosas críticas que inspirou este trabalho desde o início e pela participação em minha banca de doutorado.

À Profa. Inez Trezinha Stampa, pela generosidade, valiosos aportes e a participação em minha banca de doutorado.

Ao Prof. Marcio Eduardo Brotto, pelas importantes contribuições e sua participação em minha banca de doutorado.

Ao Prof. Mario Sérgio Ignácio Brum que gentilmente aceitou participar de minha banca de doutorado tecendo estimadas contribuições.

Ao Departamento de Serviço Social da PUC-Rio, em especial a Joana Maria Félix pela atenção e desvelo.

À PUC-Rio e à CAPES, por propiciarem as condições para a realização deste trabalho. 


\section{Resumo}

Souza, Antonio Reguete Monteiro de; Gonçalves, Rafael Soares. O papel do Estado na construção da Assistência através da ação da polícia do Rio de Janeiro: 1870-1930. Rio de Janeiro, 2015. 425p. Tese de Doutorado Departamento de Serviço Social, Pontifícia Universidade Católica do Rio de Janeiro.

A tese aqui concretizada é fruto das reflexões surgidas, ainda no Mestrado em Serviço Social, a pesquisa empreendida, naquele momento, revelou documentos históricos que permitiram inferir que deve ser creditado as instituições policiais o mesmo peso dramático e importância que a caridade e a filantropia na formação do campo da assistência social na cidade do Rio de Janeiro. Para demonstrar a pertinência ou não de tal indagação desenvolvemos pesquisa histórica a partir dos relatórios dos Chefes de Polícia e Ministros da Justiça, a qual nos permitiu afirmar que a assistência social era uma "política" de Estado para o enfrentamento da pobreza urbana, já nas últimas décadas do Império, onde as instituições policiais aparecem como uma dos principais executores e idealizadores destas práticas sociais. Nossos estudos permitem afirmar que a assistência social foi um importante fator na consolidação do Estado-nação e na modernização e civilização da cidade do Rio de Janeiro, através do ordenamento e da administração da municipalidade gestada pela polícia. Identificamos as lógicas presentes nas práticas sociais e saberes construído pela polícia que se tornaram hegemônicos para o enfrentamento da problemática da pobreza urbana, pela assistência social. Saberes e práticas que influenciaram na formulação de leis, na administração pública e na construção de um imaginário coletivo acerca das representações sobre a pobreza e suas formas de combate na cidade do Rio de Janeiro. Neste sentido, abordaremos como a assistência social pode ser considerada um mecanismo legitimador do Estado na formação da nação, através das instituições policiais.

\section{Palavras-chave}

Assistência Social; Polícia; Pobreza; Questão Social; Trabalho. 


\section{Abstract}

Souza, Antonio Reguete Monteiro de; Gonçalves, Rafael Soares (Advisor). The role of the State in the construction of assistance through the action of the Rio de Janeiro police: 1870-1930. Rio de Janeiro, 2015. 425p. Tese de Doutorado - Departamento de Serviço Social, Pontifícia Universidade Católica do Rio de Janeiro.

The thesis here achieved is the result of reflections arising still in the Master of Social Work the research undertaken at that time revealed historical documents that allowed to infer that must be credited police institutions the same dramatic weight and importance of charity and philanthropy in the formation of the social assistance field in the city of Rio de Janeiro. To demonstrate the relevance or not of this inquiry we developed historical research from the reports of the Police Chiefs and Justice Ministers which allowed us to affirm that the social assistance was a "policy" of State for coping with urban poverty where the police institutions appear as one of the main executors and idealizers of these social practices. Our study allows us to affirm that the social assistance was an important factor in the consolidation of the nation-state and modernization and the civilization of the city of Rio de Janeiro through the municipality administered by police. We identified the logics present in the social practices and knowledge constructed by police who have become hegemonic for coping with the problems of urban poverty through the social assistance. Knowledge and practices that have influenced in the formulation of laws public administration and construction of a collective imagination about the representations of poverty in the city of Rio de Janeiro. In this sense we will discuss how the social assistance can be considered a legitimating mechanism of the State in the formation of the nation through police institutions.

\section{keywords}

Social Assistance; Police; Poverty; Social Question; Work. 


\section{Sumário}

1. Agudeza: introdução 11

1.1. Assistência social: limites e abrangência enquanto objeto de 19 estudo

1.2. A polícia como objeto de estudo 25

1.3. Percurso teórico-metodológico 38

1.3.1. O tempo histórico 43

1.3.2. Analisadores $\quad 45$

1.3.3. A pesquisa empírica $\quad 47$

2. Amálgamas: questão social e assistência na formação do 54

Estado-nação

2.1. Escravidão, vadiagem e anarquismo: o sentido do trabalho. 66

2.2. Imigração e questão social - Do Tejo a Guanabara 72

2.3. A seguridade do social 98

3. Pobreza: uma questão de Estado 105

3.1. Assistência social: manutenção da tranquilidade pública 130

3.1.1. Tranquilidade pública: a pobreza inválida. 169

3.1.2. Tranquilidade pública: a pobreza válida 234

4. Conhecer: poder e saber policial na administração pública 269

4.1. Polícia e municipalidade: administração da pobreza urbana 269

4.2. Saber e política: os chefes de polícia e a construção da nação 282

5. Práticas de polícia: instituições de Assistência Social: 305

5.1. O Asylo de Mendicidade 311

5.2. Escolas da Polícia 339

6. Para aqueles que necessitam: considerações finais 353

7. Bibliografia e fontes 375

$\begin{array}{ll}\text { 7.1. Bibliografia } & 375\end{array}$

7. 2. Fontes 394

8. Anexos 401

8.1. Anexo 01 - Leis 401

8.2. Anexo 02 - Exemplo de documentos 403

8.3. Anexo 03 - Matérias de Jornais 408 


\section{Lista de Tabelas e gráficos}

Tabela 1. Nacionalidade dos presos 86

Tabela 2. Sexo dos presos de nacionalidade portuguesa 87

Tabela 3. Estado civil dos presos $\quad 87$

Tabela 4. Motivo da prisão dos presos de nacionalidade 88 portuguesa

Tabela 5. Número de pessoas recolhidos ao xadrez/depósito da polícia

262

Tabela 6. Número de pessoas admitidas no ano nas instituições policias (1909 a 1913)

Tabela 7. Movimento do Asylo de Mendicidade no ano de 1890

308

Tabela 8. Número asilados por ano na Albergaria de Mendigos e Asylo de Mendicidade

Tabela 9. Leis, decretos, alvarás e regulamentos que incidem diretamente sobre as instituições policiais no período estudado.

401

Gráfico 1. Idade dos presos por nacionalidade brasileira e portuguesa 
Pobre como os pobres, agarro-me como eles a esperanças humilhantes, como eles, para viver me bato dia a dia.

Mas na minha desoladora condição de deserdado, possuo a mais exsaltante das posses burguesas, o bem mais absoluto.

Todavia, se possuo a história, também a história me possui e me ilumina mas de que serve a luz? As cinzas de Gramsci IV - Pier Paolo Pasolini 


\section{Agudeza: introdução}

Ciência, arte e filosofia crescem tão juntas em mim que um dia parirei centauros

(Nietzsche, 1969, p. 63)

A tese que aqui se materializa tem mais implicações da maneira de perceber a construção do conhecimento como processo de uma consciência autônoma significando a realidade, do que a necessidade de se enquadrar em constructos teóricos a priori. O local escolhido para a materialização deste processo de construção de conhecimento foi o campo da formação da assistência social no tempo presente, a partir do uso de determinados modelos histórico de investigação e reflexão e da execração dos limites impostos pelas disciplinas. Ao ter a pretensão de abolir determinadas fronteiras temporais, teóricas e disciplinares, impomo-nos desafios maiores, pois além de nos expormos as intempéries da não aceitação, também enfrentamos o risco de fazer da contradição a pedra fundamental do edifício a ser construído, criando fissuras conceituais de difícil reparo, a não ser pela construção de algo novo, visto que estamos pouco preparados para transpor fronteiras ou propor novos reagrupamentos dos saberes instituído (Braudel, 1990).

Não posso me furtar às reflexões referentes aos métodos científicos que identifica este ao aquele campo do saber com uma espécie de imaculado reduto donde transpassar as fronteiras estabelecidas por determinado status quo científico, criado a partir de interesses e intenções, nem sempre óbvias e transparentes nos métodos, constitui-se em ato quase insano. Por não aceitar esta fronteira marcante entre os conhecimentos científicos é que na maioria das vezes nos tornamos um sem lugar, um desterrado, visto que as novas realidades e possiblidades de construção de saberes nos permite conhecer o tempo passado sob nova perspectiva do presente e, com isto, reinterpretar ou criar novos paradigmas. É neste sentido que propomos refletir sobre a atualidade da assistência social a partir de uma visão do que foi a constituição histórica desta prática social e desta disciplina acadêmica. Entendendo que novas revelações do passado nos ajudam a ter mais lucidez sobre 
o presente e que, se não tecermos certos questionamentos aos saberes instituídos, jamais construiremos algo novo. Disposto a correr os riscos necessários, construiremos nossos argumentos, no sentido de demonstrar que a "assistência social” era uma "política de Estado" para o enfrentamento da pobreza urbana já nas últimas décadas do Império, onde a polícia foi um dos principais executores e idealizadores destas ações de Estado.

Não é decisão simples e muito menos falta de amabilidade e reconhecimento ir de encontro ao pensamento institucionalmente aceito como verdade acabada. É sofrido e espinhoso, mas é inevitável o caminho, pois somos impulsionados para este fim, não como o herói a caminho da tragédia, mas como o poeta - aquele que segundo Platão, a República não necessita - que assume a rebeldia de sua mera intuição, onde a franqueza e desassombro das convicções se apoiam na realidade. Ainda que esta realidade seja percebida como a afirmação de um ponto de vista controverso do hegemonicamente aceito.

A maneira de produzir conhecimento passa pelo barroco que há em mim, de modo que possa sorver e provar o palatável sentido do saber aqui produzido, visto que, é a partir da dúvida e da resposta inusitada que a pergunta possa suscitar que o conhecimento se faz, antes pelos sentidos e a intuição do que a pela razão. É a partir da região nebulosa e pantanosa das ideias e dos escuros da percepção que surgem as mais instigantes formas de entendimento da realidade, primeiro como poeta, após como um cientista. No entanto, há de se navegar com cautela e prudência, pois as águas somente se tornam calmas e cristalinas se conseguirmos decifrar a esfinge que a pergunta suscitou. Desta monta, estruturamos nossos argumentos a partir de métodos epistemologicamente reconhecidos como científicos, para que, o que antes era conhecimento baseado nos sentidos ${ }^{1}$ e intuição possa ser comprovado e estruturado a partir do que é estritamente empírico, sistematizável e observável.

O presente trabalho demonstra as correlações entre a formação do Estadonação no Brasil e o projeto de civilizar e regenerar a cidade do Rio de Janeiro pela via da municipalidade instrumentalizada pela instituição policial, a qual usava a "assistência social" como técnica de administrar a pobreza urbana. Além deste aspecto, discutiremos a maneira como a polícia produziu conhecimentos sobre a

\footnotetext{
${ }^{1}$ Aristóteles é enfático ao afirmar na "Retórica" que o conhecimento primeiro passa pelos sentidos, bem como, a Gestalt do início do século XX e as modernas pesquisas da neurociência do século atual não refutaram sua afirmação.
} 
pobreza urbana, a ponto de influenciar os mais diversos setores da sociedade na criação de um pensamento hegemônico de como o Estado deve enfrentar esta problemática. Neste sentido, abordaremos como a assistência social pode ser considerada um mecanismo legitimador do Estado na formação da nação, através das instituições policiais. E mais, que deve ser creditado à polícia o mesmo peso dramático que a filantropia e a caridade na conformação do campo da assistência social. Se conseguirmos demonstrar no decorrer de nossa tese que a afirmação acima é consoante com a realidade, por uma questão de lógica, teremos que rever alguns pontos que instituíram a interpretação hegemônica sobre a questão social no Brasil. Ora, ao demonstrarmos que a polícia pensava e exercia, entre outras funções da administração pública, a "assistência social" e médica, teremos que rever a ideia cristalizada de que a questão social no Brasil era somente caso de polícia até 1930. Esta interpretação, como evidenciaremos, enxerga a polícia do final do século XIX e início do XX com a perspectiva de hoje. Ao demonstrarmos que as estratégias de controle social da pobreza urbana pela mão do Estado incluíam a gestão de intuições de assistência social pela polícia e a regulação da filantropia, ainda no Império, somos levados a refazer o aforisma hegemônico que caracterizou a interpretação da questão social no Brasil, para afirmar que a questão social já era tratada como caso de política, de maneira explícita e concisa desde a segunda metade do século XIX no Brasil. Comprovaremos estes aspectos no decorrer de nossa narrativa, ao demonstrar que a polícia era uma instância administrativa do Estado, onde seu aspecto político era tão ou mais importante que o criminológico. A esse respeito nos juntamos as interpretações de Rangel (2014) e Gomes (1979), que também discordam deste modo de explicar a questão social no Brasil. O ponto de vista destas autoras pode ser sintetizado na seguinte frase de Rangel (2014, p. 31): “a questão social constituía-se num dos mais importantes problemas políticos da época, sendo a dimensão policial (enfrentamento meramente repressivo) insuficiente para a sua caracterização".

Estas primeiras afirmações, este primeiro momento, sob o qual já de início apresentamos e circunscrevemos o objeto de nossa tese é o primeiro cume de um caminho que começou numa certa manhã de abril de 2008, quando diante da minha primeira caixa de documentos, em meu primeiro dia de pesquisa documental em toda minha vida acadêmica apareceu-me a ata de fundação do Asylo de Mendicidade. Peço licença para evidenciar este fato devido à importância que este 
se inscreve em minha forma de produção de saber. Um reflexo puramente intuitivo, no qual um único documento demonstrou um caminho nunca antes navegado. Com inesperável sutileza e agudeza veio de súbito a correspondência entre as interpretações históricas. Em imediato insight pensei: ora, o que caracteriza o entendimento e a afirmação de que a caridade e a filantropia se constituem como o processo histórico fundante do que hoje chamamos de assistência social? Podemos responder de maneira sucinta que o fato de estar à frente de práticas sociais e de discursos que buscavam enfrentar a problemática da pobreza, especificamente a urbana, os credenciavam como percursores da atual política e práticas de assistência social. Se, desta forma, podemos caracterizar os motivos que levam a classificar a caridade e a filantropia como pilares históricos da assistência social, temos que incluir neste "clube" a polícia. Como representante e executora de ações do Estado diante da população, a polícia criou e gerenciou instituições de assistência social e médicas, além de produzir discursos e indicar técnicas que influenciaram a construção de um saber acadêmico e jurídico sobre o controle da pobreza criminalizada e também da não criminalizável.

Naquele momento, nunca havia me aventurado pelas fontes documentais, pois minha formação de psicólogo, com atuação junto à política de assistência social, me levou a trabalhar durante anos com pobres que perambulavam ou viviam nas ruas da cidade do Rio de Janeiro, os quais continuam nesta tese como fonte direta de interesse e cumplicidade. O documento da fundação do Asylo de Mendicidade me levou a construção de um novo tópico em minha dissertação de Mestrado $^{2}$ no capítulo conclusivo chamado "A polícia e a ideia de assistência". Neste tópico, evidenciam-se os primeiros argumentos que culminaram na atual tese. O cerne da questão a qual construímos nosso objeto já estava posto nas considerações finais de nossa dissertação de Mestrado, e mesmo diante dos novos

\footnotetext{
${ }^{2}$ A dissertação de mestrado aprovada pelo Programa de Pós-graduação em Serviço Social da PUCRio, cujo título é "Da Desumanização e da Norma: A construção social das noções de vadio e vagabundo em meio as atribulações da fabricação do Estado-nação no Brasil (1870-1900)" (Souza, 2010), teve como objetivo investigar os diferentes aspectos e fatores, presentes na construção social da problemática das crianças e jovens pobres que usam as ruas da cidade do Rio de Janeiro, como meio de sobrevivência e/ou moradia. Analisou a construção social das noções de vadio e vagabundo a partir das crianças e jovens recolhidas das ruas do Rio, no fim do século XIX, por motivo de vadiagem e vagabundagem. A dissertação abordou ainda a maneira pela qual a necessidade de fabricação do Estado-nação brasileira e a experiência social do cativeiro se inscreveram na arquitetura dos significados presentes na construção social das noções de "vadio" e "vagabundo". Por fim, demostrou o papel central da polícia no processo histórico de construção das práticas de assistência social na cidade do Rio de Janeiro.
} 
estudos empreendidos, o ponto central de construção do objeto não se alterou, ao contrário aprofundou e solidificou os argumentos que demonstram a importância da polícia como um dos principais atores na formação do campo da assistência social. Estes argumentos iniciais afirmavam categoricamente que a polícia se valia de um amplo leque de estratégia para regular o ordenamento urbano, entres eles a filantropia, a gestão de instituição de assistência social e médicas, a estatística e a administração pública (Souza, 2010, p. 169). Assegurava ainda que a polícia exercia um papel de articuladora dos recursos filantrópicos existentes na época para lidar com a pobreza urbana como demonstrado no relatório referente aos anos de 189293, no qual o chefe de polícia pede ao poder Legislativo que dote as "Instituições philantropicas, como os asylos de D. Josina Peixoto e D. Bernardina de Azeredo", - que recebiam os menores abandonados e recolhidos pela polícia em vias públicas - “com um subsidio annual, de modo a habilita-los a estender por maior número de criança os seus grandes beneficios, visto não possuírem elles fundos de attender ás suas despezas" ". Isto enquanto não fossem criadas as colônias correcionais, reivindicação presente em diversos relatórios dos chefes de polícia, para as quais deveriam ser enviados os "indivíduos que procuram na mendicidade e no roubo os meios de subsistencia, encontrem accolhimento seguro e regenerador, e de outras, sob regimen mais brando, para collocalção dos menores abandonados na via pública",5.

A ideia de que a instituição policial deve ser incluída na formação da assistência social já se encontrava posta - sem o rigor necessário, como é o caso agora - em nossa dissertação de Mestrado (Souza, 2010, p. 182), onde afirmamos categoricamente que o saber e a técnica policial para lidar com a pobreza urbana se aproximava da ideia de filantropia, como fica notório no relatório do diretor do Asylo de mendicidade relativos aos anos de 1892-93, ainda sob a gestão da polícia, o qual afirmava que:

por maiores que sejam as difficuldades com que luta ainda a nova éra politica deste paiz, para estabelecer casas deste gênero [abrigos para "menores"], de harmonia com as leis de hygiene e as exigências da civilização hodierna, nenhuma deve embaraçar um emprehendimento que não póde ser descurado, sem grave injustiça

\footnotetext{
3 Passaremos a usar o itálico na formatação de textos, todas as vezes que estiver transcrevendo citações no português do século XIX ou em expressões em outras línguas.

${ }^{4}$ BRASIL. Ministério da Justiça, relatório dos anos de 1892-93 (apud Souza, 2010, p. 179).

${ }^{5}$ Idem.
} 
e inconvenientes, para aquelles que não perderam o seu jus á proteção social ${ }^{6}$ (grifo nosso).

- Para este intento, buscaremos identificar as principais ideias e práticas presentes nos discursos da polícia relativos a "assistência social" e evidenciar o lugar que a instituição policial ocupou no interior do aparelho de Estado em relação à administração da cidade e a municipalidade da capital, por ocasião da formação do Estado-nação no Brasil.

A lógica de nossa narrativa se amarra a dois pontos específicos da história da assistência social, os quais estão totalmente imbricados um no outro, quais sejam: o fato de que os saberes e práticas de Estado relativo às ideais de "assistência social" compuseram as estratégias, não econômicas, que atuaram ativamente para a consolidação do projeto hegemônico de construção do Estado-nação e; a evidência de que a polícia produziu um saber e uma prática relativa à administração da cidade que incluía a "assistência social" como estratégias, as quais não podem ser enquadradas em modelos de caráter meramente repressivo. Deste modo, destacaremos a formação do campo da "assistência social" como um importante fator para a modernização e civilização da cidade do Rio de Janeiro, através do ordenamento e da administração da municipalidade gestado pela polícia, de maneira que possamos identificar as lógicas presentes nas práticas sociais e saberes que se tornaram hegemônicos para o enfrentamento da problemática da pobreza urbana. Demonstraremos, assim, que os discursos e práticas produzidos pela instituição policial na gestão da "assistência social" foram geradores de saberes que extrapolaram os limites da própria instituição, a ponto de influenciar na formulação de leis, na administração pública e na construção de um imaginário coletivo acerca das representações sobre a pobreza e suas formas de enfrentamento na cidade do Rio de Janeiro.

Ao vislumbrarmos a formação do campo de saber e prática da "assistência social" como objeto de estudo na perceptiva proposta acima, evidencia-se, por analogia, um eminente problema de fundo teórico conceitual acerca das ideias cristalizadas e hegemônicas que interpretaram a questão social no Brasil exclusivamente como caso de repressão até 1930. Segundo Rangel (2014, p. 7),

\footnotetext{
${ }^{6}$ Esta expressão tornou-se emblemática para nossa tese e retornaremos a ela em diferentes momentos do texto. Idem, op. cit. p. 133, nota 131.
} 
"Yazbeck (2012) aponta que somente a partir dos anos 1930 foi reconhecida a legitimidade da questão social no âmbito das relações entre capital e trabalho". No decorrer do texto, demonstraremos que esta afirmação não se sustenta ao analisarmos detalhadamente as implicações sociais, políticas e econômicas dos principais centros urbanos do Brasil desde a segunde metade do século XIX.

$\mathrm{O}$ fato de demonstrarmos - como veremos no decorrer do texto - que a polícia exercia um leque muito mais amplo de funções na gestão da municipalidade, implica também em rever a afirmação sobre a qual se caracterizou a questão social no Brasil. Ora, se a polícia exerceu funções de municipalidade e de Estado no controle da pobreza urbana na cidade do Rio, este fato associa a polícia a um papel político e administrativo, não só como mero constructo teórico, mas como prática social efetiva. Onde o controle urbano se realizada não só pela repressão através do emprego da força, mas também pelo disciplinamento, que se coadunava com os mais modernos princípios científicos e pedagógicos da época, como veremos detalhadamente no Capítulo III. Princípios estes importados pelos chefes de polícia e seus assessores mais próximos das principais experiências administrativas da Europa e dos Estados Unidos, de como lidar com a pobreza urbana pela razão dada administração pública. Deste modo, a questão social ao ser caso de polícia era também caso de política.

Desta monta, podemos resumir o percurso que traçaremos em nossa narrativa sobre a formação histórica do campo da assistência social no Brasil especificamente na cidade do Rio de Janeiro - em dois pontos, são eles: (1) a assistência social fez parte das estratégias formais e do imaginário social construído na formação do Estado-nação, compunha o repertório de técnicas que se dispunham a modernizar e "civilizar" a cidade do Rio de Janeiro, era sinônimo direto de modernidade e fazia parte da constituição das estruturas de poder $^{7}$; (2) o campo de saber e prática da construção histórica da assistência social teve o braço do Estado

\footnotetext{
${ }^{7}$ A assistência social como parte das estruturas de poder pode ser vista em Quiroga (2009), Sanglard (2005, 2008a) e Rangel (2014), Abreu (2010) Neste sentido vale reproduzir as palavras de Van Leeuwen (apud Abreu, 2010, p. 352) para o qual as práticas de assistência social tinham múltiplas motivações pelo lado das elites; de foro religioso e moral - as primeiras que a historiografia identifica -, mas muito mais para além delas: entre suas preocupações estavam a estabilização da ordem social e pública, as necessidades do mercado de trabalho, o receio do contágio epidémico e, naturalmente, o capital social associado às práticas caritativas, que lhes granjeava oportunidades políticas, patronato sobre importantes instituições, facilidades financeiras, aumento de autoridade ou sua legitimação. Tratava-se, em síntese, de uma forma específica de investimento com retorno garantido (Abreu, 2010, p. 352).
} 
- através da polícia e depois da municipalidade - como um dos pilares de sua formação, concomitante e com a mesma relevância que campo filantrópico privado e caritativo. Com isto, acreditamos que podemos contribuir para o debate atual sobre as implicações do processo histórico de constituição do campo da assistência social demonstrando a maneira como o passado se projeta nas formas atuais desta prática social.

Antes de prosseguirmos se faz necessário nos atermos a algumas premissas que se constituem em bases para edificação de nossos argumentos. A principal premissa que nos possibilita pensar a assistência como fundamental para a formação do Estado-nação e a questão social como caso de política já no século XIX se constitui no fato de que a assistência tem uma vinculação direta com as dinâmicas de poder econômico e Estatal. Da mesma forma deve ser enquadrada enquanto parte das ações que fundamentaram o ideário político e social na formação do Estadonação no Brasil. Neste víeis que a assistência social, enquanto prática das instituições policiais, representa na trama das relações sociais o desenvolvimento de uma ideologia da pobreza. De modo que, buscaremos nesta trama social as razões e os motivos que colocam a assistência social inserida dialeticamente como prática referente ao governo das cidades pela polícia. É preciso destacar que a assistência na virada do século XIX para o XX no Brasil já se consistia em uma prática com intencionalidade claramente definida de poder e parte manifestante do processo de modernização e "civilização" da cidade do Rio de Janeiro. Havia uma complexidade das diferentes percepções sociais e ações políticas que estavam associadas as ideias e práticas de assistência, enquanto aspectos fundamentais na institucionalização dos poderes do Estado moderno, seja no Brasil, seja na Europa.

A segunda premissa que se constitui em pilar dos nossos argumentos, diz respeito ao fato de que a instituição policial esteve diretamente imbricada em todo o processo de constituição dos modernos Estados-nações na Europa e nas Américas (Gonçalves, 2011 \& Foucault, 2001). Suas práticas estavam diretamente acordadas com a gestão das cidades, tinha a pobreza como objeto de intervenção e o trabalho como imperativo categórico ${ }^{8}$ para a fundamentação e experimentação de suas teses, muitas das quais transformadas em leis.

\footnotetext{
${ }^{8}$ No sentido Kantiano.
} 
No sentido do exposto acima que construiremos nossos argumentos, no entanto, se faz necessário nos atermos a mais alguns pontos de caráter teórico metodológico, quais sejam: definir sob que perspectiva trabalharemos com a ideia de assistência social e como este termo será abordado ao longo do tempo histórico; o modo pelo qual trataremos a polícia como objeto de estudo e, por fim, o percurso teórico metodológico. Neste último trataremos da pesquisa empírica, dos pressupostos teóricos que construirão os analisadores e a maneira epistêmica sobre a qual balizaremos nossa noção de tempo histórico.

\subsection{Assistência social: limites e abrangência enquanto objeto de estudo}

Estudar a assistência social no Brasil nos obriga a entender a particularidade da dimensão da assistência social em Portugal ${ }^{9}$. Se quisermos analisar e entender as instituições de assistência social em toda sua complexidade, contradições, historicidade e, principalmente o lugar que ocuparam no projeto de poder que construiu a oficialidade do Estado brasileiro e o imaginário social da nação, temos que entender a assistência em Portugal. Ainda que seja possível ouvir o eco francófono das luzes na transformação que Portugal operou em sua assistência pública e privada a partir do século XVIII, a história da assistência, naquele país, de caráter privada, mas regulada pelo poder central e balizada na moral cristã suplantaram as racionalidades iluministas. É relevante para nossos estudos que um dos principais articuladores e gestores das mudanças operadas na assistência em Portugal com fins de modernização foi um Intendente Geral de Polícia da cidade de Lisboa, Pina Manique, como veremos adiante, que entre outras coisas, criou as Casas Pias, as quais se transformaram em exemplo de instituição para o modelo de assistência que estava em discussão na Europa no final do século XVIII (Abreu, 2010). Não é intento nosso aprofundar na complexidade e no longo período que significa a prática da assistência social em Portugal. O que nos interessa em relação

\footnotetext{
${ }^{9}$ Para nossos objetivos trataremos como marco da assistência social em Portugal a relação direta desta com a razão de Estado a partir do "ciclo político iniciado pelo governo de Sebastião José de Carvalho e Melo" (Abreu, 2010, p. 49) através do qual os princípios iluministas criaram novos paradigmas sociais relacionados a ideia de progresso econômico e social.
} 
a assistência social em Portugal, entre outros aspectos, é o fato da Intendência Geral de Polícia ter sido a responsável pelas profundas mudanças na assistência em Portugal no final do século XVIII e ter servido de modelo para construção da polícia aqui.

Diante do objeto de estudo não podemos prosseguir sem antes nos atermos aos preceitos do termo assistência social, de modo a demonstrar os limites e abrangência que caracterizam o significado assumido pelo termo "social", principalmente em relação ao período (1870 a 1930) eleito como foco de nossos estudos. Segundo nosso ponto de vista, a ideia de "assistência social" é um constructo que, por excelência, não dissocia, sob nenhum aspecto, teoria de prática. Todas as vezes que nos referimos à ideia de "assistência social" estamos falando de uma teoria e de uma prática conjuntas e indissociáveis, seja na perspectiva iluminista, caritativa ou positivista, que propõe ajuda, apoio ou regeneração. No caso caritativo, a teoria deve ser substituída pela moral ou, para afiançar melhor a analogia proposta, por uma teologia.

Definir "assistência social” em perspectiva histórica no caso do Brasil é tarefa que não permite uma linearidade temporal e conceitual, visto que sua inspiração teórica remonta dos filósofos das luzes, em seu aspecto filantrópico (Sanglard, $2003)^{10}$ e sua inclinação de gestão prática tem caráter nitidamente luso (Abreu, 2010 \& Quiroga, 2009). Desta monta associa-se às instituições de caráter assistencial no Brasil um corpo filosófico nitidamente francês anexo a uma moral caritativa justificada pela certeza da epifania em céu, inferno e purgatório. É preciso destacar que a invenção do purgatório no final da idade média propiciou um grande impulso para as obras de caridade (Abreu, 1999, 2000). Apesar da cultura francesa das luzes se pautar por severas críticas ao catolicismo, aqui a assistência amalgamou a ideia de salvação, como demonstra as diversas instituições laicas, filantrópicas e estatais que dependiam profundamente de financiamentos atrelados ao salvamento das almas, com métodos e práticas de intervenção social pautados na razão iluminista.

\footnotetext{
${ }^{10}$ Neste sentido vale destacar a afirmação de Sanglard (2003, p. 1095) segundo a qual "a filantropia pode ser entendida, grosso modo, como a laicização da caridade cristã, ocorrida a partir do século XVIII, e que teve nos filósofos das luzes seus maiores propagandistas. O fazer o bem, o socorro aos necessitados, deixa de ser uma virtude cristã para ser uma virtude social; e a generosidade é entendida pelos filósofos ilustrados como a virtude do homem bem-nascido, que tem inclinação para doar, doar largamente, daí a forte presença das grandes fortunas entre os principais filantropos”.
} 
A ideia de assistência também deve estar relacionada com a sua forma de financiamento. Estas formas e as intenções explícitas ou implícitas, presentes na motivação e formas de financiamento, por vezes, não nos permite definir de maneira clara de que modelo estamos tratando: se caridade, filantropia privada ou filantropia pública. São poucos os modelos de assistência que podemos identificar com "puros", quando olhamos para seus meios de financiamento. O uso social do dinheiro da forma como se deu aqui e em Portugal não nos permite tecer fronteiras claras, entre a caridade e a filantropia ${ }^{11}$, esta diferença pode ser mais explícita em termos políticos e nas práticas sociais efetivas. A filantropia estava posta tanto como ação estatal, quanto por grupos particulares, outras vezes as ações de filantropia geridas pelo Estado tinham por financiamento a caridade, como veremos no caso específico do Asylo de Mendicidade, abordado no Capítulo IV. É possível destacar que identificamos em Portugal ações de assistencial social e médica por parte do Estado como pressupostos de políticas públicas nos aspetos relativos a capacidade de organização e financiamento, que remontam ao século XVI (Abreu, 2010, p. 349).

É neste sentido que demonstraremos que o Estado, seja no final do Império, seja na República aparece tanto como financiador de ações de filantropia, quanto captador de recurso junto a filantropos e obras de caridade para financiar ações próprias de assistência social. Para nosso ponto de vista a definição da ideia de assistência social no período focado por nossos estudos passa pela definição política e institucional de uma prática social para o enfrentamento da problemática da pobreza urbana que envolve a captação e alocação de recursos financeiros e administrativos. É no sentido de prática social, que produz e, ao mesmo tempo, justifica um saber teórico, que olharemos a construção histórica da assistência social na virada do século XIX para o XX na cidade do Rio de Janeiro.

A partir do processo de especialização que foi se dando concomitantemente com o desenvolvimento do capitalismo e a redefinição dos meios de produção, as ações de assistência foram se modificando. Esta redefinição significou eleger

\footnotetext{
${ }^{11}$ Segundo Ruonavaara (1997) na caridade não há uma preocupação com a forma como se usa o dinheiro doado na perspectiva do doador, visto que, o importante para ele é o ato de doar, o qual já lhe garante posição favorável no juízo final, já na filantropia o doador espera resultados efetivos através de seus "investimentos", seja em termos de poder, reconhecimento ou mesmo pelo caráter subjetivo da resolutividade da problemática a ser enfrentada, o que leva ao filantropo a necessidade de prestar contas.
} 
critérios que pudessem classificar de maneira objetiva os doentes, os pobres e os doentes pobres, de maneira que pudessem ser aplicadas estratégias cabíveis para cada caso definindo e que tipo de recurso assistencial seria disponibilizado. Este processo de especialização é o que vai coadunar, no caso do Brasil, a história da assistência social com a polícia e a municipalidade.

Para nós, a ideia de assistência social se caracteriza por uma prática, que produz e é produzida por um corpo teórico, cujo objetivo é a organização do mundo do trabalho através da intervenção na problemática da pobreza urbana. No Brasil esta intervenção esteve diretamente associada a construção do Estado-nação e a consolidação da República. O esforço de definição de conceitos para determinar o real nos impele a usar o método histórico para entender, sob um viés epistemológico, a maneira como a assistência social é pensada e gerida no presente, e demonstrar os modos pelos quais suas forças simbólicas e seu saber se traduzem em correntes hegemônicas de se pensar as políticas atuais deste campo. Não por acaso que as instituições de caridade dão lugar as intuições filantrópicas públicas e particulares ao mesmo momento em que a cidade do Rio de Janeiro passava pelas transformações técnicas, urbanísticas e estruturais. Portanto, analisamos a assistência social de base científica, como um tipo de prática característica das sociedades capitalistas e que, no caso do Brasil, necessitava também deste modelo de instituição para a entrada na modernidade. Neste sentido que buscaremos compreender a assistência social em sua roupagem atual como um instrumento técnico-científico a serviço da edificação do projeto de nação, que significava em última instância a construção da modernidade no Brasil, que para o foco que escolhemos nos remete a instauração da ordem urbana na cidade do Rio de Janeiro. A ideia de assistência social é a categoria principal para nosso estudo, no entanto não pretendemos aqui travar uma discussão bibliográfica que referencia a discussão histórica desta prática. O que nos cabe aqui é demonstrar a maneira como este termo aparece nos documentos pesquisados enquanto práticas sociais desenvolvidas no interior de instituições com mecanismos reais de imposição destas técnicas.

Para historiografia clássica é uma incongruência falar especificamente no termo "assistência social" no século XIX. No entanto, encontramos este conceito associado a mesma grafia no relatório referente aos anos de 1904 e 1905. Se pensarmos na perspectiva de Hobsbawm (1997), não seria impróprio creditar determinados acontecimentos do início do século XX como próprio do século XIX. 
Podemos ver o conceito de assistência social nitidamente expresso em relatórios oficiais do governo conforme escreveu o chefe de polícia Dr. Antonio Algusto Cardoso de Castro:

\begin{abstract}
A regularidade dos novos serviços ha de attestar a affirmação solemne e categorica de que o Estado quer desta vez fazer parar e extinguir a anarchia que reina em nosso paiz sobre a assistência social (grifo nosso), compenetrado da importância e a necessidade de regularizar conscientemente esse nobre ministerio, que constitue a própria vida da nação; ella servirá para testemunhar a generosidade da nossa geração actual, consignando que a sorte dos pobres é uma causa comum e que não póde servir de bandeira exclusiva dos partidos, das seitas e da politica; e, finalmente, a fundação da nova, empreza de caridade publica (grifo nosso) ${ }^{12}$ certificará o empenho e cuidado com que, no louvável movimento em favor do saneamento e dos melhoramentos materiaes da capital da União, não são esquecidos os desamparados e os miseráveis, e que os seus direitos também serão defendidos e patrocinados pelos altos poderes públicos (grifo nosso), da nossa pátria"li3.
\end{abstract}

Claramente estava posto, como podemos ver acima a ideia de assistência. Neste sentido que pretendemos pensar a assistência enquanto valores morais e econômicos socialmente realizáveis na regulação da problemática da pobreza urbana. Estas formas de perceber e os modos e meios de enfrentar esta problemática é o que vai caracterizar as ideais e práticas do que se convencionou chamar de assistência social. Este modo de entender e representar a ideia de assistência em sua realização associada ao conceito de social balizará nossa narrativa. Estas mesmas ideias de assistência social, expostas pelo chefe de polícia no início do século XX, podem ser também vislumbradas no relatório do ministro da justiça Dr. Alfredo Pinto Vieira de Mello, referente aos anos de 1919 e 1920, segundo o qual,

quasi nada tem feito o Estado, até agora, no tocante ao problema de hygiene e de assistência á infância. Devemos a algumas instituições de iniciativa privada, nesse particular, esforços meritórios; a sua acção, porém, não pode generalizar-se, como a sociedade requer e a justiça impõe, cumprindo ao poder publico intervir, solicitado por uma das nossas mais evidentes necessidades de assistência social. (Grifo nosso) Depois das ideas externadas a respeito por V. Ex., na Mensagem de 3 de maio do corrente anno, é desnecessário salientar aqui a importância desse capitulo de hygiene publica, ligado ao próprio futuro da nacionalidade ${ }^{14}$.

\footnotetext{
${ }^{12}$ Esta expressão confirma e demonstra a dificuldade de classificarmos os modelos de assistência entre filantropia e caridade na cidade do Rio de Janeiro, conforme discutido acima.

${ }^{13}$ BRASIL. Ministério da Justiça e Negócio Interiores. Relatório dos anos de 1904 e 1905 - Volume II. Rio de Janeiro. Imprensa Nacional, 1905b, p. 239.

${ }^{14}$ BRASIL. Ministério da Justiça e Negócio Interiores. Relatório dos anos de 1919 e 1920. Rio de Janeiro. Imprensa Nacional, 1920, p. XXVII.
} 
Havia uma clara associação de ideias entre assistência social e assistência pública. Este termo assistência pública servia para designar de forma generalizada um variado espectro de práticas sociais, médicas ${ }^{15}$ e jurídicas, como veremos detalhadamente no Capítulo III. Dentre o vasto universo do que se entendia por assistência na virada do século XIX para XX no Brasil classificaremos como assistência social aquelas instituições ou práticas que seriam, ao olhar de hoje, indubitavelmente entendidas como tal. Para evidenciar e ser mais preciso no que passaremos a chamar de assistência social, seja no século XIX, seja no XX, seja no século atual, nos valeremos da definição que a comissão encarregada de proferir parecer sobre o projeto de lei da Assistência Pública lhe conferiu. Segundo esta comissão, a assistência pública deveria se encarregar " $d a$ velhice desamparada, da infância desvalida e de quaesquer outras misérias da humanidade" ${ }^{16}$. Outro aspecto que aponta nítida diferença, eram que as instituições e práticas de assistência de caráter social não envolviam qualquer tipo de medicalização.

Por fim, outra ideia ligada a assistência social que assume extraordinária relevância para nossa análise diz respeito a classificação entre a pobreza válida e inválida (Castel, 2001). Estas classificações, que remontam ao século XVI, busca distinguir a pobreza conjugando teologia e economia, messianismo moral e os sentidos do trabalho. Segundo Castel (2001, p. 54), "em toda sociedade, um sistema coerente de assistência só pode se esturrar a partir de uma clivagem, ente os bons e os maus". Primeiro deveria separar os que podem dar cabo de sua própria sobrevivência daqueles que precisam de apoio e ajuda para tal intento, os inválidos. Estes últimos, representados pelas crianças, velhos enfermos, doentes pobres $\mathrm{e}$ "alienados", são categorias que tanto inspiravam a piedade cristã, quanto o humanitarismo laico. A classificação da pobreza válida era assentada em forte conotação moral, os que podem trabalhar e não o fazem por vícios e pelo hedonismo. No entanto, esta classificação da pobreza válida incorpora, a partir do

\footnotetext{
${ }^{15}$ Segundo Sanglard (2008b, p. 61 apud Rangel, 2014, p. 74) a ideia de assistência pública abrangia "um vasto e abrangente leque de ações as quais se atribuía um caráter público - desde os cuidados à infância e à maternidade, até a velhice e a loucura -, e que envolvia um conjunto de instituições públicas e privadas, laicas e religiosas - hospitais, asilos, orfanatos, colônias, creches, ligas, postos médicos, maternidades, hospícios, dispensários, policlínicas". A este respeito conclui Rangel (2014, p. 74) que "na Primeira República, o campo da assistência no Brasil traduzia-se em uma estruturação institucional permeada por uma ambígua relação público-privado".

${ }^{16}$ BRASIL. Ministério da Justiça e Negócio Interiores. Relatório dos anos de 1903 e 1904. Rio de Janeiro. Imprensa Nacional, 1904, p. 67-8.
} 
século XVIII com os fenômenos do pauperismo, uma subdivisão. Esta subdivisão diz respeito aos aspectos morais que identificava os pobres que não queriam trabalhar por serem lenientes e, aqueles que estavam vitimados pelas condições econômicas da falta de trabalho. Sobre este último tipo de pobre válido que se concentra o principal paradoxo da assistência social: agir sobre o mundo do trabalho, estando fora dele (Castel, 2001). Como demonstraremos no Capitulo III, os chefes de polícia usavam de maneira explicita estas classificações da pobreza para eficácia de suas práticas. Do mesmo modo como discutiremos no Capítulo final, esta classificação relativa à pobreza pode ser vislumbrada nas condicionalidades dos programas sociais, seja enquanto serviços ou transferência de renda.

Através destas ideias e concepções de assistência social que navegaremos por nossa narrativa, fazendo coro e assumindo para nós a interpretação da Rangel (2014, p. 20), segundo a qual "a filantropia [que para nós poderia ser ampliada para a ideia assistência] deveria ser tratada como uma forma de relação público-privado fundamentalmente política". De modo que, também pretendemos demonstrar os aspectos históricos de longa duração, tempo que se faz presente na vida social atual enquanto substância de um passado múltiplo e contraditório (Braudel, 1990). Neste sentido, afirma Del Priori (2012, p. 247) que "a história do Brasil tem fenômenos de longa duração", dentre os quais, destacamos a assistência social.

\subsection{A polícia como objeto de estudo}

Ao tratarmos da polícia como objeto de estudo é necessário esclarecer que esta não se constitui no objeto central de nossa tese. Este local é ocupado pela história da assistência social, a qual, segundo nossos estudos, foi influenciada decisivamente pela polícia na criação e institucionalização desta prática social e deste campo de saber. Desta maneira a polícia, enquanto instituição, prática social e instância produtora de saber se constitui objeto para nós somente enquanto produtora de práticas de assistência social. Neste sentido, somos obrigados a entender os aspectos relevantes à construção de saberes científicos produzidos cujo objeto central é a polícia. Esta necessidade se dá como meio de criar condições acadêmicas objetivas de nos posicionar acerca do lugar que nos sentimos 
pertencente no vasto campo de estudo sobre a polícia. Mesmo não sendo a polícia nosso principal objeto, nossa tese dispensa a ela o protagonismo para demonstrar a maneira e os meios pelos quais o saber construído nas instituições policiais influenciou a maneira como o Estado lida historicamente com a pobreza urbana na cidade do Rio de Janeiro e, por conseguinte, o modo como esta participou ativamente da construção da assistência social. Por este motivo que inevitavelmente teremos que abordar a história da polícia na cidade do Rio de Janeiro - detalhada no Capítulo III -, bem como, trataremos dos campos de análises e os respectivos autores que tem a polícia como objeto central.

Não temos a intenção de desenvolver longo estudo sobre a produção cientifica e análises que tem a polícia como foco ou que a usa como fonte para desvendar outras questões. No entanto, teremos que nos ater, ainda que de maneira breve, aos campos de estudo da historiografia e da sociologia, que tem a polícia como objeto e, compreender como a história da polícia no Brasil se relaciona com o desenvolvimento global e a estruturação da moderna polícia na Europa e nos Estados Unidos no período abordado por nossos estudos.

Ainda é bastante tímida a produção acadêmica e estudos que trabalham na perspectiva da polícia como instituição estatal na manutenção e no gerenciamento da urbanidade. A polícia, mesmo historicamente, ainda é pensada como objeto de estudo sobretudo como instituição ligada ao controle do crime. No entanto trabalhos como Brandão (et al, 1981). Vianna (1999) e Santos (1979) apontam diretamente a correlação do polícia com a formação do mundo do trabalho. No extrato mundial encontramos eco em atores como Gonçalves $(2007,2011)$ em Portugal que apontou o lado de assistência social da polícia de Lisboa, Monkkonen (1989) que relata este aspecto na polícia de Nova Iorque e Winberger e Reinke (1989) que compara as instituições policiais das cidades industriais de Manchester (Inglaterra) e Wurppertal (Alemanha) no período de 1870 a 1930 com o objetivo de "ampliar ainda mais e tornar mais precisas as relações entre a polícia e a ordem pública e as questões de assistência social" (Monkkonen, 2003, p. 590).

No percurso do século XX, apesar de existirem estudos que datam de 1913, a polícia ganhou relevância como objeto de estudo acadêmico e pesquisas pela historiografia e a sociologia somente nas décadas de 1960 e 70 (Gonçalves, 2007, 2011 \& Bretas, 1997). No Brasil, o início destes estudos pode ser circunscrito ao final dos anos de 1980, mas principalmente na década de 1990 que aparecem os 
principais trabalhos historiográficos e sociológicos sobre a polícia brasileira, como veremos adiante. Importante destacar que o estudo realizado em 1913 e publicado em 1915 sob o título de European Police Systems investigou de forma comparativa vinte e uma (21) polícias de cidades de seis países europeus. Este estudo realizado por Raymond Fosdick e financiado pela fundação Rockefeller tinha por objetivo pesquisar as formas de atuação da polícia na administração das cidades. Fosdick tinha especial interesse no tema da administração pública, visto que, ocupara o cargo na cidade de Nova Iorque de Commissioner of Accounts onde estudou e desenvolveu propostas para as práticas de governo nas cidades relacionadas à transparência e eficiência administrativa. Este livro foi referência acadêmica para o estudo das instituições policiais até a década de 1970 (Gonçalves, 2007). Outro aspecto destacado por Fosdick no sentido comparativo da polícia, que de certo modo, inspira, em parte, nossa observação da história da polícia na cidade do Rio de Janeiro é o fato de ter demonstrado que a polícia inglesa, inspiração para as polícias no mundo, tinha suas ações dentro de um modelo civil, pautadas pela impessoalidade, pelo respeito aos direitos civis e pelas liberdades individuais, enquanto que, as polícias do continente, principalmente as da Alemanha e da França, tinham um caráter mais paternalista e militarizado (Gonçalves, 2007). Chamamos atenção para o aspecto administrativo que assume relevância deste o primeiro estudo que tem a polícia como objeto, apesar desta perspectiva mudar para os aspectos criminais como predominante nos estudos da polícia a partir da década de 1960.

Após o trabalho de Fosdick, somente em 1950, através de William Westley ${ }^{17}$, a polícia volta a ser objeto de investigação acadêmica relevante. Este trabalho refletia o papel da polícia na relação entre a sociedade e o Estado, de certa forma, se conectava os conflitos raciais acontecidos nos Estados Unidos na época. No entanto, os estudos sobre a polícia somente tornam-se de interesse mais geral da sociedade e da academia na década de 1970, devido, entre outros fatores, a publicação do estudo de Westley vinte anos depois de realizado (Gonçalves, 2007, 2011 \& Bretas, 1997).

\footnotetext{
${ }^{17}$ Anterior a 1950 e posterior a 1915 os americanos August Vollmer e O. W. Wilson que eram chefes de polícia desenvolveram estudos sobre a atuação da polícia, apesar de algum destaque, seus trabalhos não ganharam relevância no mundo acadêmico, a preocupação com os "elementos tecnológicos na prática policial", bem como as "discussões em torno do mandato policial" eram as tônicas de seus trabalhos (Gonçalves, 2007, p. 8).
} 
Os estudos sobre a instituição policial que na década de 1970 se consolidam como um importante e vasto campo de investigação da história, de certo modo, se ligam enquanto reflexões acadêmicas as agitações dos anos de 1960. No percurso acadêmico que consolida a polícia como objeto de estudo nos Estados Unidos a partir da década de 1970 destacam-se; Roger Lane (1967), James F. Richardson (1970) e Wilbur Miller (1976), entre outros. A importância destes autores se dá pelo fato de distinguirem, de maneira inaugural, os estudos da polícia relativo à própria instituição policial e os estudos que abordavam a relação da polícia com aqueles que devem ser policiado: comunidade-sociedade (Gonçalves, 2007).

Os primeiros trabalhos relevantes no século XX na Europa que tem a polícia como objeto de estudo surgiram na Inglaterra com autores como Charles Reith $(1950)^{18}$ e Sir Leon Radzinowicz (1948) ${ }^{19}$. Na década de 1960, surgem também na Inglaterra os estudos dos sociólogos Michael Baton $(1964)^{20}$ e T. A. Critchley $(1967)^{21}$ depois na década de 1970 o historiador marxista Robert Storch $(1976)^{22}$, cujos trabalhos criaram linhas de investigações persistentes até nossos dias. Segundo Stroch (1976 apud Gonçalves, 2007, p. 10) a polícia tinha como ação na relação cotidiana com a população transmitir para as "classes trabalhadoras os valores de uma burguesia dominante". Como "renovação da história social de pendor marxista" (Gonçalves, 2011, p. 2), E. P. Thompson $(1978)^{23}$ assume o protagonismo no trato da polícia como fonte histórica para desvendar as vozes dos debaixo. Cabe destacar também, por volta das décadas de 1960 e 1970, George Rudé, entre outros da Ecóle des Annales que através da história social passaram a problematizar o lugar do crime e das leis na construção da ordem. Na década de 1980, destacam-se os trabalhos sobre criminalidade do historiador Clive Emsley (1979) e Steedman (1984), que buscaram compreender o papel exercido pela polícia na construção de conceitos e práticas relacionados a constituição histórica do poder estatal na Inglaterra. Na França destacam-se os trabalhos de Williams (1979) que

\footnotetext{
${ }^{18}$ A Short History of the British Police by Charles Reith. Journal of Criminal Law and Criminology (1931-1951). Vol. 40, No. 5 (Jan. - Feb. 1950), pp. 675-677.

${ }^{19}$ Entre outros trabalhos relativo ao estudo da polícia e da criminologia, Radzinowicz destaca-se como fundador do Institute of Criminology da Universidade de Cambridge, em 1960.

${ }^{20}$ BANTON, Michael. The Policeman in the Community. London, Tavistock Publications, 1964.

${ }^{21}$ CRITCHLEY, T. A. A History of Police in England and Wales. London, Constable, 1967.

22 STORCH, Robert D. The Policeman as Domestic Missionary: Urban Discipline and Popular Culture in Northern England, Journal of Social History, 1976, 9: 481-509.

${ }^{23}$ E. P. Thompson assume para nós especial importância visto que seus estudos se coadunam como referências, seja na maneira de como tratar a fontes policiais e judiciárias nos aspectos teóricometodológicos, seja por sua interpretação para ideia de classe.
} 
estudou a relação entre a polícia de Paris e os espaços urbanos nos séculos XVII e XVIII. Emsley (1983) retoma o tema dos primeiros estudos comparativos entre a polícia de Londres e a francesa e o historiador Jean Marc Berliere (1991) ${ }^{24}$ completam o quadro dos principais estudos sobre a polícia francesa. Podemos citar ainda como referência no estudo da instituição policial na Europa os alemães Marc Raeff (1983) $)^{25}$, Alf Ludkte (1982), Elaine Glovka Spencer (1992) ${ }^{26}$ e Herbert Reinke (1992) ${ }^{27}$. O modelo policial alemão configura-se em importante influência para as polícias no mundo visto, por exemplo, as práticas burocráticas de registro da população, a militarização e a influência no direito policial desde o século XVIII (Gonçalves, 2007). Apesar de estarmos circunscrito a descrição dos principais autores e linhas de estudos sobre a polícia no século XX, Foucault (2001) aponta "que uma das primeiras e mais robustas publicações sobre a polícia foi Delamare", não início do século XVIII.

No decorrer da trajetória acadêmica da polícia como objeto de estudo, destacamos a produção de Eric H. Monkkonen (1981) que enfatizou em seus estudos as discussões sobre as funções administrativas exercidas pela polícia. Evidencia-se que o olhar para os aspectos administrativos da polícia na gestão das cidades é mais presente nos estudos surgidos nos Estados Unidos do que na Europa. Nesta, os aspectos administrativos das cidades pelas polícias aparecem na discussão sobre o Estado de Polícia, principalmente na Alemanha do século XVIII. Os aspectos administrativos da pobreza urbana pela polícia americana, especificamente a nova-iorquina, evidenciam-se nos estudos de Monkkonen (1981), segundo o qual "as funções policiais oscilavam entre o controle mais repressivo e um conjunto de funções de cariz assistencialista (grifo nosso)" (apud Gonçalves, 2007, p. 9) ${ }^{28}$.

\footnotetext{
${ }^{24}$ L'institution policière en France sous la Troisième République (1875-1914), thèse de doctorat, Histoire, Université de Bourgogne, Dijon, 1991.

${ }^{25}$ The Well-Ordered Police State: Social and Institutional Change through Law in the Germanies and Russia, 1600-1800 (Yale University Press, 1983)

${ }^{26}$ SPENCER, Elaine Glovka. Police and the Social Order in German Cities: The Düsseldorf District, 1848-1914. Northern Illinois University Press, 1992.

${ }^{27}$ Reinke participa junto com outros autores de importante publicação, referência sobre os estudos da polícia na Europa, Polices d'Europe publicado na França em 1992.

${ }^{28}$ Gonçalves (2007, p. 9) demonstra que, "ao constatar que durante longos períodos as esquadras de polícia americanas albergavam mais mendigos e crianças perdidas que criminosos, Monkkonen introduziu um olhar sobre a polícia que fugia aos normais parâmetros - violência, coerção e repressão. $\mathrm{O}$ autor definiu então que as funções policiais oscilavam entre o controlo mais repressivo e um conjunto de funções de cariz assistencialista".
} 
Nos estúdios sobre a polícia de Nova York no século XIX Monkkonen (2003, p. 578) demonstra a inovação social e política que esta representou como "componente do governo local" e "parte dos serviços urbanos".

Segundo Gonçalves (2007), os estudos sobre a polícia se estruturam em duas grandes linhas de investigação, aquela que prioriza o caráter da organização policial enquanto instituição administrativa inserida no aparelho de Estado e aquela voltada a investigar a relação entre polícia e sociedade. No entanto, percebemos, como veremos adiante, que estas duas linhas de pesquisa, mesmo a que olha para o caráter administrativo acaba dando ênfase aos aspectos criminológicos. Não por acaso, esta é a característica principal que nos salta aos olhos no primeiro contato com a ideia de polícia e sua história. Para nós, interessa-nos estudar a instituição policial na virada do século XIX para o XX na cidade do Rio de Janeiro tanto pelo seu caráter administrativo, quanto pela relação direta que estabelecia com a sociedade, de modo que possamos vislumbrar uma via de pesquisa que estuda a polícia como meio para desvendar a formação de outros saberes e práticas sociais que a princípio parecem alheios à história da polícia, como por exemplo, a assistência social.

De certa forma estes campos instituídos por uma maneira disciplinar de se conceber determinado fato social como objeto de estudo demostra diretamente a dificuldade que se constitui em delimitar o objeto a partir de um único prisma. A polícia como objeto de estudo é um destes campos das práticas sociais e institucionais que impõe a necessidade de transpor determinados limites das disciplinas acadêmicas. Os aspectos difusos, a amplidão e a variedade de análise torna "muito difícil incorporar tudo o que é passível de ser designado de polícia em um "explicandum passível de ser estudado"” (Bayley, 1977, p. 13 apud Gonçalves 2011, p. 2).

Segundo Monkkonen (2003: 584-5) “alguns historiadores (Blackburn, 1979 \& Rippy, 1985) argumentam que a polícia foi criada em resposta ao aumento de crimes, mas há poucas evidências empíricas que apoiem tal ideia, porque muitos cientistas sociais aceitam agora que, no longo prazo, as tendências das taxas de crime eram decrescentes (Gurr, 1989)". Este argumento corrobora que a ideia de polícia teve mais importância na sociedade capitalista organizando o mundo do trabalho do que reprimindo e prevenindo crimes, ou seja, esteve mais para o controle das classes do que dos crimes. Isto fica claro nos relatórios dos chefes de polícia analisados por nós, pois a polícia do Rio de Janeiro primeiro empregou suas 
energias, principalmente, no controle dos vadios e vagabundos e depois direcionouas para o controle dos anarquistas e comunistas, ou seja, buscou controlar diretamente o mundo do trabalho.

A relação das instituições policiais com a organização do mundo do trabalho pode ser verificada, por exemplo, em estudos que analisam a polícia em relação ao processo de industrialização da cidade de São Paulo, como Cruz (1987) ${ }^{29}$ e Santos $(2006)^{30}$ que afirmam que a polícia se colocava como o principal interlocutor entre a população pobre e o Estado na organização a força de trabalho no final do século XIX e início de XX. Encontramos também esta perspectiva explicitamente em Brandão (et al 1981) que nomeia um capitulo de seus estudos como "A polícia e o mundo do trabalho". Do mesmo modo Harring $(1983)^{31}$, em perspectiva marxista, aponta a relação direta da polícia de Chicago (1865 a 1915) no controle da organização operária e do mundo do trabalho. Este mesmo ponto de vista podemos vislumbrar em Lane (2003) para o qual as instituições policias foram o modo criado pelo Estado para ordenar as exigências comportamentais do mundo do trabalho, que diante dos aspectos da modernização e interesses capitalistas não cabia mais os moldes de relação comerciais baseado no mundo rural. Segundo Weinberger e Reinke (1989, p. 14 apud Monkkone, 2003, p. 590) na Inglaterra era "por si só evidente" uma orientação da polícia para o controle de classes. Na Alemanha, a polícia se concentrava claramente no controle da política dos trabalhadores e nos sindicatos e, ao mesmo tempo, para implementar a crescente especialização nestas áreas "foram criadas mais duas polícias distintas: uma para a saúde e a outra para a área sanitária" (Weinberger \& Reinke, 1989, parte 2, p. 8-9 apud Monkkone, 2003, p. 590). Monkkonem (2003, p. 603) afirma que a polícia americana se posicionou mais intensamente "em prol do controle do crime e distanciamento da assistência social", enquanto que a europeia se orientou "para a assistência social e ampliação de serviços (controle de classes) (Weinberger \& Reinke, 1989)".

$\mathrm{Na}$ sociedade industrial o comportamento em relação ao trabalho fora dos padrões estabelecidos não poderia mais ser tolerado, como foi anterior ao modo de

\footnotetext{
${ }^{29}$ CRUZ, Heloisa de Faria. "Mercado e Polícia - São Paulo 1890-1915" in Revista Brasileira de História, São Paulo, v.7, n.14, pp.115-130, mar/ago, 1987.

${ }^{30}$ SANTOS, Marco Antonio Cabral dos. A polícia e a organização dos trabalhadores urbanos em São Paulo (1890- 1920). Texto integrante dos Anais do XVIII Encontro Regional de História - O historiador e seu tempo. ANPUH/SP - UNESP/Assis, 24 a 28 de julho de 2006.

${ }^{31}$ HARRING, Sidney. Policing a Class Society: the experience of american cities (1865-1915). New Brunswick, N. J., Rutgers University Press, 1983.
} 
produção capitalista, pois "o trabalho de cada um, dependeria do comportamento previsível dos outros" (Lane, 2003, p. 47). Neste aspecto a polícia estaria pronta para o controle das classes sociais com ações que incluíam, inevitavelmente, as práticas de assistência social. Este aspecto por si só já qualifica nosso ponto de vista sobre a necessidade de incluir as instituições policiais como formadoras do campo da assistência social no Brasil, quiçá, no mundo ocidental cristão. O vasto campo de atuação da polícia se estendia por diferentes tipos de assuntos, muitos dos quais presentes nos dias atuais, como a especialização em crimes. A dimensão do campo de atuação da polícia se circunscreve principalmente nos espaços públicos e se relaciona diretamente com a regulação de comportamentos, que passam desde a violência doméstica - quando o espaço privado vira público - ao controle do transito, a ações relacionadas a moralidade como no caso da prostituições e jogos, bem como, a mendicidade, de maneira que é o principal instrumento Estatal que consegue penetrar e estabelecer relação com os mais diversos segmentos da sociedade, e oferece um vasto contingente de serviços públicos. Neste sentido, o estudo das instituições policiais nos oferece a perspectiva de conhecimento para diversas realidades sociais, institucionais e políticas.

É fato que a polícia enquanto um objeto específico da historiografia ou da sociologia, seja pelas correntes de vertente marxistas ou não, está majoritariamente ligada aos estudos da justiça criminal, do crime e do criminoso. Ainda que seja usada como meio de se estudar as classes populares, o campo principal de saber que os estudos da polícia se relacionam, indubitavelmente, é o campo jurídico criminal. No entanto podemos vislumbrar, ainda que minoritariamente, no sentido da quantidade de interesses acadêmicos pelo tema, a polícia ser usada, ainda timidamente, nos estudos do urbanismo, da formação do campo de trabalho, da administração, e das instituições em geral (Gonçalves, 2011). Observando as fontes citadas por Gonçalves (2007) percebemos, por exemplo, que em organizações, como a Social Science History Association, os estudos relativos à polícia se agrupam necessariamente na seção criminal-justice/legal-history. Este fato demonstra a relação direta e hegemônica dos estudos da polícia com os aspectos relacionados ao monopólio da violência pelo Estado, justificado em princípios científicos, meramente teóricos ou empíricos, materializado em leis e saberes sobre o crime e o criminoso no contexto social. Do mesmo modo, esta concepção de estudos sobre a polícia pode ser vislumbrada na revista Crime, Histoire \& 
Sociétés/Crime, History \& Societies, uma das principais publicações europeias a tratar de estudos sobre a polícia ${ }^{32}$.

Podemos, sem dúvida creditar esta maneira de ver a polícia como o principal papel no qual esta instituição Estatal se especializou ao longo do século XIX, se consolidando na prática social que conhecemos hoje. Para Gonçalves (2011, p. 2), “o longo século XIX testemunhou uma completa transformação no que se entendia então por polícia, conferindo-lhe características que continuam hoje a marcar os sistemas públicos de policiamento". Sob esta perspectiva os estudos sobre a polícia, em sua maioria, esboçam a preocupação de desvendar os aspectos da criminalidade como problemática social, visto que as instituições policiais, segundo convergem os pontos de vistas da maioria dos historiadores e sociólogos, surgiram como meio de prevenir e reprimir o crime e o criminoso. Estes aspectos se sobressaem nos estudos sobre a polícia, menos por uma decisão autocrática dos pesquisadores e mais pela percepção de que ao longo do século XIX a relação com o crime e a criminalidade passou a ser a especialidade da polícia. Neste sentido, também podemos observar que o principal constructo teórico criado para explicar o surgimento da polícia na sociedade moderna diz respeito à necessidade do Estado enfrentar a problemática do crime e do criminoso. De certo modo, há um consenso da moderna historiografia, que percebe a polícia como uma das criações do estado moderno.

Por estes fatos, torna-se mais árduo apresentamos um caminho que demonstra uma representação social da polícia diferente daquela usualmente construída e que não esteja ligado à dissecação jurídico-criminal. No entanto, com olhar mais aguçado é possível demonstrar na história da polícia, seja na Europa, nos Estados Unidos ou no Brasil, principalmente no século XIX e início do XX, aspectos que vão além das funções sobre as quais a polícia atual se especializou e sobre a qual foi construída sua representação social. Neste sentido, Gonçalves (2011, p. 3) assinala que determinados autores, seja da História, seja da Sociologia, respectivamente, Monkkonen (2004), Punch e Naylor (1973), demonstram "que debaixo da extrema visibilidade pública do crime, mas permanecendo opacas aos

\footnotetext{
${ }^{32}$ Para um aprofundamento sobre esta perspectiva de estudos sobre a polícia ver: $<$ http://ssha.org/networks/criminal-justicelegal-history>, <http://chs.revues.org/>, $<$ http://irhis.recherche.univ-lille3.fr/ANR-CIRSAP.html>, <http://socialhistory.org>. Acesso em: 10 jan. 2015.
} 
olhos do público, um amplo conjunto de funções e de práticas eram e são continuamente executadas pelas organizações policiais".

No entanto, cabe ressaltar que estas perspectivas de análises da polícia, não são excludentes, ao contrário elas se complementam e o mais prudente é olhar como complementariedade e não como um paradoxo ou uma contradição, mas como um continuo de ações complexas dialeticamente estruturada para o enfrentamento de uma questão também complexa, a pobreza urbana. Para tal enfrentamento, eram necessárias a prática repressiva, a prática ordenadora e a prática assistencial que poderia se subdividida em práticas de assistência médica e social na qual a última poderia ser dívida em práticas de "ajuda e apoio" e práticas regeneradoras para e pelo trabalho.

O problema enfrentado por aqueles que estudam a polícia em definir os limites do campo disciplinar ao qual se está inserido, configura-se para nós também em conflito, pois, apesar de estarmos claramente vinculado com aqueles que percebem a polícia como uma peça da administração pública das cidades, não podemos deixar de dar relevância aos aspectos institucionais relacionados ao Estado e os estudos que priorizam a relação da polícia com aqueles que devem ser policiados. Ainda assim nossa ênfase se dá nos aspectos administrativos acerca de como o Estado lidava com a pobreza urbana.

A polícia na Europa ao longo do século XIX foi gradativamente se especializando e se profissionalizando no caráter judiciário-criminal, o que aconteceu também no Brasil, se tronando o que conhecemos hoje por polícia. É fato que esta especialização se deu diante de um cenário que generalizava as funções para a organização dos mais diferentes aspectos da vida civil nas relações sociais na urbe. De maneira que não podemos pensar na construção social de campos como, por exemplo, o urbanismo, as instituições asilares, os complexos gerenciamentos de fluxos de pessoas e as relações de comércio sem pensarmos historicamente na instituição policial. O gerenciamento através de diversificadas técnicas de controle, umas mais sutis e outras mais violentas, dos espaços públicos e a pobreza urbana é parte do vasto material de técnicas policiais. Estas técnicas estavam diretamente associadas a regulação das relações sociais na urbe com vista a manutenção do status quo dos meios de produção e do modo de vida burguês, mas que de outro modo também foram peças fundamentais nas constituições dos Estados-nações da 
Europa ocidental como parte intrínseca do equilíbrio de forças entre Estados (Foucault, 2001).

"Desenvolver e explicar porque o policiamento mudou de uma questão ampla como o controle de classes, para uma questão mais delimitada, que é o controle do crime" (Monkkonen, 2003p, p. 603) é ainda hoje tarefa pouco exitosa, pois ainda perseguida por poucos. Sem dúvida há uma mudança radical do modelo de polícia do século XIX para o século XX. Definir o momento exato dependerá de que tipo de fator se estará dando ênfase na multifacetada história das instituições policiais. No entanto, é possível afirmar genericamente que no mundo ocidental cristão, esta transitoriedade se deu nas últimas décadas do século XIX e início do XX. No caso do Brasil, é possível afirmar que, a partir dos anos de 1920 e 30, esta especialização em crime se completa como único víeis de atuação das instituições policiais. Da mesma forma, Monkkonen (2003, p. 588-9) demonstra que no caso da polícia nos Estados Unidos, alguns historiares vão datar estas transformações em 1890 e outros, como por exemplo Wertsch (1987, p. 448 apud Monkkonen, 2003, p. 588-9), defende que esta mudança ocorreu somente nos anos de 1920. Este movimento de transformação da instituição policial se dá entre a mudança de gestão das populações nas cidades para uma ação puramente jurídico criminal. A polícia do século XX, ou moderna polícia, vai ser cada vez mais especializada ao ter como missão a exclusividade de prevenção e repressão aos crimes e será também exclusivamente pública ${ }^{33}$ a partir de uma gestão profissional a partir de conceitos como desempenho e eficácia. A mudança de definição da ação de polícia demonstra e corrobora com nossa afirmação que as instituições policiais estiveram diretamente implicadas na formação do campo da assistência social, como instância da administração pública. Segundo Monkkonen (2003, p. 597), "nem o afastamento da polícia dos serviços sociais, nem o enfoque nas detenções relacionadas com crimes estão de acordo com o quadro profissional descrito por policiais de destaque como August Vollmer". Chefe da polícia de Berkeley, em 1905, Vollmer ganha notoriedade local e nacional ao promover mudanças na polícia local que incluíam ações de assistência social. "Suas inovações incluíam uma clínica de aconselhamento com um assistente social psiquiatra" (...) com ênfase à intervenção em assuntos pessoais e à prevenção através de método prescritos pelas novas ideias

\footnotetext{
${ }^{33}$ Segundo Bayley (2001, p. 64-65) no caso dos Estados Unidos a polícia só se torna exclusivamente pública no século XX.
} 
do movimento da higiene mental (Liss \& Shhlossman, 1984 apud Monkkonen, 2003, p. 597). Do mesmo modo que os chefes de polícia da cidade do Rio de Janeiro - no período de nossos estudos -, Vollmer buscava influenciar politicamente no curso da sociedade de forma mais geral escrevendo inúmeros artigos e publicando livros. No entanto, como nos lembra Monkkonen (2003), a “orientação de Vollmer para o serviço social" não representava um retorno "à multiplicidade de serviços policiais do século XIX" ou uma reação a especialização dos serviços policiais estritamente criminológicos. Esta inclinação para as ações de assistência social estava claramente pensada como meios de controle da população pobre e prevenção de crimes. Em relação ao Rio de Janeiro (Werneck da Silva, 1981, p. 37), é taxativo ao afirmar que "o próprio conceito de polícia se há de transformar: da interpretação dos aspectos administrativos e preventivo/repressivo, ou até da ascendência do primeiro sobre o segundo, nos últimos anos da década dos anos vinte [1920]", permanecendo "a predominância do preventivo/repressivo sobre o administrativo".

No caso brasileiro, daremos especial atenção aos estudos que privilegiam a formação histórica da polícia na cidade do Rio de Janeiro. Neste sentido, destacamos Werneck da Silva (et al, 1981) Brandão (et al., 1981), Bretas (1997, 1998), Holloway (1997) e, mais especificamente Vianna (1999), um dos poucos trabalhos a olhar a história da polícia pelo viés administrativo nos aspectos mais gerais da gestão das cidades, ainda que ligado especificamente ao problema da menoridade. Cabe destacar que em Brandão (et al, 1981), encontramos profunda inspiração para nossos estudos, pois afirma categoricamente a importância da polícia para o governo da cidade e sua relação com a municipalidade, engenhosamente pensando a relação da polícia com o "mundo do trabalho", o "mundo do governo" e o "mundo da desordem". Do mesmo modo que no final da década de 1980, os estudos sobre polícia na Europa discutem a vinculação desta com "às transformações das formas de Estado e de governo" (Gonçalves, 2011, p. $3)^{34}$, no Brasil, também os estudos apontam nesta direção como, por exemplo, Brandão (et al, 1981) e Holloway (1997). Vale frisar que pensar no papel exercido pela polícia no governo das cidades, seja no Brasil, na Europa ou nos Estados Unidos é estar atendo as múltiplas dimensões de sua atuação, bem como, na dinâmica social que influenciou uma diversidade de instituições da administração

\footnotetext{
34 "Em comparação com outras ciências sociais, a chegada dos historiadores à polícia pode ser caracterizada como tardia" (Gonçalves, 2011, p. 3).
} 
pública. No entanto devemos estar atento a dois aspectos que trataremos de maneira mais pormenorizada no decorrer do texto, que são a definição de prática social que determina a legitimidade da polícia como elementos estruturados de sua hegemonia institucional e os saberes que justificam e/ou emanam desta prática. Estes saberes que se constituem em práticas e que ao mesmo tempo produz saberes é uma das principais características que podem ligar diretamente as intuições policiais com o campo da assistência social, impulsionado pela necessidade de controlar a pobreza urbana, através do ato de "conhecer". O modo de exercer o controle social passa necessariamente pela posse e domínio do conhecimento, no qual entre outros mecanismos científicos destaca-se a estatística ${ }^{35}$. Conhecer e sistematizar o conhecimento permite a maior eficácia para o emprego da técnica e das práticas sociais que possibilitavam uma relação de maior mobilidade com os conflitos diários da urbanidade e melhor ordenamento do mundo do trabalho. De certo modo que a força administrativa da polícia, tem um papel fundamental na consolidação dos Estados-nações, na medida da necessidade direta do Estado construir conhecimentos científicos sobre o próprio Estado, entendido como a particularidade do conjunto hegemônico de forças sociais que regem a sociedade em geral. Foucault (2008) vai ainda mais longe e afirma que o Estado de polícia foi o percursor dos estudos que mais tarde vieram a se caracterizar pelo nome de econômica política.

Ainda que as afirmações de Roger Lane (2003, p. 25-6) ${ }^{36}$ de que são "duvidosas as interpretações do que venha a ser meramente administrativo ou do que é forçosamente político". "Não há dúvida de que no século XIX, a polícia claramente realizava parte dos serviços sociais da cidade ou a função distribucional” (Monkkone, 2003, p. 603). A história da polícia deixa claro sua mudança funcional com o passar do tempo, expressa na problemática de análise de

\footnotetext{
${ }^{35}$ Neste aspecto afirma Foucault (2008, p. 424) que a estatística justamente se estabeleceu "pela polícia, porque a polícia, como arte de desenvolver as forças, supõe que cada Estado identifique exatamente quais são as suas possibilidades, as suas virtualidades. A estatística se toma necessária por causa da polícia, mas também se toma possível por causa da polícia”. Mais adiante, na mesma página Foucault argumenta que o conhecer sistematizado em estatísticas pelo polícia torna-se também importante para equilíbrio geopolítico europeu: "Polícia e estatística se condicionam mutuamente, e a estatística é, entre a polícia e o equilíbrio europeu, um instrumento comum. A estatística é o saber do Estado sobre o Estado, entendido como saber de si do Estado, mas também saber dos outros Estados".

${ }^{36}$ Polícia Urbana e Crime na América do Século XIX in TONRY, Michael; MORRIS, Norval (Orgs.). Policiamento Moderno. Edusp, São Paulo, 2003.
} 
Peterson ${ }^{37}$, qual seja, a problemática sobre a "função e distribuição do governo da cidade" (Monkkonen, 2003, p. 603). Fica evidente, como demonstrado acima, que encontramos ecos perfeitamente audíveis em estudos que demonstram ações, práticas e discursos sobre a assistência social em instituições policias na Europa e Estados Unidos, tal qual demonstraremos a existência também no Brasil. Estaremos atento, pois enxergar a história da polícia na perspectiva da administração das populações nas cidades impõe questões teóricas sobre a construção do urbano em oposição ao rural, questão que embora não trataremos em nossa tese, aparece em vários momentos como pano de fundo. Ainda que a polícia tenha se especializado em controle do crime em detrimento ao controle da classe a partir do século XX, esta "tornou-se essencial nas funções promocionais da cidade, através das quais ela ajudou a fornecer um ambiente mais seguro para as atividades econômicas urbanas" (Monkkonen, 2003, p. 603).

\subsection{Percurso teórico-metodológico}

Antes de iniciarmos qualquer tentativa de circunscrever um método, seja de trabalho investigativo, seja de pressupostos teóricos é preciso destacar que anterior a qualquer método, o produto final de uma tese - em nosso campo de saber -, tratase de uma narrativa. Ainda que baseados em métodos validados por uma epistemologia que o certifique como científico o produto final no qual as tramas dos argumentos são tecidas está limitado ao sentido estrido de narrativa, não em sentido literário, mas como signo da construção de conhecimento sobre um dado problema subjetivamente interpretado. Não é tarefa difícil demonstrar que narrativas consistentes conseguem engendrar mais sentido aos fatos do que pesquisas consistentes (Ginzburg, 1989), de modo que, quando se trata de pesquisas, cujo o método historiográfico é o motor, a maneira como se constrói a narrativa torna-se fundamental para o sucesso dos argumentos. Não é de se estranhar que o processo de construção da história e da sociologia no Brasil passam

\footnotetext{
37 “Paul Peterson (1981), em City Limits (Limites da Cidade), argumenta que o policiamento é uma função de "distribuição" do governo da cidade" (Monkkonen, 2003, p. 603).
} 
diretamente pelo gênero literário. No entanto ao tratarmos dos aspectos da produção de conhecimento científico nos limites de uma tese somos impulsionados a demonstrar aqui o caminho percorrido que possibilitou imprimir veracidade epistemológica à narrativa construída. Afinal a teoria "não pode, de modo algum, ser absoluta, rígida e acabada" (Quiroga, 1989, p. 3), deve ser vista em seus limites, nos ajudando a confrontar a realidade, mas sem a imposição de modelos teóricos e metodológicos a priori.

O modo e os meios de conhecer a realidade direta e dinâmica e refletir sobre esta realidade a ponto de criar constructos teóricos é parte soberana de cada pensador, visto que sua autonomia de pensamento, seja em relação a realidade, seja em relação a qualquer campo teórico é um axioma da própria construção teórica do pensamento racional. É com este sentido de autonomia do pensar, tanto em relação a realidade estudada empiricamente, quanto em relação ao campo teórico, que passaremos a discutir as interações conceituais que influenciaram nosso modo de interpretar esta realidade. Não há aqui escolha teórica a ser seguida enquanto verdades inquestionáveis, mas uso de categorias teóricas de análise relativas a alguns autores específicos que aparecerão ao longo do texto. O diálogo com estes autores representa instâncias metodológicas e reflexivas que nos permitem demonstrar a coerência e fundamentação científica de nossos argumentos.

Este diálogo qualifica nossos argumentos, visto que, não se consegue resolver determinados problemas somente com o raciocínio individual e que e nos posiciona diante de certa direção do pensar coletivo em resolver questões apontadas por nossa autonomia de pensamento. O que pretendemos é interrogar o passado a partir do que podemos vislumbrar no presente, ou seja, é o olhar construído na atualidade que possibilita traçar novos questionamentos sobre o passado e por consequência rever o que pensamos sobre o presente.

Toda escolha teórica é deliberadamente polêmica, visto que, inicialmente se apresenta o axioma da justificativa do porquê se escolheu este campo teórico e não aquele. A necessidade dê a todo tempo termos que esclarecer com quais referenciais teóricos estamos dialogando ao exercer reflexões sobre nosso objeto de estudo demonstra, por sua vez, muita mais a necessidade de vinculação a um campo instituído do saber, do que necessariamente luz que tal teoria possa impor na maneira como enxergamos nosso objeto de estudo. Esta postura teórica se dá devido a acreditar que a realidade se impõe sobre qualquer teoria a priori. Da mesma forma, 
a contradição se dá, pois de certo modo acabamos caindo, ainda que inadvertidamente, nas referências teóricas que iluminam nossa intuição ao pesquisarmos a realidade empírica. No entanto, nosso caminho é o inverso, partimos da realidade para o campo teórico, e este fato nos causa determinados problemas epistemológicos e semânticos, visto que a realidade suplanta qualquer teoria, ao mesmo tempo em que nos impõe a necessidade de transpor barreiras disciplinares, muito mais do que teóricas, visto que, as disciplinas são vinculações institucionais que de certo modo o pensamento necessita ter para sua sobrevivência no sistema de poder/saber, sob qual se assenta a construção de conhecimento científico. Neste sentido, rever as relações tradicionais de subordinação, que imperam nos movimentos de apropriação dos saberes, acaba, por vezes, sendo necessário quando todo e qualquer constructo teórico esteja a reboque da realidade empiricamente pesquisada.

Acreditamos já transparecer na maneira como construímos nossos argumentos, no método utilizado para a reflexão, nas escolhas das fontes e documentos que estamos nos aliando aos princípios metodológicos e teóricos de $\mathrm{E}$. P. Thompson (1981, 1988), por um lado e a Fernand Braudel (2005) por outro, além de buscar inspiração também em Walter Benjamim $(1987)^{38}$. Em Thompson nos interessa sua vinculação com "os de baixo" pelo uso das fontes policiais e, principalmente, seu constructo teórico de "consciência de classe", de certa monta vinculado ao modo de interpretação do ser em Lukács (1979, 2003). Neste sentido, que admitimos para nossa reflexão enquanto campo epistemológico, a "categoria da experiência", "uma categoria que, por mais imperfeita que seja, é indispensável (...), já que compreende a resposta mental e emocional, seja de um indivíduo ou de um grupo social, a muitos acontecimentos inter-relacionados ou a muitas repetições do mesmo tipo de acontecimento" (Thompson, 1981, p. 15). O conceito de experiência em Thompson se coloca como balizador, não de uma teoria a priori, mas de uma realidade a priori. "A experiência surge espontaneamente no ser social, mas não surge sem pensamento. Surge porque homens e mulheres (e não apenas

\footnotetext{
${ }^{38}$ Cabe ressaltar que nos associamos tanto em Benjamim, Thompson e Braudel com postura de um pensador autônomo, sem preocupações quanto a seus enquadramentos na escala de valores das escolas de pensamento. E muito menos estaremos aqui propondo análise sobre seus constructos teóricos. A citação destes autores tanto prepara o leitor quanto as referências de análises que estarei seguindo, quanto fundamenta as posturas teóricos-metodológicas que estarei assumindo na construção do objeto.
} 
filósofos) são racionais, e refletem sobre o que acontece a eles e ao seu mundo" (Thompson, 1981, p. 16) ${ }^{39}$. "Na história a teoria não precede a empiria" (Chalhoub, 2009, p. 199). Na mesma direção, Thompson (1981:24), afirma que "o rigor formal de tais procedimentos é a única prova da "verdade" desse conhecimento, e de sua correspondência com os fenômenos "reais": o conhecimento-concreto". Para ele, o real só se "pode tornar objeto da investigação epistemológica no ponto em que penetra o campo de percepção, ou conhecimento. (Thompson, 1981, p. 26).

Já a vinculação com Braudel se dá devido a maneira como este propõe pensar os processos históricos de longa duração, no qual localizamos as práticas de assistências sociais, de modo que nos possibilita tecer considerações sobre a atualidade da assistência social a partir da revisão de sua construção histórica. $\mathrm{Na}$ tradição da Escola dos Annales, da qual pertence Braudel, entre outros, também encontramos críticas a epistemologia que propõe a história como mera narrativa ${ }^{40}$ de fatos e eventos encadeados cronologicamente dentro de uma razão pura. $\mathrm{Na}$ tradição dos Annales a história é vista como problema onde a partir de novas questões colocada no tempo presente se apreende novos pontos de vista do passado. Propõe a noção de tempo histórico usando as categorias "tempo do acontecimento, da conjuntura e da longa duração ou estrutura" (Bittencourt, 2004, p. 146 apud Quiroga, 1989), realizando uma "verdadeira reconciliação da estrutura com a história" (Quiroga, 1989, p. 4).

Ainda procuraremos auxílios nas concepções de Walter Benjamim, que busca justificar de maneira epistêmica o manejo e a análise das fontes históricas em relação ao que podemos chamar de tempo social, como discutiremos no próximo tópico. Estes autores nos permitem navegar com sentido teórico-metodológico pela ceara histórica como método e como reflexão teórica. Além destes autores nos valeremos de alguns conceitos elaborados por Gramsci (2006, 2004, 1989) os quais nos auxiliaram teoricamente no manejo das evidências históricas apresentadas nos documentos pesquisados, principalmente as ideias de hegemonia e cosmopolitismo.

\footnotetext{
39،“A experiência entra sem bater à porta e anuncia mortes, crises de subsistência, guerra de trincheira, desemprego, inflação, genocídio. Pessoas estão famintas: seus sobreviventes têm novos modos de pensar em relação ao mercado. Pessoas são presas: na prisão, pensam de modo diverso sobre as leis. Frente a essas experiências gerais velhos sistemas conceptuais podem desmoronar e novas problemáticas podem insistir em impor sua presença” (Thompson 1981, p. 17).

${ }^{40}$ Aqui cabe um esclarecimento, a ideia de narrativa não se aplica, no sentido acima, a construções estilísticas na produção de textos, científicos ou não. Aqui narrativa assume a ideia restrita de descrição de fatos, narrar.
} 
Cabe ressaltar que não era intento nosso incialmente, mas ficou evidente em nossa análise final que em muitos casos estávamos transitando pela ceara teóricoconceitual das representações sociais (Moscovici, 2003, 1978). A este respeito evidenciou-se uma série de fatos que demonstraram o quanto os chefes de polícia e as instituições policias foram responsáveis pela criação de um conjunto de explicações, ideias e crenças que resultaram em representações sociais presentes nos discursos oficiais sobre o pobre, a pobreza e a assistência. Este conjunto de explicações que representavam socialmente a pobreza ultrapassou em muito os limites das instituições policias. A representação simbólica do cotidiano pelas instituições policiais construíram um conjunto de ideias sobre o pobre e a pobreza urbana que expressavam a totalidade das tradições, da cultura, do indivíduo e do econômico. De modo que é largamente identificável no discurso oficial e cientificamente qualificado das instituições policias no século XIX a atual representação do senso comum sobre o pobre e a pobreza, com o mesmo misto entre indolência e falta de oportunidades.

A necessidade de contextualização histórica, como método, deve-se por aceitarmos a premissa de que os discursos e práticas institucionais demonstram referência de assimilação ou negação da hegemonia do Estado na produção de um quadro de códigos, ideias e práticas sociais, construídos historicamente. E, para nosso caso, a instituição policial é parte significativa do processo histórico de legitimação do Estado, no qual inclui de maneira taxativa as práticas e métodos que hoje classificamos como assistência social. Desta monta, acreditamos que pelo meio da reconstrução histórica da assistência social na cidade do Rio de Janeiro através das instituições policiais podemos contribuir para desvendar outros "conjuntos cristalizados de tensões que contém uma totalidade histórica" (Walter Benjamin apud Löwi 2005, p. 132).

Nesse sentido, apesar de estarmos usando como pesquisa empírica o tempo circunscrito entre 1870 e 1930, nosso foco principal é o tempo presente e nosso engajamento é total. Para nosso intento o distanciamento metodológico é somente um constructo incapaz de ser verificado na autenticidade da prática, aqui reside o comprometimento e o envolvimento emocional, e por isto, a parcialidade diante da fonte de pesquisa é uma qualidade e não um problema de método. Ao questionar o passado através de conceitos formulados no tempo presente estamos nos colocando diante de nosso objeto tanto quanto um problema, quanto uma narrativa, visto que 
a interrogação, a escolha e a conceituação é parte da independência intransferível do pensar e representar a realidade apreendida por uma subjetividade específica.

\subsubsection{O tempo histórico}

O nosso tempo histórico de análise é o tempo presente reinterpretado por uma pesquisa histórica datada entre as três últimas décadas do século XIX e as três primeiras do século XX (1870 a 1930). Este período em nosso ponto de vista é crucial na formação do Estado-nação no Brasil, seja pelos aspectos políticos, sociais, econômicos, científicos, tecnológicos e instrucionais, seja pela formação do mundo do trabalho. A década de 1870 também é considerada como o momento onde a cidade do Rio de Janeiro passa (Abreu, 1987; Benchimol, 1985; Chalhoub, 1986, 1996; Carvalho, 2006, 1999, entre outros) ser alvo de constantes intervenções urbanísticas e sociais.

Neste período, encontramos o auge das cidades imperiais (Hahner, 1993) e ao mesmo tempo as revoltas urbanas. É logo posterior ao fim da guerra do Paraguai, instância que mexeu diretamente no cotidiano político e social da cidade do Rio de Janeiro, é o momento da intensificação dos movimentos abolicionistas e republicano, o momento fundante do Estado moderno no Brasil. O nosso tempo histórico do passado se constitui exatamente entre duas grandes depressões econômicas da história, a de 1870 (Hobsbawm, 1997, 1988) a qual ao estudar a pobreza urbana na cidade do Rio de Janeiro nos deparamos com as consequências cosmopolita deste colapso e a crise de 1929 . O período de 1870 a 1930 é o momento da construção da ordem burguesa no Brasil, estudar as instituições policiais neste período possibilita entender a relação entre a sociedade e o Estado nas tensões que viabilizaram a criação desta ordem.

Em relação especificamente aos estudos sobre a polícia, o tempo histórico está estabelecido num diálogo com os estudos longitudinais que dissecaram a história da polícia no mundo. Percebemos que tanto a manutenção da ordem pública como a prevenção de crimes se inscrevem como objetivos comuns a estas instituições. Isto pode ser verificado tanto na polícia de Londres, Paris, Lisboa, Nova York ou Rio de Janeiro durante todo o século XIX e, por que não, até em nossa atualidade. Este fato que une de maneira genérica os objetivos das polícias 
nas principais cidades do mundo ocidental se torna menos relevante, para nós, do que a ação, meios e métodos empregados para se atingir o objetivo proposto. No entanto é preciso destacar que o tempo histórico escolhido para nossa análise também se configura como o tempo histórico da profissionalização de instituições e práticas sociais e, a consolidação do papel da polícia nas principais cidades do mundo ocidental.

Pensar no tempo histórico como uma sucessão de fatos e encaminhamento temporal de acontecimentos é sem sombra de dúvida estar onipresente com todas as lógicas positivistas e evolucionistas. O tempo mecânico racionalizado não deve ser parâmetro para entender o tempo histórico, do mesmo modo que tempo histórico não exprimi o entendimento do tempo geológico. O tempo inseparável de seu conteúdo não permite, de maneira categórica, que pensemos o século XIX ou XX, por exemplo, como um homem daquele tempo. Isto é uma impossibilidade categórica, é um imperativo intransponível do ponto de vista estritamente metodológico que sejamos capazes de pensar com a lógica e a cognição especifica do passado, em última análise é um sofisma. Qualquer tentativa deste tipo de aproximação se constitui em usurpação da atualidade do pensamento, pois a produção científica, mesmo sobre o passado trata do modo presente na atualidade do pensamento. Mesmo que esta produção se refira ao estudo histórico dos fenícios, este estudo trata-se da atualização da história dos fenícios no presente, portanto em perspectiva nunca nos referimos ao passado mesmo estando tratando dele. Somente somos capazes de tratar do passado em perspectiva do presente. Escrevemos a história para nós mesmos, ou para as gerações futuras, nunca aos mortos.

Neste sentido o diálogo com Benjamin no que diz respeito à concepção de tempo histórico nos propiciou de maneira mais fecunda a construção da epistemologia e argumentos que sustentam nossa tese. Benjamin possibilita a convivência de determinadas contradições aparentemente inconciliáveis no tratamento das fontes e informações históricas que permeiam o modo como construímos nosso objeto. Tempo e historicidade na sua relação da produção do presente com o passado revelado, aparentemente demonstra uma relação inconciliável, segundo determinados métodos da historiografia clássica que impulsiona pensar o passado com a cabeça - significação - do passado. Em nosso modo de interpretar a construção da historicidade a significação do tempo passado é indissociável do modo de pensar o tempo presente, o que parece ser uma 
contradição inconciliável acaba se constituindo na possibilidade de instituir o novo pela problematização presente ao passado.

O amalgama, melhor expressão em nosso ponto de vista para definir os acontecimentos societários na formação do Estado-nação no Brasil, não é feito para aquilo que pertence a uma mesma categoria de coisas ou de ideias que se auto conciliam. O amálgama por definição etimológica diz respeito, a conciliar o que, por conceitos e/ou práticas parece inconciliáveis. Somente é possível falar em amálgama se a contradição for aparente e se o inconciliável for o tom. O que se concilia não se amálgama. No que não há contradição também torna-se desnecessário o amálgama. O amálgama em sua existência é a força dialética em ação e contradição. Neste sentido, afirma Lucáks (2003, p. 6) que foi decisivo "um amálgama de teorias internamente contraditório" para a formação de seu pensamento no pós-guerra "de um lado tendências simultâneas de apropriação do marxismo e ativismo político e de outro, uma intensificação constante de problemáticas éticas puramente idealista" (Lucáks, 2003, p. 6) No mesmo tom continua Lucáks (2003, p. 6), “se a Fausto é permitido abrigar duas almas em seu peito, por que uma pessoa normal não pode apresentar o funcionamento simultâneo e contraditório de tendências intelectuais opostas".

Não há um consenso sobre qual é a verdadeira imagem do passado ou a interpretação que mais lhe imprime veracidade. Neste sentido, encontramos em Benjamin o respaldo epistêmico necessário para fundamentação teóricometodológica do imperativo de amalgamar a intepretação do presente assentado em dados historiográficos. Não há aqui a pretensão de conhecimentos isentos, cartesianamente sistematizáveis, há, em última instância, um comprometimento ontológico e político com o tempo presente na articulação histórica do passado, de modo que, tanto passado quanto presente sejam confrontados como problema e narrativa. Sobre estes aspectos que construiremos nossa narrativa, sem a preocupação de demonstrar uma lógica temporal de encadeamentos de fatos, mas construir uma cronologia onde as ideias impõem sentido de tempo.

\subsubsection{Analisadores}


O pensamento tem uma dependência direta da instituição na qual foi desenvolvido, e isto tanto vale para análise de nosso objeto, o conhecimento produzido pela instituição policial, bem como, o conhecimento aqui formulado, ou mesmo em relação aos autores aos quais nos associamos. De certo modo, compartilhamos categorias de pensamento que possam estabelecer um diálogo acadêmico e cientifico entre nosso objeto e os modos instituídos de construir conhecimento, reconhecidamente relevante para a comunidade científica. Assentado nestas premissas, usaremos o conceito de "trabalho" enquanto um imperativo categórico formulado como o principal analisador para a construção de nossos argumentos. Buscaremos em nossas análises privilegiar os movimentos da sociedade, ainda que através de documentos produzidos pelo Estado. Este foco que busca primeiro o entendimento da sociedade visa "escapar das tendências de encarar o Estado - vale dizer, o aparelho Estatal - como um poder imposto de fora à sociedade, ocupando lugar diferente, o que não raro se apresenta como tendência na produção historiográfica brasileira" (Brandão et al, 1981, p. 5-6). Este movimento que parte do entendimento do Estado como ente intrínseco à sociedade requer um olhar específico para a tensão dialética entre os conceitos e práticas de centralização/descentralização, repressão/administração e público/privado pelos quais podemos identificar a formação da assistência social dentro da formação geral do Estado. Neste sentido, faz-se necessário destacar que as generalizações são difíceis de serem aplicadas quando falamos da complexidade de uma sociedade, principalmente generalizações que tem como base a realidade alheia - ainda que a lógica da mais valia seja a mesma a construção social que a justifica e a possibilita não o é.

Em nosso entendimento, torna-se revelador de um pensamento com pouca autonomia de análise sobre o objeto de estudo aquele que trata as realidades históricas em comparação com outras realidades históricas. Este fato leva a embaraços por não poder transportar alguns acontecimentos para esta ótica comparativa, como por exemplo, a experiência societária na conformação da República e da parcela chamada povo. Por mais que não possamos fugir de nos referenciarmos no pensamento e na experiência societária dos países centrais da Europa - onde devemos incluir Portugal, não por ser um país central para a formação do capitalismo europeu no século XIX, mas por sua implicação na formação do Brasil, principalmente na cidade do Rio de Janeiro -, visto a nossa 
própria formação histórica, não devemos usar esta realidade para propor inferências comparativas, ou seja, criar conceitos por contraste. Em nosso ponto de vista, a ideia de atraso ou de tardio como referência para nosso capitalismo está claramente associada a concepção histórica criticada por Thompson (1981, p. 29) para o qual um tipo de "historicismo impregnou certa parte da tradição marxista, com a noção de uma sucessão programada de "fases" históricas impulsionadas rumo a um fim predeterminado pela luta de classes".

Em nosso ponto de vista, as experiências societárias na formação dos Estados europeus devem ser vistas com um processo de continuidade entre "velho" e "novo" mundo, que, a partir principalmente da segunda metade do século XVIII se constituem em mercado global de circulação de mercadoria, força de trabalho, ideias, modelos de negócios e gestão das cidades. Neste sentido, a urbanização torna-se a principal noção de modernidade e a meta a ser atingida tanto pela Europa quanto pelos países periféricos. De modo que os aspectos ligados a urbanidade se constituem também em importantes analisadores na formulação de nossas ideias. Cabe ressaltar, como veremos no Capitulo III, o processo de consolidação das polícias como instrumento administrativo das cidades e sua posterior especialização no aspecto jurídico criminal deu-se quase que concomitante em todo o mundo ocidental cristão durante todo o século XIX e início do XX. Não é de se estranhar que a unificação da Alemanha foi na segunda metade do século XIX, que a unificação italiana só se resolve por completo no século XX e que a República primeiro é instaurada no Brasil e depois em Portugal.

\subsubsection{A pesquisa empírica}

Nunca há um documento da cultura que não seja, ao mesmo tempo, um documento da barbárie. E, assim como ele não está livre da barbárie, também não o estão processo de sua transmissão, transmissão na qual ele passou de um vencedor a outro. (Tese VII - Walter Benjamin apud Löwy, 2005, p. 70)

Nossa empeira se deu em dois campos destinos, o de base documental e campo alicerçado por nossa experiência profissional atuando junto às políticas de assistência social. O primeiro campo empírico, o da pesquisa documental ${ }^{41}$, é a base

\footnotetext{
${ }^{41}$ Todos as fontes de pesquisa documentais citadas neste tópico encontram-se com suas devidas referências junto a bibliografia.
} 
central de nossa narrativa, cabendo à empiria da experiência profissional as correlações e análises finais. Esta empiria profissional baseia-se em mais de 20 anos de atuação junto as políticas sociais voltadas para a população pobre, que vive das ruas e sua correlata ação política em fóruns e conselhos de direito. A empiria que se baseou na pesquisa documental analisou as seguintes fontes, presentes, sobretudo no Arquivo Nacional ${ }^{42}$ : os relatórios do ministério da justiça, dos quais faziam parte os relatórios dos chefes de polícia, os livros de entrada de presos na Casa de Detenção da cidade do Rio de Janeiro, alguns jornais publicados no período de nossa pesquisa, leis, decretos e regulamentos. Ainda pesquisamos, na qualidade de documento histórico, o livro "Portugal e Brazil: emigração e colonização", publicado em Lisboa em 1878 e fizemos usos de informações contidas em Anuários Estatísticos da cidade do Rio de Janeiro.

O percurso metodológico concebido partiu incialmente das análises dos relatórios do Ministério da Justiça para o restante da documentação analisada. Neste caminho chegamos aos registros de entrada presos na Casa de Detenção na cidade do Rio de Janeiro ${ }^{43}$. Nestes documentos, que se encontram no Arquivo Geral da Cidade do Rio de Janeiro - AGCRJ, analisamos as informações de todos os presos por vadios, vagabundo e ratoneiro, que deram entrada nesta instituição entre os anos de 1878 a 1881. Esta amostra nos permitiu tecer comparações entre as informações contidas no livro "Portugal e Brazil: emigração e colonização" (1878), de modo a poder analisar sob a luz de documentos históricos o cosmopolitismo da questão social e a criação de seu correlato, a assistência.

Os jornais publicados na época foram usados como recurso documental para exemplificar a história do Asylo de Mendicidade, abordada no Capítulo IV. A história desta instituição policial de assistência foi recontada a partir das informações colhidas nos relatórios pesquisados e também com ajuda de autores atuais. Ainda nos remetemos aos Annuarios de Estatística da Cidade do Rio de Janeiro, de onde baseamos nossas informações sobre a municipalidade. Por fim, os

\footnotetext{
${ }^{42}$ Apesar dos relatórios estarem depositados no Arquivo Nacional é possível acessá-los remotamente através do Center for Research Libraries. Global Resources Network. Disponível em: <http://www.crl.edu/>. Acesso em: 09 jan. 2015.

${ }^{43}$ Arquivo Público do Estado do Rio de Janeiro, Fundo/Coleção Casa de Detenção do Rio de Janeiro, composta por livros de matrículas de presos. "A Casa de Detenção criada em 1856 funcionava nas dependências da Casa de Correção, com um único diretor subordinado ao chefe de Polícia da Corte e era destinada a prisão dos indiciados pelas autoridades policiais e judiciárias". Disponível em: <http://www.aperj.rj.gov.br>. Acesso em: 05, fev. 2012.
} 
relatórios pesquisados nos levaram a diversas leis, decretos, regulamentos e avisos os quais foram consultados a partir de base de dados digitais dos governos brasileiro e português. Foi ainda realizada pesquisa documental em outras bases de dados, como a biblioteca da Torre do Tombo, em Lisboa, outras fontes europeias sobre crimes, bem como coleções de leis e decretos do governo.

Todo este percurso teve com gênese a leitura dos relatórios dos chefes de polícia e ministros da justiça elaborados entre os anos de 1870 a 1930. Diante da importância destes relatórios, peças centrais para a construção de nosso objeto, cabe tecer algumas considerações iniciais para facilitar o entendimento de sua estrutura e de sua importância como peças da administração pública, quanto demonstrar o modo que farão parte da construção de nossa narrativa, enquanto elemento histórico-político da materialização do discurso oficial do Estado.

A pesquisa destes relatórios se baseou nas bases documentais do Arquivo Nacional - AN e do Center for Research Libraries. Nestas bases foram analisados 64 relatórios do Ministério da Justiça, mais de 20.000 páginas dissecadas e outras caixas de documentos que demonstram o período de 60 anos da gestão administrativa do Estado sobre a pobreza urbana. Ao analisar os relatórios dos ministros da justiça e chefes de polícia estamos de posse do discurso oficial. No entanto, ao chegar mais perto dos relatórios dos chefes de polícia, somos capazes de escutar as inaudíveis vozes dos debaixo. Em pouco ou nada, quando se trata de documentação histórica, vislumbramos as vozes dos “debaixo, a fonte mais propícia de encontrá-las, ainda que também silenciadas, mas presentes, é através da polícia (Thompson, 1981). Neste sentido, entender a instituição policial é uma das poucas oportunidades que temos, via documentos produzidos pelo Estado, de estabelecermos um diálogo mais direto que nos permite, de alguma maneira, ouvir a voz da parcela chamada "povo" ou a relação do Estado com esta parcela.

Os relatórios nos permitem vislumbrar, ainda que pela visão da classe dominante, a dinâmica social na qual estava inserida a pobreza urbana na sua relação com o Estado. Esta possibilidade, imbricada no estudo das instituições policias, nos permite enxergar o movimento da sociedade. Através das análises dos relatórios podemos vislumbrar as ações e o conhecimento produzido, bem como perceber o próprio curso da criação das instituições relativas a assistência, sejam aquelas que se especializaram na medicalização ou no hospício, sejam aquelas que futuramente vieram a ser nominadas de assistência social. Neste sentido, como 
afirma Brandão (et al, 1981, p. 6), "as instituições policiais constituem um dos setores privilegiados que permitam perceber o ritmo e a direção do processo em curso" da formação do Estado-nação.

Os relatórios do Ministério da Justiça e dos chefes de polícia eram peças administrativas e políticas. Estes aspectos podem ser demonstrados, por exemplo, quando Evaristo de Morais cita o relatório do chefe de polícia de 1926 para fundamentar suas críticas à forma como este cargo vinha sendo ocupado. Segundo argumenta Evaristo de Morais, este cargo era usado de maneira política sem se observar, nos últimos tempos, a capacidade técnica de seu ocupante. Para Neder (1997, p. 106-134), os relatórios dos chefes de Polícia veem propiciando "há mais de uma década para a historiografia possibilidades de análise e interpretações de dados sobre a capoeiragem, a vadiagem, a ação policial propriamente dita, a construção do mercado de trabalho. De acordo com a referida autora é "importante frisar que os estudos até aqui realizados sobre a instituição policial na capital federal têm-se baseado nos relatórios dos chefes de Polícia e dos ministros da Justiça e nos processos criminais" (Neder, 1997, p. 106).

Os relatórios dos chefes de polícia faziam parte do relatório mais amplo do Ministério da Justiça, que no período de nossos estudos tinha sob sua responsabilidade a assistência pública, a instrução pública, a justiça e a polícia. $\mathrm{O}$ Ministério da Justiça foi criado com a denominação de Secretaria de Estado dos Negócios da Justiça pelo ato de 23 de agosto de 1821. Também era denominado nos relatórios de Ministério da Justiça. Ficou assim referido até 1891 quanto pela lei n. 23, de 30 de outubro passa a se chamar Ministério da Justiça e Negócios Interiores. Incorporava desta forma o Ministério dos Negócios do Interiores, que foi criado em 1889 e extinto em 1890. Para efeito de nossa narrativa, estaremos nos referindo nos dois períodos, ao ocupante do principal cargo do referido ministério somente de ministro de justiça, mesmo quando se tratar do período que este era ministro da justiça e negócios interiores.

Apesar dos relatórios apresentarem uma estrutura, em certa medida, padrão, que conservou seu modelo de organização do Império à República. Cada ministro ou chefe de polícia imprima estilo próprio, dando mais ênfase a um tema ou outro, de acordo com seu campo particular de interesse, pressões dos acontecimentos políticos e sociais ou ambições pessoais. Neste sentido que é possível analisar a estrutura dos relatórios levando em conta como estes se organizam os índices, de 
modo a identificar no escopo geral do ministério da justiça o lugar que polícia e a assistência pública ocupavam.

O relatório referente ao ano de 1872, por exemplo, estavam mais espelhados com os relatórios das décadas anteriores. Havia uma longa seção transcrevendo decisões, consultas e decretos, questões que vão desaparecer dos relatórios subsequentes, conforme se vai chegando próximo ao final da década de 1870 . No entanto, neste relatório identificamos um aspecto de sua estrutura que irá permanecer ao longo dos 60 anos pesquisados. Uma longa parte introdutória, onde o ministro expunha suas ideias, fazia um balanço do ano findo e propunha ações e leis. Esta parte introdutória, em poucos relatórios não foi utilizada com este fim e, dependendo da formação intelectual do ministro, suas intenções políticas ou conjuntura esta introdução era mais densa ou mais sucinta.

Apesar da regularidade dos relatórios do Ministério da Justiça, o mesmo não se verificava em relação aos dos chefes de polícia. Estes nem sempre apareciam como anexos nos relatórios ministeriais. É interessante observar que a partir da estrutura dos relatórios podemos inferir que os chefes de polícia vão gradativamente perdendo a importância na estrutura de poder do Estado. No Império havia mais páginas e importância nos dados introdutórios dos ministros creditados aos chefes de polícia. Enquanto que, na República, era mais comum encontrar as informações referente a polícia diluídas no todo dos relatórios ministeriais, alguns nem mesmo citando o nome do chefe de polícia, o que era raro.

Podemos identificar pequenas mudanças de estrutura nos relatórios, que nos propicia fazer inferência sobre mudanças administrativas. Interessante observar que no relatório referente ao ano de 1879 inaugura-se uma nova organização no índice, que permanece até o fim do Império e durante os primeiros anos da República. Estas modificações na estrutura dos relatórios demonstram, em certa medida, o modo como o ministério da justiça pensava a gestão e em qual lugar desta estrutura aparece as ações de assistência pública. Dentro desta organização da estrutura do índice, percebemos que, em alguns momentos, as instituições policiais de assistência - como denominamos o Asylo de Mendicidade, o Abrigo dos Menores Abandonados e a Escola XV de Novembro - eram alocadas nos relatórios como subitens do item "Systema Penitenciário", em conjunto com a Casa de Detenção, a Colônia Correcional de Dois Rios. Já em outros momentos, estas instituições policiais de assistência apareciam alocadas em outra parte dos relatórios, 
denominada "Serviços Policiaes". Enquanto que a Casa de Detenção e outras colônias correcionais, continuavam sob o item "Systema Penitenciário". Estes aspectos demonstram o perigo de buscar enquadrarmos em definições rígidas as interpretações dos fatos.

Podemos destacar ainda o item "Tranquilidade Pública" que era ponto presente em todos os relatórios pesquisados do Império à República. Este item ocupava um lugar de destaque nos relatórios, nele que encontramos as interpretações e ações sobre a pobreza válida, vagabundos, anarquistas e os pobres bons sem trabalho. Analisando os relatórios da polícia em perspectiva longitudinal, com foco específico no modo como se estruturava a organização lógica dos índices, poderíamos de alguma forma aceitar ou sugerir a intepretação de que as ações de assistência pública completavam o quadro geral do sistema administrativo gerido pela instituição policial sob as ordens do Ministério da Justiça.

A partir dos pressupostos aqui apresentados e partindo do princípio que toda resposta é provisória, apoiado em novas pesquisas históricas e em perspectivas epistemológicas que enxerga a priori a realidade, pretendemos demonstrar que as instituições policiais fazem parte, tal qual a caridade e a filantropia do universo de discursos e práticas sociais fundantes da assistência social na cidade do Rio de Janeiro. Após tercemos as considerações inicias que situam o local do qual estaremos falamos e, sobre quais circunstâncias nos posicionamos, passaremos a constituir nossa narrativa organizada em mais quatro capítulos, além deste introdutório.

Trataremos, no segundo Capítulo, da contextualização do período de nossos estudos discutindo as implicações da questão social relacionada a construção da urbanidade da cidade do Rio de Janeiro; da escravidão e seu correlato a imigração, no modo como seu deu na formação do trabalho livre; ainda abordaremos alguns aspectos sobre a "previdência" social no século XIX. No terceiro Capítulo, base central de nossa tese, demonstraremos a história da polícia na cidade do Rio de Janeiro e as correlações com a história da polícia na Europa, com especial atenção a Portugal. Evidenciaremos as ações e os discursos de assistência ligados a polícia, comprovando as diferenças de trato entre a pobreza válida e a pobreza inválida. Explicaremos ainda, neste capítulo, a importância dos chefes de polícia no interior da classe dominante e na administração estatal, bem como as correlações entre a polícia e a municipalidade na construção da assistência. No capítulo IV, 
recontaremos as histórias, baseado nos relatórios pesquisados, das instituições policiais de assistência citadas acima. Por fim, em nossas considerações finais discutiremos as permanências e atualizações das práticas de polícia nas políticas contemporâneas de assistência social. 


\section{Amálgamas: questão social e assistência na formação do Estado-nação}

Paiz novo, cidade em phase de pleno progresso e de actividade, o Brazil, e mais particularmente a sua capital, não devem ter, ao menos por emquanto, as prcoccupações que a miséria suggere nas sociedades envelhecidas e onde as condições de trabalho se tornam difliceis pelo excesso da população. Comvém, entretanto, distinguir a miséria occasional resultante de fautores economicos, da miséria permanente inseparável de todas as grandes cidades e constituída pelo avultado numero dos infelizes a quem a vida não sorriu ${ }^{44}$.

Dr. Antonio Algusto Cardoso de Castro ${ }^{45}$

A nova produção da historiografia não permite mais "falar da sociedade brasileira do século XIX como se falava a trinta ou vinte anos atrás" (Chalhoub, 2009, p. 196), neste sentido que pretendemos rediscutir o Rio de Janeiro e o conceito de questão social a partir da formação da classe de trabalhadores livres e da conformação do Estado-nação brasileiro "em função de outro jeito de conhecer aquela sociedade" (Chalhoub, 2009, p. 196). A relevância do passado para o entendimento do presente, principalmente no que concerne às escolhas de que fatos do passado continuam a pertencer ao presente, torna-se central para nosso trabalho. O que somos hoje não é resultado de todo o passado que vivemos, somos resultados dos fatos que marcaram nosso passado, seja por serem trágicos ou triunfos pessoais e/ou coletivos. De maneira que, cabe a nós pesquisadores definir quais acontecimentos do passado são relevantes para nossa experiência societária do presente. Quais eventos ainda podem ser vislumbrados no presente, não como meras lembranças, mas como fatos presentes na maneira de agirmos e pensarmos. Nesta definição de quais fatos são, realmente, relevantes para nossa história social, capazes de explicar o presente, é que reside o maior grau de subjetividade e de impossibilidade de objetividade epistemológica, como presume e impõe os métodos das ciências sociais. É neste sentido que estudar o século XIX, principalmente no que diz respeito a sua segunda metade, bem como, o início do século XX nos

\footnotetext{
${ }^{44}$ BRASIL. Ministério da Justiça e Negócio Interiores. Relatório dos anos de 1904 e 1905 - Volume I. Rio de Janeiro. Imprensa Nacional, 1905a, p. A-G-189.

${ }^{45}$ Chefe de Polícia do Distrito Federal (1904-1905).
} 
permite vislumbrar a formação da identidade nacional e da parcela chamada "povo". Da mesma forma, estudar este período nos possibilita entender a formação das instituições que estarão consolidadas na primeira metade do século $\mathrm{XX}$ e a maneira como se constituiu aqui a questão social.

Talvez precisemos tomar emprestada a questão que Graça Aranha formulou para entender a metafisica do ser $^{46}$ e reformulá-la na perspectiva de entendermos o Brasil, desta maneira perguntamos: "Como definir o Brasil? Restrinjamos a nossa impossibilidade a este axioma: o Brasil é o Brasil”. É fato que desde a geração de 1870, na qual podemos destacar Silvio Romero, o Brasil é submetido, voluntária ou involuntariamente, as mais modernas técnicas de dissecação da realidade histórica e social que permaneceram se reinventando até nossos dias. É também a partir desta década que se iniciam as transformações urbanísticas e arquitetônicas (Rodrigues, 2009), que almejavam civilizar e regenerar a cidade do Rio, como meio de se fundar uma nação e forjar a criação de um "povo" pela mão benevolente e ordenadora do Estado.

Entender o Brasil pelo viés urbano ou de qualquer estado da arte que tenha o Rio de Janeiro como ponto central significa dimensionar a urbanidade como a moeda forte da entrada no mundo civilizado e europeu. Esta era a dinâmica a qual buscava aludir outra poética como meio de entendimento do que viria ser a nação, afinal poderia Macunaíma ter nascido na Gamboa? É nessa dinâmica de pensar o que é o Brasil e o brasileiro que a polícia assume importante contribuição, incluindo no debate, de maneira definitiva, o pobre urbano. Neste sentido que "é impossível estabelecer o quadro urbano carioca se não se estiver atento à ação da polícia na cidade" (Rodrigues, 2009, p. 88). Da mesma maneira, não podemos falar na formação da assistência na cidade do Rio de Janeiro sem dar a devida importância ao papel que a polícia exerceu neste campo.

Para nosso ponto de vista o marco da formação do capitalismo no Brasil e as características e os contornos que a questão social assumiu aqui se relacionam diretamente com o desenvolvimento das grandes cidades do litoral no século XIX. As principais cidades do século XIX no Brasil eram a expressão direta da internacionalização da questão social e do cosmopolitismo (Gramsci, 2006 e 2004). As críticas que imputam falta de autenticidade e atraso ao pensamento brasileiro

\footnotetext{
${ }^{46}$ Como definir o Ser? Restrinjamos a nossa impossibilidade a este axioma: o Ser é o Ser (Aranha, s/d, p.3).
} 
seja social, filosófico ou estético, pelos diversos autores que buscavam verdadeiro sentido novo na superação e libertação do processo de dependência cultural (NETO, 1973) não vislumbraram, em certa medida, o mundanismo da cidade do Rio de Janeiro. Cidade que naquele momento - final do século XIX e início do XX - era o "centro de todas as questões que dizem respeito ao Brasil" (Rodrigues, 2009, p. $103)$.

Nas esquinas do centro, a cidade burguesa se acotovelava com a cidade barroca (Rodrigues, 2009) e nestes caminhos de tensões, as querelas tanto existenciais, quanto culturais e econômica matizavam o vasto horizonte da explicação ou do entendimento de quem somos. É neste horizonte que as contradições da cidade emergem como empecilhos a fundação da nação pela via da regeneração das mentalidades e da tradição e o Rio torna-se o local, o ponto onde estas transformações se transfiguram em poder político e afazia barroca de ruas tortuosas e de gente caótica - para o olhar burguesamente treinado. A formação do Estado-nação no Brasil não diz respeito apenas às transformações políticas e sociais, neste processo também é possível observar um rearranjo e a organização de um conjunto de intuições e práticas sociais. A passagem do século XIX para o XX é para a "cidade-capital o momento de sua definição institucional e cultural" (Rodrigues, 2009, p. 103). Neste sentido, é demandada a formulação de um saber absolutamente novo, capaz de responder às necessidades de modernização e civilização da sociedade da capital.

Fundar a nação pela via do Estado significava, entre outras coisas, civilizar o Rio de Janeiro pela via da urbanidade burguesa, a qual deveria controlar o mundanismo entranhado na cidade barroca de contornos árabes, que também era o Rio. A população da cidade tornava-se cada vez mais complexa e multifacetada a partir da década de 1870, os movimentos de imigração, principalmente de colonos portugueses pobres, a migração gerada pela seca e a abolição antecipada no Ceará, completavam o enredo dos de baixo na formação da multirracial e multicultural cidade do Rio de Janeiro. A importância do Rio de Janeiro para o Brasil pode ser vislumbrada no fato de que esta é a maior cidade do país desde "o final do século XVIII até meados do século XX" - "o centro da vida cultural, econômica e intelectual - arena política, matriz para experiências na mudança social e política" (Hahner, 1993, p. 10). 
Embora o poder do grande capital estivesse na roça, nas últimas décadas do século XIX não mais se fazia distinção entre o grande proprietário de terra exportador e o comerciante, além de ser nas grandes cidades que se conquistava prestígio. E no caso do Rio de Janeiro, capital durante todo o período de nossos estudos, conquistar prestigio significava agregar o poder político de grande influência conquistado na cidade ao capital gestado a partir da roça. As grandes cidades do Império causavam espanto e admiração aos viajantes (Hahner, 1993). Dentre elas, no Rio de Janeiro, estes viajantes ficavam impressionados tanto pela paisagem, quanto pela arquitetura dos edifícios públicos e religiosos. É possível demostrar através dos diversos relatos dos estrangeiros que viajavam pelo Brasil que o movimento das ruas das grandes cidades impressionava. Em especial o Rio de Janeiro ${ }^{47}$ que intensifica este movimento ao torna-se capital, em 1763, da colônia e, principalmente, depois da chegada da família real em 1808. De 1808 até 1822 o Rio tornou-se a capital do Império Português, que se estendia da Europa a Ásia. A cidade, posteriormente, viu sua população crescer de maneira exponencial na virada do século XIX para o XX. No período de nosso estudo, entre 1870 a 1930, o Rio de Janeiro teve um aumento de mais de 300\% em sua população. Em 1870 tinha $274.972(100 \%)$ habitantes, enquanto que em 1890 contava com 522.651. Já em 1906 eram 811.443 habitantes e, em 1930, a sua população já chegava aos 1.157.873, aferindo um crescimento de 419\% (Hahner, 1993, p. 21). Somente para ilustrar este crescimento, segundo Hahner (1993, p. 24), “em 1808 o Rio de Janeiro contava com 75 ruas, beco e praças; em 1870, já totalizavam 563". As inovações tecnológicas também impulsionavam este desenvolvimento, por exemplo, o telégrafo no Rio de Janeiro data de 1854. Em 1873, foram colocados os cabos submarinos, que ligava o Rio ao sul e ao norte do país e, em 1874, cabos que ligavam o Brasil à Europa. (Hahner, 1993, p. 26). Em 1858, a conclusão do primeiro trecho da estrada de ferro D. Pedro II a atual Central do Brasil e 1868 começaram a circular regularmente o serviço de bondes sobre trilhos com tração animal.

Com a expansão da cidade através dos transportes começa a haver, já na segunda metade do século XIX, no Rio de Janeiro, uma maior estratificação de

\footnotetext{
${ }^{47}$ Segundo Hahner (1993, p. 10), "na década de 1870, as principais cidades brasileiras haviam perdido muito do seu aspecto colonial e podiam orgulhar-se das melhorias nos transportes públicos, iluminação e fornecimento de agua, assim como várias ruas pavimentadas, mais prédios públicos elegantes e populações cada vez maiores".
} 
renda de nível muito mais evidente. No período abordado por nossos estudos, a cidade apresenta uma expansão em direção à zona sul pela elite, que deixava de morar na zona central tomada por cortiços e obras de intervenção urbanística. O principal local escolhido pela elite de comerciantes e funcionários públicos foi o bairro de Botafogo o qual tinha um serviço regular de bonde que circulava com pontualidade e causavam boa impressão a qualquer europeu e tinha carros de segunda classe "para os negros e pessoas de descalças" (Hahner, 1993, p. 28).

É fato que a cidade do Rio de Janeiro passava por transformações agudas a partir da segunda metade do século XIX. Segundo Silvia (1990, p. 15), em 1852 o bairro de "botafogo se desenvolveu a tal ponto [que a] companhia Niteróiinhomirim estabeleceu uma linha de barca a vapor para aquele bairro". O Rio era uma cidade cosmopolita fruto da experiência liberal na gestão das cidades, tinha iluminação a gás em quase todo o centro desde a década de 1850. Em 1862 o serviço de esgotos sanitários foi entregue à empresa inglesa Rio de Janeiro City Improvements Company Limited (Silvia, 1990, p. 17), e em 1865 o gás passou a ser gerido pela também inglesa, Rio de Janeiro Gás Company Limited. Vale ressaltar que o Rio na virada do século XIX era o ponto onde se indicava o que é e o que poderá ser o Brasil, o local privilegiado onde "irrompem, com todas as fanfarras as voltas do escândalo e do terror, as novas teorias científicas, filosóficas e literárias, as tentativas de deposição, de mudança de regime, etc.” (Neto, 1973, p. 63). Do mesmo modo Rodrigues (2009, p. 85) aponta que "a cidade do Rio de Janeiro exercia, assim as funções de centro aglutinador dos mecanismos de superação das crises e de depositário da confiança no progresso da "civilização brasileira"”. Era o local das tensões e conflitos sociais de onde se questionava e enfrentava o poder do Estado, ao mesmo tempo que é local onde este Estado equaciona seu poder e o das elites. A cidade é local onde a população pode tornarse ameaça, por isto a necessidade de conhecer para controlar. Do modo como expressava o chefe de polícia, Dr. Tito Algusto Pereira de Matos, que a “agglomeração de habitantes nas grandes cidades, centralisando a multidão, centralisa também as necessidades, ao passo que difficulta os meios de satisfazel$a s^{48}$

\footnotetext{
${ }^{48}$ BRASIL. Ministério da Justiça. Relatório do ano de 1883. Rio de Janeiro. Typographia Nacional, 1884, p. A-G-7.
} 
No período de nossas pesquisas, a cidade do Rio de Janeiro tinha significativo crescimento industrial e um cosmopolitismo que propiciava expressiva diversificação sociocultural, na qual a urbanidade conferia sentido ao significado de progresso e as marcas "da transição da formação social brasileira" (Neder \& Naro, 1981, p. 231). Neste contexto, os debates no campo da assistência se colocavam na interseção direta entre a prática cotidiana de ordenamento da cidade pela via do controle da pobreza urbana e a temática nacional que significava "enfrentar o problema da escravidão e seu correlato, a imigração estrangeira" (Carvalho, 2006, p. 23). A institucionalização das práticas público/privadas de assistência, seja pela polícia, seja pela filantropia, seja pela caridade, estão inscritas nas primeiras tentativas do Estado e da sociedade no enfrentamento do "problema social da escravidão, (...) da incorporação dos ex-escravos à vida nacional e, mais ainda, à própria identidade da nação" (Carvalho, 2006, p. 23-4), pois a maneira como saímos da escravidão comprometeu inteiramente a República. Sob este ponto de vista que a discussão acerca dos modelos e instituições de assistência, seja pela via das "práticas de ajuda ou apoio", seja pela via dos direitos sociais, convinham ao "liberalismo que adquiria um caráter de consagração da desigualdade" (Carvalho, 2006, p. 25).

O Estado como o grande organizador da sociedade necessitava de mecanismos que o legitima-se tanto aos olhos de elite, quanto nos sentimentos das classes populares, visto que, o liberalismo não veio de baixo e tampouco animou a democracia. É neste intento que a assistência se inscreve pela via da legitimação no projeto de nação. O projeto de nação passava pela instauração de sistemas de proteção social contributivos, direcionados ao apoio da industrialização e ao trabalho formal no meio urbano, voltado claramente para o imigrante branco. Neste projeto não estava incluído o ex-escravo, no entanto, afirmar que para ele restava à polícia, a repressão e o controle, é um reducionismo que não leva em conta o amplo papel administrativo do qual se ocupava a polícia na gestão das cidades.

A concessão foi usada indiscriminadamente como meio de contenção - de maneira que os laços verticais de solidariedade eram usados estrategicamente como meio de enfraquecer as solidariedades horizontais - estratégia política da qual fazia parte a polícia. A patronagem, o clientelismo e o paternalismo tinham sua força na formação de laços de solidariedades de dominação vertical ao terem sob seus auspícios o controle dos meios de mobilidade social ascendente. O que era visado 
por certo tipo de pobre urbano, que viviam como proletário, pelo emprego de segunda classe no comércio, na indústria e nas empresas de serviço público. $\mathrm{O}$ paternalismo e clientelismo como meio de controle social, incluía a assistência, tanto em seus aspectos de filantropia quanto de caridade. As sociedades beneficentes ou de ajuda mútua uniam diferentes classes sociais por uma característica cultural comum. O sentido de pertencimento a uma cultura foi a base das primeiras experiências "universais" de assistência social no Rio de Janeiro, ainda que o universal significasse todos que pertencesse a um grupo determinado, independe se contribuíam ou não para a caixa ou fundo que propiciava a ajuda. No cenário político tínhamos, de modo geral nos últimos anos do Império o declino da monarquia, o declino do café, o sucesso da campanha abolicionista e republicana, o incremento da imigração europeia e a formação de uma elite paulistana que buscava se auto afirmar no cenário nacional, pela defesa de seus interesses particulares.

Pensar nos resultados da "influência do capital e da propriedade" por meio do papel exercido pela assistência na "ocidentalização" das cidades imposta por “elites militarizadas" (Werneck Vianna, 1991, p. 149) e refletir sobre as práticas e políticas de assistência no enfrentamento da problemática social gerada pelo estatuto da escravidão e pela imigração em massa é nosso intento maior. Esta articulação se conecta a nossa necessidade de elaborar questões e fundamentar argumentos que demonstre a pertinência de pensar a assistência pela chave da formação do Estado-nação, com ênfase na lógica da legitimação dos métodos de ordenamento da pobreza urbana pelas "práticas de ajuda e apoio" implantadas e gerenciadas pela polícia.

Pela via dos pressupostos descritos acima indagamos se é possível pensar em algum tipo de continuidade sobre o lugar que o papel da problemática da pobreza e do pobre se inscreveu e ainda se inscreve no Estado-nação. Não seria pretensão demasiada e nem mesmo irresponsabilidade metodológica fazer induções da continuidade de determinadas práticas de assistência no campo histórico, no entanto, o que pretendemos identificar é a maneira como as "práticas de ajuda e apoio" se constituíram num acionador para a legitimação da desigualdade e da naturalização do processo histórico de produção da pobreza no Brasil. Entendendo que a nação brasileira é uma "criação demiúrgica" do Estado "numa espécie de ideologia natural nascida das próprias condições singulares em que se teria forjado 
o nosso Estado-nação" (Werneck Vianna, 2012a) é que propomos pensar a assistência como parte fundamental do "jogo de manter os contrários em permanente equilíbrio" (Werneck Vianna, 2012a). Por este ponto de vista que indagamos se é possível vislumbrar na conformação da assistência a empiria do clientelismo e do patrimonialismo pela via da legitimação. Com este escopo que pretendemos "refazer a memória num sentido contrário a da classe dominante, de modo que o corte histórico-cultural seja um corte de classe" (Chauí, 2006, p. 26) ${ }^{49}$, na medida em que pensar a assistência como parte fundamental do jogo de harmonizar as tensões entre os contrários, requer definir quem são os contrários que estamos falando.

Destacamos como ponto fundamental para nossa análise que no Brasil o moderno e o atraso sempre conviveram em tensa harmonia, surpreendente para um teórico que busca enquadrar nossa realidade em formulações importadas, as quais não contemplem os problemas reais que enfrentamos em nossa sociedade. Este fato demonstra a dificuldade de articular a realidade local a princípios epistêmicos construídos em outra paisagem, pois é certo que a formação do capitalismo no Brasil se apresenta "dentro das inúmeras situações particulares que não se enquadram em tipologias demasiado genéricas" (Abreu, 1999, p. 713). Aqui conviveram o latifúndio escravista e as modernas concepções de filosofia política surgidas na Europa no século XIX. "Elites agrárias e tradicionais, camuflado por uma vistosa arquitetura institucional de inspiração liberal (Werneck Vianna, 2012b)", funda um "liberalismo de ranço darwinista (Werneck Vianna, 2012b)", cuja relação entre público e privado, herdado da tradição ibérica deságua numa espécie de "liberalismo de Estado".

É clara a influência do iberismo na formação da assistência, não sendo plausível falar num campo de disputa em relação aos americanistas, como na política. Em matéria de instituições de assistência a lusofonia sempre foi à linguagem predominante, ainda que, quase sempre possamos ouvir os ecos francófonos nas bases desta elocução, visto que, via Portugal, somos inevitavelmente levados à França. É fato que “em matéria administrativa, a inspiração veio de Portugal e da França, pois eram esses os países que mais se aproximavam da política centralizante do Império" (Carvalho, 2006, p. 23). Esta

\footnotetext{
${ }^{49}$ Da maneira como aponta Chauí (2006, p. 26) na perspectiva gramsciana.
} 
influência continuará sendo a marca na República. Podemos vislumbrar desta forma as instituições e práticas de assistência como expressão de um iberismo e afirmação de uma ordem patrimonialista, centrada numa cidadania cartorial.

Por este ponto de vista que credenciamos a assistência como um mecanismo legitimador de um tipo de liberalismo de Estado que despudoradamente me atrevo a chamar de "liberalismo tropicália". Um liberalismo que da mesma forma que a tropicália de Mautner, Gil e Caetano, entre outros, ou a antropofagia modernista de Oswald, é um movimento dos de cima - seja pela via da economia ou da intelligentsia - que se faz parecer de massa e que introduz singularidades a partir dos modelos de fora. Esta interação surpreendente e inédita entre moderno e atraso não provocou rupturas ou dissonâncias inaudíveis, ao contrário, construiu uma "tensão harmônica", inventando um novo repertório de "acordes musicais" jamais escutados, capazes de construir belas e trágicas sinfonias, resultando em vibração sonora ímpar e "elaborando formas próprias de cultura e tipos sociais inéditos" (Werneck Vianna, 1991, p. 146), ainda que sem se "desprender dos ideais de progresso e de civilização que herdou." (Werneck Vianna, 1991, p. 149).

O liberalismo imposto por meios autoritários propiciou a convivência, ainda que tensa, entre o "moderno" e o "atraso". Esta convivência não gerou rupturas capazes de superar as desigualdades historicamente constituídas, ao contrário, harmonizou a dissonância e naturalizou as diferenças. O processo de modernização do Estado passou inevitavelmente pela construção de uma civilidade urbana, no qual o ordenamento das cidades tornou-se caro ao projeto de formação do Estadonação no Brasil. É nesta perspectiva, e também sob a égide da singularidade, que pretendemos entender o papel da assistência na harmonização tensa entre os contrários, diante do projeto de civilizar as cidades para construir a nação. Vislumbramos também o papel exercido pela assistência na convergência entre o moderno e o atraso, refletida na face regulatória e institucional da maneira como se enfrenta a problemática da pobreza urbana.

Nossos estudos apontam que não só é possível pensar na assistência por esta chave analítica, como também é factível afirmar que a assistência se configura como uma das principais chaves para entender o clientelismo e a manutenção da ordem diante do modelo jurídico e econômico liberal instaurado no Brasil. A chave que propomos como central para nossa análise, ou seja, a convivência das tensões entre os opostos, o moderno e o atraso na conformação das políticas sociais, pode 
ser confirmada, entre outras evidências, pelo fato de que os avanços percebidos na legislação relativa aos direitos sociais não atingiram as instituições e os valores, pois continuam avessos à equidade destes direitos.

É também sob a ótica da tensão harmônica entre o moderno e o atraso que podemos identificar a assistência como uma importante arena onde aconteceram batalhas entre Igreja e Estado. "O simbolismo da figura paternal do rei” (Carvalho, 2006, p. 24) e a caridade cristã, em certa media, foi substituída pelo simbolismo da benevolência de Estado. Esta mudança em parte deve ser creditada a forma como o positivismo $^{50}$ foi lido e aplicado aqui, o qual percebia o Estado como "um agente do bem comum, um promotor de políticas sociais" (Carvalho, 2006, p. 31). Neste aspecto que perguntamos em que sentido as práticas de assistência, principalmente as desenvolvidas pela polícia, contribuíram para uma gestão sem conflitos capazes de provocar rupturas na formação da República. Por este viés é possível reconhecer que o positivismo foi o fermento que deu a liga entre a assistência e polícia na incorporação do pobre pela via do trabalho. "De preferência esta incorporação deveria ser feita pelo reconhecimento, por parte dos ricos, do dever de proteger os pobres, por meio da mudança de mentalidade, e não pelo conflito de classes" (Carvalho, 2006, p. 31).

A possibilidade de pensar a assistência pela chave da formação do Estadonação, diz respeito à interface da prática cotidiana da polícia no controle da pobreza urbana e "o arsenal teórico positivista [que] trazia armas muito uteis" (Carvalho, 2006, p. 27) na formação de um saber capaz de orientar o Estado na maneira de como lidar com a pobreza urbana. A influência da polícia pode ser percebida pelo que representava "a elite política no império (...) dominada por advogados e juízes" (Carvalho, 2006, p. 138). Todos os chefes e delegados de polícia vinham das faculdades de direito, dos quais, muitos seguiram a carreia política tornando-se, deputados, senadores e ministros de Estado, como veremos no próximo capítulo. Por este viés que discutiremos a seguir se é possível falar na assistência como legitimadora de uma República militarizada.

Nossa pesquisa demonstrou que os saberes e práticas policiais empregados no controle do "corpo social" e no ordenamento urbano eram relativos não só as técnicas de repressão, mas também aos métodos de prevenção, correção,

50 Segundo Carvalho (2006, p. 130), “Comte colocou o sentimento do altruísmo, substituo da caridade cristã". 
reeducação pelo trabalho e assistência. Este saber construído na prática cotidiana da interação com os pobres eram traduzidos pelos chefes e delegados de polícia, a partir das modernas teorias jurídicas da época. É possível vislumbrar no saber construído pela polícia como prática de assistência a continuidade de um processo de militarização que demonstra a maneira como a sociedade lida com a pobreza no processo de "ocidentalização" das cidades, não como mero caso de polícia, mas como um saber sofisticado capaz de influir em legislações, em instituições e na construção de representações sociais sobre a pobreza. A construção de um saber jurídico a partir da prática policial é a constatação de uma "práxis que se transforma em logos" (Faoro, 2007, p. 36) e que "expressa o quantum possível de saber formulado a partir da experiência" (Faoro, 2007, p. 138).

A sofisticação do saber policial acerca das práticas de assistência não se relacionava somente ao altruísmo comtiano ou aos modelos franceses de correção e tratamento, mas também através da experiência cotidiana de gestão da cidade, cuja via da assistência imprimia legitimidade. No momento em que a questão nacional significava também civilizar as cidades, principalmente a capital, a instância pública mais preparada para esta gestão, que cumpria os principais rituais burocráticos, era a polícia. Não podemos vislumbrar a polícia no final do século XIX e início do XX somente pela via da repressão sem olhar atentamente para o aspecto administrativo de sua gestão da cidade. Por esta via que a legitimação pela assistência se inscreve como uma importante estratégia para o Estado formar a nação, visto que, como observa Hanna Arendt, "jamais existiu um governo baseado exclusivamente nos meios da violência" (Arendt apud Faoro, 2007, p. 188). Neste sentido, o poder se qualifica não só por meio das regras jurídicas (Faoro, 2007, p. 189), mas pela assistência, seja a da caridade cristã, seja a do altruísmo positivista. A assistência sob suas diversas nuance se configura como um mecanismo de legitimidade do Estado na formação da nação, não pela imposição da lei, mas como uma espécie de prática que se inscreve no que Faoro (2007, p. 190) chama de legitimidade que se impõe pela "densidade que está atrás e acima da lei”. "A legitimidade vem de baixo, como reconhecimento em torno de valores" (Faoro, 2007, p. 190), é neste sentido que a assistência é tão cara ao projeto de nação, visto que, é um importante instrumento legitimador do Estado perante a parcela chamada "povo". Esta importância se dá pelo fato de que os mecanismos legitimadores da 
ação do Estado devem vir de valores "historicamente realizáveis e socialmente atuantes" (Faoro, 2007, p. 216).

A assistência se constituiu no Brasil, principalmente a partir da segunda metade do século XIX como uma das práticas institucionais na "busca dos ideais civilizatórios do Ocidente (Werneck Vianna, 2012b)". No Rio de Janeiro as modernas instituições laicas de assistência, o Estado - através da polícia e da justiça -, as caixas de ajuda mútua, a filantropia empresarial e a Igreja animavam o debate sobre a assistência, que por sua vez, veio a influenciar diretamente na conformação de práticas e fundamentos jurídicos ligados aos direitos sociais. Compreender o papel da assistência na "longa revolução burguesa no país (Werneck Vianna, 2010)" e discutir seu posicionamento como mecanismo de incorporar de forma subalterna os "rudes compatriotas retardatários (Werneck Vianna, 2012b)" se configura, para nós, como importante aspecto para entender os arranjos de poder no seio da classe dominante e na formação do Estado-nação.

As práticas de assistência existentes desde o século XIX no Brasil mantiveram aspectos presentes até os dias atuais, não como uma armadilha do capital sobre o trabalho, como geralmente se lê, mas como uma conjuração do Estado, representante do capital, sobre o trabalho. Entendemos que compreender e desvendar a historicidade da conformação do campo da assistência e o papel exercido por ela na formação do Estado-nação brasileiro se constitui como meio de dar sentido às lutas do presente em prol do desafio de incorporar nas políticas sociais tradicionais, como saúde e educação, as demandas de direitos humanos e sociais. Consideramos, ainda, a priori, que ao analisarmos a maneira como governos e sociedade civil lidam historicamente com a questão social no Brasil, é possível enxergar algumas características que se constituem mais como uma linha de continuidade, do que propriamente rupturas com o modelo fundacional do papel da assistência na sociedade Brasileira. Esta linha de continuidade é possível de ser demonstrada principalmente através das instituições públicas e privadas de assistência que compõem a armadura material dos direitos sociais.

Entender a formação do Estado-nação a partir da chave da institucionalização da assistência se inscreve na singularidade da formação da sociedade brasileira, cuja expressão, o messianismo e os contrastes nos remetem ao barroco, tanto pelo que acirra, quanto pelo que repreende. Neste viés, aceitamos o ponto de vista que percebe historicamente as políticas sociais como geradoras de desigualdades e, que 
só poderíamos falar em rupturas reais com os modelos de assistência oriundos do século XIX no Brasil se houver um reposicionamento do "lugar das políticas sociais no enfrentamento das desigualdades, sem se transformar em paliativos à pobreza" (Sposati, 2011, p. 110). Por acreditar que não podemos construir nada sobre um diagnóstico equivocado, que arquitetamos os argumentos acima, no sentido de indagar se há pertinência em pensar a formação e legitimação do Estado-nação pela chave da assistência, visto que, esta faz parte dos recursos extra econômicos que o liberalismo usou para se impor no Brasil.

\subsection{Escravidão, vadiagem e anarquismo: o sentido do trabalho.}

Ha factos extraordinarios na vida de todos os povos; mas nenhum haverá de certo que se assemelhe em phenomenos ao povo brasileiro (Pércheiro, 1878, p. 278).

A busca pela modernização na Primeira República e a tentativa de sair do tradicional para o moderno é questão perseguida por intelectuais e pelo Estado na época, onde se buscava substituir o que era afetivo pelo racional e sobrepor o rural (ou o atrasado) em nome de um moderno que fosse urbano e científico. Esta busca pela modernização conduziu a República - ainda assentada sobre os pilares da grande propriedade e dos resquícios da escravidão - na direção da urbanização e da imigração branca, numa tentativa de branqueamento ${ }^{51}$ do brasileiro. Como parte do processo de modernização, começa a surgir uma classe de trabalhadores concomitante a manutenção da escravidão -, que se impunha a partir da criação do mercado de trabalho livre, principalmente nos grandes centros, mas também na lavoura. No mesmo sentido, Gomes (2006, p. 26) argumenta que o "referencial da escravidão se impõe para a construção de qualquer tipo de discurso que envolva uma ética do trabalho". É fato que o término do período monárquico não gerou transformações profundas na sociedade brasileira, aconteceram adaptações e acomodações da elite, mantendo-se as estruturas racistas e discriminatórias que

51 “O brasileiro é uma sub-raça mestiça crioula, nascida da fusão de duas raças inferiores o índio e o negro e uma superior a branca. Para evitar a degeneração da nova raça mestiça, será preciso estimular seu embranquecimento, promovendo a imigração”. (Romero, 1992 [1897], p. 49). Silvio Romero publicou, "O caráter nacional e as origens do povo brasileiro em 1881", e "A história da literatura brasileira” em 1888. 
constituíam o pensamento dominante e as práticas institucionais, sob a égide do liberalismo (Carvalho, 1999, 2006).

Ao entrarmos em contato com este vasto e instigante universo histórico fomos levados, quase que inevitavelmente, a perguntar de que forma as ideias raciais, eurocêntricas e eugênicas, de base evolucionista, surgidas na segunda metade do século XIX - centrais na construção da intelligentsia brasileira na Primeira e Segunda República - e as questões escravocratas incidiram sobre a construção de discursos, práticas e modelo de assistência aos pobres e desvalidos. A necessidade se deve ao entendimento de que o período histórico abordado se caracteriza por profundas transformações nas relações sociais e econômicas, sendo estratégico o seu estudo para o entendimento da formação da classe de trabalhadores livres no Brasil. De maneira que as singularidades das relações sociais sejam percebidas, não só como fruto das relações de produção, mas também como fator de interferência capaz de alterar as próprias relações de produção, numa perspectiva dialética entre estrutura e superestrutura. Tais indagações me impulsionaram a elaborar reflexões teóricas resultantes das próprias evidências e fatos históricos. De modo a questionar, em que medida as teorias produzidas na Europa foram capazes de proferir análises satisfatórias sobre os processos históricos e sociais relativos à experiência da constituição de um Estado-nação, no hemisfério sul, cujo principal triunfo é a capacidade de se amalgamar. A formação da classe de trabalhadores livres assalariados é mais uma das muitas expressões deste amálgama, como afirma Coggiola (2003) "a luta contra a escravidão, portanto, misturou-se com as primeiras manifestações de luta originadas pela introdução das relações capitalistas de produção". É fato que a formação da classe operária no Brasil, é mais um acontecimento dentro da formação do aspecto mais geral da formação da classe de trabalhadores assalariados no país, mas não pode representá-la em sua totalidade.

Entendemos que a acumulação do capital, fundamentada na apropriação da mais valia e na exploração do trabalho como mercadoria já estava presente no Brasil, tomando como parâmetro a cidade do Rio de Janeiro, desde o século XIX. $\mathrm{O}$ fato de termos uma economia exportadora eminentemente rural e escravocrata não deve ser o fiel da balança que justifica a criação de conceitos como capitalismo de desenvolvimento tardio, principalmente se tomarmos como base os grandes centros urbanos da época, Rio de Janeiro, Salvador, Recife, Porto Alegre e mais para o final do século XIX, São Paulo. É certo que o desenvolvimento urbano destes 
centros de concentração populacional, sua industrialização e o crescimento do comércio devem-se ao capital gerado na roça. Fato que, ao invés de desqualificar, amplifica e aprofunda a economia cosmopolita destas cidades, principalmente no Rio de Janeiro, foco de nossos estudos.

Da mesma forma que fomos capazes de conjugar escravidão e liberalismo, também amalgamamos modo de produção baseado na força de trabalho escravo com o desenvolvimento dos meios de produção assalariados e da organização social da força de trabalho. Tratamos do pleno desenvolvimento do capitalismo concomitante com a escravidão na cidade do Rio de Janeiro. Pensar nosso capitalismo como desenvolvimento tardio ${ }^{52}$ é comungar com a linha de pensamento de Roberto Schwarz (1997), de que no Brasil as ideias estão fora de lugar e, de certa maneira, repercutem o modelo "desenvolvimentista" que reproduz em sua gênese ideias positivistas e evolucionistas, tal qual na teoria da "dependência"53". Associamo-nos a interpretação de Werneck da Silva (1981, p. 37), para o qual "as ideias liberais não estavam fora do lugar, estavam no lugar que os segmentos sociais hegemônicos lhes destinavam". Podemos ainda identificar a "ideologia" do atraso como ponto de convergência das análises sobre o Brasil em Graça Aranha (1923, p. 9), entre outros, quando afirma que "o irremediável anachronismo da cultura brasileira dá á nossa poesia e á nossa literatura e á nossa arte a sensação singular de inspirar-se de uma sensibilidade vivida (...) No Brasil quando um escriptor, um artista apparece, em geral a sensibilidade, que o inspira, já passou".

É óbvio que se trata, aqui, da periferia do capitalismo no mundo judaico cristão, mas ao associar a ideia de atraso ao que é periferia, acaba-se por inferir

\footnotetext{
${ }^{52}$ Segundo Coutinho (2001, p. 38-9 apud Silva 2012, p. 1), "no Brasil o conceito de capitalismo tardio foi utilizado para tratar de um processo histórico totalmente distinto daquele tratado pelos autores estudados. O economista João M. C. de Mello, em sua tese de doutorado apresentada em 1975 e publicada em 1982, utilizou o termo para caracterizar a emergência do modo capitalista de produção no Brasil. Segundo Coutinho, “(...) O capitalismo tardio refere as origens da industrialização brasileira à diversificação da economia cafeeira e ao transbordamento do capital cafeeiro pelos vários segmentos da economia regional paulista. O fundamental no trabalho, no entanto, é a caracterização das etapas do desenvolvimento econômico brasileiro, que se baseia em dois elementos: por um lado, em uma revisão da noção de industrialização, entendida como um processo de implantação de "forças produtivas capitalistas"; por outro, em uma peculiar caracterização das 'forças produtivas especificamente capitalistas', que as associa à montagem de um setor interno de bens de produção. Para Mello, a trajetória do desenvolvimento econômico brasileiro seria a de constituição de 'forças produtivas especificamente capitalistas', no sentido aludido".

${ }^{53}$ Para um maior entendimento do sentido do termo "desenvolvimentista" e "teoria da dependência" sugerimos ver "Do ISEB e da CEPAL à Teoria da Dependência", Luiz Carlos Bresser-Pereira. O qual afirma que "os economistas da CEPAL são, com frequência, chamados de estruturalistas. Essencialmente, porém, foram desenvolvimentistas, como os do ISEB".
} 
interpretações estritamente pela ideia hegemônica da classe dominante sobre o "desenvolvimento". Tal qual no século XIX, a ideia de que não éramos "civilizados", a qual hoje corresponderia a não sermos do "primeiro mundo", é a mesma lógica racional do constructo teórico de capitalismo "atrasado" e "tardio". Estes conceitos de atraso e tardio imputado ao nosso desenvolvimento social e econômico só são possíveis de serem estabelecidos enquanto lógica construída em comparação ao que é adiantado e sem anacronismo. Não existe atraso se a este não estiver associado o que é adiantado, não existe tardio se a este não estiver associado àquele que é e está em seu tempo "certo". É impossível construir qualquer ideia de atraso e de algo que acontece tardiamente a não ser em comparação.

Este modo de analisar a nossa realidade em comparação e, somente por este prisma, leva, segundo nosso ponto de vista, a duas contradições. A primeira contradição é que, ao comprarmos nossas idiossincrasias com as realidades alheias, no caso a europeia, esperamos primeiro montar aqui o cenário de lá para que possamos inferir a mesma interpretação e a aplicar o mesmo conceito. Este aspecto acaba por colocar nossas particularidades em segundo plano de modo a subjugar a realidade pela teoria. A segunda contradição que vislumbramos nesta ideia de capitalismo atrasado e tardio, deve-se ao fato de que deste o final do século XVIII, o Rio de Janeiro, como outras cidades do litoral brasileiro, eram parte da cadeia mercantilista das cidades atlânticas, integrantes direto da engrenagem que instituiu a hegemonia do modo de produção capitalista. Brasil e Europa passavam ao mesmo tempo, cada um a seu modo, pela mesma questão social, a questão do trabalho posta lá era claramente refletida aqui, como veremos no próximo tópico em relação a Portugal. O cosmopolitismo da questão social nos impele para a ideia de que o conceito de periferia não deve ser associado à ideia de atraso, como fora de seu tempo, mas entendido como um produto direto da questão social, próprio de seu tempo. Questão social, que em nosso caso temos que incluir a escravidão como parte inerente de sua formação. Podemos, claramente, perceber o cosmopolitismo da questão social, a que estamos nos referindo, com outras particularidades, no prefácio da segundo edição russa de 1882 do Manifesto Comunista. Segundo Marx e Engels ${ }^{54}$ “os Estados Unidos absorviam pela imigração o excedente da força

\footnotetext{
${ }^{54}$ Disponível em: <https://www.marxists.org/portugues/marx/1848/ManifestoDoPartidoComunista/prefacios.htm>. Acesso em: 09 ago. 2014.
} 
proletária da Europa (...) abasteciam a Europa de matérias-primas e eram simultaneamente mercados de escoamento dos produtos industriais desta". Afirmavam mais adiante que os Estados Unidos eram um dos "pilares da ordem europeia vigente". Pretensiosamente, incluímos o Brasil neste raciocino, não com o peso da concorrência americana que abalou a propriedade fundiária e o monopólio industrial europeus, mas sem dúvida como parte integrante do cosmopolitismo do capital e da força de trabalho no século XIX.

Aqui, a questão social já estava posta pelos acontecimentos de lá (Europa). Já estávamos experimentando em larga escala, para época, o aprofundamento do cosmopolitismo. Neste sentido, pensar, no caso do Rio de Janeiro, no grande número de imigrantes vindo de Portugal, um país fora do eixo da industrialização europeia, mas que também sofreu influências diretas desta industrialização, nos permite vislumbrar a formação da classe de trabalhadores assalariados no Brasil, pela perspectiva do capital internacionalizado.

A esse respeito Dr. Epitácio Pessoa, então ministro da justiça durante o Governo Provisório, dava "immediatas satisfação", em seu relatório ministerial referente a 1889, "ás justas reclamações que, desattendidas e menosprezadas pela monarchia, tinham descontentado numerosas e importantes classes sociaes", os comerciantes e os produtores rurais. Estas classes, segundo o referido ministro, estavam sofrendo com "restricção de credito e óbices oppostos á immigração por instituições obsoletas", sustentado por uma lei que não acompanhou "as medidas necessárias para a regular transformação do trabalho, e descurar a sorte futura assim dos redimidos da escravidão" 55 .

No período focado por nossos estudos, "verifica-se a constituição de um mercado de trabalho livre que se desenvolve nesta cidade em torno dos setores comercial, manufatureiro, de transporte, portuário e do funcionalismo público" (Neder \& Naro, 1981, p. 231). Juntava-se a este quadro de trabalhadores livres, basicamente da área do serviço e do funcionalismo público, o homem livre pobre, uma categoria identificada "no mapa da polução, feito por ordem do Vice-Rei, Conde de Rezende em 1799" (Werneck da Silva, 1981, p. 9). Neste mapa aparecia a "população livre branca e de cor, a dos "agregados às casas" (Werneck da Silva, 1981, p. 9). De modo que o trabalho para homem livre que ocupava o espaço do

55 BRASIL. Ministério da Justiça. Relatório do ano de 1889. Rio de Janeiro. Imprensa Nacional, 1891 b, p. 5. 
favor vai se atualizar na relação com o imigrante. Estes trabalhadores livres terão significativa importância ao longo de todo o século XIX na cidade do Rio de Janeiro. Otávio Tarquíno de Souza (apud Werneck da Silva, 1981, p. 43) denominou esses trabalhadores de "gente desocupada, sem posição estável e socialmente indefinida".

Segundo Werneck da Silva (1981, p. 43), era possível identificar três tipos de classes social. A classe senhorial a única que poderia ser considerada como "uma camada social em si, "com culturas e expectativas herdadas e, para si". Os "seguimentos sociais urbanos intermediários", mais difícil de serem alocados em categorias "histórico-analíticas" de classe. E, por fim, a "classe dos seguimentos sociais inferiores" que era alvo das ações de assistência e da polícia, as quais, segundo Werneck da Silva (1981, p. 43), é o "mais complexo de se considerar, à luz" da categoria da classe.

Esta complexidade era exposta pela diversidade dos tipos de trabalhadores e pelas diversas modalidades de trabalho. No entanto se a luz de categoria históricas e sociais não podemos, ainda no século XIX incluir os "debaixo" enquanto classe social, não se pode negar na mesma sociedade a luta de classe. Segundo Werneck da Silva (1981, p. 44), foi possível identificar a utilização do termo classe "significando categoria social, em 10 de fevereiro de 1865" no ofício enviado por Pedro José Pinto Cerqueira, subdelegado de Paquetá, a Ilustríssima Câmara Municipal. Além deste significado, Werneck da Silva (1981, p. 45) demonstra que o termo classe era usado no século XIX no Brasil, também para designar a ideia de categorias profissionais e de "camadas sociais, hierarquizadas política e economicamente".

Estes aspectos tornam-se importantes para nós, pois é exatamente a partir destas classificações relacionada a "classes" de pobres que a política e a assistência social definem suas práticas. Esta tensão social gerada na luta de classe pode ser vislumbrada, por exemplo, no fato de que o espaço dedicado nos relatórios dos chefes de polícia para descrever e propor soluções para a problemática social dos vadios e vagabundos vai perdendo, gradativamente, a partir da década de 1880 , espaço para as questões envolvendo os anarquistas, as greves e os operários. Interessante observar que nos dois casos trata-se da organização do mundo do trabalho, lidando com os pobres válidos não pela lógica do crime, mas usando o limiar da criminalização como estratégia de controle. As inúmeras greves, motins e 
revoltas acontecidas no final do século XIX e início do XX, constituem fartos exemplos desta luta de classe. Só a crédito de lembrança podemos citar a greve dos cocheiros e carroceiros "mal aconselhados por agitadores vulgares, que exploraram a ignorância e credulidade alheias" 56 ocorridas em dezembro de $1890^{57}$; a greve dos empregados da Estrada de Ferro Central do Brasil, ocorrida em fevereiro de 1891, na qual morreu um grevista. A esse respeito relatava o chefe de polícia Dr. Pedro Antonio de Oliveira Ribeiro que "alguns trabalhadores da linha procuraram embaraçar o trafego, sendo morto nessa occasião, em Cascadura, o portuguez Martinho José de Moraes, por um agente da força publica ${ }^{58}$. O chefe de polícia buscava responsabilizar os sindicalistas pela morte ao afirmar que "os propagandistas da guerra contra o capital, a accumularem entre as classes menos abastadas os elementos das explosões contra os princípios conservadores da ordem" "59. Por fim, podemos citar a greve dos operários da Societé Anonyme du Gaz, em junho de 1910, "que resultou ficar a cidade privada de illuminação por espaço de uma semana" $"$.

Diante deste complexo contexto que significava o mundo do trabalho, serviços formais e informais, comércios formais e informais, indústrias, funcionários públicos, profissionais liberais, amalgamados com a escravidão e seu correlato direto a imigração que devia agir a polícia para controlar e disciplinar, mais do que punir. Parte significativa da tensão social direta na formação do urbano e da classe de trabalhadores assalariado no Rio de Janeiro deve-se a maciça presença de imigrantes, como veremos no próximo tópico, os quais, diferente dos escravos e ex-escravos, estavam incluídos no projeto de Estado-nação.

\subsection{Imigração e questão social - Do Tejo a Guanabara}

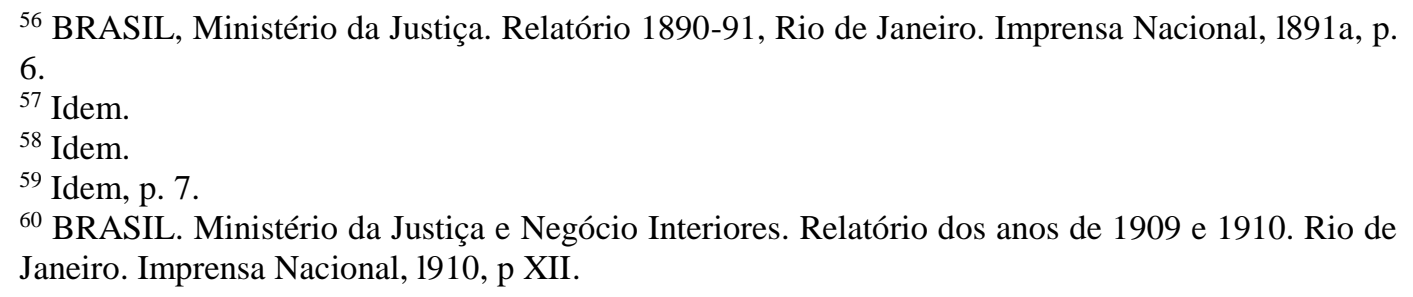


Ao elegermos o estudo dos pobres urbano na virada do século XIX para o XX a fim de demonstrar a formação da assistência social pelo viés da polícia, nos deparamos com a necessidade estudar os meandros da questão social no Brasil, com o olhar voltado especificamente para a cidade do Rio de Janeiro. Nesta cidade, o imigrante português era a nacionalidade mais representativa durante todo o Império e na formação da República, superando a soma dos imigrantes de outras nacionalidades. Por serem em sua esmagadora maioria homens jovens, solteiros, desqualificados tecnicamente, muitos deles analfabetos, passaram a ser parte importante da preocupação da polícia no ordenamento da cidade, não só pela via da repressão aos crimes contra a pessoa e a propriedade, mas também por serem os imigrantes os escolhidos pelo projeto de nação, pois os escravos não saberiam trabalhar pelo salário e nem teriam a capacidade de se qualificarem para as exigências tecnológicas da urbanidade da época, segundo a elite dirigente. Por este motivo e, por ser a categoria trabalho a mais importante para a formação da parcela chamada "povo", que entender a imigração portuguesa na cidade no Rio de Janeiro no século XIX nos proporciona vislumbrar tanto a internacionalização da questão social, quanto a formação da assistência social via trabalho e ordenamento urbano, gerenciado e executado pela instituição policial.

Para nossa análise da relação entre a imigração, a formação da assistência e a questão social, além dos autores referenciados ao longo do texto, nos valemos aqui de críticas comparativas entre o livro "Portugal e Brazil: emigração $e$ colonização", escrito por Domingos Antonio Gomes Pércheiro e publicado no ano de 1878 em Portugal, os relatórios do Ministério da Justiça e chefes de polícia e os livros de registro de entradas de presos na Casa de Detenção da cidade do Rio de Janeiro. Cabe destacar em relação ao livro "Portugal e Brazil: emigração $e$ colonização" que o intento do autor era "achar a causa do mal" da emigração para Brasil e "apontal-a aos verdadeiros medicos da nação, para que lhe appliquem um remédio energico e salutar" (Pércheiro, 1878, p. 10). Nosso autor português, que havia trabalhado na Agencia Telegraphica Americana no Pará, travou uma incansável batalha contra as publicações que circulavam, principalmente na cidade do Porto, com propagandas ufanistas sobre as vantagens da emigração para o Brasil. Seu principal inimigo na época, ao qual dedicou as mais ferozes críticas, foi o escritor brasileiro Augusto de Carvalho "a quem a fama tem elevado ao apogeo de literato distincto" (Pércheiro, 1878, p. 62). Carvalho publicou em 1874 o livro 
"Estudo sobre a colonisação e a emigração para o Brazil”. O livro de Carvalho que provocou a ira em Pércheiro, intitulado "O Brazill", circulava no Porto em 1875 e seu principal assunto, segundo nosso autor português, era "advogar a causa da colonisação e da emigração para o imperio americano" (Pércheiro, 1878, p. 62). Segundo Pércheiro (1878, p. 104)

O auctor do livro o Brazil, ignora ou finge ignorar, que a maior parte dos portugueses saidos de nossos portos, com destino ás terras de Santa Cruz, são alliciados com mentidas promessas e falsas illusões, incutidas por grande numero de especuladores, dos quaes, talvez sem o desejar parecer, o sr. Augusto de Carvalho seja o chefe.

Pércheiro buscava assumir o púlpito literário para advogar contra as consciências avaras de riquezas e "descrever os horrores da emigração, em linguagem que o povo entenda e ao qual especialmente destinamos este trabalho" (Pércheiro, 1878, p. 136). Para nosso autor, as "tentações ambiciosas de ser rico n'um paiz onde o sol e a humidade inutilisa a saude do europeu [e o] preço dos salarios no Brazil e o custo da vida não compensa o sacrificio que o portuguez vae fazer" (Pércheiro, 1878, p. 13-4). Para defender seus argumentos, Pércheiro usava dos artifícios científicos disponíveis à época para provar as desvantagens, os perigos e as agruras que seus patriotas sofreriam ao emigrarem para o Brasil, neste sentido reproduz o trecho do "primeiro inquerito parlamentar sobre a emigração portuguesa” de 1873, segundo o qual:

A mortalidade de Lisboa, segundo a estatistica publicada no Diario do Governo $n$. $^{\circ}$ 285, de 1872, é de 30,4 individuos para cada 1:000, um pouco mais do que a da cidade de Londres, que desce a 27, e um pouco menos do que a de Roma, que sóbe a 35. No Cabo da Boa Esperança e na Serra Leoa, a mortalidade é de 200 individuos para cada 1:000, e a da população portugueza residente no Rio de Janeiro, segundo o relatorio do ministro do commercio, agricultura e obras publicas foi, em 1870, de 270 para 1:000!!! (Pércheiro, 1878, p. 18-9).

O imigrante português se tornou um problema para o ordenamento da cidade do Rio de Janeiro e este fato se relaciona diretamente com a administração da cidade

\footnotetext{
${ }^{61}$ Pércheiro (1878: 53) afirmava que "o livro a que nos queremos referir teve primeiro o seguinte titulo - Estudo sobre a colonisação e emigração para o Brazil - e o actual apparece com o de Brazil-simplesmente. Não se lhe mudou apenas a capa; fez-se mais: antepôz-se ao texto - que éo mesmo - os elogios da imprensa portugueza, para que no imperio fosse mais facil a extracção do livro"!
} 
pela polícia. Vale ressaltar que a polícia desempenhou um importante papel na formação do Estado-nação no Brasil, onde ordenar as cidades e principalmente civilizar a corte nos moldes dos países cultos era a meta a ser perseguida. A cruzada moralizadora, civilizatória e ordenadora da cidade se voltou com especial atenção para os classificados como vadios, vagabundos, ratoneiros, desordeiros e turbulentos $^{62}$, os quais deveriam ser integrados, pela via do trabalho no reduzido escopo que significava a cidadania no Império. A necessidade da formação de uma classe de trabalhadores subalternos livres e assalariados, que pudesse não só substituir a mão de obra escrava no campo, a partir da proibição do tráfico negreiro, mas principalmente formar um proletariado urbano branco capaz de qualificar a mão de obra nas transformações que sofria a cidade - a iluminação a gás, água e esgoto, construção de estradas de ferro, no comércio e na indústria - foi à tônica do projeto político e econômico que per si buscava o branqueamento da sociedade.

Para termos uma ideia, o Rio, segundo Pércheiro (1878, p. 16), "pela estatística official de 1873, [contava] 228:743 habitantes incluídos 78:583 estrangeiros, dos quaes 53:213 são portugueses". Para nosso autor, a população do Rio de Janeiro neste período era praticamente igual a de Lisboa. De acordo com Pércheiro, "Portugal [possuía] uns quatro milhões de habitantes e pouco mais comporta o seu territorio. O Brazil deve possuir uns dez milhões, mas comporta duzentos! É impossivel que o nosso paiz possa supprir o imperio de tão grande falta" (Pércheiro, 1878, p. 65). Neste contexto que o enredo da imigração de trabalhadores pobres europeus se colocava como a solução para civilizar o país pelas regras liberais do trabalho livre, importante alternativa ao fim prenunciado do estatuto da escravidão, ao mesmo tempo, como um paradoxo, o imigrante pobre e desqualificado, se tornava o principal ingrediente da problemática dos vadios $\mathrm{e}$ vagabundos no ordenamento da cidade. Para nosso intento, tanto as falas de Pércherio em Portugal, quanto às posições dos chefes de polícia e ministros da justiça no Brasil, nos conduzem para o mar das evidencias históricas e desta forma não teremos como desviar a rota de nossos argumentos da necessidade de trasladar textualmente o que consideramos relevante nas fontes analisadas. Com isto,

\footnotetext{
62 Termos usados na época para classificar os motivos de prisão nos livros de entradas de presos na Casa de Detenção da cidade do Rio de Janeiro. Vale ressaltar que o termo se referia a pessoa e não ao ato cometido por ela, visto que, encontramos no campo motivo da prisão a expressão preso por vadio ou vagabundo e não por vadiagem ou vagabundagem. (Arquivo Público do Estado do Rio de Janeiro - APERJ /Fundo Casa de Detenção).
} 
buscamos discutir as implicações da imigração portuguesa para a construção da assistência e a questão social na formação do Estado-nação.

O Brasil como o principal destino da emigração portuguesa durante o séc. XIX desenvolveu processos históricos, que apesar de distinto dos de Portugal é possível identificar diversos fatores de influência mútua. O caso da imigração é um destes fatores que diretamente impõe questões tanto aqui quanto lá. Entre as causas apontadas, relativas à intensificação da emigração portuguesa a partir da década de 1870, destacamos o fraco rendimento oriundo do trabalho, os conflitos entre operários e patrões, o grande peso do rural e o recrutamento. Maria de Fátima Bonifácio (1986: 331), por sua vez, vai traçar o paralelo da questão social imbricada no conflito entre o cartismo e o setembrismo que significava a "exploração da dicotomia do livre-cambismo versus o proteccionismo" Desta maneira, a questão social em Portugal se colocava no conflito ente as aspirações do "grande comércio nacional e estrangeiro" e aos anseios desenvolvimentistas e emancipadores das "classes industriais" (Bonifácio, 1986, p. 331). De acordo com a autora, os defensores do comércio se impuseram sobre as classes industriais dificultando o desenvolvimento econômico e o progresso social de Portugal. Para a autora, este conflito se localizava como nas interpretações de Antônio Sérgio e Albert Silbert "na reedição oitocentista das seculares tensões entre 'transporte' e 'fixação", (Bonifácio, 1986, p. 331).

A emigração portuguesa que se intensifica na década de 1870 e servia para suprir a mão de obra "necessária à modernização" da corte entra em choque com os princípios do projeto civilizatório da cidade do Rio de Janeiro. Criava-se, assim, um paradoxo, pois o projeto civilizatório que, entre outras coisas, propunha a substituição da mão de obra escrava e incentivava o branqueamento da população, via na imigração de homens pobres, solteiros e desqualificados um problema para o ordenamento da cidade e a segurança pública. O grande número de portugueses; jovens, sozinhos, e semianalfabetos, que desembarcavam diariamente no Rio de Janeiro aparece como uma das grandes preocupações para ordenamento urbano nos relatórios dos chefes de polícia da capital no período de nosso estudo.

Em 18 de novembro de 1872, o diretor da Casa de Correção da Corte destaca em relatório o problema da imigração, em especial a portuguesa, nos termos que podemos ver a seguir: 
Peço permissão a $V$. Ex. para continuar algumas considerações feitas no anterior rolatorio (...) como o numero de portugueses condemnados e que têm cumprido pena nesta casa é considerável, eleva-se a muito mais da metade do das outras nacionalidados, inclusive os brazileiros, e a maior parte por attentados contra a propriedade, vou occupar-me delles em primeiro logar. Como sabemos, moços até imberbes avultão na massa dos emigrantes dessa nação, e que aqui chegados não tem, por via de regra, quem os guie, quem lhes reprima as paixões próprias dessas idades, quem finalmente os sustenta no plano inclinado do vicio o do crime. Muito cedo independentes, com dificuldade sujeitão-se ao que deles rasoavelmente exigem seus patrões; em pouco tempo as casas commerciaes, conhecedoras dos desregramentos delles, os repellem, e eil-os com a miséria em perspectiva; ora, se o homem já feito, e mesmo de espirito tanto ou quanto cultivado, algumas vezes claudica, o que será desses, a quem tudo falta na terra estrangeira, desses que eu poderia chamar verdadeiros orphãos! ${ }^{63}$

No relatório do ano de 1875 do Consul Geral de Portugal no Rio de Janeiro, transcrito por Pércheiro (1878, p. 67), podemos conferir uma preocupação aproximada a do chefe de polícia citado acima:

Dos emigrantes, aquelles a quem cabe mais desgraçada e commovente sorte, são os que vem para fugir ao recrutamento; não os clandestinos, mas os menores de 14 annos, e infelizmente é avultado o numero d'estes; porque, como só depois dos 14 annos é que são obrigados a prestar fiança, os paes para os não verem soldados preferem arremessal-os para o Brazil, muitas vezes sem a mais leve recommendação, entregues completamente á sua inexperiencia, se não acham a quem os vender! É ignobil, mas é verdade. Estes infelizes assim vendidos, vão para o interior do paiz ser barbaramente explorados pelos compradores, que os obrigam a todo o genero de serviços, muitas vezes superiores ás suas forças, tratando-os peor que aos seus escravos, porque estes representam um capital consideravel e aquelles sómente a importancia da passagem.

Com o mesmo tom é possível vislumbrarmos no "Diario das Camaras dos Senhores Deputados de Portugual, Sessão de 26 de março de 1877” na transcrição de Pércheiro (1878: 156-7) que "é grande a corrente da emigração, e para a engrossar não concorrem pouco algumas das nossas leis, (...) A lei do recrutamento é pessima, a sua execução é detestavel. Ha muita gente que foge para o Brazil para não ser soldado”. O problema que se constituía a imigração de portugueses pobres e sem qualificação profissional para o Rio de Janeiro era a outra face de uma mesma moeda que tinha principalmente na cidade do Porto e nas ilhas portuguesas a prensa da emissão. Seja o diretor da Casa de Detenção da cidade do Rio de Janeiro, em 1871, seja o Consul Geral de Portugal no ano de 1875, seja o Diário da Câmara dos

${ }^{63}$ BRASIL. Ministério da Justiça. Relatório do ano de 1871. Rio de Janeiro. Typographia Nacional, 1872, p. A-171. 
Deputados em Lisboa no ano de 1877, a problemática do português pobre estava posta. Tanto aqui quanto lá a questão social se colocava via questão agraria, pois a roça aqui e lá integravam por aspectos diferentes a problemática da imigração. $\mathrm{O}$ trecho da "Sessão de 26 de março de 1877 do Diario das Camaras dos senhores deputados" afiança que a "emigração dos portuguezes para o Brazil tem nos ultimos tempos attingido proporções verdadeiramente collossaes e gigantescas, o que é uma grande calamidade, calamidade assustadora especialmente para a indústria agricola, que é a principal fonte da nossa riqueza" (Pércheiro, 1878, p. $355)$.

Uma carta escrita pelo presidente da Caixa de Soccorros D. Pedro V, e "dirigida ao Consul geral de Portugal, no Rio de Janeiro, em 21 de julho de 1872" descreve como se dá o destino do imigrante português a partir da "observação dos resultados colhidos pelos emigrantes". Nesta carta é possível perceber "como se tornaram em realidades os sonhos dourados d'aquella possante juventude, que em demanda de tão cubiçada riqueza abandonou a patria e a familia". Nestes termos escreve o senhor presidente da Caixa de Soccorros D. Pedro V:

\begin{abstract}
V. ex. ${ }^{a}$, que é portuguez, disponha o seu animo para contemplar desgraças e misérias taes e tamanhas, que a imaginação espavorida mal compreende como ainda tão severa illusão não bastou para pôr barreira a esta corrente de suicídios. (...) Nos sete annos decorridos, desde 1864 a 1871, a Caixa de Soccorros de D. Pedro V, pagou a passagem para voltarem á patria, a 2:304 portuguezes, e o numero dos que tem soccorrido eleva-se a 9:000 inscriptos até hoje. (...) Estes algarismos, ex. ${ }^{m o}$ sr., continúa o presidente da associação, representam homens inteiramente abandonados, sem mais recursos alguns e que morreriam ao desamparo se esta associação não fôra etc., etc (Pércheiro, 1878, p. 105-6-7).
\end{abstract}

A "desqualificada" massa de imigrantes que chegava pode ser vislumbrada, tanto junto aos relatórios dos chefes de polícia, quanto nos argumentos de Pércheiro (1878, p. 153). Este último afirmava textualmente que "no geral todos os individuos que vem para colonias não sabem ler nem escrever". Este fato - o analfabetismo do colono português que emigrava para o Brasil - era o que prenunciava, segundo nosso autor português, o sucesso dos engajadores de imigrantes e a ineficácia das propagandas contra a emigração. Para Pércheiro (1878, p. 16), o analfabetismo além de permitir um fácil aliciamento, tornava ineficaz a "medida de publicar as relações nominaes dos súbditos portuguezes, fallecidos no Brazil, com a declaração da 
moléstia de que tinham sucumbido [como] fôra lembrada pelo conde de Thomar, em 1860, com o fim de evitar a emigração".

De acordo com Silva (1990, p. 36) “o analfabetismo e a ignorância caracterizam, segundo a diretoria da Caixa [de Socorros D. Pedro V] de 1866, a classe dos operários e dos trabalhadores portugueses no Rio de Janeiro. Entre aqueles que tinham recorrido a instituição, havia 75\% analfabetos". Da mesma maneira o cônsul de Portugal no Maranhão escreve que "no geral todos os individuos que vem para colonias não sabem ler nem escrever, e isto faz que elles não possam adquirir outro modo de vida menos perigoso do que o trabalho nas terras" (Pércheiro, 1878, p. 153). Pércheiro ainda acusava o governo português e a grande imprensa da época de ser conivente com o fluxo de emigração para o Brasil, na medida em que não apoiava ações de propaganda contra esta prática. $\mathrm{O}$ trecho abaixo descrito por Pércheiro (1878, p. 165) reproduz parte do oficio de 07 de maio de 1860 no qual o conde de Thomar se queixa ao governo Português a este respeito:

\begin{abstract}
Sinto que o governo não julgasse aproveitavel a idéa que suggeri na minha correspondencia, fazendo publicar diariamente na folha official e nos jornaes sobre que podesse exercer alguma influencia, a relação dos portuguezes mortos n'este imperio, declarando-se sempre a molestia de que são victimas, e a sua edade. É isto muito facil, pelo menos quanto ao Rio de Janeiro, porque nada mais haveria a fazer senão transcrevêr o obituario, que diariamente publicam os jornaes brazileiros, que mando para a secretaria a cargo de v. ex. ${ }^{a}$.
\end{abstract}

Segundo Pércheiro estas ações não foram eficazes devido a falta de apoio do governo português e ao fato de não encontrarem eco junto a seu principal destinatário, pois a maioria não sabia ler. Neste sentido afirma Pércheiro (1878, p. 164-5) que:

\begin{abstract}
são insignificantes os resultados tirados da publicação das relações do obituario, que os nossos consules nos enviam do imperio. E a razão é simples: é que a nossa população d'onde sahem os emigrados não sabe lêr; ou se sabe não está ao alcance de lêr os jornaes mais importantes, onde apparecem publicadas essas listas, que muito poderiam influir no animo dos que em tão horrorosa quadra entendem dever deixar a pátria
\end{abstract}

A desqualificação do imigrante pela falta de instrução era um fato que repercutia tanto nas falas dos chefes de polícia aqui no Rio de Janeiro, quanto nos argumentos de Pércheiro na defesa pelo fim da emigração em Portugal. Tanto lá quanto aqui a educação era o antídoto capaz, no caso do Brasil, de transformar 
imigrantes vagabundos em trabalhadores naturalizados brasileiros e no caso de Portugal "o remédio infallivel que preferimos applicar ao mal da emigração" (Pércheiro, 1878, p. 22). Da mesma forma que o chefe de polícia da corte, Pércheiro via na escola a vacina contra o mal da ambição - "combata-se o mal da ambição, pela escola" (Pércheiro, 1878, p. 20) -, que se materializava no caso de Portugal pela busca da riqueza no além-mar e, no caso do Brasil, nos gatunos, ratoneiro, falsificadores de moedas e vagabundo de toda a sorte que abundavam na corte. Neste sentido afirmava o chefe de polícia que a "educação do povo, [é a] primeira necessidade, e sem a realização da qual os resultados de quaesquer meios serão improfícuos, ou pelo menos pouco satisfactorios" $" 64$.

A problemática dos estrangeiros, principalmente os portugueses que engrossava as maltas, era uma preocupação constante para as autoridades que visavam "civilizar" a corte através de um processo de ocidentalização da cidade do Rio de Janeiro. Esta preocupação fica evidente nos trechos selecionados dos relatórios dos chefes de polícia reproduzidos abaixo. Afirmava no relatório referente aos anos de 1880 e 1881 o chefe de polícia Dr. Ovídeo Fernando Trigo de Loureiro afirmava que "com relação aos ratoneiros e vagabundos notáveis e incorrigíveis, a autoridade policial deverá também ser armada da indispensável e proficua faculdade de deportar àquelles d'entre esses constantes perturbadores do socego publico, que forem estrangeiros" ${ }^{25}$. Segundo o referido chefe de polícia

outra providencia efficaz poderia ser igualmente adoptada. Sendo o maior numero de vagabundos de nacionalidade estrangeira, especialmente portugaeza e italiana, seria de alta conveniencia a adopção dos arts. 259 do codigo penal portuguez, e 272 do codigo penal francez, por virtude dos quaes os estrangeiros vagabundos, que se torbam recalcitrantes, são entregues ao Governo, para fazel-os retirar do paiz ${ }^{66}$.

O mesmo argumento podia ser encontrado no relatório relativo ao ano de 1877, que também citava como "medida efficaz, a adopção dos Arts. 259 do Código Penal portuguez e 272 do Código Penal francez". Segundo o chefe de polícia da época Dr. Tito Algusto Pereira de Matos "a maior parte dos vagabundos é de

${ }^{64}$ BRASIL. Ministério da Justiça. Relatório do ano de 1871. Rio de Janeiro. Typographia Nacional, 1872, p. A-171.

${ }^{65}$ BRASIL. Ministério da Justiça. Relatório do ano de 1880 e 1881. Rio de Janeiro. Typographia Nacional, 1882, p. A-G-4.

${ }^{66}$ Idem, p. A-G-7. 
nacionalidade estrangeira, especialmente portuguesa e italiana"67. Afirmava Dr. Tito Matos que "o assumpto é da máxima gravidade por entender com importantes interesses da sociedade; urge providenciar desde já no intuito de reprimir de modo mais efficaz a audacia dos vagabundos"68. A questão dos vadios e vagabundos era agravada por "outra chaga de nossa sociedade", o grande "numero de menores que, orphãos ou abandonados por seus próprios pais, vagam pelas ruas da cidade,

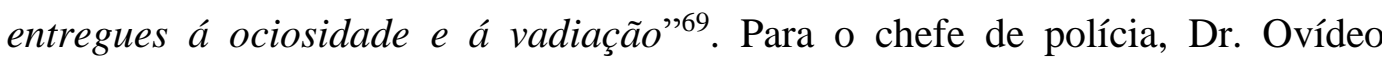
Fernando Trigo de Loureiro, em seu relatório referente aos anos de 1880 e 1881, entre os menores "avultam os estrangeiros, principalmente portuguezes e italianos que, apparentando viverem da industria de vender Gazetas, engraxar botas ou tocar instrumentos de musica, da-se na realidade á pratica de pequenos delictos e de actos immoraes" $" 70$.

Estes dados nos levam a perceber certas características da imigração portuguesa e abre uma nova perspectiva para o entendimento da problemática da infância desvalida na virada do século no Rio de Janeiro, bem como da assistência. Como demonstra o relatório da Caixa de Socorros D. Pedro V do ano de 1864, muitos dos menores de 14 anos que fugiam do recrutamento em Portugal, vendiam sua força de trabalho a engajadores desonestos para trabalhar na roça no Brasil e “atribuíam pais fictícios para enganar as autoridades" (Silva, 1990, p. 40). No entanto, estes jovens preferiam ficar vagando pelas ruas do Rio de Janeiro a trabalhar na pesada lida do campo, "motivando pelos atos a intervenção da polícia e do consulado português e, por esta razão, logo desde os primeiros anos do seu funcionamento, a Caixa [de Socorros D. Pedro V] pretendeu criar um asilo onde os menores pudessem aprender um ofício" (Silva, 1990, p. 41).

A problemática da pobreza urbana válida e inválida se configurava num grave empecilho ao ordenamento urbano da cidade do Rio de Janeiro, dentre ela a parcela de estrangeiro, principalmente portugueses, era extremamente significativa, como podemos observar nas estatísticas policiais. A gravidade do problema pode ser demonstrada em diversos relatórios do Ministério da Justiça, como, por exemplo

67 BRASIL. Ministério da Justiça. Relatório do ano de 1877. Rio de Janeiro. Typographia Perseverança, 1878, p. A5-36.

${ }^{68}$ Idem.

${ }^{69}$ BRASIL. Ministério da Justiça. Relatório do ano de 1880 e 1881. Rio de Janeiro. Typographia Nacional, 1882, p. A-G-8.

${ }^{70}$ Idem, p. A-G-7-8. 
“em 1877 cumpriram penas por quebras de termo 230 individuos, 108 nacionaes e 122 estrangeiros"71.

A relação entre o imigrante pobre e a ideia de "vadio" e "vagabundo", associado aos dados apresentados acima, reforça nosso argumento de que os imigrantes portugueses representavam um grave problema para o ordenamento e segurança da cidade do Rio de Janeiro. Este fato fica evidenciado segundo o que pensava os próprios chefes de polícia da época nos diferentes relatórios, tal qual veremos abaixo:

o numero de indivíduos que, sem emprego ou morada conhecida, vivem de vários expedientes illicitos, augmenta progressivamente. Na maior parte estrangeiros, esses vadios e vagabundos, ou são portuguezes desarranjados das casas de commercio, ou marinheiros desembarcados dos navios que aportam ao nosso ancoradouro, e que, habituando-se á vida dos publichouse onde pernoitam mediante poucos vinténs, percorrem as ruas e praças, muitos delles esmolando. Esse numero é engrossado por grande quantidade de menores entre os quaes muitos italianos, que munidos de uma harpa ou rabeca, ou sob a occupaçao de engraxadores de sapatos, vivem sobre si, sem parentes que os protejam, a menos que alguns especuladores da mesma nacionalidade não usufruam o producto de sua pequena industria ${ }^{72}$.

"Os vadios e vagabundos, a que alludo, são pela maior parte estrangeiros que, recusando-se ao trabalho que poderia dar-lhes largos meios de subsistência, preferem viver no ocio, entregues aos vicios, e mantendo-se á custa da fazenda alheia. O numero de estrangeiros assim viciosos, augmenta-se de dia em dia; sendo certo que cegos e aleijados, fingidos ou verdadeiros, aportam a nossas praias, vindo com intenção de se entregarem á mendicidade. À ordem publica e a segurança de propriedade reclamam enérgicas providencias ",73.

É já por demais notável o grande numero de menores que, ou não tendo pais vívem sobre si, por não importarem-se os seus outros parentes, ou que os tendo, são abandonados como íncorregiveis pelos próprios progenitores, que confessam a autoridade não poderem contel-os, nem dar-lhes destino. Esses menores, assim entregues á ociosidade e á vadiação, engrossam as maltas de capoeiras e são os auxiliares de ratoneiros, que os aproveitam na exploração de furtos e gatonices, servindo, ora para esconderem as armas daquelles, ora para darem a estes - dica\{segundo sua giria\} sobre os attentados contra a propriedade. Entre elles avultam os de nacionabdade estrangeira, principalmente portugueses e italianos, que são enviados dos seus paizes aos irmãos tios e primos que, quando não lhes servem para alguma especulação, os abandonam, deixando-os expostos a todos os vícios, (...),

71 BRASIL. Ministério da Justiça. Relatório do ano de 1877. Rio de Janeiro. Typographia Perseverança, 1878, p. A5-35.

${ }^{72}$ BRASIL. Ministério da Justiça. Relatório do ano de 1876. Rio de Janeiro. Instituto Typographico do Direito, 1877, A - 254.

${ }^{73}$ BRASIL. Ministério da Justiça. Relatório do ano de 1875. Rio de Janeiro. Instituto Typographico do Direito, 1877b, p. A-186. 
dão-se á pratica de pequenos delictos, a actos inmoraes, depredações e assim preparam-se na carreira do crime $^{74}$.

A problemática dos vadios e vagabundos se atrelava a outros tipos de crimes, que propiciava terreno fértil para a construção de uma imagem de desclassificados e imorais para os imigrantes pobres que abundavam o porto do Rio no período abordo por nossos estudos. Neste aspecto, destacamos os crimes de moedas faltas, que nos relatórios dos chefes de polícia fica evidente que eram praticados em quase sua totalidade por estrangeiros, os brasileiros envolvidos geralmente estavam ligados a alguma rede que incluía a presença de estrangeiros. Entre os estrangeiros, os portugueses eram a nacionalidade que mais aparecia nos relatórios dos chefes de polícia. No entanto, cabe destacar que na maioria das vezes tinha mais de uma nacionalidade, como espanhóis e franceses, constituindo num problema internacional, na qual a diplomacia esteve em cena. É possível vislumbrar diversos documentos das autoridades relativos ao crime de moeda falsa, bem como é plausível ver que Pércheiro construiu uma crítica sobre este tema que fugia das evidências apontadas pelos documentos oficiais.

No relatório referente ao ano de 1880 e 1881, encontramos descrito o drama da portuguesa "Marianna do Rosario, passageira do paquete ollemão Rio vindo da Europa" onde na alfandega da cidade do Rio de Janeiro foi encontrado em sua “mala cedulas falsas, no valor de 39:980\$000". Ainda faz parte deste enredo "o hespanhol José Manoel Ribas, e o portuguez João da Silva Machado que se achavam em sua companhia"75. No relatório do ano de 1879 “o súbdito portuguez Joaquim Carneiro Frião" fora preso por tentar "falsificar libras sterlinas e moeda do Brazil" "76. No ano de 1877, foram presos, no Pará, os portugueses Francisco Vieira da Motta e Manoel Souza de Macedo após buscas realizadas pela polícia em seus quartos, onde "foram apprehendidos moldes e outros objectos próprios para" falsificação de moedas"77.

\footnotetext{
${ }^{74}$ BRASIL. Ministério da Justiça. Relatório do ano de 1877. Rio de Janeiro. Typographia Perseverança, 1878, p. A5-36.

${ }^{75}$ BRASIL. Ministério da Justiça. Relatório do ano de 1882. Rio de Janeiro. Typographia Nacional, 1883 , p. 73.

${ }^{76}$ BRASIL. Ministério da Justiça. Relatório do ano de 1879. Rio de Janeiro. Typographia Perseverança, 1880 , p. 50.

77 BRASIL. Ministério da Justiça. Relatório do ano de 1877. Rio de Janeiro. Typographia Perseverança, 1878, p. 45.
} 
Dentre os muitos casos que podemos colher em todos os relatórios do Ministério da Justiça durante a década de 1870, destacamos a trágica história do português Luiz Dias de Oliveira que no dia 16 de Abril de 1874 fora preso pelo inspetor da alfandega "ao desembarcar no caes de Marinhas, vindo da Europa a bordo do paquete Tíber com pequenos artigos de contrabando" e mais "304 notas falsas do valor de 50\$000, que o mesmo individuo trazia em um saco atado ao corpo". Este português foi condenado "nas penas do art. 174 do código criminal" e faleceu na Casa de Detenção da cidade do Rio de Janeiro a 11 de Fevereiro de $18^{78}$. Outro caso que demonstra a importância dos crimes de moeda falsa na construção de um conceito pejorativo sobre os imigrantes pobres e o internacionalismo da problemática criminal vivida no Rio de Janeiro está transcrito no relatório publicado no ano de 1874 , como podemos ver:

segundo as ultimas communicações, foi preso em Paris, pelo crime de fabrico de moeda falsa, o súbdito brasileiro Anibal Alves dos Santos, natural do Jaguarão, provincia do Rio Grande do Sul. Este individuo tinha estabelecido naquella cidade uma loja de papel de lithographia, e contratára um habil gravador, a quem promettera 6,000 francos para copiar uma nota do thesouro nacional do valor de 20\$000. Já estava prompta a gravura, quando foi apprehendida pela policia com os instrumentos necessarios a esta criminosa industria, e bem assim toda a correspondencia de outros indiciados. Annibal confessou o crime, declarando que fôra aconselhado e induzido peto portuguez Francisco José de Souza, o qual foi logo preso na cidade do Porto, onde residia ${ }^{79}$.

A internacionalização deste tipo de crime levava a uma interlocução direta entre as polícias de Lisboa e do Rio de Janeiro como demonstra os relatórios referentes aos anos de 1879, 1880 e 1881, onde a Legação Imperial em Lisboa era constantemente acionada para descobrir as ramificações dos crimes de falsificação de moedas ${ }^{80}$. Estas questões relativas aos crimes de moeda falsa demonstra o ponto de vista que defendemos sobre o cosmopolitismo da cidade do Rio de Janeiro.

Cabe destacar que a polícia tinha um destacamento próprio que realizava o controle de entrada e saída de imigrantes e agia junto com a comissão de higiene, “a que estão sujeitos todos os navios, nacionaes e estrangeiros, exceptuando os de

78 BRASIL. Ministério da Justiça. Relatório do ano de 1874. Rio de Janeiro. Typographia Americana, 1875, p. 215.

79 BRASIL. Ministério da Justiça. Relatório do ano de 1873. Rio de Janeiro. Typographia Americana, 1874, p. 7.

${ }^{80}$ BRASIL. Ministério da Justiça. Relatório do ano de 1880 e 1881 . Rio de Janeiro. Typographia Nacional, 1882, p. 73. 
guerra" ${ }^{81}$. Esta fiscalização não impedia a entrada de imigrantes portugueses clandestinos, ao contrário, os navios portugueses adotavam a bandeira brasileira como meio de não ser fiscalizado por alguma autoridade portuguesa nos portos brasileiros. "Houve armadores de navios portuguezes que substituiam a nossa bandeira pela brazileira, para evitar a fiscalisação das nossas autoridades consulares!" (Pércheiro, 1878, p. 78). Do mesmo modo, Pércheiro acusava também as autoridades portuguesas: "havemos de provar se o não está já, que as auctoridades do nosso paiz, pódem, mais ou menos, ser tambem accusadas de negligencia e conniventes com os aliciadores" (Pércheiro, 1878, p. 211).

A importância do movimento no porto do Rio de Janeiro pode ser demonstrada pela estatística da divisão de polícia do porto, segundo a qual:

durante o anno de 1873 entraram neste porto 18.916 estrangeiros, sendo 4.981 procedentes de diversas províncias do Império e 13.932 do exterior",82. "No anno de 1875 entraram neste porto 34.319 estrangeiros, sendo 29.063 do exterior, e 5.236 dos portos do Império" 83 . "Em 1879, entraram 27.250 estrangeiros, sendo 23.530 do exterior e 3.720 de diversas províncias" $"$. No ano de 1880 "entraram do exterior 23.688", e no ano de 1881 "entraram do exterior 24.238 estrangeiros $^{85}$.

Como podemos perceber, a imigração portuguesa no Rio de Janeiro envolvia por um lado, a problemática da infância desvalida, a pobreza e a falta de educação formal e, por outro, representava a saída honrosa para adequação do mundo do trabalho aos princípios liberais. Com uma feição barroca, os imigrantes portugueses no final do século XIX, no Rio de Janeiro, representavam o que se deveria prevenir - o vadio e o vagabundo - e ao mesmo tempo a solução para civilizar a cidade e construir a nação - o trabalhador branco e assalariado. É por este viés que a polícia torna-se o principal agente governamental, seja para prevenir os crimes, seja para civilizar a cidade.

81 BRASIL. Ministério da Justiça. Relatório do ano de 1877. Rio de Janeiro. Typographia Perseverança, 1878, p. A-5-51.

${ }^{82}$ BRASIL. Ministério da Justiça. Relatório do ano de 1872. Typographia Americana, 1873, p. A199.

${ }^{83}$ BRASIL. Ministério da Justiça. Relatório do ano de 1874. Typographia Americana, 1875, p. A250.

${ }^{84}$ BRASIL. Ministério da Justiça. Relatório do ano de 1879. Typographia Perseverança, 1880, p. AG-21.

${ }^{85}$ BRASIL. Ministério da Justiça. Relatório do ano de 1880 e 1881. Typographia Nacional, 1882, p. A-G-48. 
Através do registro de presos na Casa de Detenção do Rio de Janeiro podemos demonstrar a preocupação administrativa da polícia com a gestão - o próprio fato de podermos acessar as estatísticas policiais da época demostram este feito -, e ao mesmo tempo confirmar os aspectos descritos acima, nos relatórios do Mistério da Justiça e por nosso autor português, sobre as características a imigração portuguesa na cidade do Rio de Janeiro, no final do século XIX. A amostragem dos registros de presos da Casa de Detenção analisada em nossa pesquisa ${ }^{86}$ evidenciou os dados descritos nos relatórios acima, bem como apontou que, guardando as devidas parcialidades, Pércheiro sabia muito bem a dura realidade que o sonho juvenil do colono pelo capital novo enfrentaria. O número de portugueses presos era tão significativo que a Caixa de Socorros D. Pedro V criou uma comissão de prisão somente para tratar destes assuntos (Silva, 1990, p. 42). Do total de presos por "vadios, vagabundos, ratoneiros, desordeiros e ou turbulentos" de nossa amostra, $41,2 \%$ eram de nacionalidade portuguesa, como demonstra a tabela abaixo.

\section{Tabela 1. Nacionalidade dos presos.}

\begin{tabular}{l|c} 
Nacionalidade & $\%$ \\
\hline Português & $41,20 \%$ \\
\hline Brasileiro & $36,8 \%$ \\
\hline Outros países da Europa & $13,7 \%$ \\
\hline América do Norte & $4,2 \%$ \\
\hline Africano & $2,3 \%$ \\
\hline Orientais & $0,7 \%$ \\
\hline Outros países da América do Sul & $0,5 \%$ \\
\hline IN-IL* & $0,7 \%$ \\
* Incompleto ou ilegível. $\quad$ n. $=864$ &
\end{tabular}

A amostra pesquisada ratificou todas as falas dos relatórios ministeriais que afirmam a presença do grande número de imigrantes portugueses, homens, jovens e solteiros, da maneira como podemos observar nas tabelas e no gráfico abaixo:

\footnotetext{
${ }^{86}$ Foram analisados dois livros de registro de entrada de presos na Casa de Detenção da cidade do Rio de Janeiro - notações 06 e 08 - que cobriam o período de outubro de 1870 a maio de 1871 (Arquivo Público do Estado do Rio de Janeiro, Fundo/Coleção Casa de Detenção). Cada livro possui um total de 250 folhas com 04 registros por folha, o que compreende 1.000 registros por livro. Foram analisados 2.000 registros e sistematizado todos os que haviam sido presos pelos motivos, "vadios, vagabundos, ratoneiros, desordeiros e ou turbulentos".
} 
Tabela 2. Sexo dos presos de nacionalidade portuguesa.

\begin{tabular}{l|l} 
Masculino & $96,8 \%$ \\
\hline Feminino & $3,0 \%$ \\
\hline IN-IL* & $0,2 \%$
\end{tabular}

$*$ Incompleto ou ilegível. n. $=356$

\section{Tabela 3. Estado civil dos presos.}

\begin{tabular}{|c|c|c|c|}
\hline & Português & Brasileiro & Outras nacionalidades \\
\hline Solteiro & $36,6 \%$ & $28,9 \%$ & $17,4 \%$ \\
\hline Casado & $3,5 \%$ & $4,6 \%$ & $0,9 \%$ \\
\hline Viúvo & $0,7 \%$ & $2,3 \%$ & $0,9 \%$ \\
\hline IN-IL* & $1,9 \%$ & & \\
\hline
\end{tabular}

\section{Gráfico 1. Idade dos presos por nacionalidade brasileira e portuguesa.}

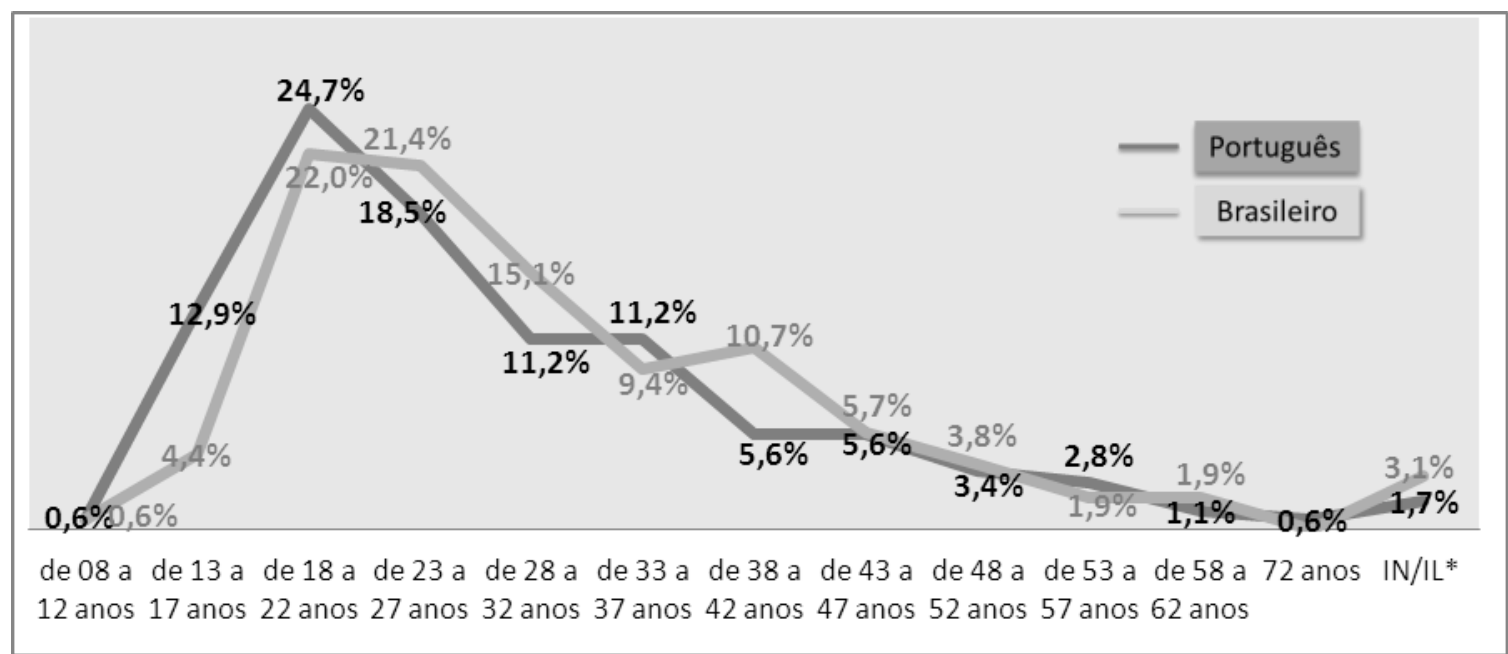

* Incompleto ou ilegível.

n. $=864$

No gráfico acima é possível vislumbrarmos o número maior de presos jovens portugueses do que brasileiros, principalmente no que se refere à idade de 13 a 17 anos, quando se verifica quase o triplo. Abaixo podemos verificar os motivos de prisão dos presos de nacionalidade portuguesa. Cabe ressaltar que foram analisados todos os registros de nossa amostragem que tinham como motivo de prisão a expressões "vadios, vagabundos, ratoneiros e/ou turbulentos". A tabela abaixo demonstra que $51 \%$ dos presos de nacionalidade portuguesa foram para prisão por 
serem classificados pela polícia única e exclusivamente como vagabundos. Os outros motivos de prisão apareciam, às vezes, associados ao termo vagabundo ou eram classificados como vadios, ratoneiros, desordeiros e turbulentos.

Tabela 4. Motivo da prisão dos presos de nacionalidade portuguesa

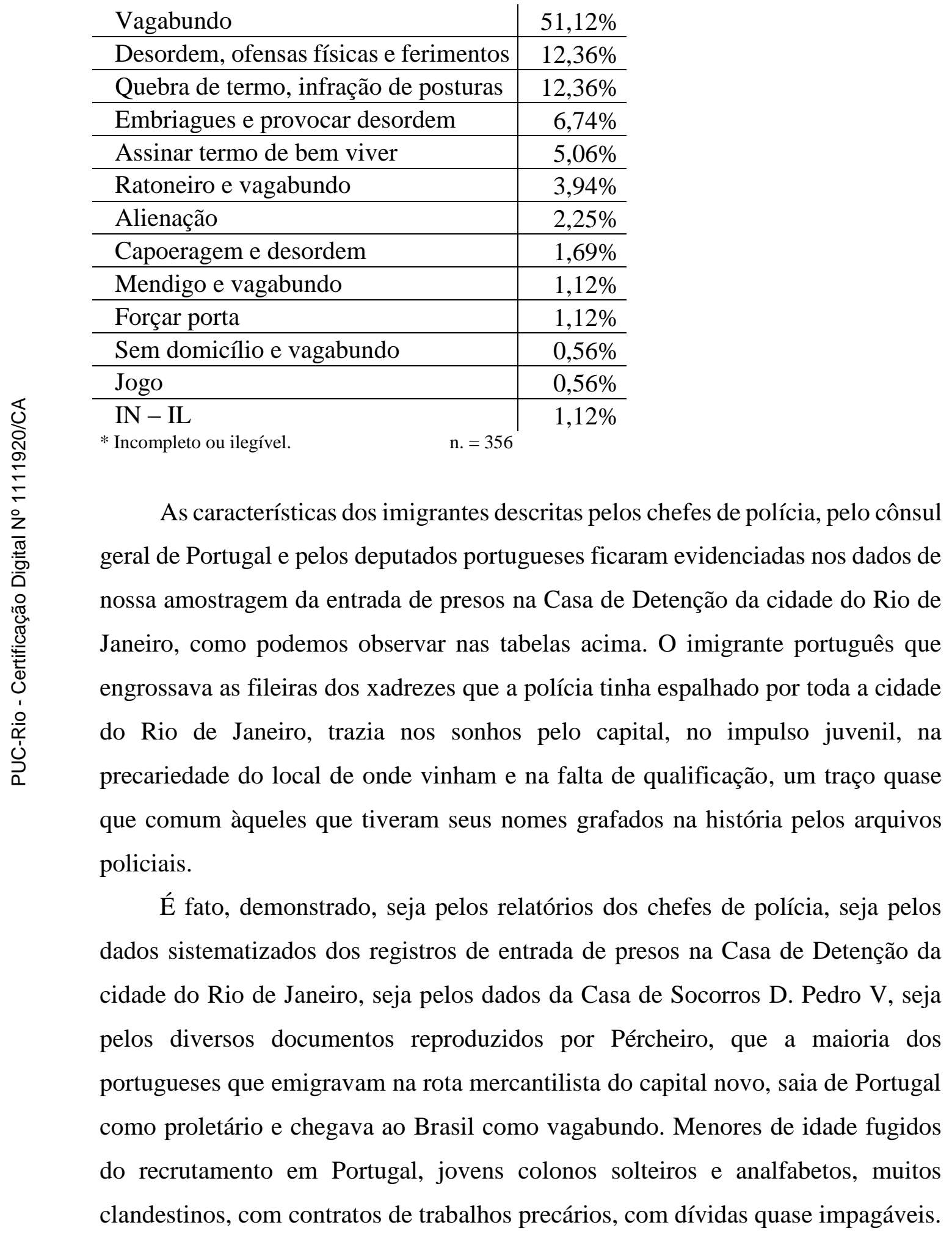


Rapidamente perdiam os vínculos de trabalho, que muitas vezes se quer existiam da maneira como fora contratado nos portos portugueses.

De um lado, os engajadores que "apregoam phantasias e do outro as companhias e os capitalistas a protegel-os" (Pércheiro, 1878, p. 43) colocavam o proletariado português a viverem o sonho do capital novo ao lado da ética do trabalho produtivo e da reprovação da vadiagem. A virtude do trabalho como contraponto do vício da vadiação pode ser verificada no final do século XVII nas Ordenações Filipinas que "determinavam que os vadios, 20 dias após chegaram a qualquer cidade, vila ou lugar, deveriam ser presos e açoitados se não arranjassem ocupação" (Silva, 1994, p. 813). A autora afirma que o recrutamento de jovens "era a melhor forma de transformar em utilidade o peso dos vagabundos sobre o corpo social, consoante a mentalidade crescente capitalista" (Silva, 1994, p. 813). Neste aspecto, é possível vislumbrar mais um ponto de contato entre o vagabundo no Brasil e em Portugal na época focada em nossos estudos, qual seja: o fato de que o recrutamento usado em Portugal para prevenir a vadiação foi o motivo de muitos jovens de 14 anos emigrarem de maneira clandestina, o que os transformavam em "vagabundos" ao aportarem no Brasil.

Por este viés, fica evidente a maneira como a internacionalização da questão social estabelece um ponto de confluência entre o Tejo e a Guanabara via contrato liberal de trabalho. Contrato que ao não dar garantias para o trabalhador que vendia sua força de trabalho empurrava este, em sua chegada ao Rio ou logo após a esta, para uma transfiguração de trabalhador em vagabundo. Por estes motivos e pelo fato do incentivo oficial da imigração branca como meio de qualificar o trabalhador e realizar o processo de branqueamento da sociedade ou a forma jurídica sobre a qual o imigrante era tratado, que não poderíamos falar, como Pércheiro e outros autores da época, - ou mesmo historiadores atuais - em escravidão branca, mas sim na transfiguração de trabalhadores em vagabundos. As relações de trabalho se davam via contrato, sob os moldes do liberalismo, visto que, sendo abusivo ou não, sua relação de venda ou aluguel da força de trabalho era baseada num contrato de princípios liberais.

A defesa dos princípios liberais se dava tanto pelos chefes de polícia, como veremos adiante, bem como por Pércheiro. Segundo nosso autor português "póde- 
se dizer, sem medo de errar”, que somente após a expulsão dos jesuítas, ${ }^{87}$ em 1759, "que começou florescer o Brazil". A reforma pombalina havia expulsado os jesuítas de todos os domínios de Portugal por considera-los "inimigos do progresso da pátria" (Pércheiro, 1878, p. 95). As consequências dessa expulsão, de acordo com nosso autor português, foram "iminentemente favoraveis e proveitosas aos povos". Pércheiro em sua defesa enfática do liberalismo afirmava que

as idéas liberaes proclamadas pela França, foram pouco a pouco fazendo echo nos differentes povos da Europa; e Portugal, um dos paizes mais livres, sendo um dos primeiros a tomar-lhe o exemplo, teria feito hoje dos seus antigos dominios brazileiros uma nação essencialmente liberal (Pércheiro, 1878, p. 94).

O liberalismo aprece sobre vários aspectos, entre eles, na defesa de Pércheiro sobre os mecanismos de controle da emigração nos portos portugueses, como vemos a seguir:

a inspecção da emigração não é cousa nova. Está estabelecida nos paizes mais adiantados e se o Brazil a não estabeleceu, como já fez a America do norte, é porque n'aquelle paiz como em Portugal não se estuda a serio estes assumptos economicos. Á America do norte não comvem o engajamento forçado, isto é, a illusão. Á America do norte comvem que a introducção dos colonos seja feita com a maxima liberdade, por que nos processos liberaes do engajamento está a riqueza dos grandes nucleos da emigração e por consequencia do paiz que acolhe os emigrantes (Pércheiro, 1878, p. 26).

O nosso autor português acusa o Brasil de não ser liberal. Neste sentido, afirma que os brasileiros ilustres que defendem a imigração deveriam apontar ao governo imperial "as disposições liberaes das leis americanas, que fazem dos Estados-Unidos um paiz livre, dirigido por cidadãos e não por jesuitas" (Pércheiro, 1878, p. 21). Como meio de demonstrar que o Brasil era avesso ao liberalismo e exortar ao colono português que não imigre escrevia Pércheiro (1878, p. 56), que

aroça no imperio do Brazil, segundo diz o author das Farpas, é como em Portugal o banco. É ella que faz a lei, a justiça e o direito. Com uma pequena differença nos resultados d'esta influencia do capital e da propriedade no Brazil e em Portugal: é que em Portugal é contrastada pelas benéficas rezistencias de alguns milhares de cidadãos que mantem a liberdade por meio da independencia facultada pelo

${ }^{87}$ De acordo com Pércheiro " $n$ o meado do seculo XVIII eram elles, por assim dizer, os principaes senhores das vastissimas regiões brazileiras. O governo da metropole tinha sido até então impotente contra a força dos sectarios de Loyola" (Pércheiro, 1878, p. 93). 
trabalho; no Brazil não, porque no Brazil quem trabalha é o escravo, e a quantidade chamada povo não existe.

O imigrante português saía da Europa, iludido ou não, com um contrato de trabalho assinado, ainda que este contrato o transformasse num devedor de um pecúlio impagável ${ }^{88}$. A condição de escravidão branca, como muitos apregoavam ao colono português imigrante no Brasil, se configurava pela impossibilidade de pagar a dívida adquirida, pelas cláusulas abusivas do contrato, pela arbitrariedade das autoridades brasileiras e/ou pela condição de clandestinidade. Os argumentos de Pércheiro que imputavam ao imigrante português a condição de escravo branco não se referiam diretamente a sua condição de liberdade, mas pelo fato de que a liberdade do imigrante português pobre que vinha para o Brasil, através de contrato de trabalho, significava a falta de qualquer "direito" ou "seguridade social", a qual o escravo "usufruía", tendo comida e acesso a saúde, por ser um "bem" e não força de trabalho. Muitos dos argumentos que concorriam para a afirmação de que acontecia com o imigrante português pobre uma espécie de escravidão branca se relacionava diretamente a "Lei Brazileira n. ${ }^{\circ} 108$ de 11 de outubro de 1837 " que legislava sobre as providências a serem tomadas em relação aos contratos de locação de serviços de colonos estrangeiros. Segundo Pércheiro, "o consul no Rio de Janeiro descreve os efeitos praticos da tal monstruosidade" dos contratos de locação da força de trabalho. No documento reproduzido por Pércheiro, o cônsul de Portugal relata que os brasileiros não "quizeram [a lei n. 108 de 11 de outubro de 1837] para regular a locação de serviços de seus compatriotas, e só a destinaram a regular a locação de serviços dos estrangeiros" (Pércheiro, 1878, p. 14). A referida lei em seu artigo primeiro legislava que:

o contrato de locação de serviços celebrado no imperio ou fóra, para se verificar dentro d'elle, pelo qual algum estrangeiro se obrigar como locador, só póde provarse por escripto se o ajuste fôr tratado com interferencia de alguma sociedade de colonisação reconhecida pelo governo no municipio da côrte, e pelos presidentes nas provincias. Os titulos por ellas passados, e as certidões extrahidas dos seus livros terão fé publica para prova do contrato.

${ }^{88}$ É preciso levar em conta que na época - a segunda metade do século XIX - os direitos sociais relativos à venda da força de trabalho pelo proletariado ainda careciam de muitas lutas internacionais que vieram a posteriori. 
O nome de locador imputado a aquele que aluga sua força de trabalho como consta no primeiro artigo da citada lei, demonstra que por mais que tenha cláusulas abusivas na lei do Império brasileiro que regulava o contrato de trabalho de colonos, trata-se de uma relação liberal de trabalho e não escravocrata. Ao analisar mais atentamente o artigo inicial da lei $n .^{\circ} 108$ de 11 de outubro de 1837, percebemos que era o colono português que se obrigava como locador de sua força de trabalho, sem qualquer ato alheio a sua vontade que o levasse compulsoriamente a trabalhar como imigrante do outro lado do atlântico. Tratava-se da mesma relação capital trabalho do chão de fábrica, pois nos dois casos era da força de trabalho enquanto mercadoria que se tratava. O próprio modo locador para se referir nos contratos ao imigrante que vende antecipadamente sua força de trabalho, demonstra que esta já se tornou mercadoria.

A referida lei propiciava munição para as críticas de Pércheiro, seu brado muitas vezes se dirigia ao artigo sétimo, o qual impunha que: "será justa causa para a despedida" em caso de "doença do locador, por fórma que fique impossibilitado de continuar a prestar os serviços; condemnação do locador á pena de prisão; embriaguez habitual do mesmo; injuria feita pelo locador; se mostrar imperito no desempenho do serviço" para o qual foi contratado. Neste sentido, Pércheiro (1878, p. 140) afirmava que:

á parte a desigualdade da pena, por que não pode equiparar-se o delicto de um colono cahir doente, com a falta que levára outro colono a ser julgado $e$ condemnado a prisão, perguntamos nós, como poderá qualquer d'elles exonerar-se dos seus encargos, quando lhes faltem absolutamente os meios? O escravo era muito mais feliz. Pelo menos tinha a comida certa, quando impossibilitado de trabalhar. O senhor era o primeiro interessado na liberdade do escravo, quando este era preso por ter commettido algum delicto.

Cabe ressaltar que no artigo oitavo a lei citada legislava que o locador, ou seja, o colono imigrante português, ao ser demitido por justa causa, nos motivos apresentados acima, deveria indenizar o locatário de seus serviços pelo tempo que restasse no contrato firmado. Este artigo obrigava o locador a pagar ao locatário

tudo quanto dever, e se não pagar logo, será immediatamente preso e condemnado a trabalhar nas obras publicas por todo o tempo que fôr necessario, até satisfazer com o producto liquido de seus jornaes tudo quanto dever ao locatario, compreendidas as custas a que tiver dado causa. 
O artigo nono é ainda mais contundente e impunha ao

locador, que, sem justa causa, se despedir, ou ausentar antes de completar o tempo do contrato, será preso onde quer que fôr achado, e não será solto emquanto não pagar em dobro tudo quanto dever ao locatario, com abatimento das soldadas vencidas: se não tiver com que pagar, servirá ao locatario de graça todo o tempo que faltar para o complemento do contrato.

A legislação do contrato de trabalho para o imigrante privilegiava intencionalmente as obras públicas que transformaram a cidade do Rio de Janeiro em toda a segunda metade do século XIX. Neste sentido é possível observar no relatório de 30 de julho de 1872 do cônsul geral de Portugal no Brasil, reproduzido por Pércheiro, que para sanar as dívidas contraídas os imigrantes portugueses viamse "forçados a renovar os contractos, até que perdida toda a esperança de resgate, fogem, não obstante o risco que correm de serem presos e condemnados a trabalhos publicos, na fórma da legislação que rege a matéria” (Pércheiro, 1878, p. 111). A lei n. ${ }^{\circ} 108$ de 11 de outubro de 1837, transformava qualquer imigrante pobre que não tivesse cumprido o contrato de trabalho, de proletário a vadio e vagabundo.

$\mathrm{O}$ fato dos colonos portugueses pobres que imigravam serem vistos pelos engajadores, autoridades do Império e proprietários de terras como força de trabalho, de maneira como explicita a referida lei - apesar das arbitrariedades contidas nela, pela visão de hoje - e em momento algum ser tratado como um "bem", que poderia ser comercializado, mas como força de trabalho que podia ser alugada, demonstra que não podemos falar tal qual afirmava nosso autor português, que houve escravidão branca no Brasil aos critérios da escravidão que havia na época. Processava-se aqui, guardadas as devidas especificidades, os abusos e arbitrariedades que durante todo o século XIX pautaram as lutas dos proletários do mundo em busca de seus direitos sociais. $\mathrm{O}$ engajamento se colocava muito mais no repertório das regras abusivas da venda de força de trabalho que imperava no século XIX, justificado juridicamente pela doutrina liberal, seja no Brasil ou em Portugal, do que por qualquer aspecto de base escravocrata.

A questão do trabalho urbano estava posta na cidade cosmopolita que era o Rio, já no século XIX. Este aspecto pode ser observado na descrição de Pércheiro (1878, p. 47), segundo o qual "o colono trabalhador que antes de partir para a America se occupava na cultura dos nossos fertilissimos campos, vae occupar no 
Brazil o logar de aguadeiro, carroceiro, catraeiro, ou na immensa deversidade de serviços que entre nós costumam fazer os filhos da Galliza". Os dados sistematizados de nossa amostra de registros de presos na Casa de Detenção da cidade do Rio de Janeiro relativos à ocupação dos presos por vadiagem com nacionalidade portuguesa abonam a afirmação de Pércheiro. Segundo nossa amostra, $21,9 \%$ dos portugueses presos por serem classificados como vagabundos tinham no campo ocupação a indicação genérica de trabalhador e 12,9\% de caixeiro. Após estas, aparecem as ocupações de carroceiro, ferreiro, marinheiro e padeiro que juntas representam $15,7 \%$ do total de nossa amostragem. Em seguida verificamos as ocupações de marítimo, pescador charuteiro cuja soma representa 9,55\% da amostra pesquisada. Ainda podemos destacar outro grupo de ocupações, alfaiate, cozinheiro, mascate, pintor, catraeiro, servente, quitandeiro e pedreiro que juntas abarcam 18,57\% dos dados sistematizados em nossa amostragem. Outras profissões aparecem em nossa amostragem, tais como: sapateiro, tamanqueiro, tipógrafo, ajudante de cozinha, carregador de caixas, chapeleiro, cigarreiro, cocheiro, comerciante, compositor, copeiro, criado, etc.. Este aspecto do tipo de ocupação confirma que o colono português imigrante estava complemente relacionado à dinâmica econômica e social do cosmopolitismo do Rio de Janeiro e não tinha quase ou nenhuma identificação com a roça.

Pérchero ainda destacava que "ha outro colono - o artista - que reune mais algumas economias, porque os lucros são outros" (Pércheiro, 1878, p. 47) e que "ha ainda outro colono, além do trabalhador e do artista - o comerciante - que sae da sua aldeia com a ideia de ser caixeiro no Brazil” (Pércheiro, 1878, p. 48). Nosso autor combatia a emigração para o Brasil "quer os colonos se dediquem ao trabalho braçal, ao commercio ou á indústria" (Pércheiro, 1878, p. 50), pois acreditava que

o europeu, uma vez chegado ás margens d'esse paiz de fadas, convertido no que realmente é - cemiterio do proletário - vê-se na impossibidade de empregar as suas já quebrantadas forças, por effeito do clima, no serviço arduo de arrotear aquellas terras, que por todos espalha o desanimo e a morte (Pércheiro, 1878, p. 73).

Além destes aspectos presentes nas características da imigração portuguesa para o Brasil na época focada por nosso estudo, alguns fatos seriam considerados por Pércheiro como confirmadores de todos os seus argumentos contra emigração 
para o Brasil. Neste sentido poderíamos destacar o suicídio do português João José Gomes Braga que ao ser perseguido pela polícia cometeu insano ato. E talvez o exemplo mais contundente contato por Pércheiro que evidencia toda a discussão acima - acerca da transformação de proletários em vagabundos - é a história de Joaquim de Sequeira Pinto que emigrou do Porto com sua mulher Josepha de Jesus no vapor Julio Diniz, chegando ao Rio de Janeiro em novembro de 1873 para trabalhar na fábrica de fiação em Santo Aleixo, Magé cujo

administradores os srs. Guerreiro Simas \& $C^{a}$, a quem vamos dirigidos, e a estes nos obrigamos com os nossos serviços na mesma fabrica a pagar a quantia de cento e trinta e oito mil e nove centos réis, que nos foram abonados para as nossas passagens e mais arranjos, a cujo cumprimento nos obrigamos por nossas pessoas e bens (Pércheiro, 1878, p. 144-5).

Ao chegar ao porto do Rio de Janeiro foram encaminhados para tal fábrica que estava ainda em construção, com isto passaram a trabalhar de servente de pedreiro e doméstica. Como foram contratados por suas habilidades técnicas de fiadores de tecidos e estavam insatisfeitos, "pediram licença ao administrador da fabrica para ir para a côrte trabalhar pelo seu officio, a vêr se arranjavam dinheiro para pagar o quedeviam" (Pércheiro, 1878, p. 143), o que fora concedido.

\begin{abstract}
Passaram-se dois ou tres mezes, portanto, sem que podessem ter arranjado dinheiro para pagar a divida. Começava o marido a trabalhar pelo officio, quando foi preso com a mulher, em virtude d'uma precatoria vinda do juiz de paz de Magé, e lá seguiram os dois infelizes com um filhinho, de cadeia em cadeia até á de Magé, para alli serem processados por quebra de contracto de locação de serviços.
\end{abstract}

A imaginária ponte do Tejo a Guanabara se concretizava via burocracia, relações sociais, justiça, economia, assistência e histórias de vidas. Segundo as vozes unânimes dos chefes de polícia, no período estudado, e o nosso autor português a solução, seja para evitar a emigração, seja para prevenir os vadios e vagabundos, tanto aqui, quanto lá era a educação. Na tentativa de responder "quaes são as razões que induzem o portuguez a emigrar para o Brazil", Pércheiro (1878, p. 10) afirmava que a ambição é o pior dos males e contra este somente a educação seria eficaz. De lugares diferentes, porém a partir de uma mesma perspectiva liberal, os chefes de polícia da cidade do Rio de Janeiro e nosso autor português chegavam a uma mesma equação, a qual imputava à educação um proficiente antídoto contra 
a ambição que levava os colonos a emigrarem e os trabalhadores a buscar o ganho fácil pela vadiagem. No relatório publicado no ano de 1872 o chefe de polícia da corte reafirma a causa da ambição como o motor dos imigrantes pobres e jovens, segundo tal autoridade a "observação prova tambem que o espirito de aventuras é mais próprio da idade juvenil" e que é "innegavel que um espirito aventureiro esta mais exposto aos raios da desgraça, porque não são muitas as vezes que a fortuna corôa-lhe os desejos, que facilmente degenerão em ambição" ${ }^{" 89}$. Pécheiro explicava também pela chave da educação a pobreza na qual estava inserida a maioria dos portugueses emigrados para o Brasil. Ao contrário, aponta Silva (1990, p. 36) que ao analisar o tema os dirigentes da Caixa de Socorros de D. Pedro V imputavam a culpa ao "sistema de imigração e colonização", visto que, segundo estes dirigentes a maioria dos socorros aos portugueses pobres foram feitos para aqueles que vieram engajados. A pobreza tanto aqui quanto em Portugal era a pauta que cerzia a necessidade de modernização do Estado. No Brasil esta modernização significava, entre outras coisas, civilizar a cidade do Rio de Janeiro e por este viés construir a nação. $\mathrm{O}$ intento de civilizar a cidade passava pela ordenação, na qual os vadios e vagabundos representavam importante problemática a ser combatida.

No liame desta fronteira imaginária Portugal e Brasil se entrelaçam de maneira íntima, de modo que Estado e nacionalidade se confundem com língua e cultura na formação da parcela chamada "povo". A necessidade de fundar uma tradição, que não fosse lusitana, e elevar o país aos graus da civilização, garantiu ainda mais pólvora para os que enxergavam nos imigrantes pobres a representação dos vadios e vagabundos, um entrave para o ordenamento da cidade do Rio de Janeiro. A relação entre progresso e tradição, contrapunha a criação da nação ao modelo português, visto que, este era a referência do atraso. Nesta chave enxergamos o paradoxo que representava o imigrante português, pois ao mesmo tempo em que o governo brasileiro incentiva a imigração, as autoridades policiais enxergavam no fluxo destes pobres proletários o gene dos crimes de vadiagem e a formação de um tipo de vadio. Este paradoxo que se interpunha no conflito entre imigrantes portugueses e os brasileiros na conformação de uma sociedade via modelo liberal pode ser visualizada na publicação do jornal "Commercio a Retalho" de Pernambuco:

${ }^{89}$ BRASIL. Ministério da Justiça. Relatório do ano de 1871. Rio de Janeiro. Typographia Nacional, 1872 p. A-172. 
o que contribue directamente para que o povo, habitando n'um paiz tão fertil, viva opprimido pela miseria, são duas causas - a estupida, anti-patriota gestão dos negocios publicos, e o commercio a retalho ser exclusivo dos portuguezes! Se desde que organisou-se o governo brazileiro, este tivesse tratado de preparar o paiz, por meio de reformas liberrimas e economicas, por certo que hoje não teriamos de lamentar tantas vexações e desgraças: não teriamos de ver só portuguezes no commercio (Pércheiro, 1878, p. 244).

Estava posta a questão social entre o Tejo e a Guanabara. Desta maneira, fica evidente o internacionalismo das relações de trabalho nos dados apresentados, da mesma maneira que é possível vislumbrar a especificidade da questão social na formação da classe de trabalhadores assalariados e suas relações com a formação do campo da assistência social. Cabe ressaltar que a formação da classe de trabalhadores livres se dava concomitantemente com a existência de um estatuto escravocrata que garantia o cativeiro, ainda que no momento de nossa análise, a partir da década de 1870, este modelo estivesse cambaleante. Ao percebemos que em plena vigência da escravidão existia uma lei - de 1837 - que regulava o contrato de locação de serviços de colonos estrangeiros monstra a incongruência que é pensar o Brasil exclusivamente sobre qualquer chave analítica criada no velho mundo.

Importante destacar que o campo da assistência social que se constituía no século XIX na cidade do Rio de Janeiro, teve o imigrante pobre, principalmente o português como o principal beneficiário, seja pelo mutualismo, seja pela igreja, seja pelas inciativas de governo. A regeneração pela via do trabalho e pela educação, promovidas por instituições governamentais, religiosas e particulares não eram destinadas aos escravos, muitos menos aos seus filhos após a lei do ventre livre, por exemplo. Era para o imigrante europeu que existia o projeto de nação via formação da classe de trabalhadores livres assalariados, para este também, o branco urbanizado, que foi pesando primeiramente as práticas de ajuda e apoio, as formas de previdência e a conformação dos direitos sociais no Brasil. A preocupação com os imigrantes pobres era diferente das preocupações com os escravos, aqueles estavam incluídos no projeto de nação, para aqueles se promovia a assistência e, ainda que timidamente, conquistavam direitos sociais e buscava-se a inclusão via 
trabalho assalariado, para estes - os escravos - só lhes restavam a negação de pertencimento ao projeto de nação, mesmo após a abolição.

\subsection{A seguridade do social}

Talvez pelo fato de que a primeira constituição da República (1891) não faça nenhuma menção sobre qualquer aspecto do que hoje chamamos de seguridade social e o primeiro decreto considerado como propulsor da previdência social no Brasil seja a Lei Elói Chaves de $1923^{90}$, não se leve em consideração as outras iniciativas como forças sociais transformadores para a conquista deste aspecto da seguridade social. Pretendemos enxergar pelo viés que privilegia os movimentos da sociedade, de modo a entender sua dinâmica e seus modos de deslocamento ou de inércia. No devir da sociedade e na dimensão das relações sociais e econômicas, que pretendemos transitar, é possível vislumbrar a existência de aspectos previdenciários para uma determinada classe de trabalhadores urbanos brancos no século XIX.

Ao verificar a incidência histórica dos montepios e caixas de pensão observamos que não se constitui em equívoco falar em previdência via Estado e/ou sociedade desde o século XVIII ${ }^{91}$. Nas iniciativas particulares é datado do século $\mathrm{XVI}^{92}$ o início da atividade previdenciária no Brasil. No entanto, é no século XIX

\footnotetext{
${ }^{90}$ Decreto no. 4.682 de 24 de janeiro de 1923. Segundo Lima (2007, p. 20) "inicialmente, essa lei criou Caixa de Aposentadoria e Pensões para os funcionários de cada empresa ferroviária. Essa Caixa deveria fornecer ajuda médica, aposentadoria, pensões para os dependentes e auxílio funerário. Posteriormente, o regime da Lei Elói Chaves foi estendido aos portuários e marítimos, aos trabalhadores de serviços telegráficos e radiotelegráficos. Em 1931, esse regime foi finalmente estendido aos empregados dos demais serviços públicos, além disso, a legislação referente às Caixas de Aposentadorias e Pensões foi consolidada. Nos anos que se seguiram, mais classes profissionais foram incluídas no regime da Lei Elói Chaves, como mineradores, trabalhadores de empresas de transporte aéreo. Em 1932 se iniciou a institucionalização dos Institutos de Aposentadorias e Pensões, que eram de âmbito nacional. E a Constituição de 1934 considerou vários tipos de assistências e seguros, inclusive acidentes de trabalho.

${ }^{91}$ Como, por exemplo, o alvará de 23 de setembro de 1795 que aprovou o Plano de Montepio dos Oficiais da Armada Portuguesa.

92 "O início da atividade previdenciária no Brasil foi no século XVI quando houve um intenso surgimento de misericórdias, que evoluiriam para os montepios. O primeiro montepio foi constituído em 1543 quando Brás Cubas, ao criar a Santa Casa de Santos, instituiu um plano de pensão para seus empregados. Várias classes profissionais, que à época eram socialmente importantes, também instituíram seus montepios" (LIMA 2007, p. 18).
} 
que o governo aprofunda os sinais de preocupação com os aspectos previdenciários e institui diversas caixas de pensão como descrevemos abaixo.

Em $1821^{93}$, foi elaborado o primeiro texto legal, relativo à previdência social no Brasil. Por decreto de $1^{\circ}$ de outubro daquele ano Dom Pedro I concedia aposentadoria aos mestres e professores com 30 anos de serviços. No ano de 1835 foi aprovado por decreto imperial "o Plano do Montepio de Economia dos Servidores do Estado, como a primeira previdência privada no país”. Em 1888, foi "regulamentado o direito à aposentadoria dos empregados dos Correios com 30 anos de serviço e idade mínima de 60 anos". No ano da abolição, 1888 foi criada a “Caixa de Soccorros para os Ferroviários das Linhas do Estado". No ano de 1889, tanto o Império, quanto a República criaram fundo de pensões. O primeiro criou o Fundo de Pensões para os Tipógrafos da Imprensa Régia e, o segundo, o Fundo de Pensões do Pessoal das Oficinas da Imprensa Nacional. Um dos primeiros decretos republicanos foi a aprovação dos Estatutos do Montepio Popular. Ainda podemos citar o decreto $\mathrm{n}^{\circ} 221$ de 1890, que instituía a aposentadoria para os empregados da estrada de ferro Central do Brasil. Esta aposentadoria foi estendida a toda a categoria dos ferroviários pelo decreto $\mathrm{n}^{\circ} 565$ do mesmo ano. Este decreto de 12 de julho de 1890 instituída para todos "aos empregados de todas as estradas de ferro geraes da Republica, em trafego ou em estudos" terem direito a "aposentadoria nas condições estabelecidas, em relação aos empregados da Estrada de Ferro Central do Brazil, no regulamento approvado pelo decreto n. 406 de 17 de maio de 1890"94. Os operários do arsenal de marinha do Rio de Janeiro passaram a ter direitos, pela lei $\mathrm{n}^{\circ} 217$ de 1892, a aposentadoria por invalidez e a pensão por morte. Ainda no século XIX, mais precisamente no ano de 1894 "foi proposto o primeiro Projeto de Lei sobre seguro contra acidentes do trabalho". Para ser aprovado só em 1919 o Decreto Legislativo $\mathrm{n}^{\circ} 3.724$, a primeira "lei sobre acidente do trabalho, cujo conceito é o mesmo dos tempos atuais". Em 1923 o decreto $n^{\circ} 4.682$, de 24 de janeiro, conhecido como Lei Eloy Chaves, considerado o marco inicial da

\footnotetext{
${ }^{93}$ As informações de decretos e datas deste parágrafo, bem como, todo o texto entre aspas tem como fonte: JB Serra e Gurgel. Evolução Histórica da Previdência Social. Pesquisa cronológica de dispositivos constitucionais, Leis Complementares, Leis, Decretos, Decretos-Lei; Medidas Provisórias, Legislação Constitucional e Infraconstitucional. Brasília, FUNPREV, Fundação ANASPS, 2008.

${ }^{94}$ Coleção de Leis do Brasil - 1890, Página 1510 Vol. Fasc. VII (Publicação Original). Disponível em: <http://www2.camara.leg.br/legin/fed/decret/1824-1899/decreto-565-12-julho-1890-532108publicacaooriginal-68829-pe.html> Acesso: 06 jun. 2014.
} 
Previdência Social no Brasil; era na verdade um aperfeiçoamento da lei $\mathrm{n}^{\circ} 565$ de 12 de julho de 1890, que dispunha sobre o mesmo objeto.

Como podemos observar, a questão previdenciária estava posta e já se configurava no Brasil no século XIX, suas formas de financiamento ${ }^{95}$ e cobertura estavam bem definidas e estas questões eram pautas recorrentes das lutas de trabalhadores, onde mais uma vez se evidencia a luta de classe. Cabe destacar a criação do Montepio Popular em 1890. Segundo o Jornal do Comércio em sua edição de 02 de março de 1890, "esta instituição moralizadora e tutelar vem suprir a falta do antigo Montepio Geral que liquidou-se por engano de cálculo nas joias e pensões".

A esse respeito destacamos alguns exemplos encontrados nos relatórios do ministério da justiça pesquisados. No relatório referente ao ano de 1889, o ministro Dr. Manoel Ferraz de Campos Salles nos informa que "foi instituído o montepio obrigatório dos empregados do Ministério da Justiça, pelo decreto n. 956 de 6 de Novembro findo, 9 dias antes da proclamação da republica" ${ }^{\text {"96 }}$. Depois este montepio foi regulado na República pelo decreto n 942 A, de 31 de outubro de $1890^{97}$. No relatório referente aos anos de 1905 e 1906, encontramos, em anexo, extenso estudo realizado pelo Dr. Hilário de Gouveia sobre as leis alemãs de seguro obrigatório dos operários, baseado nas discussões ocorridas na conferência internacional de Berlim sobre a tuberculose. Defendia Dr. Hilário de Gouveia que, tal qual as leis alemãs, o Brasil deveria ter seguro obrigatório para o "operário contra as moléstias, os acidentes de trabalho, a invalidez e a velhice" ${ }^{98}$. Como meio de demonstrar a questão previdenciária gerida pelo Estado, podemos ainda verificar no relatório do Ministério da Justiça referente aos anos de 1916 e 1917 que "por decreto de 14 de junho foi aposentado João Burgos" "99, ajudante do diretor da Casa

\footnotetext{
${ }^{95}$ Podemos citar como exemplos: a "Lei no 90, de 29 de outubro de 1835, concedeu quatro loterias anuais de cem contos de réis cada uma, por espaço de seis anos, a favor do Montepio Geral dos Servidores do Estado. Dom Pedro II concedeu, pelo Decreto no 749, de 12 de julho de 1854, o usufruto do próprio sítio na Travessa das Bellas Artes, no Rio de Janeiro, que era o edifício sede do Montepio Geral dos Servidores do Estado, que nesta época já pagava 1.095 pensões a famílias de servidores civis e militares" (Fundação ANASPS, 2008).

${ }^{96}$ BRASIL, Ministério da Justiça Relatório 1889, publicado em 1891, p. 23.

${ }^{97}$ BRASIL. Ministério da Justiça e Negócio Interiores. Relatório dos anos de 1925 e 1926. Rio de Janeiro. Imprensa Nacional, 1928, p. S2-129.

${ }^{98}$ BRASIL. Ministério da Justiça e Negócio Interiores. Relatório dos anos de 1905 e 1906 - Volume 02. Rio de Janeiro. Imprensa Nacional, 1906b, p. A-G-15.

${ }^{99}$ BRASIL. Ministério da Justiça e Negócio Interiores. Relatório dos anos de 1916 e 1917. Rio de Janeiro. Imprensa Nacional, 1917, p. 72.
} 
de Correção. No relatório referente aos anos de 1927 e 1928, podemos ler que a lei $\mathrm{n}^{\mathrm{o}} 13.828$ art. 114 de 14 de novembro de 1919, "concede às famílias dos guardascivis, mortos em serviço, uma pensão correspondente a $2 / 3$ dos seus vencimentos $" 100$, bem como, afirmava categoricamente o ministro da justiça Dr. Augusto de Vianna do Castello que a "aposentadoria a funcionários da União" estava regulada de modo universal para este seguimento pelo "artigo 121 da lei n. 2.924, de 5 de janeiro de 1915, incorporado a legislação pelo art. 132 da lei $n^{\circ} 3.089$, de 8 de janeiro de 1916"101.

Todos estes aspectos relativos a aposentarias, imigração e formação do campo de trabalho livre demonstram que a questão social estava posta aqui em toda a sua dimensão e expressões, com nossas particularidades, de modo concomitante com a Europa. Afirmar que a questão social no social no Brasil, entendida como a luta de classes pela construção de direitos sociais, só se realizam a partir dos anos 1930, de certo modo é desconsiderar ou reinterpretar, por um viés estruturalista e evolucionista, as evidências e os fatos históricos acontecidos na cidade do Rio de Janeiro. Não tenho a pretensão de dissecar a questão teórica, que envolve o conceito de questão social no Brasil, mas buscar as dimensões deste conceito que se relaciona aos argumentos defendidos em nossos estudos sobre a polícia na formação da assistência social na cidade do Rio de Janeiro. Importante destacar, que agrupamos nosso ponto de vista com aqueles que acreditam que as noções e conceitos não devem subestimar a dinâmica viva da sociedade, através da qual podemos elaborar novos conceitos, reveladores de uma dada realidade. Neste sentido, afirma Thompson (1981, p. 17)

que conhecimentos se formaram, e ainda se formam, fora dos procedimentos acadêmicos. E tampouco eles têm sido, no teste da prática, desprezíveis. Ajudaram homens e mulheres a trabalhar os campos, a construir casas, a manter complicadas organizações sociais, e mesmo, ocasionalmente, a questionar eficazmente as conclusões do pensamento acadêmico.

De modo algum há aqui a desconsideração de que as forças produtivas de uma determinada base econômica produzem uma superestrutura ideológica, mas percebemos um processo dialético, no qual, sob determinadas condições, a vontade

\footnotetext{
${ }^{100}$ BRASIL. Ministério da Justiça e Negócio Interiores. Relatório dos anos de 1927 e 1928 . Rio de Janeiro. Imprensa Nacional, 1930, p. 205.

${ }^{101}$ Idem, p. S1-89.
} 
de homens, grupos ou classes sociais age intencionalmente a partir dos elementos e expressões relativos à superestrutura capaz de interferirem na estrutura, visando a sua modificação ou a sua manutenção. Por este viés, buscamos entender o jogo servidão-resistência que a estética do mundanismo aplicou as estratégias de sobrevivência dos pobres na urbanidade da cidade do Rio de Janeiro.

É fato e podemos demonstrar, que mesmo diante de uma cadeia de acontecimentos que expressam o cosmopolitismo é possível identificar uma diversidade de forças sociais que imprimem a necessidade de pensarmos nossa sociedade desvinculada do determinismo de um único fator, cuja exclusão enclausura os demais acontecimentos com resultantes do primeiro. Ao entender que a questão social no Brasil está colocada apenas a partir da organização dos trabalhadores ligados ao chão de fábrica, inevitavelmente associa-se ao pensamento desenvolvimentista, gênese de uma tradição acadêmica que influenciou os intelectuais de esquerda no Brasil. Vislumbrar a questão social no Brasil como questão de política somente a partir de 1930 é tratar a questão social como questão operária. Desconsiderar a organização dos trabalhadores brasileiros e estrangeiros no Rio de Janeiro no século XIX é de certa maneira enxergar, pelo viés estruturalista, a dinâmica de formação do Estado-nação.

Ao entendermos que a questão social está posta politicamente somente a partir de 1930 pelo fato da organização dos trabalhares da indústria, do impulso da industrialização e de um Estado como gestor de uma previdência social, estaremos imputando uma leitura estruturalista ${ }^{102}$ como um método análise desta realidade. Não é intenção nossa retirar o econômico de certa centralidade, já que estamos falando de uma sociedade capitalista, na qual o capital é o valor impositivo nas relações sociais ${ }^{103}$. Estamos pontuando que as questões econômicas no seio da sociedade carioca daquele momento, a divisão do trabalho e os meios de produção no conflito capital $\mathrm{x}$ trabalho não sejam percebidos somente com a formação da

\footnotetext{
102 Estamos nos referindo ao estruturalismo como método de análise, que consiste em construir modelos explicativos, geralmente arquetípicos, as estruturas, presentes nas mais diferentes realidades. O estruturalismo tem sua origem na linguística, mais especificamente no Curso de Linguística Geral, de Saussure e foi apropriado na antropologia por Lévi-Strauss, na psicanálise por Lacan e na interpretação da teoria social de Marx por Althusser, entre muitos outros autores. De certa maneira o estruturalismo impregnou todas as searas das humanidades, de modo que, não é possível tratar de qualquer assunto no campo das ciências sociais e psicologia sem abordá-lo, nem que seja para negar seus princípios.

${ }^{103}$ Neste sentido afirma Quiroga $(1989$, p. 6) que "uma segunda distorção diz respeito a um Marxismo reduzido ao entendimento do desenvolvimento da sociedade como produto reflexo da infraestrutura material sobre a superestrutura, supervalorizando a determinação econômica".
} 
classe operária. Ao vislumbrarmos o Rio de Janeiro como foco de nossas análises sobre a questão social, não podemos usar somente a lógica do chão de fábrica para entender a relação capital x trabalho.

Pensar na assistência social somente a partir de década de 1930, nominando tudo que há anterior a isto de "protoforma" é de certa forma reafirmar uma posição positivista e evolucionista da história. Como se fosse necessário passar por fases inevitáveis, ou ter o mesmo cenário para se atingir determinado processo evolutivo ou de progresso social. O que, por sua vez, restringe a prática social dos sujeitos em mera reprodutora da história dos meios de produção. De certa forma poderíamos agrupar este tipo de pensamento, tanto na linha da interpretação marxista em Plekhânov ${ }^{104}$, quanto em Adam Smith ou Tavares Bastos ${ }^{105}$. Ainda que o primeiro veja o determinismo econômico pela ótica do proletário e os dois últimos enxerguem este determinismo pelo processo liberal que perpetua a dominação da burguesia. O tipo de visão que considera a assistência social no Brasil somente como "protoformas" antes de 1930 e exclusivamente enxerga a dicotomia capital x trabalhado na formação hegemônica do campo de luta dos trabalhadores do chão de fábrica, acaba, por sua vez, supervalorizando a

\begin{abstract}
determinação econômica, ocultando o que ela tem de fundamental — ser uma relação social historicamente determinada e estabelecida entre os mesmos homens. Esse ocultamento leva a obscurecer, a secundarizar o caráter mutante e histórico da sociedade, provocando o alijamento do homem como sujeito histórico (Quiroga, 1989, p. 13).
\end{abstract}

Desde a geração de 1870 se buscava as causas do atraso do Brasil, traduzido como subdesenvolvimento a partir da década de 1940. Os diagnósticos do atraso no século XIX imputavam o mal ao clima tropical, a alta proporção de população de origem não europeia, a preguiça herdada dos índios, ao fato de ser uma sub-raça mestiça, a tradição católica, a formação ibérica, a instabilidade política e, por fim, já na segunda metade do século XX o conceito de dependência e a ideia de

\footnotetext{
${ }^{104}$ De acordo com Quiroga (1989, p. 13) "segundo Andrew Arato, Plekhânov foi o mais expressivo expoente do polo materialista determinista pois (...) na tradição marxista, ninguém nutriu maior respeito pelo poder de explicação geral da ciência objetiva, ninguém se esforçou mais para colocar os resultados da ciência num sistema materialista que a tudo compreendesse".

${ }^{105}$ Para a dimensão de Tavares Bastos como ideólogo do Estado brasileiro ver: BOTELHO, A. e SCHWARCZ, L. M. Um enigma chamado Brasil. Companhia das Letras. São Paulo, 2009.
} 
capitalismo tardio ${ }^{106}$. Fica evidente como a experiência europeia e principalmente a inglesa, ao falarmos da formação da classe de trabalhadores, serviam como paradigmas para interpretações sobre nossa realidade.

O fato do operário somente ganhar relevância como força política por volta dos anos de 1930, visto que "foi com a industrialização acelerada de inícios do século XX que o transformou em uma das principais forças sociais e políticas de sua época" (Coggiola, 2003) não deve credenciar os argumentos de que a questão social não estava posta anteriormente como questão de política. Neste caso, não podemos nos furtar de citar o clientelismo e o patrimonialismo como categorias de análise fundamentais para entendermos a formação do capitalismo no Brasil. Segundo Coggiola (2003) “o clientelismo e a "patronagem” vigentes excluíam da participação política a imensa maioria dos trabalhadores, não apenas dos escravos".

Do mesmo modo, as discussões sobre a questão social da maneira como a concebe Gisalio Cerqueira Filho (1982), como caso de polícia antes de 1930 demonstra, por um lado que o autor analisa a questão social na perspectiva exclusiva do Estado e, por outro lado, desconsidera a amplitude de ações, para além da mera repressão, que empreendia e significava a polícia antes de 1930. É fato que esta interpretação de Cerqueira Filho diz respeito a ideia de fazer um contraponto entre períodos de maior e menor controle dos grupos militares sobre a República e não de uma análise societária das relações capital-trabalho ${ }^{107}$. A amplitude das ações empregadas pelas instituições policias, que incluía a assistência social, entre outras coisas, permitem afirmar que a questão social era caso de política no século XIX, como demonstraremos nos capítulos a seguir.

\footnotetext{
106 Segundo Coggiola (2003) "É comum afirmar que o movimento operário brasileiro teve um caráter "tardio" (inclusive quando posto no marco histórico latino-americano), tão tardio quanto o próprio capitalismo no país." Mas adiante o autor afirma que "mas, também no Brasil, as primeiras notícias de lutas operárias remontam a 1858, quando tipógrafos do Rio de Janeiro entraram em greve reivindicando aumento de salários. Este fato invalida a perceção comum inicialmente apontada". ${ }^{107}$ Podemos inferir que o ponto de vista de Cerqueira Filho - construído de modo admirável balizou certa hegemonia do modo como se interpreta a questão social no Brasil. Sua interpretação no entanto referia-se aos períodos políticos de maior e menor presença militar no governo.
} 


\title{
3. Pobreza: uma questão de Estado.
}

\begin{abstract}
A verdadeira imagem do passado passa célere e furtiva. É somente como imagem que lampeja justamente no instante de sua recognoscibilidade, para nunca mais ser vista, que o passado tem de ter capturado. "A verdade não nos escapará" - essa frase de Gottfried Keller indica, na imagem que o Historicismo faz da história, exatamente o ponto em que ela é batida em brecha pelo materialismo histórico. Pois é uma imagem irrestituível do passado que ameaça desaparecer com cada presente que não se reconhece como nela.
\end{abstract}

(Tese V. Walter Benjamin apud Löwy, 2005, p. 62)

Neste capítulo trataremos do aspecto central de nossa tese, demonstrando os meandros pelos quais podemos afirmar que a polícia se constituiu ao longo da formação do Estado brasileiro como uma das principais forças que influenciaram diretamente na formação do campo da assistência social na cidade do Rio de Janeiro. Evidenciaremos que as técnicas empregadas no intuito de promover a tranquilidade pública eram mais sofisticadas e muito mais sutis do que o mero emprego da força - conforme é o lugar comum que costumam creditar à polícia no aparelho de Estado. Estas técnicas estavam alinhadas com as modernas teorias científicas da época, bem como, espelhadas em modelos administrativos e organizacionais dos chamados "países cultos".

É evidente a dificuldade de olharmos a polícia - mesmo buscando uma aproximação com os contemporâneos do final do século XIX no Brasil - a não ser pela ótica da repressão através do emprego da força e da violência autorizada pelo Estado. É fato que mesmo dentre a maioria da população da época focada em nosso estudo, seja para imprensa, para elite ou para a parcela chamada povo, e mais ainda por este último personagem, a polícia era vista quase que unanimemente pela via da repressão e do controle pela força, bem como, muitas vezes caracterizada pelo abuso de poder. Da mesma forma, esta perspectiva é predominante nos estudos de historiadores, sociólogos e antropólogos que tem a polícia como objeto, conforme abordado na introdução.

Como ressalva, admitimos previamente que se pudéssemos medir imageticamente os movimentos da sociedade por uma balança, no caso da polícia o caráter repressivo pelo uso da força, para falarmos de forma genérica, se apresentaria como o que mais pesa. Ao analisarmos a representação social da polícia na formação do Estado-nação, seja no Brasil, seja na Europa ou nos Estados 
Unidos é o aspecto repressivo que, sem dúvida, mais se evidencia. Não é intento nosso confrontar os estudos que enxergam o caráter repressivo da polícia como lócus que a representa no aparelho de Estado. Sabemos ser este o caráter predominante da polícia, seja para elite, seja para o povo, no entanto iremos discordar daqueles que imputam à história da polícia como uma única história, restrita ao emprego da violência e, tão somente, como a exclusiva técnica usada por esta instituição na "construção da ordem", na formação do "moderno" e na organização dos Estados-nação. Mesmo levando em conta a afirmação de Hahner (1993, p. 74), segundo a qual “o comportamento da polícia ganhou então o ressentimento e a hostilidade total da classe baixa" no período focado por nossos estudos, não devemos perceber a polícia no Império e na primeira República no Brasil com a ideia de que o único instrumento e técnica policial para a manutenção da ordem - a maneira de "civilizar" a cidade do Rio de Janeiro - era o emprego da força e da violência como monopólio do Estado. É fato, porém, que este era o aspecto que mais sobressaia na ação do corpo policial e o que mais a caracterizava diante da classe baixa e dos trabalhadores de forma geral; o ordenamento da cidade pelo emprego da força ${ }^{108}$. Ou ainda, se considerarmos a interpretação de Neder, Naro e Silva (1981) para os quais após a reorganização da força policial da Corte em 1866 esta passa a ter ações de maior força jurídico criminal em detrimento aos aspectos administrativos da cidade, não devemos creditar unicamente a repressão através da violência como a única técnica policial emprega no ordenamento urbano.

Ao aumentarmos nossa lupa na dissecação da instituição policial inevitavelmente perceberemos a importância fundamental desta na constituição do Estado brasileiro, visto que, como discutimos no capítulo anterior, "civilizar" a cidade do Rio de Janeiro, significava, de certo modo, construir a nação. Esta importância se realça não pela força empregada no ordenamento da cidade pela violência, mas pelos saberes produzidos, que influenciaram diretamente na criação de leis, técnicas e instituições, bem como na gestão de instituições asilos de assistência médica e social e na administração dos fluxos de pessoas e de bens comércio e abastecimento - no interior da cidade.

Apesar do uso da força está concentrado diretamente para a relação com os pobres, com exceção de uns poucos casos de uso da força policial contra membros

108 “(...) em seus jornais, trabalhadores qualificados criticavam severamente a polícia por toda "espécie de agressão à integridade pessoal e a ordem pública"” (Hahner, 1993, p. 74). 
da elite nos últimos meses do Império como, por exemplo, o caso de Lopes Trovão, preso no final do Império em manifestações republicanas. Neste sentido, cabe destacar que, conforme enfatiza Brandão (et al, 1981, p. 85), "a polícia tinha também a função de organizar a classe senhorial "nos termos da vaga liberal". Desta maneira, durante os últimos anos de cativeiro, cabia ao chefe de polícia fiscalizar e punir os senhores que aplicassem castigos desmedidos aos escravos, bem como ficava a cargos dos praças e policiais de menores patentes dar conta dos negros fugidos. Ao mesmo tempo que juntavam-se todos, pequenos e grandes escalões do corpo policial quando se tratava de revoltadas, sejam elas urbanas ou rurais, encabeçadas por escravos, trabalhadores livres ou pela parte contrariada da elite. A polícia tanto reprimiu manifestações republicanas no final do Império quanto atuou na manutenção da tranquilidade pública na afirmação da República perante o povo e a parcela descontente da elite.

Antes de nos atermos diretamente aos fatos que justificam nossa afirmação sobre o papel da polícia na formação da assistência social na cidade do Rio de Janeiro, temos que nos remeter as transformações que a ideia e prática do que se convencionou chamar de polícia teve ao longo de sua história. Faz se necessário compreender as profundas mudanças por que passou a ideia e prática de polícia no mundo ocidental cristão no século XVIII e XIX, principalmente no que diz respeito às funções que esta assumia no aparelho de Estado, enquanto instância administrativa das cidades. Estas mudanças dizem respeito a diferença do que se entendia por Estado de polícia e a representação social que temos hoje da instituição policial. Além deste aspecto é preciso estar atento para o fato de que a definição mais precisa de um modelo policial se circunscreve na razão exata da definição de que tipo de Estado se está falando em determinada sociedade e em localizado tempo histórico.

O termo polícia com o significado que conhecemos hoje é uma construção social embasada empiricamente e solidificado durante o percurso do século XIX e em alguns casos até o início do XX. Seja etimologicamente, seja pelo papel e função social exercida ao longo de sua história, o termo polícia surge para designar a politéia e surge com advento da Cidade-Estado entre os séculos VIII e VII a.C. (Costa, 2004). Portanto sua razão direta com a polis e a urbes são características que estão em seu cerne, seja etimologicamente, seja nos aspectos historiográficos de sua ação para a manutenção da unidade e da ordem no interior da cidade. A 
história da polícia no mundo ocidental judaico-cristão trata do modo de se exercer o governo sobre as pessoas e suas relações sociais na urbanidade.

Para a manutenção da ordem num conjunto heterodoxo de pessoas, cujo bem supremo seria a democracia para os considerados cidadãos e, portanto, a ausência de arbítrio entre os considerados pares, foram criadas as leis, as quais precisavam dos agentes que garantisse a efetividade e aplicabilidade delas, seja pela via da política, seja pela via da polícia. De modo que a polícia de um Estado constitucional deva ser "hermética e quintada" e que a de um soberano absolutista possa ser “ostensiva e brutal” (Candido, 1980, p. 113 apud Neder \& Naro, 1981, p. 237). Não é por acaso que política e polícia pertencem à mesma raiz etimológica. Este sentido amplo observado tanto nas ideias quanto nas práticas da polícia, como "instituições direcionadas para o funcionamento e para a conservação da polis" (Costa, 2004, p. 35), somente se transformou no significado que temos na atualidade sobre a ideia e prática policial no final século XIX e início do XX, seja no Brasil, seja na Europa, seja nos Estados Unidos (Gonçalves, 2007).

Cabe aqui uma ressalva; ao citar o sentido etimológico do termo polícia ligada a formação das cidades-estados A.C., não nos associamos aos historiadores mais tradicionalistas da polícia que localizam suas origens “em tempos remotos, entre os germanos, os normandos ou os egípcios" (Bretas, 1997a, p. 39). Esta concepção vislumbra as instituições policiais como uma espécie de "naturalização", negligenciando a historicidade, pois o que se naturaliza perde a possibilidade da dialética da existência. Para Bretas (1997a), esta naturalização evidencia-se também nas interpretações da historiografia crítica na qual a polícia aparece naturalmente cumprindo seu papel de assegurar o desenvolvimento das forças capitalistas. Estes aspectos de naturalização levam a um desaparecimento da polícia quando se trata da historiografia clássica e a descontextualização de sua historicidade quanto se trata da historiografia crítica nos estudos que abordam a formação dos Estados modernos e das instituições que compõe estes Estados. Tanto uma interpretação quanto a outra consideram a polícia como mecanismo constante e inalterado da racionalidade da administração do Estado, como algo intrínseco, natural a este Estado. A percepção da polícia como elemento externo a política a excluiu das análises e estudos sobre o Estado e as instituições e impossibilitam que a enxergue em perspectiva dialética. 
Assumimos o ponto de vista que, para entendermos a história da constituição da moderna polícia no mundo ocidental judaico-cristão temos que olhar para a concepção que o termo polícia e práticas sociais associadas a este termo tinham no século XVI na Europa e a marcha para a especialização que conhecemos hoje concomitante com o desenvolvimento capitalista. Para nós, a instituição policial se inscreve diretamente na razão administrativa das cidades da Europa ocidental a partir do século XVI e passa ser fundamental no ordenamento do mundo do trabalho a partir da revolução industrial. Do século XVI ao início do século XVIII o sentido da palavra polícia na Europa ocidental assume características bem distintas do que entendemos hoje pela ideia de polícia. Estas características podem ser traduzidas como relativa à ideia de uma comunidade ou associação regida por uma autoridade pública. Neste período o termo a polícia designava o todo da comunidade agregada a um regimento, no sentido de reger, governar sob a autoridade pública. A palavra polícia neste período ainda podia ser empregada como o resultado de um governo (Foucault, 2001). Importante enfatizar que estas duas características presentes na ideia de polícia podem ser reconhecidas na experiência da formação da polícia na cidade do Rio de Janeiro no século XIX. Estas duas características também podem ser vislumbradas em diferentes polícias do mundo, quais sejam, a relação direta com a governabilidade das cidades e sua característica eminentemente pública, ou ainda, poderíamos traduzir estas duas características como a peça fundamental da criação da administração pública das cidades. A transformação entre o que significava a ideia e a prática de polícia e o que entendemos hoje por polícia se deu ao longo de todo século XVIII e XIX. No Brasil, a formação da polícia e a implantação de tais ideias se dá nas mesmas direções que são esboçadas na experiência europeia e nos Estados Unidos, considerando evidentemente suas idiossincrasias. Esta semântica social do termo polícia podia ser também observada no dicionário de Raphael Bluteau que, em 1728, dava uma extensa definição para o termo, já dividindo em polícia civil e militar e a relacionando com a "as leis que a prudência estabeleceu para a sociedade humana nas cidades (...) concernente ao bom governo na República" (Bluteau, 1728, p. 575). Esta semântica repercutia em dicionários do início do século XIX que descreviam o vocábulo polícia como “o governo e administração interna da República, principalmente no que respeita ás comodidades, limpeza, aceio, fartura de víveres, e á segurança dos Cidadãos (...). 
No tratamento decente; cultura, adorno, urbanidade dos cidadãos" (Silva, 1813, p. 464).

A polícia tal qual a conhecemos hoje é resultado de uma transformação que se deu em todo o mundo ao longo dos séculos XVIII e XIX. A palavra e a ideia de polícia a partir do século XVII ${ }^{109}$ podia ser empregada como sinônimo de governo das cidades e de instituição Estatal na gestão da urbanidade. A ideia de polícia estava diretamente ligada à governabilidade, tinha uma característica eminentemente pública, como uma peça fundamental da administração das cidades. Seu ponto fundamental era a gestão da vida urbana - comércio, trabalho e assistência para os pobres válidos e inválidos -, de maneira que era necessário garantir a circulação, a ordem, a segurança, a propriedade, as instituições, o Estado, "toda essa espécie de sociedade que deve ser tarefa da polícia” (Foucault, 2001, p. 438). É o que no século XVII e XVIII será a abrangência do domínio da Politzeiwissenschaft ${ }^{110}$, "a coexistência e a comunicação dos homens uns com os outros" (Foucault, 2001, p. 438). Estes aspectos que irão caracterizar o que na Alemanha se convencionou chamar de "Estado de polícia".

O Estado de polícia se caracterizou na Europa nos séculos XVI e XVII como a racionalização do processo de governo das cidades, tanto nos aspectos políticos, quanto nos de caráter social, no qual a instituição policial era parte fundamental na consolidação deste poder Estatal. A Alemanha no século XVII foi quem, de certo modo, concerne inicialmente corpo prático a ideia do Estado de polícia, de maneira que influenciou diretamente na replicação desta experiência de gestão das cidades em diversos grandes centros da Europa. Este poder de polícia a serviço da consolidação dos Estados modernos é majoritariamente percebido como o exercício do monopólio da força, no entanto o Estado moderno se consolida menos pelo exercício da força e mais pela extinção do arbítrio, pela racionalização da administração e ordenamento das relações sociais e econômicas dos citadinos. Neste sentido, percebemos que a relação entre polícia e a formação dos Estados-

109 "A partir do século XVII vai-se começar a chamar de "polícia" o conjunto dos meios pelos quais é possível fazer as forças do Estado crescerem, mantendo ao mesmo tempo a boa ordem desse Estado" (Foucault, 2008, p. 421).

${ }^{110}$ Segundo Foucault (200, p. 427), polizeiwissenschaft é "a ciência política, essa ciência da polícia que, desde o meado, quer dizer desde o fim do século XVII até o fim do século XVIII, vai ser uma especialidade totalmente alemã, uma especialidade alemã que se difundirá pela Europa e que terá uma influência capital". (...) "Teoria da polícia, livros sobre a polícia, manuais para os administradores, tudo isso proporciona uma enorme bibliografia da Polizeiwissenschaft no século XVIII, desenvolvido nas universidades alemãs sem correlato equivalente na Europa". 
nações - não somente pelo monopólio da força -, faz sentido como um fato comum aos países do ocidente cristão do século XVII ao início do século XX. O fato de que a polícia tem em uma de suas primeiras funções o caráter administrativo das pessoas nas cidades como poder direto do Estado sobre a população e, que este caráter é possível de se observar na Europa, Estados Unidos e no Brasil ainda no início do século $\mathrm{XX}$, imprime mais argumentos favoráveis a nossa tese, que imputam à polícia papel fundamental da formação da assistência social. No caso do Brasil, especificamente no Rio de Janeiro - como demonstraremos adiante através dos documentos pesquisados - é possível observar práticas de gestão da cidade pela instituição policial, para além do meramente repressivo e criminal, ainda no primeiro quartel do século XX.

Segundo Foucault (2008), a partir do século XVII a palavra polícia passa a ser associada ao "esplendor do Estado". Cabe aqui reproduzir alguns trechos citados por Foucault (2008) de autores dos séculos XVII e XVIII que demonstram a maneira como se concebia a ideia de polícia e qual era seu papel e representação na formação e consolidação dos modernos Estados-nação. $O$ francês Turquet de Mayeme (1611), definia polícia como "tudo que deve dar ornamento, forma e esplendor à cidade" (Foucault, 2008, p. 429). Para o alemão Hohenthal (1776), a polícia é "o conjunto dos meios que servem ao esplendor de todo o Estado e a felicidade de todos os cidadãos" (Foucault, 2008, p. 422). O também alemão Johann Heinrich Gottlob van Justi (1720 - 1771) considerado por Foucault como um dos maiores teóricos da época sobre o assunto, definia a polícia como conjunto das "leis e regulamentos que dizem respeito ao interior de um Estado e procuram consolidar e aumentar o poderio desse Estado, que procura fazer um bom uso das suas forças" (Foucault, 2008, p. 422). Foucault ainda cita como referência de trabalhos que expressam a ideia e a prática de polícia antes do século XVIII na Europa os “pedagogos dos príncipes" como Fénélon, e o tratado de economia política de Antoyne de Montchrélien (1615) no qual encontrou a expressão "Estado da polícia", "que corresponde exatamente ao Polizeiwissenschaft dos alemães" (Foucault, 2008, p. 428). Ainda cita como referência a compilação da legislação da polícia feita por Delamare, "publicado em 1711 ou 1708 e republicada várias vezes no século XVIII" (Foucault, 2008, p. 449-50).

Foucault (2008, p. 422) faz coro com o texto do alemão van Justi escrito no século XVIII ao afirmar que "o bom uso das forças do Estado - é esse o objeto da 
polícia" Acrescentaria eu: o bom uso das forças do Estado na organização do trabalho urbano, é disto que se tratou a organização da polícia na Europa e é disso que se tratou diretamente a organização da assistência social na cidade do Rio de Janeiro pela instituição policial. Esta força organizativa do Estado não se caracteriza pelo sentido estrito do termo polícia que conhecemos hoje, mas pela amplitude que vai de ações de saúde, conservação de vias, fiscalização da moral e dos costumes, instrução, regeneração, repressão e solução de crimes. "Portanto, a polícia é de fato a arte do esplendor do Estado como ordem visível e força brilhante" (Foucault, 2008, p. 422). Ordem e força são práticas complexas do exercício de poder que envolve, antes de tudo, concepções de vida, moral e crenças. Deste modo, vislumbramos que é na magnitude de todas as coisas que dizem respeito à gestão da convivência entre homens e classes de homens nas cidades que se envolve a polícia. Para Foucault, (2001, p. 434) a moderna ideia de polícia se associa a "utilidade pública a partir da ocupação, da atividade, a partir do fazer dos homens".

A organização do mundo do trabalho é um dos aspectos centrais do qual historicamente se ocupa a polícia e que passa a ter ainda mais centralidade com as necessidades impostas pelo desenvolvimento dos novos modos de produção a partir do século XVIII. Como discutiremos no capítulo final, a regulação e controle do mundo do trabalho pelo não trabalho é um dos aspectos que vislumbramos nas práticas de assistencial social como fora objeto de preocupação e intervenção da polícia. Estes aspectos de ordenamento urbano pelo mundo do trabalho podem ser observados tanto na afirmação de Turquet de Mayerne (1611), segundo o qual, para a polícia, o que importa não é a "distinção entre os nobres e plebeus, não é portanto a diferença de estatuto, é a diferença das ocupações" (Foucault, 2001, p. 432), quanto no fato de que a classificação de vadio e vagabundo, no século XIX e parte do XX, na cidade do Rio de Janeiro, estava associada não ao fato de ser ter ao não trabalho, mas principalmente as características e aceitação social que este trabalho possuía $^{111}$. Queremos demonstrar com esta afirmação que apesar das questões de classe estarem posta na diferenciação de tratamento entre a elite e a parcela chamada povo desde, e principalmente, no século XIX no Brasil, o aspecto da

111 Sobre a ideia de vagabundo relacionado não ao fato de ter trabalho mas a que tipo de trabalho se está associado, ver SOUZA, Antonio Reguete Monteiro de. Da Desumanização e da Norma: A construção social das noções de vadio e vagabundo em meio as atribulações da fabricação do EstadoNação no Brasil (1870-1900). Dissertação de Mestrado. Programa de Pós-graduação em Serviço Social, Pontifícia Universidade Católica do Rio de Janeiro - PUC-RIO, Rio de Janeiro, 2010. 
classificação pelo trabalho torna-se fundamental para a polícia identificar no interior da parcela chamada povo os diferentes tipos de pobres e de pobreza. Esta classificação é fundamental para a racionalidade cientifica da época, pois isto indicará qual técnica de controle é mais eficaz para o caso: educação, regeneração, punição. "Entender, antes de mais nada, o fato de que não fiquem ociosos. Pôr para trabalhar todos os que podem trabalhar é a política voltada para os pobres válidos. Prover unicamente às necessidades dos pobres inválidos" (Foucault, 2001, p. 436). O principal critério analisador que imprimia veracidade e rapidez classificatória para saber com que tipo do pobre se estava lidando era o trabalho, critério este que se tornará central para a assistência social até nossa atualidade. Para Foucault (2001, p. 433), o interesse que mais caracteriza o Estado de polícia é o fazer do que se ocupa os homens, "é a atividade do homem como elemento constitutivo da força do Estado, (...) numa palavra, trata-se da criação da utilidade estatal, a partir de e através da atividade dos homens".

O trabalho enquanto instância racional produtiva e reguladora da ordem em substituição ao suplício rigoroso como meio de impor trabalho era um dos desafios de que devia se ocupar a polícia. O governo das cidades e das populações não deveria, ou não poderia mais, diante das demandas sociais, ser feito pelo medo e o arbítrio, mas pela regulação racional da força de trabalho, este é o sentido para o qual a polícia desenvolve seus saberes e práticas sociais. Este fato deve ser creditado quando observamos práticas que vão desde a conservação de vias públicas aos cuidados com os "alienados" realizadas pelas instituições policiais. Neste sentido, vale destacar o pensamento de Montchrétien, que em um tratado de economia política de 1615, afirmava que "o homem mais entendido em matéria de polícia não é o que, por suplício rigoroso, extermina os bandidos e os ladrões, mas o que, pela ocupação que dá aos que são subordinados ao seu governo, impede que eles existam"112 No mesmo sentido que Montchrétien afirmava no século XVII o então chefe de polícia Dr. Bellarmino Peregrino da Gama e Mello em relatório do ano de 1882 era taxativo ao aifmrar que o pensamento dominante é o de “imprimir á policia um caracter meramente civil, mas respeitável, poupando-se quanto possível os

112 Antoyne de Montchrétien (Montchrestíen, 1575-1621), Traité de l'oeconomie polilique (1615), ed. por Th. Funck-Brentano, París, E. Plon, 1889, livro 1, p. 27 (apud Foucault, 2001, p. 433). 
instrumentos e emprego da força material, reservada para os casos extremos" $"$. Ainda que somos inevitavelmente levados pelos fatos a enxergar a polícia com uma ordem monolítica pelo exclusivo emprego da violência na manutenção da ordem, não é este o seu caráter no interior do aparelho administrativo do Estado, embora possa ter sido este, ao logo de sua história o aspecto que mais relevância teve, principalmente em países com acentuada desigualdade social.

A necessidade de classificar as populações pelo viés do trabalho e do não trabalho foi ponto crucial na formulação da estratégia de intervenção junto a pobreza urbana, como aconteceu na Europa desde o século XVII e no Brasil no século XIX e início do XX, pela instituição policial. Para Foucault (2008, p. 433) o ponto central do objetivo da atividade policial é "o controle e a responsabilidade pela atividade dos homens", pois é desta atividade - trabalho - que se constitui a força do Estado. Este aspecto, segundo Foucault, é o que caracteriza o Estado de Polícia como ficou conhecido na expressão alemã e, que foi implementado através do projeto Turquet de Mayerne, no século XVII na Holanda. O objetivo central para o qual o rei criou a polícia deve-se a necessidade da invenção de uma gestão racional das cidades e das populações, ou seja, a polícia foi feita para dar conta do controle e organização de toda a complexidade da vida nas cidades. Segundo Foucault (2008, p. 438) os "teóricos do século XVIII dirão: no fundo é da sociedade que a polícia se ocupa". Mas não se trata apenas de organizar e controlar a sociedade como um bem, ou um fim em si mesmo, havia uma finalidade clara e, seu intento era o fortalecimento do Estado através da promoção de um viver melhor na cidade capaz de abonar um coexistir que garanta o bom funcionamento dos meios de produção e a docilidade da força de trabalho. De modo que, com isto, possa-se fazer "da felicidade dos homens a utilidade do Estado, fazer da felicidade dos homens a própria força do Estado" (...) "de tal sorte que o bem-estar dos indivíduos seja a força do Estado, é esse, parece-me, o objetivo da polícia” (Foucault, 2008, p. 439) ${ }^{114}$. Desta monta que o sentido do termo polícia, no século XVII e XVIII, e das coisas que ela deve se ocupar se relaciona com o sentido geral do viver e do

\footnotetext{
${ }^{113}$ BRASIL. Ministério da Justiça. Relatório do ano de 1882. Rio de Janeiro. Typographia Nacional, 1883 , p. 119.

${ }^{114}$ Foucault $(2008$, p. 439) cita a afirmação de Delamare para o qual o único objeto da polícia "consiste em levar o homem à mais perfeita felicidade de que ele possa desfrutar nesta vida", cita ainda Hohenthal que afirma que "a polícia é o conjunto dos meios que asseguram"reipublicae splendorem", o esplendor da república, "et externam singulorum ávilium feticitatem", e a felicidade externa de cada indivíduo".
} 
conviver nas cidades, mas não simplesmente viver, sobretudo o "melhor viver. Como dizia Montchrétien, não só é preciso ser, mas também é preciso "bem ser". Bondade, conservação, comodidade, aprazimentos da vida - é disso mesmo que se trata" (Foucault, 2001, p. 450) a ideia de polícia no século XVII e XVIII e, que, em certa medida, podemos vislumbrar em diversas grandes cidades do mundo ocidental cristão no início do século XX. No mesmo sentido, aponta Dr. Tito Algusto Pereira de Matos, chefe da polícia da cidade do Rio de Janeiro, em 1883, quando afirma que o objetivo da polícia é "tranquillidade, segurança, saúde e commodidade dos habitantes" ${ }^{\prime 15}$. Neste sentido, é emblemático o ministro da justiça e negócio interiores. Dr. Rivadavia da Cunha Corrêa, ao declarar no relatório referente aos anos de 1910 e 1911 que

O povo já não é tão ingênuo que acredite que só são bons os que estão fora das situações officiaes e que os outros, os que têm a responsabilidade governamental, sejam creaturas que unicamente se dirijam por maos caprichos, preoccupados tão somente em fazer o mal e tudo derrocar - leis e fortuna publica. Não; os que governam podem errar e necessariamente, errarão muitas vezes, mas, o que é natural, o que é lógico, o que é humano é que o seu desejo, o seu principal e permanente objecto seja a felicidade da Patria ${ }^{116}$.

Devemos estar atento ao fato de que o bem-estar dos indivíduos tem sua localização precisa; a cidade. Nesta monta podemos afirmar que a polícia está imbricada no problema criado pela urbanidade, a qual se baseia na regulamentação urbana que foi desenvolvida a partir da idade média "que dizia respeito à coabitação dos homens, à fabricação das mercadorias, à venda dos gêneros" (Foucault, 2008, p. 452). A polícia é fruto direto da regulamentação urbana e da força armada que servia ao poder régio, estava diretamente ligada na resolução imediata dos problemas cotidiano da subsistência, da escassez de alimentos, da produção e circulação de mercadorias, da circulação de pessoas, do deslocamento e fixação de mendigos e vagabundos, da saúde, da moral, da propriedade, das ruas, tudo que significava a relação direta entre homens e classes de homens nas cidades. É preciso destacar que a necessidade de regulação e controle desta coexistência tinha por intuito o bom funcionamento e segurança das cidades para o bom desenvolvimento

${ }^{115}$ BRASIL. Ministério da Justiça. Relatório do ano de 1883. Rio de Janeiro. Typographia Nacional, 1884, p. A-G-20-1.

${ }^{116}$ BRASIL. Ministério da Justiça e Negócio Interiores. Relatório dos anos de 1910 e 1911. Rio de Janeiro. Imprensa Nacional, 1911, p. XIII. 
do mercado e dos meios de produção. "De maneira geral no fundo, o que a polícia vai ter que regular e que vai constituir seu objeto fundamental são todas as formas, digamos, de coexistência dos homens uns em relação aos outros”. (Foucault, 2001, p. 437).

A ideia de polícia relacionada à organização das relações sociais na polis está diretamente associada à disseminação das cidades como mercados, a partir de uma prática de governo justificada por um princípio racional da "vontade" de Estado. Todo o fim da intervenção policial no controle e ordenamento da coexistência na cidade se assenta no crescimento e solidificação das forças do Estado, mas do que se trata esta força, se não, basicamente do mercado - produção e consumo - e seu correlato a força de trabalho. Deste modo, pode-se afirmar que polícia, urbanidade, mercado, meios de produção e força de trabalho são arestas de uma mesma teia na formação dos grandes centros urbanos e dos Estados modernos. "Há cidades porque há polícia (...), no sentido estrito do termo policiar e urbanizar é a mesma coisa" (Foucault, 2008, p. 453). Neste sentido, a polícia constrói um modelo baseado no urbano e enfrenta diretamente a questão da organização do comércio nas cidades criando um conjunto tecnológico de gestão racional deste urbano, do qual deriva a economia política ${ }^{117}$ e boa parte do que mais tarde passou a se chamar de políticas públicas de saúde, educação e assistência social. "Digamos, em suma, que a polícia é essencialmente urbana e mercantil, ou ainda, para dizer as coisas mais brutalmente, que é uma instituição de mercado, no sentido bem amplo" (Foucault, 2001, p. 450).

Para a formação e consolidação do mercado necessitava resolver o problema das condições e da segurança da circulação e da troca, circulação de mercadoria e de pessoas. E entre os problemas das pessoas que se deslocam, destacavam-se os vadios e vagabundos, os que por invalidez ou imoralidade se atinham ao não trabalho ou a trabalhos desclassificados moralmente. A assistência aos pobres válidos e inválidos está implicada diretamente na arte de governar as cidades como um instrumento da razão de Estado da qual pertencia, a saúde, a instrução, a moradia e a circulação urbana, entre outros campos administrativo da

117 Segundo Foucault (2001, p. 427) economia política “é uma área do conhecimento que deriva diretamente do saber produzido pela polícia, (...) não como simples conhecimento de procedimentos para enriquecer o Estado, mas como conhecimento dos processos que ligam as variações de riquezas e as variações de população em três eixos: produção, circulação, consumo. Nascimento, pois, da economia política". 
governabilidade das cidades. Em perspectiva de gestão das cidades e ordenamento do mundo do trabalho, o cuidado e o disciplinamento dos pobres e da pobreza pela exclusão dos que não podem trabalhar e a obrigação para os que efetivamente podem", torna-se "uma parte considerável do bem público" (Foucault, 2001, p. 450).

Numa perspectiva genealógica, segundo Foucault (2001), a primeira preocupação da qual a polícia se ocupa é com o quantitativo populacional, para que da utilidade do trabalho desta população fortaleça a razão de Estado, pois "não se pode administrar justiça, fazer guerra, levantar finanças, etc., sem que haja abundância de homens vivos, sadios e pacíficos. Quanto mais há, mais o resto é fácil, mais o Estado e príncipe são poderosos" (Foucault, 2001, p. 434) ${ }^{118}$. A racionalidade administrativa inaugurada pela polícia pode ser localizada nas análises dos recursos e possibilidades do Estado na razão direta entre território e população, o que Hohenthal ${ }^{119}$ chamará, em seu Tratado de polícia, de copia civium, "a quantidade, a abundância de cidadãos" (Foucault, 2001, p. 435).

Além de ser importante a quantidade da população, necessitava-se que esta estivesse suprida das "necessidades da vida" e que os cidadãos fossem saudáveis do ponto de vista da saúde. Este aspecto fica evidenciado na polícia da cidade do Rio de Janeiro durante todo o período relativo à nossa pesquisa. A polícia de 1870 a 1930, no Rio de Janeiro, estava ligada, de maneira mais ou menos intensa, a diversas ações de saúde, seja pela junta da Higiene, seja pelo recolhimento e encaminhamento de doentes, seja pelo gerenciamento das instituições de alienados. Segundo Foucault (2001: 435), “a saúde toma-se um objeto de polícia na medida em que a saúde é efetivamente uma das condições necessárias para que os homens numerosos (...) possam trabalhar, exercer atividades, ocupar-se" (Foucault, 2001, p. 435-6). Mais do que afastar dos centros comerciais e segregar os contagiosos, a preocupação e intervenção das instituições policias no campo da saúde decorre, como também no caso da assistência social, da necessidade de ordenar a cidade,

118 Estes eram ensinamentos do abade "Claude Fleury (1640-1723), padre e historiador, subpreceptor dos filhos do rei com Fénélon (...) autor de numerosas obras, a mais célebre das quais são as Institutions du droit français, París, 1692”, que reproduzia ideias que circulavam no final do século XVII na Europa, como por exemplo a de que "extensão de terras não faz nada para a grandeza do Estado, mas fertilidade e quantidade de homens sim" (Foucault, 2001, p. 434). Uma clara ideia sofisticada de relação demográfica e não somente o número absoluto de pessoas.

${ }^{119}$ Reichsgraf von Hohenthal, Liber de politia. adspersis observationibus de causarum politiae el justitiae differentiie. Leipzig, C. G. Hílscherum, 1776, § 2, p. 10 (Foucault, 2001, p. 443). 
entre outras coisas, pelo "cuidado" necessário que deve ser dispensado na formação do trabalhador adaptado e dócil, "portanto toda uma política do espaço urbano ligada a esse problema de saúde" (Foucault, 2001, p. 436). O problema da saúde é um correlato direto para prover o trabalhador saudável de condições para exercer as atividades úteis para o Estado. Para as quais, precisava-se garantir a circulação dos produtos oriundos destas atividades e das pessoas que os produzem. Em relação a importância da saúde para intervenção polícia na população podemos observar a afirmação do chefe de polícia Dr. Tito Algusto Pereira de Matos em 1883 para o qual "a saúde é o primeiro e o mais precioso de todos os bens: riqueza, força, trabalho, tudo perde o seu valor, diz Schützenberger, para aguelle que soffre; a energia se extingue com as forças physicas; populações difinhadas, enervadas e enfraquecidas perdem toda a acção e se tornam incapazes de grandes cousas"

Trata-se sempre de uma intervenção do Estado nas questões do imediato e com necessidade de ordenamento, prevenção, instrução e cuidado com os necessitados. "A polícia é de fato, tomada nesse nível, exatamente a inteira arte de governar" (Foucault, 2008, p. 422). Para Turquet de Mayerne (1550-1615) que, em 1611, apresentou aos estados-gerais da Holanda uma "das primeiras utopiasprogramas de Estado policiado" (Foucault, 2008, p. 444), a arte de governar as cidades implicava, entre outras coisas, na formação de uma polícia, cuja principal função seria nutrir o povo de uma "singular prática de modéstia, caridade, indústria e harmonia" (Mayerne, 1889 apud Foucault, 2008, p. 429). De modo que a polícia deve cuidar das condições gerais da sociedade "efetivamente conservada de acordo com a sua bondade, a sua comodidade, os seus aprazimentos" (Foucault, 2001, p. 450).

Os sistemas policiais tal qual foram criados nas principais cidades da Europa no século XVII e XVIII não tinham as características que vislumbramos hoje do que entendemos pela ideia de polícia. Como estas características foram se estabelecendo ao longo da história é matéria de polêmicas e vasta discussão que nos remete a questão de como a institucionalização do poder policial foi pilar da consolidação do poder político e vice-versa. Não é intento nosso entrar nesta difícil ceara de interjeições teórico-históricas sobre o papel das polícias na constituição dos Estados-nações. Grande parte dos autores vão creditar a transformação que a

${ }^{120}$ BRASIL. Ministério da Justiça. Relatório do ano de 1883. Rio de Janeiro. Typographia Nacional, 1884, p. A-G-12. 
polícia, em sua representação e ação, foi obtendo ao longo do século XVIII e XIX a própria especialização e racionalização científica da estrutura dos Estados-nações (Gonçalves, 2011) e as transformações dos meios de produção e por conseguinte do mundo do trabalho e das cidades. Em sua relação direta com a parcela da população chamada "povo", demonstram diretamente a importância na institucionalização de normas, costumes e classificações para o gerenciamento das cidades.

Poderíamos, grosso modo, reunir os diferentes autores e concepções sobre o processo de institucionalização da representação e prática que hoje vislumbramos na polícia em dois grupos, qual sejam: o primeiro que relaciona a formação e consolidação do poder dos Estados-nações e o segundo grupo que vislumbra a criminalidade associada a causas, como o crescimento das cidades e a industrialização. Estes dois pontos em nosso entendimento, não podem ser excludentes, ao contrário, constitui-se em partes de um mesmo processo histórico no qual a relação da formação dos Estados-nações com a classe de trabalhadores principalmente os trabalhadores sem trabalho - e os novos meios de produção na formação das grandes cidades vão concorrer para a especialização nas ações e na representação que temos hoje da ideia de polícia. Para Gonçalves (2007) o processo histórico de formação da polícia com as características tal qual conhecemos hoje não deve ser creditado ao único fator ou a uma única razão "que tenha diretamente influenciando este processo de institucionalização, mas antes um conjunto de explicações e a confluência de diferentes mudanças sociais que conduziram à configuração contemporânea do policiamento" (Gonçalves, 2007, p. 15).

As características que estavam presentes na prática e ideia de polícia anterior ao século XVIII na Europa, em certo grau, manteve-se em grande escala na polícia do Rio de Janeiro - aliado as modernas concepções da época e ao grau de especialização para o crime - até a Primeira República. Estas características são observáveis na gestão cotidiana dos pobres válidos e inválidos para organização do mundo do trabalho urbano, do qual a assistência social era peça fundamental. Como veremos adiante - ainda neste capítulo - a instituição policial no Brasil, como no restante do mundo ocidental cristão, estava implicada diretamente na consolidação do Estado, seja no Império, seja na República. É este papel da polícia, o que remonta a sua história na formação do Estado pela governabilidade das cidades, que apresenta-se para nós como um dos pontos cruciais que impõe veracidade aos 
nossos argumentos. Pela necessidade de administrar as populações na gestão das cidades a polícia criou certo grau de especialização no controle da pobreza urbana que incluía ações de assistência social.

Tal ideia do Estado de Polícia dividia a gestão por território e pelas problemáticas urbanas que deveriam ser enfrentadas, como podemos vislumbrar através dos birôs de polícia criados na França no século XVIII como um dos meios de efetivar pela mão do Estado a igualdade, a fraternidade e a liberdade. Os birôs de polícia deveriam cuidar da instrução de crianças e jovens, do registro destes jovens e de suas ocupações. As funções dos birôs de polícia nos permite vislumbrar, mais uma vez, a relação direta da criação instituição policial para organização do mundo do trabalho. Dentre os diversos birôs destacamos o birô da caridade que deveria se ocupar dos pobres validos e inválidos, emprestava dinheiro a pequenos artesões e concedia benefícios a quem de direito. Além destes contava com um birô especifico para regular o comércio e um birô para a regulação dos bens fundiários, edifícios públicos, heranças, estradas e rios (Foucault, 2008, p. 430-31). É nisto que se constitui a polícia antes do século XVI ao XVIII e da qual encontramos eco no final do século XIX e XX no Rio de janeiro; Lisboa, Nova York, Londres, Berlim e Paris; a arte de governar a cidade, menos pela força e mais pelo controle das normas e regulamentos, a polícia é para regular e a justiçar para punir, apesar de, em diversos momentos, estas duas instâncias se conjugarem como veremos no caso da polícia do Rio de Janeiro.

A polícia junto com a justiça, o exército e as finanças constituem-se nas quatro funções pilares que materializaram a gestão do Estado moderno (Foucault, 2008). Nesta junção, cabia a polícia cuidar da harmonia e da funcionalidade das cidades com vistas a manutenção dos meios de produção pela lógica da moralidade e do trabalho. Não se tratava somente da organização do mundo do trabalho como instância incólume das razões de classe e dos meios de produção, trava-se também, e antes de tudo de uma moralização da pobreza pela ótica do trabalho e do não trabalho. De maneira que, não é possível separar a ideia de trabalho da de moralidade, do mesmo modo que toda a moralidade relativa a construção social do pobre válido e do pobre inválido tem sua representação social balizada pela ideia de trabalho.

A nova racionalidade do poder Estatal, de certo modo imposto pela razão econômica, vai definir o caráter de especialização cada vez mais assentado no 
conhecimento cientifico e racional, de maneira a impor durante todo o século XVIII e XIX a criação de diversas instituições para cuidar de forma compartimentalizada das questões da urbanidade. Deste modo a polícia foi se tornando ao longo do século XIX nesta prática e ideia meramente criminológica e repressiva tal qual a conhecemos hoje e, suas outras funções foram gradativamente ganhando autonomia através da economia política e da racionalização da gestão pública das cidades.

A racionalidade da gestão da cidade irá retirar cada vez mais, durante os séculos XIX e início do XX, dos domínios da intuição policial os assuntos e as problemáticas da economia e das populações, ficando a polícia cada vez mais circunscrita com a questão da desordem, do desvio, das forças criminais que ameaçavam a boa coexistência nas cidades. O aprofundamento da razão de Estado, os novos meios de produção e a necessidade de formular e institucionalizar um sistema de leis que garantisse as liberdades e aprofundasse a experiência liberal da regulação do mercado e das novas relações sociais de classes, as quais buscavam manter a doçura da força de trabalho faz, por um lado aparecer uma polícia meramente especializada na repressão aos crimes contra a pessoa e a propriedade, e, por outro, uma polícia que deveria garantir as liberdades individuais dos "cidadãos" e a boa ordem para o bom funcionamento das "regulações" e instituições liberais.

A partir do século XIX a polícia foi perdendo gradativamente de seus domínios os aspectos da gestão das populações que não fosse meramente da repressão e prevenção da desordem urbana, dos desvios, das delinquências, dos crimes. "O antigo projeto de polícia, tal como havia aparecido em correlação com a razão de Estado, se desarticula, ou antes, se decompõe entre quatro elementos prática econômica, gestão da população, direito e respeito às liberdades, polícia (Foucault, 2008, p. 476). A polícia foi gradativamente ficando circunscrita ao crime, e tudo o que era do domínio de sua ação na sociedade foi paulatinamente alocado em agencias administrativas, criadas especificamente para tal, como secretarias, ministérios, instituições, municipalidades e políticas públicas. Cabe ressaltar que na cidade do Rio de Janeiro este campo administrativo da cidade, do qual inclui a assistência social, ficou num limbo entre a polícia e a municipalidade, com diferentes graus de interações e responsabilização durante todo o século XIX e o primeiro quartel do XX. Pode-se dizer que este processo de transformação que retirou da polícia as funções administrativas da gestão das populações durou 
aproximadamente um século e meio, levando-se em conta as práticas das polícias nas principais cidades da Europa e América no século XIX e XX. Gonçalves (2007, p. 20) aponta que a criação da Metropolitan Police de Londres em 1829 é considerada "como um momento fundador da transformação" da polícia na que conhecemos hoje. Esta transformação se deu devido a introdução dos princípios organizacionais da produção industrial e da ideia de eficácia e resultado.

Poderíamos identificar, grosso modo, que ao longo da história tivemos duas fazes bem distintas, que caracterizam a polícia sob ideias e práticas bastante diferentes, qual seja, em uma palavra, a polícia que se ocupava da sociedade e a polícia que passou a se ocupar exclusivamente dos crimes, a polícia que ordenava a conivência entre classes e a polícia especializada em ordenar a convivência entre pessoas. Estes dois "tipos" de polícia, ou estas características, principalmente em matéria de que tipo de função exerciam, estavam presentes na polícia da cidade do Rio de Janeiro, em maior ou menor grau, no período focado por nossos estudos. A moderna polícia e as práticas de polícia relativa ao Estado de Polícia na administração das populações nas cidades podiam ser claramente vislumbradas nas funções exercidas e nos discursos relativos a instituição policial na cidade do Rio de Janeiro de 1870 a 1930.

Este fato é de suma importância na construção de nosso objeto, a ponto de reconstruir paradigmas, pois ao comprovar - aspecto demonstrado pela documentação analisada, como veremos adiante - que a polícia no século XIX e no primeiro quartel do século XX, no Rio de Janeiro, tinha características possíveis de serem vislumbradas na ideia e prática do Estado de polícia relativo ao século XVII e XVIII na Europa, e ao mesmo tempo sorvia de grande expertise e especialização na repressão aos crimes e criminosos pautados nas teorias e experiência das modernas polícias dos grandes centros europeus do século XIX, demonstramos que a polícia estava a serviço de uma razão administrativa, cujos aspetos repressivos, eram mais uma de suas técnicas, tal qual a assistência social e a estatística, entre outras, na relação com a pobreza inválida e válida para o controle das populações nas cidades. As funções de regulação do território e da população nas cidades poderiam ser impressas como características presentes tanto na polícia do século XVII, nos principais centros urbanos da Europa ocidental, quanto na polícia da capital do Império ou na Primeira República no Brasil. De um lado, vamos ter até o primeiro quartel do século XX uma polícia ainda investida de mecanismos ligados 
a gestão das poluções na cidade, que incluem a gestão de instituições de assistência social, de saúde e gestão da circulação. De outro, podemos vislumbrar uma polícia criminológica, judiciária, científica lombrosiana e repressiva aos desvios da pobreza urbana válida. Estes dois aspetos que demoraram no mínimo três séculos para se constituírem nas técnicas e práticas que consolidaram na sociedade atual a moderna polícia, estavam combinados, amalgamados na cidade do Rio de Janeiro na virada do século XIX para XX. A polícia foi deixando o domínio administrativo das populações somente a partir do segundo quartel do século XX no Brasil ${ }^{121}$.

A criação da polícia no Brasil está diretamente ligada de forma categórica ao modo como se consolidou esta instituição em Portugal a partir das reformas do iluminismo pombalino na gestão das populações nas cidades, e posteriormente a partir do maior reformador da polícia, Pina Manique, um implacável perseguidor dos ideais da revolução francesa. É perfeitamente identificável como correlato da polícia de Lisboa toda a discussão que contemporaneamente se dava na Europa, bem como foi esta polícia que deu origem direta a polícia do Rio de Janeiro.

Apesar do Brasil estar também como todos as nações ocidentais cristãs no século XVIII e XIX voltados para os acontecimentos na França, Inglaterra, Alemanha e mais tarde Estados Unidos, é possível afirmar que Portugal se constituía em uma importante influência da institucionalização de práticas de assistência social e médica e dos modos de governo das populações na cidade do Rio de Janeiro e, principalmente a polícia, como veremos. É obvio que também Portugal se referenciava nos modelos e discussões dos modernos Estados dos países citados acima, como podemos ver no debate ocorrido no final do XVII e início XVIII por ocasião da restruturação de todos os serviços de assistência social e médica em Portugal, nas chamadas reformas pombalinas. Em nosso ponto de vista, não se torna possível compreender a complexidade da formação do campo da assistência social no Brasil nos remetendo somente a França e/ou a Inglaterra. Sem nos remetermos fielmente aos movimentos sociais que originaram a assistência em Portugal - ainda que inevitavelmente cheguemos em Paris ou Londres via Lisboa

\footnotetext{
${ }^{121}$ Segundo Gonçalves (2007, p. 19) “o desaparecimento daquilo que o historiador americano Eric H. Monkkonen designou como police welfare (Monkkonen, 2004) conduziu a polícia a um lugar na "guerra ao crime. Como neste campo, a administração central, assumiu, na década de 1920, um papel mais ativo, percebe-se que as polícias tenham sofrido uma maior interferência por parte do governo. Essencialmente funções assistencialistas. Mas também uma forma mais pedagógica de enfrentar certos problemas como por exemplo a delinquência juvenil (Wolcott, 2001)".
} 
quando olhamos para as reformas da assistência no século XVIII - não daremos conta da concretude e amplitude das ações diretas de assistência a pobreza urbana no Rio de Janeiro. Ainda que a influência francesa seja a predominante, principalmente em relação a Inglaterra e Alemanha, quando falamos da formação e gestão das instituições de assistência no Brasil, não podemos desconsiderar que o Rio de Janeiro já pertencia a experiência de assistência construída em Portugal e reproduzida aqui desde o século XVI, como sistema público/privado-laico/religioso que eram as Santas Casas. Para entendermos o que propomos como a interpretação da história da constituição da moderna assistência social no Brasil - consolidada na política atual do Estado nacional - necessariamente precisamos levar em conta os acontecimentos em Portugal no século XVIII, por ocasião da revolução francesa e industrial, que levou a reorganização da assistência secular daquele país ${ }^{122}$. Dentre os inúmeros acontecimentos do processo de construção histórico da assistência social e médica em Portugal que foram reproduzidos aqui, ou mesmo que foram realizados lá com financiamentos de doações de portugueses estabelecidos aqui, gostaríamos de destacar a experiência das reformas levadas acabo por Pina Manique no final do século XVIII.

Para a organização da assistência daquele país tiveram inúmeras proposta, no entanto os historiadores da assistência em Portugal destacam duas "pela coerência das medidas sugeridas e profundidade das reformas que comportavam, num caso, e pela capacidade de realização do outro" (Abreu, 2011, p. 143). Interessa-nos este fato tanto pelas propostas da reorganização da assistência social em si, quanto pelo fato de uma destas propostas estar diretamente ligada à Intendência Geral da Polícia, na pessoa de Diogo Inácio de Pina Manique ${ }^{123}$. A outra proposta destacada leva a assinatura do Dr. Rodrigo de Sousa Coutinho ${ }^{124}$ que pregava, entre outras

122 Relevantes estudos a cerca desta nova organização da assistência podem ser encontrados em Abreu (2011), Tavares e Pinto (1990), Biléu (1995), Carvalho (1939), e Lopes (2000).

${ }^{123}$ Segundo Abreu (2010, p. 350-51) Diogo Inácio de Pina Manique (1733-1805), foi uma figura relevante e "controversa do final do Antigo Regime em Portugal" que "desempenhou vários cargos na administração pública ao tempo do Marquês de Pombal", mas que se destacou foi "como intendente-geral da Polícia já no reinado de dona Maria I". Permaneceu por 23 anos no cargo (1780 a 1803), quando por certa imposição de Napoleão Bonaparte foi demitido por D. João VI ainda na qualidade de príncipe regente. Era um defensor da Monarquia Portuguesa e incansável repressor das ideias da Revolução Francesa, perseguindo intelectuais simpatizantes destes ideais e proibindo publicações que fizessem alusão a elas. Estava atendo e pronto para reprimir no âmbito da polis o que significasse ameaça o reino em Portugal.

${ }^{124}$ Diplomata e depois Secretário de Estado da Marinha nos governos da regência de D. João VI (Abreu, 2011, p. 143). 
coisas, a perseguição implacável a vagabundagem e mendicidade "que devia ser extirpado substituindo-o pelo "imperativo categórico do trabalho" (Abreu, 2011, p. 143). Enquanto Pina Manique, que apesar de também ser implacável contra a vagabundagem e ter o trabalho como imperativo, buscava estruturar sua ideia de reorganização da assistência através das Casas Pias ${ }^{125}$.

As Casas Pias foram "criadas por ordem régia de 20 de Maio de 1780" (Abreu, 2011, p. 144) cinco meses após a posse de Pina Manique como Chefe de Polícia. Começou a funcionar em 1781 no Castelo de São Jorge em Lisboa, destinada a recolher e regenerar mendigos e órfãos. Estas casas eram coordenadas e dependentes da Intendência-Geral da Polícia (Abreu, 2010, p. 367), onde Pina Manique conseguiu demonstrar na prática suas ideias sobre assistência à pobreza urbana. Pina Manique se posiciona na celeuma teórica que eclodia na Europa naquele momento sobre os modelos de intervenção Estatal se aproximando mais do modelo "mercantilista prussiano da medical police e não o do humanitarismo iluminista de pendor filantrópico e cívico, defendido pelo Dr. Rodrigo de Sousa Coutinho" (Abreu, 2010, p. 365). O que mais nos interessa neste debate é perceber que estava em jogo a discussão de modelos e maneiras de como o Estado deveria se posicionar diante da problemática da pobreza válida e inválida e, no centro desta discussão de intervenção e prática no cotidiano das cidades estava a polícia. Nesta disputa podemos observar de maneira categórica as mesmas questões que atravessava o restante da Europa (Abreu, 2011, p. 144), sobre qual tipo de tipo de intervenção o Estado deveria ter nos processos socais relativo ao controle da pobreza urbana.

\footnotetext{
${ }^{125}$ A Real Casa Pia de Lisboa foi criada por decreto de D. Maria I "a piedosa" em 3 de junho de 1780, influenciada diretamente por Pina Manique que, enquanto Intendente Geral de Polícia também era quem detinha o poder de implantação e gestão das Casas Pias. As Casas Pias ainda existem em Portugal, hoje chamada de Casa Pia de Lisboa Pina Manique é hoje um importante centro de profissionalização para jovens pobres do governo português e pode ter suas informações atuais acessadas em seu próprio site e em redes sociais. No texto de apresentação de seu site lê-se: "provisoriamente instalada no Castelo de S. Jorge recebe crianças, órfãs e abandonadas, além de mendigos e prostitutas, em sectores diferenciados (...) No Castelo de S. Jorge foram aplicados os mais modernos e audaciosos métodos pedagógicos que transformaram a Casa Pia numa escola precursora do ensino técnico-profissional, do ensino artístico e do ensino musical no nosso país. Treze anos depois da sua fundação, em 1793, a Casa Pia de Lisboa, de humilde recolhimento de crianças órfãs e abandonadas, tinha-se transformado numa grande Instituição de Solidariedade Social, uma escola moderna, com mais de um milhar de alunos". Disponível em: <http://www.casapia.pt/>. Acesso em: 07 dez. 2014. Nas redes sociais: <https://www.facebook.com/ Casa-Pia-Lisboa-Pina-Manique>. Acesso em: 07 dez. 2014.
} 
A especificidade da experiência secular da assistência em Portugal imprime questões particulares no modo sobre quais teorias alheias foram lá aplicadas. As reformas realizadas não foram capazes de provocar rupturas nos modelos pombalinos de intervenção social (Abreu, 2010, p. 365). Este aspecto de mudanças sem rupturas, propondo muito mais uma estética capaz de vislumbrar a continuidade é o que, por vezes, também caracterizou o processo de formação da assistência social na cidade do Rio de Janeiro. Mesmo não provocando rupturas estas reformas nos interessam de maneira especial por conjugar três aspectos que consideramos serem, entre outros, os que propiciam afirmar que a polícia na cidade do Rio de Janeiro esteve diretamente ligada na formação do campo da assistência social e, por sua vez, na formação do Estado-nação.

O primeiro aspecto a ser evidenciado é o fato de Pina Manique ser um Chefe de Polícia que tinha entre suas atribuições realizar uma reforma na assistência social e médica em Portugal. Este aspecto nos remete diretamente a toda discussão anterior sobre o Estado de Polícia e o controle das populações na cidade. O segundo ponto que nos chama atenção era a base teórica sobre a qual assentava seus argumentos que justificavam as ações. Esta base consistia, entre outros, dos "pressupostos teóricos da medical police contextualizados por Johann Peter Frank com os princípios das ordenações da Polícia de Nicolas de la Mare (1705-1738)" (Abreu, 2010, p. 365; Foucault 2003) ${ }^{126}$. O terceiro aspecto é a preocupação com a organização do mundo do trabalho como o bem supremo para o fortalecimento do Estado, o sentido final das suas ações. A perspectiva ampla que Pina Manique enxergava o objetivo cuidar da "tranquilidade pública e segurança" envolvia administrar as "questões sanitárias, de saúde pública e de assistência, como outros tantos programas de controle social e de civilidade da sociedade" (Abreu, 2010, p. 367). De modo que, no dizer de Abreu (2010, p. 367), desenvolveu-se "uma política social compósita, que juntava práticas caritativas de pendor tradicionalista com ações de repressão com base no trabalho forçado e com o investimento na educação e formação profissional, estas de acordo com os ideais iluministas".

\footnotetext{
${ }^{126}$ Segundo Abreu (2011, p. 144) Pina Manique apensar de ter desenvolvido seu "projeto social sob as premissas carmelitas", este foi "formatado no conceito da medical police, cunhado pelo germânico Johann Peter Frank na sua obra System einervollständigen medicinisçhen Polizey, (primeiros volumes publicados em 1779), e assumido seguidor das ordenações da polícia de Nicolas de la Mare (1705-1738)".
} 
A alusão a história de Pina Manique nos proporciona entender também o modo pelo qual a Intendência Geral da Polícia ${ }^{127}$ torna-se uma instância administrativa da cidade no modelo Português, de modo a assumir importância de governabilidade para coroa com referência os modelos de Estado de Polícia alemão - Polizeiwissenschaft. Além disto, Pina Manique nos proporciona perceber a maneira como os chefes de polícia - com alusão direta ao caso brasileiro mediaram a discussão sobre a condução da organização do poder político do Estado na formulação de práticas e discursos sobre a assistência e a pobreza. É possível identificar, tal qual no caso de Portugal, a maneira pela qual também no Brasil foram os chefes de polícia os principais responsáveis por pautarem as discussões sobre os métodos de intervenção e a classificação da pobreza válida e inválida e as maneiras de gestão administrativa, repressivas, instrutivas, regenerativas e de "ajuda" que deveriam ser tomadas, ainda que muitas não saíssem do campo das propostas.

Pina Manique torna-se para nós como também em Portugal um personagem emblemático para a história da assistência, pois configura-se em sua dramaticidade toda uma trama que buscamos desvendar ao traçar os paralelos entre a polícia e a construção histórica das práticas de assistência social. Ao assumir o cargo de Intendente Geral da Polícia de Lisboa, Pina Manique passa a desenvolver as reformas que acreditava serem necessária para modernizar a assistência em Portugal a luz das novas práticas e teorias surgidas no calor das discussões do século XVIII e na gestão da população nas cidades. Como método de regeneração buscava a "transformação de cada delinquente, ou virtual malfeitor, num membro útil ao Estado" através das Casas Pias. Tinha como pressuposto que "a regulação social era o verdadeiro motor do desenvolvimento econômico" (Abreu, 2011, p. 144). Portugal naquele momento passava por profundas transformações em seus sistemas de assistência social e médica não menos diferente que o movimento que também acontecia nos países centrais da Europa, como Inglaterra, França e Alemanha.

\footnotetext{
${ }^{127}$ Segundo Abreu (2010, p. 365) "a Intendência-Geral da Polícia, criada por diploma de 25 de junho de 1760, recebia competências alargadas para o combate à criminalidade, que incluía vasto leque de medidas de fiscalização social e de ações tendentes à prevenção de comportamentos considerados desviantes". A Intendência-Geral da Polícia teve seus poderes ampliados pela carta régia de 15 de janeiro de 1780 e se consolidou com instância da administração pública no governo de Dona Maria I, com a nomeação de Pina Manique como intendente-geral da Polícia "assumindo a liderança na implementação de novas políticas sociais e de saúde pública”.
} 
O que por sua vez temos que acrescentar diz respeito ao fato de podemos identificar nos trezes domínios dos quais deveria se ocupar a polícia, segundo Delmare, no início do século XVIII tanto na gestão de Pina Manique, quanto nas práticas e ações da polícia no Rio de Janeiro, no período focado por nossos estudos. Segundo a "grossa compilação da legislação de polícia em três volume" feita por Delmare, publicada por volta de 1708 e "republicada várias vezes no século XVIII" os treze domínios de que a polícia deve se ocupar são:

a religião, os costumes, a saúde e os meios de subsistência, a tranquilidade pública, o cuidado com os edifícios, as praças e os caminhos, as ciências e as artes liberais, o comércio, as manufaturas e as artes mecânicas, os empregados domésticos e os operários, o teatro e os jogos, enfim o cuidado e a disciplina dos pobres, como "parte considerável do bem público (Foucault, 2008, p. 450).

Como podemos observar os domínios de que devia se ocupar a polícia envolvia desde o século XVIII aspectos que hoje entendemos ser relativos a municipalidade. Estes domínios podem ser facilmente observáveis em menor ou maior proporção nas instituições policiais na cidade do Rio de Janeiro. O que estava em jogo era a arte de governar, principalmente governar cidades e não somente a mera repressão a crimes, para isto precisava-se da municipalidade dentro de uma administração racional como vinha gradativamente acontecendo na Europa. Quem estava preparada para assumir as funções da municipalidade, da estatística ao controle dos mananciais de água, em nosso caso era a polícia, tal qual remonta a ideia de ordenamento urbano pelo Estado de Polícia. A instituição policial no Brasil no período de nossos estudos era um pacote de ideias, técnicas, métodos, práticas de gestão racional das populações nas cidades, dentre as quais encontrava-se, a saúde das populações, a gestão de instituições asilos, o gerenciamento, ordenamento e classificação dos pobres válidos e inválidos nas cidades, a busca de regeneração pelo trabalho e a técnica de conversão na docilidade da pobreza naturalizada pela ajuda, apoio e "inclusão subalterna" pelo trabalho.

Tanto a perspectiva que enxerga o processo histórico de formação da polícia atual como estrutura da consolidação do Estado-nação, quanto a perspectiva que vê o aumento da criminalidade como expressão da questão social a mola propulsora da atual polícia, constituem-se em terreno fértil capaz de germinar nossos argumentos. Seja por um aspecto ou por outro cabia a polícia civilizar e ordenar as 
cidades em seus diferentes graus, que prezam desde a circulação de pessoas e bens, atendendo aos novos meios de produção, o deslocamento de trabalhadores e mercadorias, até o zelo pela moral e a preocupação humanitária com os desvalidos: crianças abandonadas, loucos, velhos e doentes sem recursos, ou seja a assistência médica e social. Desde a criação do chamado Estado de Polícia no século XVII na Alemanha, o qual influenciou a formação das principais polícias no mundo, que as preocupações com as ações de assistência médica e social fazem parte da estrutura histórica das polícias na formação das grandes cidades do mundo ocidental cristão, o que não foi diferente no Brasil.

Em nossos estudos sobre a polícia não nos cabe entrar na extensa e permanente discussão sob os aspectos que justificam o surgimento das instituições policiais concomitante com as modernas concepções de Estado-nação. Bem como não é intento nosso discutir como se deu o processo de transformação da polícia de seus aspectos administrativos das cidades para seu caráter exclusivamente jurídicocriminal. No entanto, necessitamos entender, o modo como determinadas práticas de assistências social de deslocaram das instituições policiais para a administração direta da municipalidade. Demonstrar como se deu esta passagem e transformação nos possibilita desvendar a lógica das práticas de assistência social em constituição histórica pela via do Estado na cidade do Rio de Janeiro.

Para entendermos melhor a transformação que estava em curso, da maneira como as práticas de polícia incluem práticas de assistência social devemos usar o pobre urbano válido e sua relação com trabalho como o problema central que deveria ser enfrentado pela polícia em sua função do ordenamento das populações. O problema do pobre válido não criminalizado e inválido nas cidades que era atribuído a polícia no século XIX e no início do XX passa a ser transferido gradativamente para as práticas que se convencionou chamar de assistência social. Como vemos, ordenar o mundo do trabalho e do não trabalho relativo a pobreza válida é uma linha de continuidade que enxergamos entre o Estado de Polícia, as instituições policiais e as práticas atuais de assistência social ${ }^{128}$, pois nos dois casos ordenar o mundo do trabalho fora do mundo do trabalho é a tônica.

A história da polícia é uma história de longa duração (Braudel, 2005) que se "naturalizou" enquanto uma estrutura do aparelhamento de Estado no percurso

${ }^{128}$ Estes aspectos são melhores discutidos capítulo final? 
inventivo dos séculos XVIII e XIX. A sua estruturação como aparelho administrativo das cidades se dá tanto na Europa, quanto na América. Para entendermos este percurso atento aos aspectos administrativos que nos interessa, passaremos a discutir os meandros que definem os aspectos policiais relacionados às ações da manutenção da tranquilidade pública, entre outras coisas, através de ações de "assistência social". Fundamentado pelos aspectos históricos e sociais conjurados na formação da instituição policial passaremos a demonstrar as práticas e os discursos que, de maneira categórica, confirmam o caráter administrativo das populações na cidade do Rio de Janeiro pela instituição policial. Dentre estas práticas destacaremos a assistência social como técnica específica de intervenção para determinadas populações no ordenamento e gestão da cidade.

\subsection{Assistência social: manutenção da tranquilidade pública}

A relação da polícia com a formação da assistência social está posta ao verificarmos o papel que esta estabeleceu na formação dos Estados modernos no mundo cristão ocidental, como vimos acima. O domínio do urbano e a organização do mundo do trabalho era o local privilegiado no qual as ações de assistência social realizada pela polícia estavam a serviço da construção da ordem social assentada sobre o capital e a ideologia liberal. A "construção da ordem” não é monolítica, nela está inscrita toda uma cadeia de acontecimentos implícitos e explícitos, gerados cotidianamente nas interações entre a elite - mais através de seus representantes do que propriamente de seus membros - e a parcela chamada povo. A construção da ordem urbana foi uns dos primeiros quadros a serem enfrentados pela recém-criada e emancipada classe burguesa e industrial durante todo o século XVIII e XIX nos principais centros urbanos ocidentais da época. Para tanto foi criada e instrumentalizada a polícia. A polícia é uma invenção administrativa que se consolidou enquanto meio de gestão das cidades no século XIX em todo ocidente judaico-cristão ${ }^{129}$, “cuja semântica social nos leva, inevitavelmente, a confluência do administrativo, com o judicial e o político" (Werneck Da Silva, 1981, p. 3).

\footnotetext{
${ }^{129}$ Segundo Gonçalves $(2011$, p. 2) “a polícia, como hoje a conhecemos, foi, nas suas características essenciais, uma "invenção" do século XIX".
} 
No caso do Rio de Janeiro, como em outros, o controle e o disciplinamento urbano não se davam somente pela via da repressão, a assistência social e médica e a regeneração pelo trabalho - claro que nos postos mais subalternos da cadeia produtiva - faziam parte do arsenal de técnicas que a polícia usava para efetivar o projeto de nação e sustentar "a não inclusão [como] a forma de dominação assumida pelo Estado" (Rodrigues, 2009, p. 87). Aqui já aparece uma das principais características da assistência social que tanto podemos vislumbrar nos dias atuais, como reconhecer nas práticas da polícia no final do século XIX na cidade do Rio de Janeiro, qual seja: a não inclusão como forma de dominação, ou melhor dizendo, a inclusão subalterna como meio de regular o mundo do trabalho.

Não se tratava apenas de afastar as chamadas "classes perigosas" do centro financeiro e administrativo da cidade do Rio de Janeiro, tratava-se, antes de tudo de regenerar, de construir uma nação, de "civilizar" uma cidade. Diferente da maioria dos discursos sobre o progresso e a regeneração que não especulavam “em trono do problema da miséria e da pobreza da população urbana" (Rodrigues, 2009, p. 88) a polícia construiu um saber baseado em seu cotidiano e nas principais teorias da época que se concretizou em técnicas e métodos de como o Estado deveria lidar com a problemática da pobreza urbana. É possível observar nos discursos e práticas das instituições policiais que a cientificidade era estratégica para justificar suas ações e métodos, o que ficará mais evidente a partir da década de 1860. Seguir a cientificidade da época era ponto fundamental para a construção do Estado-nação, tendo a cidade do Rio de Janeiro como correlato direto desta construção. Rodrigues (2009, p. 95) aponta que "tornava-se urgente a construção de uma cidade-capital mais bem definida por todos, a ser inventada pela municipalidade e instrumentalizada pela polícia”. Essa chave para a modernidade - uma cidade "inventada pela municipalidade e instrumentalizada pela polícia" - confere ainda mais peso e veracidade aos nossos argumentos sobre a relevância da polícia na formação da assistência social.

A polícia da cidade do Rio de Janeiro durante todo o século XIX e parte inicial do XX geriu instituições de assistência social, organizou o fluxo de atendimento aos pobres urbanos válidos e inválidos, criando classificação apropriada para tal distinção. Classificação esta que influenciou diretamente no imaginário social da classe dominante sobre qual era o perfil do pobre urbano e quais tipos de delitos e inflações de posturas estavam geralmente propensos a cometer, como podemos 
observar em artigos na imprensa, discursos legislativos e propriamente nas leis. A polícia ainda influenciou decisivamente através de seus discursos e práticas na maneira como no final do século XIX e início do XX a municipalidade passou gradativamente a gestar tais instituições e os fluxos de atendimento e classificação da pobreza urbana. A maneira como a polícia instrumentalizava a municipalidade passava inevitavelmente pelo desenvolvimento de práticas de assistência social e pelo gerenciamento de instituições para "aquelles que não perderam o seu jus á proteção social" ${ }^{130}$ como escreveu literalmente o Dr. Manoel Pinto de Souza Dantas, Chefe de Polícia da capital nos anos de 1880 e 1881.

Os significados do papel da polícia na cidade do Rio de Janeiro no período de nossos estudos estão diretamente relacionados com a formação da nação e identificados com as análises que se aventuram pelas conexões lógicas entre Estado e sociedade. Tanto na sociedade imperial, quanto na República é possível evidenciar que a polícia não tinha uma função exclusivamente repressiva, ou mesmo quando exclusivamente repressiva seus métodos eram, muitas das vezes, mais sutis que o emprego da força pelo uso da violência. Esta sutileza de ação se expressa principalmente em seu caráter administrativo que competia às diversas funções relativas à municipalidade para a qual era única instituição capaz de assumir tais funções. Sua forma de administração pública incluía, entre outras estratégias, o emprego de métodos de assistência social e médica, a estatística, o conhecimento das populações, a territorialização, o controle das vias e moradias, a regulação do mundo do trabalho e seu correlato o comércio, como, por exemplo, a regulação do sistema de pesos e medidas ${ }^{131}$. A maioria das funções da polícia de ordenamento urbano são hoje exercidas pela municipalidade e, apesar de podermos classificar a gestão do atual prefeito ${ }^{132}$ como repressora das chamadas "classes populares", não é sob estes significados - o da mera repressão e controle - que entendemos e representamos a administração pública municipal. Desta monta, devemos admitir que tendo a polícia exercido funções administrativas da municipalidade, esta não deve ser vista como mera reprodutora da violência estatal

\footnotetext{
${ }^{130}$ Argumentos do chefe de polícia no relatório referente aos anos de 1880-81 ao escrever sobre a técnica policial, assistência e práticas filantrópicas (BRASIL, Ministério da Justiça, relatório dos anos de 1892-93 apud Souza, 2010).

${ }^{131}$ No Brasil esta regulação se deu no início da década de 1870 e ficava a cargo da polícia. Foi motivo de muitos conflitos pessoais e revoltas coletivas como o "quebra-quilos" no nordeste.

${ }^{132}$ No momento da elaboração deste texto o alcaide municipal atende pelo nome de Eduardo Paes.
} 
pelo emprego da força, a não ser que enxerguemos o controle administrativo, burocrático, jurídico e assistencial também como violência estatal, que é uma vertente interpretativa que não descartamos.

É importante ressaltar a especificidade que a polícia na cidade do Rio de Janeiro tinha em função de estar próxima ao poder central, seja pela ressonância que partir do Rio repercutia para o restante do Brasil, seja pela ressonância que os acontecimentos no restante do Brasil, quiçá do exterior, faziam-se sentir no Rio. Diversos autores das mais variadas correntes historiográficas concordam que o Rio no período de nossos estudos era a "caixa de ressonância" dos acontecimentos nacionais. Isto se deve, entre outros motivos, "porque o Rio de Janeiro reproduzia, em ponto menor e de forma saturada, as relações sociais presentes na formação brasileira" (Neder \& Naro, 1981, p. 233-4). Esta relação da polícia com o poder central no Rio de Janeiro configurava "uma exigência de exemplaridade" seja pelos aspectos da manutenção da ordem, seja pelo aspecto da gestão administrativa. Aliando-se a isto o fato de que a municipalidade era gestada também pelo poder central, misturando-se em práticas, legislação e sentido; a municipalidade com as instituições policiais e o Estado nacional. Estas características se inscrevem na idiossincrasia da polícia do Rio de Janeiro, a "convergência de jurisdição e de competência" (Werneck da Silva, 1981, p. 2) entre poder local e o poder central, onde o poder central do Estado era diretamente influenciado e formado administrativamente também pela municipalidade. Esta convergência se transformara em confusão quanto a competências e financiamentos no fim do Império e no início da República, de modo a haver grandes discussões sob os pontos que deveriam ser da municipalidade ou das instituições policiais.

A ação da polícia diz respeito não só a repressão e prevenção de crimes, mas a necessidade de promover e controlar uma população saudável para o trabalho, o que na cidade do Rio de Janeiro no final do século XIX significava cuidar do trabalhador pobre livre e do escravo. É necessário enfatizar que o objetivo da polícia não se restringia à prevenção e repressão de crimes como nos dias atuais, muito mais do que isto, era do controle da população em sua totalidade e de seus fluxos na cidade que se tratava o papel de polícia. Neste sentido não podemos esquecernos da amplitude do sentido do termo polícia, quando associado à gestão das populações nas cidades. As funções da polícia médica, por exemplo, se relacionavam diretamente ao controle da saúde da população de forma geral que 
incluía desde a prevenção de acidentes, controle de epidemias, produção de estatísticas e a organização do espaço urbano público e privado (Machado, 1978). Os aspectos administrativos da polícia e o significado de tal termo mais associado a gestão da cidade, se evidencia ao olharmos para a criação do polícia médica a qual passa a assumir diversas funções anteriormente sob a responsabilidade da Intendência Gera da Polícia. Alguns fatos demonstram a íntima relação entre a Intendência Geral da Polícia e a Provedoria de Saúde que "recobrem e se complementam em suas funções" (Machado, 1978, p. 244), como no caso do Instituto Vacínico que em 1810 era composto pelo Intendente Geral da Polícia, o Físico-mor e o subdelegado do $1^{\circ}$ distrito Dr. João Pires Farinha. Outro fato que demonstra esta íntima relação pode ser descrito pela composição das comissões de saúde nas paróquias por subdelegados e médicos. Além destes aspectos havia ações diretas de assistência gratuita aos pobres e recolhimento de mendigos (Machado, 1978), bem como, inúmeras vistorias e fiscalizações em estalagens, oficinas, matadouros e casas particulares, entre outros.

O fato do processo de "civilização" da cidade do Rio de Janeiro não ter sido resultado da pujança capitalista, imputou ainda mais responsabilidade a polícia, responsabilidade que era muito mais sofisticada e cientifica do que reprimir revoltas e prender ratoneiros pelo emprego da força. Ela também agia para instrumentalizar as ações de assistência à saúde, dando apoio à junta de higiene, como gestora de instituições para alienados e como parte do serviço de recolhimento de doentes nas ruas. Ainda geria albergues para mendigos, controlava os fluxos de pobres inválidos e "menores" recolhidos por ela das ruas e fiscalizava a chegada e saída de navios através de seu departamento de polícia do porto. Além destes aspectos práticos da administração direta da municipalidade a polícia atuava politicamente, através de seus chefes, com o propósito de legislar sobre as questões diárias vivenciadas pelo seu corpo.

A ação das instituições policiais é muito mais sutil e profunda na construção do Estado-nação via a "civilização" da cidade do Rio de Janeiro, do que somente armadura do ordenamento via repressão. O controle se dava nos mais diversos mecanismos e setores da sociedade, do qual a assistência social e médica eram pontos fundamentais desta racionalização na gestão das cidades. Com seus superiores sensíveis às últimas novidades científicas, sua função moralizadora era 
também um esforço para a construção do Estado-nação através do controle da pobreza urbana e organização do mundo do trabalho.

Pela polícia que o Estado chegava à população pobre urbana, isto não significa dizer, como discutimos no Capítulo II, que a questão social no Brasil se caracteriza como caso de polícia até por volta de 1930. Este tipo de interpretação da formação do capitalismo no Brasil aponta para uma total ausência de ações e debates entre a sociedade e o Estado sobre as causas e o enfrentamento da pobreza e sua relação direta com o mundo do trabalho, no século XIX. Quando olhamos para os relatórios dos chefes de polícia da cidade do Rio de Janeiro e dos Ministros de Justiça, não se torna mais viável sustentar tal afirmação sobre a questão social no Brasil. Ao contrário, a função civilizadora da polícia confere a ela um papel muito mais sofisticado na constituição da nação pela mão do Estado. Segundo Rodrigues (2009: 89), "as manifestações públicas do Estado e a forma de ordenamento da sociedade dá a polícia uma função civilizadora, definindo-a como intermediária entre a população urbana e o governo". E esta intermediação não se dava somente pela via da repressão, ela também produziu um conhecimento, que inaugurou as discussões dos instrumentos que o Estado possuía para lidar com a problemática da pobreza urbana pela via do trabalho e da garantia do bom funcionamento do mercado.

A ideia de trabalho como meio de regeneração dos de baixo era marcada por um clima de servidão, visto que, não eram as mudanças econômicas que propiciaram a modernização da cidade, mas a consolidação de um modelo que incluía depender das elites e reconhecer o poder do Estado no ordenamento urbano. Estava posta a questão social como debate político no interior da elite e do Estado, principalmente pelos representantes das instituições policiais, que a enxergavam como correlato das discussões sobre o ordenamento do mundo do trabalho. Nesta perspectiva não seria equivocado fazer coro com a interpretação hegemônica da Sociologia e do Serviço Social no Brasil de que a questão social era caso de polícia até 1930, visto que os principais personagens que discutiam politicamente a questão da pobreza em relatórios, discursos, estudos, artigos e ações, além de uns poucos filantropos (médicos) concentrados basicamente na problemática da infância desvalida, eram os bacharéis que haviam construído carreira nas instâncias administrativas do Ministério da Justiça e nas instituições policiais. O erro crasso desta interpretação hegemônica da questão social no Brasil é que a polícia somente 
aparece única e exclusivamente carregada de seus aspectos jurídicos-criminais, negligenciando ou mesmo desconhecendo os aspectos administrativos na gestão da municipalidade e os aspectos políticos traduzido diretamente em atuações na formulação de leis, criação de instituições e na influência direta nos diversos negócios do Império e da República ${ }^{133}$.

O espaço urbano complexo e diversificado do Rio que sempre fora palco das mais criativas formas de sobrevivência inventadas pelas chamadas "classes perigosas" ou de modo mais eufemístico as chamadas "classes populares", tinha na polícia o fator capaz de legitimar o progresso e civilizar a cidade para construir a nação. Tanto pela legalidade do emprego da violência e das estratégias meramente repressivas, quanto pela capacidade gestora de instuições asilares e dos fluxos da pobreza urbana. Mesmo com a especialização centrada na manutenção da ordem urbana pelo monopólio da força, o caráter administrativo e gestor que a polícia exercia sobre a cidade não desaparece por completo se tornando cada vez mais organizado na proporção direta da desorganização dos outros quadros da administração pública municipal. "A atividade de polícia é, portanto, política, uma vez que diz respeito à forma como a autoridade coletiva exerce seu papel" (Costa, 2004, p. 35), de modo que podemos identificar "o lugar das instituições policiais no modo de produção de bens materiais e de bens simbólicos e nos mecanismos de dominação/direção manejados pelos sociais hegemônicos" (Werneck da Silva, 1981, p. 4).

Não podemos vislumbrar a polícia no final do século XIX e início do XX somente pela via da repressão sem olhar atentamente para o aspecto administrativo da gestão da cidade e da produção simbólica da representação da pobreza urbana. Por esta via que a legitimação pela assistência social se inscreve como uma importante estratégia para o Estado formar a nação. Neste sentido, o poder se qualifica não só por meio das regras jurídicas, mas pela assistência, seja a da caridade cristã, seja a do altruísmo positivista. A assistência sob suas diversas nuances se configura como um mecanismo de legitimidade do Estado na formação da nação, não pela imposição da lei, mas como uma espécie de prática que se inscreve no que Faoro (2007, p. 190) chama de legitimidade ${ }^{134}$. É neste sentido que a assistência, seja a social ou a médica, e mais a seguridade social para certas

${ }^{133}$ Conforme abordado no segundo capítulo.

${ }^{134}$ Abordado na página 65. 
classes, são importantes para o projeto de construção do Estado-nação. Esta é a mudança sutil e gradativa, que apesar de todos os abusos e arbítrios, as instituições policiais da cidade do Rio de Janeiro serão parte dos instrumentos de mudança; a passagem da coerção e do medo como forma de organizar o mundo do trabalho para obediência internalizada pelo reconhecimento, respeito e gratidão.

O fato do local da polícia no aparelho de Estado está circunscrito de forma geral na representação da sociedade - seja dos contemporâneos da época focada em nosso estudo, seja dos atuais - como o local meramente da repressão, faz com que não a olhemos com mais cuidado ao tratar da maneira como construiu conhecimentos para gerenciar a população na cidade do Rio de Janeiro, mais especificamente, os modos pelos quais a polícia lidou com a problemática da pobreza urbana válida e inválida no ordenamento do mundo do trabalho. É evidente que para a formação do capitalismo no Brasil "a instituição policial cumpre tanto um papel de incorporação, quanto de circunscrição, além daquela meramente repressiva" (Brandão et al, 1981, p. 68) na gestão da cidade e na organização do mundo do trabalho. Neste sentido afirmava o ministro da justiça Dr. Diogo Velho Cavalcanti de Albuquerque, no relatório referente ao ano de 1875 que "o principal objetivo da policia é a vigilância", não a violência. "É pela vigilância que ella se torna a garantia de todos os direitos"135.

Ainda que a violência e a repressão direta sejam os aspectos que mais carregaram as cores da imagem da polícia ao longo de sua história na cidade do Rio de Janeiro e mesmo no mundo cristão ocidental, nos interessa aqui chamar a atenção para um caráter específico que apenas alguns historiadores o olharam: os aspectos administrativo e gerencial que envolvem a vida nas cidades e dentre eles a assistência social. Ainda que este aspecto seja o de menor expressão no imaginário social sobre o papel da polícia ele não é menos importante quanto se trata da história da constituição do Estado-nação, e mais especificamente a história da assistência social na cidade do Rio de Janeiro. Por este viés que nossos argumentos se sustentam, pois é fato a importância do aspecto administrativo da polícia na formação da gestão pública das cidades. No entanto, o aspecto que nos interessa dentro do caráter administrativo das populações nas cidades pela polícia é algo inédito da maneira de enxergar a polícia no Brasil, pois não encontramos nenhuma

${ }^{135}$ BRASIL. Ministério da Justiça. Relatório do ano de 1875. Rio de Janeiro. Instituto Typographico do Direito, 1877b, p. A-230. 
referência historiográfica, sociológica, antropológica ou no campo da psicologia social e do serviço social que expressasse nossa tese de que a polícia tem um papel determinante e fundante, tal qual a caridade e a filantropia na formação das ideias, das instituições e práticas de assistência social na cidade do Rio de Janeiro. Apesar de não ser intento nosso ampliar a discussão para além dos limites geográficos da cidade do Rio de Janeiro e por vezes do Brasil, é possível afirmar mesmo com poucas evidências que a as instituições policiais também exerceram determinante influências na formação da assistência social em todo o mundo ocidental judaicocristão (Gonçalves, 2007, 2011; Monkkonen, 1981, 2003).

A polícia faz parte do modelo de implantação de uma nova governabilidade mais racional do Estado, ao contrário do que usualmente parece, e mesmo ao contrário do que de fato se tornou a realidade da prática policial ao longo do século XIX e XX, a racionalidade da força deve ser empregada para se evitar o emprego da força pelo meio da violência estrita. Para o controle das populações o emprego racional e administrativo da força pelo Estado através das polícias se constituía no modo em que o arbítrio dos antigos regimes foi, de certo modo, organizado em regulamentos e instituições gestoras das populações nas cidades. Apesar da polícia surgir diretamente do poder régio e ter papel já determinante na gestão das cidades pelo poder absolutista ela também se constituiu em uma instituição que garantiu e, em certo modo deu efetividade, a criação dos modernos Estados contemporâneos e democrático.

É para demonstrar os modos de gestão empregados pela instituição policial na cidade do Rio de Janeiro, no qual estava posto os discursos e práticas de assistência social, que traçaremos em linhas gerais alguns pontos que consideramos relevantes na história da polícia na cidade do Rio de Janeiro. Antes de prosseguirmos cabe uma ressalva. Não é intento nosso, reescrever ou analisar a história da polícia na cidade do Rio de Janeiro e, por conseguinte, no Brasil. No entanto, torna-se inevitável para a compreensão dos argumentos que fundamentam nossa tese nos atermos aos aspectos que consideramos relevantes nesta história, de modo que possa confirma-la, ou expor as contradições que teremos que enfrentar. Neste sentido, passaremos a demonstrar os aspectos presentes nesta história que justificam fazer a afirmação de que a polícia participou ativamente na construção 
das ideias e práticas de assistência social na cidade do Rio de Janeiro, tal qual e com a mesma importância que se imputa a filantropia e a caridade ${ }^{136}$.

A história da polícia na cidade do Rio de Janeiro é complexa e multifacetada e está imbricada diretamente na criação do Estado brasileiro, no qual ocupa lugar privilegiado quando se refere a relação direta e cotidiana do Estado com a parcela chamada "povo" no ordenamento das cidades. Ela está imbricada diretamente com a formação, no sentido de ordenamento, da classe dos trabalhadores assalariados, com a implantação do capitalismo e com a formação de um Estado-nação liberal. A sistematização da história da polícia no Rio de Janeiro, apesar de existirem claros elementos de continuidade, expressa pouca linearidade no que diz respeito a criação, dissolução e reformas de suas instituições. Identificamos momentos distintos da formulação de ideias e práticas policiais na gestão das populações na cidade do Rio de Janeiro como processo de acomodação e modernização na construção da ordem burguesa.

Há um consenso historiográfico que credita à chegada da família Real no Rio de Janeiro a criação da polícia (Bretas, 1997, 1998; Holloway, 1997; Werneck Da Silva, 1981; Brandão et al, 1981). Segundo este consenso, a criação da Intendência Geral da Polícia da Corte e do Estado do Brasil em 10 de maio de $1808^{137}$, com fins de manter a ordem e a tranquilidade pública na capital do Império Português, é considerado o marco inaugural de nossa moderna instituição policial. Por volta de um ano após a criação da Intendência Geral da Polícia da Corte, já com a Secretaria de Polícia organizada sob a batuta do Desembargador Paulo Fernandes Viana foi criada em 13 de maio de 1809 a Divisão Militar da Guarda Real de Polícia. Segundo a interpretação de Werneck da Silva (1981), a Intendência Geral da Polícia foi o primeiro núcleo do que hoje chamamos de Policia Civil e a Divisão Militar da Guarda Real o que denominamos atualmente de Policia Militar. Tal qual na formação dos modernos Estados europeus a polícia do Rio de Janeiro e, por conseguinte do Brasil, deriva do poder régio.

\footnotetext{
136 Para construção da história da polícia na cidade do Rio de Janeiro nos valemos de fontes secundárias - as excelentes pesquisas e análise dos diversos autores, que estudam a polícia ou daqueles que a usam para discutir outras categorias e objetos, os quais aparecerão ao longo do texto - e das leis, decretos e regulamentos que incidem sobre a organização da polícia e do que e quem policiar.

${ }^{137}$ Note-se que este foi um dos primeiros atos de organização do aparelho administrativo do Estado, implantada menos de dois meses depois da chegada da Família Real.
} 
A polícia neste primeiro momento se estruturava em seu organograma em Intendente Geral da Polícia, Magistrados Criminais da Corte, Ouvidores de Crime nas Relações e Juízes de Paz. Estes acumulavam "todas as atribuições policiais" (Brandão et al, 1981, p. 86), ou seja, eram também os gestores diretos da cidade. Cabe destacar que a figura do juiz de paz criado pela Constituição 1824 buscava desvincular a polícia das questões judiciárias e de determinado poderes sobre o controle populacional. Estes poderes retomaram para as mãos das instituições policias na reforma de 1841, quando se inicia o que poderíamos chamar em nosso entendimento do momento que norteou, deu direção jurídica na história das instituições policiais na cidade do Rio de Janeiro.

A primeira faze histórica da polícia na cidade do Rio de Janeiro é uma expressão direta do que significou a ideia e a prática de polícia em Lisboa ${ }^{138}$, para nosso entendimento, com exceção do período que vai de 1831 a 1841 é possível vislumbrar ecos lisboetas do século XVIII na polícia carioca durante todo o século XIX e início do século XX. Esta primeira fase histórica pode ser pensada temporalmente restrita ao período que vai da chegada de D. Joao VI no Rio de Janeiro até o seu retorno a Portugal. É nitidamente o período joanino da gestão da polícia na cidade do Rio de Janeiro, onde evidencia-se traços marcantes do estilo de gestão de Pina Manique. A importância e abrangência de poder que se constituiu a Intendência Geral de Polícia dentro do organograma do poder político da corte e mais tarde do município neutro pode ser vislumbrada já na primeira gestão o chefe de polícia Desembargador Paulo Fernandes Viana, que permaneceu no cargo de 1808 até 1821, saindo no final do período joanino. Este Desembargador ficou notório em seu tempo pelas diversas transformações urbanísticas na cidade do Rio de Janeiro, melhorando o abastecimento de agua, as condições das vias públicas, organizando o comércio, a circulação de bens e pessoas, a entrada e saída dos portos, a moralização dos costumes, e a repressão de crimes. Buscou organizar a cidade do Rio de Janeiro com atribuições que hoje seriam creditadas tanto ao secretário de segurança pública, quanto ao prefeito municipal.

No sentido do exposto acima, torna-se necessário - ainda que seja em linhas gerais - abordar algumas das principais práticas e princípios sob os quais agia a

\footnotetext{
138 No mesmo sentido afirma Werneck da Silva $(1981$, p. 22) que as "instituições policiais, inicialmente, não escaparam ao paralelismo, quase que diríamos mimetismo, em relação a Lisboa, que caracterizou a implantação da administração joanina no Rio de Janeiro".
} 
Intendência Geral da Polícia da Corte e do Reino de Lisboa, um dos órgãos centrais da administração pública, principalmente entre os anos 1760 a 1833. O Modelo de polícia de Lisboa que identificamos nos primórdios da polícia no Rio de Janeiro em menor ou maior grau até o primeiro quartel do século $\mathrm{XX}$ - pode ser vislumbrado no Alvará com força de lei de 25 de Junho de $1760^{139}$ que cria o cargo de Intendente Geral da Polícia. Este cargo terá seus poderes administrativos ampliados por ocasião do período da regência de D. Maria I que através do Decreto de 3 de junho de 1780 expandiu os poderes e competências da polícia, criando as Casas Pias e nomeando como Intendente Geral da Polícia da Corte e do Reino o Dr. Diogo Inácio de Pina Manique, fundador das Casas Pias que se manteve no cargo até 1805 , conforme abordado no tópico anterior.

Existem outros correspondentes nas principais cidades da Europa neste mesmo período que exerciam funções correlatas com as do chefe de polícia de Lisboa, como, por exemplo, o ministro da polícia da França. Dois aspectos centrais podem ser observados nos moldes da L'intendance de Police francesa relacionados à maneira como se estruturaram a polícia em Lisboa e no Rio de Janeiro. Esta se caracterizava tanto como um "instrumento do príncipe para impor sua própria presença e autoridade contra as forças tradicionais da sociedade imperial" (Carvalho, 2008, p. 110) ou aquelas que representavam ameaça a seu poder, quanto um "lugar de administração, onde se desenrolavam as funções de urbanização, saneamento, saúde pública, iluminação pública, etc.” (Cotta, 2006, p. 41 apud Batitucci, 2010, p. 38-9). Cabe chamar a atenção que em todos os casos existem a função especifica de ações e práticas de assistência social, bem como dizem respeito à economia das populações na gestão das cidades. Como demonstram as preocupações do Alvará de 25 de Junho de $1760^{140}$ em Portugal - que regulamenta

\footnotetext{
139 Arquivo Nacional Torre do Tombo - “Alvará com força de lei que estabelece a polícia e a paz pública da Corte e do Reino, criando o cargo de Intendente Geral com ampla jurisdição privativa". 1760-06-25. Cota: Portugal, Torre do Tombo, Leis e Ordenações, Colecção de Leis, mç. 6 n. ${ }^{\circ} 25$. Disponível em: <http://antt.dglab.gov.pt/exposicoes-virtuais-2/intendencia-geral-da-policia/>. Acesso em: 05 out. 2014.

${ }^{140}$ Impulsionado e influenciado por Marques de Pombal o Rei de Portugal D. José I “o reformador" cria a figura do Intendente Geral de Polícia. "Hei por bem criar um lugar de Intendente Geral da Polícia da Corte e do Reino, com ampla e ilimitada jurisdição" (...). Alvará, com força de Lei, em que se determina a Polícia da Corte, para conseguir a pública paz da mesma Corte e Reino (25 de Junho de 1760). Neste mesmo alvará El Rei nos brinda com a citações de Leis que seus "predecessores promulgaram em 12 de Março de 1603, em 30 de Dezembro de 1605, em 25 de Dezembro de 1608, e em 25 de Março de 1742 para regularem a Polícia da Corte e Cidade de Lisboa”. O Alvará buscava corrigir o que se considerava distorções nas leis anteriores separando a
} 
a polícia da corte - com a higiene, os imigrantes, os vagabundos, o comércio e a moradia. Este alvará do século XVIII em Portugal torna-se importante para nós devido ao fato de regular as funções e poderes do Intendente Geral da Polícia da cidade do Rio de Janeiro, tal qual ficou estabelecido pelo Alvará de 10 de Maio de 1808 "que Crêa o logar de Intendente Geral da Policia da Corte e do Estado do Brazil”.

Eu o Principe Regente faço saber aos que o presente Alvará virem, que tendo consideração á necessidade que ha de se crear o logar de Intendente Geral da Policia da Côrte e do Estado do Brazil, da mesma forma e com a mesma jurisdicção que tinha o de Portugal, segundo o Alvará da sua creação de 25 de Junho de 1760, e do outro de declaração de 15 de Janeiro de $1780^{141}$.

Em outro alvará também da mesma data D. Joao VI cria em "beneficio do augmento e prosperidade da causa publica” o Superior Tribunal de Justiça, “e ordenou que todos os processos os aggravos ordinarios e appellações" das demais colônias e de outras províncias do Brasil que antes eram remetidos para a Lisboa fossem agora enviados para o Rio de Janeiro. Buscava-se ordenar a sociedade pelos atos de legislação real, onde a polícia representava uma instância administrativa que continha em seu bojo dar conta dos crimes contra a pessoa e a propriedade, cuidar dos fluxos populacionais e de bens e, organizar e controlar o mundo do trabalho. Ao administrar as populações e suas interações na cidade, a instituição policial atuou em diferentes frentes, umas que a aproximaria da municipalidade, outras que as deixariam próximas das atuais secretarias de segurança pública.

Neste sentido, ao nos remeter ao Alvará de 25 de Junho de 1760, torna-se possível identificar as características e correlações, que vislumbramos nas práticas administrativas das populações pela polícia de forma a justificar e demonstrar os aspectos de assistência social a ela creditado. Se tratasse de intento nosso fazer uma genealogia das práticas e discursos sobre a assistência social relacionado a polícia na cidade do Rio de Janeiro, deveríamos sem sombra de dúvida nos remeter ao

polícia da justiça, discussão que iremos verificar durante todo o século XIX no Brasil. Arquivo Nacional Torre do Tombo. Disponível em:

<http://antt.dglab.gov.pt/exposicoes-virtuais-2/intendencia-geral-da-policia/>. Acesso em 05 out. 2014.

${ }^{141}$ Colecção das Leis do Brazil de 1808. Rio de Janeiro: Imprensa Nacional, 1891. p. 26-27. Disponível em:

<http://www.planalto.gov.br/ccivil_03/revista/Rev_25/alvar100502.htm>. Acesso em: 05 dez. 2014. 
referido Alvará, que, por sua vez, está alinhado com as principais discussões e práticas que aconteciam no mesmo período na Europa, ainda que, em Portugal estivesse presente o componente de repressão as ideias vindas da revolução francesa, pois estas ameaçavam o poder régio, e a experiência secular da assistência público/privado das Santas Casas. É possível vislumbrar no Alvará de 1760, a preocupação com a segurança e manutenção do poder da corte que tinha como um dos principais focos desta segurança cuidar da pobreza urbana de modo a traçar estratégias de controle do pobre inválido e combater efetivamente o pobre válido, "transformando" o ultimo em força de trabalho "útil".

A assistência social constituía-se como meio eficaz de controle da população pobre na cidade pela via da "proteção" para os que faziam jus e, de um misto de punição-reeducação-inserção subalternizada para aqueles que deveriam ser controlados e regenerados pelo trabalho. Diversas competências do Alvara de 1760 que cabiam ao Intendente Geral da Polícia da cidade de Lisboa podem ser observadas nas ações realizadas pela polícia da cidade do Rio de Janeiro durante todo o século XIX e início do XX, entre as quais, destacamos a fiscalização do porto e de imigrantes, expedindo passaporte e controlando o fluxo de pessoas, a inspeção sobre as hospedagens, cortiços e as moradias de maneira geral e, por fim, o registro de todos os moradores de cada bairro identificando os ociosos e libertinos. "Tais amplas atribuições coincidiam com a semântica social do termo polícia, no início do século XIX" (Werneck da Silva, 1981, p. 23). Este fato nos permite demonstrar que "algumas das funções que competiam ao Intende Geral, frente a repartição de polícia, eram de caráter municipal" (Werneck da Silva, 1981, p. 23), e que estas funções de municipalidade, da qual faz parte a assistência social, permaneceram em maior ou menor grau até o primeiro quartel do século XX na cidade do Rio de Janeiro. No Alvará de 1760 já aparece de maneira explicita a relação direta da polícia com as práticas e ações de assistência social como meio organizar o mundo do trabalho nas cidades. Importante observar que neste Alvará já estava explícita a ideia do pobre válido e inválido e a maneira diferente como devia ser tratado o primeiro com punição/regeneração pelo trabalho e o segundo com proteção e cuidado conforme se verifica nas ações da assistência social seja pela caridade, pela filantropia ou pela polícia ao longo dos séculos e na forma com podermos verificar ainda na atualidade em diversos discursos, práticas e leis relativas à assistência 
social $^{142}$. Além destes aspectos presentes diretamente no referido Alvará deve-se levar em conta a própria prática de intervenção social que significou a criação das Casas Pias. Esta amplitude de ações que englobava as instituições policiais desde o século XVII na Europa pode ser verificada no Rio de janeiro em, 1877, conforme demonstra chefe de polícia Dr. Tito Algusto Pereira de Matos.

Com effeito, o quadro destas attribuições, segundo as classificações da sciencia da administração, se encerra nas seguintes cathegorias: I. Policia geral, comprehendendo os passaportes e títulos de residência, a prevenção e repressão da mendicidade e vagabundagem, a policia das prisões e casas publicas de hospedagem e venda de alimentos e bebidas alcoólicas, etc, as de jogo, prostituição, os tumultos, os theatros, os caminhos de ferro, machinas e barcas de vapor, depósitos de pólvora, de matérias facilmente inflammaveis e explosivas, os templos e casas de culto publico, o uso de armas defesas, as festas publicas, a pesquisa dos desertores. II. A policia politica comprehende a manutenção da ordem e segurança publicas, e a prevenção dos delictos que as podem ameaçar. III. A policia de

${ }^{142}$ Neste sentido vale reproduzir o longo trecho do referido Alvará onde podemos perceber a relação direta de organização e ordenamento do mundo do trabalho pela instituição policial, como o tomo 18 e 19. Tomo 18. "Tendo mostrado a experiência os perniciosos abusos, que de muito tempos a esta parte fizeram os Vadios e os Facinorosos, das virtudes da caridade e devoção, muito louváveis nos meus fiéis Vassalos, para nutrirem os vícios mais prejudiciais ao sossego público e ao bem comum, que resulta sempre aos Estados do honesto trabalho dos que vivem em ociosidade: Estabeleço, que em nenhuma casa pia, ou Misericórdia deste Reino, se possa dar Carta de Guia a pessoa alguma, que não apresentar para isso Bilhete do Intendente Geral da Polícia, com que se legitime: e que com as ditas Cartas de Guia, que se lhas passarem, sejam obrigados a trazer sempre $o$ referido Bilhete para o apresentarem, quando lhes for pedido: sob pena de serem presos, remetidos e castigados, como vadios, na forma acima declarada". Tomo 19. Porque os Pobres mendigos, quando pela sua idade e forças corporais podem servir o Reino, são a causa de muitas desordens e o escândalo de todas as pessoas prudentes, excitando o que a respeito deles está determinado pelo Alvará de 9 de Janeiro de 1604(I), e pelo meu Real Decreto de 4 de Novembro de 1755: Mando, que nenhuma pessoa Nacional, ou Estrangeira, possa pedir esmolas nesta Corte sem licença expressa do Intendente Geral da Polícia, e nas outras Cidades e Vilas das Províncias sem faculdade também expressa e escrita dos respectivos Comissários, que para este efeito deputar o mesmo Intendente. As sobreditas licenças, que se concederem às pessoas, que conforme a razão e Direito podem pedir esmolas, serão sempre concedidas por tempo de seis meses até um ano, que depois poderão ser prorrogadas, se para isso concorrer justa causa; precedendo sempre para elas certidão do Pároco da Freguesia, onde viverem os sobreditos pobres, pela qual conste que se confessaram e satisfizeram ao preceito da Igreja na Quaresma próxima precedente. E todas as pessoas, que forem achadas pelos Oficiais da Polícia, pedindo esmolas sem as ditas licenças por escrito, serão levadas nesta Corte perante o Intendente Geral da Polícia, e nas Cidades das Províncias perante os Comissários, constituídos nas Cabeças de Comarca, os quais ouvindo verbalmente os Réus, sem outra ordem, nem figura de Juízo, lhes imporão as penas, estabelecidas pela referida Lei de 9 de Janeiro de 1604, e Decreto de 4 de Novembro de 1755, fazendo-as executar na forma por eles ordenada. E porque entre os referidos Mendigos aqueles, que forem cegos $e$ impossibilitados para todo o trabalho, se fazem dignos da minha Real Piedade, ordeno, que o mesmo Intendente Geral faça formar uma relação deles em cada Freguesia pelos Ministros dos respectivos Bairros, para que eu possa dar a este respeito a providência necessária”. Alvará, com força de Lei, em que se determina a Polícia da Corte, para conseguir a pública paz da mesma Corte e Reino (25 de Junho de 1760). Arquivo Nacional Torre do Tombo - “Alvará com força de lei que estabelece a polícia e a paz pública da Corte e do Reino, criando o cargo de Intendente Geral com ampla jurisdição privativa”. 1760-06-25. Cota: Portugal, Torre do Tombo, Leis e Ordenações, Colecção de Leis, mç. 6 n. ${ }^{\circ}$ 25. Disponível em: <http://antt.dglab.gov.pt/exposicoes-virtuais2/intendencia-geral-da-policia/> Acesso em: 05 dez. 2014. 
segurança, que tem por fim prevenir, e sorprehender os attentados contra a segurança, a propriedade e direitos dos cidadãos. IV. A policia administrativa que se dedica a facilitar aos cidadãos os gozos da vida, e prevê a sua subsistência, livre circulação e salubridade ${ }^{143}$

Para traçarmos um pequeno inventário das leis, regulamentos e decretos que versam sobre a história da organização da polícia na cidade do Rio de Janeiro ${ }^{144}$ temos que necessariamente nos remeter, além dos alvarás de 1760 e 1780 em Portugal, a Constituição de 1824, a lei da municipalidade de 1828 e aos códigos criminal de 1830 e de processo criminal de 1832 , bem como as diversas leis que regulamentavam o funcionamento da polícia, principalmente a reforma criminal de 1841-42. Na constituição de 1824, podemos destacar o artigo 179, parágrafo XVIII, que legisla sobre a necessidade de organizar "quanto antes um código civil, e criminal, fundado nas sólidas bases da Justiça, e Equidade"145. O código criminal foi criado seis anos depois, enquanto que o código civil foi criado somente na República $^{146}$.

No relatório do Ministério da Justiça no ano de criação da República, podemos observar que o processo civil ainda estava vigente segundo "o Livro 3 o das Ordenações Philippinas modificadas por uma infinidade de alvarás e assentos, interpretados pelos praxistas que tomaram o logar do legislador para supprir as deficiências dos textos. A incerteza do direito juntou-se a da acção" ${ }^{\prime 147}$. Neste mesmo relatório, reclama o Ministro da justiça que "solemnemente prometlido pela lei constitucional de 1824”; o código civi1 ${ }^{148}$ não foi promulgado nos " 68 annos de

143 BRASIL. Ministério da Justiça. Relatório do ano de 1877. Rio de Janeiro. Typographia Perseverança, 1878 p. A5-4-5.

${ }^{144}$ Sistematizadas em tabela no Anexo I

${ }^{145}$ Constituição Política do Império do Brasil, outorgada pelo Imperador D. Pedro I, em 25.03.1824. Disponível em: <http://www.planalto.gov.br/ccivil_03/Constituicao/Constituicao24.htm>. Acesso em 03 ago. 2014.

${ }^{146}$ Sobre esta discussão ver SOUZA, Antonio Reguete Monteiro de. Da Desumanização e da Norma: A construção social das noções de vadio e vagabundo em meio as atribulações da fabricação do Estado-Nação no Brasil (1870-1900). Dissertação de Mestrado. Programa de Pós-graduação em Serviço Social, Pontifícia Universidade Católica do Rio de Janeiro - PUC-RIO, Rio de Janeiro, 2010. ${ }^{147}$ BRASIL. Ministério da Justiça. Relatório 1889. Rio de Janeiro. Imprensa Nacional, 1891, p. 21. ${ }^{148}$ Foram várias as tentativas e longo o processo de elaboração do código civil no Brasil, como podemos ver em diversos relatórios. Em 15 de fevereiro de 1855 foi celebrado com o Dr. Augusto Teixeira de Freitas um contrato "a fim de reformar a legislação civil e predispor os elementos do Código Civil Brasileiro (...) tratando assim de realizar a promessa exarada no art. 179 do parágrafo 18 da Constituição" (BRASIL. Ministério da Justiça. Relatório do ano de 1871. Rio de Janeiro. Typographia Americana, 1872a, p. A-5). Em 11 de dezembro de 1872 um novo contrato é celebrado pelo decreto n. 5164, agora celebrado com o Conselheiro de Estado José Thomaz Nabuco de Araujo, para a redação do Código Civil do Império (BRASIL. Ministério da Justiça. Relatório do ano de 1871. Typographia Americana, 1872a, p. A-5). 
duração do império" e o Brazil continuou a reger-se pelas Ordenações Philíppinas, já revogadas em Portugal, que nos legara esse vetusto monumento da

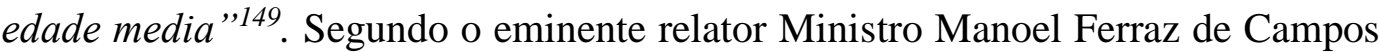
Salles,

os contractos feitos em 1859 com o Dr. Antonio Teixeira de Freitas, em 1872 com o Conselheiro José Thomaz Nabuco de Araujo,(...) a commissão nomeada em 1881 para examinar o esboço de um código civil, (...) organizado pelo Dr. Joaquim Felício dos Santos, nem mesmo a ultima commissão nomeada em julho do anno passado (...) completou esse trabalho nem offereceu outro em substituição, (...) sendo celebrado o contracto de 12 de julho deste anno, no qual o Dr. Antonio Coelho Rodrigues, emérito professor de direito e advogado (...) se comprometteu a concluir o trabalho no prazo máximo de tres anos ${ }^{150}$.

O processo de criação do código civil demonstra que não era fato isolado chegar até a República padrões jurídicos, posturas institucionais e leis, vindas do Império e das Ordenações Filipinas ${ }^{151}$. Se para a elaboração do código civil demoramos o Império inteiro e parte da República, o código criminal já estava posto desde $1830^{152}$, regulamentado e operacionalizado pelo código de processo criminal de 1832. Estes códigos irão estabelecer as formas jurídicas de organização dos poderes de polícia. Importante evidenciar que até $1916^{153}$ boa parte das relações jurídicas cotidianas entre as pessoas eram ordenadas pelo chefe de polícia, delegados e subdelegados, como "praxistas" que necessitavam dar respostas jurídicas a situações concretas para as quais não havia texto legal. Lembremos que para ocupar este cargo tinha por primeira exigência ser bacharel em direito. Por um lado, este aspecto aponta para uma especialização no conhecimento da discussão jurídica e das modernas teorias do mundo civilizado, por outro, era motivo de um excesso de "praxismos" jurídicos por base da polícia. Neste sentido, podemos observar a afirmação do Ministro da Justiça Dr. Lafayette Rodrigues Pereira: "sobre a esphera da acção policial escapam ás nossas leis muitos assumptos, que

\footnotetext{
${ }^{149}$ BRASIL. Ministério da Justiça Relatório 1889. Rio de Janeiro. Imprensa Nacional, 1891, p. 16. ${ }^{150}$ Idem.

${ }^{151}$ A dinastia Filipina corresponde ao período de 1581 a 1640 e cobre os reinados de Felipe I, II e III. Disponível em: 〈http://www.casarealportuguesa.org/dynamicdata/Cronologia.asp >. Acesso em: 05 nov. 2014

152 Código Criminal de 1830 lei de 16 de dezembro de 1830. Disponível em: <http://www.planalto.gov.br/ccivil_03/leis/lim/lim-16-12-1830.htm〉. Acesso em 07/08/2014>. Acesso em: 05 nov. 2014.

${ }^{153}$ Ano de promulgação do primeiro Código Civil.
} 
o progresso e a experiência foram posteriormente suscitando" ${ }^{154}$. Aquilo que escapa a lei, a experiência e o progresso legislam. O cotidiano, a necessidade das respostas imediatas e a ciência respondiam na forma de justificativas jurídicas para criação de leis na regulação das relações sociais, civis e criminais que escapavam ao texto legal. Propriamente deveríamos falar muito mais em regulamentos como o termo apropriado para o "praxismos" dos chefes de polícia, delegados e subdelegados, do que em lei. Como afirmava Dr. Tito Algusto, chefe de polícia em 1883; “a segurança publica, a protecção das pessoas e propriedades, não podem descançar tranquillas no domínio da deficiente legislação actual”'155.

Este aspecto de legislar sobre o comportamento pode ser facilmente percebido nas celeumas entre a polícia e as câmaras municipais pelo poder de elaborar os códigos de posturas municipais e os temos de bem viver ${ }^{156}$. Neste sentido podemos observar os argumentos do chefe de polícia Dr. Tito Algusto Pereira de Matos no relatório do ano de 1883 transcrito abaixo.

Cabem, pois, cumulativamente á policia o ás câmaras municipaes todos os meios administrativos, mencionados nos arts, 66 a 73 da citada lei, os quaes caracterisamse pela summa importância dos objectos a que se referem. São estes: Tranquillidade, segurança, saúde e commodidade. Mas, pelo art. 71 daquella lei, compete às câmaras formar posturas. Ora, occorre que sobre alguns serviços, que se filiam áquellas rubricas, o código municipal não possue posturas, que os regulamentem, $e$ sobre outros as posturas adoptadas são sem alcance pratico, quando, pela imperfeição, nao acoroçôam delictos ${ }^{157}$.

A partir dos códigos criminais que foram elaborados as leis, decretos e regulamentações para institucionalização e aplicabilidade dos poderes de polícia. Como podemos ver no Anexo I ${ }^{158}$ era constante a criação de novas leis, bem como, alterações das existentes, seja no Império, seja na República como se “convenceram desde logo o Governo Provisório de que, sem uma revisão das leis civis e criminaes

154 BRASIL. Ministério da Justiça. Relatório do ano de 1878. Rio de Janeiro. Typographia Perseverança, 1879, p. 71.

${ }^{155}$ BRASIL. Ministério da Justiça. Relatório do ano de 1883. Rio de Janeiro. Typographia Nacional, 1884, p. A-G-20-1.

${ }^{156}$ Para os termos de bem viver sugerimos ver, Eduardo Martins. "A invenção da vadiagem. Os termos de Bem Viver e a sociedade disciplinar no Império do Brasil”. Curitiba, Editora CRV, 2011. ${ }^{157}$ BRASIL. Ministério da Justiça. Relatório do ano de 1883. Rio de Janeiro. Typographia Nacional, 1884, p A-G-12,

${ }^{158}$ Ver Tabela 09, p. 402. 
e decretação de reformas e disposições complementares ${ }^{159}$ não poderia o Brasil almejar a modernidade e agir sobre os preceitos da ciência. No entanto, em relação ao código criminal afirma categoricamente o Ministro Campos Salles que esta foi "a melhor legislação que nos deixou a monarchia”, ainda que "já muito deficiente, porém, na qualificação dos crimes, incompleta na applicação de muitas theorias ${ }^{160}$.

Podemos considerar como importante marco jurídico para nossos estudos a promulgação do código criminal em 1830 e o código de processo criminal em 1832, mas principalmente a lei de revisão destes códigos de 1841 como veremos adiante. É pelo código criminal de 1830 e de processo criminal 1832 que se extingue a Intendência Geral da Polícia e a Guarda Real do período joanino, substituídas, respectivamente, pela Secretaria de Polícia da Corte e pelo corpo de Guardas Municipais Permanentes de 1831. Segundo Holloway (1997) a Secretaria de Polícia da Corte é o início do processo de modernização do que hoje se constitui a polícia civil, enquanto que o corpo de Guardas Municipais Permanentes de 1831, renomeado para Corpo Municipal Permanente da Corte em 1842 é o início da modernização da atual polícia militar ${ }^{161}$.

$\mathrm{O}$ artigo $1^{\circ}$ do Código Criminal de $1830^{162}$ criou muito mais a necessidade de responder uma pergunta do que a afirmação positiva de uma lei, pois ao afirmar pela negação de que "não haverá crime, ou delito sem uma lei anterior, que o qualifique" levou os chefes de polícia à necessidade de realizarem esforços, no sentido de produção de conhecimento através de sua prática e de seus estudos para influenciar as assembleias legislativas na produção de leis. Neste sentido percebeu-

${ }^{159}$ BRASIL. Ministério da Justiça. Relatório do ano de 1889. Rio de Janeiro. Imprensa Nacional, 1891, p. 14.

${ }^{160}$ Idem, p. 18.

${ }^{161}$ Em relação a polícia militar esta passou por diferentes denominações até a década de 1920, como podemos observar: Divisão Militar da Guarda Real de Polícia - 1809, Corpo de Guardas Municipais Permanentes - 1831, Corpo Municipal Permanente da Corte - 1842, Corpo Policial da Corte 1858, Corpo Militar de Polícia da Corte - 1866, Corpo Militar de Polícia do Município Neutro 1889, Regimento Policial da Capital Federal - 1890, Brigada Policial da Capital Federal 1890, Força Policial do Distrito Federal - 1905, Brigada Policial do Distrito Federal - 1911, Polícia Militar do Distrito Federal - 1920. Não é intento nosso mas seria possível associar cada mudança de denominação a reformas no seio do Estado, geradas por tenções sociais, seja no interior da própria classe dominante, seja pela luta de classes. Neste sentido Werneck da Silva, (1981: 176) aponta que "houve corpos de polícia militar com denominações diferentes. Corpo de guardas municipais permanente, criado em 1831 e reorganizado em 1842. Corpo policial da corte, criado em 1858 engajado na guerra do Paraguai em 1866, ano também em que reconstituiu, passou a se chamar corpo e polícia militar da corte, corpo militar da foça policial da cidade do Rio de Janeiro, chegando até a República.

162 Código Criminal de 1830 lei de 16 de dezembro de 1830. Disponível em: <http://www.planalto.gov.br/ccivil_03/leis/lim/lim-16-12-1830.htm>. Acesso em 07 ago. 2014. 
se a necessidade de produção de conhecimento da dinâmica social para determinar em forma de lei o que é um ato ou comportamento criminoso. Diante do retardo que significava a criação de uma lei e a necessidade de agir no imediato das relações sociais cotidianas os chefes de polícia, delegados e subdelegados, agiam como "praxistas" que enquadravam situações novas não previstas nas leis, menos pelo arbítrio, e mais por uma sinalização de cientificidade do modo que estas situações eram tratadas nos países "cultos". Dr. Tito Algusto, chefe de polícia em 1883 afirmava categoricamente que,

sem sancção penal, porém, contra os transgressores das ordens policiaes, não ha correctivo algum e é assim nulla a intervenção da autoridade. $O$ código municipal na secção $2 a$, tit. $4^{\circ}, \S \S 1^{\circ}, 2^{\circ}$ e $3^{\circ}$, estatuindo relativamente a actos, que importam perturbação do socego e offensa á moral, embora applicavel a casos que occorrem em ajuntamentos ou reuniões publicas, não compreende aquellas espécies ${ }^{163}$.

O código de processo criminal de 1832 que reorganiza a polícia dá aos juízes de paz certa centralidade na condução do controle e ordenamento das populações e das atribuições judiciárias, como por exemplo o controle sobre o processo de aplicação dos códigos de "bem viver". O fato do cargo dos Juízes de Paz ser eletivo pelo restrito grupo dos que possuíam cidadania política, "tornava a autoridade judiciária independente do poder administrativo"164 a ponto de parte da historiográfica tradicional "rotula-lo como democrático" (Werneck da Silva, 1981, p. 65). O código de processo criminal de 1832 além de regular diversos aspectos da atividade policial estabelece a figura do Juiz de Paz como peça fundamental no controle da população, a ponto da Câmara Municipal da Corte estabelecer uma postura municipal que criava o livro de matrícula de escravo sob a reponsabilidade do juízos de paz o qual entre outras determinações apontava que nenhum escravo poderá ser vendido "senão perante o juiz de paz" (art. $5^{\circ}$ )", bem como, deverão os libertos apresentar seus títulos perante aquele juízo (art. 11º) (Werneck Da Silva, 1981, p. 57-8).O Juizado de Paz foi uma das primeiras ações no sentido de separar as funções judiciárias e as propriamente policiais. Estes foram incumbidos de cuidar dos crimes relacionados diretamente a desordem na cidade, como a vadiagem, a

${ }^{163}$ BRASIL. Ministério da Justiça. Relatório do ano de 1883. Rio de Janeiro. Typographia Nacional, 1884, p A-G-13.

${ }^{164}$ José Murilo de Carvalho (2010) e Werneck da Silva (1981), entre outros, apontam este momento como o da vitória dos grupos liberais e da descentralização como marca política. 
mendicância e o meretrício, a fim zelar pela segurança pública. A figura do Juiz de Paz junto com as Câmaras de Vereadores eram os responsáveis diretos pelo controle da população na esfera da municipalidade. Tinha entre outros poderes, a capacidade de legislar através dos códigos de posturas e regulamentos.

Somente em 1841 através da lei no 261 de 3 de dezembro daquele ano que reforma a estrutura judiciaria é que a polícia retoma o poder "ilimitado" sobre os citadinos, tal qual lhe fora concedido por D. João VI, e que, por sua vez, remota ao alvará de 1760 . De 1832 a 1841 a polícia estava subordinada ao judiciário "e a polícia administrativa ainda não se confundia muito com a judiciária", com a reforma de 1841 "não havia uma distinção mais nítida entre a polícia administrativa e a polícia judiciarias" (Werneck Da Silva, 1981, p. 175). Na reforma de 1841 que culminou com a regulamento $\mathrm{n}^{\circ} 120$, de 31 de janeiro de 1842, que "regula a execução da parte policial e criminal da Lei n 261 de 3 de dezembro de 1841 ", o chefe de polícia e a instituição policial assumem as diversas funções que anteriormente eram dos Juízes de Paz e das Câmaras Municipais. A reforma de 1841 passou para a competência dos Chefes de Polícia, delegados e subdelegados as atribuições conferidas aos Juízes de Paz nos art. $4^{\circ}$ e art. 12 parágrafos $1^{\circ}, 2^{\circ}, 3^{\circ}$, $4^{\mathrm{o}}, 5^{\mathrm{o}}$ e $7^{\mathrm{o}}$ do Código do Processo Criminal ${ }^{165}$. Artigo estes que diziam respeito as posturas municipais, a polícia judiciaria e a competência para a formalização de culpa. A autorização para que delegados e sub delegados "começarem um processo de formação da culpa" lhes garantiam amplo poder de ação contra todas as espécies de perturbação da ordem social e urbana nas cidades. Este fato além de aumentar enormemente o poder do chefe de polícia e de seus subordinados diretos, delegados

\footnotetext{
${ }^{165}$ Código do Processo Criminal 1832. Art. 12. Aos Juizes de Paz compete: $\$ 1^{\circ}$ Tomar conhecimento das pessoas, que de novo vierem habitar no seu Districto, sendo desconhecidas, ou suspeitas; $e$ conceder passaporte ás pessoas que lh'o requererem. $\$ 2^{\circ}$ Obrigar a assignar termo de bem viver aos vadios, mendigos, bebados por habito, prostitutas, que perturbam o socego publico, aos turbulentos, que por palavras, ou acções offendem os bons costumes, a tranquillidade publica, e a paz das familias. $\$ 3^{\circ}$ Obrigar a assignar termo de segurança aos legalmente suspeitos da pretenção de commetter algum crime, podendo cominar neste caso, assim como aos comprehendidos no paragrapho antecedente, multa até trinta mil réis, prisão até trinta dias, e tres mezes de Casa de Correcção, ou Officinas publicas. $\$ 4^{\circ}$ Proceder a Auto de Corpo de delicto, e formar a culpa aos delinquentes. $\S 5^{\circ}$ Prender os culpados, ou o sejam no seu, ou em qualquer outro Juizo. $\S 6^{\circ}$ Conceder fiança na fórma da Lei, aos declarados culpados no Juizo de Paz. $7^{\circ}$ Julgar: $1^{o}$ as contravenções ás Posturas das Camaras Municipaes: $2^{\circ}$ os crimes, a que não esteja imposta pena maior, que a multa até cem mil réis, prisão, degredo, ou desterro até seis mezes, com multa correspondente á metade deste tempo, ou sem ella, e tres mezes de Casa de Correcção, ou Officinas publicas onde as houver. $\$ 7^{\circ}$ Julgar: $1^{\circ}$ as contravenções ás Posturas das Camaras Municipaes: $2^{\circ}$ os crimes, a que não esteja imposta pena maior, que a multa até cem mil réis, prisão, degredo, ou desterro até seis mezes, com multa correspondente á metade deste tempo, ou sem ella, e tres mezes de Casa de Correcção, ou Officinas publicas onde as houver.
} 
e subdelegados, impõe a necessidade de identificar previamente os culpados, aliado a ideia de prevenção de crime e organização do espaço urbano.

A lei de 3 de dezembro de 1841 que reformou a polícia pode ser vista como o marco de novo momento na história da polícia na Corte e no Distrito Federal. Esta lei tirou dos Juízes de Paz às atribuições policiais, administrativas e judiciais, bem como, propiciou que em 1842 o Regulamento 120 concentrasse as funções da polícia administrativa e judiciária que estavam sob autoridade direta do Ministro da Justiça. A importância da reforma de 1841 pode ser vislumbrada no fato de que estas se consolidaram como modelo e base da gestão das instituições policiais por todo o século XIX e parte do XX. Ainda que possamos vislumbrar algumas mudanças em âmbito operacional a base jurídica que justifica o tipo de inserção das intuições policiais no corpo do Estado e na relação direta com a municipalidade da cidade do Rio de Janeiro pouco ou nada se alterou desde 1841, até o primeiro quartel do século XX.

As reformas de 1841 estavam assentadas na percepção social da classe dominante do aumento da criminalidade, aliado a pouca eficiência dos juizados de paz na prevenção da vadiagem e outros crimes de postura e moralização. Para autores como Carvalho (2001) tratava-se do retorno da ala mais conservadora da classe senhorial, um endurecimento para organização do trabalho urbano livre, em outras palavras, um controle mais direto sobre o homem pobre livre e a circulação de bens. A reforma do Código de Processo Criminal de 1841 devolveu o controle da estrutura administrativa e judiciária para as intuições policiais com o claro objetivo de agir onde os juízes de paz houvera falhado; o controle das populações pobres na cidade. Reduzia-se com isto a importância da eleição dos Juízes de Paz. O juizado de paz conforme fora proposto pelas leis de 1830 e 1832 significava a descentralização do poder dentro da própria classe senhorial, o que foi desconstruído com a reforma de 1841. Esta interpretação encontramos tanto em José Murilo de Carvalho (2001), quanto em Holloway (1997, p. 158) segundo o qual a lei de 3 de dezembro de 1841 reestabelece o modelo de "hierarquia centralizada". No regulamento $\mathrm{n}^{\mathrm{o}} 120$, de 31 de janeiro de 1842 que regula a execução da parte policial e criminal da lei $n^{\circ} 261$ de 3 de dezembro de 1841 podemos observar o quanto foi o ganho de poder da polícia. Segundo "Zacarias de Góes e Vasconcelos (apud Werneck da Silva, 1981, p. 157), presidente do conselho e Ministro da Justiça do gabinete de 15 de janeiro de 1864, pela lei de 3 de dezembro 
de 1841 "a polícia foi organizada de tal forma que compreendia no âmbito de suas atribuições o poder de julgar. Confundiram-se o administrativo e o judiciário"

Houve um esvaziamento de poder e competência dos Juízes de Paz no campo judicial, criminal e policial a ponto de perderem o poder de jugaram as posturas municipais, transferindo esta atribuição para o chefe de polícia, delegados e subdelegados, nomeados diretamente pelo poder central. Esta organização administrativa e judiciária da polícia tinha como o "primeiro chefe e centro de toda a administração policial"166 o ministro da justiça, após, na estrutura de poder, encontrava-se os presidentes das províncias ${ }^{167}$, depois os chefes de polícia, seguidos pelos delegados de polícia e subdelegados, somente após estes apareceriam os juízes municipais e juízes de paz no organograma de poder das reformas de 1841, apenas a frente dos inspetores de quarteirão e das Câmaras Municipais e seus fiscais. Werneck da Silva (1981, p. 134) aponta que "se o município da corte, durante a ação, foi o município do juiz de paz, durante a reação e transição seria do chefe de polícia" (Werneck da Silva, 1981, p. 134) ${ }^{168}$.

A reforma criminal de 1841 normatizada pelo regulamento 120 de 1842 conferiu ao chefe de polícia as atribuições de "tomar conhecimento das pessoas, que de novo vierem habitar no seu districto", tal qual era previsto no Alvará de 1760 em Portugal. Do mesmo modo o Alvará 1760 se aproxima da reforma de 1841 ao tratar "dos mendigos, bebados por habito, prostitutas, que perturbão o socego publico". Ainda competia ao chefe de polícia "examinar se as Camaras Municipaes tem providenciado sobre os objectos de policia, que por Lei se achão a seu cargo, representando-lhes com civilidade sobre as medidas que entenderem convenientes, para que se convertão em Posturas". Cabia ainda ao Chefe de Polícia as atribuições de "organisar a estatistica criminal da Provincia e a do Municipio da Côrte" e o "arrolamento da população da Provincia" 169. Sem muito esforço é possível identificar na reforma de 1841 um retorno ao modelo de chefe de polícia muito próximo ao que foi determinado pelo Alvará de 1760, qual seja, uma autoridade policial centralizadora com um amplo campo de atuação no conjunto da

\footnotetext{
${ }^{166}$ Artigo $1^{\circ}$ do Regulamento ${ }^{\circ} 120$, de 31 de janeiro de 1842.

${ }^{167}$ Cabe a ressalva que no Rio de Janeiro não havia presidente da província a relação era direta entre o poder central na figura do Imperador ou Presidente, sendo o Chefe de Polícia parte do segundo escalão de poder executivo, abaixo apenas do Ministro da Justiça.

${ }^{168}$ Segundo o referido autor o momento da ação vai de 1831 a 1836/1840 e o momento da reação de 1836/1840 a 1866 (Werneck da Silva, 1981).

${ }^{169}$ Lei de 3 de Dezembro de 1841 .
} 
sociedade, para a qual os aspectos admirativos das populações nas cidades são muito mais relevantes do que reduzir seu papel à mera ação repressora de crimes com base na violência.

Podemos ainda traçar precisas comparações entre o regulamento $\mathrm{n}^{\circ} 120$, de 31 de janeiro de 1842 que regula a execução da parte policial e criminal da Lei no 261 de 3 de dezembro de 1841 com o Alvará de 1760 em Portugal, mais precisamente o Capítulo I. Neste regulamento na Secção I - Das atribuições do Chefe de Polícia vislumbramos em seu artigo 58, parágrafo $1^{\circ}$ as mesmas atribuições do Alvará de 1760, qual seja: "tomar conhecimento das pessoas, que de novo vierem habitar no seu distrito, sendo desconhecidas, ou suspeitas, e conceder, na forma da Secção $1^{a}$ do Capitulo $5^{o}$ deste Regulamento, passaportes ás pessoas, que lh'o requererem". A necessidade de conhecer e identificar a população de forma geral deve-se, entre outras coisas, para conseguir distinguir entre aqueles que contribuíam para desordem urbana, quais eram criminosos e/ou ociosos e vagabundos, os quais deveriam ser regenerados pelo e para o trabalho, quais eram os pobres inválidos que não podiam trabalhar e, por isto eram merecedores da assistência. Podemos ainda destacar outros aspectos que incitam comparações precisas entre os dois regulamentos demonstrando uma relação direta entre a polícia de Lisboa na metade do século XVIII e a polícia do Rio de Janeiro durante todo século XIX e início do XX.

No regulamento $\mathrm{n}^{\mathrm{o}} 120$, de 31 de janeiro de 1842 encontramos a base do que significou, ao menos em forma de lei, a instituição policial na formação do Estadonação no Brasil. Entre outras medidas "o regulamento n. 120 de 31 de janeiro de 1842, art. 135, confere á policia a autorização de permitir divertimentos públicos, aprovar seus programas e fiscalisar a execução" ${ }^{170}$. Vale ressaltar que esta regulamentação foi motivo de constantes querelas entres os grupos no interior da classe dominante e sustentou judicialmente as diversificadas ações e reponsabilidades de controle da população na cidade da qual estava a polícia incumbida. Este regulamento reforça a ideia de uma impossibilidade de dissociar a polícia administrativa da judiciaria.

${ }^{170}$ BRASIL. Ministério da Justiça. Relatório do ano de 1883. Rio de Janeiro. Typographia Nacional, 1884, p. A-G-13. 
A tranquillidade, a segurança, a saúde e a commodidade dos habitantes são recomendadas pela lei de 1 de outubro de 1828, e o regulamento n. 120 de 31 de janeiro de 1842 conferiu a autoridade policial, cumulativamente com as câmaras municipaes, todas as attribuições administrativas atinentes a tão sérios serviços ${ }^{171}$.

A polícia administrativa tal qual consta no regulamento 120 de $1842^{172}$ amplia seus poderes de gestão da cidade, passando a exercer funções que outrora estava entregue as Câmeras Municipais, como o Titulo $3^{\circ}$ da Lei do $1^{\circ}$ de Outubro de 1828 que versa sobre as posturas policias como podemos observar no art. $66^{173}$ :

Terão a seu cargo tudo quanto diz respeito á policia, e economia das povoações, $e$ seus termos, pelo que tomarão deliberações, e proverão por suas posturas sobre os objectos seguintes: Alinhamento, limpeza, illuminação, e desempachamento das ruas, cães e praças e quaesquer outras construcções em beneficio commum dos habitantes, ou para decôro e ornamento das povoações. (...) Sobre as vozerias nas ruas em horas de silencio, injurias, e obscenidades contra a moral publica. Sobre os damninhos, e os que trazem gado solto sem pastor em lugares aonde possam causar qualquer prejuizo aos habitantes, ou lavouras. Sobre construç̧ão, reparo, $e$ conservação das estradas, caminhos, plantações de arvores. Proverão sobre lugares onde pastem e descancem os gados para o consumo diário. Protegerão os criadores, e todas as pessoas, que trouxerem seus gados para os venderem.(...) Proverão igualmente sobre a commodidade das feiras, e mercados, abastança, e salubridade de todos os mantimentos, e outros objectos expostos á venda publica, tendo balança de ver o peso, e padrões de todos os pesos, e medidas para se regularem as aferições; (...) Poderão autorizar espectaculos publicos nas ruas, praças, e arraiaes, uma vez que não offendam a moral publica, mediante alguma medica gratificação para as rendas do Conselho, que fixarão por suas posturas.

Podemos observar que as posturas policiais previstas na lei do $1^{\circ}$ de outubro de 1828 se relacionavam, entre outras coisas, com as questões do provimento de víveres na cidade, com a garantia da produção e da circulação de bens, principalmente os ligados ao abastecimento. Deveria cuidar da aferição de medidas e pesos, da moral, dos costumes e dos espetáculos artísticos. Para nós é emblemático o artigo 69 do título $3^{\circ}$ da lei do $1^{\circ}$ de outubro de 1828 , o qual pelo regulamento 120 de 1842 deixa de ser de responsabilidade da Câmara Municipal e passa diretamente para os cuidados da polícia. O artigo 69 determina que as instituições

\footnotetext{
${ }^{171}$ BRASIL. Ministério da Justiça. Relatório do ano de 1883. Rio de Janeiro. Typographia Nacional, 1884, p. A-G-17.

${ }^{172}$ Regulamento no 120, de 31 de janeiro de 1842. "SECÇÃO I - Da Policia Administrativa. Art. $2^{\circ}$ São da competencia da Policia Administrativa geral, além das que se achão encarregadas ás Camaras Municipaes pelo Tit. $3^{\circ}$ da Lei do $1^{\circ}$ de Outubro de 1828".

${ }^{173}$ Lei do $1^{\circ}$ de Outubro de 1828. Disponível em: <http://www.planalto.gov.br/ccivil_03/Leis/LIM/LIM-1-10-1828.htm\#art73>. Acesso em: 07 ago. 2014.
} 
policiais “Cuidarão no estabelecimento, e conservação das casas de caridade, para que se criem expostos, se curem os doentes necessitados, e se vaccinem todos os meninos do districto, e adultos que o não tiverem sido, tendo Medico, ou Cirurgião de partido" "174. Além destes aspectos ligados diretamente ao que chamaríamos hoje de assistência social e médica, tinham que inspecionar "as escolas de primeiras letras, e educação, e destino dos orphãos pobres, em cujo numero entram os expostos; e quando estes estabelcimentos, e os de caridade, de que trata o art. 69. Deveira a polícia "promover e manter a tranquillidade, segurança saude, $e$ commodidade dos habitantes; o asseio, segurança, elegancia, e regularidade externa dos edificios, e ruas das povoações, e sobre estes objectos formarão as suas posturas" 175 . Além de todas as funções descritas acima cabia "julgar as contravenções ás Posturas das Camaras Municipaes", além de poderes de formular leis e posturas municipais. Estas mudanças tinham por objetivo, principalmente, atingir a vadiagem. Neste sentido, o Dr. Tito Matos, chefe de polícia, afirmava em 1883 que "o regulamento 120 de 31 de janeiro de 1842, art. 23, entre as attribuições, que conferiu á autoridade policial, inclue as do tit. $3^{\circ}$ da lei de 1 de outubro de $1828 " 176$.

O período de 1841 a 1866 é definido como o período do amadurecimento das instituições policiais. Segundo Holloway (1997) a polícia [na cidade do Rio de Janeiro] já havia atingido a sua "maturidade institucional" na década de 1870 . Neste período devemos ressaltar o decreto $\mathrm{n}^{\circ} 1746$ de 16 de abril de 1856 que segundo relatório do ano de 1883 do Dr. José Antonio Gomes continua a reger a secretaria de polícia ${ }^{177}$. O decreto $\mathrm{n}^{\mathrm{o}} 3.598$ de 27 de janeiro de 1858 que organizou a força policial da corte em corpo militar de polícia e guarda urbana ${ }^{178}$. E, o decreto $\mathrm{n}^{\circ} 3598$ de 27 de janeiro de $1866^{179}$ que dividiu a polícia em “dous corpos, o militar e o civil

\footnotetext{
174 Idem, art. 70.

175 Idem, art. 71

${ }^{176}$ BRASIL. Ministério da Justiça. Relatório do ano de 1883. Rio de Janeiro. Typographia Nacional, 1884, p. A-G-11.

177 BRASIL. Ministério da Justiça. Relatório do ano de 1884. Rio de Janeiro. Imprensa Nacional, 1885 p. A-F-15.

178 BRASIL. Ministério da Justiça. Relatório do ano de 1871. Rio de Janeiro. Typographia Americana, 1872a, p. A-19.

179 "A " corpo militar, creado por decreto n. 3598 de 27 de Janeiro de 1866, competem, alem da guarnição do quartel e de outros estabelecimentos, inclusive as estações da guarda urbana, a conducção e guarda dos presos, diligencias nos districtos dos subúrbios, rondas e outros misteres. Á guarda urbana, creada pelo mesmo decreto, incumbe a vigilância nos districtos centraes da cidade. Existe ainda uma companhia de 34 pedestres, distribuídos pelas freguesias de fora".
} 
ou paisano" 180 . Ainda que as "reformas progressistas de 1866" (Werneck da Silva, 1981, p. 167) possam ter alterados pontos da administração policial estas não interferiram diretamente na conjuntura verificada a partir de 1841, qual seja; centralização de poderes judiciais e municipais junto ao chefe de polícia, delegados e subdelegados. Estas reformas instituídas pelo decreto n ${ }^{\circ} 3598$ de 27 de janeiro de 1866, que reorganizou a força policial da corte em militar e civil e o decreto $\mathrm{n}^{\circ}$ 3609 de 17 de fevereiro de 1866 que regulamentou a guarda urbana ${ }^{181}$, não alteram as circunstâncias impostas pelas reformas de 1841-42. Nem mesmo a reforma judicial do ano de 1871 aterrou os preceitos da lei de 1841 ou minimizou a influência do regulamento 120 de 1842, ou mesmo conseguiu resolver a questão dos limites entre justiça, polícia e municipalidade. Conforme apontava em 1878 o ministro Dr. Lafayette Rodrigues Pereira;

convém, pois, definir, ampliar, e mesmo codificar as attribuições da policia, indicando-se claramente as que the são exclusivas, $e$ as que deve exercer cumulativamente com outras autoridades, ou cooperando com ellas, ou auxiliandoas, ou finalmente representando obrigatoriamente perante quem fôr de direito ${ }^{182}$.

A importância da lei de dezembro de 1841 se dá devido esta pautar as ações da polícia até as primeiras décadas do século XX e ao mesmo tempo em que podemos identificar claros pontos em comum com o alvará de 1760. Esta importância pode ser observada nas discussões suscitadas nos diversos relatórios dos chefes de polícia nas décadas de 1870 e 1880 e 1890 . Apesar de ser "geralmente sentida e reconhecida a necessidade de reformar as leis, que regulam a administração da justiça" ${ }^{\text {183; }}$; podemos observar práticas e discursos policiais nas

(BRASIL. Ministério da Justiça. Relatório do ano de 1875. Rio de Janeiro. Instituto Typographico do Direito, 1877b, p. 34).

180 BRASIL. Ministério da Justiça. Relatório do ano de 1873. Rio de Janeiro. Typographia Americana, 1874, p. 33.

${ }^{181}$ Segundo Werneck da Silva (1981, p. 178) a guarda urbana criada em 1866 "foi constituída como o corpo apaisano da força policial da cidade do Rio de Janeiro (...) apesar de uma tênue militarização, se pretendeu fazer a base de uma polícia civil, mas uma polícia civil, definitivamente personalizada em face de uma polícia militar, só se definira na conjuntura seguinte o que escapa ao nosso estudo". Em 1870 na corte a Força Policial estava dividida em "Corpo Militar com 360 praças, e Guarda Urbana com igual número" (BRASIL. Ministério da Justiça. Relatório do ano de 1870. Rio de Janeiro. Typographia Nacional, 1871, p. 12).

182 BRASIL. Ministério da Justiça. Relatório do ano de 1878. Rio de Janeiro. Typographia Perseverança, 1879, P 71.

${ }^{183}$ BRASIL. Ministério da Justiça.Relatório 1870. Rio de Janeiro. Typographia Nacional, 1871, p. 5. 
primeiras décadas do século XX com referências nítidas a reforma policial de 1841 42.

Mesmo sendo a reforma judiaria de 1841-42 hegemonicamente defendida pela classe dominante, no relatório de 1870, por exemplo, podemos vislumbrar argumentos para a alteração da lei $\mathrm{n}^{\mathrm{o}} 261$ de 3 de dezembro de 1841. Segundo estes argumentos "os progressos da civilisação bem persuadem a conveniência de serem alterados os princípios adoptados $" 184$ por tal lei, que segundo opinião do ministro da justiça Dr. Francisco de Paula Negreiro Sayão Lobato continua influenciando as práticas das instituições policiais. Uma das principais críticas que sofria a lei de 1841 era a necessidade de separar polícia e justiça, ainda "que se mantenha aos chefes de Polícia a faculdade de processar e pronunciar no caso do art. 60 do regulamento de 31 de janeiro de 1841"185. Para Lobato "A actual organização policial é, no sentir geral, menos ajustada aos princípios da sciencia. É inquestionável que jamais se deve confundir a policia com o poder judiciário, por ser ela exclusivamenteum ramo do poder administrativo" ${ }^{186}$.

O experiente chefe de polícia da corte Dr. Tito Algusto Pereira de Matos afirmava categoricamente que a organização da polícia "no Império data de 1840" época em que "a população desta capital era então pequena, e composta de nacionais em sua maioria" ${ }^{187}$. Os estrangeiros que havia entregavam-se a indústria e ao trabalho, segundo o eminente doutor. Precisava a polícia de uma organização que a adequasse as novas exigências sociais e econômica pelo qual passava o Brasil. Analisava o Dr. Tito e 1877 que

nos 36 annos decorridos depois da promulgação desta lei, as condições materiaes e moraes da Capital do Império têm soffrido grandes alterações, já pelo considerável desenvolvimento da sua área, população, commercio e industria, já pelos elementos heterogêneos e delecterios, que se introduziram na sua população, e pela consequente degeneração dos costumes públicos e desenvolvimento dos vícios $e$ crimes. Bastaria esta consideração para convencer da necessidade de rever a nossa organisação policial, afim de accommodal-a ao estado actual e necessidades desta Capital $^{188}$.

\footnotetext{
${ }^{184}$ BRASIL. Ministério da Justiça. Relatório 1870. Rio de Janeiro. Typographia Nacional, 1871, p. 5.

${ }^{185}$ Idem, p.6.

${ }^{186}$ Idem, p. 19.

${ }^{187}$ BRASIL. Ministério da Justiça. Relatório do ano de 1875. Rio de Janeiro. Instituto Typographico do Direito, 1877b, p. A-229.

188 BRASIL. Ministério da Justiça. Relatório do ano de 1877. Rio de Janeiro. Typographia Perseverança, 1878, p. A5-3.
} 
O Chefe de polícia Dr. Tito Algusto Pereira de Matos afirma de maneira categórica no relatório do ano de 1877 que a "actual organisação policial" data da Lei de 3 de Dezembro de $1841^{189}$ e devido as novas condições socioeconômicas da corte eram urgentes as reformas. No entanto o que se percebeu foi a permanência das formas jurídicas de 1841 como norteador das instituições policiais. Mesmo diante das reformas acontecidas em 1871 que buscavam estancar o abuso e o arbítrio das instituições policiais acostumadas com um "praxismo jurídico" não houve mudanças que pudesse significar um novo direcionamento na metodologia de ação e intervenção na manutenção da ordem social. Ao contrário, com o poder que tinha conquistado em 1841 a grita e as reivindicações mudaram de direção na busca da conservação da polícia administrativa misturada com a judiciária, pois só assim seria eficaz a manutenção da tranquilidade pública. Nesta perspectiva afirmava o ministro de justiça, em 1876, Dr. Francisco Januário da Gama Cerqueira que "a recente reforma judiciaria, no empenho de separar a justiça da policia e de dar garantias á liberdade individual, foi alem do que prescreviam os princípios o exigiam as conveniências publicas" ${ }^{190}$. No mesmo sentido o chefe de polícia Dr. Ovídeo Fernando Trigo de Loureiro afirmava em relatório referente aos anos de 1880 e 1881 que a

\begin{abstract}
dura experiência dos poucos annos decorridos, depois da promulgação dessa lei, autoriza os homens pensadores e amantes do progresso de seu paiz a affirmarem afoutamente, que desarramou ella a policia em presença dos delinquentes, e difficultou a prisão e o processo destes, tornando ainda mais escassos e deficientes os meios de prevenção e repressão dos crimes ${ }^{191}$.
\end{abstract}

A reforma imputada pelo regulamento de 22 de novembro de 1871, tinha em seu cerne a mudança na "marcha dos inquéritos policiaes", e no "preparo dos processos chamados policiaes" $" 192$. Neste ponto, a reforma de 1871, segundo a opinião do ministro da justiça, em relatório do ano de 1889, Dr. Francisco d’Assis

189 BRASIL. Ministério da Justiça. Relatório do ano de 1877. Rio de Janeiro. Typographia Perseverança, 1878, p. A5-3.

${ }^{190}$ BRASIL. Ministério da Justiça. Relatório do ano de 1876. Rio de Janeiro. Instituto Typographico do Direito, 1877a, p. 24.

${ }^{191}$ BRASIL. Ministério da Justiça. Relatório do ano de 1880 e 1881. Rio de Janeiro. Typographia Nacional, 1882 b, p. A-G-3.

${ }^{192}$ BRASIL. Ministério da Justiça. Relatório do ano de 1882. Rio de Janeiro. Typographia Nacional, 1883 , p. 121 
Rosa e Silva, deu margens a formação de "dous processos de formação de culpa, um policial e outro judicial, sendo este em geral copia do primeiro, com demora da administração da justiça"193. O regulamento de 22 de novembro de 1871 retornou para a competência de juízes de direito e de paz as atribuições judiciárias retiradas pela lei de 3 de dezembro de 1841 e regulamento n. 120 de 31 de janeiro de $1842^{194}$, sem que no entanto estas fossem retiradas da competência da polícia, acarretando muitas vezes a formação de um duplo processo.

Não estavam satisfeitos os chefes de polícia com a reforma de 1871 materializada na lei 2.033 de 20 de setembro que "no justo intuito de retirar da polícia as funcções judiciarias, vedou-lhe a prisão preventiva, que lhe é indispensável para o desempenho de sua difficil missão". A reforma de 1871 gerou uma grita geral como protesto aos poderes que haviam sido retirados da polícia, principalmente no que dizia respeito a prisão por "vadio e vagabundo", visto que agora para obriga-los a assinar os termos de bem viver seria preciso prova testemunhal "dificílima em muitos casos, por ser notória a relutância com que prestam depoimentos em juízo ${ }^{195}$ ". Reclamava a polícia que esta medida a impediu de realizar a tarefa de reprimir e prevenir os crimes contra a ordem pública, especificamente os vadios e vagabundos. Era uma reclama geral dos chefes de polícia contra a reforma de 1871, apesar de todos os argumentos virem acompanhado da conveniência e necessidade de "reformar as disposições legaes sobre a espécie" ${ }^{" 196}$, sem que, no entanto, mexesse no poder conferido a polícia pela reforma de 1841 de realizar a prisão preventiva e formular a culpa. "Prender os culpados antes mesmo de formada a culpa, assim como colligir as provas do delicio, são funcções essenciaes á policia e que não lhe podem ser tiradas, sem os gravíssimos inconvenientes, que por toda parte se estão observando"197 era o que argumentava o ministro Dr. Francisco Januário da Gama Cerqueira no relatório de 1876. Segundo o eminente magistrado o "art. $13 \S \S 2^{\circ}$ e $3^{\circ}$ da lei $n .2033$ de 20 de

\footnotetext{
${ }^{193}$ BRASIL. Ministério da Justiça. Relatório do ano de 1888. Rio de Janeiro. Imprensa Nacional, 1889 p. 6.

${ }^{194}$ BRASIL. Ministério da Justiça. Relatório do ano de 1882. Rio de Janeiro. Typographia Nacional, 1883, p. p. 121.

${ }^{195}$ BRASIL. Ministério da Justiça. Relatório do ano de 1871 Rio de Janeiro. Typographia Nacional, 1872 b p. A-22.

${ }^{196}$ BRASIL. Ministério da Justiça. Relatório do ano de 1875. Rio de Janeiro. Instituto Typographico do Direito, 1877b, p. A-231.

${ }^{197}$ BRASIL. Ministério da Justiça. Relatório do ano de 1876. Rio de Janeiro. Instituto Typographico do Direito, $1877^{\mathrm{a}}$, p. 24.
} 
Setembro de 1871 tem-se mostrado prejudicial ${ }^{\text {"198 }}$ levando a polícia a agir fora dos preceitos legais para garantir a manutenção da ordem urbana. "Urge restituir á autoridade policial a attribuição de prender os culpados de crime inafiançável" 199 .

O chefe de polícia Dr. Tito Algusto Pereira de Matos é enfático quando em 1883 escreve que "muitas e instantes necessidades, que por mais tempo não podem ser desatendidas, sem evidente desvantagem dos habitantes desta capital". Entre estas necessidades que deveriam ser atendidas era a separação da polícia e judiciário. No entanto, conforme argumento repetido por vários chefes de polícia esta necessidade não podia ser atendida, pois atendê-la significava tirar da polícia as atribuições do "regulamento $n .120$ de 31 de janeiro de 1842, [que] inclue as do tit. $3^{\circ} \mathrm{da}$ lei de 1 de outubro de $1828^{\prime 200}$. No relatório referente ao ano de 1886 , apenas para citar alguns, continuava a reclama das alterações feitas pela lei $n^{\circ} 2033$ de 20 de Setembro de 1871. Neste relatório o ministro Dr. Samuel Wallace MacDowell era taxativo ao afirmar que

\begin{abstract}
é hoje convicção geral que a reforma de 1871 tolheu de mais a acção da autoridade policial, mormente diante dos indiciados em crimes inaffiançaveis. Sem restituir-lhe a faculdade de prisão preventiva, independente de mandado judicial, conviria permittir-lhe, ainda fora do caso de flagrante delicto, conduzir o indiciado em crime inafiançável á presença do juiz.
\end{abstract}

Em 1883 o chefe de polícia Dr. Tito Algusto Pereira de Matos engrossa o coro afirmando que

\begin{abstract}
Essas medidas se prendera ou se referem aos recursos e meios legaes e materiaes, de que deve dispor a autoridade policial, para bem cumprir a sua grande e elevada missão de garantir a vida e a propriedade dos cidadãos e de manter e fazer respeitar a ordem e a paz publica. Para esse desejado e nobre fim, me parece indispensável, antes de tudo, que seja ainda uma vez alterada a grande lei de nossa organização judiciaria, restituindo-se ao principio elementar e base fundamental da autoridade a força e prestigio que lhe roubou a nova reforma de 2 de setembro de $1871^{201}$.
\end{abstract}

\footnotetext{
${ }^{198}$ BRASIL. Ministério da Justiça. Relatório do ano de 1876. Rio de Janeiro. Instituto Typographico do Direito, $1877^{\mathrm{a}}$, p. 24.

199 Idem.

${ }^{200}$ BRASIL. Ministério da Justiça. Relatório do ano de 1883. Rio de Janeiro. Typographia Nacional, 1884.

${ }^{201}$ BRASIL. Ministério da Justiça. Relatório do ano de 1880 e 1881 . Rio de Janeiro. Typographia Nacional, 1882b, p. A-G-3.
} 
A reclama se dava de forma geral pelas autoridades policias como podemos observar em todos os relatórios até a mudança de regime. A reclama para que se alterasse a lei devia-se ao fato de não haver correspondência da lei com a prática policial e não deveria mais a autoridade "ser compellida, para praticar o bem, a infringir a mesma lei" ${ }^{202}$. A polícia irá reivindicar a continuidade de ação ex-officio contra os infratores, pois somente desta forma seria possível conter sua "constante reprodução"203. Esta reclamação está diretamente ligada ao ordenamento e controle dos vadios e vagabundos através da aplicação e formulação das posturas municipais, que com a reforma de 1871 volta juridicamente para a mão da municipalidade na figura do juiz de paz e de direito. De fato, quem continuou prendendo os considerados vadios e vagabundos e formulando a culpa ex-officio durante todo o período abordado em nossos estudos foi a polícia. Não haveria como ser diferente pois a municipalidade não possuía organização administrativa e nem pessoal que pudesse dar conta a aplicação das posturas. O chefe de polícia Dr. Tito Matos argumentava que "em todos os paizes cultos as atribuições" de prevenir e reprimir os pobres válidos classificados por vadios e vagabundos "são da exclusiva competência da autoridade policial". O eminente bacharel insiste demonstrando que em Portugal "o código administrativo de 1842, contempla entre as attribuiçõss do administrador do conselho, que é a autoridade policial do districto"204.

A discussão que estava posta na contradição dos que defendiam as reformas de 1871 e a incongruência que esta reforma tinha em relação a prática de prisão e formação de culpa que continuava apoiada nas leis de 1841-42 relacionava-se diretamente a questão do arbítrio e do abuso da polícia para o conjunto da sociedade. Principalmente quando o arbítrio e o abuso eram deferidos contra a parcela descontente da elite. "Os espiritos naturalmente vacillam entre o receio de reforçar a acção da autoridade, e o reconhecimento dos perigos que origina a fraqueza do poder"205, era que afirmava o ministro Dr. Francisco Prisco de Souza Paraizo. Mais adiante o ministro agrumetava que

\footnotetext{
202 BRASIL. Ministério da Justiça. Relatório do ano de 1875. Rio de Janeiro. Instituto Typographico do Direito, 1877b, p. A-231.

${ }^{203}$ Idem, p. A-232.

${ }^{204}$ Idem.

${ }^{205}$ BRASIL. Ministério da Justiça. Relatório do ano de 1876. Rio de Janeiro. Instituto Typographico do Direito, 1877a, p. 80.
} 
criticava-se o regimen da Lei de 3 de Dezembro de 1841, que em verdade armava de largo arbítrio funccionarios pouco escrupulosos e dominados de paixão politica. Hoje vai tomando vulto a opinião contraria a certos preceitos da ultima reforma, por embaraçarem de algum modo a prevenção e repressão do crime ${ }^{206}$.

A necessidade de conter os abusos do jogo de poder entre os hegemônicos da época e a tentativa de não permitir o arbítrio contra as tensões dentro da própria classe dominante, em certa medida impulsionou a reforma de 1871 . No entanto a insegurança e a criminalidade espelhadas na pobreza urbana e encarnada da figura do vadio e vagabundo continuavam sendo argumentos, de certo modo, irrefutáveis pelos contemporâneos para manter a ação da polícia tal e qual descrita no regulamento 120 de 1842 . Em seu retorno a chefia da polícia em 1883 o experiente Dr. Tito Algusto Pereira de Matos faz longas considerações indicando "as falhas do serviço policial desta já importante e sempre crescente capital" e aponta quais são "as medidas mais urgentes a adoptar-se, para approximar do nosso adiantamento a organização da policia",207.

Diversas são as evidências da influência do regulamento ${ }^{\circ} 120$ de 1842 . No relatório referente ao ano de 1872, por exemplo, podemos ler que é dever do chefe de polícia "satisfazer o preceito imposto pelo artigo 181 do regulamento $\mathrm{n}^{\circ} 120$ de 31 de Janeiro de 1842 "208 para que este preste conta ao ministro da justiça. Novamente aparece no relatório de 1873 referência ao artigo 167 do regulamento n. 120 de 31 de janeiro de $1842^{209}$, do mesmo modo que também podemos observar esta mesma referência no relatório referente ao ano de $1880^{210}$, apenas para citar alguns.

A década de 1880 foi também assinalada pelas inúmeras propostas de reforma da polícia, algumas que viraram leis ou regulamentos e outras que não passaram de propostas. Das propostas que não foram materializadas em leis e práticas nos interessa em especial a organizada pelo bacharel Pedro de Barros Cavalcante de

\footnotetext{
${ }^{206}$ BRASIL. Ministério da Justiça. Relatório do ano de 1876. Rio de Janeiro. Instituto Typographico do Direito, $1877^{\mathrm{a}}$, p. 80.

${ }^{207}$ BRASIL. Ministério da Justiça. Relatório do ano de 1883. Rio de Janeiro. Typographia Nacional, 1884, p A-G-20-1.

${ }^{208}$ BRASIL. Ministério da Justiça. Relatório do ano de 1872. Rio de Janeiro. Imprensa Nacional, 1873, p. 193

209 BRASIL. Ministério da Justiça. Relatório do ano de 1873. Rio de Janeiro. Typographia Americana, 1874, p. A-162.

${ }^{210}$ BRASIL. Ministério da Justiça. Relatório do ano de 1880 e 1881. Rio de Janeiro. Typographia Nacional, 1882b, p. A-G-3.
} 
Albuquerque em 1880, relativos aos vários serviços de natureza policial e revisadas por uma comissão nomeada pelo Ministro de Justiça em 1882, da qual fazia parte o chefe de polícia. A necessidade da elaboração desta proposta se dá, segundo o ministro dá justiça de 1880 Dr. Manoel Pinto de Souza Dantas devido “ao progressivo desenvolvimento da riqueza e commercio desta capital, e ao grande crescimento da população, suppra de alguma sorte a aç̧ão punitiva que a recente legislação retirou dos agentes policiaes" ${ }^{211}$. Os resultados do novo projeto de organização da polícia e o parecer da comissão foram apresentados no relatório do ministério da justiça de 1882. O que nos interessa neste projeto é o fato de que tal proposta demonstra a relação direta que existia tanto nos preceitos administrativos quanto nas representações sociais ligando municipalidade e instituições policiais, associando diretamente a figura do prefeito e do chefe de polícia. Esta relação pode ser vista, por exemplo, na proposta de extinção do cargo de chefe de polícia, delegado e subdelegado de polícia e inspetor de quarteirão, substituídos respectivamente pelo prefeito de polícia, subprefeito de polícia, comissário de polícia e inspetor de polícia ${ }^{212}$. Na proposta o prefeito de polícia seria "nomeado por decreto demittido por decreto, devendo a nomeação recahir em doutor ou bacharel em direito" "213. Competia ao prefeito de polícia "além das attribuições que actualmente exercem os chefes de policia, e daquellas que the conferirem os regulamentos que se crearem" 214 .

No relatório do último ano do Império (1888) podemos ver de forma categórica a importância das leis de 1841-2 na afirmação do ministro Dr. Francisco d'Assis Rosa e Silva, segundo o qual

a policia a cargo deste ministério, seja a administrativa, na parte em que se destina a prevenir os factos que possam perturbar a segurança publica ou individual, seja a judiciaria, auxiliar da justiça criminal no descobrimento e prova dos delidos, na prisão dos delinquentes, continua a ter a mesma organisação que lhe foi dada pela lei de 3 de dezembro de 1841, com a differença das attibuições que a reforma de 1871 transferiu paro os juizes. Esta reforma, pela discriminação das funcções,

\footnotetext{
${ }^{211}$ BRASIL. Ministério da Justiça. Relatório do ano de 1880 e 1881. Rio de Janeiro. Typographia Nacional, 1882b, p. 144.

${ }^{212}$ BRASIL. Ministério da Justiça. Relatório do ano de 1882. Rio de Janeiro. Typographia Nacional, 1883 , p. p A-I-2.

${ }^{213}$ Idem.

${ }^{214}$ Idem.
} 
melhorou consideravelmente o serviço policial e o judiciario, mas não abrangeu a organização da policia. Para este assumpto chamo a vossa esclarecida atenção $0^{215}$

Chegamos na República com a polícia ainda gerida pelas de leis de 1841-42, que nos remete para a representação de polícia no século XVIII na Europa, particularmente em Portugal. Este fato se verifica, entre outros, no relatório de 1890, onde já na República reclama o Ministro Desembargador Antonio Luiz Afonso de Carvalho que a "as reformas os seus effeitos sobre a organização policial, aliás no empenho de separal-a completamente do poder judiciário" enfrequeceu a autorida policial e por isto "reclama medidas no intuito de fortalecer e tornar mais expedita e efficaz a acção policiai em todas as suas manifestações", visto que, a "organização do serviço policial data de 1840, e com ligeira modificação foi reproduzido pela lei $n$. 2033 de 20 de setembro de 1871 ,216.

Uma nova organização da polícia em civil e militar pode ser vislumbrada na “lei $n$. 947, de 20 de dezembro do 1892, [que] autorisou o Poder Executivo a reorganizar a policia do Districto Federal, dividindo-a em civil e militar: a fazer nova divisão das circumscripções policiaes, attendendo ao desenvolvimento $e$ extensão do mesmo Districto, e ás exigencias creadas pela reforma "217. No entanto, somente mais de 10 anos após a instauração do novo regime, em 1902 a polícia sofre reformas em sua organização com a lei n. 947, de 29 de dezembro daquele ano que reorganizou novamente a polícia em civil e militar. É apenas a partir do século XX que iniciam-se reformas capazes de institucionalizar novas práticas policias iniciando uma desvinculação com as leis 1841-42. Neste sentido podemos citar o decreto $\mathrm{n}^{\circ} 4.272$, de 11 de dezembro de 1901 que regulamentava a Brigada Policial $^{218}$, a reforma do serviço policial decretada pela lei $\mathrm{n}^{\circ} 917$, de 20 de dezembro de $1902^{219}$, em 1903 o decreto $n^{\circ} 4.762$ que trata do funcionamento da

\footnotetext{
${ }^{215}$ BRASIL. Ministério da Justiça. Relatório do ano de 1888. Rio de Janeiro. Imprensa Nacional, 1889 p. 1-2.

${ }^{216}$ BRASIL. Ministério da Justiça. Relatório dos anos de 1890 e 1891. Rio de Janeiro. Imprensa Nacional, 1891b, p. 4.

${ }^{217}$ BRASIL. Ministério da Justiça e Negócio Interiores. Relatório dos anos de 1902 e 1903. Rio de Janeiro. Imprensa Nacional, 1903, p. 77.

${ }^{218}$ BRASIL. Ministério da Justiça e Negócio Interiores. Relatório dos anos de 1904 e 1905. Rio de Janeiro. Imprensa Nacional, 1905a, p. 152.

${ }^{219}$ BRASIL. Ministério da Justiça e Negócio Interiores. Relatório dos anos de 1903 e 1904. Rio de Janeiro. Imprensa Nacional, 1904, p. 107.
} 
Guarda Civil, o decreto $n^{\circ} 4763$ que regulamenta o serviço policial, e ${ }^{\circ} 4764$ que dá novo regulamento a Secretaria de Polícia 220

Em 1907 através do decreto $\mathrm{n}^{\circ}$ 6.440, de 30 de março, a polícia civil torna-se mais profissional e técnica, instituindo os métodos lombrosianos e a reforma de 1912 cria a primeira escola de polícia. Ainda, na reforma de 1907 a polícia cria o boletim como meio de comunicação interna, demonstrando sua capacidade administrativa e gestora enquanto instância da administração pública. Para Neder e Naro (1981, p. 250), é a partir da década de 1910 "que o jogo começa a literalmente mudar”, de uma polícia que ainda tinha traços da administração municipal e, portanto continha ações de assistência social, para uma polícia meramente criminológica. Na década de 1910 inicia-se o descolamento definitivo da polícia da assistência social que se completará somente no final da década de 1920. No entanto, mesmo começando a se afastar definitivamente das ações de assistência social e administração das populações, a polícia continua tendo como cerne de suas ações a visão de que para ela está reservada a "missão civilizadora"221. Este aspecto remonta ao Estado de polícia alemão e pode ser vislumbrado nos discursos e práticas da polícia no Rio de Janeiro durante todo o século XIX e parte do XX.

A partir da escola de polícia o mote da produção de conhecimento passou a ser notoriamente lombrosiano. Os aspectos relacionados a certeza do fracasso de ações de prevenção e regeneração e a ênfase "dada à índole do povo brasileiro, enquanto massa mestiça, incapaz, carente de moral" (Neder \& Naro, 1981, p. 249) aprofunda-se e justifica, em parte, a prática de ações de cunho de assistência social, como podemos ver na afirmação de Elsio de Carvalho em 1910 (apud Neder \& Naro, 1981, p. 251) “a nossa generosa doutrina de regeneração pelo trabalho naufragou tenhamos coragem de dizê-lo”. Nader e Naro (1981, p. 261) sugerem que somente em 1930 a polícia começa o "processo de incorporação da ideologia do Estado", o que nos leva a concluir que podemos verificar a ideologia da reforma de 1841 nas primeiras décadas do século XX. A principal mudança introduzida na reforma de 1841, que consideremos presentes até as primeiras décadas é a necessidade de classificar e conhecer previamente os potenciais culpados. A parti

${ }^{220}$ BRASIL. Ministério da Justiça e Negócio Interiores. Relatório dos anos de 1902 e 1903 . Rio de Janeiro. Imprensa Nacional, 1903, p. 77.8.

${ }^{221}$ Elsio de Carvalho. A polícia carioca e a criminalidade contemporânea, rio de Janeiro, Imprensa Nacional 1910, p. 8 (apud Neder e Naro, 1981, p. 250). 
da possibilidade de formar a culpa se faz necessário identificar os culpados e estes aspectos continuaram presentes na polícia mesmo com todas as reformas posteriores a 1841 e a formação da República. É preciso destacar que não há a necessidade de transformação da polícia para que esta se adeque ao modelo liberal republicano das instituições, nem da polícia, nem de outras instituições do Império como, por exemplo, o modelo público-privado da assistência social e médica que passa do Império à República ${ }^{222}$. A polícia já havia sido criada como instituição de cunho liberal e não necessitavas de mudanças profundas em suas estruturas para servir ao novo regime. Isto fica evidente na fala do Ministro Campos Salles, segundo o qual "foi provisoriamente conservada a organização policial do regimen anterior, não convindo decretar a reforma geral de um serviço, que cada Estado deve regular segundo as suas circumstancias peculiares ${ }^{223 "}$. No período de nossos estudos 1870 a 1930 a polícia segundo interpretação de (Neder \& Naro, 1981, p. 291) podem ser definidas pelas mudanças ocorridas “em sua organização, ideologia e atuação", de modo que "foram criadas novas forças policias e abolidas outras" (Neder \& Naro, 1981, p. 271). Em nosso ponto de vista estas mudanças não implicaram em transformação da semântica social que significava a polícia, até a década de 1920. A polícia do Rio de Janeiro que vai somente se profissionalizar a partir da década de 1920 pode ser entendida como uma linha histórica que segundo que Werneck da Silva (1981, p. 178) deve-se incluir "os soldados e oficiais das policias militares de 1831, 1858, 1866 e os guardas urbanos de 1833 e $1866 "$ ".

Poderíamos dizer que nas duas primeiras décadas do século $\mathrm{XX}$ a polícia do Rio de Janeiro passou por inúmeras e intensas reformas culminando como a gestão do chefe da polícia civil em 1917, Aurelino Leal, que aprofundou a profissionalização e especialização da polícia instituindo a admissão via concurso públicos, por exemplo. No entanto, podemos observar em discurso do mesmo chefe de polícia por ocasião da “Conferencia Judiciária-policial” em $1917^{224}$, que os assuntos abordados foram, a meu ver, uma atualização do Alvará de 1760,

222 “A revolução de 15 de Novembro não alterou em parte alguma do Brazil a tranquillidade publica, e pôde offirmar-se que o poiz ainda não atravessou quadra mais pacifico do que o anno decorrido após a queda da monarchia" (BRASIL. Ministério da Justiça. Relatório do ano de 1889. Rio de Janeiro. Imprensa Nacional,1891, p. 4).

${ }^{223}$ BRASIL. Ministério da Justiça. Relatório do ano de 1889. Rio de Janeiro. Imprensa Nacional,1891, p. 7.

${ }^{224}$ Segundo Neder e Naro (1981, p. 255), a Conferencia Judiciária-policial "ocupava naquele ano, ao lado das manifestações do movimento operário grande destaque na imprensa". 
mantendo em extensão, tipos e meios a missão civilizadora da polícia, construída em Portugal no século XVIII por influência do Politzeiwissenschaft ${ }^{225}$. Segundo o Dr. Aurelino os "loucos e mendigos, hospedarias e casas congêneres, diversão pública, meretrício escandaloso, infância abandonada, repressão ao alcoolismo, uso e venda de armas, casas de penhores, além da própria constituição da polícia" (Neder \& Naro, 1981, p. 257) continuavam sendo objeto de preocupação e intervenção policial. É nesta medida que conseguimos compreender a lógica construída dentro de um processo histórico de longa duração, sobre a qual a polícia pode ser pensada a partir da organização de uma ideia e uma prática de como se lidar com a pobreza urbana, a qual entre outras estratégias se valeu da assistência social.

A convergência entre o que era a municipalidade e polícia em relação ao poder central na gestão da cidade do Rio de Janeiro fica mais evidente quando tratamos das ações de assistência social. De modo que encontramos nesta relação direta entre as instituições policiais e as práticas de assistência social um "aperfeiçoamento da civilização e da moral publica através das instituições liberais" (Werneck da Silva 1981, p. 37). No relatório de 1920 o ministro Alfredo Pinto Vieira de Mello afirma categoricamente que

\begin{abstract}
tamos atrazados de meio século quanto ao processo judiciário. As normas existentes continuam a ser no civil geralmente inspiradas no regulamento $n$. 737, de 25 de novembro de 1850, e no crime pelo Código do Processo de 1832, lei de 3 de dezembro e regulamento $n .120$ de 31 de janeiro de 1842. As alterações que essas leis teem sofírido, sem obedecer ao critério de um plano ou sequer de um methodo, são muita vez perturbadoras das relações jurídicas e formam hoje um verdadeiro labyrintho de disposições incongruentes ${ }^{226}$.
\end{abstract}

O relatório referente ao ano que foi instaurada a República ${ }^{227}$ elaborado sob a coordenação do ministro da justiça Campos Salles endereçado formalmente ao chefe do governo provisório ${ }^{228}$, podemos observar em linhas gerais as ideias da

\footnotetext{
${ }^{225}$ Idem, op. cit., nota 110, p, 111.

${ }^{226}$ BRASIL. Ministério da Justiça e Negócio Interiores. Relatório dos anos de 1919 e 1920 . Rio de Janeiro. Imprensa Nacional, 1920, p. XXXII.

${ }^{227}$ BRASIL. Ministério da Justiça. Relatório do ano de 1889. Rio de Janeiro. Imprensa Nacional, 1891.

228 Os relatórios anteriores (1870 a 1888) eram endereçados à Assembleia Legislativa e os posteriores aos presidentes da República (1890 a 1930).
} 
fundação das instituições jurídicas e de assistência, "com inteira fidelidade aos princípios que havia sustentado durante 20 annos de activa propaganda"229. Segundo Campos Sales urgia

que assumisse a responsabilidade de, immediatamente, proscrever as instituições incompativeis com a democracia, e decretar as reformas mais instantemente reclamadas pela opinião publica (...) a que foram surdos os governos monarchicos, e que desde logo determinaram o Governo Provisório da Republica (...) não só procurar corrigir os abusos das passadas administrações, mas ainda propor as medidas tendentes a melhorar os serviços, e preparar as organizações do novo regimen ${ }^{230}$.

Para um resumo sobre a história da polícia no Rio de Janeiro em poucas linhas poderíamos nos valer da interpretação de Bretas (1997) segundo o qual a polícia militar tem sua origem no "patrulhamento uniformizado das ruas" e a polícia civil se associa aos aspectos administrativos e de funções judiciárias. Do mesmo modo, assinalam Neder e Naro (1981, p. 291), que a "organização policial se divide em guarda civil e brigada policial, mantendo assim a despeita da mudança de nomes, a continuação das duas forças criadas durante o império". Vale destacar que a polícia militar deriva diretamente do poder régio, enquanto que a polícia civil se liga indiretamente a este pela intermediação do Intendente de Polícia, mais tarde os Chefes de Polícia. Ainda que as denominações militares da polícia estivessem subordinadas ao Chefe de Polícia, havia uma vinculação mais direta com os poderes militares do que com as forças policiais chamadas de civis. Este aspecto pode ser verificado no fato de "a brigada subordinada diretamente ao ministro da justiça, se colocava ao dispor do Chefe de Polícia” (Neder e Naro, 1981, p. 272), ao contrário do corpo civil que estava diretamente subordinado ao Chefe de Polícia.

As principais mudanças estruturais e, de certo modo, ideológicas que sofreram as intuições policiais, significou vis a vis o processo de legitimação da ordem burguesa na consolidação do capitalismo e da ideologia liberal no Império e na República. O momento inicial da polícia no Rio de Janeiro é claramente a repetição do que significava a polícia em Lisboa. Poderíamos dizer que o período seguinte pode ser pensado a partir da implantação do código criminal de 1830 até a reforma deste código em 1841. Segundo Holloway (1997) este período pode ser

\footnotetext{
${ }^{229}$ BRASIL. Ministério da Justiça. Relatório 1889. Rio de Janeiro. Imprensa Nacional, 1891, p. 3.

${ }^{230}$ Idem, p. 3-4.
} 
caracterizado como momento de transição de um poder de polícia que havia passado por espasmos de descentralização. O que na interpretação de Werneck da Silva (1981) significa a vitória dos liberais radicais na disputa de poder no interior da classe senhorial. Esta vitória, no entanto, dura até a reforma policial de 1841, considerada por Carvalho (2001) como o retorno do conservadorismo. Esta reforma de 1841-2, vai permanecer, segundo nosso ponto de vista, como norteador regimental e ideológico da polícia até as primeiras décadas do século XX.

Embasados pelo contexto histórico da formação da polícia exposto acima e na conjuntura do que significava esta instituição para a formação do Estado-nação que passaremos a tratar no próximo tópico dos pontos explicitamente associados a governança da pobreza válida e inválida pela polícia através de práticas de assistência social para aqueles que faziam "jus a proteção social”, pois "não houve problema social que não merecesse attenção das autoridades " 231 policiais.

\subsubsection{Tranquilidade pública: a pobreza inválida.}

Podemos ler no jornal "A Tribuna" de 20 de fevereiro de 1905 a seguinte matéria; "Notas do Dia-Os Mendigos e a Policia". Com este título a nota, que é bastante extensa para o que hoje seria uma nota, aborda o projeto de assistência a pobreza que diretamente relacionava a luta da polícia "para poupar ao habitante carioca ou ao forasteiro a triste impressão da miséria que implora na via publica" 232. Afirmava o referido jornal que "a luta é velha e o resultado improfícuo" 233 contra o pauperismo. Podemos ler na aludida nota que "houve um momento em que parecia ter sido achada a solução procurada" ${ }^{234}$ e esta solução mais uma vez apontava na direção do melhoramento e ampliação das instituições asylos e do serviço a assistência pública. Informava o referido jornal que "o Sr. Dr. Cardoso de Castro, chefe de policia, chegou a visitar o Asylo de de S. Francisco de Assis, instituição municipal destinada ao abrigo dos mendigos inválidos, e trocou

\footnotetext{
${ }^{231}$ BRASIL. Ministério da Justiça e Negócio Interiores. Relatório dos anos de 1927 e 1928 . Rio de Janeiro. Imprensa Nacional, 1930, p. 154.

${ }^{232}$ BRASIL. Ministério da Justiça e Negócio Interiores. Relatório dos anos de 1904 e 1905 - Volume I. Rio de Janeiro. Rio de Janeiro. Imprensa Nacional, 1905a, p. A-G-192.

${ }^{233}$ Idem.

234 Idem.
} 
impressões com o Sr. Dr. Pereira Passos, prefeito" ${ }^{235}$. É preciso destacar a relação de proximidade entre a polícia e a municipalidade na condução dos negócios da assistência como desmontaremos adiante.

Deste encontro e conversa, segundo o jornal chegaram a conclusão de que "asylo não satisfazia os fins para que fora creado", que a mendicidade "não encontra obstáculos" ${ }^{236}$ para o seu desenvolvimento na cidade do Rio de Janeiro, "e o mal não esta só na assistência prejudicial que lhe dá a caridade publica o que antes lhe parece um estimulo, sinão na falta de leis especiais que a regulamentem" 237. Afirmava a eminente nota que a única coisa que temos para o pobre inválido é o "o asylo que o municipio custeia. Mas esse, já o dissemos, não está em condições de os recolher. A sua lotação é insufficiente, irrisória mesmo", em torno de "cento e tantos logares" 238 . Segundo apresentava a nota o "Dr. Cardoso de Castro propoz as medidas que lhe pareceram indispensáveis para o auxilio que o Estado deve aos que não podem, por invalidez comprovada, prover á sua subsistência” 239. Afirmava o Dr. Cardoso de Castro, chefe de polícia, que "não se pense que augmentada a lotação para quinhentos ou mil que já seria uma media mais que razoável, estaria resolvida a questão. O problema é complexo e haveria de ser encarado por uma outra face" ${ }^{240}$. Entre os inválidos havia a nítida preocupação com os "mendigos atacados de moléstias chronicas ou contagiosas", pois estes não "poderiam beneficiar do recolhimento ao Asylo S. Francisco de Assis" que segundo seu regulamento não aceita mendigos nestas condições ${ }^{241}$. Apresentava claramente seu incomodo com tal situação o chefe de polícia ao afirmar que "com estes a situação da autoridade é ainda mais angustiosa que a enfermidade minaz que lhes extingue a vida. Não há onde acolhel-os" 242.

Aparece no texto pelas inflexões a sincera angústia do chefe de polícia, pois nem mesmo a Santa Casa os acolhia, ao perguntar: "que fazer então? (...) eliminalos pela morte ou deixal-os arrastarem-se pela cidade em uma exhibição

${ }^{235}$ Ibidem.

${ }^{236}$ Idem.

${ }^{237}$ Idem.

${ }^{238}$ Idem.

${ }^{239}$ Idem.

${ }^{240}$ Idem.

${ }^{241}$ Idem.

242 Idem. 
vergonhosa, que não condiz com o nosso gráo de civilisação" 243 . O Dr. Cardoso de Castro chefe de polícia em 1904 se envolveu diretamente na discussão da formação da assistência pública, sistematizou ações e práticas e, neste sentido apresentou no "relatório anual um plano geral de assistência do Estado aos necessitados", 244, embasando o projeto de organização da assistência pública do ministro J. J. Seabra.

Neste tópico demonstraremos através de práticas e discursos das instituições policiais da cidade do Rio de Janeiro, que estas protagonizaram em conjunto com a caridade e a filantropia a formação da assistência na modalidade que hoje denominamos de "social”. Não pretendemos aqui organizar em sentido cronológico os fatos, mas demonstrar as ideias, práticas e instituições que fundamentam nossa tese. Construiremos nossa análise demonstrando a presença e a importância de práticas e ideias que hoje seriam denominadas de assistência social no cerne das instituições policias. Constataremos o como e o quanto estas ideais e práticas de polícia influenciaram Estado e sociedade na construção do campo de saber e prática da assistência social na cidade do Rio de Janeiro, quiçá no Brasil.

É preciso ressaltar que, como discutido na introdução, não havia pelo aspecto semântico uma clara separação entre a ideia de assistência social, médica e jurídica. Muitas das vezes estas práticas do Estado e da iniciativa privada vinham denominadas, durante o período abarcado por nossos estudos, de assistência pública ou simplesmente assistência. Em vários momentos não conseguimos estabelecer os limites claros do que dentro da assistência no final do século XIX e início do XX na cidade do Rio de Janeiro era social ou médico. Havia também o aspecto jurídico da assistência e o mutualismo, no entanto estes tinham limites claros quanto ao escopo e abrangência de suas atuações. O caso mais emblemático da interseção entre o aspecto médico e social da assistência é o dos pobres acometidos por transtornos mentais, classificados na época de alienados. Estes, apesar de estarem confiados ao discurso médico, estavam sujeitos a administração policial no ordenamento da cidade, a qual criou e gerenciou hospícios ${ }^{245}$. Outro aspecto onde os limites são tênues diz respeito a relação entre crimes e sua prevenção relacionado

\footnotetext{
${ }^{243}$ Ibidem.

244 Idem.

245 A esse respeito ver o último capítulo da dissertação de mestrado "Da Desumanização e da Norma: A construção social das noç̃̃es de vadio e vagabundo em meio as atribulações da fabricação do Estado-Nação no Brasil (1870-1900)". SOUZA, Antonio Reguete Monteiro de. Programa de Pósgraduação em Serviço Social, Pontifícia Universidade Católica do Rio de Janeiro - PUC-RIO, Rio de Janeiro, 2010.
} 
a pobreza. Neste particular, apesar de quase sempre sobressair os aspectos da repressão, encontramos a proteção também como prática.

Apesar de não haver uma separação semântica clara entre o que era assistência social e médica ou formas de assistência ligadas a repressão e formas de assistência ligadas a prevenção e proteção, é possível demonstrar através de discursos e práticas que havia uma nítida razão administrativa que diferenciava estrategicamente os tipos de assistência gerenciados pelo Estado através do Ministério da Justiça, cujo a polícia era seu principal executor. Estas estratégias de intervenção, vislumbrava categorias específicas de intervenção a partir dos diferentes tipos de assistência. Separava claramente o discurso e prática média, que necessariamente se associava a intervenções medicamentosas e cirúrgicas, dos discursos e práticas meramente relacionados a pobreza enquanto problemática social pertinente ao trabalho. Neste último aspecto havia uma nítida separação nos discursos e práticas que imputavam diferentes metodologias de intervenção social; as que destinavam-se a proteção dos pobres inválidos e as direcionadas a repressão dos pobres válidos.

Importante destacar para nossos argumentos, que no interior do Estado e, por conseguinte, no interior da classe dominante, enquanto que o discurso da saúde era, obviamente, apropriado pelo médico, nem tão óbvio assim era o fato de que o discurso do "social" foi apropriado pelos bacharéis, principalmente os que ocuparam cargos públicos de relevância. É preciso destacar que durante todo o século XIX e o primeiro quartel do XX os aspectos administrativos do Estado brasileiro no gerenciamento da saúde ${ }^{246}$, instrução (educação) e o que hoje denominamos de assistência social estavam a cargo do Ministério da Justiça, além claro dos aspectos relacionados propriamente a justiça e polícia, no sentido estrito do termo. Por este motivo não era de se estranhar que as propostas de organização da chamada assistência pública partiram dos ministros de justiça e dos chefes de polícia, pois o Ministério da Justiça era o gestor direto da saúde, instrução e

${ }^{246}$ A assistência médica, mesmo não sendo foco de nossos estudos acabará aparecendo, ainda que, de forma célere, secundária e superficial, através principalmente do "alienado". Aqui cabe uma ressalva - já que para nosso entendimento em última instância a assistência social é a expressão direta da questão do trabalho e do não trabalho nos últimos anos da escravidão. Cabe ressaltar que os escravos na cidade do Rio de Janeiro tinham mais "acesso" a saúde do que os imigrantes e homens livres pobres, pois aqueles representavam um bem em si mesmo e seu dono tinha interesse que a "máquina" estivesse "funcionando" corretamente - principalmente após a proibição do tráfico negreiro em 1850 -, enquanto que o segundo só poderia contar com a "sorte" da caridade. 
assistência. Através das propostas de organização da assistência poderemos vislumbrar os limites e as interseções de discursos e práticas que relacionava o social e o médico como medidas assistenciais do Estado, claramente identificadas já na segunda metade do século XIX.

A assistência como meio de gestão da pobreza e ordenamento urbano, seja nos aspectos sociais, seja na perspectiva médica, pode ser verificada em todos os relatórios analisados, o que corresponde a um período de 60 anos (1870 a 1930) da administração pública da cidade capital, Rio de Janeiro. Em matéria de assistência social duas principais ações nos interessa no repertório que a instituição policial usava administrativamente para o gerenciamento da cidade. A primeira diz respeito a criação e gerenciamento de intuições de assistência social pela polícia como a Albergaria de Mendigos, o Asylo de Mendicidade, Abrigo dos Meninos Desvalidos e a Escola XV de Novembro. A segunda ação diz respeito ao gerenciamento de fluxo e controle da pobreza urbana feita através do xadrez da polícia, que mais tarde passou a se chamar depósito da polícia, bem como, toda a articulação de uma rede de financiamento e sustentação política destas ações.

As instituições policiais no Rio de Janeiro não deixaram de fazer jus a tradição da Intendência de Polícia do século XVIII em Portugal, as ideias de Estado de polícia alemão do século XVII, aos birôs da polícia da francesa do XVIII, as experiências comunitárias da polícia londrina do XIX e, aos resultados dos sistemas penitenciários irlandeses e norte-americanos do XIX. O Intendente de Polícia do Império e mais tarde o Chefe de Polícia da capital da República estavam diretamente interessados e eram responsáveis enquanto representantes do Estado pela gestão da pobreza urbana, deveriam conhecer e administrar os pobres inválidos - crianças, alienados, velhos e doentes; os que faziam "jus a proteção social” - nos fluxos populacionais e habitacionais urbanos.

Este interesse e responsabilização direta por esta parcela da população pela via da "ajuda e apoio" é o que demonstraremos, tanto no que diz respeito as práticas instituídas pela experiência da polícia, quanto aos regulamentos e leis que fundamentaram, em certa medida, estas práticas. Destacamos inicialmente esta prática - assumido por nós como o marco fundacional de práticas do Estado em relação a assistência social - pelo Aviso de 14 de agosto de $1854^{247}$ que funda a

${ }^{247}$ BRASIL. Ministério da Justiça. Relatório do ano de 1870. Rio de Janeiro. Typographia Nacional, 1871 , p. 28. 
Albergaria de Mendigos na praia de Santa Luzia. Neste aviso podemos ler: "aproveitando-se para tal fim o telheiro á praia de Santa Luzia, que a Camara Municipal possuía à titulo de aforamento e cedeu à policia em officio de 14 de Janeiro daquelle anno" 248 , para que instale no local, que anteriormente funcionava como cocheiras, a Albergaria de Mendigos. Já neste momento podemos demonstrar o que discutiremos mais adiante da relação direta entre a polícia e a municipalidade na formação do campo da assistência social na cidade do Rio de Janeiro.

Em 1870 afirmava o então chefe de polícia Dr. Francisco de Faria Lemos em relação a Albergaria de Mendigos que este "humanitário estabelecimento" servia "não só para recolhimento de mendigos propriamente ditos, como também de outros infelizes que pelo estado de abandono em que se acham, reclamam amparo que não seria possível negar sem ofensa dos princípios de humanidade" (grifo nosso $)^{249}$. Fica evidente, já neste momento o protagonismo da polícia na criação desta albergaria de modo a ser o principal articulador e gestor desta prática de assistência, que pelas características e natureza da ação classificaríamos ao olhar de hoje como social, ou seja, práticas de ajuda e apoio para os pobres inválidos.

No relatório de 1870 - que inaugura a série histórica dos relatórios analisados por nós (1870 a 1930) - podemos perceber no dizer do Ministro Francisco de Paula de Negreiros Sayão Lobato ${ }^{250}$ que a questão da assistência e da caridade já assumia um discurso alinhado com o altruísmo positivista na condução dos negócios do Estado. Este altruísmo amalgamou no Brasil, ao mesmo tempo, a negação da caridade pela lógica da recompensa do paraíso e a incorporação desta mesma caridade nos negócios do Estado traduzido pela ideia de um humanitarismo científico positivista, decodificado de forma pragmática na filantropia privada e nas ações de assistência social, médica e jurídica do Estado.

Nossa pesquisa evidenciou a maneira como as ideias e práticas de assistência social estavam presentes nos discursos e ações das instituições policias durante todo o século XIX e início do XX. No relatório referente ao ano de 1873, por exemplo, aparece um item chamado "instituições preventivas" 251 . A descrição e análises

\footnotetext{
${ }^{248}$ BRASIL. Ministério da Justiça. Relatório do ano de 1877. Rio de Janeiro. Typographia Perseverança, 1878, p. A5-53.

${ }^{249}$ BRASIL. Ministério da Justiça. Relatório do ano de 1870. Rio de Janeiro. Typographia Nacional, 1871, p.28.

${ }^{250} \mathrm{Idem}$

${ }^{251}$ BRASIL. Ministério da Justiça. Relatório do ano de 1873. Rio de Janeiro. Typographia Americana, 1874, p. 29.
} 
destas instituições aparecia, especificamente, na parte do relatório ministerial elaborado diretamente pelo chefe de polícia. Este item, "instituições preventivas" passa a abordar de maneira sistemática e contínua nos relatórios dos chefes de polícia a questão da infância desvalida e da pobreza inválida - doentes, idosos e alienados - até o final do período analisado em nossos estudos (1930). Dentro deste item encontramos uma criteriosa descrição da Albergaria de Mendigos, mais tarde Asilo de Mendicidade, depois a do Abrigo dos Menores Desvalidos, da Escola XV de Novembro, bem como, de outras instituições congêneres pública e privadas, além de uma discussão apropriada e avançada para época sobre as providências a serem tomadas para o "tratamento" da pobreza inválida.

A classificação da pobreza inválida é nitidamente definida, em todos os relatórios pesquisados, a partir das "três grandes categorias de infelizes: as crianças, os enfermos e os velhos ${ }^{\text {252 }}$. As três categorias da pobreza inválida irão estar presentes como um problema relativo a gestão da polícia em todos os relatórios analisados. Neste sentido, podemos observar nos argumentos da comissão de constituição e justiça do Senado Federal em parecer favorável a criação do Ofício Central de Assistência, transcrito pelo ministro Dr. José Joaquim Seabra entusiasta da organização da assistência como veremos adiante - em seu relatório referente anos de 1904 e 1905. Neste parecer, a comissão embasava seus argumentos citando que já havia leis na França que garantiam os direitos destas três categorias. Em relação as crianças a "lei de 5 de maio de 1860" e a "famosa lei Rossuell" de 24 de julho de 1889 "que protegeu as crianças" permitindo a retirada do pátrio poder "aos pais indignos". Em relação aos enfermos a comissão cita a "lei de 30 de junho de 1838, que regulou a colocação dos alienados nos estabelecimento públicos e privados, e pela de 7 de agosto de 1851, que providenciou sobre o recolhimento dos enfermos aos hospitais ${ }^{2} 253$ e que de maneira incompleta se referia aos velhos.

Decididamente, verificamos nos relatórios pesquisados várias propostas feitas por chefes de polícia para organização de práticas de assistência social, médica e jurídica de caráter eminente protetivo ou de "ajuda e apoio", como veremos adiante, mais detalhadamente, através da proposta do ministro J. J. Seabra

\footnotetext{
${ }^{252}$ BRASIL. Ministério da Justiça e Negócio Interiores. Relatório dos anos de 1904 e 1905 - Volume II. Rio de Janeiro. Imprensa Nacional, 1905b, p. 231.

${ }^{253}$ Idem.
} 
para organização da assistência pública. Se estas propostas e, por que não, se estas tentativas de construir políticas públicas via Estado, tiveram sucesso ou não passaram de leis, ou de simples projetos; é outra discussão que não nos furtamos a enfrentar, mas que no momento não impõe importância. $\mathrm{O}$ que nos interessa na ocasião é demonstrar que o debate sobre estas questões estava devidamente colocado no seio do Estado e era de suma importância para a classe dominante. Este debate era imposto pela própria necessidade e condição de institucionalização de práticas sociais. Verificado o protagonismo que tal questão assumia e as paixões que demovia nos debates públicos e legislativo, via imprensa, publicações, discurso e leis, como demonstraremos no decorrer deste capítulo. E mais, que este debate do ordenamento da pobreza válida e inválida por parte do Estado é um dos aspectos fundante do Estado-nação, visto que, "civilizar" a cidade do Rio de Janeiro era ponto central na fundação do Estado a na consolidação da nação.

Nos discurso e práticas relacionados a pobreza inválida - ainda que possamos enxergar aos olhos de hoje como mera repressão e controle - é preciso destacar que esta tinha larga diferença em relação aos discursos e práticas relacionados ao mero controle e disciplinamento da pobreza válida. Ainda que nos dois casos trata-se de controle e disciplinamento é nítida a diferença de ação e discurso, imprimindo benevolência e proteção para aqueles classificados como impossibilitados de trabalhar e, que tanto o altruísmo positivista, o humanitarismo cientifico e a busca do paraíso constituíam seu fim. Por estes princípios como fim que a pobreza inválida era tratada, não pela lógica do trabalho e do não trabalho que imputava ideias de repressão, esta classificação pelo trabalho e o não trabalho estava posta apensas para sua classificação inicial. Após ser classificado como pobre inválido cabiam medidas que incluíam não a punição ou regeneração, mas os cuidados humanitários de ajuda e apoio. Para os pobres inválidos não era imputada a lógica do incorrigível que se configurava quando se tratava dos classificados como vadios e vagabundos. Os pobres válidos que necessitavam de punição para ser tornar "dócil" e de regeneração pelo trabalho para se tornar "útil" nos postos mais subalternos da cadeia produtiva. Aos pobres inválidos estava reservado, pelos homens cultos de espírito científico e consoante com o pensamento de sua época, a benevolência estatal.

A classificação da pobreza como válida e inválida é uma semântica presente na distinção dos pobres urbanos que remonta ao século XVII na Europa, como 
podemos ver no caso de Portugal, entre outros países da Europa. Estas duas noções se estruturam como juízo de valor pela lógica comparativa entre os que podem e os que não podem dar cabo de sua subsistência, ou seja, aqueles que podem ou não trabalhar. É fato comprovável que esta lógica em torno da semântica do trabalho permeou e permeia toda a estruturação das práticas e discursos em torno da assistência social até nossa atualidade. Por estes aspectos que sistematizar os discurso e práticas das instituições policias entre aqueles relacionados aos pobres inválidos que mereciam proteção e aos direcionados aos pobres válidos que deveriam ser corrigidos e regenerados, abre em perspectiva a análise direta e factual da intervenção das instituições policiais pela prática e pelo discurso na formação do campo da assistência social. Esta sistematização, por um lado vai nos permitir demonstrar os aspectos que, muitos poderão considerar mera repressão ou apontar que não se poderia falar especificamente de assistência social, quando estivermos tratando do pobre válido. Por outro lado, demonstrará aspectos que não poderão ser refutados em seu caráter meramente protetivo e de "ajuda e apoio" quando estivermos abordando as práticas de polícia relacionadas aos pobres inválidos. $\mathrm{O}$ primeiro caso trata-se dos pobres válidos: trabalhadores sem trabalho ou em trabalhos "indignos" classificados por vagabundos, vadios e mais tarde também por arnachista. No segundo caso encontramos as crianças órfãos, os doentes pobres, os velhos pobres e os alienados.

É preciso destacar que os chefes de polícia e ministros da justiça, seguindo as discussões e documentos produzidos desde o século XVII na Europa sobre os meios de intervenção da pobreza urbana também classificavam, para a eficácia de sua administração da cidade, o pobre como válido e inválido. Podemos ver esta classificação explicitamente nos documentos analisados e em documentos da idade média (Abreu, 1999, 2000, 2010, 2011; Castel, 2001; Foucault, 2001) da mesma forma que em práticas, discurso e políticas atuais de assistência social. Esta classificação cunhada como meio de estabelecer parâmetros de intervenção do Estado na pobreza via a lógica do trabalho e do não trabalho é que guiava, tanto as análises dos chefes de polícia sobre os métodos de intervenções a serem empregados, quanto é o que se apresenta nas condicionalidades "para aqueles que necessitam", principalmente nos programas de transferência de renda das políticas 
de assistência social na atualidade ${ }^{254}$. Dentre a pobreza invalida encontramos, claramente, de acordo com a definição dos diversos chefes de polícia e ministros da justiça pesquisados a velhice desamparada, o alienado, o doente pobre sem recursos para a seu tratamento e a infância desvalida. Os dois primeiros estão descartados do mundo do trabalho e para estes se reserva a benevolência da sociedade e do Estado, mas para os dois últimos ainda resta: a esperança, no caso do doente e, a "certeza" no caso da criança, caso esta seja educada adequadamente, que se tornarão força de trabalho e, que poderão retribuir para a sociedade o bem lhes conferido.

O tema dos menores abandonados que coaduna tanto a pobreza inválida, quando ainda não pode trabalhar, quanto a pobreza válida, quando atinge a idade para o trabalho, demostra por um lado a linha tênue que estava posta entre proteção e repressão, ao mesmo tempo que, demonstra tanto no nível do discurso, quanto da prática, que havia uma nítida distinção entre estes dois mundos. Um dos aspectos que misturavam prevenção e repressão no caso da criança abandonada é a associação lógica do pobre invalido como a causa futura na criação do pobre válido criminoso. Podemos ver esta lógica, claramente no dizer o ministro Dr. Carlos Maximiliano, que em 1918 afirmava que “outra parte, aliás a mais importante, da acção preventiva contra o crime pela repressão da vadiagem é a que diz respeito aos menores abandonados ${ }^{255}$. Da mesma forma podemos observar no trecho do relatório, escrito pelo chefe de polícia Dr. Tito Algusto Pereira de Matos, em 1883, o quanto que se misturava a questão do vagabundo e do órfão, ao mesmo tempo em que, tinha um claro limite entre as iniciativas a serem empregadas para um ou para outro. Percebe-se as contradições entre os limites e interseções do que significava o pobre inválido e o pobre válido para a estratégia a ser definida. Neste sentido, escreveu Dr. Tito:

Pensando-se na mendicidade e vagabundagem, attrahe particular attenção um ramo dessa phalange de gente nociva, que em toda a parte suscita a philantropia dos corações bem formados, e desperta a previsão do governo: - fallo dos menores vagabundos. Esses pequenos árabes das ruas e praças publicas, provado o desamparo ou justificada a impossibilidade, em que se achem seus pais de educalos, com a justa razão devem ser os pupillos do Estado, ou antes da sociedade. Em estreitos limites tem actuado a protecção dos poderes públicos (grifo nosso), e bem pouco tem collaborado nessa obra de beneficência e de futuro a generosidade

\footnotetext{
${ }^{254}$ Melhor discutido no capítulo final

${ }^{255}$ BRASIL. Ministério da Justiça e Negócio Interiores. Relatório dos anos de 1917 e 1918. Rio de Janeiro. Imprensa Nacional, 1918, p. 76.
} 
privada. $O$ asylo de meninos desvalidos e as companhias de menores dos arsenaes de guerra e marinha não bastam para acolher quantos meninos pollulam nesta capital, sem pais ou parentes, que os protejam. Nobre e generoso é o movimento, que tem dotado esta côrte de escolas de instrucção primaria, recommendando á gratidão nacional os illustres cidadãos e o governo, que, como verdadeiros apóstolos do bem, têm-se dedicado a espancar as trevas da ignorância, em que se envolve o filho do povo. Assim, a educação profissional ha de ser também cuidada com o ardente desvelo, de que tem sido objecto o ensino elementar ${ }^{256}$.

O então chefe de polícia Dr. Tito Mattos vai ainda mais longe em seu entendimento das soluções para a problemática da pobreza urbana via trabalho afirmando que "a educação profissional ha de ser também cuidada com o ardente desvelo, de que tem sido objecto o ensino elementar" 257 . Era para formar cidadãos úteis ao Estado do que deveria se ocupar a polícia. Podemos perceber a sutil diferença entre infância desvalida e menores abandonados quando escreve Dr. Tito Algusto em seu primeiro exercício como chefe de polícia em 1877,

é já por demais notável o grande numero de menores que, ou não tendo pais, vivem sobre si por delles, não importarem-se os seus outros parentes, ou que os tendo, são abandonados como incorregiveis pelos próprios progenitores, que confessam a autoridade não poderem contel-os, nem dar-lhes destino ${ }^{258}$.

É possível enxergar a lógica administrativa da pobreza válida e inválida nas recomendações do Congresso Internacional Penitenciário de Estocolmo. Segundo estas recomendações apresentadas pelo Dr. Tito Algusto Pereira de Matos - chefe de polícia por duas vezes, na década de 1870 e na de 1880 , de quem falaremos inúmeras vezes - o Congresso de Estocolmo apontava em suas resoluções que devese "distinguir no mendigo, o infeliz e o miserável". Segundo Dr. Tito, citando as resoluções do congresso, o primeiro "esmola pela impossibilidade, em que a idade avançada, as enfermidades e os defeitos physicos o collocam de ganhar a vida. Para esse conta esta capital um asylo, que, devo dizel-o, já carece de desenvolvidomento ${ }^{259}$. Enquanto o segundo, o miserável "por negação inveterada ao trabalho (...) usa da boa fé e arranca da caridade privada os meios de viver,

\footnotetext{
${ }^{256}$ BRASIL. Ministério da Justiça. Relatório do ano de 1883. Rio de Janeiro. Typographia Nacional, 1884, p. A-G-10.

${ }^{257}$ Idem.

258 BRASIL. Ministério da Justiça. Relatório do ano de 1877. Rio de Janeiro. Typographia Perseverança, 1878, p. A5-36.

${ }^{259}$ BRASIL, op. cit., p. A-G-7.
} 
que a preguiça e a ausência total de brio não permitem adquirir honestamente" 260 . Apesar de muitas vezes não parecer que havia uma linha, ainda que tênue, separando o menor desvalido, do vagabundo, muito embora aparecessem severamente misturados em discursos e práticas, esta separação é possível de ser observada. A distinção entre aqueles que mereciam proteção, ajuda e apoio, os pobres inválidos e, aqueles que deveriam ser punidos e regenerados, os pobres válidos; pode ser claramente demonstrada na classificação de "mendigo válido" feita pelo chefe de polícia Tito Mattos que contrasta com a definição de inválido, visto acima. Segundo o referido chefe de polícia "o mendigo valido e habitual e o vagabundo confundem-se pela corrupção, que os inficiona, pelas tentações, que os arrastara ao crime. Preoccupação de todos os governos e de associações de beneficência, ainda em paiz algum se conseguiu curar essa chaga social "261 . É fácil identificar esta linha, tênue e muitas das vezes inexistente entre práticas sociais de proteção para o pobre inválido e práticas punitivas e de regeneração para o pobre válido. No entanto, também é de fácil demonstração que esta linha estava bem definida nos discursos e nas metodologias das instituições asilos. Metodologia esta que pode ser vislumbrada em forma de regulamento de funcionamento e decretos cujo o teor demonstrava os métodos e justificativas usados por tais instituições estatais de assistência da área social. Ao mesmo tempo que identificamos esta distinção na prática e nos discursos que imputam meios de intervenção diferenciado para os pobres válidos e inválidos, percebemos que este discurso juntava numa mesma categoria, por vezes, os órfãos que precisavam de proteção com os vagabundos que precisavam de correção e regeneração. Mesmo assim buscamos seguir as definições de pobre válido e inválido, pois estas imperavam e ainda imperam no modo como o Estado organiza a administração da pobreza urbana.

É possível também verificar este sentido da pobreza válida e inválida na citação do ministro da justiça J. J. Seabra em seu relatório referente aos anos de 1903 e 1904. Segundo o referido ministro a "lei entendeu conferir um encargo generoso e humanitário, dos mendigos" 262 que "apesar de achar-se salvaguarda pela multiplicidade dos meios coercitivos traduzidos na repressão penal"263 e por

260 Ibidem.

${ }^{261}$ Idem.

262 BRASIL. Ministério da Justiça e Negócio Interiores. Relatório dos anos de 1903 e 1904. Rio de Janeiro. Imprensa Nacional, 1904, p. 70.

${ }^{263}$ Ibidem. 
ser "comprovada a impossibilidade da internação em massa nos asylos" "264 que se faz necessário o "exercício bemfasejo da beneficancia, aliada a missão da justiça ${ }^{\text {"265 }}$. O referido ministro buscava o sentido e o meio de enfrentamento da problemática da pobreza urbana. Podemos ver na citação acima o quanto se misturava as duas classificações de válido e inválido e o quanto de buscava fazer uma separação como condição para definir o tipo de prática a ser empregada. A divisão entre a pobreza válida e inválida tornava-se clara e evidente nas práticas de polícia referente as instituições preventivas, como a já citada Albergaria dos Mendigos, o Asilo de Mendicidade, o Abrigo dos Menores desvalidos e a Escola XV de Novembro. Estas instituições, apesar de fazerem parte - em alguns momentos sim e outros não - do sistema penitenciário e, até mesmo uma delas funcionar em ala separada da Casa de Detenção, possuíam claramente características que as tornavam distintas em finalidade, metodologia - vide regulamento - e público alvo do que representavam e, propriamente, eram as prisões.

A partir do relatório de ano de 1874 podemos observar que a questão das instituições preventivas relacionadas aos pobres inválidos se avulta em importância. A Albergaria de Mendigos da praia de Santa Luzia, por exemplo, deixa de ser informada somente nas páginas referentes ao relatório especifico do chefe de polícia e passa a ser abordada também nas páginas introdutórias onde os ministros de justiça discorriam sobre suas ideias, os problemas que mais se evidenciaram no período, as propostas para a organização dos serviços do Estado e a criação de leis. Estava bastante evidente que havia uma distinção entre a prevenção e a repressão e que estes dois aspectos se conjugavam como inerentes as instituições policiais. A esse respeito escreveu o ministro da justiça Dr. Manoel Pinto de Souza Dantas, em seu relatório referente ao ano de 1879 , que a " $A$ boa organização da policia, attendendo-se muito ao elemento preventivo como ao repressivo, e definindo-se claramente as attribuições exclusivas ou cumulativas das respectivas autoridades $" 266$

\footnotetext{
${ }^{264}$ Idem.

${ }^{265}$ Idem

266 BRASIL. Ministério da Justiça. Relatório do ano de 1879. Rio de Janeiro. Typographia Perseverança, 1880, p. 3.
} 
Dentre as diversas propostas de reorganização dos serviços do Estado, aquelas relativas a criação e organização de "instituições preventivas" que pudesse regular a questão do trabalho, dos trabalhadores sem trabalho e dos impossibilitados de trabalhar na cidade do Rio de Janeiro, passa a ser uma constante em todos os relatórios analisados (1870 a 1930). Estes assuntos eram intensamente abordados pelos chefes de polícia e pelos ministros de justiça, estes últimos usualmente se valiam dos argumentos e dados apresentados nos relatórios elaborados pelos primeiros para embasar suas ideias. Neste sentido, podemos observar no relatório de 1874 a maneira como o Ministro Manoel Antonio Duarte de Azevedo segue as recomendações do chefe de polícia Dr. Ludgero Gonçalves da Silva, ao apontar as incontestáveis vantagens de se criar "instituições preventivas de que carecemos ${ }^{267}$ ". Dizia o ministro que

especialmente em relação aos vadios, vagabundos e indigentes, os jovens desamparados, orphãos, engeitados e outros semelhantes, que por ahi vivem sem occupação honesta, nem meios de adquirir o indispensável para a própria subsistência, urge tomar providencias que estanquem em sua origem a fonte de desvios faltas e crimes, a que são inevitavelmente arrastados esses infelizes ${ }^{268}$.

A ideia de que "seriam impellidos pela miséria" ao crime e a necessidade de impor uma "ocupação útil" 269 como medida preventiva e regeneradora é ponto em comum dentro de um quadro geral da ideologia dominante no controle do urbano, que remonta as experiências administrativas das principais cidades europeias no século XVII. Conforme discutiremos em nosso capítulo final, estas ideias continuam presentes nas justificativas, métodos e representações sociais sobre a eficácia das políticas de assistência social no século XX e XXI no Brasil. Menos pelo aspecto da criminalização da pobreza e, mais pela presença maciça de ações e políticas voltadas para a promoção de uma "ocupação útil”, de modo a prevenir e regenerar, geralmente nos postos mais baixo da cadeia produtiva que a polícia pensava nas ações de regeneração para os pobres válidos, conforme abordaremos mais detalhamento no tópico seguinte. Este aspecto de inclusão dos pobres urbanos via mundo do trabalho, nos postos mais baixos e subalternos da cadeia produtiva é

267 BRASIL. Ministério da Justiça. Relatório do ano de 1873. Rio de Janeiro. Typographia Americana 1874, p. 29.

${ }^{268}$ Idem.

${ }^{269}$ Idem, p. 30. 
fato que não se alterou nas ações de assistência social do Estado deste o século XIX até os dias atuais. Apesar de podemos identificar também nestes pressupostos as ideias de criminalização da pobreza, a medida do trabalho e do não trabalho aliado ao modo como vivenciamos e saímos da escravidão é o que acaba pautando as propostas dos chefes de polícia para as ações de assistência no campo social, seja para o pobre válido, seja para o pobre inválido, através das instituições preventivas.

Neste sentido, afirma o Ministro Duarte de Azevedo que "como instituição preventiva, e com o emprego do trabalho agrícola dever-se-hia fundar nas visinhanças desta cidade um asylo para menores desvalidos e desamparados"270. O ministro chama a atenção para examinar "o que se tem feito em paizes mais adiantados, onde encontramos modelos dignos de serem imitados"271. Do mesmo modo afirmava o chefe de polícia da corte Dr. Miguel Calmon du Pin e Almeida demonstrando conhecimento sobre as experienciais de instituições preventivas na Europa e ao mesmo tempo analisando a especificidade da realidade brasileira. Neste sentido afirmava o referido chefe de polícia que

\begin{abstract}
para esses jovens criminosos creou a França colônias agrícolas, onde, a par da instrucção primaria necessária, entregam-se os meninos aos trabalhos do campo e recebem a educação agrícola. Este systema tem produzido excellentes resultados. $O$ nosso paiz, essencialmente agrícola, encontrará na adopção desta medida um viveiro de trabalhadores para o campo, de que muito necessita. Por outro lado, não sendo estes meninos verdadeiros criminosos, a sua detenção só é legitima porque a sociedade tem o direito de precaver contra o perigoso gênero devida que levam, e o dever de dar-lhes uma educação moral, religiosa e artistica, que os habilite a serem bons e úteis cidadãos ${ }^{272}$.
\end{abstract}

Entre os diversos exemplos de instituições preventivas citados pelos ministros e chefe de polícia podemos destacar a escola de reforma de Ruysselede e de Beernem, a primeira para meninos e a segunda para meninas, fundada por Duepetiaux, "onde são recolhidos menores de sete a dezoito anos de idade, que ahi se accupam de lavoura" 273 e trabalhos mecânicos. O Ministro Manoel Antonio elogiava o fato do sistema das diversas oficinas "produzirem lucro ou receita para

\footnotetext{
${ }^{270}$ Ibidem, p. 31.

${ }^{271}$ Idem.

${ }^{272}$ BRASIL. Ministério da Justiça. Relatório do ano de 1875. Rio de Janeiro. Instituto Typographico do Direito, 1877b, p. A-255.

273 BRASIL. Ministério da Justiça. Relatório do ano de 1873. Rio de Janeiro. Typographia Americana, 1874, p. 31.
} 
$o$ Estado" ${ }^{274}$. Conforme discutiremos no capitulo conclusivo, é claramente identificável este tipo de discurso nas "modernas" postulações da lógica da responsabilidade social em projetos do terceiro setor que buscam a auto sustentabilidade.

Em 1873, continua o referido ministro dissertando sobre a solução do problema da prevenção de crimes, cuja causa é a miséria. Segundo preconiza, chegaria a uma solução satisfatória se

habiliteis o governo com os meios necessários para a remoção e reorganização do asylo de mendigos, e para a fundação de um estabelecimento semelhante ao dos menores artezoes, em que os orphãos e menores desvalidos e abandonados, aplicando-se de preferencias à lavoura, possam receber a instrucção intelectual e religiosa e aprender algum officio, como meio auxiliar para a futura subsistência ${ }^{275}$.

Apesar de não ter sido institucionalmente formalizado como uma ação de Estado, o envio de menores e mendigos para a "roça" ganhou vulto na gestão do chefe de polícia Dr. Tito Mattos, por exemplo, no ano de "1877 foram recolhidos á casa de detenção 395 menores, dos quais foram entregues a diversos reclamantes 62, e 333 a alguns fazendeiros, restando ainda 25 para terem destino" ${ }^{276}$. Em 1884, quando Dr. Tito Mattos não é mais chefe de polícia o recolhimento de menores cai pela metade, naquele ano foram recolhidos "194 menores, que vagaram pelas nas desta cidade em completo abandono"277. É possível observar esta prática como uma constante durante todo Império e na primeira República.

Em 1886, o chefe de polícia desembargador João Coelho Bastos citando o relatório de seu "ilustre antecessor" Dr. José Antonio Gomes aponta a "necessidade da creação de asylos correccionaes e colónias orphanologicas", afirmando que "são estabelecimentos que interessam muito a um bom systema policial, porque previnem e corrigem os delitos a que estão sujeitos os menores, abandonados á vagabundagem e á perversão moral" ${ }^{278}$. Propõe o desembargador chefe de policia que o "o asylo correccional poderia constituir uma secção do Asylo de

\footnotetext{
274 Ibidem, p. 32.

275 Idem.

276 BRASIL. Ministério da Justiça. Relatório do ano de 1877. Rio de Janeiro. Typographia Perseverança, 1878, p. A5-36.

${ }^{277}$ BRASIL. Ministério da Justiça. Relatório do ano de 1884. Rio de Janeiro. Imprensa Nacional, 1885, p. A-F-17.

${ }^{278}$ BRASIL. Ministério da Justiça. Relatório do ano de 1885. Rio de Janeiro. Imprensa Nacional, 1886, p. 135.
} 
mendicidade, onde já se recolhem alguns menores, que devem ficar inteiramente separados" ${ }^{279}$. No relatório, referente ao ano de 1878 , afirmava categoricamente o chefe de polícia Dr. Tito Algusto Pereira de Matos que

as instituições as casas de reforma e especialmente as escolas do trabalho para os menores vagabundos mereceram largo estudo, e hoje parece que occupam a atenção dos Governos tanto quanto as questões, que se referem particularmente ao regimen das prisões ou ao tratamento dos criminosos ${ }^{280}$.

Esta análise do chefe de polícia Dr. Tito Matos confirma nossa interpretação de que havia uma clara diferença no método de intervenção relacionado a análise referente ao tipo de pobre e de pobreza que estava lidando. E, partir desta análise, o Estado, através do Ministério da Justiça, operacionalizado pelas instituições policiais buscava construir respostas, na prática e no discurso, que envolviam repressão e proteção, como meios diferentes para o mesmo fim, o controle e o disciplinamento para a manutenção da tranquilidade pública.

As instituições preventivas ervam vistas como "condição indispensável da diminuição dos crimes "281. Nesta perspectiva acrescentava o ministro Dr. João Ferreira de Moura em uma seção específica de seu relatório intitulado asylo para menores que

a nossa crescente população, augmentada por grande numero de ingênuos, reclama a instituição de asylos que ministrem á infância desvalida a conveniente educação intellectual, moral e profissional" (...) Deste modo se daria um passo avantajado para a prevenção dos delidos, corrigindo-se desde logo os tendências perniciosas que mais tarde tornarão indispensáveis as medidas repressivas ${ }^{282}$.

A lógica de análise imputada pelo ministro demonstra a nítida separação entre práticas repressivas e protetivas, pois a primeira medida é um recurso indispensável na falha da aplicabilidade da segunda.

Em 1884 afirmava Dr. Affonso Algusto Moreira Penna que "asylos correccionaes para menores e colônias orphanologicas são estabelecimentos que

\footnotetext{
${ }^{279}$ Ibidem

280 BRASIL. Ministério da Justiça. Relatório do ano de 1878. Rio de Janeiro. Typographia Perseverança, 1879, p. A4-9-10.

${ }^{281}$ Idem, p. A4-9.

${ }^{282}$ BRASIL. Ministério da Justiça. Relatório do ano de 1882. Rio de Janeiro. Typographia Nacional, 1883, p. 132.
} 
interessam muito a um bom systema policial, porque previnem e corrigem os delictos a que estão sujeitos os menores abandonados á vagabundagem e á perversão moral" ${ }^{283}$. Aqui mais uma vez podemos vez a conjugação na representação social da lógica que os menores abandonados são os vagabundos em potencial. Fundamentalmente, podemos perceber que era parte da lógica dos homens que guiavam o Estado a existência de uma nítida diferença de método entre o que era um asylo correcional, uma colônia ophanologica e uma prisão, o que era proteção, o que era regeneração e o que era punição. Fica ainda mais evidente que as instituições preventivas e asilos para abrigar se configuravam em ajuda e apoio e eram parte de um “bom systema policial”. Dr. Joaquim Delfino Ribeiro da Luz, ministro da justiça, reconhece em 1885 “que seria da maior vantagem a creação de taes instituições á sua realização, porém, oppõe-se a falta de meios e a impossibilidade de obtel-os, pelo empenho em que esta o governo de equilibrar a receita com a despeza que deve ser reduzida" ${ }^{284}$. Desta forma, e em acordo com a "regularidade" da administração limitou-se o ministro a um "empreendimento mais modesto", construiu na Casa de Correção da Corte uma "seção correcional $e$ depósito "a primeira para os menores condemnados na conformidade do artigo 13 do código criminal, e a segunda para recolhimento daquelles que forem alli postos á disposição do chefe de policia e dos juizes de orphãos afim de terem o destino conveniente 285 . Como veremos adiante, o deposito de presos se constituirá em um dos principais locais de triagem e encaminhamentos das instituições policias. Local onde era feita a identificação de quais pobres eram válidos ou inválidos para o trabalho, cabendo a cada um o tipo de encaminhamento que lhes eram de "direito".

A ótica sobre a qual estava posta a criação e o gerenciamento das instituições de asilos de caráter preventivas, pensadas e construídas para a pobreza inválida pelo Estado, através da polícia, estava muito mais associada a ideias de educar do que de reprimir, ainda que aos olhos de hoje o segundo sobressaia ao primeiro. Atuar nas causas da criminalidade, ou seja, atuar sobre a miséria não se caracterizava exclusivamente pela repressão, mais efetivamente significava desenvolver ações que pudesse docilizar pelo trabalho e educação os trabalhadores válidos sem

${ }^{283}$ BRASIL. Ministério da Justiça. Relatório do ano de 1884. Rio de Janeiro. Imprensa Nacional, 1885 p. 164.

${ }^{284}$ BRASIL. Ministério da Justiça. Relatório do ano de 1885. Rio de Janeiro. Imprensa Nacional, 1886 p. 136.

${ }^{285}$ Idem. 
trabalho - vagabundo e vadios - e tratar humanisticamente o controle dos fluxos dos pobres incapacitados para o trabalho nas cidades. Nesta perspectiva, afirmava o Ministro Manoel Antonio que "encarada sob o aspecto da prevenção dos delictos, sua utilidade é incontestável. Educar a inteligência e o coração, eis o grande meio de imprimir moralidade ás acções humanas, muito mais eficaz do que a repressão aos delictos" ${ }^{286}$. Em 1870, o chefe de polícia Dr. Francisco de Faria Lemos é taxativo ao apontar a "educação civil" com o único meio que "incute no homem ideais de sociabilidade", pois na medida em que "não há, em geral, educação civil sobre tudo nas classes menos favorecidas da sociedade" estas "somente guardam os preceitos da lei pelo receio do castigo por ella imposto"287. Já em 1910, o chefe de polícia Dr. Belisario Fernandes da Silva Távora argumentava que o Estado falhou na tarefa de educar e regenerar para o trabalho e por isto devia a polícia abandonar todos os métodos de controle urbano e prevenção de crimes ligados a educação e assistência e se concentrar na repressão. Ora, se deveria abandonar é porque desenvolvia estas práticas.

Demonstrando a interação contemporânea com seus pares europeus, o ministro Manuel Antonio Duarte de Azevedo argumentava em 1873 que "há alguma coisa melhor do que punir, diz Meichaux no seu excelente trabalho sobre a questao das penas, melhor do que perdoar, do que regenerar, do que rehabilitar; é prevenir a falta" ${ }^{288}$. E esta prevenção está claramente a cabo da educação e do trabalho. Educar a inteligência e o coração demonstra claramente o amálgama da ciência com a moral, que retoma pela via racional, através do altruísmo positivista, o que negara pela via do interesse na mística da salvação. Esta afirmação pode ser verificada na expressão do ministro Duarte de Azevedo quando assertivamente dizia em 1873 que "difundir a instrucção publica é preparar as condições da hygiene moral da sociedade politica" ${ }^{289}$. Esta higiene moral da sociedade política vai se traduzir em discursos e ações relacionados diretamente ao amparo e a proteção. Este amparo e proteção está direcionado para os pobres inválidos como os "menores ainda não sujeitos á acção da justiça criminal", que "entre os ociosos

\footnotetext{
${ }^{286}$ BRASIL. Ministério da Justiça. Relatório do ano de 1873. Rio de Janeiro. Typographia Americana, 1874, p. 33.

${ }^{287}$ BRASIL. Ministério da Justiça. Relatório do ano de 1870. Rio de Janeiro. Typographia Nacional, 1871, p. A-21.

${ }^{288}$ BRASIL, 1973, op. cit.

${ }^{289}$ Idem.
} 
vagam pela cidade" e que "acabam por se perverterem, adquirindo vícios que lhes impoem novas necessidades" pela ausência de "amparo e de protecção" 290 . Falando no mesmo tom, Franco Vaz em relatório sobre a Escola XV de Novembro, enviado ao ministro J. J. Seabra em 1905, apresenta na epígrafe a citação de Santo Agostinho, que exorta; "que o zelo que vos anima á punição dos crimes, não vos faça esquecer o que a humanidade vos prescreve! Por atrozes que possam ser os crimes, não os encareis tanto como um objecto de cólera e de vingança quanto como uma ferida que vos deveis esforçar por curar" ${ }^{291}$. Podemos perceber claramente que esta lógica estava posta nas ideias dos diversos chefes de polícia e ministro de justiça. De certa monta, demonstra a lógica premente nas ideias de como o Estado e sociedade deveriam imprimir as ações em prol da tranquilidade pública.

No sentido de ações preventivas, educativas e não repressivas aponta o ministro Duarte de Azevedo em 1873 que "é geralmente sentida nesta capital a falta de um estabelecimento onde possam ser recolhidos os menores que por ahi vagão sem qualquer sujeição habitoando-se à occiosicíade, e á pratica de vícios torpes, detrimento da sociedade que os aproveitariam no futuro, se fossem convenientemente educados" 292 . O recurso encontrado pelos chefes de polícia, que deveriam apontar soluções imediatas para a problemática dos menores e, que passou a ser institucionalizado pelo Estado " $n$ a falta de estabelecimento tao necessario", foi enviar estes "menores com idade legal e boa construcção physica para os corpos de aprendizes marinheiros e artilheiros, e os demais para aos juízos de orphãos ${ }^{, 293}$.

Em 1877 fazia coro o ministro Dr. Lafayette Rodrigues Pereira que "seria também de utilidade (...) destinar estabelecimentos apropriados onde sejam educados e afeitos ao trabalho os menores abandonados, que actualmente são recolhidos á Casa de Detenção, ou confiados a particulares por meio de contrato no juizo de orphãos ${ }^{\text {"294 }}$. Muitas foram as tentativas e os discursos do Estado voltados para a ações preventivas, muitos dos quais não saíram do papel ou

290 BRASIL. Ministério da Justiça. Relatório do ano de 1873. Rio de Janeiro. Typographia Americana, 1874, p. 30.

${ }^{291}$ Santo Agostinho apud Franco Vaz in BRASIL. Ministério da Justiça e Negócio Interiores. Relatório dos anos de 1904 e 1905 - Volume II. Rio de Janeiro. Imprensa Nacional, 1905b, p. A-G3 .

${ }^{292}$ BRASIL, 1874, op. cit., p. A-205.

${ }^{293}$ Idem.

${ }^{294}$ BRASIL. Ministério da Justiça. Relatório do ano de 1877. Rio de Janeiro. Typographia Perseverança, 1878, p. 82. 
fracassaram como o Instituto dos Menores Artesões, "fundado na casa de correcção pelo decreto $n .2745$ de 13 de Fevereiro de 1861 " que em "pouco tempo depois teve de desaparecer" por estar "em local tão inconveniente", fora instalado na Casa de Correção, que por sua vez era um anexo da Casa de Detenção. Este instituto

era dividido em duas secções; na primeira comprehendiam-se os menores presos pela policia por vadios, vagabundos e abandonados, e os de tão má índole que não podiam ser corrigidos por seus paes ou tutores, e quando estes pediam a sua admissão no estabelecimento; a segunda secção era composta dos orphãos, que não podiam receber uma educação conveniente e apropriada em outro lugar”. (...) a incoveniencia do local e considerações de outra ordem determinaram a sua supressão ${ }^{295}$.

Aqui evidencia-se de maneira transparente o entendimento da necessidade de metodologia diferenciada para lidar com o pobre inválido e válido, da mesma forma, que é possível vislumbrar a interseção presente nas representações destes personagens diante das necessidades de razões administrativas. O mesmo sentido conferido acima, no trecho do relatório do ano de 1873, para diferenciação do tipo de instituição indicada a cada tipo de pobre, pode ser identificado também na transcrição do trecho do relatório abaixo, elaborado pelo chefe de polícia, desembargador Dr. Manoel José Espinola, em 1906.

Fôra para desejar a creaçao de estabelecimentos em que a infancia abandonada, sem lar, sem protecção, atirada á miséria, perdida nas ruas, encontrasse o abrigo, o agasalho, a instrucção, o trabalho, o conselho, a educação, de modo que os já viciados e carecedores de regeneração e aquelles que, ainda innocentes e puros, apenas acossados pela miséria e abandono corriam o risco de perder-se, encontrassem o remédio para a sua situação e salvação, havendo para cada uma dessas classes o asylo adequado e evitando-se assim a promiscuidade, em ordem a mais facilmente attingir-se os fins almejados ${ }^{296}$.

Neste sentido a ideia de pobre válido e inválido se apresenta enquanto discurso qualificado e alinhado cientificamente com a época sobre a relação da problemática social e as condições econômicas e demográficas, de modo que pode ser verificado em diversos relatórios ao longo do período estudado. Em 1875

${ }^{295}$ BRASIL. Ministério da Justiça. Relatório do ano de 1873. Typographia Americana, 1874, p. 301.

${ }^{296}$ BRASIL. Ministério da Justiça e Negócio Interiores. Relatório dos anos de 1905 e 1906 - Volume 01. Rio de Janeiro. Imprensa Nacional, 1906a, p. A-E-5. 
afirmava o ministro Diogo Filho Cavalcanti de Albuquerque que "as necessidades sociaes desenvolvem-se, e modificam-se as condições econômicas" e que a "policia não satisfaz as exigências elementares do regímen preventivo e repressivo" ${ }^{297}$. Podemos perceber que o ministro da justiça, em 1875, exercia na cidade do Rio de Janeiro, principalmente através da polícia, funções que estavam descritas pelo alvará português de 1760 e que remetiam a ideia do Estado de polícia alemão do século XVII. Interessante observar que não só no Brasil este fato ocorria, mas também em boa parte do mundo ocidental cristão considerado como exemplo de civilização moderna. Neste sentido podemos observar o caso no qual o Dr. Ludgero Gonçalves da Silva chefe de polícia da Corte, em seu quinto ano de mantado, intercede junto ao recém empossado ministro Cavalcanti de Albuquerque para que o Dr. Pedro José Netto Teixeira fosse encarregado de maneira remunerada para

estudar a organisaçao do serviço da segurança publica nos Estados Unidos da America e nos principaes paizes da Europa, e indicar o que fosse adoptado no Brazil, segundo a respectiva legislação e costumes, sobre os seguintes assumptos: Organisação da policia preventiva nas grandes capitaes; Meios empregados na repressão da vagabundagem e da mendicidade; Systema administrativo das colônias correccionaes; Regulamentos das albergarias, hospicios, estalagens, theatros e espectáculos públicos; Fiscalização exercida pelos agentes da segurança publica na venda dos gêneros alimentícios e de medicamentos; Regulamentos a que estão sujeitos os indivíduos empregados no serviço domestico, vehiculos e transportes urbanos ${ }^{298}$

Percebemos aqui não só a questão das instituições preventivas como pauta de discussões internacionais, mas também a amplitude de gestão que significava o cargo de chefe de polícia no final da década de 1870 e que perdurou durante todo o período abordado em nossos estudos. Estava ainda sobre forte determinação da necessidade de gerenciamento dos fluxos populacionais, comerciais e de subsistência, tal qual se vinculavam a ideia de polícia no século XVII e que vai tomar corpo de cientificidade no século XVIII. A organização do mundo do trabalho, do qual depende diretamente a organização do Estado, é um imperativo da ordem social e bem supremo para a elite dirigente, para este fim havia a polícia. Cabia ainda a polícia, segundo o ministro da justiça Dr. Lafayette Rodrigues

\footnotetext{
${ }^{297}$ BRASIL. Ministério da Justiça. Relatório do ano de 1875. Rio de Janeiro. Instituto Typographico do Direito, 1877 b, p. 33.

${ }^{298}$ Idem, p. 35.
} 
Pereira, regular os teatros, os cortiços e "definir a competência da policia sobre a conservação das mattas, florestas e jardins públicos ${ }^{299}$.

No relatório de 1877, escrito pelo chefe de polícia Dr. Tito Algusto Pereira de Matos podemos observar ainda mais esta amplitude dos trabalhos da polícia, através de um item do relatório denominado "Policia e economia particular da cidade" ${ }^{\natural 00}$. Neste item reclama o magistrado que a polícia responsável "sobre todas as acções e actos, que, não sendo propriamente crimes, por não atacarem a segurança publica, individual ou de propriedade, affectam todavia à ordem e os bons costumes" 301 , deve ser quem fiscaliza, regula e legisla sobre as "posturas municipaes". Segundo Dr. Tito Algusto havia a necessidade "de uma revisão methodica e clara do Codigo de posturas municipaes", pois estas "são já obsoletas (...) tornando-se além disso a maior parte delias sem execução por falta de observância dos agentes municipaes, cuja vigilância pode-se dizer que é nulla ${ }^{302 "}$. Aqui, evidentemente, nos deparamos com a amplitude da ação policial nos aspectos administrativos da cidade e, com uma separação bastante nítida no ordenamento urbano do que significava ação de repressão e punição ao crime e o criminoso e práticas de gestão da "economia particular da cidade". Não por acaso a afirmação de Foucault (2001) de que a economia política nasceu da ideia e prática do "estado de polícia" nos interessa como aspecto de relevância na análise de nosso objeto.

A necessidade de uma resposta imediata aos problemas urgentes do controle e ordenamento dos fluxos populacionais urbanos, principalmente no que concerne à pobreza válida e inválida, levaram a criação de soluções que envolviam ajuda, apoio e proteção para os pobres inválidos e, trabalho, regeneração e punição para os pobres válidos. Neste sentido afirma o chefe de polícia Dr. Tito Algusto Pereira de Matos que "clamam por satisfação muitas e instantes necessidades, que por mais tempo não podem ser desatendidas, sem evidente desvantagem dos habitantes desta capital $^{\prime 303}$. A necessidade da resposta imediata é um aspecto capital para o entendimento da formação do campo da assistência nas suas diversas modalidades. À polícia era exigida resposta imediata, soluções prementes para os principais

\footnotetext{
299 BRASIL. Ministério da Justiça. Relatório do ano de 1877. Rio de Janeiro. Typographia Perseverança, 1878, p. 82.

${ }^{300}$ Idem, p. A5-69.

${ }^{301}$ Idem.

${ }^{302}$ Idem.

${ }^{303}$ BRASIL. Ministério da Justiça. Relatório do ano de 1883. Rio de Janeiro. Typographia Nacional, 1884, p. A-G-11.
} 
problemas populacionais urbanos. Não havia tempo para criar leis, as repostas tinham que ser imediatas, instantâneas. Diante desta imposição, a polícia não se furtava, ou não podia se furtar de dar respostas, cunhava as próprias soluções, como o caso do hospício da Ponta do Galeão - criado pelo chefe de polícia Desembargador Monoel José Espínola - e dos asilos para mendigos e para infância desvalida. Esta necessidade de respostas imediatas fica ainda mais manifesta quando destacamos o

ofício de 15 de novembro de 1888 destinado ao Secretário do Estado e Negocios Estrangeiros. Neste ofício, o chefe de polícia da corte pede consentimento ao secretário para "obter a vinda de quatro religiosos da ordem dos trapistas, que tanto se há distitguindo na Europa, especialmente na Italia, (...) para a direção da colonia agricola fundada pelo Governo Imperial na Ilha do governador, destinada a corrigir e regenerar pelo trabalho os mendigos e vagabundos "304 (Souza, 2010, p. 175).

Este hospício mais tarde foi transferido dando origem a Colônia Juliano Moreira.

A questão do alienado demonstra a amplitude de ação de assistência das instituições policias e a necessidade de construir respostas imediatas para gestão das populações na cidade do Rio de Janeiro. Esta necessidade levou a polícia a realizar diversas articulações no sentido de encaminhamento dos alienados recolhidos. Durante o império estes eram encaminhados para o Hospício de D. Pedro II. Este por sua vez não supria a demanda como demonstra o ofício de 27 de setembro de 1869 enviado pelo Conselheiro Provedor da Santa Casada Misericórdia ao chefe de polícia Dr. Francisco de Faria Lemos no qual expunha que, "ser inteiramente impossível a admissão de alienados no Hospício de D. Pedro II, em razão de se achar já excedido o numero de trezentos lugares, fixado para os indigentes por Aviso do Ministério do Império de 10 de Janeiro de 1830”305. Diante das faltas de vagas, tinha o chefe de polícia que conseguir solução para esta problemática, neste sentido afirmava Dr. Francisco de Faria Lemos em 1870 que

em conjunctura tal, não podendo ser indifferente á sorte dos alienados, que por ahi vagam com iminente perigo para si e para outros, deliberei mandar para a Casa de Detenção os mais furiosos e para a Albergaria de mendigos os menos furiosos. (...) A existência do alienados nesses estabelecimentos, além de ser obviamente prejudicial ao seu regimen interno, é tambem nociva aos mesmos alienados, que

\footnotetext{
${ }^{304}$ AN - Série Justiça IJ 6 - 302.

${ }^{305}$ BRASIL. Ministério da Justiça. Relatório do ano de 1870. Rio de Janeiro. Typographia Nacional, 1871, p. 28.
} 
ficam privados de tratamento especial, que só no Hospício poderia ser-lhes ministrado proveitosamente. Urge adoptar alguma providencia no sentido de fazer cessar tão gravo inconveniente, habilitando a Policia, com os meios adequados, a providenciar a respeito da sorte desses infortunados que não podem ser assim abandonados ${ }^{306}$.

Em 1890, o Hospício Pedro II passa para as mãos do governo federal por decreto n. 142 A, de 11 de janeiro de 1890 sendo nominado Hospital Nacional de Alienados. Naquele momento havia internado "300 enfermos". Em 1903 foram realizadas obras e ampliou o número de vagas para 800, mas segundo o chefe de polícia "foi tão excedido esse numero que, actualmente, o livro de matriculas consigna a existência de 4.476 internados"307.

A polícia para responder a necessidade imediata da demanda social articulava com diversos setores da sociedade meios para dar respostas imediatas as problemáticas que enfrentava. Uma destas principais articulações era com os proprietários de terras para o envio de menores para a campo. Segundo o chefe de polícia Dr. Tito Algusto Pereira de Matos apesar de tal medida já ter resultados em benefícios é de se esperar que o governo atento

para o alcance provisório desta providencia, filha da immediata necessidade pelo bem publico, não prescindirá de prover opportunamente de remédio à lacuna apontada, creando estabelecimentos adequados, onde se ensinem os meios de trabalho a esses infelizes, que um dia poderão tornar-se cidadãos úteis ao Estado ${ }^{308}$.

A imediata necessidade fazia com que a polícia tivesse que criar respostas para diferentes questões pertinentes a problemática social. Dentre elas, destacavase a questão da infância desvalida, que se colocava como o principal problema de assistência a ser enfrentado pela polícia, bem como, aquele que pauta as principais discussões e mobilizava as paixões juntos aos expoentes da classe dominante. Neste sentido afirmava o ministro da justiça e negócios interiores Dr. Alfredo Pinto Vieira de Mello em seu relatório que "a policia não pode passar despercebido o relevantíssimo problema da infância abandonada" ${ }^{309}$. Neste sentido afirmava, em

\footnotetext{
${ }^{306}$ Ibidem, p. 28-9.

${ }^{307}$ BRASIL. Ministério da Justiça e Negócio Interiores. Relatório dos anos de 1919 e 1920. Rio de Janeiro. Imprensa Nacional, 1920, p. XLVII.

${ }^{308}$ BRASIL. Ministério da Justiça. Relatório do ano de 1877. Typographia Perseverança, 1878, p. A5-36.

${ }^{309}$ BRASIL, 1920, op. cit., p. 71.
} 
1905, o chefe de polícia Dr. Antonio Algusto Cardoso de Castro que "tirar da miséria e do vicio as crianças abandonadas e dellas fazer trabalhadores honestos e úteis a si e á sociedade, nada mais util e digno"310. Este aspecto que não envolvia criminalização, sem dúvida era claramente uma função social da polícia tornada oficial e institucionalizada pelo Estado no período de nossa pesquisa.

Neste sentido, em 1885, o então Desembargador João Coelho Bastos, chefe de polícia da Corte, em relação ao "já crescido o numero de menores que vagam pelas ruas da cidade do Rio de Janeiro" ${ }^{311}$ e, seguindo as orientações das práticas de gestão explicitadas nos relatórios dos chefes de polícias que no, "intuito de garantir a sorte desses infelizes" 312 , havia desenvolvido uma rede de encaminhamentos junto as forças militares, proprietários de terras, os asylos existentes e as famílias de comerciantes e funcionários públicos para absorver os "menores desvalidos" nos trabalhos domésticos. Neste sentido, o ministro João Coelho Bastos determinou aos "juizes de ophãos da côrte" que

$1^{\circ}$. Solicitem ao ajudante general do exercito, ao da armada, ou ao director do arsenal de guerra a admissão dos mesmos menores em qualquer das companhias de aprendizes da guerra ou da marinha. $2^{\circ}$. Requisitem ao ministério do império, quando não possam ser alli aceitos, para que sejam admittidos no asylo de meninos desvalidos. $3^{\circ}$. Dêm á soldada, na fôrma da ord. liv. $1^{\circ}$ tit. $88 \$ 13$ e da disposição do aviso $n .312$ de 20 de outubro de 1859, não só os menores orphãos como os filhos de pais incognitos. $4^{\circ}$. Finalmente que reconhecida a nacionalidade do menor estrangeiro, antes de dar-lhe o destino legal, communiquem ao agente consular respectivo ${ }^{313}$.

É possível descrever a relação das soluções para a infância desvalidada que envolviam as forças militares de maneira oficial até as últimas décadas do século XX na cidade do Rio de Janeiro, como veremos com mais propriedade no capitulo conclusivo.

A infância era o problema central da assistência durante todo o período de nossa pesquisa, podemos observar sua importância e amplitude na fala dos diversos chefes de polícia e ministros da justiça. "Salvar as crianças, cuidar das enfermes, si se pretende organizar um novo serviço da assistência publica (...) é por ahi,

\footnotetext{
${ }^{310}$ BRASIL. Ministério da Justiça e Negócio Interiores. Relatório dos anos de 1905 e 1906 - Volume 01. Rio de Janeiro. Imprensa Nacional, 1906a, p. A-E-5.

${ }^{311}$ BRASIL. Ministério da Justiça. Relatório do ano de 1885. Rio de Janeiro. Imprensa Nacional, 1886 p. 135.

${ }^{312}$ Idem.

${ }^{313}$ Idem.
} 
parece, que se deve começar. Essa dupla missão resume, principalmente, a razão do ser do presente projecto de lei" "314, afirmava em 1904 o ministro da justiça J. J. Seabra. O tema dos menores abandonados, "esta outra chaga de nossa sociedade, tão bem estudada e descripta"315 por diversos chefes de polícia ocupava espaços de destaques nos relatórios estudados. O referido ministro afirmava que "para cuidar, antes de tudo, da causa sagrada da infância, dos seus direitos (grifo nosso) e dos seus interesses", deveria colocar a "a assistência publica ao lado da justiça, funccionando directamente, mas também servinde-lhe de auxiliar, afim de que a criança deixe de ser um perigo para os seus contemporâneos e se transforme em um elemento de vida, em uma força social"316. Podemos ver indubitavelmente já explicitada em intenção e ato a relação entre a assistência e justiça na condução e formação do que mais tarde se convencionou nominar de garantia de direitos para infância. Nesta perspectiva argumentava o referido ministro que "sem leis precisas, sem educação adequada, sem amparo verdadeiro, sem casas de preservação scientificamente organizadas, nem mais dolorosa, nem mais impressionante pode ser a sorte dos menores e orpbãos - principalmente na grande massa populosa da capital da União"’317.

Em 1906, o Desembargador Manoel José Espinola ${ }^{318}$, chefe de polícia do distrito federal faz preciosa análise do modo como o Estado estava enfrentando a questão da infância abandonada e desvalida. Chamava a atenção, o chefe de polícia, para o fato de que "a creação ou antes a adaptação da Escola Correciaonal Quinze de Novembro, não resolveu o problema da infancia abandonada" ${ }^{319}$. Logo em que tomou posse na repartição da polícia, segundo suas próprias palavras, o desembargador voltou suas vistas para a infância abandonada. Neste sentido, ele desenvolveu estudos, fiscalizações e engrossava o coro das autoridades que

${ }^{314}$ BRASIL. Ministério da Justiça e Negócio Interiores. Relatório dos anos de 1904 e 1905 - Volume II. Rio de Janeiro. Imprensa Nacional, 1905b, p. 235.

${ }^{315}$ BRASIL. Ministério da Justiça. Relatório do ano de 1880 e 1881. Rio de Janeiro. Typographia Nacional, $1882 b$, p. A-G-7.

${ }^{316}$ BRASIL, 1905b, op. cit.

${ }^{317}$ Idem.

318 "Nomeado, por decreto de 21 de novembro de 1905, Chefe de Policia do Districto Federal, tomei posse e entrei em exercício deste cargo no dia 22 do mesmo mez, succedendo ao Dr. João Baptista de Campos Tourinho, que ficara servindo interinamente na vaga aberta pela nomeação do Dr. Antonio Augusto Cardoso de Castro para o cargoro de Ministro do Supremo Tribunal Federal" (BRASIL. Ministério da Justiça e Negócio Interiores. Relatório dos anos de 1905 e 1906 - Volume 01. Rio de Janeiro. Imprensa Nacional, 1906a, p. A-E-3).

${ }^{319}$ Idem. 
preconizavam a remoção da Escola Correcional Quinze de Novembro "para uma fazenda, dentro do Distrcito Federal". Nas palavras do chefe de polícia este ato ofereceria "por fim um asylo amplo para todos esses menores, que actualmente nem polícia, nem os magistrados sabem onde recolher" ${ }^{320}$. Reconhecia o chefe de polícia que o local onde se encontrava instalado a Escola Quinze de Novembro não prestava a este fim. "Seria de vantagem collocal-a afastada do centro, em pleno campo e em logar saudável e ameno, accommodada em casa vasta e hygienica e dispondo o asylo de terra em seu redor, de modo a estabelecer o ensino agrícola" 321. No relatório referente aos anos 1917 e 1918 esta questão permanecia com relevância. Neste sentido afirmava o então ministro Dr. Carlos Maximiliano Pereira dos Santos que "nada se tem feito para proteger a infância abandonada",322.

Em 1924 o ministro Dr. Aníbal Freire da Fonseca destaca "a organização da assistência aos menores abandonados e delinquentes em todo o pais e a creação do juizo de menores", como uma dos principais feitos de sua gestão. Concorrendo junto com a "a reforma da Justiça Local do Districto Federal e a decretação dos Códigos do Processo Civil e do Processo Penal" ${ }^{323}$ como os atos que contribuirão decisivamente para o desenvolvimento do Estado e bem ultimo da nação. A importância da assistência a infância pode ser também verificada, agora vinculado diretamente a polícia como podemos ver abaixo:

desde muito me interessa o magno problema da assistência aos menores abandonados e deliquentes. No meu relatorio de 1908, quando chefe de policia desta Capital, depois de algumas considerações sobre o assumpto, resumi a questão nos termos seguintes: A grande preocupação dos criminalistas sociólogos tem sido sempre demonstrar aos homens de Estado que a educação profissional da infância moralmente abandonada constitue o fundamento da prevenção criminal. Basta um detido exame das estatisticas criminaes para demonstrar a preponderância numérica dos criminosos de 16 a 23 annos. Esta circumstancia nasce do abandono dos menores; das sugestões perniciosas que recebem quotidianamente nas viellas e nos prostíbulos; do analphabetismo em que os deixam os próprios paes que a luta pela vida obriga a não cuidarem dos filhos (grifo nosso), abandonados $e$ pervertidos nas ruas ou nessas vergonhosas e infectas habitações, denominadas hospedarias e casas de commodos ${ }^{324}$.

${ }^{320}$ BRASIL. Ministério da Justiça e Negócio Interiores. Relatório dos anos de 1905 e 1906 - Volume 01. Rio de Janeiro. Imprensa Nacional, 1906a, p. A-E-5.

${ }^{321}$ Idem.

322 BRASIL. Ministério da Justiça e Negócio Interiores. Relatório dos anos de 1917 e 1918 . Rio de Janeiro. Imprensa Nacional, 1918, p. 76.

${ }^{323}$ BRASIL. Ministério da Justiça e Negócio Interiores. Relatório do ano de 1924. Rio de Janeiro. Imprensa Nacional, 1926, p. X.

${ }^{324}$ BRASIL. Ministério da Justiça e Negócio Interiores. Relatório dos anos de 1919 e 1920 . Rio de Janeiro. Imprensa Nacional, 1920, p. XLV- XLVI. 
A lógica assistencial de ajuda, apoio e proteção estava posta nos discursos e práticas da elite dominante no final do século XIX. A questão que se coloca não é o fato desta ter ou não ter existido como um instrumento direto do Estado de intervenção e controle da pobreza urbana. A questão que se coloca é para quem estava destinada a assistência. Uma das vertentes desta problemática pode ser insistentemente comprovada pelas análises dos chefes de polícia sobre as diversas vertentes que contribuíam para a problemática da infância desvalida na cidade do Rio de Janeiro. As ações governamentais, geralmente com parceiras privadas, que imputavam ajuda, apoio e proteção aos pobres válidos e inválidos tinha no imigrante pobre, branco, menor de idade a principal preocupação. $\mathrm{O}$ chefe de Polícia Dr. Tito Mattos aponta em uma das muitas de suas análises sobre esta problemática que "é facto denunciado pela imprensa, e verificado nesta Corte (...) ha pessoas que sem consciência e baldas de moralidade, percorrendo os campos da Itália e Portugal, costumam agenciar os menores, enviando-os a este paiz”. No propósito de propiciar um melhor futuro para estes “jovens desgarrados”, livrandoos da vida nas prisões, o Dr. Tito acordou com os juízes de órfãos da Corte "mandar-lhes apresentar todos os menores nas circumstancias expostas, a fim de fazel-os admittir nas fazendas particulares do interior" 325 . E outros enviados a seus consulados ou para as beneficências relativas a suas nacionalidades. Neste sentido vale lembrar os pontos discutido no capítulo segundo sobre a importância da imigração na consolidação dos aspectos relacionados a classificação dos pobres pela ideia de trabalho e não trabalho. A polícia buscava soluções para os menores abandonados de maneira diferente das questões orientadas para o crime, principalmente se estes fossem imigrantes brancos. O modo de desenvolver ações diferenciadas para o pobre inválido ligado ao apoio, ajuda e proteção pode ser verificado no caso dos "menores abandonados" para os quais a ajuda, apoio, proteção e instrução deveriam vir anterior ao trabalho, regeneração e punição. Neste sentido afirma o ministro Dr. Rivadavia da Cunha Corrêa em 1910 que o

problema da infância delinquente, ou simplesmente abandonada ou orphanada, avulta dentre os serviços que mais urgentemente requerem prompta solução; porquanto, as tres escolas existentes, das quaes só uma com organização regular,

325 BRASIL. Ministério da Justiça. Relatório do ano de 1877. Rio de Janeiro. Typographia Perseverança, 1878, p. A5-36. 
não podem attender ás necessidades actuaes, tal é o numero de crianças que reclamam a sua internação nos estabelecimentos de Policia ${ }^{326}$.

Aqui cabe uma ressalva; através da problemática da infância abandonada podemos ver claramente que as "escolas" existentes para a infância abandonada eram "estabelecimentos da polícia”. Este aspecto reforça e revela ainda mais a importância das instituições policias na formação do campo da assistência social na cidade do Rio de Janeiro.

Em 1918, repetindo a mesma arenga que seus antecessores do século XIX, afirmava o ministro Dr. Carlos Maximiliano; "nada se tem feito para proteger a infancia abandonada"327, quando já havia sido enfático no relatório anterior afirmando que "não é licito adiar mais a solução do problema da infância desvalida"328. Empregando o mesmo raciocínio lógico que encontramos na atualidade, especialmente no pensamento do senso comum, afirmava o ministro que "emquanto consentimos que creanças dignas de cuidado e de carinho, que podem vir a ser úteis a si próprias e ao paiz, descambam, pela falta de quem lhes aconselhe e guie (...)cada uma delles occupará certamente amanhã um logar de destaque no exercito do crime" ${ }^{329}$. O senso geral aceitava a ideias expressas nas palavras do chefe de polícia Dr. Ovídeo Fernando Trigo de Loureiro de que "esses menores, sem educação, sem ocupação e sem trabalho, ou vão engrossar as maltas dos capoeiras, ou tornam-se auxiliares dos vagabundos, que os aproveitam para as suas excursões criminosas"330.

No entanto, a análise do menor abandonado apontado como "um futuro hospede das prisões"331 - visão comum e fato previsível também na atualidade era acrescido de diagnóstico mais sensível pelo Dr. Carlos Maximiliano em 1917, quando afirmava que "a sociedade, culpada do infortúnio delle, ainda castiga a sua victima desgraçada" ${ }^{332}$. Dr. Carlos Maximiliano apontava que constrangia-lhe o

\footnotetext{
${ }^{326}$ BRASIL. Ministério da Justiça e Negócio Interiores. Relatório dos anos de 1910 e 1911 . Rio de Janeiro. Imprensa Nacional, 1911, p. 77.

${ }^{327}$ BRASIL. Ministério da Justiça e Negócio Interiores. Relatório dos anos de 1917 e 1918. Rio de Janeiro. Imprensa Nacional, 1918, p. 76.

${ }^{328}$ BRASIL. Ministério da Justiça e Negócio Interiores. Relatório dos anos de 1916 e 1917. Rio de Janeiro. Imprensa Nacional, 1917, p. XI.

${ }^{329}$ BRASIL, 1918, op. cit.

${ }^{330}$ BRASIL. Ministério da Justiça. Relatório do ano de 1880 e 1881. Rio de Janeiro. Typographia Nacional, 1882 b, p. A-G-7.

${ }^{331}$ BRASIL, 1917, op. cit.

${ }^{332}$ Idem.
} 
"coração ao ver os pequenos em deleteria promiscuidade com os profissionaes do delicio nas salas da Casa de Detenção, bem como, se horizava com a idéa de que partiam para a Colônia Correccional de envolta com a escoria da sociedade, com os vagabundos e os gatunos" ${ }^{333}$. Para diminuir, de certo modo, a dissonância com seus princípios e minimizar o sofrimento, expresso em seu relato, Dr. Carlos Maximiliano "com a escassa verba" preparou "numa dependência da Detenção, um aposento arejado e vasto para os menores encarcerados" 334 . No relatório do ano subsequente, Dr. Carlos Maximiliano, no mesmo intuito, melhorou os edifícios e officinas da Escola Premunitoria e entreguei a direcção zelosa e desinteressada a Escola de Menores Abandonados" 335 .

A problemática da infância desvalidada estava presente em todos os relatórios. Como meio de resolver esta questão a medida de aproveitar os "míseros meninos, que o abandono atira no caminho da perdição e do crime" ${ }^{336}$ na "cultura da terra" era umas da que mais ganhava eco. Para isto o chefe de polícia realizava acordos junto a proprietários rurais para que contrate os menores apreendidos ${ }^{337}$. Considerava Tito Mattos a necessidade de institucionalizar tal prática como a ação de Estado e não somente como uma inciativa isolada de sua gestão à frente da polícia. Neste sentido, afirmava que esta experiência seria um "ensaio rudimental, como devia ser" 338 . Adiante afirmava que estava convicto que "systematisada a medida, seriá fertil de resultados" ${ }^{339}$. Dr. Tito alinhado as modernas teorias produzidas na Europa sobre os meios eficazes do Estado enfrentar a problemática da pobreza urbana, proferia que,

depósitos condignos, onde, de par com a regeneração preparatória pela acquisição de hábitos de respeito e obediência, sejam applicados, durante tempo conveniente, a serviços de lavoura ou de qualquer industria, conforme a aptidão que demonstrem, e contratos por prazo certo até a maioridade, dispensados os concessionários do ônus do salário emquanto durar o aprendizado, me parece que de muito adiantariam a solução do delicado problema social — a educado da infância desamparada ${ }^{340}$

\footnotetext{
${ }^{333}$ Ibidem.

${ }^{334}$ Idem

335 BRASIL. Ministério da Justiça e Negócio Interiores. Relatório dos anos de 1917 e 1918. Rio de Janeiro. Imprensa Nacional, 1918. P. XVII.

${ }^{336}$ BRASIL. Ministério da Justiça. Relatório do ano de 1883. Rio de Janeiro. Typographia Nacional, 1884, p. A-G-11.

${ }^{337}$ Neste sentido podemos ler no relatório de 1883: "entendi-me com alguns proprietários ruaes; $\boldsymbol{e}$, em tão boa hora, que quantos foram apprehendidos, foram contratados" (Idem).

${ }^{338}$ Idem.

${ }^{339}$ Idem

${ }^{340}$ Idem.
} 
A lógica da construção de experiências governamentais no campo da assistência social seguia um padrão, que aos olhos de hoje descreveríamos, como experiência piloto, sistematização, avalição e generalização como política pública. Nas soluções apontadas para o problema da infância desvalida percebemos nitidamente esta lógica administrativa. O Dr. Tito Augusto Pereira de Matos, chefe de polícia pela terceira vez em 1883, em longo relatório, no qual discutia os problemas que interferiram na tranquilidade pública e na maneira de construir respostas capazes de produzir resultados, descreve nitidamente esta lógica administrativa de construção de políticas públicas. O referido chefe de polícia tinha profundas críticas ao fato dos menores serem encaminhados para a Casa de Detenção. Apesar de não estarem misturados com criminosos, "não é menos verdade que, detidos dentro dos muros de nau prisão, nem os conquistavam os sentimentos do brio e dignidade, nem o asylo os recommendava pela moralidade e idoneidade a quem os podia pretender como pequenos trabalhadores" ${ }^{\text {"341. }}$. Evidencia-se aqui mais uma vez a análise feita anteriormente relacionada a infância desvalida enquanto categoria classificada como pobreza inválida. Esta estava posta dentro das ações de ajuda, apoio e proteção, mas que precisavam ser orientadas e corrigidas pelo e para o trabalho, pois ela era em potência ou um trabalhador dócil necessário para a construção da nação ou um criminoso incorrigível. Percebemos na lógica do chefe de polícia Dr. Tito a necessidade de responder de forma a problemática da pobreza nitidamente classificada em válida e inválida. Para ele, não seria mais aceitável a situação a que se encontravam os menores na casa de detenção, afirmava que "antes de qualquer reflexão, assalta o coração a repugnância do deposito provisório (...) entretanto, si, não obstante todos estes senões, a benevolência os acolheu” ${ }_{342}$. Dr. Tito afirmava ainda que "o asvlo de meninos desvalidos e as companhias de menores dos arsenaes de guerra e marinha nao bastam para acolher quantos meninos pollulam nesta capital, sem pais ou parentes, que os protejam"343.

Esta reflexão do chefe de polícia abre a possibilidade de vislumbrar nitidamente a relação entre a infância desvalida que poderia ser a fonte da

\footnotetext{
${ }^{341}$ Ibidem.

342 Idem.

${ }^{343}$ Idem, p. A-G-10.
} 
mendicidade e vagabundagem que deveria ser extirpado pela educação. Mas o que mais nos chama a atenção é o fato de que estava nítido a posição do Estado de que cabia a ele construir respostas para as problemáticas sociais, principalmente a pobreza urbana. Dr. Tito é veemente em suas críticas afirmando que "em estreitos limite tem actuado a protecção dos poderes públicos, e bem pouco tem collaborado nessa obra de beneficência e de futuro a generosidade privada" ${ }^{344}$. No entanto, segundo o referido chefe de polícia, "fagueira esperança sorri, felizmente, ao filho do pobre”, a fundação pela "associação protectora da infância desamparada, sob a alta, benéfica e promissora direcçïo de S. A. o sr. conde d'Eu” de um

estabelecimento rural, onde sejam educados profissionalmente os infelizes privados dos cuidados paternos, virá encher sensível lacuna e desafiar a philantropia dos homens de coração, no tocante empenho de prevenir uma das maiores desgraças, que podem ferir a sociedade - a precoce e inevitável depravação da infância desvalida ${ }^{345}$.

Dr. Tito ainda elogiava o "movimento, que tem dotado esta corte de escolas de instrução primaria" ${ }^{346}$, o qual devia aos esforços de "illustres cidadãos" e do governo "que, como verdadeiros apóstolos do bem, têm-se dedicado a espancar as trevas da ignorância, em que se envolve o filho do povo" ${ }^{347}$. Em 1920 o ministro Dr. Alfredo Pinto Vieira de Mello dá continuidade a cantilena quanto à necessidade de organizar a assistência a infância e a crítica as iniciativas do Estado. Este aspecto é tão premente nos relatórios, que poderíamos inferir, que, de certo modo, este era o discurso oficial, proferido desde o século XIX, como análise da problemática da assistência a infância. Neste sentido escreve o referido ministro que

quasi nada tem feito o Estado, até agora, no tocante ao problema de hygiene e de assistência á infância. Devemos a algumas instituições de iniciativa privada, nesse particular, esforços meritórios; a sua acção, porém, não pode generalizar-se, como a sociedade requer e a justiça impõe, cumprindo ao poder publico intervir, solicitado por uma das nossas mais evidentes necessidades de assistência social. (Grifo nosso) Depois das ideas externadas a respeito por V. Ex., na Mensagem de 3 de maio do corrente anno, é desnecessário salientar aqui a importância desse capitulo de hygiene publica, ligado ao próprio futuro da nacionalidade ${ }^{348}$.

\footnotetext{
${ }^{344}$ Ibidem.

345 Idem.

${ }^{346}$ Idem.

347 Idem.

${ }^{348}$ BRASIL. Ministério da Justiça e Negócio Interiores. Relatório dos anos de 1919 e 1920 . Rio de Janeiro. Imprensa Nacional, 1920, p. XXVII.
} 
Cabe aqui uma importante ressalva, como abordado na introdução, é a segunda vez que aparece o termo assistência social, nos relatórios pesquisados, cunhado no sentido que a semântica atual o classifica. Vale salientar que o modo empregado demonstra o mesmo sentido de assistência pública, utilizado para designar os diversos ramos da administração da pobreza urbana, neste caso relacionado diretamente ao pobre inválido.

Segundo o Dr. Muniz Barreto, chefe de polícia em 1902, “a protecção á infância (grifo nosso) desvalida é um dos assumptos que deve merecer toda a attenção dos poderes públicos, quaesquer que sejam os sacrifícios que ella nos imponha”. Abaixo podemos vislumbrar a proposta do citado chefe de polícia para a proteção e assistência a infância. Chama a atenção a proximidade com a atual organização deste campo, bem como podemos vislumbrar que as necessidades apontadas, muitas delas, ainda persistem na atualidade, muitas das quais aventadas na fala dos principais filantropos da época.

Neste intuito, auxiliando-se o Instituto de Proteção e Assistencia á Infância do Rio de Janeiro, cujo fim principal e humanitário é proteger as crianças pobres, doentes, defeituosas, maltratadas e moralmente abandonadas; e promovendo-se a creação de pequena asylos de maternidade, para recolher as mulheres pejadas nos ultimos mezes da gravidez, de pequenos dispensários nos bairros pobres do Rio de Janeiro, de creches, de officinas para crianças, de hospital infantil, e de outros serviços necessários para que o pobre desvalido encontre um apoio tutelar (grifo nosso) que o acompanhe e o encaminhe, desde o berço até á maioridade, ter-se-ha prestado ao paiz um serviço relevante e immorredouro ${ }^{349}$.

E nítido e perfeitamente identificável a importância da infância para a formação do campo da assistência social, bem como é facilmente demonstrável a importância da polícia na construção de respostas alheias a relação direta com a criminalidade, referente aos cuidados com a infância. Afirmava literalmente, em 1905, o chefe de polícia Desembargador Manoel José Espinola em 1905 que " $a$ policia não pode ser estranha, nem indifferente a esse ramo de assistência, quando lhe incumbe não só a vigilância, a manutenção da ordem, o descobrimento dos de actos criminosos, como prevenir os delitos" ${ }^{\prime 50}$. A relação da infância com a assistência nos permite identificar as propostas que houve na direção da

${ }^{349}$ BRASIL. Ministério da Justiça e Negócio Interiores. Relatório dos anos de 1902 e 1903 . Rio de Janeiro. Imprensa Nacional, 1903, p. 71-2.

${ }^{350}$ BRASIL. Ministério da Justiça e Negócio Interiores. Relatório dos anos de 1905 e 1906 - Volume 01. Rio de Janeiro. Imprensa Nacional, 1906a, p. A-E-5. 
organização e regulamentação, que envolviam a assistência de maneira geral e, ao mesmo tempo, a infância em particular. Neste sentido, vale explorar a proposta de organização da assistência pública, feita pelo ministro J. J. Seabra em meados da primeira década do século XX. Antes, porém, proveitoso é informar que o ministro se destacava como articulador da sociedade na construção, organização e regulação do campo da assistência social e, que esta foi uma bandeira, uma luta incansável da qual o ministro não media esforços. Em todos os relatórios de sua gestão (19021906) podemos ver longas análises e projetos de lei referente à organização da assistência pública. O ministro J. J. Seabra era um grande animador do debate da assistência pública e privada e mobilizava diversos setores da sociedade em prol de uma das principais, senão, a principal bandeira de sua gestão, como não deixa de revelar os relatórios pesquisados.

Para sustentar ainda mais a necessidade da organização da assistência e "amparar com interesse a propaganda generosa que foi feita para a organização definitiva da assistência, movimento que repercutiu nos próprios Estados da União" 351 , o ministro J. J. Seabra tomou como "as primeiras providencias para uma solução conveniente" ${ }^{\prime 35}$ a contratação do

ilustre magistrado Sr. Dr. Ataulfo de Napoles Paiva, do Tribunal Civil e Criminal, para encarregar-se de elaborar o plano do serviço projectado, visto ter o mesmo assistido em Pariz ao funcionamento do Congresso em que foram discutidas as theses atinentes a essa matéria, tão complexa e especial ${ }^{353}$

Em resposta ao ofício enviado pelo desembargador Ataúlfo de Paiva, que havia solicitado afastamento da "comissão que lhe estava incumbida, de auxiliar este Ministério na organização da Assistência Publica" 354 , pelo fato der sido nomeado para a Corte de Appellação, o ministro J. J. Seabra foi enfático afirmando que não poderia “dispensar a sua esclarecida collaboração naquele assumpto, $e$ espero que V. S., com a dedicação de que tem dado prova, não se recusará a coadjuvar o Governo no empenho de estabelecer nesta Capital a Assistencia

${ }^{351}$ BRASIL. Ministério da Justiça e Negócio Interiores. Relatório dos anos de 1903 e 1904. Rio de Janeiro. Imprensa Nacional, 1904, p. 70.

${ }^{352}$ Idem.

${ }^{353}$ Idem.

${ }^{354}$ BRASIL. Ministério da Justiça e Negócio Interiores. Relatório dos anos de 1904 e 1905 - Volume

II. Rio de Janeiro. Imprensa Nacional, 1905b, p. 243. 
Publica, a que liga máxima importância" ${ }^{, 35}$. E, que poderia o desembargador assumir as duas funções.

O objetivo do Ministro J. J. Seabra era sistematizar a assistência em geral para, entre outras coisas, demonstrar os benefícios que a beneficência particular presta a população e influenciar na aprovação da lei da assistência pública. $\mathrm{O}$ ministro reconhece que será "complexa e difícil a funcção que terá que desempenhar a nova organização da Assistencia Publica"356 devido, principalmente, a ausência de sistematização destes serviços. Aqui podemos ver a estatística como técnica policial na organização da assistência, pela necessidade de sistematizar "o ilimitado numero de associações e obras pias, que honram os créditos da vida nacional" ${ }^{\prime 357}$.

A outra medida deliberada pelo Ministério da Justiça foi "recommendar o assumpto ao estudo e ponderação do illutre Sr. Prefeito do Districto Federal, pela necessidade de uma acção commum com a Muncipalidade, que tem várias instituições pias sujeitas á sua jurisdição $o^{\prime 358}$. Cabe aqui atentar para a fato de que o prefeito era nomeado pelo governo central e que estava na estrutura de poder federal sob a governança do Ministério da Justiça, mas principalmente relvar o fato de que já havia sido criado o "Officio de Assistencia Municipal” pelo decreto $n$. 441, de 26 de junho de 1903, o qual já estava em elaboração a estatística geral das obras e associações de beneficencia do Districto Federal, base indispensavel para o regular e prudente funcionamento do Instituto "359.

Na busca pela organização da assistência pública o ministro J. J. Seabra contava como o apoio de filantropos como Moncorvo Filho ${ }^{360}$, que como médico se interessava pela temática da infância. Moncorvo Filho, enquanto diretor do Instituto de Proteção e Assistência a Infância do Rio de Janeiro, envia em 07 de março de 1903 ofício ao, então, ministro J. J. Seabra apresentando o projeto de lei de proteção a primeira infância, elaborado pelo próprio a pedido do V Congresso Brasileiro de Medicina e Cirurgia levado ao senado pelo Senador Dr. Nogueira

\footnotetext{
355 Ibidem.

${ }^{356}$ BRASIL. Ministério da Justiça e Negócio Interiores. Relatório dos anos de 1903 e 1904 . Rio de Janeiro. Imprensa Nacional, 1904, p. 68.

${ }^{357}$ Idem.

${ }^{358}$ Idem, p. 71.

359 Idem.

${ }^{360}$ Sobre Moncorvo Filho ver Rizzini (2008) e Freire (et. al. 2011).
} 
Paranaguá, presidente naquele momento do Instituto de Proteção e Assistência a Infância. Frisava Moncorvo Filho no citado ofício que,

como se trata de uma questão politico-social, que na França immortalisou o nome do senador Théophile Roussel, cuja lei tem poupado a esse adeantado paiz milhares de vidas, tomo a liberdade de submetter o alludido projecto á esclarecida consideração de V. Ex., que tão interessado se tem mostrado sempre por todas as questões de assistência publica ${ }^{361}$.

Outro aspecto que monstra os esforços empreendidos pelo ministro J. J. Seabra para organização da assistência e que por sua vez evidencia a importância da infância para esta matéria foi ter encarregado Franco Vaz então "secretario da Escola Correccional Quinze de Novembro de estudar o assumpto e apresentar-me a tal respeito um trabalho, no prazo de seis mezes ${ }^{\text {"362 }}$. Após seis meses, como fora acertado, o estudo foi apresentado em 14 de fevereiro de 1905. Franco Vaz analisa a infância em diferentes aspectos "com a largueza que o tempo permitia”. Dividiu, o autor em duas "partes capitaes: a primeira, menos desenvolvida" onde discorria sobre o abandono material e a mortalidade infantil e, a segunda, mais vasta, intitulada $O$ abandono moral, onde o autor se occupa das crianças moralmente abandonadas e delinquentes e das múltiplas questões que lhes dizem respeito"363. No ofício endereçado por Franco Vaz ao Ministro J. J. Seabra na entrega do estudo encomendado podemos ver interessante levantamento bibliográfico do que havia sido publicado no Brasil sobre a infância. Afirmava Franco Vaz que "emquanto a Europa possue uma littcratara inteira e, o que é mais ainda, uma litteratura vasta e copiosa, no Brazíl esse magno assumpto permanece quasi na penumbra, á falia de quem lhe queira trazer as luzes do seu saber e o concurso do seu entendimento" ${ }^{364}$. A pouca luz que sobressaia na penumbra era no dizer de Vaz a

palavra falada e escrita do ilustre Dr. Moncorvo Filho, director do Instituto de Protecção e Assistência á Infância do Rio de Janeiro; um excellente estudo jurídico - mas só jurídico - da lavra do nosso mallogrado compatriota dr. Tobias Barreto, subordinado ao titulo de Menores e loucos; um opúsculo - Crianças abandonadas e crianças criminosas - publicado ha quatro annos pelo talentoso advogado do nosso fôro Sr. Evaristo do Moraes; um curto capitulo, da meia dúzia de paginas,

${ }^{361}$ BRASIL. Ministério da Justiça e Negócio Interiores. Relatório dos anos de 1903 e 1904. Rio de Janeiro. Imprensa Nacional, 1904, p. 72.

${ }^{362}$ BRASIL. Ministério da Justiça e Negócio Interiores. Relatório dos anos de 1904 e 1905 - Volume

II. Rio de Janeiro. Imprensa Nacional, 1905b, p. 240.

363 Idem.

${ }^{364}$ Idem, p. 240-1. 
inserto em seu livro A nova escola penal, pelo preclaro membro do nosso Poder Judiciário o desembargador dr. Viveiros de Castro, todos suffietentemente aptos para melhor se desempanharem da incumbência que me coube $e^{365}$.

Segundo Franco Vaz, além desta produção poderia se incluir

um discurso proferido pelo dr. Lopes Trovão, na sessão do Senado Federal de 11 de setembro de 1896, e outro pronunciado pelo dr. Pinto Portella, na sessão da Academia de Medicina, do $1^{\circ}$ de julho do anno passado, quando aquella douta agremiação commemorava o $75^{\circ}$ aniversario da sua fundação; algumas linhas traçadas apressadamente pelo nosso ilustre conterrâneo dr. Aureliano de Araujo Leal [que será chefe de policia da capital federal de 1914 a 1919], actual chefe de policia do Estado da Bahia, em sua obra Germens do crime, escripta quando o autor era ainda bastante joven, e uma dezena, si tanto, de artigos de jornal e de revista, de trechos rápidos de livro, com um caracter puramente impressionista ${ }^{366}$

Como podemos observar J. J. Seabra tinha firme propósitos de organizar a assistência, que passa a ser pauta ainda mais relevante para o poder central a partir do novo regime. Neste sentido afirmava o referido ministro que é "imprescindível e urgente necessidade de ser uniformizado de maneira completa e radical o serviço da assistência publica e privada em suas varias e múltiplas modalidades"367. Fica evidente esta necessidade como mais um dos aspectos de gestão administrativa do Estado sobre a pobreza urbana no início do século XX. A tentativa do ministro J. J. Seabra de criar a "Diretoria Geral de Assistencia Publica" "com o fim de congregar, uniformizar e sujeitar a severa fiscalização os serviços e interesses da assistência publica e beneficencia particular em suas variadas modalidades" era uma das necessidades de organização das instituições na República, muitas das quais criadas no Império. A importância de organizar esta prática social já existente desde o Império pode ser observada no trecho transcrito abaixo referente a introdução do relatório publicado em 1904 pelo ministro em questão. Neste relatório, o Ministro da Justiça Dr. José Joaquim Seabra ${ }^{369}$ afirmava

\footnotetext{
${ }^{365}$ Ibidem.

${ }^{366}$ Idem.

${ }^{367}$ BRASIL. Ministério da Justiça e Negócio Interiores. Relatório dos anos de 1903 e 1904. Rio de Janeiro. Imprensa Nacional, 1904, p. 68.

${ }^{368}$ Idem.

${ }^{369}$ Apesar do ministro J. J. Seabra manter basicamente a mesma estrutura do índice dos relatórios de seus predecessores, passa a publicar este em quatro volumes cada um destinado a uma diretoria específica, a saber: diretoria de justiça responsável pelas crianças abandonadas, mendigos, alienados e o sistema penal, a diretoria do interior que cuidava da instrução pública e das intuições de pesquisa, a diretoria de contabilidade e, promoveu a divisão de saúde pública para o status de diretoria de saúde pública.
} 
categoricamente, que "urge, também, organizar o Offirio Geral de Assistência 370 , (...) sendo de esperar que o Congresso Nacional providencie a respeito, inspirandose em elevados sentimentos de caridade e justiça ${ }^{371}$. Na proposta elaborada pelo ministro J. J. Seabra e sua equipe previa a criação da Diretoria Geral de Assistência Pública como uma instituição dependente do Ministério da Justiça e Negócios Interiores, que tinha por objetivo "encaminhar a obra meritória do bem e da caridade, exercida por iniciativa particular ou amparadas pelo poder público",372.

A creação do Officio Geral de Assistência, para o fim de uniformizar e methodizar os variados Serviços de assistência publica e beneficência particular em suas modalidades, sujeitando-os a severa, moralizadora e proveitosa fiscalização, assim como a construção de habitações commodas e hygienicas para as classes operarias e decretação de outras medidas necessárias para attender, acautelar e curar da sorte e do futuro das ditas classes, afigura-se-me serem problemas cuja solução prompta e intelligenle se impõe; e, pois, não pôde egualmenle ser protelada ${ }^{373}$.

Na visão do ministro J. J. Seabra o governo não podia mais ser indiferente devido ao "movimento de propaganda que entre nós se desenvolveu, ha dous annos pouco mais ou menos, em favor da reforma, ou melhor, da regular organização da assistência privada ou oficial" ${ }^{374}$.

Como podemos observar a discussão sobre a organização de assistência envolvia a questão do trabalho, dos trabalhadores sem trabalho, dos mendigos aos operários, de certo modo, a totalidade da classe trabalhadora. Esta organização estaria amparada pelas ideias "que tem sido postas em prática nas nações mais adeantadas da Europa e da America" e aproveitaria "os elementos esparsos que neste particular já possue o nosso paiz, especialmente no grande centro da Capital Federal” ${ }^{\prime 375}$. A necessidade de organizar a assistência também se impunha pela existência de "factos abusivos que merecem a attenção da autoridade, que tem o dever de zelar pela boa fama e escrúpulo das verdadeiras instituições de

\footnotetext{
${ }^{370}$ Segundo a proposta apresentada a "funcção do Officio Central, será exercida, gratuitamente, por um Conselho Supremo, sendo os seus membros de livre nomeação do Poder Executivo, que em regulamento especial, definirá as respectivas atribuições (BRASIL. Ministério da Justiça e Negócio Interiores. Relatório dos anos de 1904 e 1905 - Volume II. Rio de Janeiro. Imprensa Nacional, 1905b, p. 226).

${ }^{371}$ BRASIL. Ministério da Justiça e Negócio Interiores. Relatório dos anos de 1903 e 1904. Rio de Janeiro. Imprensa Nacional, 1904, p. 4.

${ }^{372}$ Idem, p. 68.

${ }^{373}$ BRASIL. Ministério da Justiça e Negócio Interiores. Relatório dos anos de 1905 e 1906 - Volume 01. Rio de Janeiro. Imprensa Nacional, 1906a, p. 4.

${ }^{374}$ BRASIL, 1904, op. cit.

${ }^{375}$ Idem.
} 
caridade" $^{376}$. Era notório, segundo os relatórios ministeriais, a existência de um grande número de instituições de assistência social na cidade do Rio de Janeiro, boa parte criadas no Império, que a República deviria organizar. O olhar voltado para as soluções das "nações mais adeantadas da Europa" e o aparecimento de forma explícita da preocupação com casos de abusos, desvios e falta de escrúpulos de algumas instituições de caridade e filantropia, concorriam ainda mais para a necessidade de regulação. Com fins de fiscalização foram nomeadas "comissões especiais de inquéritos" ${ }^{377}$, que segundo o Ministro J. J. Seabra "seria mais vantajoso previnil-os por intermedio de uma corporação estável e bem assente" ${ }^{\text {378 }}$. Para tanto deveria ser criado o Offício de Assistencia, subordinado a Diretoria Geral que

além das suas varias funcções, terá esta alta vantagem - de constituir-se o centro fiscalizador de todos os serviços correlativos - fiscalização essa necessária aos interesses officiaes e públicos e de manifesta utilidade para as próprias administrações das associações particulares, que zelam pela correcção de sua vida intima e que precisam ficar livres de todas e quaesquer suspeições ${ }^{379}$

Esta fiscalização já era feita nos asylos de orphãos, de alienados e de mendigos, sem o mérito se era ou não a contento, mas já sob égide de decretos e regulamentos, como demonstra o decreto 1030 de 14 de novembro de $1890 \mathrm{em} \mathrm{seu}$ artigo174, a formação das comissões fiscalização prevista no artigo 12 da lei n. 1132, de 22 de dezembro de 1903 e o artigo $2^{\circ}$ do decreto n. 1154, de 7 de janeiro de 1904 que passaria esta função para o exercício da Directoria Geral de Assitencia Publica $^{380}$. Este aspecto da fiscalização governamental sobre as instituições de asilos e de caridade já estava posto como disposição legal que foi ratificado pelo acto n. 1154, de 7 de janeiro de 1904 que "taxou de modo formal essa funccão fiscalizadora, nomeando uma commissão permanente junto ao Instituto de Protecção á Infância, que é uma associação de caracter particular,"381. Percebemos aqui que já havia meios instituídos de fiscalização no qual as

${ }^{376}$ BRASIL. Ministério da Justiça e Negócio Interiores. Relatório dos anos de 1903 e 1904 . Rio de Janeiro. Imprensa Nacional, 1904, p. 68-9.

${ }^{377}$ Idem, p. 69.

${ }^{378}$ Idem.

${ }^{379}$ Idem.

${ }^{380}$ BRASIL. Ministério da Justiça e Negócio Interiores. Relatório dos anos de 1905 e 1906 - Volume 02. Rio de Janeiro. Imprensa Nacional, 1906b p. 299.

${ }^{381}$ BRASIL. Ministério da Justiça e Negócio Interiores. Relatório dos anos de 1904 e 1905 - Volume

II. Rio de Janeiro. Imprensa Nacional, 1905b, p. 238. 
instituições privadas eram fiscalizadas e ao mesmo tempo fiscalizadoras. O que propunha a lei de assistência é que esta fiscalização ficasse centralizada no Ofício Geral de Assistência que seria também composto por membros das instituições particulares e do governo, tal qual já instruía citado ato de 7 de janeiro de 1904.

Além da função fiscalizadora da assistência privada, feito pelos próprios integrantes da assistência privada, estaria a cargo também da Directoria Geral de Assitencia Publica "a complicada questão da assistência á infância moralmente abandonada, a da delinquência juvenil" e o "da mendicidade"382. Segundo o referido Ministro estes fatos presentes nas "sociedades modernas” requerem "medidas bem coordenadas e permanentes", que não devem "continuar entregue tão somente a autoridade judiciaria" ${ }^{383}$. Esta última afirmação do ministro J. J. Seabra confirma de maneira categórica nossa posição de que as instituições policias atuavam pela estratégia da assistência social e médica no enfrentamento da problemática da infância abandonada e da mendicidade, pois a autoridade judiciária a que ele se refere atuava diretamente junto as populações através, e tão somente, das instituições policiais.

O referido projeto de lei, ajuda-nos a entender a amplitude do termo Assistência Pública. Segundo o referido projeto assistência pública compreende:

a) A assistência orphanologica propriamente dita, comprehendida a da infância desvalida ou moralmente abandonada, e a delinquência juvenil (...), b) A assistência judiciaria, estatuída pelo decreto $n$. 1030, de 14 de novembro de $1890^{384}(\ldots)$, c) $\mathrm{A}$ assistência medica gratuita, a domicilio, para os enfermos privados de recursos, provida dos postos médicos com os respectivos dispensarios e bem assim das ambulâncias urbanas destinadas á prestação de soccorros imediatos (...), d) A assistência á velhice desamparada, aos estrangeiros, desde que haja accôrdo entre os governos e reciprocidade de benefícios nos paizes a que pertencerem, e, em geral, a todos quantos se acharem nas condições previstas na segunda parte do art. $1^{\circ} \mathrm{da}$ presente lei ${ }^{385}$.

Vale destacar que segundo o referido projeto, em seu artigo $5^{\circ}$ "Ficam sujeitas á fiscalização todas as instituições e associações de beneficencia e caridade

\footnotetext{
382 Ministério da Justiça e Negócio Interiores. Relatório dos anos de 1903 e 1904. Rio de Janeiro. Imprensa Nacional, 1904, p. 69.

${ }^{383}$ Idem.

${ }^{384}$ Assistência judiciária "para o patrocínio dos pobres nos processos criminaes e civeis, e que continuará mantida gratuitamente, fazendo, porém, o Governo no decreto $n$. 2457, de 8 de fevereiro de 1897, que a organizou, as alterações que julgar convenientes, afim de tornar mais efílcaz o seu exercício e acção" (BRASIL. Ministério da Justiça e Negócio Interiores. Relatório dos anos de 1905 e 1906 - Volume 02. Rio de Janeiro. Imprensa Nacional, 1906b p. 299).

385 Idem.
} 
publicas ou particulares, quer gozem ou não de favores do Estado" ${ }^{386}$. Ao seguirmos as referências do artigo mencionado encontramos uma larga abrangência do que eram as "instituições e associações de beneficencia e caridade publicas" 387. Entre elas encontramos, “aylos, hospícios e hospitais de quaisquer espécies, as sociedades de socorros e auxílios mútuos, estabelecimentos pios, fabris, e insdustriaes, onde existam menores" ${ }^{388}$. Visava, ainda, tal projeto regular " $o$ trabalho e os interesses dos menores de ambos os sexos empregados nos nos estabelecimentos fabris e industriaes existentes na Capital Federal”389.

Através da crítica feita pelo ministro J. J. Seabra sobre o que "tem-se chamado assistencia publica", percebemos que esta ideia se associa diretamente ao que hoje denominamos de "social". Segundo o referido ministro a assistência pública estava “anexa aos encargos da hygiene" e em função disto

não tem passado de um mero rotulo, de uma simples fórmula, sem significação alguma, pois que a respectiva repartição, mui naturalmente preoccupada com a salubridade e presa ás dificuldades para dizimar as epidemias que assolaram a nossa Capital, nunca teve tempo e nem conseguiu dar attenção á parte do serviço propriamente chamado de "assistência publica" ${ }^{390}$.

Percebemos nitidamente, corroborado pelos diversos relatórios pesquisados que a "parte do serviço propriamente chamado de assistência pública" referia-se aos serviços de proteção à infância, criado pelo decreto n. 5849 de 9 de janeiro de 1875, a fundação do Asylo de Meninos Desvalidos “mais tarde modificado pelo de 17 de março de 1883 e ainda pelo de 13 de agosto de 1890", entre outros serviços. Estava envolto também nos serviços propriamente ditos da assistência, naquele momento, a assistência médica e jurídica. No entanto é claramente identificado que a ideia relacionada ao termo assistência pública se inscreve em maiores aproximações com a ideia que hoje denominamos de social. No relatório referente ao ano de 1906, por exemplo, encontramos uma seção denominada de assistência pública, nela podemos ler os relatos dos acontecimentos referentes ao recolhimento de mendigos e a situação dos asilos. Informava o referido relatório que "durante $o$

\footnotetext{
${ }^{386}$ BRASIL. Ministério da Justiça e Negócio Interiores. Relatório dos anos de 1905 e 1906 - Volume 02. Rio de Janeiro. Imprensa Nacional, 1906 b p. 299.

${ }^{387}$ Idem.

${ }^{388}$ Idem.

${ }^{389}$ Idem, p. 300.

${ }^{390}$ BRASIL. Ministério da Justiça e Negócio Interiores. Relatório dos anos de 1904 e 1905 - Volume

II. Rio de Janeiro. Imprensa Nacional, 1905b, p. 233.
} 
anno findo, fora remettidos por esta repartição para o Asylo S. Francisco de Assis 48 mdividuos encontrados a mendigar nas ruas, sendo 26 homens e 22 mulheres; 21 nacionaes e 27 estrangeiros" ${ }^{\prime 391}$. Tratava-se especificamente de aspectos que aos olhos atuais, classificaríamos como da ordem da assistência social.

$\mathrm{O}$ interesse pelo assunto da assistência pública e privada e, com ela dos cuidados com a infância, estavam na ordem do dia no início do século XX. Ainda assim, na visão dos contemporâneos, longe de ser resolvida. Este aspecto pode ser revelado quando ainda em 1908 o Desembargador Ataulpho de Paiva - conhecido pelo ardor com que se dedicou ao estudo de todas as questões que interessam a infância ${ }^{392}$ - então presidente do Conselho Administrativo do Patrimônio do Hospício Nacional de Alienados escreveu ao ministro Dr. Augusto Tavares de Lyra que

vive-se a bradar pela sagrada sorte dos orphãos desamparados, pela protecção a infância abandonada, pelo problema da mendicidade, pela deficiência dos meios de socorros nas vias urbanas, pelo flagelo da tuberculose, pela devastação que acarreta o alcoolismo, pelos horrorosos desastres produzidos pela syphilis, pela crise das habitações populares, pela repressão do lenocínio, pelo destino á velhice desamparada, pela falta de assistência aos enfermos desvalidos, como se a tudo isso fosse possivel attender sem a intervenção directa e desassombrada do Estado e, principalmente, sem a centralização e uniformidade dos serviços em um órgão bem definido e bem normatsado da vida governamental de uma nação ${ }^{393}$.

A razão administrativa do Estado tinha na Assistência Pública uma das principais questões que deveriam ser resolvidas para modernização das relações sociais. A organização da "assistência publica será nesse sentido auxiliar da Justiça, podendo, porém, promover os meios de soccorro ou amparo, directamente, e requisitar da autoridade as medidas necessárias para execução das suas providencias e ordens" 394.

Mesmo com toda a mobilização de setores importante da sociedade, a organização da assistência pública não foi concretizada, não obteve apoio do Senado. Mesmo com os esforços, influência e prestígio que gozava o Ministro J. J.

\footnotetext{
${ }^{391}$ BRASIL. Ministério da Justiça e Negócio Interiores. Relatório dos anos de 1905 e 1906 - Volume 01. Rio de Janeiro. Imprensa Nacional, 1906a, p. A-E-14.

${ }^{392}$ BRASIL. Ministério da Justiça e Negócio Interiores. Relatório dos anos de 1917 e 1918 . Rio de Janeiro. Imprensa Nacional, 1918, p. XIX.

${ }^{393}$ BRASIL. Ministério da Justiça e Negócio Interiores. Relatório dos anos de 1907 e 1908 - Volume 01. Rio de Janeiro. Imprensa Nacional, 1908a, p. XXVIII.

${ }^{394}$ BRASIL. Ministério da Justiça e Negócio Interiores. Relatório dos anos de 1904 e 1905 - Volume

II. Rio de Janeiro. Imprensa Nacional, 1905b, p. 223.
} 
Seabra, o qual permaneceu no cargo de 1902 a 1906 durante todo o período do governo do presidente Rodrigues Alvez, enfrentando motins e greves como a revolta da vacina, a proposta a assistência pública não prosperou. Apesar do parecer unânime da comissão de finanças que "entendeu conferir ao Governo a faculdade de crear nesta Capital uma repartição central encarregada de congregar e uniformizar os interesses da assistência publica e da beneficência privada, promovendo, ao mesmo tempo, de modo amplo, a respectiva fiscalização $e$ ordem "395. Mesmo referendado pela commissão de legislação e justiça do Sendao Federal, segundo a qual, o projeto de lei

obedece á necessidade de aproveitar os grandiosos recursos, já concedidos pelo Estado, juntando-os aos meios também já organizados pela caridade individual. Creando no Dístricto Federal a Directoria Geral de Assistência publica, a quem competirá os serviços de soccorros aos indigentes de todo gênero, e autorizando a fundação do Officio Central de Assistência, com o fim de aproveitar a acção da beneficencia privada, o projecto, si de um lado faz convergir para uma repartição geral do Estado as attribuicões da assistencia, com o intuito de uniformízal-as, por outro lado confere a uma associação protegida oficialmente, e que viverá com a representação das associações particulares, regalias e distincções, que muito contribuirão para o seu necessário desenvolvimento ${ }^{396}$.

Insistia o ministro afirmando que organizar a assistência é propiciar um "serviço de protecção aos infelizes, aos desafortunados, serviço que exprime eloquentemente o espirito humanitário" ${ }^{397}$. De modo que "a nítida comprehensão dos seus mais sagrados deveres, por parte daquelles que enfeixam em suas mãos, legislativa e administrativamente, a directriz e a gestão dos negocios públicos" incida sobre a generosa inciativa de aprovar a lei que organiza a assistência pública na capital federal. Como meio de convencimento, argumentava o ministro que:

não esqueçcamos, tampouco, essas crianças precocemente atiradas ao vicio e ao crime, que as prisões, de modo o mais inconveniente, recolhem com frequencia, concorrendo, na maioria dos casos, para a sua perdição, em vez de intervir em favor do seu levantamento moral; nem esses miseros enfermos, outrora cheios de vigor e produzindo para consumir, que hoje se veem prestes a extinguir-se, á falta de um soccorro capaz de reerguel-os por mais algum tempo; nem esses desgraçados a quem os annos e os enfermidades afastaram do trabalho e, para fazerem face ás exigências da vida, ficam expostos á contingência de recorrer á caridade publica, dando o espectáculo desolador e importuno que apresenta a mendicidade das nossas

395 BRASIL. Ministério da Justiça e Negócio Interiores. Relatório dos anos de 1903 e 1904. Rio de Janeiro. Imprensa Nacional, 1904, p. 67.

${ }^{396}$ BRASIL. Ministério da Justiça e Negócio Interiores. Relatório dos anos de 1904 e 1905 - Volume

II. Rio de Janeiro. Imprensa Nacional, 1905b, p. 233.

${ }^{397}$ Idem, p. 224. 
ruas. Considere-se bem tudo isso e veja-se si é possível demorar por mais tempo a creação de serviços da monta dos que aqui me limito a indicar em ligeiros traços, cujos grandes proveitos ninguém quererá negar, cuja insuperável urgência todos são compellidos a reconhecer ${ }^{, 398}$.

No entanto, mesmo com todo os esforços realizados, não consegue o ministro J. J. Seabra organizar a Assistência Pública. Mesmo com a insistência na relevância do tema, abordado de forma contundente em todos os relatórios do referido ministro, a proposta da criação de uma Assistência Pública não encontrou eco e relevância nos grupos de poder a ponto de conquistar certa hegemonia na elite governante. Queixava-se o ministro que "infelizmente, algumas das medidas e reformas (...) julgadas necessárias, e até inadiáveis, não tiveram ainda a fortuna de merecer solução por parte do Congresso Nacional " ${ }^{399}$. No entanto, mesmo com as queixas não deixava de insistir para o "Congresso dispensar-lhe-há a atenção que merece, votando uma lei cuja utilidade é indiscutivel e pela qual a imprensa e a opinião pública começam também a reclamar com insistencia" ${ }^{400}$.

Em seu último relatório volta a ser enfático, o ministro, tal qual, houvera assinalado em seus relatórios anteriores, expondo "com algum desenvolvimento", o seu

modo de pensar em matéria de beneficencia publica", assinalando novamente a inadiável necessidade de crear nesta Capital um serviço regular e, tanto quanto possível, completo de assistência aos velhos, aos enfermos, ás crianças material e moralmente abandonadas, e aos iadividuos pobres submetlidos a processos criminaes e civis, precisando de amparo para a boa marcha das questões que lhes digam respeito, sempre que semelhante intervenção parecer justa ${ }^{401}$.

Importante destacar que o trecho do relatório transcrito acima evidencia a relação direta, quase semanticamente idêntica, dos discursos e práticas englobados na ideia e representação do termo assistência pública e do termo assistência social. Estes dois termos envolvem enquanto ideia, as crianças, os velhos pobres, os enfermos pobres e, segundo o ministro J. J. Seabra, a gratuidade de acesso à justiça.

\footnotetext{
${ }^{398}$ BRASIL. Ministério da Justiça e Negócio Interiores. Relatório dos anos de 1904 e 1905 - Volume II. Rio de Janeiro. Imprensa Nacional, 1905b, p. 224.

${ }^{399}$ BRASIL. Ministério da Justiça e Negócio Interiores. Relatório dos anos de 1905 e 1906 - Volume 01. Rio de Janeiro. Imprensa Nacional, 1906a, p. 3.

${ }^{400}$ Idem, p. 297.

${ }^{401}$ BRASIL, 1906b, op. cit., p. 295.
} 
Esta insistência tinha claros propósitos, na medida que afirmava o ministro J. J.

Seabra, em seu último ano no cargo, que

não me cansarei de insistir por aquella medida de alto interesse, porque estou cada vez mais convencido da improficuidade de quaesquer esforços empregados pelas autoridades publicas, no momento actual, relativamente á repressão exercida contra a mendicidade, á prisão dos menores moralmente abandonados e delinquente $e$ outros de natureza mais ou menos semelhante, cujos effeitos rapidamente desapparecem, guando não produzem resultados oppostos áquelles que se tem em vista attingí ${ }^{402}$.

Mesmo não tendo êxito em seu intento nos interessa ater alguns instantes para entendermos do que se tratava a regulamentação da assistência pública. Através do parecer da comissão de finanças do Senado, transcrita no relatório referente aos anos de 1903 e 1094 e do parecer da comissão de constituição e justiça, também do Senado, transcrita no relatório dos anos subsequentes (1905 e 1906) podemos empreender analises que vislumbra o modo como a ideia de assistência social estava posto no início do século XX na cidade do Rio de Janeiro e, por que não, no Brasil. Segundo a comissão de finanças do Senado Federal,

\begin{abstract}
convém e é mesmo urgente que se imprima direcção e uniformidade aos elementos esparsos da assistência publica e privada, de que já dispõe esta Capital (grifo nosso), sem quebrar-se, entretanto, a autonomia das associações e estabelecimentos já existentes, no sentido de supprimir-se a mendicidade publica, de soccorrer-se á velhice desamparada, á infância desvalida e a quaesquer outras misérias da humanidade, não sendo possivel internar, por differentes motivos, grande numero de taes infelizes nos asylos já fundados; e para isso deseja o Governo ficar autorizado a crear e organizar no Districto Federal e em regulamento especial o Offlcio Geral de Assistência, com o fim de congregar os interesses da assistência publica o da beneficencia privada, promovendo a respectiva fiscalização e ordem, podendo entrar em accôrdo com a Prefeitura do Districto Federal quando julgar conveniente, e abrir créditos, para isso necessários, até 40:000\$000 $0^{403}$.
\end{abstract}

Neste parecer da comissão de finanças é possível vislumbrar os principais aspectos que definem as linhas de atuação do que poderíamos chamar de uma política de assistências social. No primeiro momento podemos extrair a definição de assistência através de para quem esta era feita, ou seja, "aqueles que dela necessitam" ou "aqueles que fazem jus a proteção social"; "a mendicidade, a

${ }^{402}$ BRASIL. Ministério da Justiça e Negócio Interiores. Relatório dos anos de 1905 e 1906 - Volume 02. Rio de Janeiro. Imprensa Nacional, 1906b p. 295.

${ }^{403}$ BRASIL. Ministério da Justiça e Negócio Interiores. Relatório dos anos de 1903 e 1904. Rio de Janeiro. Imprensa Nacional, 1904, p. 67-8. 
velhice desamparada, a infância desvalida e a quaesquer outras misérias da humanidade". Evidencia-se aqui o caminho que iremos percorrer para demonstrar que determinados modos de como controlar e organizar a pobreza inválida na cidade do Rio e Janeiro foram instituídos pela polícia, enquanto executor direto das demandas impostas pelo Ministério da Justiça, o qual influenciava diretamente na priorização de tais demandas. Segundo a comissão de finanças "só porque essa proposição importava na creação de serviço, deixou a mesma de ter o necessário encaminhamento no referido orçamento" ${ }^{" 404}$. De acordo com a mesma comissão não é pela falta do Estado dispender "avultadas sommas em benefícios directos $e$ indirectos a toda sorte de infortuonios que occorrem na nossa sociedade mantendo orçamentos consideraveis em prol da caridade publica, e favorecendo de mil modos a centenares de instituições espalhadas pela vasta zona do nosso território" 405 , nem pela falta de atos filantrópicos da beneficência particular, "é que toda essa acção publica ou privada é feita com uma tal desharmonia de vistas, com um tal desequilíbrio de forças, com uma tal dispersão de elementos, que improfícuos, sinão quasi nullos, são, a certos respeitos, as execuções e os seus resultados". Critica a comissão que todos estes decretos e mesmo "quasi todas as instituições de caridade do nosso paiz", independente do zelo, da "notável abnegação" e do "intuito genereso", nenhuma destas instituições ou "desses actos se nota o accento de systema, de methodo, de organização equilibrada, e de disciplina, que são as condições imprescindíveis para o triumpho dos problemas sociaes" 406.

Além da comissão de finanças, importantes argumentos foram construídos pela comissão de constituição e justiça a "favor de habilitar o Governo a crear nesta Capital o Officio Geral Assistencia instituição que tem os nobres intuitos de harmnoizar os interesses das assistencias publica e privada, provendo as suas necessidades communs" ${ }^{407}$. A referida comissão começa justificando que há um clamor público, pela imprensa, instituições e personalidades "impetrando uma decisão prompta sobre a matéria, apontando, ao mesmo tempo, as irregularidades,

\footnotetext{
${ }^{404}$ BRASIL. Ministério da Justiça e Negócio Interiores. Relatório dos anos de 1904 e 1905 - Volume

II. Rio de Janeiro. Imprensa Nacional, 1905b, p. 228.

${ }^{405}$ Idem, p. 229.

406 Idem.

407 Idem, p. 228.
} 
os defeitos, os vícios, os abusos e as lacunas que existem"408 que se enfrente e solucione "o delicado e complicado problema da assistência publica, que convém ficar, sinão definitivamente organizado em seus complexos ramos, ao menos, em bases firmes, seguras e permanentes" 409 .

Segundo as análises proferidas pela citada comissão, não se poderia “em rigor dizer que o serviço da assistencia estivesse desorganizado, pois este nunca nos mereceu a vigilância e desvelo para uma prévia e regular systematisação" ${ }^{410}$. Desta vez, no dizer da comissão, devia o poder público "armar-se de meios para encaminhar a resolução das grandes e capitaes questões que affectam o exercício da assistência em geral". Esta ação deveria ser guiada pelo "espirito de solidariedade" e pelos "princípios da fraternidade que são, e não podem deixar de ser, os fundamentos do direito actual perante as sociedades modernas" ${ }^{\prime 411}$. Em seus estudos a comissão destacava que

\begin{abstract}
é bem recente a historia das reformas da assistência publica nos paizes em que ella se tem desenvolvido de um modo magistral (...) sendo de alta conveniência que sejam abandonados os velhos moldes que são mui louváveis em seus intuitos e em suas predisposições, mas, que só servem para retardar, entorpecer e paralysar a acção de preciosos elementos, que, uma vez convergentes, trarão a victoria dessa causa social, que evolue atravez das tristes crises do pauperismo e da miséria humana ${ }^{412}$.
\end{abstract}

A França que, segundo a comissão, iniciou a reforma da assistência por volta de 1880 "concentra princípios dignos de imitação" Organization Societies, fundadas em Londres em 1869, e as que foram inauguradas em Buffalo, nos Estados Unidos da America do Norte" ${ }^{414}$. De acordo com a referida comissão, estas instituições foram as "precursoras dessa benéfica agitação revolucionaria da verdadeira politica scientifica, pois que a assistência publica emerge como uma das mais bellas formulas e um dos aspectos mais curiosos da questão social" (grifo nosso) ${ }^{415}$. Afirmava que a partir deste momento mudou " $a$ attitude dos poderes públicos e bem différente se tornou o exercício da philantropia social" ${ }^{416}$.

${ }^{408}$ Idem, p. 229.

${ }^{409}$ Idem.

${ }^{410}$ Idem

${ }^{411}$ Idem.

${ }^{412}$ Idem.

${ }^{413}$ Idem.

${ }^{414}$ Idem, p. 230.

${ }^{415}$ Idem.

${ }^{416}$ Idem, p. 231. 
Segundo os estudos apontados pela comissão C. S. Loch e Nathaniel Rossenau

descortinaram, em 1899, as primeiras linhas e os verdadeiros horisontes sobre o objecto, as condições, os methodos e as teorias sabiamente coordenadas. Cada um delles desenhou com nitidez e verdade os abalos do pauperismo no mundo actual, $e$, criticando os meios retrógrados então existentes, mostraram como é surprendente e maravilhoso o exercício da caridade methodica e como a regularidade da assistência, limitada às condições ordinárias da vida e fiscalizada convenientemente, póde operar as mais salutares o efflcazes aplicações ${ }^{417}$.

A comissão cita literalmente C. S. Loch. Para o filantropo, "o pauperísmo é o inimigo social do Estado moderno. O Estado tem necessidade de cidadãos; não ha logar no Estado para a classe dos enjeitados, dos párias, dos cidadãos que não são cidadãos"418. Afirmava categoricamente que o objetivo final da caridade "é prevenir o pauperismo", que "muitas causas tende a creal-o" 019 . Este objetivo era parte dos deveres do Estado para com os cidadãos, “assim como dos deveres dos ricos para com os pobres". "Todos teem o nome de cidadãos, e o Estado deve preoceupar-se para que todos o sejam na realidade ${ }^{420}$. O que difere para o citado filantropo francês, do modo de assistência praticado até então e o modo como o Estado e os ricos deveriam agir pela nova ótica para prevenir o pauperismo, é que esta deveria ser organizada e dirigida "segundo certos principio e segundo certos methodos" ${ }^{\prime 21}$. Segundo as análises dos chefes de polícia e ministro da justiça, no período pesquisado, a "administração tal como existe actualmente produz muitas vezez o pauperismo" ${ }^{422}$. Segundo esta análise, defendida ferozmente pelo ministro J. J. Seabra, a solução seria organizar administrativamente o que já se realizava, Estado e sociedade civil.

A comissão continua tecendo argumentos em seu parecer a favor da criação do Ofício Geral da Assistência, agora valendo-se das ideias de Nathaniel Rossenau para demonstrar um panorama dos aspectos da assistência no mundo ocidental “civilizado". Segundo Nathaniel, citado pela referida comissão,

\footnotetext{
${ }^{417}$ BRASIL. Ministério da Justiça e Negócio Interiores. Relatório dos anos de 1904 e 1905 - Volume II. Rio de Janeiro. Imprensa Nacional, 1905b, p. 230.

418 Idem.

419 Idem.

420 Idem.

421 Idem.

422 Idem.
} 
os americanos são liberaes na caridade; e sua generosidade é responsável em grande parte pelo crescimento do pauperísmo, numa proporção muito maior, que não comporta o augmento da população. Dirigir essa liberalidade de uma maneira calculada, de modo a obter resultados vantajosos, em vez de resultados perniciosos, é uma questão da hora presente, cuja solução acreditamos, se encontra na organização scientifica da caridade ${ }^{423}$.

Para a comissão, a criação do Oficio Geral de Assistência deveria ser inspirada no "grande modelo da Charity Organization Society, cujo papel representa, na coordenação do methodos de vigilância e na harmonia do trabalho, a ultima palavra da perfectibilidade em matéria de assistência" ${ }^{\text {24 }}$. Segundo a comissão, mesmo a França já possuindo "maravilhosas instituições de caridade" e "leis de proteção á infância e aos enfermos, já promulgadas mal havia feito os prodromos da primeira concentração dos serviços" ${ }^{2425}$. Neste sentido, não seria de se estranhar que também estávamos premente desta necessidade. Como argumento a favar da fundação do Oficia Central de Assistência, frisava a comissão que "cercado de prestigio unanime que o parlamento francez começou a agir sobre todas as leis de assistência e notadamente promulgando, num largo descortino, o acto de 15 de julho de 1893 sobre a Assistência Medica aos enfermos pobres" ${ }^{\text {"26 }}$. Argumenta a comissão que "em seis annos apenas, fornecidos soccorros a quinhentos mil infelizes, porque o interesse do enfermo pobre foi o unico guia do legislador de 1893"427.

Mais adiante, o ministro J. J. Seabra afirma que a Directoria Geral de Assistencia Publica estaria no primeiro momento lidando apenas com a velhice desamparada, mendicidade e infância desvalida, mas que no futuro deveria se ater a "outros assumptos que lhe são inherentes, e que constituem os ramos desse tronco comum, isto é, assistência medica, a assistencia judiciaria" ${ }^{228}$. Aqui mais uma vez podemos ver nitidamente que apesar da ideia de assistência pública ser mais ampla do que a ideia de assistência social, esta estava contida naquela. Mas o ponto central para o qual nosso olhar converge é que tanto uma quanto a outra dizem respeito a processos de ajuda, apoio e proteção para "quaesquer outras misérias da

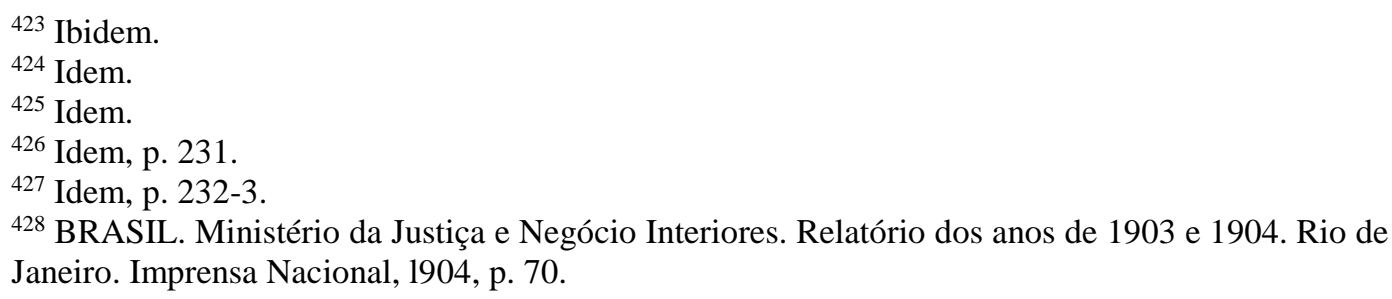


humanidade" além da "mendicidade, a velhice desamparada, a infância desvalida". No entanto, havia também no projeto de assistência pública a assistência judiciária que "já é uma instituição organizada entre nós - com fórma legal e perfeitamente amparada pelo Poder Publico - em vista das disposições do decreto n. 2457, de 8 de fevereiro de 1897"429. Ao justificar a existência e organização da assistência judiciária o ministro J. J. Seabra deixava transparecer em seus argumentos a correlação entre a ideais de caridade e direito, associando este último ao fato jurídico do direito amplo a defesa, como podemos ver o trecho do relatório transcrito abaixo:

Pela sua organização, pelos seus fins altamente generosos e pela gratuidade das suas fuocções - a assistência judiciaria, como o nome o indica, é uma instituição puramente de caridade -, pois o seu nobre escopo foi e é, como diz a exposição de motivos do decreto alludido a realização dos meios práticos assecuratorios do estabelecimento do direito offendido, ou sua simples anffirmação e integração, em favor dos desprotegidos da fortuna, a quem, portanto, faltassem recursos pecuniários para fazel-o valer ou para consegair o reparo de iniquidades sofridas ${ }^{430}$.

Estava explicito na proposta de organização da assistência pública os interesses que a ligavam à beneficência particular. Esta conjugação, segundo apontava os relatórios, era indispensável para enfrentamento das necessidades e demandas e, demonstram a benevolência, a boa vontade e o compromisso da classe dominante com o enfrentamento da problemática da pobreza urbana. Estas associações e estabelecimentos terão sua autonomia interna respeitada "no que concerne á sua direção e economia intima, pretendendo mesmo que tomem parte como auxiliares da missão os representantes da beneficencia privada"431. O que propunha era a continuidade e consolidação do modelo liberal de gestão do Estado com as idiossincrasias e amalgamas do caso brasileiro, promovendo uma "justa e proveitosa harmonia e alliança dos interesses do Estado com os da assistencia privada, na forma das recentes decisões dos Congressos especiaes realizados no mundo civilizado, fazendo que dessa concórdia resulte a effectividade dos intuitos que tem em vista a philanthropia social" ${ }^{32}$. A proposta de organização da

${ }^{429}$ BRASIL. Ministério da Justiça e Negócio Interiores. Relatório dos anos de 1904 e 1905 - Volume II. Rio de Janeiro. Imprensa Nacional, 1905b, p. 236-7.

${ }^{430}$ Idem, 1905 b, p. 237.

${ }^{431}$ BRASIL. Ministério da Justiça e Negócio Interiores. Relatório dos anos de 1903 e 1904. Rio de Janeiro. Imprensa Nacional, 1904, p. 71.

${ }^{432}$ Ibidem. 
assistência, confere o status liberal permitindo e respeitando a "autonomia dos estabelecimentos e associações" ao mesmo tempo em que vê nos representantes da beneficência privada, os auxiliares que compartilham da mesma missão, sem os quais, intento de tal monta e complexidade não teria êxito.

Muitos eram "asylos, hospícios, associações e casas de caridade, muitas dellas maravilhosamente installadas e prestando os mais úteis e assignalados serviços". No entanto, não havia coordenação que pudesse aproveitar "esses recursos, centralisando-os e harmonizando-os, para maior força e mais accentuada effectividade ${ }^{\sharp 33}$. Quem tinha expertise para tal ato administrativo era o Ministério da Justiça e Negócios Interiores, através de sua instituição melhor a aparelhada para esta tarefa a polícia. Podemos elencar diversos discursos e práticas imputadas a polícia que confirmam nossa assertiva, de que esta protagonizou ao lado da caridade e da filantropia a construção do campo da assistência social na cidade do Rio de Janeiro. A ligação direta da polícia com ações de assistência social relacionadas a administração das populações na cidade, pode ser verificado, entre outros fatos, junto a proposta de lei da primeira infância. Tal proposta, elaborada com o aval do V Congresso Brasileiro de Medicina e Cirurgia reserva à polícia um importante papel na execução das ações protetivas e regulatórias. Propunha o projeto que, para criar filhos de outros pais e trabalhar como ama de leite era necessário obter um certificado da polícia com a declaração de seu domicilio e suas condições sociais, de maneira a demonstrar que estava moral e financeiramente apta para desempenhar tais funções. Podemos ver tal determinação no Art. $9^{\circ}$ de tal projeto de lei, onde lê-se: "Toda pessoa que receber para criar qualquer criança, seja ou não mediante paga, devera, de accôrdo com esta lei, fazer á autoridade policial superior do logar as seguintes declarações" ${ }^{434}$. Estas declarações eram documentos, como comprovação de domicílio, aferição de renda e comprovação das condições morais para cuidar da infância, além de fazer a estatística que deveria ser enviada anualmente para o Conselho Superior de Proteção a Primeira Infância ${ }^{435}$, como propunha o referido projeto de lei. Como podemos ver o local de

\footnotetext{
${ }^{433}$ BRASIL. Ministério da Justiça e Negócio Interiores. Relatório dos anos de 1904 e 1905 - Volume II. Rio de Janeiro. Imprensa Nacional, 1905b, p. 232.

${ }^{434}$ BRASIL. Ministério da Justiça e Negócio Interiores. Relatório dos anos de 1903 e 1904 . Rio de Janeiro. Imprensa Nacional, 1904, p. 74.

435 "No Districto Federal a Commissao compor-se-ha dos directores de Hygiene e de Saúde Publica e de cinco administradores de instituições de assistência publica, taes coma: os directores do Hospital da Santa Casa de Misericórdia, do Instituto de Protecção e Assistência á Infância do Rio
} 
ordenamento das relações sociais, mesmo nas propostas mais avançadas e políticas da época, tinha na polícia seu principal executor quando se tratava do controle da população.

Podemos ainda ver os aspectos administrativos de controle populacional pertinentes a polícia, propostos na lei, também no art. 10, segundo o qual deverá haver "na repartição policial superior do logar um registro especial para as declarações obrigadas na presente lei" ${ }^{436}$. Estes aspectos demonstram e confirmam nossos argumentos de que quem estava preparada e tinha a estrutura administrativa para o contato direto com a população pobre não criminalizada, mas com necessidade de controle, mesmo nas primeiras décadas do século XX era a polícia. E disto sabia os filantropos e médios do V Congresso Brasileiro de Medicina e Cirurgia ao colocar na proposta de lei que buscavam aprovação, a polícia como a responsável pela regulamentação para as "amas de leite ou as pessoas que tomarem a criar crianças" ${ }^{\prime 37}$. Na proposta de lei da proteção da primeira infância podemos perceber o movimento de especialização médica de cuidados e um distanciamento da polícia como gestora de instituições. Ao mesmo tempo em que podemos demonstrar que as instituições policiais continuavam na base do ordenamento e gestão das populações com ações de controle não relacionada ao crime.

$\mathrm{O}$ aspecto que mais nos chama atenção, neste sentido, e confirma diretamente nossa tese sobre o protagonismo das instituições policiais na construção da assistência social, é o fato de verificar muitas das propostas defendidas pelos Chefes de Polícia no final do século XIX, ainda no Império, materializada em leis, instituições, análises e novas propostas de filantropos, ministros da justiça e chefes de polícia nas três primeiras três décadas do século XX. Este aspecto pode ser constatado, por exemplo, em grande parte das propostas de Moncorvo Filho médico e principal filantropo do "Instituto de Protecção e Assistência a Infância do Rio de Janeiro" ${ }^{438}$ referendadas pelo V Congresso Brasileiro de Medicina e

de Janeiro, da Policlínica Geral do Rio de Janeiro, da Policlínica de Botafogo e da Maternidade do Rio de Janeiro e, na falta destes, os administradores de outras instituições de beneficencia publica á escolha do Governo. Commissões locaes serão nomeadas pelas autoridades de hygiene, depois de aviso da commissão central, nos Estados do Brazil, nos pontos em que fôr reconhecida a sua utilidade para recorrer á applicação de medida de protecção â infância e de vigilância das amas e das mulheres que criam crianças alheias" (BRASIL. Ministério da Justiça e Negócio Interiores. Relatório dos anos de 1903 e 1904. Rio de Janeiro. Imprensa Nacional, 1904, p. 72).

${ }^{436}$ Idem, p. 74.

${ }^{437}$ Idem, p. 75.

${ }^{438} \mathrm{O}$ "Instituto de Protecção e Assistência a Infância do Rio de Janeiro" é mais um dos muitos casos da relação público privado na gestão da assistência na cidade do Rio de Janeiro. Como 
Cirurgia. Afirmava o chefe de polícia Dr. Tito Algusto Pereira de Matos, em 1883, que "o estado de saúde da ama de leite, porém, escapa a toda a inspecção da autoridade. A influencia nociva, que dessa omissão pode resultar ao desenvolvimento e vida da criança, não se discute"439. A partir desta análise, propunha o Dr. Tito que convinha

sem demora, providenciar em ordem a que se institua o serviço da amamentação em condições de prevenir os males, que do deleixo podem derivar-se. A matricula, mediante exame prévio, e a fiscalísação da ama, tendo em vista os interesses concordantes da família e da autoridade, são medidas de incontestável proficuidade. ${ }^{440}$

Importante frisar que, como demonstrava Foucault (2001), a saúde era uma das preocupações da polícia para a consolidação e expansão das forças do Estado, que somente se dá pela quantidade de cidadãos saudáveis para compor a força de trabalho produtora de riqueza. O mesmo sentido apontado por Foucault (2001), sobre a polícia no século XVII, podemos observar no relatório do chefe de polícia referente ao ano de 1883. Segundo Dr. Tito Algusto Pereira de Matos

a saúde é o primeiro e o mais precioso de todos os bens: riqueza, força, trabalho, tudo perde o seu valor, diz Schützenberger, para aquelle que soffre; a energia se extingue com as forças physicas; populações definhadas, enervadas e enfraquecidas perdem toda a acção e se tornam incapazes de grandes cousas ${ }^{441}$.

No mesmo sentido expressa o ministro J. J. Seabra no relatório referente aos anos de 1904 e 1905, afirmando que a "organização da assistência medica, que constitue a grande base e a pedra fundamental de todos os serviços desta natureza"

podemos ver "pelo decreto legislativo n. 1154, de 7 de janeiro de 1904, foi o Governo autorizado a ceder a esse Instituto um dos próprios nacionaes existentes nesta Capital ou a dar o auxilio mensal de 500\$, para aluguel de casa ao mesmo Instituto, que continua a prestar bons serviços á humanidade, e principalmente aos entes fracos - á infância. Na conformidade do art. $2^{\circ}$ do dito decreto, o Ministério da Justiça e Negócios Interiores, por intermédio de uma commíssão, composta do director geral de saúde publica, de um dos procuradores seccionaes e do curador de orphaos, exercerá a suprema inspecção no Instituto. Por aviso de 6 de abril, foi designado o $1^{\circ}$ procurador para fazer parte desta comissão. Pelo decreto do Poder Executivo $n$. 5301, de 5 de setembro de 1904, foi aberto o credito de 3:000\$, para despezas com o auxilio destinado a aluguel da casa em que funcciona o Instituto, relativo ao período de $1^{\circ}$ de julho a 31 de dezembro seguinte" (BRASIL. Ministério da Justiça e Negócio Interiores. Relatório dos anos de 1904 e 1905 - Volume II. Rio de Janeiro. Imprensa Nacional, 1905b, p. 222).

${ }^{439}$ BRASIL. Ministério da Justiça. Relatório do ano de 1883. Rio de Janeiro. Typographia Nacional, 1884, p. A-G-12.

${ }^{440}$ Idem.

${ }^{441}$ Idem. 
442. Para que desta forma seja "bem mais completa, entretanto, pôde ser a protecção que, desde logo, será, prodigalizada aos enfermos indigentes - aquelles que Diderot com muita propriedade, considerava - como a parte mais lamentável da espécie humana" ${ }^{\prime 43}$.

Em relação a saúde voltada para a primeira infância podemos ver nas análises do chefe de polícia Tito Matos as mesmas preocupações, sobre as mesmas questões e os indicativos modos de solucionar os problemas referentes a primeira infância, que o projeto de lei elaborado por Moncorvo Filho no V Congresso Brasileiro de Medicina e Cirurgia. A polícia se mostrava antecipadora de várias discussões no campo da assistência, que mais tarde seria encampada por outros setores do Estado e pela própria filantropia. A polícia já vinha pensando, se apropriando do discurso e instituindo práticas de assistência social e médica deste a segunda metade do século XIX na cidade do Rio de Janeiro.

Podemos observar esta discussão referente ao campo da assistência social enquanto ação de polícia na descrição do relatório do conselheiro André Augusto de Pádua Fleury sobre o congresso penitenciário de Stockholmo. Neste congresso para o qual o conselheiro André fora, pelo Ministério da Justiça, "encarregado de representar o Brazil e de fazer uma exposição das questões que forem tratadas no mesmo congresso (...) recebendo a quantia de seis contos de reis, que lhe será paga pela Delegacia do Thesouro, em Londres" ${ }^{444}$ podemos perceber que havia espaço de destaque para a discussão das ações preventivas.

Vale ressaltar que representantes do Ministério da Justiça estavam presentes deste o primeiro congresso internacional acontecido Frankfurt em 1847, bem como no congresso de Bruxelas em 1848, novamente em Frankfurt em 1857 e em Londres em 1872. O congresso de Londres, segundo julga o conselheiro Andre Fleury, “distingue-se dos precedentes pela sua origem e composição, pela extensão de seu objecto, pelo methodo que adoptou em seus trabalhos e, finalmente, pelas suas consequências e resultados práticos" ${ }^{\prime 45}$. Os congressos anteriores eram compostos em sua maioria por membros particulares, filantropos e estudiosos em geral. No

\footnotetext{
${ }^{442}$ BRASIL. Ministério da Justiça e Negócio Interiores. Relatório dos anos de 1904 e 1905 - Volume II. Rio de Janeiro. Imprensa Nacional, 1905b, p. 236.

${ }^{443}$ Idem.

${ }^{444}$ BRASIL. Ministério da Justiça. Relatório do ano de 1878. Rio de Janeiro. Typographia Perseverança, 1879, p. A4-3.

${ }^{445}$ Ibidem, p. A4-8.
} 
dizer do conselheiro "homens que se occupavam da sciencia penitenciaria, mais animados do sentimento de humanidade que da idéa de realisar as combinações dignas de serem adoptadas" ${ }^{446}$. Já o congresso penitenciário de Londres teve como protagonista os Estados Unidos, era em sua maioria composto por membros governamentais e suas discussões eram claramente voltada para a aplicabilidade dos métodos. Abordou “não só a reforma moral dos menores vagabundos, viciosos, como a educação de infância desvalida e abandonada"447.

Escrevendo de Paris em 19 de novembro de 1878 o conselheiro Fleury faz uma exposição das questões tratadas no Congresso Penitenciário Internacional de Stockholmo ao ministro Conselheiro Lafayette Rodrigues Pereira. Destacamos nesta exposição o trabalho como a centralidade das discussões. Ao mesmo tempo tece críticas ao fato de que precisa algo mais do que a experiência da educação pelo trabalho, pois somente este método não é capaz de "modificar o delinquente". Segundo apontou o representante do governo brasileiro, a solução da eficácia dos métodos de correção e regeneração foi uma das questões que mais mereceram atenção no congresso penitenciário. Pelo progresso da "philosophia e do direito" surgiu o "estudo da sciencia penitenciaria" como "objecto de estudo não só dos amigos da humanidade como dos Governos de todos os paizes"448.

Neste sentido vale nos atermos a parte do relatório que demonstra as discussões mais avançadas da época para o método penitenciário como instância corretiva e preventiva.

A experiência de séculos mostrara a inefficacia dos princípios da intimidação e da vindicta publica, que as legislações antigas haviam adoptado por base da justiça social. Por muito tempo se suppoz que o melhor meio de repressão fôra a suppressão do delinquente pelo banimento, pela prisão perpetua, pela privação da vida ou pena ultima, aggravada quasi sempre de praticas as mais barbaras, qne, augmentando o soffrimento do suppliciado, devessem causar terror em todos os que presenciassem a execução. (...) Mas apezar de todos esses excessos e atrocidades a intimidação não conseguia o fim, que se pretendia - porque os crimes se multiplicavam. Do outro lado os direitos do homem, examinados á luz das philosophia, começaram a ser defendidos não só por espirito de humanidade, como por interesses da sociedade. $O$ restabelecimento da ordem social alterada ou offendida pelo acto criminoso não se consegue com a aniquilação do delinquente. Outros deveram ser os meios de satisfazer a justiça penal ${ }^{449}$.

\footnotetext{
446 Idem.

${ }^{447}$ Idem, p. A4-9.

${ }^{448}$ Idem, p. A4-8.

${ }^{449}$ Ibidem, p. A4-7-8.
} 
Neste relatório podemos ver uma longa discussão acerca das instituições preventivas, aquelas que tanto estão a serviço do controle da pobreza válida quando da inválida. Na terceira seção destinada as instituições preventivas podemos ver incialmente uma discussão sobre se serve ou não patrocinar os "delinquentes que cumpriram sentença" ${ }^{450}$, se deve ou não organizá-los e de como deve ser o patrocínio destas ações. Segundo as conclusões do congresso penitenciário de Stockholmo, em 1878, “o patrocínio dos réos, que cumpriram sentença, é necessidade social e um dos elementos de todo o regimen penitenciário bem organisado. Não basta punir o delinquente, é preciso, ao relaxal-o da prisão, facilitar-lhe a entrada para a sociedade donde sahio" ${ }^{451}$. No entanto, não devia o benefício, que poderia ser organizado pela “administração das prisões ou por associações particulares" $" 452$ ser estendido indiscriminadamente, deveria ser concedido somente aos "arrependidos sinceros que se transformarão em homens de bem".

Discutiam ainda sob quais "princípios devem se organisar os estabelecimentos destinados aos jovens delinquentes, absolvidos por terem commettido crime sem discernimento e postos a disposição do Governo durante um prazo fixado por lei?"453. Buscava também responder como deveria ser as “instituições para educação de menores, vagabundos, mendigos $e$ abandonados" $" 454$. Aqui demostra mais uma vez os dois aspectos presentes na representação destes menores, não eram considerados criminosos, a não ser em potência, ao mesmo tempo em que se conjugavam diretamente com a representação de vagabundos. No entanto mesmo diante desta interseção semântica de significados havia uma clara distinção teórica das práticas destinadas aos criminosos e aos menores e mendigos. Para os delinquentes que cometem crime sem discernimento, "manda-los pra as prisões, onde criminosos cumprem sentença" $" 455$ escandaliza a "razão e os pricipios de justiça"456. Concluíra tal congresso que "colocar sobre o escabéllo dos réos uma creança, que não tem ainda oito ou nove anos de idade, é acto afflictivo que não merecerá nunca o assentimento

\footnotetext{
${ }^{450}$ Idem, p. A4-48.

${ }^{451}$ Idem, p. A4-44.

452 Idem.

${ }^{453}$ Idem, p. A4-48

${ }^{454}$ Idem.

${ }^{455}$ Idem.

456 Idem.
} 
da consciencia publica" ${ }^{457}$. A "detenção deles não é a mesma coisa, que se impõe aos criminosos" 458 e as instituições destinadas a eles "fundam-se em princípios totalmente diversos dos que regem os estabelecimentos penitenciários para adultos"459 "os menores, porém, teem de ser formados ou educados, e não reformados $" 460$. Esta lógica administrativa da pobreza urbana e este modo do Estado tratar esta problemática pode ser vislumbrado enquanto prática e representação social até nossa contemporaneidade. A preocupação de educar os menores e diferenciar o tratamento dado a eles em relação aos criminosos pode ser vista nos diversos relatórios posteriores como, por exemplo a crítica do chefe de polícia Tito Mattos ao fato dos menores serem recolhidos para a Casa de Detenção, ainda que em espaço diferente dos criminosos adultos. Para o referido chefe de polícia "a miséria, o abandono, as inclinações viciosas são as causas principaes da perdição dos menores, que assim veem a precisar de apoio, de direcção e até certo ponto de correcção moral" ${ }^{\prime 461}$. Da mesma forma apontava o conselheiro Andre Fleury que segundo afirmava Sir Walter Crofton - criador do sistema penitenciário irlandês copiado em várias partes do mundo inclusive no Brasil - em 1873 seu país contava com mais de cem escolas industriais, "cuja utilidade é incontestável; pois, ao passo que seu numero se augmenta, diminue o das escolas de reforma. É assim que, quanto mais se ampara e dirige a infância desvalida e viciosa, tanto menor é o numero dos jovens delinquentes" ${ }^{" 462}$. Para o senhor Crofton, "A disciplina de um estabelecimento correccional ou de reforma é sempre mais severa. O regimen das escolas índustriaes aproxima-se no da família" ${ }^{\text {"63. }}$. Fica mais uma vez evidente a diferença entre prevenção e repressão. No documento final produzido pelo referido congresso podemos ler que a finalidade das instituições preventivas é "prevenir os crimes e ellas teem esse lado commum com as prisões. Convém sejam organisadas por grupos e conforme o systema de famílias, mas nem sempre será possível dar-lhes semelhante organisação. Entre os

\footnotetext{
457 Ibidem.

${ }^{458}$ Idem.

${ }^{459}$ Idem.

${ }^{460}$ Idem.

${ }^{461}$ Idem.

${ }^{462}$ Idem, p. A4-51.

${ }^{463}$ Idem, p. A4-53.
} 
meios práticos mencionou a religião, o trabalho e um pessoal capaz, sem o qual nenhuma instituição poderá medrar" 464 .

O congresso penitenciário de Stockholmo torna-se emblemático devido suas análises e resoluções apontarem nitidamente uma diferença teórica-conceitual que impunha também uma diferença na institucionalização de práticas punitivas, reformativas das práticas preventivas, educacionais e humanitárias. Nos apontamentos realizados pelo conselheiro Fleury, representante oficial do governo brasileiro, no referido congresso fica nítida esta diferença: “Convém ponderar que esses menores não são criminosos, não estão sujeitos à legislação penal; são apenas infelizes" 465 . Neste sentido, aponta que "o meio mais conveniente de amparar os menores desvalidos ou viciosos é confial-os a famílias honestas, que se encarreguem de lhes dar educação, como se fossem suas próprias famílias". O modo utilizado e os métodos empregados pela The children's aid society, "associação de patrocínio dos menores de New York", no entanto, eram completamente diferentes. Segundo os apontamentos do conselheiro Fleury, o Sr. Carlos L. Brace, um dos fundadores desta instituição e, presente no referido congresso, apontava que em 1875 esta instituição contava com "seis refugios com 8.645 orphãos, não compreendeno nesse numero os recolhidos dos sylos orfhanologicos da cidade"466. Segundo o conselheiro esse método "de confiar as famílias a infância desvalida ou viciosa" que "tem sido empregado com grande vantagem na América do Norte" "não o é empregado senão excepcionalmente" nos países da Europa. Nestes, a criança em regra é "recolhida a estabelecimentos públicos ou particulares, para receberem instrucção intellectual, moral, religiosa e profissional ${ }^{\prime 467}$.

Outro aspecto que aparece com ênfase no relatório enviado de Paris pelo conselheiro Fleury é a questão de que os "estabelecimentos destinados aos jovens delinquentes e vagabundos devem depender directamente do Governo" ${ }^{\text {468. }}$. Interessante observar neste aspecto as divergências entre os principais países da Europa, nos quais o Brasil see espelha para a construção de suas instituições e práticas sociais. Segundo o Conselheiro Fleury o Sr. Choppin, diretor da

\footnotetext{
${ }^{464}$ Ibidem, p. A4-51.

${ }^{465}$ Idem, p. A4-49.

${ }^{466}$ Idem, p. A4-48.

${ }^{467}$ Idem, p. A4-49.

${ }^{468}$ Idem, p. A4-53.
} 
administração penitenciaria da França, declarou que em seu paiz os estabelecimentos particulares teem provado mal; e que por isso alli se preferem hoje os estabelecimentos públicos" $" 69$. Enquanto que "O Sr. Illing observou que na Allemanha se dava inteiramente o contrario; que havia muitas instituições particulares para educação de menores vagabundos e viciosos, estabelecimentos modestos e não ricos como os da Inglaterra e dos Estados Unidos do America;" ${ }^{470}$. Na Inglaterra, segundo Hille Davenport a situação se assemelhava a da Alemanha,

onde apezar da Lei de 1855, que autorisou o Governo a crear quantas escolas de reforma julgasse necessárias, nenhuma tinha ainda sido funduda; pois sempre a philantropia dos particulares satisfaz esta necessidade. Assim pensa que o Governo deve auxiliar e não substituir-se na caridade publica. Foi esta a opinião geralmente admitida $^{471}$.

O conselheiro Fleury lista todos os estabelecimentos que visitou ${ }^{472}$ destinados "não só a infancia desvalida e infeliz como a viciosa ou culposa, mas absolvidos por terem precedido sem discernimento, ou condemnados como na Inglaterra e na Irlanda a poucos dias de prisão antes de passarem á educação correcional" ${ }^{\$ 73}$. A conclusão do senhor André Fleury chega após as visitas é que

todos tenham por base o trabalho, a religião, a instrução elementar; que, sendo povoados quasi inteiramente de menores das classes desfavorecidas da fortuna (...)e que se busque pelos meios possiveis desenvolver nos educandos ou colonos o amor ao trabalho, ensinando-se-lhes um offíicio, por meio do qual possam prover a própria subsistência ${ }^{474}$. (...) As meninas devem aprender todo o mister do governo de casa e do serviço domestico - coser, bordar, lavar, engommar e cozinhar ${ }^{475}$.

O documento final do congresso internacional penitenciário de Stockholmo divulgado em 24 de Agosto de 1878 apontava resoluções ${ }^{476}$ que indicam com

${ }^{469}$ Ibidem, p. A4-53.

${ }^{470}$ Idem, p. A4-53-4.

${ }^{471}$ Idem.

${ }^{472}$ São eles: "Alkmaar, na Holanda; Ruysselede, Wingheme, Beernem, Saint Hubert e Namour na Bélgica; de Citeaux, Val-d'Yèvre, Douaires e Mettray na França; Artane Castle em Dublin; escola de reforma Red Hill, o asylo da infancia desvalida perto de Farningham e o de meninas, conhecido por escola industrial da Princeza Maria, todos na Inglaterra; as colônias agrícolas de Serix, os recolhimentos de Quadronno na Itália; e Rauhe Haus e Iohannesstift na Alemanha" (BRASIL. Ministério da Justiça. Relatório do ano de 1878. Typographia Perseverança, 1879, p. A4-49).

${ }^{473}$ Idem, p. A4-50.

${ }^{474}$ Idem

${ }^{475} \mathrm{Idem}$.

${ }^{476}$ Idem, p. A4-54-5. 
nitidez a diferença de tratamento que deveria ser empregado para os "menores delinquentes absolvidos por terem commetido crime sem discernimento e dos jovens vagabundos, mendigos e viciosos". Para estes não se deve, por princípios, aplicar pena ou castigo, mas uma prática “que tenha por fim habilitar os educandos a ganharem com honra os meios de subsistência e a serem úteis á sociedade, em vez de a ofenderem" ${ }^{477}$. Afirmava ainda o referido documento que "a melhor educação é a recebida no seio de uma família honesta. Mas, na falta de famílias que offereçam garantias de uma boa educação, ou que queiram encarregar-se dessa tarefa, póde-se recorrer a estabelecimentos públicos ou particulares”. Para o congresso internacional penitenciário "esses estabelecimentos devem ter por base a religião, o trabalho e a instrucção elementar". Devem ser “de preferencia entre o systema de pequenos grupos formados á semelhança da família” (...) o numero deve ser limitado de maneira que o chefe do estabelecimento possa occupar-se pessoalmente de cada um dos recolhidos". É perfeitamente reconhecível o sentido da recomendação acima nas políticas atuais de recolhimento institucional, conforme discutiremos no capítulo final. O que é ainda mais emblemático é o fato de o congresso referendar e recomendar "os esforços feitos por certas legislações em substituir a acção judiciaria por uma autoridade tutelar creada para esse fim". Algo que iremos vivenciar em nossa legislação somente após o ECA. Propunha o congresso que "o recolhimento dos jovens viciosos no seio das famílias ou nos estabelecimentos indicados deve-se fazer, se for possível, sem intervenção alguma da autoridade judiciaria”. A autoridade tutelar seria a responsável pelo ordenamento e controle da relação entre os menores desvalidos, os estabelecimentos e famílias. Importante observar que já havia uma clara razão administrativa de que estes estabelecimentos deveriam "reunir as condições, em que vivem as classes operarias; a instrucção elementar, e a maior simplicidade no alimento, no vestuário e na habitação; attendendo-se ao trabalho sobre todas as outras cousas". Era para o filho da classe operária, principalmente dos trabalhadores sem trabalho, de que dispunha a organização dos estabelecimentos para menores. Conclui o documento que a duração do recolhimento poderá ser prolongada no máximo até a idade de 18 anos completos. E, que ao final do recolhimento "a administração dos estabelecimentos será obrigada a proteger os

${ }^{477}$ Ibidem. 
menores, para que obtenham lugar em casa honesta como agricultores, creados, creadas, aprendizes, ajudantes de mestres de officio ou empregados de qualquer outro modo". Por fim, aponta que deve ser "reservada á autoridade publica a fiscalização de todos os estabelecimentos deste genero".

Em 1928 continuava em questão a organização da assistência, no entanto aparece agora no arremedo do ministério da justiça, além de todas as discussões sobre a assistência que outrora se faziam e ainda se fazem presente, a problemática da concessão de títulos de utilidade pública, neste sentido afirma o Ministro Dr. Augusto de Vianna do Castello que "ainda uma vez convém insistir na urgente necessidade de estabelecer regras que regulem este assumpto; definindo-se, de modo preciso, as vantagens decorrentes de taes concessões e a competência da autoridade para fazel-as ${ } 478$. Repetindo a mesma reclama que fizera seu antecessor Dr. Luiz Alvez em 1922 afirmava em seu relatório que

\begin{abstract}
não é demais reaffirmar a urgência de uma regulamentação para o reconhecimento de utilidade publica nas associações e fundações. O malbarateamento desse reconhecimento torna inefficaz a sua concessão. A absoluta innocuidade desse titulo torna ridicula a pratica adoptada. A lei deve regular: $1^{\circ}$ ) Os requisitos para que se possa reconhecer a "utilidade publica"; $2^{\circ}$ ) As vantagens resultantes desse reconhecimento; $3^{\circ}$ ) A competência do Governo para faze-lo ${ }^{479}$.
\end{abstract}

Não foi possível devido ao período coberto por nossa pesquisa determinar em que momento e de que forma esta organização se deu. No entanto, o que interessa para nós é demonstrar que as questões de organização e controle das iniciativas filantrópicas da sociedade civil, em sua diversidade, era ponto presente na organização do Estado brasileiro, sob os auspícios do Ministério da Justiça e Negócios Interiores. No entanto é preciso observar que já havia a lei 173 de 10 setembro de 1893 que "regula a organisação das associações que se fundarem para fins religiosos, Moraes, scientificos, artísticos, políticos ou de simples recreio, nos termos do art. $72, \S 3^{\circ}$, da Constituição" ${ }^{480}$. No artigo primeiro da referida lei podemos ler que "as associações que se fundarem para fins religiosos, moraes, scientíficos, artísticos, políticos, ou de simples recreio, poderão adquirir

\footnotetext{
${ }^{478}$ BRASIL. Ministério da Justiça e Negócio Interiores. Relatório dos anos de 1927 e 1928 . Rio de Janeiro. Imprensa Nacional, 1930, p. S1-88.

${ }^{479}$ BRASIL. Ministério da Justiça e Negócio Interiores. Relatório do ano de 1923. Rio de Janeiro. Imprensa Nacional, 1924, p. XV.

${ }^{480}$ Disponível em: <http://www2.camara.leg.br/legin/fed/lei/1824-1899/lei-173-10-setembro-1893540973-publicacaooriginal-42519-pl.html>. Acesso em: 24 jul. 2014.
} 
individualidade jurídica, inscrevendo o contracto social no registro civil da circumscripção onde estabelecerem a sua sede".

As associações de utilidades públicas passam a aparecer a partir do relatório de 1919, no qual ganham um item específico ligado a diretoria do interior. Neste item aparece a relação dos decretos conferindo o título de utilidade pública. Esta autorização tinha que ser decretada pelo congresso nacional e sancionada pelo presidente da república. Estas associações de utilidade de pública tinham diferentes perfis institucionais e de finalidade. Havia uma grande diversidade de intuições que almejavam títulos de utilidade pública, de modo que podemos também projetar uma quantidade significativa destas em todo o país ${ }^{481}$. Aqui aparece de súbito, através dos dados das instituições, interessante processo de organização da sociedade no interior do país no início do século XX.

Interessante observar que o presidente Arthur da Silva Bernardes vetou em 1923, o título de utilidade pública concedido em 1919 ao Círculo Esotérico da Communhão do Pensamento. Para este fim argumentou em seu parecer que mesmo diante das garantias constitucionais da liberdade igualdade de proferir crenças, tal instituição adota "praticas nocivas á hygiene individual ou collectiva, quer sob o ponto de vista intelectual, quer sob o aspecto da saúde physica" ${ }^{482}$. A partir deste momento passava a aparecer a necessidade de ordenamentos da concessão destes

${ }^{481}$ Entre as associações que tiveram a concessão de título de utilidade pública, no período de 1919 a 1926 destacamos: Associação das Senhoras Brasileiras, Circulo Esotérico da Communhão do Pensamento, Caixa Auxiliadora e Beneficente dos Funccionarios do Estado do Rio de Janeiro, Club Caixeiral de Porto Alegre, Escola Profissional de Cegos 17 de setembro, Centro Catharinene, Sociedade de Agricultura do Estado do Paraná, Centro Artístico Operario Eleirotral de São Luiz do Maranhão, Associação dos Bombeiros Voluntário de Jacarépagua, Liga Brasileira contra o Analphabetismo, Liga Pro-Saneamento do Brasil, Instituto de Proteção e Assistência a Infância as com sede na Capital, "bem como as suas filiaes já existentes" 481 , União Operária Beneficente da cidade de Diamantina, Associação de Chronistas Desportivos, Abrigo do Marinheiro, Liga Pedagógica de Ensino Secundário, Club de Engenharia do Rio de Janeiro, Associação Profissional Textil, Sociedade Amante da Instrucção, Liga Esperantista Brasileira, Dispensário da Glória Ubaldino do Amaral, Escola de Santa Thereza, Sociedade de Concertos Symphonicos, Alliança Academica, União dos Caixeiros Viajantes do Rio Grande do Sul, Sociedade Brasileira de Belas Artes, Liga Nacional contra o Alcoolismo, Caixa Auxiliadora e Beneficente dos Funcionários do Estado do Rio de Janeiro, Liga do Homens do Trabalho e Barbacena, Liga Brasileira de Hygiene Mental, Federação Brasileira das Ligas pelo Progresso Feminino, Liga dos Inquilinos e Consumidores do Districto Federal, Socieade União Operaria Amazonense, Associação Geral de Auxilios Mutuos da Estrada de Ferro Central do Brasil, Confederação Cathólica do Trabalho. Muito mais é esta lista. Esta pequena amostra das instituições indica o modo de organização da sociedade civil no início do século XX e o modo como as questões envoltas a assistência e seguridade social protagonizava o debate no Estado e na sociedade (BRASIL. Ministério da Justiça e Negócio Interiores. Relatório dos anos de 1919 e 1920. Rio de Janeiro. Imprensa Nacional, 1920, p. S1-28). ${ }^{482}$ BRASIL. Ministério da Justiça e Negócio Interiores. Relatório dos anos de 1923. Rio de Janeiro. Imprensa Nacional, 1924, p. S1-18. 
títulos, como demonstrado acima. "É tempo de serem regulados, de modo geral, claro e preciso, os casos de declaração de utilidade pública das associações e instituições, e definidos os direitos e deveres que dessa declaração decorrem" ${ }^{483}$.

De longe vêm as tentativas, os ensaios e os projetos de construção de ações governamentais de extensão nacional, no que hoje seria configurado, no campo da assistência social. Podemos enxergar no relatório referente ao ano de 1882 uma destas tentativas, pela lei de 28 de setembro de 1871. Esta lei previa a criação de Colônias Orphanologicas. No citado relatório o ministro Dr. João Ferreira de Moura faz um levantamento dos Estados que haviam cumprido a determinação de tal lei e aqueles que deveriam assim proceder. Afirmava o referido ministro que "era de urgente necessidade a fundação de colônias orphanologicas, principalmente depois da lei de 28 de setembro de 1871. Para obtenção de dados offlciaes foi expedida a circular de 13 de julho do anno passado". Segundo informa os presidentes das províncias do "Rio de Janeiro, S. Paulo, Santa Catharina e Rio Grande do Norte" ainda não responderam. "No Para, Píauhy, Maranhão, Parahybo, Alagoas, Sergipe, Bahia, Espirito Santo, Paraná e Rio Grande do Sul” não existiam colônias orfanológicas "Na Parahyba o antecessor do actual presidente havia recommendado, creação de taes estabeleci-mentos e No Espírito Santo promulgou-se a lei provincial n. 10 de 21 de novembro de $1876^{, 484}$.

Podemos ver outro exemplo no sentido de ações governamentais na organização da assistência pelo decreto n. 10244, de 31 de maio de 1889, promulgado para a execução do art. 10 da lei n. 3396, de 24 de novembro de 1888. Este decreto trazia a "decisão governamental que creava também o Conselho de Assistência para a Casa de S. José, Colónia de S. Bento e Asylo do Conde de Mesquita" ${ }^{485}$. Neste sentido reclamava o ministro Dr. Alfredo Pinto Vieira de Mello em seu relatório referente aos anos de 1919 e 1920 que "até hoje, porém, nada se fez de pratico, a nâo ser o projecto do Senador Alcindo Guanabara"486. Este projeto que foi estudado e sofre várias emendar pela "respectiva commissão do Senado”, bem como, foi apresentado a diversas autoridades “competentes" e

\footnotetext{
483 Idem.

${ }^{484}$ BRASIL. Ministério da Justiça. Relatório do ano de 1882. Typographia Nacional, 1883, p. 133.

${ }^{485}$ BRASIL. Ministério da Justiça e Negócio Interiores. Relatório dos anos de 1904 e 1905 - Volume II. Rio de Janeiro. Imprensa Nacional, 1905b, p. 233.

${ }^{486}$ BRASIL. Ministério da Justiça e Negócio Interiores. Relatório dos anos de 1919 e 1920 . Rio de Janeiro. Imprensa Nacional, 1920, p. XLVI.
} 
estudiosos em assembleia convocada pelo "illustre desembargador Nabuco de Abreu, presidente do Patronato de menores" 487 . Este projeto tinha praticamente os mesmos objetivos dos anteriores, quais sejam: "unificar num texto de lei todas as medidas necessárias á instituição geral da assistência aos menores abandonados e delinquentes, inclusive a assistência judiciaria especial" ${ }^{488}$. Dentre os aspectos acima apresentados, dependendo do tipo de pobre e de pobreza já se poderia falar numa certa construção de "direitos" sociais, pois como afirmava J. J. Seabra

no seio da vasta consolidação das nossas leis civis é certo que existem disposições protectoras dos orphâos, dos menores e dos loucos, e os seus direitos estão mesmo garantidos (grifo nosso) pelas formulas regulamentares de textos esparsos; mas essa acção da jurisprudência, sobre ser de proficuidade mais immediata para a classe dos abastados, accresce que mui limitada e imperfeita é a defesa dos incapazes que, actualmente, a justiça outorga e concede ${ }^{489}$.

Estes aspectos, por si só indicam, que o modo como se tratava as expressões da questão social no século XIX no Brasil era antes uma questão política, mesmo que tratado pela polícia e pela justiça, do que meramente o reducionismo de caso de polícia no sentido estrito do termo que conhecemos hoje. A evidência a mendicância poderia não ser crime e que o asylo foi feito para o pobre invalido nos permite reforçar nossos argumentos de que a polícia fez parte da construção dos discursos e práticas de assistência social na cidade do Rio de Janeiro. O trecho do relatório abaixo referente aos anos de 1904 e 1905 organizado pelo ministro J. J. Seabra, onde aparece pela primeira vez o termo "assistência social", nos permite demostrar explicitamente o modo como o Estado buscava organizar a assistência social no início do século XX. Afirmava o ministro que

a regularidade dos novos serviços ha de attestar a affirmação solemne e categorica de que o Estado quer desta vez fazer parar e extinguir a anarchia que reina em nosso paiz sobre a assistência social (grifo nosso), compenetrado da importância e a necessidade de regularizar conscientemente esse nobre ministerio, que constitue a própria vida da nação; ella servirá para testemunhar a generosidade da nossa geração actual, consignando que a sorte dos pobres é uma causa comum e que não póde servir de bandeira exclusiva dos partidos, das seitas e da politica; $e$, finalmente, a fundação da nova, empreza de caridade publica certificará o empenho e cuidado com que, no louvável movimento em favor do saneamento e dos melhoramentos materiaes da capital da União, não são esquecidos os

\footnotetext{
${ }^{487}$ Idem.

488 Idem.

${ }^{489}$ BRASIL. Ministério da Justiça e Negócio Interiores. Relatório dos anos de 1904 e 1905 - Volume

II. Rio de Janeiro. Imprensa Nacional, 1905b, p. 232.
} 
desamparados e os miseráveis, e que os seus direitos também serão defendidos e patrocinados pelos altos poderes públicos da nossa pátria" ${ }^{\prime 490}$.

Nesta perspectiva que passaremos no próximo tópico discutir as ações da polícia voltada para a pobreza válida não criminalizada.

\subsubsection{Tranquilidade pública: a pobreza válida}

As gerações futuras exigirão contas dos que não apontaram outro rumo para a mocidade desvalida sinão o que conduz ás prisões.

Antonio Algusto Cardoso de Castro ${ }^{491}$

As ações de assistência social no campo da pobreza válida estão diretamente associadas às análises pertinentes a organização do mundo do trabalho. Enquanto que a pobreza inválida se associa a benevolência e a proteção, os métodos empregados pelo Estado no controle da pobreza válida se concretizam em práticas de punição e regeneração vai trabalho e, em menor número ações de instrução e educação para o trabalho. A relação do Estado com as práticas de assistência voltadas para a pobreza válida estava claramente associada a repressão e prevenção. Estas práticas e discursos são os que induzem as interpretações que enxergam a ação do Estado junto às expressões da questão social, somente como caso de polícia até 1930, entendendo a polícia do modo como é representada socialmente em nossa atualidade. No entanto, demonstraremos que, mesmo no que dizia respeito a práticas e discursos voltados para os pobres válidos, vadios e vagabundos, a polícia era parte de uma ação política estatal sob a coordenação do Ministério da Justiça. Esta ação política que obviamente envolvia em seu escopo central a repressão, não deve ser encarada como algo uníssono. A diversidade de práticas relacionada aos tipos de classificações impetradas a pobreza inválida pode ser demonstrada como presente nas intencionalidades da polícia relacionada a pobreza válida.

${ }^{490}$ BRASIL. Ministério da Justiça e Negócio Interiores. Relatório dos anos de 1904 e 1905 - Volume II. Rio de Janeiro. Imprensa Nacional, 1905b, p. 239.

${ }^{491}$ Chefe de Polícia do Distrito Federal (1904-1905). BRASIL. Ministério da Justiça e Negócio Interiores. Relatório dos anos de 1916 e 1917. Rio de Janeiro. Imprensa Nacional, 1917, p XII. 
Quando nos referimos a pobreza válida, incluímos todos os pobres com idade e saúde com capacidade para o trabalho. Esta lógica do trabalho e do não trabalho que imputa as principais análises sobre a pobreza inválida é encontrada de maneira explícita na problemática da pobreza válida, ou seja, do vadio e vagabundo. Esta problemática, por sua vez, tinha protagonismo nos diversos círculos sociais da classe dominante da época de nossos estudos, bem como era recorrente aos principais desafios enfrentados pelo Estado. Nesta perspectiva, podemos citar o comentário feito em 1870 pelo Dr. Francisco de Paula Negreiro Sayão Lobato, então chefe de polícia da corte: "urge que alguma medida ordinária ou extraordinária se tome a respeito dos vadios e vagabundo que são uma das pragas da sociedade, e, permitta-se-me dizer, o embryão de crimes contra a segurança individual e de propriedade" ${ }^{492}$. Esta ideia de praga social, local onde se produz os crimes e os criminosos relacionados à ideia de vadio e vagabundo, pode ser verificada, de maneira geral, em todos os relatórios do período pesquisado. Do mesmo modo, 50 anos mais tarde, no relatório referente aos anos de 1919 e 1920 o ministro Dr. Alfredo Pinto Vieira de Mello expressava que,

tem impressionado vivamente a policia o crescente numero de mendigos na cidade. O espectáculo por elles proporcionado é incontestavelmente dos mais degradantes. Constata-se em todos os meios que a miséria a abranger certas" ${ }^{\text {"493 }}$ camadas sociaes é tanto mais intensa quanto mais desenvolvida a civilização ${ }^{494}$.

A amplitude da problemática a que se referia o chefe de polícia em 1870 pode ser novamente vista em 1881 quando afirma o então chefe de polícia Dr. Ovídeo Fernando Trigo de Loureiro que "continua sempre a fazer suas correrias nocturnas nesta cidade crescido numero de vagabundos". Neste ano, a polícia capturou "não menos de 2.385 vagabundos, ébrios habituaes e ratoneiros notórios" ${ }^{495}$, destes, 281 “foram obrigados a assignar termo" ${ }^{496}$. No mesmo período “cumpriram penas por quebra de termos 302 indivíduos, sendo nacionaes 185, e estrangeiros 117" 497. As

492 BRASIL, Ministério da Justiça. Relatório do ano de 1870, Rio de Janeiro. Typographia Nacional,1871, p. 23.

493 BRASIL. Ministério da Justiça e Negócio Interiores. Relatório dos anos de 1919 e 1920. Rio de Janeiro. Imprensa Nacional, 1920, p. 72.

${ }^{494}$ Idem, p. 73.

495 BRASIL. Ministério da Justiça. Relatório do ano de 1880 e 1881 . Rio de Janeiro. Typographia Nacional, 1882b, p. A-G-6.

496 Idem.

${ }^{497}$ Idem. 
discussões acerca dos vadios e vagabundos foram uma constante nos relatórios analisados, o que de fato demonstra, obviamente, que, para eles, havia tão somente as instituições policiais. Esta mesma lógica de análise social pode ser vislumbrada em 1878, quando afirma o chefe de polícia Tito Algusto Pereira de Matos que

esses menores, assim entregues á ociosidade e á vadiação, engrossam as maltas de capoeiras e são os auxiliares de ratoneiros, que os aproveitam na exploração de furtos e gatunices, servindo, ora para esconderem as armas daquelles, ora para darem a estes, dica (segundo sua gíria). ${ }^{498}$

O que devemos ressaltar é que, como demonstrado anteriormente, havia uma diversidade de instituições dentro da própria polícia. Esta diversidade expressava uma amplitude que abarcava questões médicas, sociais e criminais. Neste sentido e, através da amplitude de ações direcionadas aos vadios e vagabundos, que demonstraremos que para este estava reservado além da repressão e punição, mesmo que em menor escala, ações de assistência social e instrução pelo e para o trabalho. Havia uma lógica que imperava na representação social da pobreza inválida que juntava por um lado a ideia de que a "educação da infância desamparada é o meio preventivo, que viza os mais nobres e humanitários intuitos" $" 499$, como afirmou o chefe de polícia Dr. Tito Algusto Pereira de Matos em seu relatório referente ao ano de 1883 e, por outro que a "vadiagem é o meio que os individuos chegam mais rapidamente ao crime ${ }^{, 500}$, como pensava o ministro da justiça Dr. Carlos Maximiliano Pereira dos Santos, expresso em seu relatório referente aos anos de 1917 e 1918. Do mesmo modo exposto pelo Dr. Tito Matos, por ocasião de sua primeira passagem pela chefia da polícia em 1877, que "apesar da insistência da policia em vigial-os, perseguil-os e obrigal-os á termo de bem viver com cominação de pena afim de serem punidos na conformidade da Lei, nao cessam de attenter contra a segurança individual e de propriedade" ${ }^{501}$. Esta reclama era uma constante em todos os relatórios pesquisados. Interessante observar que já em 1877 havia "relações nominaes impressas dos vagabundos, que

\footnotetext{
498 BRASIL. Ministério da Justiça. Relatório do ano de 1877. Rio de Janeiro. Typographia Perseverança, 1878, p. A5-36.

${ }^{499}$ BRASIL. Ministério da Justiça. Relatório do ano de 1883. Rio de Janeiro. Typographia Nacional, 1884, p A-G-20-1.

${ }^{500}$ BRASIL. Ministério da Justiça e Negócio Interiores. Relatório dos anos de 1917 e 1918 . Rio de Janeiro. Imprensa Nacional, 1918, p. 75.

${ }^{501}$ BRASIL, 1878, op. cit., p. A5-35.
} 
têm assignado termos de bem viver", com "photographias" que eram "enviadas ás autoridades policiaes" ${ }^{502}$. Sobre esta questão analisava o chefe de polícia Dr. Tito Algusto Pereira de Matos, em seu relatório do ano de 1883,

o mendigo valido e habitual e o vagabundo confundem-se pela corrupção, que os inficiona, pelas tentações, que os arrastaram ao crime. Preoccupacão de todos os governos e de associações de beneficência, ainda em paiz algum se conseguiu curar essa chaga social; ou, no dizer de um moralista, extirpar esse monstro, em cujas entranhas geram-se todas as perversões possíveis. É que a agglomeração de habitantes nas grandes cidades, centralisando a multidão, centralisa também as necessidades, ao passo que difficulta os meios de satisfazel- $a^{503}$.

Podemos vislumbrar nas colocações do Dr. Tito Matos transcritas acima não só a repetição genérica alinhada com a representação social do vadio e vagabundo que tem forte conotação moral, mas também uma indicação de análise relacionando crescimento populacional e meios de subsistência. Percebemos também, nesta fala, o olhar voltado para as experiências de outros países sobre este tema, o que era também algo comum pelas autoridades da época, bem como tinha no estrangeiro um dos principais personagens a compor o vasto e diversificado perfil do vadio e do vagabundo na cidade do Rio de Janeiro.

A questão da presença de estrangeiros era uma constante entre os vadios, vagabundos, mendigos e ratoneiros. Como discutimos no capítulo anterior, este personagem, o vagabundo estrangeiro esteve diretamente ligado a formação do campo da assistência social no século XIX. Para ele, estava posto pelo Estado e por instituições privadas, tanto práticas de ajuda e apoio, quanto a repressão e punição. O mundo do trabalho livre, a pleno desenvolvimento no Rio de Janeiro desde a segunda metade do século XIX, necessitava de mão de obra, principalmente a branca, com alguma instrução. Afirmava, em 1870, Dr. Sayão Lobato, então ministro da justiça, que "convém notar que a maior parte dos vadios e vagabundos são estrangeiros" ${ }^{\prime 504}$. Em 1871, afirmava do mesmo modo Dr. Ludgero Gonçalves da Silva, chefe de polícia, que "existe neste município crescido numero de estrangeiros, que são verdadeiros vagabundos, provocadores de desordens, e

502 BRASIL. Ministério da Justiça. Relatório do ano de 1877. Rio de Janeiro. Typographia Perseverança, 1878, p. A5-35.

${ }^{503}$ BRASIL. Ministério da Justiça. Relatório do ano de 1883. Rio de Janeiro. Typographia Nacional, 1884, p A-G-7.

${ }^{504}$ BRASIL. Ministério da Justiça. Relatório do ano de 1870. Rio de Janeiro. Typographia Nacional, 1871, p. 23. 
consummados ratoneiros, tendo por diversas vezes e por taes motivos sofrido prisões, e cumprido sentenças condenatória "505. Neste sentido vale nos atermos ao interessante relato feito em 1875 pelo então chefe de polícia Dr. Miguel Calmon du Pin e Almeida. Segundo o magistrado;

o numero de indivíduos que, sem emprego ou morada conhecida, vivem de vários expedientes illicitos, augmenta progressivamente. Na maior parte estrangeiros, esses vadios e vagabundos, ou são portugueses desarranjados das casas de commercio, ou marinheiros desembarcados dos navios que aportam ao nosso ancoradouro, e que, habituando-se à vida dos public-houses, onde pernoitam mediante poucos vinténs, percorrem as ruas e praças, muitos delles esmolando. Esse numero é engrossado por grande quantidade de menores entre os quaes muitos italianos, que munidos de uma harpa ou rabeca, ou sob a occupação de engraxadores de sapatos, vivem sobre si, sem parentes que os protejam, a menos que alguns especuladores da mesma nacionalidade não usufruam o producto de sua pequena indústria ${ }^{506}$.

Dr. Tito Algusto Pereira de Matos afirmava, do mesmo modo, em 1877, que

entre os menores de idade

avultam os de nacionalidade estrangeira, principalmente portuguezes e italianos, que são enviados dos seus paizes aos irmãos, tios e primos que, afinal, quando não lhes servem para alguma especulação, os abandonam, deixando-os expostos a todos os vícios, em que depressa cahem porque ao passo que apparentão vender gazetas, engraxar sapatos tocar instrumentos de muzica, dão-se á pratica de pequenos delictos, a actos immoraes, depredações e assim preparam-se na carreira do crime $^{507}$.

No ano de 1881, o chefe de polícia Dr. Ovídeo Fernando Trigo de Loureiro é taxativo ao afirmar que é "maior o numero de vagabundos de nacionalidade estrangeira, especialmente portugueza e italiana" ${ }^{\text {"08 }}$. Os chefes de polícia da década de 1870 "não cessaram de reclamar, como medida efficaz, a adopção dos Arts. 259 do Código Penal portuguez e 272 do Código Penal francez, em virtude dos quaes os estrangeiros vagabundos, que se tornam recalcitrantes, sao entregues ao Governo para fazel-os retirar do paiz" ${ }^{\circ 09}$.

${ }^{505}$ BRASIL. Ministério da Justiça. Relatório do ano de 1871, Typographia Nacional, 1872b p. A22.

${ }^{506}$ RASIL. Ministério da Justiça. Relatório do ano de 1875. Instituto Typographico do Direito, 1877 b, p. A-254.

${ }^{507}$ BRASIL. Ministério da Justiça de 1877. Typographia Perseverança Relatório do ano, 1878, p. A5-36.

${ }^{508}$ Ministério da Justiça. Relatório do ano de 1880 e 1881. Typographia Nacional, 1882b, p. A-G-7.

${ }^{509}$ BRASIL, 1878, op. cit. 
Do mesmo modo podemos ver que em 1927 afirmava o chefe de polícia Dr. Coriolano de Araujo Góes Filho que, um de seus "mais esclarecidos antecessores, o Dr. Alfredo Pinto Vieira de Mello, já declarava, em 1907 que a nossa estatística criminal é tristemente desfavorável aos estrangeiros " ${ }^{10}$. Neste momento, já havia sido conquistado a lei de expulsão de estrangeiros "um grande elemento de defesa" (...) a exemplo de todos os Estados modernos", escrevia o chefe de polícia de 1907. Interessante reforçar, como dito anteriormente, que a promulgação de semelhante lei era matéria de inúmeros pedidos de chefes de polícia do Império como, por exemplo, escrevia em 1870 o Dr. Francisco de Faria Lemos que

os legisladores portuguez e francez, cogitaram acertadamente acerca dos estrangeiros proletários, e, por isso, aquelle no art. 230 e este no art. 212 dos respectivos códigos penais, estatuíram que o estrangeiro legalmente declarado vadio e vagabundo seja posto á disposição do governo para fazel-o sahir do território do Estado ${ }^{511}$.

Em 1927 a questão dos estrangeiros persistia e, neste sentido afirmava o ministro da justiça e negócio interiores Dr. Augusto de Vianna do Castello que "expellidos sem piedade dos seus próprios paizes de origem, em beneficio da tranquilidade publica, e que, entretanto, vinham escarnecer das nossas leis ultraliberaes para os malfeitores, positivamente draconianas para as suas victimas" ${ }^{" 512}$. Neste momento, década de 1920, já era consolidada a representação do vagabundo estrangeiro, acrescido do novo personagem o anarquista, que começa a aparecer nas estatísticas policiais a partir da década de 1890. O anarquista ameaça a tranquilidade pública, de certo modo, assumindo o lugar que outrora fora do vagabundo. Esta nossa inferência pode ser comprovada ao levarmos em conta a transformação da narrativa dos relatórios, onde as páginas dedicadas ao controle dos vadios e vagabundos, passam gradativamente a dar maior importância para os anarquistas, agitadores e grevistas. Fato que demonstra a relação direta da polícia no disciplinamento do mundo do trabalho, a serviço da lógica do proprietário. Este aspecto perfaz nossa interpretação de que a polícia era dada organizar o mundo do

\footnotetext{
${ }^{510}$ BRASIL. Ministério da Justiça e Negócio Interiores. Relatório dos anos de 1927 e 1928. Rio de Janeiro. Imprensa Nacional, 1930, p. 161.

${ }^{511}$ BRASIL. Ministério da Justiça. Relatório do ano de 1870. Rio de Janeiro. Typographia Nacional, 1871, p. 23.

${ }^{512}$ BRASIL, 1930, op. cit.
} 
trabalho e, para este intento usava diversos expedientes, entre eles a repressão - que é o lugar comum de se enxergar - e a assistência.

$\mathrm{O}$ anarquista começa a aparecer com mais ênfase a partir do relatório de $1889^{513}$, quando o ministro da justiça expõe a questão da concessão de passaportes. O ministro Manoel Ferraz de Campos Salles, ilustre teórico da República, abole a necessidade de passaporte para "entrarem e sahirem nacionaes e estrangeiros com os seus haveres" 514 dos portos brasileiros. Segundo o ministro, "emquanto as vexatórias exigências do passaporte embaraçavam a immigração, que exigia aliás promover a bem de vitaes interesses do paiz, era notável a fraqueza das autoridades imperiaes deante dos ociosos e vagabundos que infestavam a própria capital" 515 e, que dentre eles era grande o número de anarquistas e agitadores estrangeiros. A esse respeito o ministro da justiça e negócios interiores Dr. Alfredo Pinto Vieira de Mello, tecia a seguinte análise, em seu relatório referente aos anos de 1919 e 1920:

apparelhada com os necessários elementos a ordem jurídica, devemos obstar a entrada, em nosso território, dos chamados indesejáveis e punir com vigor o estrangeiro, como os próprios nacionaes, que vivem promovendo greves intempestivas, coagindo o operariado pacifico, ameaçando a autoridade $e$ constituindo núcleos de agitação facciosa, sob o rotulo de sociedades de classe, quando, sabidos os seus intuitos, não passam de ajuntamentos illicitos, de centros sediciosos, que á autoridade cumpre dissolver sem tergiversações. A autoridade não o pôde ficar, num paiz policiado, á mercê dos agitadores, desacatada e insultada em reuniões anarchistas por estrangeiros que exploram a boa fé do operariado sensato e honesto. Todos os paizes cultos veem adoptando leis mais energicas e eficientes para deter essa corrente anarchica, que, embora transitória, como transitórias são todas as idéas contrarias ás leis de equilíbrio social, pretende dominar pelo terror $^{516}$.

As ações de regeneração e punição, expressas principalmente nos "termos de bem viver" e nas penas a eles associadas, se não podem ser identificadas no escopo do que se convenciona chamar de assistência votada para o campo social, tão pouco, era de exclusiva repressão e "limpeza" social. Havia a necessidade de ocupação dos postos subalternos da cadeia produtiva. No entanto sendo a resposta estatal a pobreza válida, a mera repressão ou o misto desta com o escopo da regeneração e instrução, não se pode negar que esta se relacionava diretamente com a questão

513 Apesar de encontrarmos menções em relatórios anteriores.

${ }^{514}$ BRASIL, Ministério da Justiça Relatório 1889. Rio de Janeiro. Imprensa Nacional, 1891b, p. 9. 515 Idem.

${ }^{516}$ BRASIL. Ministério da Justiça e Negócio Interiores. Relatório dos anos de 1919 e 1920 . Rio de Janeiro. Imprensa Nacional, 1920, p. VIII. 
social enquanto formulação política do corpo estatal, ainda que, exclusivamente, através das instituições policiais. Neste sentido podemos observar as palavras do chefe de polícia do distrito federal em 1904 e 1905 Dr. Antonio Algusto Cardoso de Castro. Segundo o distinto bacharel

a vagabundagem observada no Rio é justamente aquella que forma a peior especie, pois se compõe de homens validos que não procuram trabalho e que preferem viver nessa constante alternativa da cadeia e liberdade, passando quinze dias na Detenção e outros tantos na rua, até voltarem de novo ao cubículo e sahirem para recomeçar a mesma vida ${ }^{517}$.

Podemos perceber no trecho do relatório citado acima que não só a questão do trabalho estava nitidamente ligada a pobreza válida, dos que podem trabalhar, mas fortemente a questão da reincidência e do incorrigível. Para o citado chefe de polícia no Brasil não havia "a figura clássica do vagabundo como a descrevera os criminalistas europeus, isto é o cheminau errando na ociosidade pelas estradas, “inimigo irreconciliável” do camponez". Aqui o vagabundo era um profissional de sobreviver das “oportunidades" conferidas pela urbanidade. Era um incorrigível ${ }^{518}$ contumaz, se especializara em viver dos pequenos delitos. Para estes, os incorrigíveis estavam reservadas as mais duras penas e propostas de punição. Reclamava o chefe de polícia, em seu relatório referentes aos anos de 1904 e 1905, Dr. Antonio Algusto Cardoso de Castro que a "justiça não vê ou não quer ver que o seu trabalho condemnando pela primeira vez essa gente, sahe improfícuo desde que as reincidencias ulteriores escapam impunes" 519 . Segundo o referido chefe de polícia havia no Rio do Janeiro em 1904 “cerca de quinhentos homens nacionaes e estrnngeiros que já assignaram mais de um termo de tomar occupação" ${ }^{520}$. Para o chefe de polícia, "ha muito deveriam ter sido deportados ou recolhidos á Colônia Correccional" 521 . Argumentava, o referido chefe, que para os incorrigíveis

\footnotetext{
${ }^{517}$ BRASIL. Ministério da Justiça e Negócio Interiores. Relatório dos anos de 1904 e 1905 - Volume I. Rio de Janeiro. Imprensa Nacional, 1905a, p. A-G-190.

${ }^{518}$ Para um melhor entendimento da ideia de incorrigível ver o Capítulo IV da dissetação de mestrado "Da Desumanização e da Norma: A construção social das noções de vadio e vagabundo em meio as atribulações da fabricação do Estado-Nação no Brasil (1870-1900)". SOUZA, Antonio Reguete Monteiro de. Programa de Pós-graduação em Serviço Social, Pontifícia Universidade Católica do Rio de Janeiro - PUC-RIO, Rio de Janeiro, 2010.

${ }^{519}$ BRASIL, 1905a, op. cit., p. A-G-189.

${ }^{520}$ Idem.

521 Idem.
} 
justificava o que "Du Puy chama a "illegitimidade da repressão" 522. Estes precisvam ser "duramente compellido ao trabalho" ${ }^{523}$, como método capaz de estancar que venham "a transformar-se de simples contraventores em verdadeiros criminosos". O chefe de polícia Dr. Antonio Algusto definia o vagabundo reincidente usando a expressão de Marc Dubost, segundo o qual "des individus chez lesquels cet état habituel est la conséquence d'un vice moral qui leur est propre, des mendiants et des vagabonds profissionels incorrigibles, et pour lesquels il n'y a rien à faire” ${ }^{524}$. Para o chefe de polícia Dr. José Antonio Gomes “ha infelizes tão corrompidos, que contam vinte, trinta e mais entradas na detenção, e não pequeno numero de condemnações cumpridas na casa de correcção" ${ }^{25}$. Afirmava o referido chefe de polícia que era óbvia a razão para reincidência:

recolhidos no mesmo cubículo, em desigualdade de condições, pela índole e pelos costumes, uns apenas transviados do caminho do bem, outros fundamente gangrenados pelo vicio; os primeiros, que apenas são passiveis de simples correcção, acabam por perder-se ao pernicioso contacto com desgraçados, cuja depravação os tem tornado celebres nos anoaes da policia ${ }^{526}$.

Podemos evidenciar no trecho do relatório acima a diferença de tratamento e método para os que haviam "apenas transviados do caminho do bem", para os métodos que deveriam ser empregados para os "gangrenados pelo vício". Este indicativo de diferença de método está diretamente ligado com o tipo análise classificatória realizada. O primeiro ainda era passível de correção, mas para o segundo somente o banimento era o que lhe restava. Podemos ver estes argumentos nos relatórios dos diversos chefes de polícia abordando como lidar com o vagabundo e o vadio incorrigível. Em 1920 o ministro da justiça e negócios interiores Dr. Alfredo Pinto Vieira de Mello radicaliza a postura em relação aos incorrigíveis e não mais imputa as instituições prisionais e falta de "apoio" estatal ou particular como as prováveis causas para a reincidência. Para ele o criminoso “reincidente pervertido, já considerado irreformável” deveria ir para um "pavilhão especial para delinquentes irreformáveis" e de lá ir para "estabelecimento

\footnotetext{
${ }^{522}$ Ibidem, p. A-G-190.

523 Idem.

524 Idem.

${ }^{525}$ BRASIL. Ministério da Justiça. Relatório do ano de 1883. Rio de Janeiro. Typographia Nacional, 1884, p. A-G-8

${ }^{526}$ Idem.
} 
carcerário especial”, pois a finalidade da prisão nestes casos deveria ser, para o referido ministro, a "sequestração indefinida do criminoso" 527.

Mesmo que o tom repressivo e punitivo seja o mais audível quando falamos dos métodos que o Estado usava para lidar com a pobreza válida. E, que mesmo quando se tratava da "infância desvalida" era difícil de enxergar outro método, se não, o repressivo e punitivo. Não podemos descuidar nosso olhar interpretativo, como se houvesse uma única e intermitente nota da melodia que a sociedade e Estado construíram, através da polícia, para lidar com a pobreza válida. Demostraremos que havia uma diversidade de métodos do modo como o Estado lidava com a pobreza válida. Neste sentido, afirmava, em 1875, categoricamente o chefe de polícia Dr. Diogo Velho Cavalcanti de Albuquerque que "repugna condemnar crianças, que vão adquirir nas prisões educação mais prejudicial á sociedade" 528 . Fazendo coro antecipado com as resoluções do "5० congresso penitenciário reunido em Paris em 1895”. Segundo expos, em 1904, o chefe de polícia Dr. Antonio Algusto Cardoso de Castro, o citado congresso concluiu que "si a sociedade tem o direito de tomar medidas preventivas e até coercitivas contra os mendigos e vagabundos, por outro lado, (...) corresponde o dever de organizar, segundo um methodo racional a assistencia publica, os soccorros privados, o patronato" ${ }^{529}$. Demonstrando indubitavelmente que os métodos relativos a pobreza válida, conjugavam educação prevenção, repressão e punição.

Esta diferença de método se aplica, segundo o chefe de Dr. Antonio Algusto, pois "a vagabundagem e a mendicidade teem causas de ordem physica e causas de ordem moral" ${ }^{530}$. Segundo o citado congresso, as primeiras causas, ou seja, as físicas "são tão sérias, que diminuem a gravidade do delicto e ás vezes até o fazem desaparecer" ${ }^{531}$, aparecendo aqui a relação com a pobreza inválida. Entre as causas de ordem moral foi sobressaltado a "má educação ou a falta de educação da família, dando ensejo a que dia por dia augmente a infância abandonada" ${ }^{532}$. No referido congresso, segundo o citado chefe de polícia, estabeleceu-se uma diferença

${ }^{527}$ BRASIL. Ministério da Justiça e Negócio Interiores. Relatório dos anos de 1919 e 1920 . Rio de Janeiro. Imprensa Nacional, 1920, p. 92.

${ }^{528}$ BRASIL. Ministério da Justiça. Relatório do ano de 1875. Rio de Janeiro. Instituto Typographico do Direito, 1877b, p. A-255.

${ }^{529}$ BRASIL. Ministério da Justiça e Negócio Interiores. Relatório dos anos de 1904 e 1905 - Volume I. Rio de Janeiro. Imprensa Nacional, 1905a, p. A-G-190.

${ }^{530}$ Idem.

${ }^{531}$ Idem.

532 Idem. 
entre os tipos de vagabundo. Interessante observar que este aspecto referente ao modo específico de lidar com os diferentes tipos de pobres e de vagabundos está presente em relatórios da polícia anteriores ao referido congresso, bem como, se reforça ainda mais nos relatórios posteriores. Este aspecto, de certo modo, nos permite inferir que há uma representação social da ideia de vadios e vagabundo construída dentro de um processo histórico de longa duração. Através desta longa duração, podemos vislumbrar, por um lado, correlações com a formação das grandes cidades, e, por outro lado, implicações da questão social a partir do enraizamento do modo de produção capitalista.

Segundo o chefe de polícia Dr. Antonio Algusto Cardoso de Castro o $5^{\circ}$ Congresso Penitenciário reunido em Paris no ano de 1895

estabeleceu com acerto a differeaciaçâo conveniente: "Il y a lieu de traiter différemment les vagabonds suivant qui il s'agit: a) d'indigents invalides ou infirmes ; b) de mendiants ou vagabonds accidentels; c) de mendiants ou vagabonds profissionels. Les premiers doivent être assistés tant qu'ils n'ont pas recouvré la force nécessaire pour retrouver des moyens d'existeace; Les seconds relèvent de l'assistence publique ou privée et doivent être recucillis dans des refuges ou statioas de secours méthodiquement organisés ou le travail sera obligatoire. Les troisièmos doivent être l'object d'une répression, sévère de nature à empecher la recidive ${ }^{533}$.

Podemos identificar estas categorias classificatórias do vagabundo, claramente no relatório do ministro da justiça e negócios interiores Dr. Carlos Maximiliano Pereira dos Santos, de 1917. Neste relatório, o ministro ponderava a necessidade de construir penitenciárias ou de reformar as existentes de modo que devem ficar separados: abandonados, vagabundos e delinquentes "534, ou seja, inválidos, vagabundos acidentais e vagabundos profissionais. Podemos ver claramente repensada as três categorias de vagabundos, os inválidos, discutido no tópico anterior, os vagabundos ocasionais e os vagabundos profissionais. O último, o vagabundo profissional ou o incorrigível deve ser tratado pela repressão e punição de modo a impedir a recorrência. No entanto, o segundo tipo de vagabundo - o que nos interessa em particular para discutir a assistência social - de acordo com o congresso penitenciário de 1895 deve ser colocado aos cuidados da assistência pública ou privada em asilos ou outros serviços metodicamente organizados. Este

\footnotetext{
533 Ibidem.

${ }^{534}$ BRASIL. Ministério da Justiça e Negócio Interiores. Relatório dos anos de 1916 e 1917. Rio de Janeiro. Imprensa Nacional, 1917, p XII.
} 
aspeto do modo como o Estado organiza as práticas sociais destinada a pobreza válida, quanto esta é classificada como eventual, envolve muito mais práticas de assistência do que punição, ainda que as práticas sociais relativas a pobreza válida seja de difícil diferenciação. É fato, porém, que se buscava aliar de maneira adequada as recomendações científicas da época, o tipo de método de intervenção estatal a ser empregado no controle da pobreza urbana, ao tipo de pobre que se estava lidando. A este respeito, analisava o ministro J. J. Seabra, no relatório referente aos anos de 1904 e 1905;

A assistência publica, refere, com proficiência notável, um illustre sociólogo, deve limitar o seu objecto e não pode comprehender tudo. Quando ella toma ao seu cuidado uma categoria de assistidos, deve fazel-o inteiramente, sem que nenhum dos indivíduos attingidos fique excluído dos soccorros, mas deve, ao mesmo tempo, recuzar todos os casos, mesmo os interessantes, que se encontrem fora da categoria definida ${ }^{535}$.

Esta necessidade de olhar diferenciado pode ser identificado no relatório do chefe de polícia Dr. Bellarmino Peregrino da Gama e Mello, referente ao ano de 1882, quanto afirmava que "mesmo quanto aos menores que tenham commettido delictos com discernimento ${ }^{536}$, cumpre estabelecer entre elles e os criminosos adultos a separação e differença de regimen que o simples bom senso nos indica" 537 . Deste modo, fica evidente que a necessidade classificatória da pobreza válida envolvia como analisadores idade e comorbidades relacionadas ao modo pelo qual a pobreza se instalou na vida daquela pessoa. Nesta perspectiva, afirmava, em 1883, Dr. Tito Algusto Pereira de Matos, chefe de polícia, que enquanto havia

${ }^{535}$ BRASIL. Ministério da Justiça e Negócio Interiores. Relatório dos anos de 1904 e 1905 - Volume II. Rio de Janeiro. Imprensa Nacional, 1905b, p. 239.

${ }^{536}$ Interessante observar aqui a questão do discernimento como uma característica ligada a imputabilidade ou não da infância. Lembrando, em muito, as discussões atuais sobre a maioridade penal. Cabe lembrar que em relação a imputabilidade de crianças vivemos dois momentos no período de nossos estudos (1870 a 1930). O primeiro momento é quando estava imperando o código criminal de 1832 onde podemos ler no artigo terceiro que "Não haverá criminoso, ou delinquente, sem má fé, isto é, sem conhecimento do mal, e intenção de o praticar". E assim era considerado no Art. 10 como não considerados criminosos os menores de quatorze anos e os "os loucos de todo o gênero". E o segundo momento a partir da promulgação do código penal de 1890, que abaixa a imputabilidade para 9 anos. Com a ressalva que aos menores de quatorze anos e maiores de nove que "obrarem sem discernimento". Abrindo uma brecha para que nestes casos devesse provar se ação foi praticada com discernimento ou não. Continuava inimputável os que "se acharem em estado de completa privação de sentidos".

${ }^{537}$ BRASIL. Ministério da Justiça. Relatório do ano de 1882. Rio de Janeiro. Typographia Nacional, 1883, p. 132-3. 
para a vagabundagem e a mendicidade voluntária, viveiro abundante de criminosos, o termo de bem viver e o consequente processo de quebra, cuja penalidade não corrige, perverte. Para milhares de crianças sem pais e parentes que as protejam, ou de país degenerados e perdidos, possuímos apenas, em bem estreitas proporções, as companhias de menores dos arsenaes de marinha e guerra, que já se tem tentado supprimir, e um azylo que, por maior que seja o desenvolvimento a receber, bem longe ficará de auxiliar a autoridade no destino que lhe cabe dar aos menores abandonados ${ }^{538}$.

Percebemos claramente que a reclama do chefe de polícia Dr. Tito Matos dizia respeito ao fato de que havia mais meios coercitivos do que preventivos nas práticas sociais empregadas pelo governo no controle da pobreza válida. Neste sentido afirmava que

educação ou cadeia é o critério, por onde nos devemos guiar na adopção de um systeraa de ensino industrial e agrícola, larga e generosamente dotado que, no interesse da sociedade e em desencargo da solidariedade humana, afaste dos muros da prisão infelizes creaturas, lançadas ainda em tenros annos no plano inclinado da corrupção e do crime $^{539}$.

Aqui fica nítida a necessidade do método diferenciado para o tipo de pobre ou de pobreza urbana que se estava lidando, com o fim último da tranquilidade pública. Afirmava de maneira categórica o chefe de polícia Tito Matos que "este cuidado social deve caber a um bem combinado systema de "assistência publica" como nos mais adiantados paizes" ${ }^{540}$. Neste sistema deve "pertencer a policia a apprehensão e collocação dos menores em estabelecimento, que seja como um noviciado, no qual se preparem para a definitiva colocação" ${ }^{541}$.

Percebemos que as interseções entre as ações de assistência pública e as práticas de repressão se constituíam não em casos isolados, mas de certo modo era a regra. Neste sentido, vislumbramos no relatório de 1904-1905 $5^{542}$ uma seção intitulada "A repressão das Contravenções e o Problema da Assistência Publica", aqui podemos ver no dizer do chefe de polícia Dr. Antonio Algusto Cardoso de Castro que acreditava "estar com a melhor orientação reunindo num só e mesmo capitulo as considerações que devo fazer a respeito da repressão das

\footnotetext{
${ }^{538}$ BRASIL. Ministério da Justiça. Relatório do ano de 1883. Rio de Janeiro. Typographia Nacional, 1884, p A-G-20-1.

${ }^{539}$ Idem.

${ }^{540}$ Idem.

${ }^{541}$ Idem.

${ }^{542}$ BRASIL. Ministério da Justiça e Negócio Interiores. Relatório dos anos de 1904 e 1905 - Volume I. Rio de Janeiro. Imprensa Nacional, 1905a.
} 
contravenções e do problema da assistência publica" ${ }^{543}$. Afirmava categoricamente o chefe de polícia que "parece que entre nós se vive na illusão de que essas duas questões possam ser estudadas e resolvidas em separado" 544. Argumentava com base nos escritos do magistrado da Corte de Appellação de Lyon Hubert du Puy que, "por mais dessemelhantes que á primeira vista se afigurem" as contravenções e a assistência pública pertencem a "uma mesma ordem e devem ser reunidas, para melhor comprehensão da sua natureza comum”, qual seja; o "pauperismo". Hubert du Puy "Escrevendo recentemente a respeito de vagabundagem e mendicidade - apresentava o chefe de polícia em 1904 demonstrou com muito bons fundamentos a connexidade das duas matérias". Transcrevia do próprio original as palavras do magistrado em seu relatório:

Parmi les questions qui se proposent à l'examen des juristes et des législateurs il en est peu d'aussi importantes que l'étude des moyens de prévenir le vagabondage et la mendicité. Elle touche à la fois au problème si ardu de l'exlinction du paupérisme, du développement de l'assistence et au fondement du droit de répression, que notre côde a consacré ${ }^{545}$.

A importância de estudar a vadiagem e a vagabundagem era uma constante, que devia incluir em seus estudos o difícil problema de como extinguir a pobreza e, de que maneira desenvolver a assistência e fundamentar determinados princípios em leis. É fato passível de verificação que o pauperismo era incluído nas análises dos chefes de polícia quando da execução de suas práticas. Neste sentido podemos ver importante análise do ministro Dr. Alfredo Pinto Vieira de Mello em seu relatório referentes aos anos de 1919 e 1920. Segundo o referido ministro entre os fatores "que aumenta e se torna todos os dias mais grave" 546 a mendicidade "figuram a carestia dos gêneros de primeira necessidade, dando lugar a uma insufficiente alimentação e acarretando, portanto, a miséria orgânica dos desprovidos de recursos" ${ }^{547}$. Além deste fator estritamente econômico aliava-se "diversas moléstias de caracter endêmico, em certas zonas, que atacam de

\footnotetext{
${ }^{543}$ Ibidem, p. A-G-189.

544 Idem.

545 Idem.

${ }^{546}$ BRASIL. Ministério da Justiça e Negócio Interiores. Relatório dos anos de 1919 e 1920 . Rio de Janeiro. Imprensa Nacional, 1920, p. 73.

${ }^{547}$ Idem.
} 
preferencia os menos favorecidos" 548 e fatores ambientais como "o flagello das seccas, determinando a vinda para esta Capital de muitos flagellados em sua maioria depauperados e, por isso mesmo, incapazes de se entregarem ao trabalho" 549 . Para o ministro estas eram as causas da "maior quantidade de mendigos" ${ }^{550,}$ contra os quais, queixava-se o ministro, reclamava a imprensa que "via de regra, de dirigem a polícia" 551, que tem "feito o possível para privar esta Capital de semelhante espectáculo" 552. Interessante observar que apesar do ministro recomendar a seus subordinados que "procurem afastar do centro urbano os que vivem a solicitar esmolas" 553 , o mesmo ponderava que "é força confessar que as medidas de ocasião se patenteiam ineficazes, quando não deshumanas" ${ }^{554}$. Neste sentido, o ministro desenvolve a seguinte análise:

por melhor vontade que tenha, a policia não pode, quanto á mendicidade, pôr em pratica medidas compatíveis com as necessidades do adiantamento desta Capital. $\dot{E}$ que lhe faltam precisamente estabelecimentos apropriados para recolher os indigentes. Em toda a parte onde se põem em execução providencias coercitivas da mendicidade, são numerosas, para recolher os mendigos, as instituições fundadas pelo Estado e as devidas á iniciativa particular. Nossos recursos no tocante a este assumpto, todos sabem, são limitadíssimos ${ }^{555}$.

Além destes aspetos, o referido ministro associava claramente a questão da mendicidade como um problema que seria resolvido muito mais pelos aspetos das práticas de assistência, ainda que estas envolvam o disciplinamento, do que pela criminalização. Neste sentido afirmava o chefe de polícia que um dos fatores da ineficácia da ação da polícia junto a mendicidade é que a "a assistência publica ainda, entre nós, está em estado quasi embryonario". E, que "apezar de tudo, a policia não tem estado inactiva e com critério e humanidade, tem procurado seleccionar os falsos dos verdadeiros mendigos, punindo aquelles, de conformidade com as disposições legaes e afastando estes dos centros mais concorridos". Como solução, não saía o ministro do lugar-comum de seus

\footnotetext{
548 Ibidem.

${ }^{549}$ Idem.

${ }^{550}$ Idem.

${ }^{551}$ Idem.

${ }^{552}$ Idem.

553 Idem.

${ }^{554}$ Idem.

555 Idem.
} 
antecessores propondo a "creação de asylos fora desta Capital" 556, pois "só contando com estabelecimentos que recebam esses desherdados da fortuna, poderá a policia exercer uma acção profícua sobre a mendicidade" ${ }^{257}$.

A representação social do vadio e do vagabundo, pelo que podemos perceber, difere da do mendigo, que por sua vez, difere da do menor abandonado. Neste sentido, vale-nos a descrição do Dr. Francisco de Faria Lemos, chefe de polícia da Côrte em 1870, segundo o qual "o numero dos vadios, que infestam a cidade, é excessivo. Andam bem vestidos, apresentam-se com ousada frescura nos theatros, hoteis, e outros lugares de reunião, sempre com a mira nas carteiras e jóias dos que alli concorrem" $" 558$. Nas estatísticas policiais do relatório de 1879, podemos ver claramente a diferença entres estes personagens pelo modo como se organiza logicamente as informações. Segundo estas estatísticas, foram enviados no ano "325 menores, apprehendidos nas ruas desta cidade"559 para o juízo de órfãos, "elevando-se a 829 o numero dos que têm sido confiados á particulares, mediante o pagamento de soldada"560. Enquanto que no mesmo ano 2.760 vagabundos assinaram termos de bem viver. O modo como a polícia construía sua estatística demonstra a diferença de classificação entre menores. Neste sentido podemos ver que de 16 de março de 1879 a 31 de março de 1880 "foram apprehendidos e entregues ao Juizbo de Orphãos 325 menores, que viviam abandonados nas ruas da cidade" 561 . No mesmo ano, "3.121 individuos classificados por vagabundo assinaram termo de bem viver" 562 e foram "encontradas em abandono em diversos logares públicos 12 creanças" 563 . Do mesmo modo, "durante os annos de 1880 e 1881 foram apprehendidos e entregues ao juizo de orphãos 384 menores que viviam abandonados nas ruas da cidade"564. No mesmo ano, "não menos do que 2.385 vagabundos, ébrios habituaes e ratoneiros notorios"565. Já em 1883, “120

\footnotetext{
${ }_{556}^{557}$ Ibidem.

557 Idem.

${ }^{558}$ BRASIL, Ministério da Justiça. Relatório do ano de 1870. Rio de Janeiro. Typographia Nacional, 1871, p. 22.

559 BRASIL. Ministério da Justiça. Relatório do ano de 1879. Rio de Janeiro. Typographia Perseverança, 1880, p. A-G-15.

560 Idem.

561 Idem, p. A-G-19.

562 Idem.

563 Idem

${ }^{564}$ BRASIL. Ministério da Justiça. Relatório do ano de 1880 e 1881. Rio de Janeiro. Typographia Nacional, 1882 b, p. 6.

565 Idem, p. 7.
} 
menores foram apprehendidos nas ruas da cidade, onde vagavam em completo abandono" forma colocados a disposição dos juízes de órfãos"566. Afirmava o chefe de polícia, em 1879, Dr. Tito Algusto Pereira de Matos que

é para lastimar que, a despeito dos progressos feitos pelas sociedades modernas no intuito de beneficiar os menores abandonados, creando estabelecimentos adequados á fim humanitário, seja obrigada a autoridade a regular-se ainda hoje por uma legislação que tom mais de três séculos de existência e deixa de estar por isso em harmonia com as idéas da actualidade ${ }^{567}$.

Em 1883, Dr. Tito Algusto Pereira de Matos, chefe de polícia, argumentava que "para o turbulento nacional, como para o mendigo o vagabundo, um código correccional, com processo abreviado, tendo por elemento essencial da penalidade o trabalho em colônias ou presídios militares" ${ }^{568}$. O tempo deveria ser adequado a cada caso de modo a ser o suficiente "para desarraigar o vício da ociosidade e os hábitos de desordem" ${ }^{569}$. Em 1901, do mesmo modo, afirmava o ministro Dr. Sabino Barroso Júnior que "não ha um só estabelecimento onde possam ser recolhidos esses pequenos delinquentes, a não ser a Escola 15 de Novembro, de limitadíssima capacidade, onde não podem ser recebidos mais de vinte e cinco órfãos " ${ }^{570}$. Por este aspecto, a Escola XV de novembro começa a tomar novo rumo, como veremos no próximo capitulo. No mesmo sentido, afirmava, em 1884, o ministro Dr. Joaquim Delfino Ribeiro da Luz que "asylos correccionaes para menores e colônias orfanológicas são estabelecimentos que interessam muito a um bom syslema policial, porque previnem e corrigem os delidos o que estão sujeitos

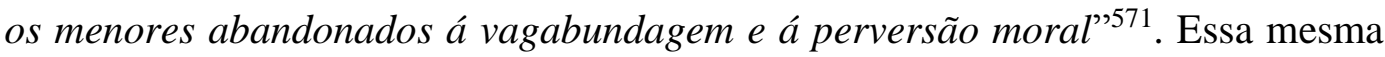
questão continua em 1920, quando afirmava o ministro Dr. Alfredo Pinto Vieira de Mello em seu relatório que

dada a quantidade de menores que reclamam amparo e educação, pôde dizer-se que é insignificante o numero de instituições particulares existentes nesta Capital e que

\footnotetext{
${ }^{566}$ BRASIL. Ministério da Justiça. Relatório do ano de 1883. Rio de Janeiro. Typographia Nacional, 1884, p A-G-45.

567 BRASIL. Ministério da Justiça. Relatório do ano de 1879. Rio de Janeiro. Typographia Perseverança, 1880, p. A-G-15.

${ }^{568}$ BRASIL, 1884, op. cit., p. A-G-10.

${ }^{569}$ Idem.

${ }^{570}$ BRASIL. Ministério da Justiça e Negócio Interiores. Relatório dos anos de 1900 e 1901. Rio de Janeiro. Imprensa Nacional, 1901, p. 39.

${ }^{571}$ BRASIL. Ministério da Justiça. Relatório do ano de 1884. Rio de Janeiro. Imprensa Nacional, 1885 p. 164.
} 
se destinam a amparal-os. Por seu turno, a União não tem um numero sufficiente de estabelecimentos onde possa ser recolhida parte apreciável desses infortunados. Em taes circumstancias, não pode a policia desenvolver uma acção completa e proficua. A policia conta, apenas, presentemente, com um estabelecimento para recolher menores, mas esse mesmo tem lotação legal somente para 250, o que é evidentemente insufficiente, tendo-se em vista a porcentagem de menores desamparados nesta Capital ${ }^{572}$.

Podermos perceber nitidamente no trecho do relatório ministerial transcrito acima é que sabia o ministério da justiça que a polícia precisava de instituições adequadas para determinados tipos de vagabundo e menores, que não as prisões. Sabendo da necessidade de instituições preventivas e correcionais para a eficácia de sua gestão, em 1904, como chefe de polícia, Dr. Antonio Algusto Cardoso de Castro, logo ao assumir, encaminhou "esforços no sentido da fundação de uma colônia correccional e de um instituto disciplinar" ${ }^{573}$. Interessante observar que a criação de instituições para disciplinamento e instrução era realmente entendida como modo eficaz, capaz de resolver a questão da mendicidade. Neste sentido, afirmava o chefe de polícia, respondendo na própria pergunta o que houvera perguntado: "Mas a mendicidade? Como eliminal-a, si o deposito municipal existente não satisfaz ao numero e si além disso ha outros ramos de assistência que ainda não existem e precisam ser creados?" 574 . Bastava o Estado estar de pose das instituições necessárias apontadas pelo saber cientifico para que fosse resolvido a mendicidade e a problemática da infância desvalida. Afirmava Dr. Antonio Algusto, chefe de polícia, que "a mendicidade apresenta varias fórmas e aspectos e nós não temos remédios para a totalidade dos casos". Reconhecia que "estamos muito longe da perfeição a que a Bélgica attingiu com os tres decretos de 27 de novembro do 1901,575 .

Criticava o ministro da justiça, em 1916, Dr. Carlos Maximiliano Pereira dos Santos que "espreme-se uma centena de meninos em escassos dormitórios; installaram as officinas em antigo pardieiro, baixo, mal ventilado e em ruinas" 576 . Acusava o ministro que o depósito provisório que houvera sido construído para 50

\footnotetext{
572 BRASIL. Ministério da Justiça e Negócio Interiores. Relatório dos anos de 1919 e 1920. Rio de Janeiro. Imprensa Nacional, 1920, p. 72.

${ }^{573}$ BRASIL. Ministério da Justiça e Negócio Interiores. Relatório dos anos de 1904 e 1905 - Volume I. Rio de Janeiro. Imprensa Nacional, 1905a, p. A-G-191.

${ }^{574}$ Idem.

575 Idem

${ }^{576}$ BRASIL. Ministério da Justiça e Negócio Interiores. Relatório dos anos de 1916 e 1917. Rio de Janeiro. Imprensa Nacional, 1917, p XII.
} 
crianças "converteu-se em asylo permanente para 380; porque não havia para onde mandal-as. Fez-se um arremedo de officinas e para alli foi a polícia enviando os desgraçados" 577 . Devido a lotação está excedia, segundo o referido ministro, “os delegados sentem a necessidade de enviar os desditosos para a Casa de Detenção" 578 . Aqui evidencia-se novamente a busca por um tratamento diferenciado a nítida separação entre a pobreza válida criminosa e a não criminosa.

Não deixa de ser contundente a análise do ministro sobre as crianças presas e enviadas para a casa de Detenção pela falta de outro local. Percebamos toda a lógica classificatória da pobreza válida na fala do referido ministro. Segundo o ministro em questão, as crianças são presas "porque não têm tecto e perderam o pae! A sociedade está formando uma legião de revoltados. Presidente, Ministro e Chefe de Policia silenciaram emquanto era possível” "579. Sobe o tom o ministro ao afirmar que "a crise apavorava; todos reprimiam os seus sentimentos generosos. Agora, porém, é demais. Urge uma providencia; e esta consiste em fazer dois pavilhões para dormitórios e concluir o edifício das officinas da Escola Premunitoria" 580. Aqui aparece mais uma vez a ideia de que ao organizar a assistência dentro do que seria recomendado pela ciência, vislumbrava-se a possível solução da problemática da infância desvalida e da mendicidade. A solução era instituições das mais diversas modalidades, a elaboração de novas leis e a inclusão de trabalhadores dóceis nos postos de trabalho mais subalternos da cadeia produtiva existente.

"A necessidade de educar de estimular beneficamente os menores desvalidos ou viciosos, acostumal-os ao trabalho profissional" 581 era tônica dos discursos policiais e a cantilena estatal. No entanto, admitia o discurso oficial, através dos relatórios ministeriais, que em relação aos menores desvalidos "reprimir-lhes os maos instintos por meio de medidas disciplinares, não se impõe somente pelos sentimentos philantropicos, mas como preciosa condição de garantia social"582 (grifo nosso). Esta discussão que envolve os aspectos social da pobreza válida é um dos pontos fundamentais imposto pela "necessidade do estudo da questão

\footnotetext{
577 Ibidem.

578 Idem.

579 Idem.

580 Idem.

${ }^{581}$ BRASIL. Ministério da Justiça. Relatório do ano de 1885. Rio de Janeiro. Imprensa Nacional, 1886 p. 136

${ }^{582}$ Idem.
} 
penitenciaria” ${ }^{583}$. Segundo estes estudos, citados, em 1878, pelo chefe Dr. Tito Algusto Pereira de Matos não era o "o elemento da intimidação” suficientemente eficaz para a manutenção da ordem social, esta só se realiza se, junto a ela também concorrer o melhoramento moral do condenado. Argumentava o chefe de polícia que

na verdade, se a pena de morte, hoje reduzida a mui poucos casos e destinada a desapparecer, nao é eficazmente repressiva, ainda quando aggravada pelas circumstancias as mais afflictivas, a privação da liberdade elevada ao isolamento absoluto poderá irritar o homem ou abater-lhe as forças e as faculdades moraes, sem o corrigir nem evitar pela intimidação a reproducçao dos crimes ${ }^{584}$.

Interessante frisar que analisava o chefe de polícia que "o trabalho, embora alimentando a actividade do homem o ennobreça, não é capaz de conseguir por si só a moralisaçfio do delinquente" ${ }^{585}$. De modo que, sabia o governo que necessitava mais do que instituições filantrópicas ou correcionais, pois era da questão do trabalho e das garantias sociais materializada em leis do que se tratava a possível direção da solução desta problemática. No sentido desta análise, que envolve o pauperismo ligado ao trabalho, podemos ver no relatório do ano de 1917 e 1918 o seguinte posicionamento do ministro da justiça Dr. Carlos Maximiliano Pereira dos Santos de que a

inspectoria, pondo em pratica o meio de repressão dos crimes dessa natureza e tendo em vista a crise do trabalho que, há muito, impera nesta Capital, julgou indispensável distinguir os "sem trabalho" dos vadios, que são também criminosos, e tem com afinco procurado desempenhar-se da tarefe a que se proporz só recorrendo á punição para os já afleitos ao crime. ${ }^{586}$

Percebermos na análise acima que o fato de haver uma conjuntura que não possibilitava conseguir trabalho, ficava a polícia, ou pelo menos seus superiores, mais condescendente com pobres urbanos identificados como "sem trabalho", o que o diferenciava do pobre urbano sem trabalho quando classificado como vagabundo e incorrigível. Este último vira imediatamente para a polícia o delinquente e, o

583 BRASIL. Ministério da Justiça. Relatório do ano de 1878. Rio de Janeiro. Typographia Perseverança, 1879, p. A4-8.

${ }^{584}$ Idem.

585 Idem.

${ }^{586}$ BRASIL. Ministério da Justiça e Negócio Interiores. Relatório dos anos de 1917 e 1918. Rio de Janeiro. Imprensa Nacional, 1918, p. 75. 
primeiro, por força da conjuntura econômica do país, eram vistos como indivíduos que não tinham "seus meios de subsistência pelo seu próprio trabalho" 587. Afirmava o referido ministro que no tocante aos "sem trabalho" e aos delinquentes que o são apenas por vadiagem " a acção da Inspectoria tem-se limitado a auxiliar o Ministério da Agricultura na remessa de trabalhadores para as fazendas e usinas do interior." 588

A perspectiva interpretativa que enxerga os meios coercitivos na relação do Estado com os pobres válidos como a única força controladora a operar, por vez, não observa a diferença classificatória que imputava um olhar diferente para o vagabundo ocasional, ou seja, os sem trabalho, e para o vagabundo profissional, o incorrigível, o delinquente. Talvez esta falta de observância para este importante detalhe, deva-se ao fato de que mesmo havendo uma classificação que separava dentre os pobres válidos os criminosos e os não criminosos, pouco era a diferença real da institucionalização estatal que sofriam. A correção, a punição e a regeneração e as vezes a prevenção resultava no mesmo tipo de encaminhamentos, a "remessa de trabalhadores para as fazendas e usinas do interior" ${ }^{589}$, para a Armada, para as colônias correcionais e a casa de Detenção.

O envio de pobres válidos não criminosos era institucionalizado pelo Estado e havia uma propaganda oficial, que aparece no relatório referente aos anos de 1917 e 1918 para estimular os pobres válidos, não criminosos, sem trabalho na cidade a irem para fazendas no interior. Neste sentido, afirmava o Dr. Carlos Maximiliano Pereira dos Santos que "cerca de 2.000 indivíduos que, dando ouvidos á sua propaganda e attendendo a esses conselhos, já auferem actualmente no interior os seus meios de subsistência pelo seu próprio trabalho" ${ }^{590}$. Era de comum acordo no pensamento hegemônico dos representantes do Estado brasileiro a ideia de que a “creação de novos Patronatos Agrícolas viria, de prompto, corresponder á necessidade de solução deste problema, cuja importância não pode ser desprezada" 591 .

\footnotetext{
${ }^{587}$ Ibidem, p. 76.

${ }^{588}$ Idem, p. 75.

${ }^{589}$ Idem, p. 76.

${ }^{590}$ Idem.

${ }^{591}$ BRASIL. Ministério da Justiça e Negócio Interiores. Relatório dos anos de 1919 e 1920. Rio de Janeiro. Imprensa Nacional, 1920, p. 72.
} 
Por estes aspectos, podemos observar que é sobre a organização do mundo do trabalho que irá agir as instituições policiais no período abarcado por nossos estudos no que diz respeito a pobreza válida não criminalizada. De modo que, em alguns casos passa a criminalizar o trabalhador, como os anarquistas e grevistas e, de outro modo busca a proteção do trabalhador, como a lei de acidentes de trabalho, as propostas de lei para regular o trabalho de menores na indústria e a construção e regulação das vilas operárias e moradias populares. A relação direta da polícia com a organização do mundo do trabalho em aspecto não criminalizados dizem respeito à regulação das relações sociais, de modo que, também havia a busca por certa proteção do trabalho e do trabalhador.

Neste sentido, podemos ver a preocupação do ministro da justiça Dr. José Joaquim Seabra para o qual o projeto de organização da Assistência Pública não devia se esquecer do "projecto de habilitar o Governo a estabelecer, desde logo, as providencias para regularizar o trabalho dos menores empregados nas fabricas da Capital Federal" 592 . Para este fim "já esteve em execução o decreto n. 1313, de 17 de janeiro de 1891 ", que segundo o ministro "devereia ser aproveitado em traços gerias" 593 . Afirmava o referido ministro que deveria ser implementado "todas as regras garantidoras das pessoas dos ditos menores, cujo numero dos que trabalham em nossas fabricas e industrias orça por muitos centenares" $" 594$.

Como estratégia para a manutenção de trabalhadores saudáveis para o trabalho podemos ler no relatório do Ministério da Justiça e Negócio Interiores do ano de 1906 um minucioso e criterioso estudo, bem como a reprodução das leis alemães de seguro obrigatório dos operários contra as doenças e a invalidez, feito pelo Dr. Hilário de Gouveia após retornar da Conferencia internacional de Berlim sobre a tuberculose. Onde esteve representando a Liga Brasileira contra a tuberculose e, que ficara surpreso ao constatar que não havia representante oficial do governo brasileiro. O qual se dispôs a relatar para o governo as resoluções da conferência fazendo um "apanhado geral das leis allemãs de seguro contra as doenças e invalidez dos operários" ${ }^{\$ 95}$. Interessante observar que apesar de não

\footnotetext{
${ }^{592}$ BRASIL. Ministério da Justiça e Negócio Interiores. Relatório dos anos de 1904 e 1905 - Volume II. Rio de Janeiro. Imprensa Nacional, 1905b, p. 237.

${ }^{593}$ Idem.

${ }^{594}$ Idem.

${ }^{595}$ BRASIL. Ministério da Justiça e Negócio Interiores. Relatório dos anos de 1905 e 1906 - Volume 02. Rio de Janeiro. Imprensa Nacional, 1906b. p. A-G-2.
} 
haver uma relação direta com o relatório do Dr. Hilario de Gouveia este se coaduna diretamente com os aspetos policiais que envolvia a gestão de tal parte da administração estatal. Esta afirmação é possível de ser feita, pois encontramos nos relatórios específicos do chefe de polícia e, era uma constante mais presente a partir do século XX, a discussão da organização do mundo do trabalho e certa proteção do trabalhador. O movimento que vinha se avultando no interior do governo quanto a organização do trabalho livre, do qual os dois movimentos acima fazem parte e podem ser vistos seus resultados no decreto n. 3.724, de 15 de janeiro de 1919 "regulamentado pelo de $n$. 13.499, de 12 de março do mesmo anno" 596 que dispõe sobre "as obrigações resultantes dos accidentes no trabalho" 597 . Este "fixou em lei, não obstante, o principio do risco profissional e assim estabeleceu novo conceito de responsabilidade civil, para melhor garantir aos operários" ${ }^{598}$, assim escreveu o ministro J. J. Seabra em 1904

Ainda como aspecto de ordenação do mundo trabalho, de modo a manter os trabalhadores sadios e aptos ao trabalho, e deste modo garantir a tranquilidade pública, podemos ver a relação direta das instituições policias com construção e fiscalização de moradias para as classes pobres. No relatório referente aos anos de 1901 e 1902 podemos ver nitidamente estes aspectos na “construcção de habitações para operários e classes pobres" ${ }^{\prime 599}$, serviço executado pela Companhia de Saneamento do Rio de Janeiro, mas a cargo da administração federal e fiscalizado pelas intuições policiais. No relatório em questão podemos ler - apesar de pouco legível - um quadro dos "terrenos e prédios adquiridos pela Companhia para a edificação das Villas Operárias, com a relação das suas superfícies e o número de pessoas para que foram destinadas estas vilas. Além dos terrenos da Companhia de Saneamento do Rio de Janeiro, também havia descrições de prédios que serviam de cortiços e estalagens para a construção de vilas operários como demonstra o quadro II da página 237. No referido relatório encontramos a informação que de 6 agosto de 1897 a 31 de dezembro de 1900 a companhia de Saneamento construiu 5 habitações, a Rui Barbosa para 52 pessoas, a Artur Sauer para 468, a Sampaio para

\footnotetext{
${ }^{596}$ BRASIL. Ministério da Justiça e Negócio Interiores. Ministro Relatório dos anos de 1919 e 1920. Rio de Janeiro. Imprensa Nacional, 1920, p. VI.

${ }^{597}$ Idem.

${ }^{598}$ Idem.

${ }^{599}$ BRASIL. Ministério da Justiça e Negócio Interiores. Relatório dos anos de 1901 e 1902 . Rio de Janeiro. Imprensa Nacional, 1902, p. 234.
} 
226, a Senador Soares para 274 e a Maxwell para 72, num total de 1.092 pessoas $^{600}$. Podemos ainda ver nos quadros estatísticos das vilas já existentes, classificações dos tipos de classe social relacionada ao tipo de construção que pertenciam e número de pessoas por habitação. Podemos ver os dados das "habitações Rui Barbosa, Arthur Sauer, Senador Soares, Maxwell, Sampaio, Ouro Preto, Rocha, Mangueira, Vieira de Castro, Portugal, Quintino Bocayuva, Botafogo, Olaria Piedade, entre outras habitações, cujo nomes estavam ilegíveis. Demonstra o relatório em questão que foram adquiridos

26 prédios e terrenos na zona urbana e á margem da Estrada de Ferro Central do Brasil e construíram-se cinco vilas operárias destinadas a habitação de 5.102 pessoas e projeta-se edificar mais 19 vilas para acomodação de 55.958 (...) assim desde que se completem as construções (...) terão acomodação nas villas operárias 61.060 pessoas $^{601}$.

O fato a destacar nesta breve descrição do controle das vilas operárias é, que a sistematização das informações feita pela Companhia de Saneamento do Rio de Janeiro era endereçada ao chefe de polícia, que neste momento era o Dr. Edmundo Muniz Barreto. Este fato nos permite interpretar que as instituições policiais continuavam a exercer papel de controle administrativo, que por hora, já deviam estar aos cuidados da municipalidade.

Outro aspecto que podemos destacar como prática social e preocupações da polícia no ordenamento do mundo do trabalho, de modo a exercer o controle e disciplinamento da pobreza inválida, sem criminaliza-la e com ares de preocupação com a saúde e condições sociais dos trabalhadores, foi a regulação dos serviços domésticos. É fato, porém, que esta preocupação se expressava muito mais em termos de proteger os empregadores. Devido ao crescimento populacional os empregadores não conheciam mais os "precedentes $e$ a moralidade" dos empregados e, diante disto ficavam inseguros de confiar os serviços doméstico. O que nos chama a atenção e aparece nas preocupações do chefe de polícia é que este aspecto refletia diretamente o final da escravidão e a organização do trabalho livre. Esta organização já se referia ao trabalho doméstico como trabalho livre, em alguns casos, durante as últimas décadas da escravidão na cidade do Rio de Janeiro.

\footnotetext{
${ }^{600}$ Ibidem, p. 258

${ }^{601}$ Idem.
} 
Escrevia, em 1883, o chefe de polícia Dr. Tito Algusto Pereira de Matos que "a medida que restringe-se o elemento servil, de onde sahiram os auxiliares do trabalho domestico, aperta-se a necessidade de buscar dentre os livres o criado de servir" 602. Para o referido ministro o serviço doméstico passou a ser "um verdadeiro tormento", tronando-se imperioso a "necessidade de regularizar" 603 tal serviço. Como uma das justificativa para a regulação dos serviços doméstico, o chefe de polícia Dr. Tito Matos afirmava que "muitas faltas são commettidas pelo criado" ${ }^{604}$, mas que não eram "passiveis de penalidade" ${ }^{605}$, pois estas faltas não podiam ser classificas como crimes ou delitos. Este aspecto nos chama a atenção para a centralidade de nosso objeto de estudo, pois demonstra o fato de que a polícia buscava regular e disciplinar as relações sociais na cidade e ordenar o mundo do trabalho fora da esfera estreita da criminalização dos comportamentos. $\mathrm{O}$ fato da polícia incidir sobre determinado fato social não significa no período abarcado por nossos estudos criminalizar, mas sim disciplinar, organizar, controlar. O que não deixa de ser características alheias as práticas e discursos relacionados a assistência social. Esta preocupação como aponta Foucault (2001) se refere a necessidade de ter cidadãos saudáveis e úteis como força de trabalho, pois é da quantidade e da qualidade de seus cidadãos que se produz a força trabalho, imperativo para a construção da riqueza do Estado. Esta preocupação, que não se associa a benevolência, mas é fruto da razão econômica e liberal fica explícita nos relatórios nos analisados.

Para conseguirmos demonstrar um panorama mais completo da atuação da polícia junto a pobreza válida, cabe escrever algumas linhas sobre a parte que era criminalizada desta atuação. Neste sentido, temos que abordar ainda que superficialmente como o sistema penal era visto enquanto parte da estratégia para lidar com os pobres válidos. Devido a precariedade do sistema, como denunciado nos próprios relatório pelos chefes de polícia, não se fazia ou não se podia fazer a separação por categoria entre os pobres válidos devido à falta de estabelecimentos apropriados. Ainda assim, é possível demonstrar a preocupação em separar o vagabundo ocasional, do incorrigível e do inimputável. Interessante observar que

${ }^{602}$ BRASIL. Ministério da Justiça. Relatório do ano de 1883. Rio de Janeiro. Typographia Nacional, 1884, p A-G-13.

603 Idem.

604 Idem.

605 Idem. 
independente se no Império ou na República, dependendo do chefe de polícia as instituições preventivas para o pobre inválido, no caso o asylo de mendicidade, ora aparecia como um sub tópico do sistema penitenciário, ora aparecia de maneira separada junto as instituições policiais e não penitenciarias. $\mathrm{O}$ mesmo acontecia com instituições classificadas como preventivas, como a Escola XV de Novembro, que ora era classificada nos relatórios dentro do sistema penitenciário, ora estava nitidamente separada como instituição preventiva dentro do sistema policial não penitenciário. Chamo atenção para este detalhe de disposição classificatória dos relatórios, pois isto indica o que estamos o tempo todo buscando demonstrar, que a polícia desenvolvia ações não criminalizantes para todo e qualquer tipo de pobreza urbana na cidade do Rio de Janeiro.

A questão do sistema penitenciário também nos interessa, pois através dele a polícia controlava a população urbana pobre flutuante. A principal instituição do sistema penitenciário era a casa de Detenção onde também funcionava a casa de correção e que mais tarde também abrigou o asylo de menores desvalido. Podemos ler no relatório referentes aos anos de 1919 e 1920 que na opinião do ministro Dr. Alfredo Pinto Vieira de Mello "a Casa de Correcção é um vetusto estabelecimento, que funcciona desde $1^{\circ}$ de agosto de 1850 nos moldes do systema de Auburn, hoje condemnado por imprestável na própria America do Norte"606. Já a casa de Detenção foi criada em 1856 junto as dependências da Casa de Correção destinado especificamente a reclusão dos indiciados criminalmente. Além destes estabelecimentos existia os diversos xadrezes da polícia e mais tarde a colônia correcional de Dois Rios.

O principal método de controle se dava através da triagem realizada no xadrez da polícia ${ }^{607}$, onde adequava a demanda aos fluxos de encaminhamentos, de acordo com a classificação de cada caso e da disponibilidade de vagas nas instituições específicas. O "xadrez da polícia", a partir do relatório referente ao ano de 1883 , passa a se chamar "depósito de presos" ${ }^{608}$, era o principal destino para onde a polícia recolhia todos aqueles apanhados nas ruas, não importava o motivo. Havia o xadrez central e diversos outros espalhados pelas freguesias urbanas e rurais do município

\footnotetext{
${ }^{606}$ BRASIL. Ministério da Justiça e Negócio Interiores. Relatório dos anos de 1919 e 1920 . Rio de Janeiro. Imprensa Nacional, 1920, p. XLVI.

${ }^{607}$ Para saber mais sobre o xadrez da polícia ver Holloway (1997).

${ }^{608}$ BRASIL. Ministério da Justiça. Relatório do ano de 1883. Rio de Janeiro. Typographia Nacional, 1884, p. A-G-43.
} 
do Rio de Janeiro. Era no xadrez da polícia que realizava-se o que poderíamos chamar hoje de triagem para encaminhamento aos seus diversos destinos. Podemos constar este aspecto, por exemplo, quando informa no relatório de 1911 o chefe de polícia Dr. Belisario Fernandes da Silva Távora que,

neste departamento policial foi construído mais um xadrez, para serem recolhidos os indigentes capturados pelo corpo de segurança publica, necessitando ainda de uma outra dependência para agasalho dos indigentes que em grande numero alli permanecem por mais de 10 dias aguardando destino ${ }^{609}$.

Neste mesmo relatório, reivindicava Dr. Belisario "a aquisição de um carro especial para transporte dos presos, a construcção de uma nova dependência para abrigo dos indigentes" ${ }^{610}$. Esses aspetos demonstram que podemos identificar uma ação de polícia com base meramente repressiva e de caráter higienistas, recolhendo mendigos e enviando para diversos destisno, com intuito de limpar a cidade, ao mesmo tempo que havia uma clara distinção entre o que era crime e o que era o enfrentamento a problemática estritamente social e o quanto estes dois aspectos se misturavam. Ainda que o pauperismo fosse o foco e o caminho mais curto e óbvio para o desenvolvimento de comportamentos criminosos este só assim se constituía se aliado a alguma preverão moral. Existia uma necessidade de separação dos diversos tipos de pobre que necessitava de uma rede de instituições para onde pudessem ser encaminhados respeitando cada perfil social e moral. No relatório do chefe de polícia relativo ao ano de 1877 , podemos perceber como se dava parte da dinâmica da triagem do xadrez de polícia. Segundo Dr. Tito Algusto Pereira de Matos, no referido relatório,

Os indivíduos recolhidos ao xadrez, são immediatamente apresentados em minha ausência aos delegados que mandam em paz aquelles, a respeito dos quaes verificam não ter havido prisão em flagrante, ou não se dar criminalidade no facto, ou ser o crime desses em que o réo se pôde livrar solto, prevenindo-se assim qualquer excesso por parte dos agentes policiaes ${ }^{611}$.

\footnotetext{
${ }^{609}$ BRASIL. Ministério da Justiça e Negócio Interiores. Relatório dos anos de 1911 e 1912. Rio de Janeiro. Imprensa Nacional, 1912, p 79.

${ }^{610}$ BRASIL. Ministério da Justiça e Negócio Interiores. Relatório dos anos de 1912 e 1913. Rio de Janeiro. Imprensa Nacional, 1913, p. 78.

${ }^{611}$ BRASIL. Ministério da Justiça. Relatório do ano de 1877. Rio de Janeiro. Typographia Perseverança, 1878, p. A5-61.
} 
O xadrez da polícia funcionava como triagem, para termos uma ideia deste fluxo, em 1870, por exemplo, passaram $7.105^{612}$ pessoas por ele, destes 2.375 $(47,5 \%)$ eram escravos. Todos foram recolhidos; por ordem do chefe da polícia (847), delegados (2.102), subdelegados (3.810) e outras autoridades (7). Do total de recolhidos 232 (3,26\%) tiveram como destino o Asylo de Mendigos. Ao serem classificados como mendigos, estavam postos dentro que significava a pobre inválido, aquele que por sua condição física e/ou de saúde o impede de exercer ofícios, portanto faziam "jus a proteção social". Outros $573(8,06 \%)$ recolhidos no xadrez foram classificados pela polícia como pobres válidos, porém não criminosos, sua situação era resolvida através de encaminhamentos para postos de trabalhados subalternos. Neste sentido eram encaminhados para Armada, Exército e diversos outros destinos como o trabalho doméstico e fazendas no interior. Dos que foram enviados ao exército no ano de 1870, 45 eram menores. Desde modo podemos concluir que segundo a classificação da polícia para os pobres recolhidos no xadrez no ano de 1870, precisamente 804 (11,32\%) eram considerados problemas de assistência social, seja pela mera via da ajuda e apoio para os inválidos, seja pela inclusão subalternizada via trabalho para os válidos não criminosos. Enquanto que $2.516(35,41 \%)$ foram classificados como praticantes de crimes, mesmo o de contravenção como a vadiagem, principalmente quando este era reincidente, ou seja, incorrigível ${ }^{613}$. Vale lembrar que trabalhar na armada ou no exército, na época, estaria muito próximo da mesma forma que submetido ao regime escravocrata.

No ano de 1871 continuamos a ver a importância que o xadrez da polícia tinha para o controle do pobre urbano, neste ano passaram 7.380 pessoas por aquele estabelecimento. Destes, 1.081 foram recolhidos pela ordem do chefe de polícia, 2.074 pelos delegados, 4.190 pelos subdelegados e 35 pelas diversas autoridades ${ }^{614}$. Em 1872, podemos perceber o quanto era intenso o fluxo e triagem no xadrez da

${ }^{612}$ BRASIL. Ministério da Justiça. Relatório do ano de 1870. Rio de Janeiro. Typographia Nacional, 1871 , p, 31.

${ }^{613}$ Foucault (2002) vai afirmar que a figura do incorrigível faz parte da genealogia da noção moderna de anormal, de modo que toda ideia de anormalidade exprime, entre outras coisas, a impossibilidade de corrigir determinada "natureza" e, por isto, a solução pelo banimento, pelo isolamento ou pelo extermínio.

${ }^{614}$ BRASIL. Ministério da Justiça. Relatório do ano de 1871. Rio de Janeiro. Typographia Nacional, 1872 b p. 10. 
polícia, dos $7.652^{615}$ indivíduos recolhidos, havia 36 menores que foram enviados para Armada e 437 remetidos para o "asylo de mendigos", 1.915 para a casa de Detenção e 4.283 postos em liberdade. Em 1873, 7.341 indivíduos foram recolhidos ao xadrez da polícia, sempre pela ordem do chefe de polícia, dos delegados e dos subdelegados. Dos detidos 159 foi encaminhado para diversos consulados, 496 para o asylo de mendigos, 1.883 para a casa de detenção, 1.476 tiveram "diversos destinos" e 3.506 foram postos em liberdade ${ }^{616}$. No ano de 1874 dos $8.778,412$ foram remetidos a armada, dos quais " 24 menores para aprendizes marinheiros" 520 para o exército, sendo 13 menores, 486 foram considerados pobres inválidos, e remetidos para o asylo de mendigos. Em 1875, o número de recolhimento sobe para 9.994 indivíduos. Deste total, 388 foram remetidos a armada dos quais 20 menores para aprendizes de marinheiro, outros 434 foram "remettidos para o asylo de mendigos", 5 para hospício Pedro II, 3.741 removidos para a casa de detenção e 4.587 postos em liberdade ${ }^{618}$. A tabela abaixo nos dá uma ideia do que presentava o xadrez de polícia.

Tabela 5. Número de pessoas recolhidos ao xadrez/depósito da polícia ${ }^{19}$

\begin{tabular}{|c|c|c|c|c|c|c|c|}
\hline Ano & \multicolumn{2}{|c|}{ Livres } & \multicolumn{2}{|c|}{ Escravos } & Nacionais & Estrangeiros & Total \\
\hline 1870 & \multicolumn{2}{|c|}{4.730} & & & 1.623 & 3.107 & 7.105 \\
\hline \multirow[b]{2}{*}{$1871 \mathrm{a}$} & \multicolumn{2}{|c|}{4.512} & \multicolumn{2}{|c|}{2.768} & & & \\
\hline & $\begin{array}{c}\text { Homens } \\
4.315\end{array}$ & $\begin{array}{c}\text { Mulheres } \\
197\end{array}$ & $\begin{array}{c}\text { Homens } \\
1.974\end{array}$ & $\begin{array}{c}\text { Mulheres } \\
794\end{array}$ & 1.983 & 2.520 & 7.380 \\
\hline \multirow{3}{*}{$1871 b$} & \multicolumn{2}{|c|}{4.340} & \multicolumn{2}{|c|}{2491} & & & \\
\hline & $\begin{array}{c}\text { Homens } \\
4.051 \\
\end{array}$ & $\begin{array}{c}\text { Mulheres } \\
289 \\
\end{array}$ & $\begin{array}{c}\text { Homens } \\
1844\end{array}$ & $\begin{array}{c}\text { Mulheres } \\
627 \\
\end{array}$ & 1.763 & 2.238 & 6.811 \\
\hline & \multicolumn{2}{|c|}{4.733} & \multicolumn{2}{|c|}{2.919} & & & \\
\hline 1872 & $\begin{array}{c}\text { Homens } \\
4.428\end{array}$ & $\begin{array}{c}\text { Mulheres } \\
305\end{array}$ & $\begin{array}{c}\text { Homens } \\
2.240\end{array}$ & $\begin{array}{c}\text { Mulheres } \\
679\end{array}$ & 2.106 & 1.627 & 7.652 \\
\hline
\end{tabular}

615 BRASIL. Ministério da Justiça. Relatório do ano de 1872. Rio de Janeiro. Typographia Americana, 1873, p. A-209.

${ }^{616}$ BRASIL. Ministério da Justiça. Relatório do ano de 1873. Rio de Janeiro. Typographia Americana, 1874, p. A-205.

${ }^{617}$ BRASIL. Ministério da Justiça. Relatório do ano de 1874. Rio de Janeiro. Typographia Americana, 1875, p. A-212.

${ }^{618}$ BRASIL. Ministério da Justiça. Relatório do ano de 1875. Rio de Janeiro. Instituto Typographico do Direito, 1877b, p. A-266 -67.

${ }^{619}$ Todos os dados os dados têm como fonte os relatórios pesquisados. (Brasil, 1871, 1872a, $1872 \mathrm{~b}$, 1873, 1874, 1875, 1876, 1877, 1878, 1879, 1880, 1881, 1882, 1884, 1887, 1889, 1901-2). Os espaços não preenchidos na tabela e a falta de sequência deve-se ao fato de nem todos os relatórios trazerem esta informação. 


\begin{tabular}{|c|c|c|c|c|c|c|c|}
\hline \multirow[b]{2}{*}{1873} & \multicolumn{2}{|c|}{4.315} & \multicolumn{2}{|c|}{3.026} & \multirow[b]{2}{*}{1.803} & \multirow[b]{2}{*}{2.512} & \multirow[b]{2}{*}{7.341} \\
\hline & $\begin{array}{c}\text { Homens } \\
4.021\end{array}$ & $\begin{array}{c}\text { Mulheres } \\
294\end{array}$ & $\begin{array}{c}\text { Homens } \\
2.650\end{array}$ & $\begin{array}{c}\text { Mulheres } \\
376\end{array}$ & & & \\
\hline \multirow{3}{*}{1874} & \multicolumn{2}{|c|}{6.337} & \multicolumn{2}{|c|}{2.441} & & & \\
\hline & $\begin{array}{c}\text { Homens } \\
5.915\end{array}$ & $\begin{array}{c}\text { Mulheres } \\
422\end{array}$ & $\begin{array}{c}\text { Homens } \\
1.750\end{array}$ & $\begin{array}{c}\text { Mulheres } \\
691\end{array}$ & 2.785 & 3.552 & 8.778 \\
\hline & \multicolumn{2}{|c|}{7.371} & \multicolumn{2}{|c|}{2.623} & & & \\
\hline 1875 & $\begin{array}{c}\text { Homens } \\
6.880\end{array}$ & $\begin{array}{c}\text { Mulheres } \\
491\end{array}$ & $\begin{array}{c}\text { Homens } \\
2.008 \\
\end{array}$ & $\begin{array}{c}\text { Mulheres } \\
615\end{array}$ & 3.244 & 4.127 & 9.994 \\
\hline \multirow[b]{2}{*}{$1876^{*}$} & \multicolumn{2}{|c|}{962} & \multicolumn{2}{|c|}{1086} & & & \\
\hline & $\begin{array}{c}\text { Homens } \\
683\end{array}$ & $\begin{array}{c}\text { Mulheres } \\
279\end{array}$ & $\begin{array}{c}\text { Homens } \\
792\end{array}$ & $\begin{array}{c}\text { Mulheres } \\
294\end{array}$ & 411 & 551 & 2.048 \\
\hline \multirow[b]{2}{*}{1877} & \multicolumn{2}{|c|}{7.917} & \multicolumn{2}{|c|}{2.459} & & & \\
\hline & $\begin{array}{c}\text { Homens } \\
6.464 \\
\end{array}$ & $\begin{array}{c}\text { Mulheres } \\
1.453 \\
\end{array}$ & $\begin{array}{c}\text { Homens } \\
2.066 \\
\end{array}$ & $\begin{array}{c}\text { Mulheres } \\
393\end{array}$ & 4.736 & 3.181 & 10.376 \\
\hline \multirow[b]{2}{*}{$1878 * *$} & \multicolumn{2}{|c|}{1.463} & \multicolumn{2}{|c|}{442} & & & \\
\hline & $\begin{array}{c}\text { Homens } \\
1.282\end{array}$ & $\begin{array}{c}\text { Mulheres } \\
181\end{array}$ & Homens & Mulheres & 513 & 950 & 1.905 \\
\hline \multirow[b]{2}{*}{1879} & \multicolumn{2}{|c|}{7.282} & \multicolumn{2}{|c|}{1.533} & & & \\
\hline & Homens & Mulheres & Homens & Mulheres & & & 8.815 \\
\hline \multirow[b]{2}{*}{1880} & \multicolumn{2}{|c|}{5.893} & \multicolumn{2}{|c|}{$\frac{1}{1.214}$} & & & \\
\hline & Homens & Mulheres & Homens & Mulheres & & & 7.107 \\
\hline \multirow[b]{2}{*}{1881} & \multicolumn{2}{|c|}{4.152} & \multicolumn{2}{|c|}{$\frac{1}{962}$} & & & \\
\hline & Homens & Mulheres & Homens & Mulheres & & & 5.114 \\
\hline \multirow{3}{*}{$1883 * * *$} & \multicolumn{2}{|c|}{5.046} & & 03 & & & \\
\hline & Homens & Mulheres & $\begin{array}{c}\text { Homens } \\
663\end{array}$ & $\begin{array}{c}\text { Mulheres } \\
440\end{array}$ & 2.533 & 2.513 & 6.149 \\
\hline & & 74 & & 91 & & & \\
\hline $1884 * * *$ & $\begin{array}{c}\text { Homens } \\
4.763 \\
\end{array}$ & $\begin{array}{c}\text { Mulheres } \\
711 \\
\end{array}$ & $\begin{array}{c}\text { Homens } \\
686 \\
\end{array}$ & $\begin{array}{c}\text { Mulheres } \\
405\end{array}$ & & & 6.585 \\
\hline & & 75 & & 66 & & & \\
\hline 1886 & $\begin{array}{c}\text { Homens } \\
6.913 \\
\end{array}$ & $\begin{array}{c}\text { Mulheres } \\
1.262 \\
\end{array}$ & $\begin{array}{c}\text { Homens } \\
549 \\
\end{array}$ & $\begin{array}{c}\text { Mulheres } \\
317 \\
\end{array}$ & & & 9.041 \\
\hline 1888 & Homens & Mulheres & Homens & Mulheres & & & 4.751 \\
\hline $1901-2$ & $\begin{array}{c}\text { Homens } \\
2.077\end{array}$ & $\begin{array}{c}\text { Mulheres } \\
461\end{array}$ & Homens & Mulheres & 1.394 & 1.144 & 2.538 \\
\hline
\end{tabular}

A pequena amostra quantitativa dos recolhidos ao xadrez da polícia ou o depósito de presos, como mais tarde passou a ser nominado tem o intuito apenas de demonstrar que este local funciona como o centro de triagem dos recolhidos nas ruas. Possibilita também vislumbrar as classificações que as instituições policiais 
faziam sobre a pobreza urbana. Este depósito funcionou durante todo o período (1870 a 1930) pesquisado. Neste sentido podemos demonstrar, por exemplo, que em 1917, 6.386 pessoas foram recolhidas ao depósito de preso. Neste relatório aparece um dado novo sobre o deposito que nos permite vislumbrar que este funcionava como regulador do fluxo da pobreza urbana. Informava o chefe de polícia Dr. Aurelino de Araujo Leal que ano de 1917 "transitaram pelo deposito e ahi receberam alimentos 2.050 indigentes, aos quaes foi dado destino"620.

Este aspecto por si só nos permite afirmar que o fato de ser recolhido nas ruas pela polícia não poderia indicar que estava tratando o recolhido como criminoso. Não só criminalizando os comportamentos e a pobreza que a polícia construía suas estratégias de controle e disciplinamento do mundo do trabalho e das relações sociais na cidade do Rio de Janeiro. Podemos perceber, como demonstrado acima, que do total de presos recolhidos no depósito em torno de $40 \%$ eram classificados como criminosos, dentre estes os vagabundos incorrigíveis, $60 \%$ eram postos em liberdade e os outros $10 \%$ aproximadamente eram classificados como pobre inválidos. Este fato é possível ser demonstrado pelos diversos destinos que eram encaminhados os recolhidos no depósito de preso. Neste sentido podemos ver o seguinte exemplo, além dos dados expostos acima. Dos 5.114 indivíduos recolhidos ao mesmo xadrez no ano de 1881, 336 indivíduos foram recolhidos ao Asylo da Mendicidade, 171 aos diversos chefes de polícia e juízes de órfãos e para armada, nestes haviam órfãos e aqueles classificados como trabalhadores dóceis sem trabalho. Totalizando $507(9,9 \%)$ pessoas recolhidas no depósito de preso classificada como pobre inválido ou pobre válido não criminalizados. Do total de recolhidos no ano de 1881, 2.278 (44,5\%) foram considerados criminosos enviados para a casa de detenção. Ao passo que $2.182(42,6 \%)$ foram postos em liberdade, por diversos motivos que não fica explícito, mas que nos permite afirmar que não foram considerados criminosos. Segundo o chefe de polícia Dr. Ludgero Gonçalves da Silva, no relatório referente ao ano de 1873, afirmava que "a quasi totalidade dos indivíduos postos em liberdade, compõe-se de bêbados, desordeiros, estrangeiros suspeitos de serem desertores, infractores e escravos. Ha bêbados e 
vagabundos que são presos quasi todos os dias"621. Nos chama a atenção, o fato de podermos demonstrar uma considerável queda no número de recolhidos no depósito de preso e um expressivo aumento dos números de alienados. Neste sentido podemos ver que em 1912 foram recolhidos ao depósito de presos 2.770 pessoas, destes 1.234 eram alienados ${ }^{622}$, enquanto que, no ano de 1913 entram 3.898 presos, destes 1.326 eram alienados ${ }^{623}$.

Importante salientar que podemos vislumbrar nos relatórios que o termo usado para se referir as pessoas levadas da rua para o xadrez ou depósito da polícia era exatamente "recolhimento". A expressão "foram recolhidos" foi observada em todos os relatórios referindo-se a ação da polícia de levar para o depósito. Do mesmo modo podemos observar que ao se referir aos diversos destinos, escrevia os chefes de polícia que "foram presos" para a casa de Detenção, enquanto que usava a expressão "foram levados" quando eram outros destinos como Armada, Juízo de Órfãos, patronato agrícolas. Estes aspectos corroboram com nossa tese que o disciplinamento e o controle urbano da população pobre, não significa que era simplesmente em sua totalidade criminalizado pelas instituições policiais, mas sim disciplinados e controlados.

$\mathrm{O}$ alto número de presos postos em liberdade depois de serem levados ao xadrez/depósito da polícia demonstra que esta usava este mecanismo como forma de regular os fluxos da pobreza válida moralmente desqualificada e da pobreza inválida moralmente "humanizada". A questão do fluxo e o pouco tempo de permanência também pode ser vislumbrada pela estatística da Casa de Detenção. No relatório referente aos não de 1901 e 1092 podemos ler que em $1^{\circ}$ de janeiro de 1902 existiam 688 detentos, dos quais 33 mulheres e 19 menores. No entanto no ano de 1901 passaram pela Casa de Detenção 7.451 pessoas, das quais 879 mulheres e 364 menores. As estatísticas produzidas não nos deixam perceber a quantidade de reincidência nestes números. Dos que entraram, saíram para diversos destinos, tais como armada, colônias agrícolas, juízes de órfãos, asylos de mendigos, instituições para menores e, postos em liberdade 7.462, dos quais 860 mulheres e 355 menores.

${ }^{621}$ BRASIL. Ministério da Justiça. Relatório do ano de 1873. Rio de Janeiro. Typographia Americana, 1874, p. A-205.

${ }^{622}$ BRASIL. Ministério da Justiça e Negócio Interiores. Relatório dos anos de 1911 e 1912. Rio de Janeiro. Imprensa Nacional, 1912, p. 79.

${ }^{623}$ BRASIL. Ministério da Justiça e Negócio Interiores. Relatório dos anos de 1912 e 1913. Rio de Janeiro. Imprensa Nacional, 1913, p. 78. 
Em 31 de dezembro de 1902 ficaram 677 detentos, sendo 52 mulheres e 28 menores ${ }^{624}$. Estes dados demonstram que também a casa de Detenção funcionava como reguladora do fluxo e também como local que, de certa forma, realizava também triagem e classificação dos pobres urbanos recolhidos.

A questão do fluxo dos pobres urbanos recolhidos nas instituições policiais relacionada a oferta e o tipo de vaga existente para cada caso era um problema que os chefes de polícia buscavam resolver e, para os quais precisavam de respostas imediatas. Ao analisarmos estes dados, evidencia-se que eram do simples encarceramento da pobreza urbana de que se tratava. Ainda que o objetivo fosse limpar a cidade da "chaga" da mendicância e todos as expressões da pobreza urbana degradante, buscava-se um critério pautado na relação entre trabalho e pobreza. No relatório referente aos anos de 1916 e 1917 podemos perceber que um dos modos que o Estado empregava para dar conta da demanda de regulação da pobreza urbana era o "embarque de presos, indigentes e outros". No relatório em questão podemos ver que "foram embarcados por ordem da Chefatura de Policia, 1.407 indivíduos, sendo: Correccionaes e menores para a Colônia, 1.248; indigentes, 143; Praças de Policia, 8; Estrangeiros requisitados pelos respectivos governos, 2. Estrangeiros reerabarcados e extraditados, 6" ${ }^{\prime 25}$.

Este aspecto da necessidade de resolver os tipos de encaminhamentos de acordo com cada caso, pode ser verificada também em relação pobre inválida, no caso, a infância desvalida. Neste sentido podemos ver no relatório referente aos anos de 1901 e 1902 os tipos de encaminhamentos feitos pela polícia. Segundo o então chefe de polícia Dr. Edmundo Muniz Barreto

foram encontradas perdidas, na via publica 22 creanças 16 do sexo masculino e 6 do feminino. Aos pretores mandou a policia apresentar 10 e entregou 12 a seus pais. Foram encontrados na via publica, em abandono, 8 recem-nascidos, sendo 5 do sexo masculino e 3 do feminino, mandando a policia recolhei-os à Casa dos Expostos ${ }^{626}$.

Dos fatos dispostos acimas e das ideias e práticas por eles reveladas que resulta nossa afirmação que deve ser creditado à polícia um protagonismo tal qual

\footnotetext{
${ }^{624}$ BRASIL. Ministério da Justiça e Negócio Interiores. Relatório dos anos de 1901 e 1902. Rio de Janeiro. Imprensa Nacional, 1902, p. 87.

${ }^{625}$ BRASIL. Ministério da Justiça e Negócio Interiores. Relatório dos anos de 1916 e 1917. Rio de Janeiro. Imprensa Nacional, 1917, p. 69.

${ }^{626}$ BRASIL. Ministério da Justiça e Negócio Interiores. Relatório dos anos de 1901 e 1902. Rio de Janeiro. Imprensa Nacional, 1902, p. 84.
} 
a filantropia e a caridade na formação do campo da assistência social. Apesar do ministro Dr. Alfredo Pinto Vieira de Mello afirmar categoricamente em 1920 que "das soluções praticas e moderadas sobre a questão social nas suas diversas modalidades, precisamos urgentemente de leis repressivas, que denominarei de prophylaxia social" ${ }^{\prime \prime 2}$, não era somente de repressão e criminalização de que se tratava a prática das instituições policiais no ordenamento urbano da cidade do Rio de Janeiro. Mesmo pedindo mais repressão é interessante observar o quanto de análise da questão social podia ser vislumbrada nos argumentos do referido ministro. A esse respeito afirmava que "o trabalho e o capital não podem viver desaggregados; devem e precisam ter a aspiração unica, o mesmo objectivo licito - o lucro; a mesma preoccupacão - a riqueza commum; o mesmo ideal - o aproveitamento de todas as forças vivas da natureza" ${ }^{628}$. Continuava o ministro afirmando que "o capitalismo deve abandonar a rotina e o egoismo. A riqueza, hoje, não consiste em accumular valores, mas em fazel-os circular. A usura tem a sua própria condemnação na improducttvidade" ${ }^{629}$. Não escapava das análises do ministro Vieira de Mello, sobre a questão social, o aspecto relativo ao trabalho. Neste sentido, afirmava que "a grande industria exige novos processos na organisação do trabalho”. Este processo deviam visar a melhoria da qualidade de vida dos trabalhadores, pois sabia o ministro, que de trabalhadores dóceis e saudáveis que se faz a riqueza de uma nação. Desta forma prescrevia que

as fabricas devem ser núcleos de actividade e de saúde de austeridade de costuimes, de instrucção profissional e intellectual, de assistencia nas suas diversas modalidaes: assistência domiciliaria com conforto e hygiene necessária para evitar essa promiscuidade aviltante das habirações colletivas; assistencia hospitalar; instrução primaria aos operários e aos seus filhos; maternidade e creches; normas especiaes de trabalho para as mulheres e os menores; diversões úteis que evitem a taberna e as consequências nefastas do alcoolismo, causa preponderante da criminalidade $^{630}$.

Acreditamos ter sido possível demonstrar neste primeiro momento que as instituições policiais eram entes administrativos que exerciam vários papéis referentes a municipalidade, composto por repressão, punição, regeneração,

${ }^{627}$ BRASIL. Ministério da Justiça e Negócio Interiores. Relatório dos anos de 1919 e 1920 . Rio de Janeiro. Imprensa Nacional, 1920, p. VIII.

${ }^{628}$ Idem, p. V.

${ }^{629}$ Idem.

${ }^{630}$ Idem. 
prevenção e assistência. Esta afirmação é reforçada pelo relatório do ministro Dr. Rivadavia da Cunha Corrêa, referente aos nãos de 1911 e 1912, no qual reclamava que deveria a polícia afastar-se das ações de assistência e, que estas deveriam ser feitas por "associações de iniciativa particular fundadas para soccorrer a velhice ou a infância desamparada". Argumentava o referido ministro que "toda esta serie de medidas ou a maioria dellas cabe perfeitamente na orbita administrativa da edilidade, escapando á acção preventiva e judiciaria da Policia que deveria limilar-se a exercer no primeiro caso a vigilancia assecuratoria da ordem publica" ${ }^{631}$. Reclamava o referido ministro que a polícia estava sobrecarregada de funções de assistência e que muitas destas eram feitas em duplicidade com a municipalidade, conforme veremos no próximo capítulo. Neste sentido afirmava o referido ministro que

só por um desvio de bons princípios é que se mantém a duplicidade administrativa em matéria de assistência e de modo tal se comprenende o assumpto que desde 1907, a Prefeitura sobrecarregou indevidamente a Policia com o serviço de verificação de óbitos, quando não ha um attestado medico de assistência privada ou particular ${ }^{632}$.

${ }^{631}$ BRASIL. Ministério da Justiça e Negócio Interiores. Relatório dos anos de 1911 e 1912. Rio de Janeiro. Imprensa Nacional, 1912, p. 92.

${ }^{632}$ BRASIL. Ministério da Justiça e Negócio Interiores. Relatório dos anos de 1911 e 1912. Rio de Janeiro. Imprensa Nacional, 1912, p 92. 


\section{Conhecer: poder e saber policial na administração pública}

\subsection{Polícia e municipalidade: administração da pobreza urbana}

Neste capítulo, demonstraremos a maneira como o cargo de chefe de polícia, principalmente na cidade capital - Rio de Janeiro -, servia do mais nobre prestígio, tanto exercia influência na direção dos negócios do Império e da República, quanto servia como base política para se alçar ministérios, mandatos legislativos ou mesmo como atalho para ser nomeado ministro do Supremo Tribunal Federal. Assumimos aqui a interpretação de José Luiz Werneck da Silva (1981, p. 1), ao defender que as instituições policiais se "inserem no movimento geral de uma sociedade de relações de trabalho predominantemente escravistas, mas articulada a totalidade da formação do capitalismo", na qual a luta de classe já era inerente à sua dinâmica, seja enquanto consciência ou ação.

Antes de prosseguimos cabe uma ressalva. Não pretendemos aqui fazer uma incursão pela história da municipalidade da cidade do Rio de Janeiro. Nosso intento e, por isto, nossa limitação é demonstrar as interseções entre as instituições policiais e a municipalidade. Buscaremos, usando a base documental dos relatórios pesquisados e mais algumas fontes secundárias - que serão citadas no decorrer do texto - evidenciar as relações e a maneira como este aspecto do poder administrativo da cidade tem interações profundas com as instituições policias nos diversos ramos que significava a gestão do Estado sobre a cidade e os citadinos. No entanto, não iremos nos ater a fatos ou descrição sobre a municipalidade, esta aparecerá apenas para demarcar ainda mais nossa interpretação de que as instituições policiais eram entes administrativos da cidade do Rio de Janeiro, para

além do aspecto meramente criminológico. Dentre os diversos ramos administrativos que verificamos interseções e duplicidade de papeis na gestão da corte e do distrito federal entre as instituições policiais e a municipalidade, daremos especial atenção, evidentemente, as ações de assistência social. 
Para uma história da assistência na cidade do Rio de Janeiro deveríamos incluir o município através das Câmaras Municipais, inicialmente. Não cabe aqui, por não ser parte do escopo direto de nosso objeto, discorrer sobre o papel das Câmaras Municipais da cidade do Rio de Janeiro na formação do campo da assistência social. No entanto, por ter relação direta com as instituições policiais na formação da assistência devemos nos ater a alguns pontos que demonstram nitidamente ações estatais de assistência, em práticas que hoje seriam denominadas de social. Segundo Werneck da Silva (1981, p. 62), “em 1853, a Ilustríssima Câmara Municipal pediu autorização ao Governo Imperial para recolher mendigo do sexo masculino no barracão que possui na Bica dos Marinheiros, e as mulheres em um edifício para isso alugado". Ainda que a câmara municipal e a municipalidade da cidade do Rio de Janeiro não tenham sido parte de nossa pesquisa documental, como fora a ação das instituições policiais, cabe enfatizar, ainda que em linhas gerais, a relação destas na construção histórica do campo da assistência social.

Segundo Nogueira (1856, p. 115), o município em Portugal nasceu "pela influencia de tradições romanas, desenvolveu-se pelo instincto de liberdade dos nossos maiores, e definhou pela acção compressora do absolutismo”. A municipalidade está presente como meio de administração legal da polis no domínio português desde as Ordenações Afonsinas. Podemos afirmar que a municipalidade da "mui heroica e amiga cidade de São Sebastiao do Rio de Janeiro", remonta a sua fundação por Estácio de Sá em 1567, que seguia a tradição portuguesa exercendo funções que incluíam administrar a cidade, ao mesmo tempo em que criava as leis que fundamentavam esta gestão. Com a chega de D. Joao VI o Rio se viu envolto a novos interesses e era preciso gerar novos meios de administração dos munícipes e, as funções executivas/legislativas anteriormente exercidas pelos membros da câmara passaram imediatamente para o recém criado cargo de Intendente Geral da Polícia. A história da municipalidade da cidade do Rio de Janeiro e sua interação com as instituições policiais remontam ao momento em que o Rio se torna capital do império português. Naquele período, a municipalidade dividia as responsabilidades de gestão do cotidiano dos citadinos com a Intendência Geral da Polícia.

Encontramos referência a municipalidade na constituição do Império de 1824, no Capítulo II artigos 167 a 169, os quais legislam sobre o modo de funcionamento 
e atribuições das câmeras de vereadores. Chamamos a atenção para o Art. 169 que dispõe sobre "o exercicio de suas funcções municipaes" " onde aprece em primeiro plano a "formação das Posturas policiaes". A lei que "dá nova fórma ás Camaras Municipaes e marca suas atribuições" é $1^{\circ}$ de outubro de $1828^{3}$, substituindo o antigo Senado da Câmara. Vale lembrar que a lei que organizou a municipalidade foi criada 20 anos depois da lei que instituiu a Intendência de Polícia. Muitas são as interpretações sobre este fato, no entanto o que nos interessa é demonstrar a íntima relação das instituições policiais com a municipalidade. De maneira a demonstrar que a administração municipal era parte integrante dos objetivos institucionais diretos e explícitos das instituições policiais, visto que, para construir a ordem, não bastava apenas reprimir, antes de mais nada, tratava-se de gerir a cidade.

No artigo 71 da lei de 1828 podemos observar que não havia limites bem definidos entre as diversas atribuições a que cabiam as duas instituições, câmara municipal da cidade do Rio de Janeiro e polícia da Corte. Neste artigo, lê-se que as câmaras "deliberarão em geral sobre os meios de promover e manter a tranquilidade, segurança saúde, e comodidade dos habitantes; o asseio, segurança, elegancia, e regularidade externa dos edificios, e ruas das povoações, e sobre estes objectos formarão as suas posturas". Como demonstramos no capítulo anterior a polícia era quem de fato gerenciava todos estes aspectos do artigo 71 da lei de 1828. Inclusive, era a polícia que dava aplicabilidade prática aos códigos de postura e termos de bem viver, bem como, influenciava e, por vezes era quem diretamente elaborava tais códigos.

Neste sentido, podemos ver a opinião literal do chefe de polícia da corte Dr.

Tito Algusto Pereira de Matos expressa em seu relatório referente ao ano de 1883

cabem, pois, cumulativamente á polícia e ás câmaras municipaes todos os meios administrativos, menciaonados nos arts. 66 a 73 da citada lei, os quaes caracterizam-se pella summa importancia dos objectos a que se referem. São estes: Tranquilidade, segurança, saúde o commodidade, Mas, pelo art, 71 daquella lei, compete ás câmaras formar posturas. Ora, occorre que sobre alguns serviços, que se filiam' áquellas rubricas, o codigo municipal não possue posturas, que os

\footnotetext{
${ }^{1}$ Constituição de 1824, Art. 169.

${ }^{2}$ Idem.

3 Disponível em: <http://www.planalto.gov.br/ccivil_03/Leis/LIM/LIM-1-10-1828.htm\#art73> Acesso em: 06 ago. 2014.
} 
regulamentem, e sobre outros as posturas adoptadas são sem alcance pratico, quando, pela imperfeição, não acoroçoam delictos ${ }^{4}$

Podemos perceber nestes aspectos relacionados a formação das posturas a afirmação de Foucault (2001, p. 458) de que "a polícia necessita mais de regulamentos do que de leis". Para as práticas e instituições policiais, sejam elas preventivas, correcionais, punitivas ou de assistência, a necessidade de controle, disciplina e proibição se dava pelo regulamento, pelo decreto e pela instrução. Neste sentido afirmava Foucault (2001, p. 459) que “comércio, cidade, regulamentação, disciplina - creio serem esses os elementos mais característicos da prática de polícia, tal como era entendida no século XVI e na primeira metade do século XVII". Podemos observar esta prática do século XIX na relação direta entre a polícia e a municipalidade explicitada na legislação, através da lei $\mathrm{n}^{\circ} 261$, de 3 de dezembro de 1841 que reformou o Código do Processo Criminal de 1832. Nesta lei podemos ver em seu artigo $4^{\circ}$ no quinto parágrafo que compete aos "Chefes de Policia em toda a Provincia e na Côrte, e aos seus Delegados nos respectivos districtos"

examinar se as Camaras Municipaes tem providenciado sobre os objectos do Policia, que por Lei se achão a seu cargo, representando-lhes com civilidade as medidas que entenderem convenientes, para que se convertão em Posturas, e usando do recurso do art. 73 da Lei do $1^{\circ}$ de Outubro de 1828, quando não forem atendidos ${ }^{5}$

Este aspecto da fiscalização da polícia demonstra claramente de que na cidade do Rio de Janeiro a câmara municipal era controlada e fiscalizada diretamente pelo poder central através do Ministério da Justiça (Werneck da Silva, 1981). Acrescentamos a esta afirmação baseada na interpretação de Werneck da Silva e nos documentos pesquisados, de que o Ministério da Justiça operacionalizava suas ações através das instituições policiais. Este aspecto fica ainda mais evidenciado no relatório do Ministério da Justiça referente aos anos de 1926 e 1927, onde lê-se que "a municipalidade foi autorizada a contrahir um empréstimo externo" . No mesmo sentido, verificamos que a partir do relatório de 1892 passa a aparecer nos relatórios

\footnotetext{
${ }^{4}$ BRASIL. Ministério da Justiça. Relatório do ano de 1883. Rio de Janeiro. Typographia Nacional, 1884, p A-G-12.

${ }^{5}$ Disponível em: <http://www.planalto.gov.br/ccivil_03/Leis/LIM/LIM261.htm>. Acesso em: 06 ago. 2014.

${ }^{6}$ BRASIL. Ministério da Justiça e Negócio Interiores. Relatório dos anos de 1927 e 1928. Rio de Janeiro. Imprensa Nacional, 1930, p. S1-5.
} 
um item chamado municipalidade. Neste item não encontramos detalhes sobre a administração municipal, somente informações sobre quem era o prefeito nomeado e o período, por vezes aparecia relatos sobre discussões acerca do processo de votação e de leis eleitorais para a câmara municipal. No entanto este aspecto nos indica e demonstra a ingerência do Ministério da Justiça na regulação e disciplinamento do tema. No mesmo sentido o regulamento n. 120 de 31 de janeiro de 1842 , art. 23, entre as atribuições que conferia a autoridade policial, inclui as do art. $3^{\circ}$ da lei de 1 de outubro de $1828^{7}$, como citado anteriormente. Este aspecto, entre outros, demonstra que polícia e municipalidade eram instâncias administrativas que se confundiam e se complementavam na ordenação do espaço urbano e na circulação de pessoas e produtos neste espaço. Havia uma rigorosa discussão teórica e inúmeras dificuldades práticas de gestão e financiamento, pela falta de discernimento de quem era a competência, se da União ou do Município. Como afirmava o Ministro Dr. Carlos Maximiliano Pereira dos Santos em relatório referente aos anos de 1915 e 1916 que "na cidade que serve de sede ao Governo da Republica, ainda se acham mal definidos os limites da competência dos poderes locaes e federaes" ". Importante frisar que a federação agia sobre as questões e problemáticas municipais ligadas a administração da cidade, quase que exclusivamente, através das instituições policiais de controle, repressão e assistência. Neste sentido afirma o chefe de polícia Dr. Tito Mattos

a tranquilidade, a segurança, a saúde e a commodidade dos habitantes são recommendadas pela lei de 1 de outubro de 1828 e o regulamento $n .120$ de 31 de janeiro de 1842 conferiu a autoridade policial, cumulativamente com as camaras municipaes, todas as attribuições administrativas attinentes a tão serios serviços ${ }^{9}$

Do mesmo modo afirmava o referido chefe de polícia que "o exame das substancias alimentícias, bebidas, drogas e medicamentos merece particular attenção á municipalidade, e é cumulativamente exercido por commissões sanitárias de nomeação do governo imperial ${ }^{10}$. Esta questão continuava em pauta

\footnotetext{
${ }^{7}$ BRASIL. Ministério da Justiça. Relatório do ano de 1883. Rio de Janeiro. Typographia Nacional, 1884, p A-G-11.

${ }^{8}$ BRASIL. Ministério da Justiça e Negócio Interiores. Relatório dos anos de 1915 e 1916. Rio de Janeiro. Imprensa Nacional, 1916, p. XIII.

${ }^{9}$ BRASIL, 1884, op. cit., p A-G-17.

${ }^{10}$ BRASIL. Ministério da Justiça. Relatório do ano de 1883. Rio de Janeiro. Typographia Nacional, 1884, p A-G-12.
} 
com o mesmo conflito em 1920, como podemos ler no relatório do ministro da justiça Dr. Alfredo Pinto Vieira de Mello, que houvera sido chefe de polícia da capital federal de 1906 a 1908. Afirmava o referido ministro que

em primeiro logar, a dualidade de serviços sanitários, com o exercido de autoridades diversas nos mesmos assumptos, ou em assumptos correlatos, é uma verdadeira anomalia administrativa. (...) Embora a capacidade technica e os recursos financeiros do Governo Municipal pudessem garantir a efficacia daquelles serviços, não deveria a União, ainda assim, abdicar de attribuições tão relevantes ou confiar a outros poderes tamanhas responsabilidades ${ }^{11}$.

Esta questão do discernimento e limites entre os poderes fica ainda mais evidente quanto olhamos para as discussões orçamentária relativas a estas questões, como podemos ver no relatório referente aos anos de 1915 e 1916. Afirmava o ministro da justiça Dr. Carlos Maximiliano Pereira dos Santos que

\begin{abstract}
são custeados pela União serviços estaduaes $e$ até alguns municipaes. Reconheceram-se, em relação a alguns delles, os deteres da Prefeitura, porém estabeleceu-se que esta pagaria as despezas depois de feitas pelo Thesouro Nacional. Nunca entrou com um ceitil, e sómente pela assistência a alienados já devia 15.691:927\$400 em 31 de dezembro de 1915. Para a hygiene ha funccionarios locaes e federaes, do que resultam a confusão de funcçoes e a falta de um plano de conjuncto ${ }^{12}$.
\end{abstract}

Esta questão orçamentária expunha a complexidade que envolvia o tema, devido a relação direta com inúmeros serviços que tinha despesas cotidianas e precisava de orçamento para a continuidade das ações que já vinham sendo desenvolvidas, inclusive com pagamentos de pessoal. A esse respeito referia-se o ministro da justiça Dr. Augusto Tavares de Lyra em seu relatório referente aos anos de 1908 e 1909 que a lei orçamentária para as despesas de $1892 \mathrm{em}$ seu artigo $4^{\circ}$ previa que "a justiça e a policia do Districto Federal serão subsidiadas com a metade das despesas pelo município"13. Esta disposição foi continuada pela lei orçamentária de ano seguinte e foi tornado permanente pelo artigo $2^{\circ}$ lei n. $126 \mathrm{~B}$ de 30 de setembro de 1893, que dispunha sobre o orçamento de 1894. A esse

\footnotetext{
${ }^{11}$ BRASIL. Ministério da Justiça e Negócio Interiores. Relatório dos anos de 1919 e 1920 . Rio de Janeiro. Imprensa Nacional, 1920, p. XXVII.

${ }^{12}$ BRASIL Ministério da Justiça e Negócio Interiores. Relatório dos anos de 1915 e 1916. Rio de Janeiro. Imprensa Nacional, 1916, p. XIII.

${ }^{13}$ BRASIL. Ministério da Justiça e Negócio Interiores. Relatório dos anos de 1908 e 1909. Rio de Janeiro. Imprensa Nacional, 1909, p. XXXI-XXXII.
} 
respeito e, demonstrando a dificuldade dos limites administrativos entre a municipalidade e a União, chamava a atenção o referido ministro que

ao mesmo tempo que se declarava permanente a disposição da lei $n .26$, em virtude da qual a Municipalidade era obrigada a concorrer com a metade das despesas com a justiça e a policia, a lei $n .191$ A, da mesma data, dispunha, no art. $6^{\circ}$, o seguinte: "Por conta da arrecadação dos impostos de industrias e profissões e de transmissão de propriedade no Districto Federal serão feitas todas as despesas com a justiça, polícia e Corpo de Bombeiros do mesmo Districto, exonerada a Municipalidade de contribuir para essas despesas ${ }^{14}$.

A polícia da cidade do Rio de Janeiro no Império e na primeira República era um braço administrativo direto do poder central, do mesmo modo que a municipalidade. As questões administrativas do município já nasciam ou rapidamente se tornavam questões nacionais e de Estado. Esta mesma interpretação encontramos em Neder (et al, 1981: 2) quando afirma que "houve uma convergência de jurisdição e de competência entre as autoridades governamentais sediadas na cidade do Rio de Janeiro, onde se confundiam o poder local, o poder regional o poder geral ou nacional e até o internacional". A constatação de que a municipalidade na cidade do Rio de Janeiro na virada do século XIX para o XX tinha o peso da ideia de nação e era uma questão de Estado pode ser observada, tanto nas mais diversas expressões da sociedade da época, quanto via burocracia estatal. A esse respeito, Rodrigues (2009: 101) nos recorda que "até 1892, a administração da cidade era feita dentro do quadro da administração central do Brasil”.

A relação entre a polícia e a municipalidade está imbricada no aspecto administrativo que passava pelo Ministério da Justiça, a partir da Constituição de 1824. As instituições policiais como instâncias formadoras de instituições de assistência se configura como um aspecto dentro do quadro mais geral da formação do Estado brasileiro.

"Proclamada a Republica, continuava a celeuma. Mas, pelo menos durante o governo provisório, segundo o decreto $\mathrm{n}^{\mathrm{o}} 1$, de 15 de Novembro de 1889 , “ $O$ território do Município Neutro ${ }^{15}$ fica provisoriamente sob administração

${ }^{14}$ Ibidem.

15 "A Constituição Republicana, de 24 de Fevereiro de 1891, prescreve no art. $2^{\circ}$ que o antigo Município Neutro constitua o Districto Federal, continuando a ser a capital da União, emquanto não fôr estabelecida a futura capital projectada no planalto central do paiz, segundo o artigo $3^{\circ}$ da 
immediata do Governo Provisório da República" ${ }^{16}$. No mês da instauração da República a câmara municipal da cidade do Rio de Janeiro foi dissolvida e substituída "por um Conselho da Intendência, composto de sete membros, sob a presidência de um delles, todos de nomeação do Governo Provisório" ${ }^{17}$. Afirmava o ministro da justiça Manoel Ferraz de Campos Salles, no seu relatório de 1891 que

o antigo município neutro, passando a constituir o Distrieto Federal, está sob a direcçõo politica dos Poderes da União, que nelle teem a sua sede; mas nem por isso pôde ser privado do seu governo municipal e de uma justiça local, independente da federal, que não deve immiscuir-se nas questões de mero direito privado ou interesse peculiar de qualquer dos membros da Federação ${ }^{18}$.

Continuava o famoso jurista e então ministro da justiça Campos Salles em sua defesa do município afirmando que,

a Pretura foi preferida ao Juizado de Paz, porque as funcções de conciliador, e as limitadíssimas attribuições a este conferidas, bem como as condições geralmente estabelecidas para sua eleição e exercício, não poderiam satisfazer as necessidades peculiares da justiça local no Distrieto Federal ${ }^{19}$

O município neutro ${ }^{20}$ assim continuou nominado e governado pelo Conselho da Intendência até dezembro de 1892, quando "tomou posse o primeiro Conselho eleito em virtude da lei $\mathrm{n}^{\circ} 85$, de 1892, assumindo na mesma data o cidadão Alfredo Augusto Vieira Barcellos o novo cargo de Prefeito, para o qual fora nomeado interinamente" ${ }^{21}$. Lei de organização municipal do distrito federal - lei $n^{\circ} 85$, de 20 de setembro de 1892 - legisla em artigo primeiro que "a gerencia dos seus negócios será encarregada a um Conselho deliberativo e a um Prefeito, de accôrdo com o que se dispõe no capítulo; seguintes" ${ }^{22}$. E, em seus artigos décimo nono e vigésimo prescreve que o

mesma Constituição" Annuario de Estatística da Cidade do Rio de Janeiro, 1923-1924. Volume V. Editora Cardinale e Cia. Rio de Janeiro, p. 9.

${ }^{16}$ Idem, p. 8.

${ }^{17}$ Idem, p. 9.

${ }^{18}$ BRASIL, Ministério da Justiça. Relatório do ano de 1889. Rio de Janeiro. Imprensa Nacional, 1891, p. 40.

${ }^{19}$ Idem, p. 42.

20 "Munícipio Neutro era a denominação vulgar dada ao município da corte desde os primeiros tempos do Império" (Annuario de Estatística da Cidade do Rio de Janeiro, 1923-1924, op. cit., nota 3 , p. 8).

${ }^{21}$ Idem, p. 10.

${ }^{22}$ Ibidem, p. 9. 
Poder Executivo Municipal é exercido pelo Prefeito, nomeado livremente por acto do Presidente da Republica, dentre os cidadãos brasileiros de reconhecida competência e conservado no desempenho de suas funç̧ões emquanto bem servir. No caso de impedimento ou faltas, o Prefeito terá substituto, de livre nomeação, também, do Presidente da Republica ${ }^{23}$.

Durante o período abarcado por nossos estudos, a cidade do Rio de Janeiro teve 27 prefeitos distribuídos em 38 anos, a partir da República. O que numa média simples daria um ano e seis meses de mandato para cada prefeito, aproximadamente. No entanto, como toda média esta também não mostra os desvios, pois neste grupo tivemos 8 prefeitos interinos, destes 5 ficaram em torno de 1 a 2 meses e o restante em trono de dois anos. Além de Barata Ribeiro que teve dois mantados o primeiro em 1892, que ficou menos de um ano e o segundo de 1910 a 1914. Estes aspectos demonstram a instabilidade que significou a primeira República refletido nos diversos aspectos da institucionalização de práticas sociais.

A municipalidade, seja no Império, seja na República representava a instância mais direta de contato entre a implantação do projeto burguês de Estado-nação brasileiro e a parcela chamada povo. A forma de comunicação direta entre o Estado e a parcela chamada "povo", os debaixo, era a municipalidade. Pela municipalidade que o Estado buscava civilizar e regenerar, geralmente pelo trabalho. Através da municipalidade, o Estado interferia no cotiando de pobres e ricos no final do século XIX com o intuito de civilizar a cidade do Rio de Janeiro, claro que com muito mais severidade para o pobre. Entretanto é preciso lembrar que a municipalidade era exercida em seus diferentes ramos pela instituição policial. Importante ressaltar que neste momento agir sobre a cidade, significava agir sobre o Estado e sobre a nação, tamanha era a representatividade do Rio, tanto para o olhar interno, quanto para a internacionalização do Brasil, que apologeticamente poderíamos conclama-lo de cidade-nação.

A instituição que durante o período de nossa pesquisa poderia de pronto atender aos anseios administrativos da municipalidade em suas mais diversas dimensões era a instituição policial. Um exemplo que nos auxilia a confirmar nossa tese da relação íntima entre polícia e municipalidade são os "termos de bem viver", uma peça da administração municipal que dependia da polícia para sua execução,

${ }^{23}$ Idem, p. 10. 
ao mesmo tempo em que sofria influência dos chefes de polícia em sua formulação. A polícia era quem estava, naquele momento, mais preparada para a administração da cidade e da parcela chamada povo, seja pela via da repressão e controle, seja pela via da assistência e burocracia e da regeneração pelo trabalho. Em relação a este particular expressa o ministro da justiça Dr. Lafayette Rodrigues Pereira que;

por mais recursos que tivessem as nossas municipalidades, seria força reconhecer a efficacia da intervenção da policia, com autoridade própria, em muitos serviços, taes como, por exemplo, a circulação nas ruas e caminhos públicos, depósitos de matérias inflammaveis, falsificação e deterioração de gêneros alimentícios expostos á venda, inspecção de certos estabelecimentos e lugares públicos, por meio de "regulamentos apropriados ${ }^{24}$.

Da estrutura do Estado existente na virada do século XIX para a administração pública, era a polícia quem lidava diretamente com a problemática dos homens, mulheres e crianças livres pobres que tinham nas ruas da cidade seu lócus de sobrevivência. Para a municipalidade, na gestão da cidade só restava a polícia, o único instrumento de governo preparado para assumir as tarefas que implicavam desde a cobrança de impostos, o ordenamento da cidade e o gerenciamento de instituições de cunho social e médico, como o Asilo de Mendicidade ${ }^{25}$ e o hospital para alienados da ponta do galeão. É preciso destacar que a polícia naquele momento tinha por objetivo também regenerar e educar para o trabalho, além de participar de uma rede de instituições de assistência pública e privada.

A relação da polícia com a municipalidade no que diz respeito as práticas de assistência podem diretamente observadas no relatório do ministro da justiça Dr. Augusto Tavares de Lyra, referente aos de 1907 e 1908. A clareza objetiva do texto do ministro para demonstrar a relação direta entre a polícia e municipalidade na conformação do campo da assistência social nos impele a transcrever o longo trecho de seu relatório.

Veio o novo regímen; e, pelo dispositivo constante do n. I. do art. $2^{\circ}$ do primeiro orçamento votado para o Ministério do Interior, ficaram pertencendo á Municipalidade do Districto Federal, entre outros, os serviços de assistência á infância, comprehendidos os menores empregados nas fabricas e os educandos das

${ }^{24}$ BRASIL. Ministério da Justiça. Relatório do ano de 1877. Rio de Janeiro. Typographia Perseverança, 1878, p. 82.

${ }^{25}$ Esta instituição será abordada no próximo capítulo. 
casas de S. José e Asvlo dos Menores Desvalidos, accrescentando-se que as despezas seriam levadas á conta do producto dos impostos a que se referia o art. $1^{o}$, já citado, da lei n. 3.096, e a receita dos asylos faria parte da renda municipal. Era a affirmação de que aos poderes locaes cabia prover ao serviço de assistência. Pouco depois, porém, appareceram, nas leis orçamentarias, os auxilios a diversas instituições, auxilios que tendiam a augmentar anno a anno. Foi então que o Congresso entendeu convir supprimil-os; e, para chegar a esse resultado, autorizou o Governo, peia lei $n$. 428, de 10 de dezembro de 1896, a regular o serviço de loterias nacionaes, (...) distribuídos a vários estabelecimentos de instrucçao dos Estados e instituições desta Capital, attendendo, quanto a estas, ao seu caracter geral de beneficência ${ }^{26}$.

Ainda podemos observar no referido relatório do Dr. Tito a relação entre polícia, municipalidade e assistência social no ato de convocação feito por decreto pelo então prefeito da capital federal General Souza Aguiar para "um Congresso de Assistência, que deverá funccionar dentro do prazo de duração da Exposição" 27 . Este ato, segundo o referido ministro, "importa no reconhecimento de que principalmente ao governo municipal compete a solução do problema” da assistência, o qual "envolve grandes interesses a que a União não pôde ser alheia e tem uma parte que é prolongamento natural da acção da policia, que está a cargo do Govemo Federal". Por estas razões não devia o governo ficar indiferente, "dahi a creação dos asylos de menores, fundados e custeados pela verba de 50:000\$ consignada no orçamento vigente" 28

Sabia o Ministro J.J. Seabra que para almejar o sucesso da implementação do projeto da assistência pública deveria contar com a municipalidade, neste sentido afirmava que "ainda deliterou este Ministério recommendar o assumpto ao estudo e ponderação do illuslre Sr. prefeito do Districto Federal, pela necessidade de uma acção commum com a Municipalidade, que tem varias instituições pias sujeitas á sua jurisdição" 29 . A organização da assistência social pela municipalidade já estava em estágio mais avançado, visto que já havia sido criado pelo decreto n. 441, de 26 de junho de 1903 o Officio de Assistência Municipal, que naquele momento estava

\footnotetext{
${ }^{26}$ BRASIL. Ministério da Justiça e Negócio Interiores. Relatório dos anos de 1907 e 1908 - Volume 01. Rio de Janeiro. Imprensa Nacional, 1908a. p. XXX.

${ }^{27}$ Sobre a importância das "Exposições" e "Congressos" na formação do campo da assistência social ver a excelente tese "Assistência no Rio de Janeiro: elite filantropia e poder na Primeira República". RANGEL, Rosangela Faria. Programa de Pós-Graduação em Serviço Social. PUC-Rio. Rio de Janeiro, 2013.

${ }^{28}$ BRASIL. Ministério da Justiça e Negócio Interiores. Relatório dos anos de 1907 e 1908 - Volume 01. Rio de Janeiro. Imprensa Nacional, 1908a, p. XXX.

${ }^{29}$ BRASIL. Ministério da Justiça e Negócio Interiores. Relatório dos anos de 1903 e 1904. Rio de Janeiro. Imprensa Nacional, 1904, p. 71.
} 
elaborando a "estatística geral das obras e associações de beneficência do Districto Federal, base indispensável para o regular e prudente funcionamento do Instituto" ${ }^{\prime 30}$.

Esta intima relação entre a polícia e a municipalidade na formação do campo da assistência também pode ser vislumbrada de maneira objetiva no relatório do chefe de polícia do distrito federal em 1904 Dr. Cardoso de Castro. Segundo Dr. Cardoso deveria ser colocado a "parte a competência para custear as despesas de assistencia, si do município, si da União, si de ambos conjuntamente, questão que seria derimida oportunamente". Para que, independente da origem do financiamento, estabeleça-se "a creação de crerches, onde serão acolhidos os filhos dos mendigos inválidos que o poder publico socorrer, o estabelecimento de albergues nocturnos para indivíduos transitoriamente privados de trabalho" 31 . Estes aspectos tratados diretamente por um chefe de polícia demonstram, ainda mais, a profundidade de envolvimento que esta instituição tinha com as questões de assistência social. Adiciona mais evidência, ao discutido anteriormente, que a polícia tinha que dar respostas imediatas e cotidianas para as problemáticas que enfrentava. E, neste aspecto, não poderia esperar a longa e complexa discussão de quem era o financiamento da assistência, sua urgência era um maior número de vagas para o encaminhamento de soluções relativas a pobreza inválida nas ruas do Rio de Janeiro. A discussão sobre o financiamento da assistência pode ser vislumbrada também no relatório do Dr. Augusto Tavares de Lyra, referente aos anos de 1907 e 1908.

Os serviços de assistência estavam subvencionados pelas loterias através da lei n. 428, de 10 de dezembro de 1896. Em virtude de terem desaparecido do orçamento do exercício de 1903 e reaparecido no orçamento de 1904, argumentava o ministro Dr. Augusto Tavares de Lyra em relatório referente ao ano de 1907 e 1908 que

não ha sobre este assumpto opiniões assentadas; e os avanços e recuos, trazendo a balbúrdia, protelaram até agora a organização normal do serviço, que requer, para

\footnotetext{
${ }^{30}$ Idem.

${ }^{31}$ BRASIL. Ministério da Justiça e Negócio Interiores. Relatório dos anos de 1904 e 1905 - Volume

I. Rio de Janeiro. Imprensa Nacional, 1905a, p. A-G-192.
} 
que seja eficazmente encaminhado, harmonia de vistas entre os poderes federaes e municipaes ${ }^{32}$.

Em 1912, esta questão persistia e, neste sentido, propunha o ministro Dr. Rivadavia da Cunha Corrêa no seu relatório que

a integração municipal dos serviços de assistência, mediante accordo entre o Governo da União e o do Município, cujas rendas foram accrescidas com a percepção do producto do imposlo de transmissão de propriedade, contribuiria decisivamente para a solução do problema, lucrando com essa medida salutar o desenvolvimento de instituições já organizadas sobre as melhores bases e dirigidas com o mais louvável critério ${ }^{33}$.

Durante toda a primeira República, houve um moroso processo de repasse da polícia para a municipalidade de diversos servidos ligados a assistência pública, ao controle da população não criminosa e da regulação de comércio e alimentos. Com a ressalva de que muitas vezes as funções eram passadas por decretos, mas na prática a polícia continuava cedendo pessoal e/ou prestando serviços em conjunto com a municipalidade. Podemos demonstrar nitidamente este aspecto através do relatório ministerial dos anos de 1927 e 1928 . Nele podemos ler que que a Policia Militar do Distrito Federal tinha "empegados externos" alocados em diversas funções relativas a atuação do ministério da justiça e negócios interiores. Havia, segundo o referido relatório 9 oficiais, 9 sargentos e 292 praças dispersos, destes "225 a disposição dos mais diversos ramos de atuação da polícia civil" ${ }^{34}$ incluindo "8 para o abrigo de menores", além de 8 cedidos para a prefeitura e 3 para o cofre de órfãos. Esta passagem da gestão policial para a municipal poderia ter sido célere no caso do Rio de Janeiro, sob o ponto de vista administrativo, pois tanto a municipalidade, quanto a polícia eram instâncias administrativas do mesmo poder e estavam sob a gestão direta do Ministério da Justiça. No entanto, se constituiu em palcos de celeumas e rusgas entre os poderes de polícia e de prefeito, e por vezes entre os poderes de chefe de polícia e de ministro da justiça.

\footnotetext{
${ }^{32}$ BRASIL. Ministério da Justiça e Negócio Interiores. Relatório dos anos de 1907 e 1908 - Volume 01. Rio de Janeiro. Imprensa Nacional, 1908a, p. XXX.

${ }^{33}$ BRASIL. Ministério da Justiça e Negócio Interiores. Relatório dos anos de 1911 e 1912. Rio de Janeiro. Imprensa Nacional, 1912, p 92.

${ }^{34}$ BRASIL. Ministério da Justiça e Negócio Interiores. Relatório dos anos de 1927 e 1928. Rio de Janeiro. Imprensa Nacional, 1930, p. 203.
} 
No Brasil, no período de nossos estudos a governabilidade da cidade do Rio de Janeiro em diversos aspectos que diziam respeito a municipalidade poderia se identificar um certo traço, um esboço e uma prática de polícia que remonta a ideia de Estado de polícia. A municipalidade da cidade do Rio de Janeiro naquele momento não possuía mecanismo de organização administrativa, de pessoal, de gestão e conhecimento que pudesse dar conta do que exigia a moderna organização da cidade. Neste sentido que a razão da governabilidade municipal amalgamou na cidade do Rio de Janeiro a instituição policial, através de conhecimentos de gestão, pessoal, prédios públicos, instituições e serviços durante o Império e boa parte da República. Neste viés a polícia configurava-se como a mais preparada das instituições para levar o projeto de legitimação do Estado perante a nação. Dito de outra forma, a polícia era quem estava preparada no final do século XIX para assumir as responsabilidades que a modernização da cidade do Rio de Janeiro exigia, era ela quem poderia se incumbir tanto de funções administrativas, como por exemplo, a realização de sensos, quanto da resolução de crimes. Era a polícia que estava preparada para territorializar a cidade em zonas boas e más, era a polícia quem sabia segundo seus critérios classificar e diferenciar, para todo o resto da sociedade, quem era o pobre trabalhador e quem era o pobre vagamundo.

A partir destas constatações passaremos a demonstrar a importância dos chefes de polícia na construção do Estado-nação. De maneira que podemos demonstrar que estes exerciam determinante influência no escopo geral da classe dominante. E, que seus discursos não só estavam alinhados aos objetivos políticos do Estado, como eram parte pensante e proficuamente atuante na construção do discurso oficial sobre a questão social. De modo que eram quem construíam os discursos oficiais sobre a pobreza e a assistência, que começava a partir da década de 1910 a aparecer claramente nominada nos documentos de "assistência social".

\subsection{Saber e política: os chefes de polícia e a construção da nação}

Neste tópico destacaremos a atuação pública dos chefes de polícia e ministros da justiça, que nitidamente influenciaram Estado e sociedade na institucionalização de práticas e saberes direcionados ao controle, disciplinamento, proteção e 
repressão da pobreza urbana válida e inválida. Demonstraremos que o cargo de chefe de polícia era eminentemente político, não só pelo fato de ser uma nomeação direta do presidente da república, do ministro da justiça ou do imperador dependendo da época -, mas principalmente por servir de vitrine política e trampolim para alçar o supremo tribunal federal, entre outros cargos de relevância da alta administração pública. Afirma Werneck da Silva (1981, p. 2) que “instituições policiais da Corte, tiveram, nesta conjuntura de 1831 a 1866, como veículo de ascensão social". Acrescentamos a esta afirmação que, este aspecto de ascensão social esteve ligado ao cargo de chefe de polícia durante todo o século XIX e, pelo menos até 1930, ponto final de nossa pesquisa. A importância deste carago para os diversos ramos da administração pública imprimiu a ele durante todo o século XIX e até, pelo menos, 1930 característica que presumiam ascensão social. Estes aspectos podem ser vislumbrados na pequena descrição, que faremos a abaixo, da vida de servidores públicos dos chefes de polícia da cidade do Rio de Janeiro. Era um cargo de ascensão meramente político, mas que como podemos ver foi ocupado no período de nossos estudos por pessoas com comprovado e notório conhecimento técnico e estudos sobre o tema que atuavam: a gestão das populações, o comércio e o abastecimento nas cidades, bem como, a manutenção da segurança pública e a assistência pública.

Para este fim traçaremos uma breve descrição histórica da carreira profissional e política de alguns chefes de polícia, bem como, demonstraremos a importância social e política da qual sorvia o cargo de chefe de polícia da cidade capital. Evidenciando que esta importância traduzia-se em influência direta na construção de um discurso oficial balizado pelas modernas teorias cientificas da época. Demonstraremos ainda a importância destes chefes na construção de um saber jurídico e de um poder político que envolvia os diversos temas na formação do Estado-nação entre eles, e com bastante relevância, assistência e pobreza urbana.

Os chefes de polícia da época frequentavam as rodas da intelectualidade carioca, todos eram bacharéis em direito, transitavam pelos círculos políticos do poder, seja na corte, seja na República. Almejavam ou já tinham carreira política o próprio cargo de chefe de polícia funcionava quase como antessala do Ministério da Justiça - visto que alguns dos chefes de polícia tornaram-se ministros de Estado - frequentavam as altas rodas do poder, da ciência e da literatura no Rio, em Paris ou Londres. Ainda podemos destacar que muitos dos chefes de polícia eram 
membros do $\mathrm{IHGB}^{35}$, ou seja, eram homens da elite que pensava o Brasil pela via do Estado. A influência da polícia pode ser percebida pelo que representava "a elite política no império (...) dominada por advogados e juízes” (Carvalho 2006, p. 138). Os ministros da justiça e chefes de polícia acompanhavam diretamente, via o envio de representantes ou pelos próprios, os principais congressos mundiais sobre os temas referentes as instituições policiais. "Estes representantes do Ministerio da Justiça estavam presentes deste o primeiro congresso internacional acontecido em Francfort em 1847"36, Muitos tinham fluência em inglês e francês e, em alguns casos em alemão, pois somente assim podiam ler os "numerosos livros, que formamvam já copiosa litteratura e de relatórios e trabalhos de encarregados dos diversos paizes, nos congressos internacionais".

O cargo de chefe de polícia, era tradicionalmente o local de bacharéis, juiz e desembargadores. Esta tradição inaugurada pelo desembargador Paulo Fernandes Viana com a chegada de D. João VI, foi institucionalizada pela lei de 3 de dezembro de 1841 , operacionalizada no regulamento 120 de 1842 e ratificada na reforma judiciária de 1871, a qual reforça a nomeação de chefes de polícia somente " $d$ 'entre os doutores e bacharéis em direito, que tenham quatro annos de prática de foro ou de administração" ${ }^{37}$. Durante o período de nossos estudos este aspecto foi quebrado poucas vezes, uma delas foi pelo decreto presidencial de 20 de novembro de 1922 que modificou este dispositivo para que o Marechal Manoel Lopes Carneiro da Fontoura pudesse assumir o cargo chefe de polícia do distrito federal. Uma manobra do presidente Artur Bernardes, com menos de uma semana no cargo, para conter a grave crise política da década de 1920, com o levante militar de 1922, visto que o citado marechal era conhecido como implacável perseguidor dos militares revoltosos. ${ }^{38}$

Apesar deste momento e, também do fato de estarmos já na década de 1920, ocasião em que começa de fato a especialização da polícia estritamente na repressão de crimes, esta não se afasta por completo dos outros aspectos que envolvia a administração municipal e o disciplinamento da população não criminosa. Não foi

\footnotetext{
${ }^{35}$ Instituto Histórico Geográfico Brasileiro

36 BRASIL. Ministério da Justiça. Relatório do ano de 1878. Rio de Janeiro. Typographia Perseverança, 1879, p. A4-8.

${ }^{37}$ BRASIL. Ministério da Justiça. Relatório do ano de 1871. Rio de Janeiro. Typographia Nacional, 1872 b, p. 10.

${ }^{38}$ BRASIL. Ministério da Justiça e Negócio Interiores. Relatório dos anos de 1922 e 1923 . Rio de Janeiro. Imprensa Nacional, 1923.
} 
ponto de nossa pesquisa, mas não podemos deixar de comentar que os aspetos da repressão aos crimes políticos foi sempre uma das funções presentes nas práticas das instituições policiais. É fato porém, que mesmo neste momento, como nos anteriores, o cargo de chefe de polícia “englobava poderes legislativos, executivos e judiciários (Holloway, 1997, p. 46). Desde do desembargador Paulo Fernandes Viana, que herdou a lógica das instituições policiais de Portugal, estes aspectos administrativos estavam presentes nas instituições policiais. Os chefes de polícia da Corte e, posteriormente, do Distrito Federal, estavam no terceiro escalão do poder central, acima só havia o ministro da justiça e o imperador ou o presidente, dependendo do período. Nas províncias ocupavam o segundo escalão diretamente abaixo dos presidentes. Não é se estranhar que muitos chefes de polícia da capital foram de ocuparem o cargo presidentes de províncias. Neste sentido afirmava o então chefe de polícia Aurelino Leal em seu livro "Policia e poder de policia" que

de facto, um chefe de Policia é um alto representante do Poder Executivo, e deve, neste caracter, procurar os membros da magistratura, com elles conferenciar em nome da ordem publica, esclarecendo a sua conducta em relação as providencias que haja tomado, susceptiveis de reflectir no dominio judiciário (Leal, 1918, p. 7).

Para uma clara compreensão da importância dos chefes de polícia da cidade do Rio de Janeiro no processo de formação política do Estado brasileiro, descreveremos de maneira sucinta a trajetória pública de alguns dos principais chefes de polícia do período coberto por nossos estudos. Destacamos que de 1870 a 1889 período do Império coberto por nossas pesquisas, houveram um total de 11 chefes de polícia em 19 anos, enquanto que "com 29 anos de República o distrito federal teve 28 chefes de polícia” (Neder \& Naro, 1981, p. 258). Nos 60 anos coberto por nossas pesquisas tivemos um total de 39 chefes de polícia, destes 14 tornaram-se ministro do supremo tribunal federal, sem falar os que foram, após exerceram o cargo de chefe de polícia, presidentes de província, membros de tribunais de contas e do superior tribunal militar, entre outros. De modo que, podemos afirmar categoricamente que todos os chefes de polícia do período pesquisados ocuparam cargos de servidores da alta administração pública, além de mandatos legislativos.

O caminho para as cortes superiores da justiça era quase uma trajetória natural após ter servido na administração pública como chefe de polícia. Como podemos 
ver no art. 22 do regulamento 120 de 1842 que trata da "nomeação, demissão, vencimentos, e substituição dos empregados". Este artigo é literal ao dispor que os chefes de polícia "serão conservados nos lugares, emquanto bem servirem, e o Governo julgar conveniente". E, que entre os motivos (art. 23) para ser retirado do cargo de chefe de polícia lê-se a "mera deliberação do Governo" ou serem "promovidos ao Supremo Tribunal de Justiça, quando forem Desembargadores". Desta forma passaremos a traçar breves perfis profissionais dos chefes de polícia, de modo que este aspecto se some ao nosso argumento, que interpreta as instituições policiais como fundamentais na formação do estado-nação e, por conseguinte, na fundação da assistência social na cidade do Rio de Janeiro.

O chefe de polícia da corte em 1870 ano inicial do período focado por nossos estudos foi Francisco de Faria Lemos, nascido em Recife no ano de 1828, faleceu na cidade do Rio de Janeiro em 1904. Seguiu a carreira militar do pai até 1852, quando pede baixa do $10 .^{\circ}$ Batalhão de Infantaria após ter concluído o curso de bacharel em ciências jurídicas e sociais. Sua trajetória na administração pública e jurídica inicia-se em 1852, quando de sua nomeação como juiz municipal suplente da $1^{\text {a }}$ Vara da cidade do Recife. No ano seguinte foi $1^{\mathrm{o}}$ suplente de delegado de polícia do Recife e logo depois, ainda no mesmo ano, nomeado juiz municipal e de órfãos de Quixeramobim (CE). Foi juiz de direito da comarca de Paranaguá (PI) em 1858 e de Boa Vista (PE), em 1859. Foi nomeado pela primeira vez como Chefe de Polícia na província do Piauí em1868, no mesmo ano foi transferido para o Rio Grande do Norte e logo depois para Pernambuco. Em 1869 é nomeado chefe de polícia da cidade do Rio de Janeiro e 1879 é nomeado desembargador da relação de Fortaleza. Exerceu a alta administração pública em quatro províncias, foi presidente de Pernambuco em 1872, do Ceará em 1876, do Rio Grande do Sul em 1877, de Minas Gerais em 1886 e, em 1892 é nomeado Ministro do Supremo Tribunal Federal, seu último cargo da administração pública.

Miguel Calmon du Pin e Almeida chefe de polícia da corte em 1875, era sobrinho do Marques de Abrandes, por quem foi criado após a morte prematura de seu pai. Formou-se em direito pela faculdade do Largo de São Francisco em 1863. Foi promotor de justiça em Cabo Frio, juiz de Paraíba do Sul. Elegeu-se deputado provincial em 1871, mesmo ano em que foi nomeado chefe de polícia no Maranhão. Em 1876, foi nomeado por D. Pedro II para ser chefe de polícia da corte. Em 1882 foi juiz em Guaratinguetá (SP), depois no Rio de Janeiro onde passou a 
desembargador. Em 1885 foi presidente da província do Ceará e no ano seguinte do $\underline{\text { Rio Grande do Sul. Interessante observar que do mesmo modo, o chefe de polícia }}$ Dr. Tito Algusto Pereira de Matos chefe de polícia da corte de 1877 a 1879, voltando depois em 1883, foi também presidente da província do Maranhão em 1889 e também juiz de direito da comarca de Guaratinguetá.

O chefe de polícia da corte de 1880 e 1881 Ovídio Fernandes Trigo de Loureiro era filho de desembargador, nasceu em 1828 em São Paulo e faleceu no Rio de Janeiro em 1904. Foi nomeado novamente chefe de polícia em 1889 como interino, diante das incertezas da mudança de regime. Se formou em direito em 1848 em São Paulo. Foi nomeado em 1850 juiz municipal e de órfãos de Cachoeira (RS), Caçapava (SP), Bagé (RS), Santos (SP) e Itapetininga (SP) antes de ser nomeado desembargador da relação de Cuiabá em 1875, de Ouro Preto em 1877 e para a da Corte em 1882. Foi nomeado Ministro do Supremo Tribunal Federal em $1890^{39}$ e ainda exerceu o cargo de Procurador Geral da República ${ }^{40}$ em 1894, quando foi aposentado.

Como trajetórias de influência nos diversos campos de poder e saber, podemos citar o discurso inaugural do curso de direito no ano 1896 publicado pela revista da faculdade de direito de São Paulo, proferido pelo "cathedratico Dezembargador Dr. Aureliano de S. e O. Coutinho, que foi chefe de policia da corte em 1881"41. Do mesmo modo podemos citar Bellarmino Peregrino da Gama e Mello, chefe de polícia da corte em 1882, que havia sido juiz municipal acumulando a função juiz de órfão do município de Vassouras 1857 e depois de chefe de polícia exerceu o cargo de desembargador da Relação de Ouro Preto em 1885.

Manuel José Espínola, chefe de polícia da corte em 1887 e 1888 e novamente na República em 1905 e 1906 era filho de magistrado, nasceu em 1841 na Bahia e faleceu em 1912 no Rio de Janeiro. Ele se formou em direito na faculdade do Recife em 1896, iniciou sua vida pública trabalhando com juiz municipal e de órfãos em Rio Preto (MG) em 1863 e Cantagalo (RJ) em 1876. Foi chefe de polícia do Piauí em 1870, onde exerceu o cargo de vice-presidente da província. Em 1872 exerceu novamente o cargo de chefe de polícia em Sergipe de onde foi, no mesmo ano, para

39 Disponível em: <http://www.stf.jus.br/portal/ministro/verMinistro.asp?periodo=stf\&id=363>. Acesso em: 05 out. 2014.

${ }^{40}$ Disponível em: <http://www.pgr.mpf.mp.br/conheca-o-mpf/procurador-geral-darepublica/galeria/biografia-de-ovidio-fernandes-trigo-de-loureiro>. Acesso em: 05 out. 2014.

${ }^{41}$ Disponível em: <http://www.revistas.usp.br/rfdsp/issue/view/5308>. Acesso em: 05 out. 2014. 
a Bahia. Em 1874 é nomeado juiz de direito de Santa Maria Madalena (RJ), sendo nomeado em 1886 como chefe de polícia da província do Rio de Janeiro. Em 1890 foi nomeado Juiz da Corte de Apelação e 1906 Ministro do Supremo Tribunal Federal $^{42}$.

Chefe de polícia em 1889 e novamente em 1898 a 1900, João Batista de Sampaio Ferraz nasceu em Campinas (SP) em 1857, se formou na faculdade de direito de São Paulo em 1878. Foi promotor público adjunto em São Paulo 1881 a 1884 e depois no Rio de Janeiro de 1884 a 1889. Foi um dos fundadores do jornal "O Correio do Povo" que defendia ideias republicanas, além de ter colaborado com o "Diário Popular" de São Paulo, "O País" e "Gazeta de Notícias" do Rio de Janeiro. Foi nomeado em 1889 por Deodoro da Fonseca com o primeiro chefe de polícia do novo regime. Foi deputado federal constituinte em 1890, permanecendo na câmara até 1893. No governo do presidente Manuel Ferraz de Campos Sales (1898-1902), novamente ocupou o cargo de chefe de polícia, onde permaneceu até 1900, quando sai para assumir novo mandato legislativo como deputado federal pelo Distrito Federal.

Pedro Antonio de Oliveira Ribeiro, chefe de polícia da capital do país em 1891, era filho do Coronel nascido em 1851 na província de Sergipe, faleceu no Rio de Janeiro em 1917. Formou-se na faculdade de direito do Recife em 1871. Foi juiz municipal e de órfãos em Montes Claros (MG) no ano de 1887. Deputado da Assembleia Geral Legislativa (1886-1889), $2^{\circ}$ Vice-Presidente da província de Sergipe em 1885, de onde foi em 1891 para o cargo de chefe de polícia da capital federal. Em 1892 foi nomeado procurador geral do Estado de São Paulo e em 1903 nomeado Ministro do Supremo Tribunal Federal, seu último cargo público foi como procurador geral da República em $1905^{43}$.

Formado em direito pela faculdade de São Paulo em 1879, Dr. Bernadino Ferreira da Silva, chefe de polícia da capital federal 1892-1893. Nasceu em Santos no ano de 1856 e faleceu no Rio de Janeiro em 1905. Em 1882 foi nomeado Juiz Substituto da $2^{\text {a }}$ Vara Cível da Comarca de São Paulo, em 1889 foi designado interinamente $1^{\circ}$ Delegado de Polícia da Corte. Foi nomeado em 1892 para o cargo

42 Disponível em: <http://www.stf.jus.br/portal/ministro/verMinistro.asp?periodo=stf\&id=155>. Acesso em: 05 out. 2014.

43 Disponível em: <http://www.stf.jus.br/portal/ministro/verMinistro.asp?periodo=stf\&id=136>. Acesso em: 05/ out. 2014. 
de chefe de polícia. Em 1893 foi nomeado por Marechal Floriano Peixoto como coronel do exército, depois nomeado em 1893 como ministro do Supremo Tribunal Militar e em 1894 ministro do Supremo Tribunal Federal ${ }^{44}$.

André Cavalcanti d'Albuquerque chefe de polícia da capital federal em 18961897, nasceu em 1834 na província de Pernambuco e faleceu em 1927 no Rio de Janeiro. Formou-se em 1859 na faculdade de direito de Recife. Em 1860 iniciou sua vida pública como Promotor Público de Recife. Foi deputado da assembleia de Pernambuco por duas vezes. Juiz de direito de Bom Jardim (RJ) em 1878, de Posse (GO) em 1880 e Juiz dos Feitos da Fazenda Municipal do Distrito Federal em 1891. Exerceu o cargo de Chefe de Polícia na Paraíba, Pernambuco, e no Distrito Federal, por convite do presidente Prudente de Morais, foi nomeado Ministro do Supremo Tribunal Federal em $1897^{45}$.

Podemos perceber a relação da influência política e econômica direta sobre o cargo de chefe de polícia. Por exemplo, em relação ao o chefe de polícia dos anos de 1897-1898, Dr. Manoel Edwiges de Queiroz Vieira, filho de grande proprietário de terras, nasceu em Santana de Macacu (RJ). Formou-se em direito em São Paulo em 1879 e retornou a sua terra natal em 1885 como juiz municipal, depois exerceu o mesmo cargo em Rio Bonito (RJ) em 1887, de onde saiu para exercer o mandato de deputado estadual em $1892^{46}$. Muitas foram as influências e a força econômica da "roça" na ocupação do cargo de chefe de polícia. Outro exemplo, neste sentido, é do chefe de polícia em 1892 Dr. João Francisco Barcelos que era um eminente político de família proprietária de terra da região de Valença ${ }^{47}$. No entanto cabe destacar que, além dos casos apontados acima, todos que ocuparam o cargo do chefe de polícia na cidade do Rio de Janeiro, eram bacharéis em direito e com experiências na administração pública em diferentes cidades de diversas províncias.

Neste sentido podemos destacar, como nos outros casos, o chefe de polícia em 1901 e 1902 Dr. Edmundo Muniz Barreto, nasceu no Rio de Janeiro em 1864, seu pai era capitão-tenente do exército e faleceu na mesma cidade em 1934. Após

\footnotetext{
44 Disponível em: <http://www.stf.jus.br/portal/ministro/verMinistro.asp?periodo=stf\&id=368>. Acesso em: 05 out. 2014.

45 Disponível em: <http://www.stf.jus.br/portal/ministro/verMinistro.asp?periodo=stf\&id=204>. Acesso em: 05 out. 2014.

46 Disponível em: <http://www.ihp.org.br/lib_ihp/docs/fjrv20010617t.htm>. Acesso em: 08 out. 2014.

47 Disponível em: <http://www.ihp.org.br/lib_ihp/docs/fjrv20010624t.htm>. Acesso em: 07 nov. 2014.
} 
se formar em direito em 1884 foi juiz municipal e de órfãos em São Borja (RS) em 1886. Foi nomeado em 1888 para o cargo de $3^{\circ}$ Juiz Substituto da Corte do Império, em 1894 como Juiz do Tribunal Civil e Criminal. Somente após esta trajetória que em 1901 ocupou o cargo de chefe de polícia da capital federal a convite do presidente Campos Sales. Foi nomeado Ministro do Supremo Tribunal Federal em 1910 e exerceu o cargo de Procurador Geral da República de 1911 a $1919^{48}$.

Outra trajetória similar é o chefe de polícia da capital federal dos anos de 1902 a 1905 Antonio Augusto Cardoso de Castro que nasceu na Bahia em 1860 e faleceu no Rio de Janeiro em 1911. Antes de ocupar o cargo de chefe de polícia se formou em direito no Recife em 1883 onde foi professor de retórica em 1884. Foi delegado de Polícia em Salvador em 1885, no mesmo ano foi promotor público de Jaboatão (PE), em 1889 foi oficial da secretaria da diocese de Pernambuco. Em 1891 mudouse para capital federal onde ocupou o cargo de auditor de guerra e depois em 1893 foi nomeado ministro do Supremo Tribunal Militar, para só então ser nomeado chefe de polícia. De onde saiu em 1905 para o cargo de Ministro do Supremo Tribunal Federal. Seu último cargo público foi o de procurador geral da República de 1910 a $1911^{49}$.

Outra trajetória que demonstra a importância dos chefes de polícia da capital no escopo político da formação do Estado brasileiro é a do chefe de polícia em 1906 e 1907 Alfredo Pinto Vieira de Mello. Nasceu em 1863 em Recife e faleceu no Rio de Janeiro em 1923, formou-se em direito no ano de 1886 na cidade de seu nascimento e em 1887 iniciou sua vida pública como Promotor Público de Baependi (MG), após não aceitar a nomeação para Juiz Municipal e de Órfãos de Palmeira (RS). Foi nomeado Juiz de Direito de Ouro Fino (MG) em 1890 e depois Chefe de Polícia de Estado de Minas Gerais de1893 a 1896. Em 1897 iniciou a carreira política como Deputado ao Congresso Nacional, onde foi Presidente da Comissão de Constituição e Justiça, e fez parte da comissão que examinou o Código Civil. Após ocupar cargos públicos na fazenda nacional foi convidado por Afonso Pena em 1906 para ser chefe de polícia da capital federal. Enquanto chefe de polícia criou o serviço de identificação e construiu a Colônia Correcional de Dois Rios. Após sua

48 Disponível em: <http://www.stf.jus.br/portal/ministro/verMinistro.asp?periodo=stf\&id=132 http://www.pgr.mpf.mp.br/conheca-o-mpf/procurador-geral-da-republica/galeria/biografia-deedmundo-muniz-barreto>. Acesso em: 05 out. 2014.

49 Disponível em: <http://www.stf.jus.br/portal/ministro/verMinistro.asp?periodo=stf\&id=227>. Acesso em: 07 nov. 2014. 
gestão à frente da polícia foi Presidente do Instituto da Ordem dos Advogados Brasileiros (1910 a 1913), professor da Faculdade Livre de Ciências Jurídicas e Sociais do Rio de Janeiro e em 1919 foi nomeado Ministro da Justiça e Negócios Interiores a convite de Epitácio Pessoa de onde saiu em 1921 para ser Ministro do Supremo Tribunal Federal. A trajetória de Alfredo Pinto Vieira de Mello demonstra, de maneira ainda mais contundente, a influência dos chefes de polícia nos aspectos mais gerais da formação do Estado. Alfredo Pinto publicou diversos estudos e artigos, entre eles destacam-se "Educação científica", "Direitos das Sucessões" e o "O Poder Judiciário no Brasil (1532-1871)" "50. Outra peculiaridade de Alfredo Pinto é que foi homenageado nominando a Escola de Enfermagem Alfredo Pinto da Universidade Federal do Estado do Rio de Janeiro. Esta homenagem deveu-se ao fato de ter sido Alfredo Pinto que enquanto ministro da justiça aprovou o Regimento Interno da Escola Profissional de Enfermeiros e Enfermeiras da Assistência a Alienados ${ }^{51}$.

O chefe de polícia da capital federal de 1909 e 1910, Carolino de Leoni Ramos, nascido em 1857 em Cachoeira (BA), falecendo em 1931 na cidade do Rio de Janeiro, como Ministro do Supremo Tribunal Federal, para o qual foi nomeado após de exercido o cargo de chefe de polícia da capital federal. Antes houvera sido chefe de polícia no Estado do Rio de Janeiro e no Ceará. Formou-se em direito no recife em 1879, foi promotor público em Pilar (AL) em 1881, depois em Itaguaí (RJ) em 1882, juiz de direito em Vila Bela (PE), Valença (RJ) onde foi eleito Vereador e Presidente da Câmara Municipal de Valença. Seguiu a carreira política tornando-se deputado à Assembleia Legislativa do Estado do Rio de Janeiro (18951897), Vereador da Câmara Municipal de Niterói em 1904 e prefeito da mesma cidade em $1906^{52}$.

Belisário Fernandes da Silva Távora chefe de polícia da capital federal de 1910 a 1913, natural de Jaguaribe (CE), formou-se em direito na cidade do Recife em 1892, onde foi aluno de J. J. Seabra, por quem nutria profunda admiração. Em

\footnotetext{
50 Disponível em: <http://www.stf.jus.br/portal/ministro/verMinistro.asp?periodo=stf\&id=197>. Acesso em: 07 nov. 2014.

${ }^{51}$ Disponível em: <http://www.unirio.br/enfermagem/historia-da-eeap/historia-da-eeap>. Acesso em: 07 nov. 2014.

52 Disponível em: <http://www.stf.jus.br/portal/ministro/verMinistro.asp?periodo=stf\&id=151>. Acesso em: 08 out. 2014.
} 
1897 foi morar no Rio de Janeiro onde exerceu a advocacia e a função de delegado de polícia, chegou a chefe de polícia em 1910, de onde foi nomeado desembargador.

O chefe de polícia da capital federal de 1914 a 1919, Aurelino de Araújo Leal, filho de coronel e fazendeiro da Bahia onde nasceu em 1877, faleceu 1924 na cidade do Rio de Janeiro. Formou-se em direito pela faculdade da Bahia, onde foi deputado estadual, diretor de penitenciária, chefe de polícia de Salvador e secretário geral de Estado. Em 1912 muda-se para o Rio de Janeiro, onde exerce a advocacia e dois anos mais tarde é nomeado chefe de polícia do distrito federal. Em 1918 foi nomeado $1^{\circ}$ representante do Ministério Público, junto ao Tribunal de Contas da União. Foi deputado federal eleito pela Bahia e nomeado em 1923 pelo presidente Artur Bernardes como interventor federal no Estado do Rio de Janeiro (LACOMBE, 1973). Aurelino Leal foi diretor e redator de diversos jornais na Bahia e no Rio de Janeiro onde foi redator chefe do Diário de Notícia e um dos fundadores da revista Brasil Econômico e Financeiro. Além de ter atuado como professor de direito constitucional da Faculdade de Ciências Jurídicas e Sociais do Rio de Janeiro e catedrático da Faculdade de Direito da Universidade do Rio de Janeiro.

De trajetória similar, como não poderia ser diferente, o chefe de polícia da capital federal de 1919 a 1920, desembargador Dr. Geminiana da Franca, também se formou em direito em Recife em 1892. Filho de um major nascido em 1870 na Paraíba, faleceu em 1935 no Rio de Janeiro. Sua trajetória pública inicia-se em 1893 ao ser nomeado como promotor público de Tietê (SP). Foi nomeado 1893 delegado de polícia de Niterói (RJ). Após passar por outros cargos públicos foi nomeado juiz de direito do Distrito Federal em 1906, desembargador da Corte de Apelação em 1913, para depois assumir o cargo de chefe de polícia em 1919. Foi nomeado em 1922 como ministro do Supremo Tribunal Federal

Ainda podemos citar, Armando Patrício de Azambuja chefe de polícia do distrito federal em 1921 e, depois novamente em 1924 era filho de coronel nascido em 1865 em Rosário do Sul (RS), formou pela Faculdade de Direito de São Paulo em 1890 e em 1891 foi nomeado Juiz Municipal de Uruguaiana, onde em 1892 foi promovido para juiz de direito, cargo que exerceu também em Santa Maria, Bagé, Piratini, Pelotas, Rio Grande e Dom Pedrito de onde foi em 1912 nomeado como juiz da primeira Vara da Comarca da Capital federal e depois nomeado desembargador em 1915. Foi nomeado procurador geral do Estado em 1921, deixando em 1924 para mais assumir o cargo de chefe de polícia. Permaneceu 
procurador até 1932 quando é eleito Vice-Presidente do Tribunal Eleitoral do Estado.

Por último citamos Dr. Coriolano de Araújo Góes Filho, chefe de polícia nos anos de 1927-1928. Nascido em 1896 em Salvador, faleceu em 1967 em São Paulo. Formou-se em 1916 na faculdade nacional de direito. Exerceu funções de delegado de polícia em diversas cidades do estado de São Paulo. Em 1916 foi nomeado Delegado Auxiliar do Distrito Federal e, com a chegada de Washington Luís a presidência foi nomeado chefe de polícia do distrito federal de onde saiu em 1930 para assumir o cargo de Ministro do Supremo Tribunal Militar.

Devemos chamar a atenção que nosso objetivo ao descrever de maneira sucinta as trajetórias dos diversos chefes de polícia, temos o único intento de mostrar as dimensões das relações sociais e de poder que tinham os representantes da elite que ocuparam o referido cargo. Pretendemos, com isto, desmontar que o cargo de chefe de polícia era cobiçado pelos bacharéis como meio de acessão social. Um dos caminhos mais diretos para ascender aos diversos tribunais superiores de justiça. A aleatoriedade na escolha dos chefes de polícia que levantamos alguns aspectos de suas histórias de servidores públicos, foi com o propósito de demonstrar que as características descritas acima sobre a trajetória profissional dos chefes de polícia serão indubitavelmente encontradas em todos os casos dos que ocuparam o referido cargo na cidade do Rio de Janeiro, durante todo século XIX e pelo menos até 1930, limite temporal de nossa pesquisa.

Como podemos ver nas pequenas descrições acima os chefes de polícia da Corte e do Distrito Federal tinham uma trajetória quase que comum. Esta trajetória que os credenciavam ao cargo de chefe de polícia envolvia profundos conhecimentos jurídicos e boa articulação política. Atentamos para o fato que este cargo público apesar ser preenchido primeiramente pelo critério político, só se escolhia entre os políticos amigos, aqueles com competência técnica para a gestão dos negócios do Estado e as formulações jurídicas. Esta trajetória envolvia um caminho conhecido por todos, ser formado em direito, ter bom relacionamento com a elite e ligações profundas com os poderes locais e de certo modo sobressair nos conhecimentos entre seus pares. Ao relatar estas pequenas trajetórias de servidores públicos, sem pretensão alguma de sistematização objetiva, nos chama atenção, à primeira vista, o quantitativo de chefes de polícia com formação nas faculdades do Recife e Bahia, em maior número dos que os formados no Rio e em São Paulo. 
Também solta nos aos olhos o fato de todos os chefes terem tidos experiências jurídicas e administrativas em diversas cidades do interior em diferentes províncias antes de ser erradicarem no Rio de Janeiro. O que por sua vez demonstra uma vivência de diferentes realidades do Brasil.

A relevância do cargo de chefe de polícia e a importância de seu discurso no contexto da oficialidade do governo e as incursões no campo teórico podem ser verificar, por exemplo, no relatório referente aos anos de 1880 e 1881, elaborado pelo então chefe de polícia Dr. Ovídeo Fernando Trigo de Loureiro. Escreveu o referido chefe sobre a administração pública, que

antes, porém, de entrar na exposição dos dados puramente estatísticos relativos aos successos mais notáveis e ao movimento das dependências desta repartição, me permittirá $V$. Ex. que, à exemplo de meus dignos e illustres antecessores, eu submetta ao seu illustrado critério e alta sabedoria, algumas considerações sobre a urgente $e$ indeclinável necessidade do emprego de medidas e providencias, que são imperiosamente reclamadas pela pratica o experiência para o bom desempenho dos vários ramos do serviço publico confiados a policia ${ }^{53}$.

O chefe de polícia da capital federal Dr. Antonio Algusto Cardoso de Castro, do mesmo modo que seus antecessores do final do século XIX, em seu relatório referentes aos anos de 1904 e 1905 faz uma longa explanação sobre com "verdadeira abundância de pormenores e com o mais largo espirito de analyse a situação real em que então se achava e ainda hoje se acha este ramo do serviço publico" ${ }^{\text {54 }}$. Este aspecto também pode ser visto no relatório de referente ao ano de 1883 quando o então chefe de polícia Dr. Tito Algusto Pereira de Matos afirmava que "é grande vantagem diagnosticar o mal, quando se pôde ter o remedio para debellal-o ${ }^{, 55}$.

Ficou demonstrado pelos relatórios que a polícia se envolvia em diversos ramos dos serviços público, e como o momento pesquisado é o momento da construção do Estado brasileiro, acreditava e trabalhava no sentido de que suas ideias e práticas seriam uteis na construção, consolidação e institucionalização e práticas sociais estatais. Neste sentido vale ressaltar o que escreveu o Dr. Antonio

\footnotetext{
${ }^{53}$ BRASIL. Ministério da Justiça. Relatório do ano de 1880 e 1881. Rio de Janeiro. Typographia Nacional, 1882b, p. A-G-3.

${ }^{54}$ BRASIL. Ministério da Justiça e Negócio Interiores. Relatório dos anos de 1904 e 1905 - Volume I. Rio de Janeiro. Imprensa Nacional, 1905a, p. A-G-V.

${ }^{55}$ BRASIL. Ministério da Justiça. Relatório do ano de 1883. Rio de Janeiro. Typographia Nacional, 1884, p. A-G-11.
} 
Algusto Cardoso de Castro no início do século XX, citando o autor francês Goron ${ }^{56}$ para embasar seus argumentos;

expuz com inteira minúcia as necessidades de cada ramo de serviço; suggeri o melhor meio de reprimir as contravenções, punindo as reincidências, que se multiplicara aos milhares; falei de mendicidade e de assistência: disse o que se deveria fazer para castigar o lenocínio; fui amplo e de uma franqueza rude e leal ${ }^{57}$.

Segundo Neder e Naro (1981, p. 250), “a boa polícia seria aquela que conhecesse todos que indistintamente forma a vida social, podendo conhecer os antecedentes de cada um". Conhecer era o primeiro princípio administrativo do qual se valia a polícia. Neste sentido a polícia precisava conhecer esta população, de modo que organiza estatísticas referentes aos números de habitantes por crime, idade, sexo, medidas relacionas ao casamento, relação das doenças e mortes em seus estabelecimentos. Tanto, ações sobre as pessoas e suas propriedades, quanto ações sobre a cidade, como por exemplo, inspeção de alimentos e dos portos, limpeza, atuação nas epidemias, regulamentação e supervisão de comércio e serviços ligada diretamente a administração pública (Machado, 1978), tal qual eram as atribuições do chamado Estado de Polícia que foi fundamental na criação dos modernos Estados europeus. Afinal a polícia foi a instância principal na constituição da ciência da estatística. Foucault (2001, p. 424) afirma que a estatística é o "domínio do conhecimento que se abre e se funda (...) justamente pela polícia, porque a polícia, como arte de desenvolver as forças, supõe que cada Estado identifique exatamente quais são as suas possibilidades, as suas virtualidades".

Ainda nos valendo das interpretações de Foucault (2001), conseguimos vislumbrar que os relatórios elaborados pelos chefes de polícia se constituía na construção de um saber do "Estado sobre o Estado". Este conhecimento gerado pelo método da estatística era abastecido pelos dados produzidos nas instituições policiais, afinal "a estatística se torna necessária por causa da polícia, mas também se toma possível por causa da polícia” (Foucault 2001, p. 424). A maneira como a polícia organizava e sistematizava os dados de sua atuação na cidade demonstrava

\footnotetext{
56 "Elles sont si multiples les questions que soulève l'organisation de la police, que sans doute je n'ai pu les traiter toutes avec l'importance qu'elles méritent. Je n'ai pu parler aussi longuement que je l'aurais voulu de cette question si palpipitante: la réformedu code d'instruction criminelle" (BRASIL. Ministério da Justiça e Negócio Interiores. Relatório dos anos de 1904 e 1905 - Volume I. Rio de Janeiro. Imprensa Nacional, 1905a, p. A-G-IX).

${ }^{57}$ Idem.
} 
a capacidade institucional na produção de estatísticas que fundamentavam sua prática e técnica e, influenciavam diretamente na produção de conhecimentos sobre a ideia de pobreza e assistência.

A polícia construía um saber técnico fundamentado na prática cotidiana, ajustado pelas diversas teorias em voga na época e, de certo modo, procurava adequar suas próprias instituições aos princípios da "ciência", como nos países "civilizados" e "cultos". De modo que podemos vislumbrar o modo como "o pensamento evolucionista da virada do século acabou por embasar o próprio discurso policial (Neder \& Naro, 1981, p. 244). Neste sentido podemos verificar nos "Annaes da Conferencia Judiciária-policial"58 realizado pelo chefe de polícia do distrito federal Aurelino Leal em seu discurso de abertura que discute qual seria o melhor modelo de polícia para a cidade do Rio de Janeiro, se o bobby inglês, seu favorito, o francês ou schutzmann alemão.

A polícia tinha uma elaboração teórica, possível de ser verifica através dos relatórios dos chefes de polícia e dos livros e artigos produzidos pelos chefes, que eram construídos a partir de uma atuação prática e cotidiana na cidade e seus fluxos populacionais. Os conhecimentos produzidos no cotidiano e sistematizados pela estatística tinham vasta influência das modernas teorias produzidas na Europa, ao mesmo tempo em que, a realidade local se impunha como soberana diante da necessidade de respostas imediata para a problemática enfrentada. Através dos conhecimentos construídos pela sistematização de dados da realidade local, alguns chefes de polícia se posicionavam de maneira consistente, teórica e empiricamente, se contrapondo as teorias alheias. Aparecendo nitidamente nos relatórios pesquisado as celeumas e amálgamas entre a polícia baseada no conhecimento empírico e os conhecimentos técnicos científicos. Estes aspectos que ora eram opositores e ora se amalgamavam em discursos e práticas possibilitaram transformar questões de ordenamento do cotidiano em consistentes questões da sociologia do direito. Estes aspectos de estudos dos chefes de polícia se dão no momento em que o direito passa a ser estudado e "considerado como fenômeno social e o estudo da criminalidade uma ciência" (Neder \& Naro, 1981). Encontramos esta celeuma e ao mesmo tempo este amálgama na obra de Elysio de

\footnotetext{
${ }^{58}$ Annaes da Conferencia Judiciária-policial convocado por Aurelino Leal, Chefe de Polícia do Rio de Janeiro, Rio de Janeiro, Imprensa Nacional, 1918 vol. 2, p. 40.
} 
Carvalho $^{59}$ (apud Neder \& NARO, 1981, p. 250) quando afirma que "a polícia e antes de tudo uma ciência experimental" mas que só é possível obter uma prática eficiente "senão com o exercício continuado da função e com o estudo prévio".

A importância do saber construído pela instituição policial a partir de sua prática cotidiana no contato direto com a população de diferentes classes e a circulação e o comércio na cidade pode ser vislumbrado nos argumentos do chefe de Polícia do Distrito Federal durante a gestão do Ministro J. J. Seabra, Dr. A. A. Cardoso de Castro. Para este influente bacharel que mais tarde vai a ser nomeado ministro do supremo tribunal,

não ha talvez por ahi quem não traga na cabeça um plano de reformas, bebido em leituras estranhas e em leis e regulamentos exóticos, quasi inteiramente incompativeis com a nossa situação, o nosso meio e os nossos recursos. $E$ isso exactamente o que nos mata, essa preoccupação de transplantar para aqui os systemas administrativos que vigoram alhures, mas que evidentemente não poderemos adoptar sem um exame detido das condições e circumstancias que nos são peculiares. O conhecimento do que entre nós existe estabelecido, a razão dos defeitos verificados no serviço, a indagação do que falta, a causa dos males que se indicam, não constituem preoccupação de espécie alguma para esses theoricos desnorteados pelo amor ás divagações e saturados de idéas novas, que nem sempre se ajustam com precisão ás cousas velhas ${ }^{60}$.

Podemos demonstrar esta mesma lógica expressa pelo chefe de polícia Dr. Tito Algusto Pereira de Matos em seu relatório referente ao ano de 1877 para o qual "a organisação de uma boa policia, modelada pela dos paizes adiantados, é aspiração tão seductora em theoria, como embaraçosa na prática" ${ }^{\prime 1}$. Exatamente expressando a mesma lógica que seu antecessor do século XIX o chefe de polícia Dr. Cardoso de Castro ao rebater as críticas que recebeu acerca dos problemas e questões que houvera levantado em seu relatório anterior aponto "uma divergência radical de pontos de vista" por ser ele um administrador que devia, ao contrário dos que o criticaram, “estudar as necessidades em face das próprias necessidades e não á luz de teorias" ${ }^{2}$. Continuava o referido chefe de polícia na construção de seus

\footnotetext{
59 "Policial e professor da escola de polícia do Rio de Janeiro desde sua fundação em 1912" (Neder \& Naro, 1981, p. 249).

${ }^{60}$ BRASIL. Ministério da Justiça e Negócio Interiores. Relatório dos anos de 1904 e 1905 - Volume I. Rio de Janeiro. Imprensa Nacional, 1905a, p. A-G-V.

61 BRASIL. Ministério da Justiça. Relatório do ano de 1877. Rio de Janeiro. Typographia Perseverança, 1878, p. 80.

62 BRASIL. Ministério da Justiça e Negócio Interiores. Relatório dos anos de 1904 e 1905 - Volume

I. Rio de Janeiro. Imprensa Nacional, 1905a, p. A-G-VII.
} 
argumentos que defendia a experiência como base do conhecimento construído pela polícia, neste sentido afirmava que, "imaginar, escrever artigos e discutir apenas sobre essa base, chega a ser uma cousa a bem dizer aleatória. No entanto ha muita gente que raciocina assim: das idéas para as factos e não dos factos para as idéas "63. Este modo de pensar nos levar a sentir fragrâncias do pensamento de Marx e evidencias de direta do modo de pensar a construção histórica em E. P. Thompson (1998)

Dentro desta mesma lógica da produção de conhecimento baseado na experiência, mas agora sobre outro aspecto, percebemos nitidamente na forma como se expressara o chefe de polícia Dr. Tito Algusto Pereira de Matos em seu relatório referente ao ano de 1883 que aqui também produzimos, ou deveríamos também produzir conhecimentos, com densidade para confrontar o conhecimento que chegava nos paquetes. Neste sentido expressava o referido chefe de polícia em relação a organização e sistematização dos serviços confiados as instituições policiais, entre eles a assistência e mais especificamente as instituições preventivas: "É verdade, porém, que si a este respeito tudo se acha por constituir entre nós, deve consolar-nos a certeza de que nos paizes mais adiantados não distanciam muito da nossa época os desejáveis progressos de uma sciencia, em que não foi ainda proferida a ultima palavra sobre certos pontos ${ }^{64}$.

Concordavam os chefes de polícia que se descaram como teóricos do Estado que a experiência e as particularidades do caso brasileiro tinha que primeiro ser levado em conta em detrimento das teorias em voga. E pela necessidade de dar respostar cotidianas a situações que seus pares discutiam em tese, expressavam, como por exemplo o chefe de polícia Dr. Cardoso de Castro que "o que resulta de semelhante systema de analyse e a convicção de que essa casta original de críticos da razão pura em que se concentrou todo o moderníssimo saber contido nos livros chegados pelos ultimas paquetes, não vale a fadiga de uma resposta" ${ }^{\circ 5}$.

Como não havia a última da palavra da ciência sobre determinados pontos, deveria o conhecimento empírico ser a base das soluções propostas, pois como escrevera o chefe Tito Matos, a falta de respostas cientificas "não quer dizer que

\footnotetext{
${ }^{63}$ Idem, p. A-G-V.

${ }^{64}$ BRASIL. Ministério da Justiça. Relatório do ano de 1882. Rio de Janeiro. Typographia Nacional, 1883, p. 132-3.

${ }^{65}$ BRASIL. Ministério da Justiça e Negócio Interiores. Relatório dos anos de 1904 e 1905 - Volume

I. Rio de Janeiro. Imprensa Nacional, 1905a, p. A-G-V.
} 
nos falleça a possibilidade de ir tentando algum melhoramento" 66 . Como, por exemplo, a proposta do referido chefe de polícia para a solução no campo das instituições preventivas - contumaz questão nos relatórios -, para o qual

a iniciativa particular sob a inspecção e auxilio do governo, conseguira, talvez com mais vantagem e menor gravame para o cofre publico, fundar estabelecimentos em que os fructos do trabalho compensem de alguma sorte a solicitude paternal, de que algumas associações privadas nos dão exemplos os mais edificantes ${ }^{67}$.

A importância dos chefes de polícia na formação do campo da assistência, bem como, a influência que exerciam diretamente na administração pública e na produção de conhecimento, pode ser exemplificado através do relatório do ministro Dr. Augusto Tavares de Lyra, referente aos anos de 1907 e 1908, quando recomendava ser "necessario pôr em pratica as providencias pedidas pelo Dr. Chefe de Policia, " 68 . Estas providências seriam:

ampliação da Escola Quinze de Novembro e organização definitiva dos dois asylos de menores; fundação de Escolas de Reforma para os meninos criminosos ou vagabundos de 15 a 20 annos, destinadas exclusivamente á agricultura; subvenção ás associações particulares, que, mediante fiscalização do Estado, mantenham creches; hospitaes para creanças desvalidas; asylos de regeneração e de trabalho para menores pervertidos; Instituição do Offcio Geral de Assistência Publica, superintendendo o serviço de soccorros aos indigentes, uniformizando e animando a iniciativa individual quanto ao regimen e direcção dos estabelecimentos de assistência orfanológica, velhice desamparada, mendicidade e outros congêneres ${ }^{69}$.

Acreditamos que através dos relatórios pesquisados e, aqui em trechos reproduzidos, foi possível demonstrar o papel da polícia na formulação de conhecimentos que se tornaram hegemônicos sobre classificação da pobreza e na institucionalização de práticas sociais relacionadas à maneira como o Estado deve enfrentar esta problemática. A nosso ver, ficaram evidentes como as atividades cotidianas da polícia revelam um amplo escopo de atribuições administrativas da cidade, bem como, eram a elas exigidas e, somente a elas, enquanto governo, dar conta das principais demandas sociais da cidade. De modo que suas ações em muito

\footnotetext{
${ }^{66}$ BRASIL. Ministério da Justiça. Relatório do ano de 1882. Rio de Janeiro. Typographia Nacional, 1883, p. 132-3.

${ }^{67}$ Idem.

${ }^{68}$ BRASIL. Ministério da Justiça e Negócio Interiores. Relatório dos anos de 1907 e 1908 - Volume 01. Rio de Janeiro. Imprensa Nacional, 1908a. p. XXXI.

${ }^{69}$ Ibidem.
} 
e, não raro, superavam em práticas e ideias o simples e exclusivo trato da criminalidade. Tratava-se de agir mais sobre os "costumes" e as "normas", questões próprias da municipalidade, do que exclusivamente sobre crimes. É fato, porém, que este transbordamento para além das questões criminológicas é parte exclusiva da história da polícia civil, enquanto continuidade direta da Intendência Geral de Polícia de Portugal. Além deste amplo escopo de práticas, cabia também as instituições policiais se apropriar do texto legal, não só através de interpretações particulares, mas também legislando como "praxistas".

Podemos demonstrar a amplitude das ações da polícia e como esta era claramente identificada enquanto agente administrativo, através do chefe de polícia Dr. Tito Algusto Pereira de Matos, que em seu relatório do ano de 1883, afirmou que "a policia, que, com razão, a sciencia administrativa, desde Macarel" considera a providencia humana pelo valor immenso dos interesses, que é

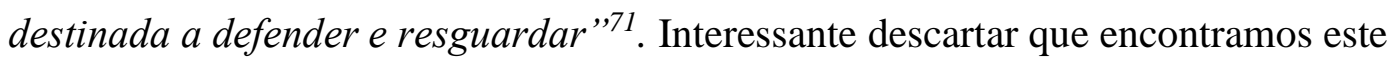
mesmo raciocínio sobre o papel administrativo da polícia, em um tratado sobre direito administrativo escrito em 1906 pelo Dr. Augusto Olimpio Vibriros de Castro, então, diretor do Tribunal de Contas da União. Afirma o referido diretor que "a policia, diz Stahl, é o mais rico domínio da administração; o fim e os interesses da nossa existência humana lhe pertencem e constituem o objecto positivo da sua acção" (Castro, 1906, p. 137). Continuava Dr. Castro em sua argumentação sobre o papel administrativo que historicamente cabia a polícia, demonstrando que

havia, é certo, no passado uma organização que correspondia, dentro de certos limites e com differenças infinitas e profundas, à administração de nossos dias; a sua denominação, porém, era - policia - como testemunham as Cartas e outros actos do ministério de Colbert, e a Correspondência de Luiz XIV (Castro, 1906, p. $\mathrm{V})$.

Cabe ressaltar que as discussões sobre as ideias se davam a partir de consistente erudição e constantes estudos produzidos no mundo "civilizado". Desde modo, podemos ressaltar a citação do Dr. Castro sobre "Traitè de la police" de De la Marre (1705-1738). Este tratado foi longamente estudado por Foucault (2001)

\footnotetext{
${ }^{70}$ Louis-Antoine Macarel (1790-1851), França. Percussor das discussões do Direito administrativo e um dos fundadores da ciência administrativa.

${ }^{71}$ BRASIL. Ministério da Justiça. Relatório do ano de 1883. Rio de Janeiro. Typographia Nacional, 1884, p. A-G-20-1.
} 
para compor suas ideias sobre segurança, território e população, e se constituía, segundo o referido autor, em um dos mais completos estudos sobre a polícia, percursor da economia política. Neste sentido afirmava o Dr. Castro que

De la Marre, commissario no Chatelet, recebeu do Regente 300.000 libras para publicar o seu Traitè de la police, que é o quadro mais completo das leis administrativas da antiga França, e apresenta uma imagem empolgante do systema regulamentar do velho direito, impondo-se, com as suas inutilidades, abusos e violências, em todas as manifestações da vida e do trabalho humano, e em todos os fenômenos económicos (Castro, 1906, p. VI).

Segundo Foucault (2008: 424), a polícia “é todo esse conjunto, numa palavra, administrativo que vai permitir que se identifique em cada Estado em que consistem suas forças, onde estão as possibilidades de desenvolvimento". De modo que se instaure procedimentos e regulamentos que possam "fazer as forças crescerem, para combiná-las, para desenvolvê-las" (Foucault, 2008, p. 424). É neste sentido que a polícia afirma-se como um importante poder no interior do sistema de regulação da ordem pública, definindo um amplo leque de estratégia, margeadas pela repressão, pela correção e pela assistência. De maneira que as análises e o exercício de poder dos chefes de polícia passavam a integrar os mecanismos legais, as representações sociais e os meios de produção na nova ordem social. Por este viés podemos perceber a ingerência da polícia na dinâmica social, sua relação com a ideia de assistência e o fato de que seu papel no ordenamento urbano é muito mais abrangente do que a representação rasa e simplória da criminalização do social.

Por estes aspectos, a polícia na cidade do Rio de Janeiro deve ser entendida como um componente da legitimação do Estado na formação da nação, através do processo de civilizar a cidade, não somente pela via da repressão, mas também pela via da assistência e da educação para o trabalho. A polícia exercia funções cruciais para o ordenamento burguês da cidade do Rio de Janeiro, tanto ao que dizia respeito a ações concretas e cotidianas da urbanidade, quanto no mundo das ideais. De modo que as representações contidas no discurso policial compunham a construção da ordem burguesa (Neder \& Naro, 1981, p. 249).

Fica demonstrado que a polícia teve uma participação ativa na formulação do campo da assistência e que esta era parte de suas práticas como podemos observar no relatório referente aos anos de 1910 e 11, ao afirmar que 
a creação do Gabinete de Identificação, da Guarda Civil, da Colônia Correccional dos Dous Rios, da Escola de Menores Abandonados, (...) e a fiscalização da Escola Premunitoria Quinze de Novembro, constituem sensíveis melhoramentos na vida policial da cidade $e^{72}$.

Do mesmo modo que, em discurso de abertura da Conferencia JudiciariaPenal de 1917, o então chefe de polícia Aurelino Leal (1918, p. 84) afirmava que entre as funções da polícia havia a de "dar destino aos loucos e enfermos encontrados nas ruas, bem como aos menores vadios $e$ abandonados $e$ aos mendigos".

É importante salientar que estávamos no momento fundante de um Estado e de uma nação e que a crenças nas soluções apontadas eram mais evidentes do que o imperativo da certeza da ineficácia das medidas de assistência social para a transformação social. Neste sentido afirmava o ministro J. J. Seabra, no relatório referente aos anos de 1904 e 1905, que

o Brasil encontra-se em condições magnificas para tomar a iniciativa de uma organização ponderada e reflectida, prudentemente aproveitadas as regras já praticadas perante os povos cultos, com a necessária adaptação ao nosso meio, aos nossos costumes e ás fôrmas actuais da nossa administração ${ }^{73}$.

As medidas de assistência estavam profundamente alinhadas ao pensamento liberal fundante do Estado brasileiro e, e eram percebidas pela certeza da ciência como meio eficaz de solucionar as problemáticas das expressões da questão social no Brasil. Do modo como assegurava J. J. Seabra que

fora dessa resumida nomenclatura encerram-se as múltiplas, variadas, complexas e infinitas fórmulas dessa questão social (grifo nosso) que, dia a dia, mais se engrandece e avoluma, desafiando a boa vontade dos governantes, e provocando a generosidade e os beneficios das almas bem formadas ${ }^{74}$.

Fica evidente que estava claramente posta a discussão da questão social no interior das forças intelectuais, políticas e econômicas da classe governante do país, da qual fazia parte, com certo protagonismo, os chefes de polícia. De modo que

\footnotetext{
${ }^{72}$ BRASIL. Ministério da Justiça e Negócio Interiores. Relatório dos anos de 1910 e 1911. Rio de Janeiro. Imprensa Nacional, 1911, p. 76.

${ }^{73}$ BRASIL. Ministério da Justiça e Negócio Interiores. Relatório dos anos de 1904 e 1905 - Volume II. Rio de Janeiro. Imprensa Nacional, 1905b, p. 232.

${ }^{74}$ Ibidem, p. 239.
} 
podemos verificar a ideia de práticas policiais a afirmação do Dr. Augusto de Castro de que

a justiça apenas conserva ou repara, e não intervém emquanto não se verifica uma violação de direito; as finanças teem o seu terreno limitado; o exercito não age senão quando ha necessidade de salvaguardar o poder. É na policia que existe a verdadeira actividade politica (grifo nosso).

Não tomaríamos para nós a afirmação, de maneira tão veemente, de que reside na polícia, a "verdadeira" atividade política. Mas, sem dúvida, assumimos o posicionamento teórico e interpretativo, que na polícia também há atividade política. Não só como o braço repressor do aparelho do Estado, como é o lugar comum e verídico creditado a esta, mas também como produtora e agente de ações estritamente políticas. Em nosso modo de ver, é exatamente este aspecto, o de produtoras de políticas, o que mais torna as instituições policiais facilmente acometidas do perigo de degenerar sua ação para a pura repressão e tirania, como por muitas vezes podemos exemplificar na história da formação do Estado brasileiro. $\mathrm{O}$ fato das instituições policias representarem o braço opressor, pela violência, do aparelho de Estado não é o que confere a polícia seu caráter mais intimidador. Ao contrário, o fato de produzir política embasada nas ações do controle diário da população na cidade, que confere as instituições policias o perigo do abuso e do arbítrio, principalmente se "as auctoridades superiores julgam do seu dever assegurara impunidade dos seus agentes, afim de não sacrificar o prestigio do Governo" (Castro, 1906: 137). Neste sentido, que Dr. Augusto de Castro afirmava que "segundo Rohmer, a intervenção livre no momento opportuno, é a essência da policia. A sua acção é indefinida como a própria vida; não é possivel aprisional-a em fórmulas (Castro, 1906: 137), por isto, estritamente, uma ação política.

Exatamente para demonstrar como se dava esta ação política - em nosso caso pelo viés assistência - que passaremos no próximo capítulo descrever como as instituições de assistência social se constituem historicamente, na cidade do Rio de Janeiro, em práticas de polícia. 


\section{Práticas de polícia: instituições de Assistência Social:}

Neste capítulo trataremos especificamente de três instituições de assistência, que aos olhos de hoje seriam nominadas objetivamente de social, as quais foram criadas e gerenciadas pela polícia. Através da histórias destas instituições podemos vislumbrar as diversas nuances das ações de cunho político e social da polícia, bem como, confirmar, ainda com mais evidência, a nossa tese de que a polícia também protagonizou a construção da história da assistência social na cidade do Rio de Janeiro. São estas as instituições: a Albergaria de Mendigos que mais tarde foi substituída pelo Asylo de Mendicidade, a Escola dos Meninos Desvalidos e a Escola Quinze de Novembro. Cabe o alerta que não é pretensão construir a história destas instituições, mas demonstrar - usando como fonte principal os relatórios pesquisados - através de suas histórias o papel da polícia na criação e gerenciamento destas. Sublinhando, para que não reste dúvidas, de que o papel que a polícia exercia através destas instituições não pode ser associado a criminalização de classes ou comportamentos, mas sim ao disciplinamento e controle, tal qual presume a assistência. Devemos pensar que o controle e o disciplinamento existem em qualquer sistema educacional ou instituições e políticas de assistência. É deste modo, controle e disciplinamento e não criminalização o que evidencia os documentos analisados, a cerca destas instituições. O modo que explicitamente havia uma diferença de método, de justificava, de classificação que buscava diferenciar a pobreza criminosa punível da pobreza que deveria ser "domesticada", "docilizada", disciplinada pelos regulamentos e regras para que se transformasse em força de trabalho, tal qual e, no mesmo ditame que o faz o disciplinamento da sociedade escolar. Com este olhar que passaremos a demonstrar o modo como a polícia esteve à frente da constituição das "instituições preventivas".

Podemos perceber que a partir da primeira década do século XX há uma clara organização da assistência social estatal por parte das instituições policiais. Esta organização para o controle da pobreza urbana seguia uma lógica de ação que inevitavelmente adotava a metodologia do recolhimento, classificação e encaminhamento para os diferentes destinos. Algo muito parecido com o que 
observarmos em diversos momentos do final do século XX e início do XXI feito por equipes da Secretaria Municipal de Assistência Social da cidade do Rio de Janeiro. Esta metodologia da polícia já presente no final do século XIX não difere em muito do que se pratica na atualidade para lidar com a problemática da pobreza urbana exposta nas ruas da cidade. Discutiremos estes pormenores demostrando a continuidade desta prática e suas aparentes rupturas no capítulo final.

Após a polícia recolher os pobres válidos e inválidos, que por diversos motivos encontravam-se em situações também diversas pelas ruas, geralmente, centrais da cidade do Rio de Janeiro, estes eram levados para o xadrez da polícia, mais tarde chamado de depósito de presos. Neste local passavam por uma triagem classificatória de onde erem enviados para as diversas instituições policiais preventivas ou punitivas. Como no dizer de Vianna (1999, p. 41), ao falar dos encaminhamentos de menores feito pela polícia, "uma certa distribuição simbólica, perceptível na construção de imagens diferenciadas para cada instituição", que serviria a cada tipo de pobre, de acordo com a classificação. Para resposta cotidiana do ordenamento e disciplinamento da pobreza urbana na cidade do Rio de Janeiro, a polícia contava com instituições próprias, particulares, além de instituições de outros ministérios. Havia também os encaminhamentos feitos diretamente pelos chefes de polícia e delegados sem a passagem pelo xadrez da polícia, ou uma triagem feita diretamente na Casa de Detenção.

Entre as inciativas particulares que a polícia contava para o encaminhamento dos pobres urbanos recolhidos, havia o encaminhamento para o juizado de órfãos, quando se tratava de menores, de onde eram enviados aos cuidados de particulares, geralmente funcionários públicos ou militares. Misturava-se nesta medida a questão do trabalho doméstico que passava a ser uma solução de encaminhamento também para os pobres maiores de idade considerados aptos. Havia ainda uma série de instituições particulares ${ }^{75}$ e diferentes perfis de asilos para os quais a polícia encaminha os pobres recolhidos. Sobre estes asilos, os chefes de polícia dirigiamse em seus relatórios as assembleias legislativas, imperador e presidentes, reivindicando subvenções. Contava, ainda, com os diversos serviços da Santa Casa de Misericórdia, que também recebia subvenção do governo. Havia ainda, quando se tratava de estrangeiros, o envio para os diversos consulados ou beneficências.

\footnotetext{
${ }^{75}$ Para saber mais sobre a quantidade e diversidade destas instituições ver Rangel (2013).
} 
Toda esta descrição acima foi baseada nos relatórios pesquisados dos chefes de polícia.

Contava também a polícia com outros setores do governo, os quais tinham estreitas relações de parceria com as instituições policiais, da mesma forma como acontecia com os diversos tipos de instituições particulares. Os chefes de polícia demonstravam claramente em seus relatórios a articulação com outros ministérios para a resolução da demanda diária dos distintos casos que tinham que resolver, para eficácia do controle e disciplinamento da população pobre urbana. Conforme podemos verificar nos relatórios, os chefes de polícia articulavam com o Ministério da Marinha para o envio de vários tipos de perfis de pobres recolhidos para a armada. Entre os tipos de pobres que eram enviados para armada, encontramos os menores e um considerável número de desertores. O que mostra que não era nada agradável ficar nesta instituição que pregava o controle e disciplinamento, via trabalho, em muitos casos forçado. Além do Ministério da Marinha, havia uma articulação direta do chefe de polícia da cidade do Rio de Janeiro com o Ministério da Agricultura, Indústria e Comércio. Esta parceria sustentou a principal ação das instituições policiais para o controle do pobre válido não criminalizado, qual seja, o envio dos menores, vadios e vagabundos "corrigíveis" para os patronatos agrícolas, que faziam parte da estrutura administrativa e ações do Ministério da Agricultura, Indústria e Comércio (1860 a 1960). Interessante observar que a relação das instituições policiais com estes ministérios não se configurava somente no exercício da demanda cotidiana junto ao chefe de polícia. No segundo momento passa a haver uma relação com as escolas industriais no grande centro, na busca por regular o conflito diário das relações de trabalho. Havia também uma articulação via ministro da justiça, na qual o chefe de polícia ajudava a embasar seus argumentos com dados estatísticos e gerencias das instituições, que dizia respeito a pleitear verbas juntos as assembleis legislativas.

Além dos recursos da rede que havia montado, a polícia, para dar resposta cotidiana no controle da pobreza inválida e válida não criminalizada, tinha suas próprias instituições. Entres estas instituições, no período de nossas pesquisas, encontramos o Asylo de Mendicidade, a Escola de Menores Abandonados e a Escola Quinze de Novembro, as quais trataremos em pormenores a seguir. Além destas instituições, havia também a Colônia Correcional dos Dous Rios para onde também se enviava menores, ainda que em número bem reduzido. A Colônia 
Correcional dos Dous Rios nos interessa como o contraponto para demonstrar a diferença que havia entre as três instituições citadas acima. A Colônia era voltada para a pobreza criminalizada, que devia ser punida e banida, enquanto que as outras três instituições citadas tinham por claro objetivo atuar junto a pobreza não criminalizada válida e inválida, que deveria ser disciplinada e humanisticamente protegida. Para a Colônia, eram embarcados em sua maioria, homens, maiores de idade, claramente envolvidos em crimes, ou classificados como vadios e vagabundo incorrigíveis. Para as outras três instituições, estava posto, ainda que somente em suas justificativas e intenções, acolher, ajudar, proteger, regenerar, disciplinar e instruir pelo e para o trabalho. Havia também o Hospício Nacional dos Alienados, entre outras instituições do gênero, que eram gerenciados pelo Ministério da Justiça. Esta instituição, anteriormente nominada de Hospício Pedro II, fazia parte do conjunto da Santa Casa de Misericórdia. Com o advento da República, passa para a gestão estatal, sobre a qual o chefe de polícia exercia poder de fiscalização e gestão, enquanto instância da alta administração do Ministério da Justiça.

A tabela abaixo confirma a clara separação das instituições policiais, entre aquelas feitas para punir e segregar e as nitidamente de assistência, concebida para regenerar e formar trabalhadores saudáveis, dóceis e úteis. Tabela 6. Número de pessoas admitidas no ano nas instituições policias
(1909 a 1913)

\begin{tabular}{|c|c|c|c|c|c|c|c|c|c|}
\hline Ano & $\begin{array}{c}\text { Escola } \\
\text { Quinze de } \\
\text { Novembro }\end{array}$ & $\begin{array}{r}\text { Esc } \\
\text { Me } \\
\text { Abanc }\end{array}$ & $\begin{array}{l}\text { a de } \\
\text { ores } \\
\text { nados }\end{array}$ & $\begin{array}{r}\text { Ho } \\
\text { Naci } \\
\text { Alie }\end{array}$ & $\begin{array}{l}\text { ital } \\
\text { aal de } \\
\text { ados }\end{array}$ & $\begin{array}{r}\text { As } \\
\text { S. Fra } \\
\text { A }\end{array}$ & $\begin{array}{l}\text { de } \\
\text { isco de } \\
\text { is }\end{array}$ & $\begin{array}{r}\text { Co } \\
\text { Corr } \\
\text { dos D }\end{array}$ & $\begin{array}{l}\text { nia } \\
\text { ional } \\
\text { Rios }\end{array}$ \\
\hline \multirow{3}{*}{$1913^{76}$} & \multirow{3}{*}{89} & \multicolumn{2}{|c|}{310} & \multicolumn{2}{|c|}{1.373} & \multicolumn{2}{|c|}{119} & \multicolumn{2}{|c|}{234} \\
\hline & & M & $\mathrm{F}$ & M & $\mathrm{F}$ & $\mathrm{M}$ & $\mathrm{F}$ & M & $\mathrm{F}$ \\
\hline & & $\begin{array}{c}176 \\
56,8 \%\end{array}$ & $\begin{array}{c}134 \\
43,2 \%\end{array}$ & $\begin{array}{c}909 \\
66,2 \%\end{array}$ & $\begin{array}{c}464 \\
33,8 \%\end{array}$ & $\begin{array}{c}63 \\
52,9 \%\end{array}$ & $\begin{array}{c}56 \\
47,1 \%\end{array}$ & $\begin{array}{c}169 \\
72,2 \%\end{array}$ & $\begin{array}{c}65 \\
27,8 \%\end{array}$ \\
\hline \multirow{3}{*}{$1912^{77}$} & \multirow{3}{*}{91} & \multicolumn{2}{|c|}{323} & \multicolumn{2}{|c|}{1.256} & \multicolumn{2}{|c|}{95} & \multicolumn{2}{|c|}{386} \\
\hline & & $\mathrm{M}$ & $\mathrm{F}$ & $\mathrm{M}$ & $\mathrm{F}$ & $\mathrm{M}$ & $\mathrm{F}$ & $\mathrm{M}$ & $\mathrm{F}$ \\
\hline & & $\begin{array}{c}177 \\
54,8 \%\end{array}$ & $\begin{array}{c}146 \\
45,2 \%\end{array}$ & $\begin{array}{c}738 \\
58,8 \%\end{array}$ & $\begin{array}{c}518 \\
41,2 \%\end{array}$ & $\begin{array}{c}54 \\
56,8 \%\end{array}$ & $\begin{array}{c}41 \\
43,2 \%\end{array}$ & $\begin{array}{c}317 \\
82,1 \%\end{array}$ & $\begin{array}{c}69 \\
17,9 \%\end{array}$ \\
\hline \multirow{2}{*}{$1911^{78}$} & & \multicolumn{2}{|c|}{697} & \multicolumn{2}{|c|}{1.204} & \multicolumn{2}{|c|}{65} & \multicolumn{2}{|c|}{216} \\
\hline & & $\mathrm{M}$ & $\mathrm{F}$ & $\mathrm{M}$ & $\mathrm{F}$ & M & $\mathrm{F}$ & M & $\mathrm{F}$ \\
\hline
\end{tabular}

${ }^{76}$ BRASIL. Ministério da Justiça e Negócio Interiores. Relatório dos anos de 1913 e 1914. Rio de Janeiro. Imprensa Nacional, 1915b, p. 91.

${ }^{77}$ BRASIL. Ministério da Justiça e Negócio Interiores. Relatório dos anos de 1912 e 1913. Rio de Janeiro. Imprensa Nacional, 1913, p. 77.

${ }^{78}$ BRASIL. Ministério da Justiça e Negócio Interiores. Relatório dos anos de 1911 e 1912. Rio de Janeiro. Imprensa Nacional, 1912, p 78. 


\begin{tabular}{|c|c|c|c|c|c|c|c|c|c|}
\hline & & $\begin{array}{c}174 \\
25 \%\end{array}$ & $\begin{array}{c}523 \\
75 \%\end{array}$ & $\begin{array}{c}762 \\
63,6 \%\end{array}$ & $\begin{array}{c}442 \\
36,7 \%\end{array}$ & $\begin{array}{c}23 \\
35,4 \% \\
\end{array}$ & $\begin{array}{c}42 \\
64,6 \%\end{array}$ & $\begin{array}{c}165 \\
76,4 \%\end{array}$ & $\begin{array}{c}51 \\
23,6 \%\end{array}$ \\
\hline \multirow{4}{*}{$1910^{79}$} & \multirow{4}{*}{92} & \multicolumn{2}{|c|}{417} & \multicolumn{2}{|c|}{1.141} & \multicolumn{2}{|c|}{99} & \multicolumn{2}{|c|}{350} \\
\hline & & M & $\mathrm{F}$ & $\mathrm{M}$ & $\mathrm{F}$ & M & $\mathrm{F}$ & M & $\mathrm{F}$ \\
\hline & & 219 & 198 & 654 & 487 & 52 & 47 & 292 & 58 \\
\hline & & $52,5 \%$ & $47,5 \%$ & $57,3 \%$ & $42,7 \%$ & $52,5 \%$ & $47,5 \%$ & $83,4 \%$ & $16,6 \%$ \\
\hline \multirow{4}{*}{$1909^{80}$} & \multirow{4}{*}{76} & \multicolumn{2}{|c|}{471} & \multicolumn{2}{|c|}{975} & & & \multicolumn{2}{|c|}{546} \\
\hline & & $\mathrm{M}$ & $\mathrm{F}$ & $\mathrm{M}$ & $\mathrm{F}$ & $\mathrm{M}$ & $\mathrm{F}$ & $\mathrm{M}$ & $\mathrm{F}$ \\
\hline & & 223 & 218 & 616 & 359 & & & 420 & 126 \\
\hline & & $47,3 \%$ & $46,3 \%$ & $63,2 \%$ & $36,8 \%$ & & & $76,9 \%$ & $23,1 \%$ \\
\hline
\end{tabular}

A sistematização da amostra acima nos permite demonstrar a correlação entre masculino e feminino quando observamos as diferentes instituições policias. Percebemos nitidamente que quando se trata das instituições preventivas ou de apoio e ajuda como são os casos da Escola de Menores Abandonados e o Asylo de S. Francisco de Assis a diferença quantitativa entre masculino e feminino fica em trono de $10 \%$. Intrigante observar que no ano de 1911 entra mais mulheres do que homens, tanto na Escola de Menores Abandonados, quanto no Asylo de S. Francisco de Assis, com expressivas diferenças. A Escola Quinze de Novembro não se inclui neste raciocínio, pois só havia vagas para o sexo masculino.

No entanto, quando olhamos para os enviados para a Colônia Correcional dos Dous Rios, percebemos uma correção estatística entre masculino e feminino que aponta uma diferença em torno de $80 \%$ de masculino. A este respeito vale ressaltar a pesquisa feita por mim para a dissertação de mestrado, que analisou os livros de entradas de presos menores de 21 anos na casa de detenção da cidade do Rio de Janeiro. A relação masculino-feminino na entrada de presos também se configurava a mais de $80 \%$ de presos masculinos (Souza, 2010). Nas duas instituições onde a polícia de fato criminalizava a pobreza era certo o número ínfimo de mulheres, o que claramente se liga aos aspectos de criminalização, deixando transparecer claramente o fato sociológico da moral, da religião e dos comportamentos que significava o local da mulher na sociedade da época. Nas instituições policiais de assistência a correlação estatística aponta certa paridade com diferenças que giram em torno de 10\%. Este fato, segundo nossa interpretação, demonstra que, dependendo do caso, não se tratava de criminalizar as expressões da questão social,

\footnotetext{
${ }^{79}$ BRASIL. Ministério da Justiça e Negócio Interiores. Relatório dos anos de 1910 e 1911 . Rio de Janeiro. Imprensa Nacional, 1911, p. 78.

${ }^{80}$ BRASIL. Ministério da Justiça e Negócio Interiores. Relatório dos anos de 1909 e 1910. Rio de Janeiro. Imprensa Nacional, 1910, p. 88.
} 
mas de disciplinar e controlar, pois o Estado precisava de formar cidadãos saudáveis, dóceis e úteis, para construir seu esplendor pela força trabalho (Foucault, 2001).

Este aspecto do baixo percentual de mulher em relação aos homens, quando se tratava de instituições policiais voltadas para o criminoso, aquelas que por definição e prática lidava diretamente com a pobreza válida classificada como criminosa. Relacionado com o fato de que a diferença quantitativa de homens e mulheres nas instituições consideradas preventivas e humanitárias ficava em torno de $10 \%$, demonstra, de acordo com nosso ponto de vista, que as instituições policiais também desenvolviam ações estritamente de assistência social, que não devem ser interpretadas como repressivas ou criminalizantes, mas sim como da ordem do controle e disciplinamento. As estatísticas policiais demonstraram claramente que quando se tratava de crime, da criminalização de comportamentos, pessoas e classes a presença de mulheres era pouco significativa, do ponto de vista quantitativo. No entanto, quanto se tratava das instituições policiais voltadas para a pobreza não criminalizada, percebemos a importância quantitativa das mulheres, em alguns casos como maioria. Esta importância quantitativa também pode ser vista quando se tratava dos alienados. A observância destas correlações estatísticas nos permite afirmar, ainda com mais veemência e consistência, o fato de que as instituições policiais protagonizaram pela via da ação estatal a construção da história da assistência social na cidade do Rio de Janeiro. Os aspectos de controle e disciplinamento da pobreza que não envolviam a ideia de criminalização, ainda que a institucionalização e o confinamento fossem a regra, afinal também assim o era nos países "civilizados" pelos modernos princípios da ciência, podem ser observadas pelos encaminhamentos realizados pela polícia. Por exemplo, em 1906, descrevia o chefe de polícia Dr. Alfredo Pinto Vieira de Mello, que

encontraram-se na via-publica: Abandonados 11 recém-nascidos, 5 do sexo masculino e 6 do feminino, os quaes a policia mandou recolher á Casa dos Expostos. A mendigar 48 indivíduos, sendo 26 homens e 22 mulheres; 21 brazileiros e 27 estrangeiros, os quaes foram enviados para o Asylo de S. Francisco de Assis ${ }^{81}$.

\footnotetext{
${ }^{81}$ BRASIL. Ministério da Justiça e Negócio Interiores. Relatório dos anos de 1905 e 1906 - Volume
} 01. Rio de Janeiro. Imprensa Nacional, 1906a, p. 82. 
Interessante observar que a Casa dos Expostos era da Santa Casa de Misericórdia e o Asylo S. Francisco de Assis foi como passou a se chamar o Asylo de Mendicidade depois que sua administração ficou por conta da municipalidade. Cabe destacar também o impositivo do verbo "mandou", ao se referir o chefe de polícia desembargador Dr. Manoel José Espínola, aos encaminhamentos realizados. É fato que o Ministério da Justiça e a polícia, enquanto sua instância executora era quem fiscalizava, influenciava na efetivação de verbas governamentais e interferia diretamente na gestão de vagas das instituições filantrópicas públicas e particulares. O movimento da Albergaria de Mendigos é bastante revelador dos destinos traçados para a pobreza inválida e das diversas articulações para a formação de uma rede para encaminhamento de cada caso. No ano de $1872^{82}$, por exemplo, 171 mendigos foram remetidos para o hospital da Misericórdia, dos quais 63 retornaram para a albergaria, 13 foram removidos para o Hospício Pedro II, 34 foram encaminhados para a lavoura, 49 assinaram "termo de tomar ocupação honesta" e "7 morreram no asylo". De modo que podemos demonstrar que, por mais que houvessem casos, não era de pobres apenados que se constituía os frequentadores das instituições policiais de assistência. Nesta perspectiva que trataremos de alguns aspectos históricos do Asylo de Mendicidade, da Escola Quinze de Novembro e da Escola dos Menores Desvalidos.

\subsection{O Asylo de Mendicidade}

Também é só o que falta no nosso paiz, devido ao descuido de alguem que deve tratar disso; apesar que já ha um projecto, para se edificar um asylo e Mendicidade; $e$ se hoje ha um muito pequeno, na paria de Santa Luzia, foi devido á mofina continuada do Periódico do Pobres, e atendida pelo benemérito cavalheiro Alexandre José Siqueira.

Periódico dos Pobres, Rio de Janeiro, 20 de abril de 1871, p. 2.

O Asylo de Mendicidade se constitui em uma das práticas sociais e institucionais relativa às ações governamentais exercidas pela polícia mais

82 BRASIL. Ministério da Justiça. Relatório do ano de 1871. Rio de Janeiro. Typographia Americana, 1872a, p. A-194. 
representativa para nossa tese. Sua história demonstra a relação direta da polícia com os meios técnicos-científicos de administração da pobreza urbana e explicita a relação entre a polícia e a municipalidade na gestão da assistência social na cidade do Rio de Janeiro. O estudo do Asylo de Mendicidade nos proporciona demonstrar os aspectos relativos ao papel da assistência social para a eficácia das técnicas e estratégias policiais. Até então, apesar de estudar durante anos a história da assistência social na cidade do Rio de Janeiro, principalmente através da história da infância, nunca havia me deparado com autores que estudassem ou ao menos citassem o Asylo de Mendicidade na perspectiva dos estudos da assistência social. Após exaustiva pesquisa em fontes secundárias - citadas no decorrer do texto -, podemos perceber que os estudos que citam o Asylo de Mendicidade, tratam deste apenas como preambulo para se contar a história do Hospital São Francisco ${ }^{83}$ de Assis, que funciona até a atualidade nas antigas instalações do asylo. Encontramos também outros trabalhos que tratam da história do asilo ligado a formação da Escola de Enfermagem Ana Neri da UFRJ. É fato demonstrável que o Asylo de Mendicidade, uma importante instituição estatal para a reconstrução histórica da assistência social e médica, teve sua história estudada exclusivamente pela medicina, enfermagem, arquitetura e urbanismo. Destacamos quatro trabalhos acadêmicos que tem o Asylo de Mendicidade como objeto central de seus estudos, quais sejam: a dissertação de Mestrado de Osnir Claudiano da Silva Junior ${ }^{84}$ apresentado ao Instituto de Medicina Social da UERJ, o qual através da história do Asylo de Mendicidade discutiu a formação da medicina social na cidade do Rio de Janeiro; a dissertação de Mestrado de Gouvêa ${ }^{85}$, que estudou o Asylo de Mendicidade pelo aspecto arquitetônico, Aguinaga. $\mathrm{H}^{86}$, médico, ex-diretor do Hospital Escola São Francisco de Assis, talvez o trabalho de maior fôlego que é publicado em 1976 por ocasião do centenário do lançamento da pedra fundamental do Asylo. E, por fim, o trabalho de Pinto, W. de M. que em 1990 discute as

83 Este hospital, atualmente da UFRJ é referência nos estudos do HIV/AIDS e continua extremamente importante para o estudo do desenvolvimento da medicina social na cidade do Rio de Janeiro, mantendo de certo modo a tradição de estar voltado ao atendimento da pobreza.

${ }^{84}$ SILVA JUNIOR, O. C. Do Asylo da Mendicidade ao Hospital Escola São Francisco de Assis: A Mansão dos Pobres. Rio de Janeiro: Papel Virtual, 2000.

${ }^{85}$ GOUVÊA, M. T. de. Hospital Escola São Francisco de Assis: um marco do neoclássico tardio. Dissertação de Mestrado apresentada à Faculdade de Arquitetura e Urbanismo da Universidade Federal do Estado do Rio de Janeiro, 1987

${ }^{86}$ AGUINAGA. Hélio. Hospital São Francisco de Assis: história. Centenário de lançamento da pedra fundamental 1876-1976. Rio de Janeiro: Companhia Brasileira de Artes Gráficas, 1976. 
características do conjunto arquitetônico do Hospital Escola São Francisco de Assis ${ }^{87}$. Além destes trabalhos encontramos alguns artigos como, por exemplo, "O Asylo da Mendicidade e os planos urbanísticos do século XIX no Rio de Janeiro" (Amora \& Souza, 2014), que traz uma interessante interpretação sobre o significado do asilo no processo de modernização e "civilização" da cidade do Rio de Janeiro, claramente associados aos planos urbanísticos.

É possível afirmar que nenhum trabalho existia até o momento de nossa pesquisa que tenha usado o Asylo de Mendicidade com relevância para os estudos da assistência social na cidade do Rio de Janeiro. Segundo nossa particular interpretação, o Asylo de Mendicidade deve ser incluído de modo relevante no espectro que instituiu as práticas de assistência social na cidade do Rio de Janeiro. Este aspecto nos levou a dedicar um pouco mais de tempo para o Asylo de Mendicidade, do que para as ouras intuições preventivas da polícia, Escola Quinze e Novembro e Escola de Menores Desvalidos. Ainda assim é preciso esclarecer que não se trata de uma reconstrução história das intuições em questão, em nenhum dos casos. Mesmo o Asylo de Mendicidade que nos ateremos um pouco mais não teve este objetivo. Nosso intento foi demonstrar através dos relatórios pesquisados que estas eram instituições policiais, não penais e, sim assistenciais.

Se quisermos buscar um sentido de continuidade para a história de como o Estado passou a lidar como a pobreza urbana na cidade do Rio de Janeiro temos que inevitavelmente nos remeter a Albergaria da Praia de Santa Luzia, em 1854. Esta passou a funcionar onde anteriormente era um matadouro, que estava estabelecido no local desde 1777. Este matadouro, por questões de higiene pública, foi transferido para São Cristóvão, de certo modo, influenciado pelas recomendações do relatório de 1843 do engenheiro Henrique Pedro Carlos de Beaurepaire Rohan que era marechal e foi diretor das obras municipais (Amora \& Souza, 2014). Estas mudanças urbanísticas foram realizadas por intervenção do Conselheiro José Tomás Nabuco de Araújo, então Ministro de Secretário de Estado dos Negócios da Justiça, que junto com Chefe de Polícia Desembargador José Joaquim de Siqueira realizaram articulações para conseguir verbas e apoio político nesta direção.

87 PINTO, W. de M. Hospital Escola São Francisco de Assis: características do conjunto arquitetônico. UFRJ, 1990 (mímeo). 
A Albergaria de Mendigos era diretamente subordinada ao chefe de polícia da Corte. A partir da criação desta albergaria com cerca de setenta vagas, foi determinado pelas autoridades judiciárias, no uso do código criminal de 1830, que todos aqueles identificados - classificados - como os mendigos encontrados na rua deveriam ser recolhidos na albergaria, que obviamente, não tinha vagas para todos os recolhidos. Funcionou no primeiro momento, basicamente, como pernoite para "indigentes". O regulamento ainda estabelecia que os aptos ao trabalho devessem ser encaminhados para a Casa de Correção e aqueles acometidos por doenças para a Santa Casa da Misericórdia.

Percebemos claramente, que já no regulamento fundante da Albergaria de Mendigos de onde se origina o Asylo de Mendicidade estava posto que sua finalidade era para os não aptos ao trabalho, ou seja, era claramente uma ação assistencial das instituições policias para a pobreza inválida. Podemos considerar pelos aspectos apresentados acima que a Albergaria de mendigos da Praia de Santa Luzia foi a primeira ação do Estado de uma prática de assistência social pública, como a base de uma estrutura governamental, que por cerca de 20 anos "acolheu" os mendigos e os "alienados mansos, não aceitos no Hospício Pedro II" (Aguinaga, 1976, p. 42 apud Silva Júnior, 2000, p. 36). A esse respeito, escreveu o ministro da justiça Dr. Manuel Antonio Duarte de Azevedo, no relatório referente ao ano de 1873, que "é justo, entretanto, confessar que a nascente instituição, que parece apenas tolerada, tem sido de grande utilidade, produzindo beneficos resultados durante o período de quasi 20 annos" $"$.

Com a epidemia de cólera, em 1855, a Albergaria de Mendigos passa a disponibilizar alimentos e vestuário, internando os acometidos de doenças incuráveis não aceitos nos hospitais da Santa Casa de Misericórdia. Neste sentido, afirmava o chefe de polícia Dr. Tito Matos, em seu relatório referente ao ano de 1873, que

na calamitosa epocha em que o cólera morbus invadio esta cidade, foram na albergaria alojados por ordem superior os mendigos, fornecendo-se-lhes alimento e roupa. Cessando a epidemia e estando esses proletários habituados ao gozo das alludidas vantagens, (grifo nosso) entendeu-se que seria deshumano prival-os do

88 BRASIL. Ministério da Justiça. Relatório do ano de 1873. Rio de Janeiro. Typographia Americana, 1874, p. 30. 
beneficio, a que se haviam acostumado. Continuou a policia, com a acquiescencia do Governo, a alimental-os e vestil-os. Eis a historia da albergaria de mendigos ${ }^{89}$.

Importante destacar no trecho do relatório transcrito acima, que confirma-se mais o fato da polícia realizar ações estritamente de assistência sem carater criminológico. Este protagonismo na ação estatal de assistência para os pobres inválidos fica ainda mais evidente quando afirma o referido chefe de polícia, que " a albergaria não tem regulamento, estando seu regimen interno dependente das providencias dadas pelo respectivo inspector e de instrucções peculiares do chefe de policia" ${ }^{90}$. Destacamos também, no trecho do relatório acima, a ideia presente no discurso do chefe de polícia de que o "assistencialismo" - fornecer alimento e roupa - mesmo após o fim da epidemia, acostumou o proletário ao "gozo das "alludidas vantagens", tornando-o dependente da assistência e um leniente pela preguiça. Encontramos claramente este tipo de ideia como uma das representações sociais da pobreza largamente difundia tanto pelo senso comum, quanto por correntes cientificas, ideologias e discursos de governos, até nossa contemporaneidade.

No mesmo sentido que escrevia o chefe de polícia Tito Matos em 1873, redigia o chefe de polícia desembargador Manoel José Espínola, no relatório referente ao ano de 1887 que,

em virtude do aviso do ministério da justiça de 14 de agosio de 1854, estabeleceuse provisoriamente o asylo dos mendigos nesta corte num telheiro na praia de Santa Luzia, de que estava empossada a Illma camara municipal, e que fôra por ella cedido á polícia em officio de 14 de janeiro daquelle anno, sob o condição de ser pago pelo estado o fôro annual de 14\$000, que ella pagava a Luiz Gomes dos Anjos, proprietário do referido terreno. Com o apparecimento do cholera-morbus, que em 1856 victimou esta cidade deu-se maior desenvolvimento ao estabelecimento, denominado então albergaria, nelle alojando-se muitos indigentes, os quaes recebiam alimento, roupa e o necessário tratamento ${ }^{91}$.

Em relação a este aspecto podemos ver interessante resumo no relatório ministério referente ao ano de 1887. Segundo o chefe de polícia Desembargador Manoel José Espínola,

89 BRASIL. Ministério da Justiça. Relatório do ano de 1877. Rio de Janeiro. Typographia Perseverança, 1878, p. A5-53.

${ }^{90}$ BRASIL. Ministério da Justiça. Relatório do ano de 1877. Rio de Janeiro. Typographia Perseverança, 1878, p. A5-53.

${ }^{91}$ BRASIL. Ministério da Justiça. Relatório do ano de 1887. Imprensa Nacional, 1888 p. 141. 
com o desapparecimento da epidemia, continuou a funccionar a albergaria sem onus para os cofres públicos, pois era sustentada por donativos. Assim esteve até que foi votado credito para a despeza com os mendigos, incluída na verba a "conducção, sustento e curativo dos presos". Tendo a lei n. 2670 de 20 de outubro de 1875 concedido o credito de 100:000\$000 para a construção de um asylo, deuse começo á obra, e em $1^{\circ}$ de junho de 1879 foi inaugurado o novo asylo ${ }^{92}$.

Desde então foi votado credito especial para o Asylo de Mendicidade, como estabelecimento a cargo do Ministério da Justiça. O mesmo chefe de polícia no relatório do ano posterior (1888) expunha seu ponto de vista sobre a criação da albergaria e do asylo.

Por falta de casas de beneficência particular, ou de assistência publica, que recolhessem os vagabundos miseráveis de toda espécie, abandonados nas ruas da cidade, o ministério da justiça em 1854 designou um telheiro da praia de Santa Luzia para o alojamento desses infelizes sob a inspecção do chefe de policia; e embora melhorado e occrescentado, esse albergue, como foi denominado, dentro de poucos annos não comportava o grande numero de mendigos, nem permittia a separação por classes, em relação á idade, ao sexo, as enfermidades ${ }^{93}$.

Segundo o desembargador Manoel José Espínola, foram estas condições depreciativas da Albergaria que levou o governo a promulgar a lei de criação do Asylo de Mendicidade em 1875. O relatório do chefe de polícia Dr. Tito Algusto Pereira de Matos referente ao ano de 1877, traz esclarecedor detalhe sobre as condições da albergaria de mendigos e tipo de ação que ali era desenvolvido pela polícia. Afirmava o referido chefe que "muito limitado era então o destino d'aquelle estabelecimento, servindo apenas para dar agasalho durante a noite aos infelizes que viviam de esmolas e por falta de domicilio dormiam nas ruas e praças, ou sob o alpendre das igrejas" "94. Segundo informava o Dr. Tito Matos, apesar das "somas consideráveis" desembolsadas "pelos cofres do Estado" a Albergaria de mendigos "não passa de um miserável pardieiro".

Este pardieiro era a única iniciativa que havia destinada a pobreza inválida, tinha em seu principal público o pobre doente incapacitado para o trabalho. Havia

\footnotetext{
92 Idem.

${ }^{93}$ BRASIL. Ministério da Justiça. Relatório do ano de 1888. Rio de Janeiro. Imprensa Nacional, 1889 p. 122.

94 BRASIL. Ministério da Justiça. Relatório do ano de 1877. Rio de Janeiro. Typographia Perseverança, 1878, p. A5-53.
} 
na albergaria a atividade econômica da qual os mendigos eram "aproveitados no serviço de desfiamento d'estôpa e ás vezes na lavagem de roupa de particulares" 95. O orçamento da Albergaria era composto pelo "producto da estopa desfiada e da lavagem de roupa" ${ }^{96}$, de onde "comprava-se o vestuario para os mendigos e alguns utensilios de valor menos elevado, correndo por conta do Estado ${ }^{97}$ a despeza com a alimentação e com o pessoal ${ }^{98}$.

Podemos demonstrar através dos relatórios analisados que a construção do Asylo de Mendicidade era questão da qual os chefes de polícia eram os principais animadores, junto com diversos outros setores da sociedade. Em ofício n. 106 de 27 de fevereiro de 1871 o chefe da polícia Dr. Ludgero Gonçalves da Silva se manifesta "sobre a remoção da albergaria de mendigos para o terreno pertencente aos religiosos carmelitas" $" 99$ ao ministro Dr. Manuel Antonio Duarte de Azevedo, nos seguintes termos:

Convém providenciar sobre a creação de um estabelecimento normal para os mendigos, com a precisa capacidade para lavanderias oficinas adaptadas ás suas forças. $O$ estado em que atualmente esta a albergaria, é por demais acanhado, e por isso vagam ahi pelas ruas muitos mengios, que deveriam ser a ella recolhidos; (...) como reclama a moralidade pública ${ }^{100}$.

Reclamava o chefe de polícia Dr. Ludgero que a albergaria recolhe

não só os mendigos propriamente ditos, como também outros infelizes, que devem ser amparados, já por não poderem socoorrer por seu trabalho ás necessidades da vida, e jà por soffrerem do alienação mental, por não haver no hospício de Pedro II lugar onde possam ser recolhidos ${ }^{101}$.

Percebemos nas citações acima que o chefe de polícia Dr. Ludgero buscava soluções e respostas para o ordenamento da pobreza inválida, entre os diversos

\footnotetext{
95 Idem.

${ }^{96}$ Idem.

97 "No exercício de 1876 a 1877 despendeu o Thesouro nacional com a albergaria de mendigos 13:5745020, sendo 12:1948020 com a alimentação, 1:380\$000 com o pessoal” (BRASIL. Ministério da Justiça. Relatório do ano de 1877. Rio de Janeiro. Typographia Perseverança, 1878, A5-55).

${ }^{98}$ Idem, p. A5-53-4.

${ }^{99}$ BRASIL. Ministério da Justiça. Relatório do ano de 1871. Rio de Janeiro. Typographia Nacional, 1872 b p. A-27.

${ }^{100}$ Idem.

101 BRASIL. Ministério da Justiça. Relatório do ano de 1872. Rio de Janeiro. Typographia Americana, 1873, p. A-207.
} 
perfis de pobres inválidos, tinha também que responder sobre os alienados. Afirmava o mesmo chefe de polícia, um ano mais tarde, em 1872, que mesmo contando com a "benevolência" do provedor da Santa Casa, que lhe dispõe algumas vagas, estas não suprem as necessidades dos alienados existentes na Albergaria. Neste sentido, reclama providencias urgentes devido a gravidade do assunto, pois

não havendo enfermaria na Albergaria, por serem os enfermos enviados para o hospital de Misericórdia, ficam os alienados, que não são aceitos neste hospital, privados de qualquer tratamento medico, tornando-se conseguintemente incuravel a cruel enfermidade que os acommettera ${ }^{102}$.

Da mesma maneira que afirmara o chefe de polícia Dr. Ludgero Gonçalves da Silva em 1872, protestou, ainda com mais veemência, o chefe de polícia Dr. Tito Algusto Pereira de Matos no relatório referente ao ano de 1877.

$E^{\prime}$ digno de compaixão o estado desses desgraçados que nao recebem socorros médicos quer para minorar o progresso da alienação mental, quer mesmo no caso de serem acommettidos de alguma outra enfermidade, por nao haver enfermaria no estabelecimento nem poderem ser removidos para o hospital da Misericórdia, onde nao se permitte o ingresso aos que apresentam o mais ligeiro symptoma de enfraquecimento das faculdades mentaes. Morrem à mingua!! ${ }^{103}$

Era uma grita geral, sociedade, imprensa e chefe de polícia denunciando que o "edifício, em que se acha a Albergaria, não tem a necessária capacidade para o fim a que pe destinado, convindo removel-a para local aporpirado, como por diversas vezes se tem representado" $" 104$. Com este fim escrevia Dr. Ludgero em todos os relatórios durante o período em que foi chefe de polícia (1871 a 1874) que "esta capital reclama imperiosamente a creação de um asylo normal para mendigos, onde possam occupar-se em trabalho compatível com suas forças ${ }^{105}$.

No relatório de referente ao ano de 1875, escreve o chefe de polícia Dr. Miguel Calmon du Pin e Almeida, que "attendendo a uma necessidade publica ha muito reclamada, decretou os fundos precisos para a construcção de um asylo de

\footnotetext{
102 Ibidem.

103 BRASIL. Ministério da Justiça. Relatório do ano de 1877. Rio de Janeiro. Typographia Perseverança, 1878, p. A5-54.

104 BRASIL. Ministério da Justiça. Relatório do ano de 1872. Rio de Janeiro. Typographia Americana, 1873, p. A-207.

105 BRASIL. Ministério da Justiça. Relatório do ano de 1873. Rio de Janeiro. Typographia Americana, 1874, p. A-201.
} 
mendicidade ${ }^{106}$, foi promulgado a lei orçamentária n. 2670 de 20 de $1875,{ }^{107}$ que prevê a construção de um asilo na rua Visconde de Itaúna. Segundo informava o referido chefe de polícia, "o novo asylo já está começado, e segundo a planta adoptada, tem capacidade para 600 asylados, com as convenientes separações para adultos e crianças, e para ambos os sexos. É de esperar que em poucos mezes possam os asylados ser transferidos para a sua nova habitação" ${ }^{108}$. Esta lei autorizava o governo a gastar cem mil reis no exercício orçamentário de 1876 e 1877 para a aquisição e construção de um edifício para instalação do asylo de mendicidade. De acordo com o ministro da justiça, Dr. Lafayette Rodrigues Pereira, "o Art. $16 \S 8^{\circ}$ da Lei n. 2670 de 20 de Outubro de 1875 autorisou o Governo para construir o novo Asylo de mendicidade e dar-lhe o necessário regulamento" ${ }^{109}$. Neste regulamento podemos ler que o asilo

é destinado para mendigos de ambos os sexos", receberá: I. Os que, por seu estado physico (quando não soffram moléstia contagiosa) ou avançada idade, não poderem com seu trabalho prover ás necessidades vitaes. II Os idiotas, imbecis, e alienados quando não forem recebidos no Hospício de Pedro II. III Os menores de 14 annos ${ }^{110}$.

Tinha como proposta metodológica a "separação de classes, conforme os sexos, idades" e procedimentos de acordo com o estado mental dos asylados. O regulamento previa que a "direcção superior do estabelecimento será confiada a uma commisção composta do chefe de policia, como presidente nato e de mais quatro membros livremente nomeados e dispensados pelo Governo" 111 . O que mais uma vez demonstra a implicação das instituições policias como protagonistas das ações governamentais de assistência. A comissão tinha plenos poderes para o todo o exercício da gestão, do financeiro, a construção de regras, a contratação e definição dos funcionários, "com excepção do de inspector, que será de livre nomeação e demissão do Governo" ${ }^{112}$. Podemos ver também neste regulamento

\footnotetext{
${ }^{106}$ BRASIL. Ministério da Justiça. Relatório do ano de 1875. Rio de Janeiro. Instituto Typographico do Direito, 1877b, p. A-266.

${ }^{107}$ Idem, p. 37.

108 Ibidem, p. A-266.

109 BRASIL. Ministério da Justiça. Relatório do ano de 1878. Rio de Janeiro. Typographia Perseverança, 1879 , p. 74

${ }^{110}$ Idem.

${ }^{111}$ Idem, p. 75.

112 Idem.
} 
em seu artigo sétimo que "os juizes de orphãos continuarão a ter sobre os asylados incapazes a interferência que lhes cabe pela legislação em vigor" 113

O chefe de polícia Dr. Tito Matos (1877 a 1879, depois em 1883) deu especial atenção em sua gestão aos aspectos da pobreza inválida, segundo ele “um dos primeiros cuidados" logo que entrou no cargo foi "visitar minuciosamente a albergaria”. É exatamente na sua gestão como chefe de polícia que acontece o fechamento da Albergaria de Mendigos e a inauguração do Asylo de Mendicidade, no prédio ainda hoje instalado na Cidade Nova ${ }^{114}$. No relato da citada vista podemos ver o que significava o pensamento do referido chefe de polícia, onde claramente encontramos o humanitarismo científico. Assim expressava Dr. Tito Matos sobre sua vista como chefe de polícia a Albergaria de Mendigos da praia de Santa Luzia:

confrangeu-se-me o coração ao ver tão crescido numero de infelizes de ambos os sexos, em um edifício sobre modo acanhado, falto de commodidades, sem observância das regras hygienicas, assemelhando-se a uma misera espelunca antes que a um asylo, cujo nome pomposo ostenta. E isto na capital do Império! Tão desagradável, tão pungente foi a impressão em meu espirito causado por aquella visita, que julguei de meu rigoroso dever representar logo a tal respeito á administração superior fazendo o pedido que ora instantemente reitero, de se concluir com presteza um dos raios do novo edifício destinado para asylo de mendigos, a fim de serem para ali removidos os desafortunados, que vegetam na albergaria, absolutamente desprovidos dos recursos indispensáveis á vida, recursos á que tem direito a creatura humana ${ }^{115}$.

O Asylo de Mendicidade é fruto tanto de um clamor público, de pressão de setores da elite, quanto à materialização da técnica e da ciência de maneira como o Estado moderno deveria lidar com a pobreza urbana no ordenamento da cidade do Rio de Janeiro. O mesmo se constituía em uma "política" de Estado, reproduzido nas principais cidades do Brasil durante o século XIX, de clara inspiração dos asilos de mendicidade da Cidade do Porto e de Lisboa. Podemos observar esta influência na edição de 04 de janeiro de 1861 do jornal “O Diário do Rio de Janeiro” o qual publicou que "continua a entrada dos pobres para o asylo de mendicidade desta cidade [Porto]. O Sr. Miguel do Couto tem mostrado ter muito a feito esta parte

\footnotetext{
${ }^{113}$ Idem, p. 76.

${ }^{114}$ Bairro atual do centro da cidade do Rio de Janeiro onde se encontra ainda hoje o prédio do Asylo de Mendicidade preservado em sua arquitetura original.

115 BRASIL. Ministério da Justiça. Relatório do ano de 1877. Rio de Janeiro. Typographia Perseverança, 1878, p. A5-55.
} 
importantíssima da policia do Porto"116. Este pequeno trecho demostra o envolvimento da polícia também na cidade do Porto com a problemática da pobreza urbana inválida pelo viés da assistência social. Tal qual como se dava em Portugal a polícia estava ligada diretamente a municipalidade, nos mais diversos ramos desta administração.

O Asylo de Mendicidade como instrumento de modernidade da maneira como Estado deveria enfrentar a pobreza urbana pode ser verificado em várias cidades do Império português. O Asylo de Mendicidade, enquanto uma instituição asilar para o tratamento da pobreza urbana era uma política do Estado português. Neste sentido podemos perceber na edição do jornal O Diário de Rio de Janeiro do dia 20 fevereiro de 1861, no qual aponta que o Asylo de Mendicidade é um dos "estabelecimentos mais úteis do Porto e um dos mais grandes elementos de policia publica" ${ }^{117}$. Nesta época fazia-se a "costumada perseguição aos mendigos" para preencher as 160 vagas disponível. E na edição do dia 19 maio de 1861, do mesmo jornal informava que no "Asylo da Mendicidade em Lisboa, ha actualmente

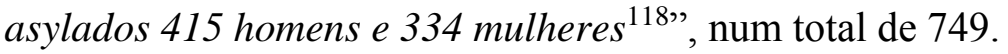

No Brasil, também podemos perceber que a ideia do Asylo de Mendicidade como meio de enfrentamento da pobreza urbana era uma ação baseada na experiência do Estado português, que buscou ser concretizado durante a segunda metade do século XIX como uma "política" de Estado. Existiu Asylos de Mendicidades associados a administração estatal executada pela polícia nas grandes cidades do Brasil, como Recife, Salvador, Fortaleza, Porto Alegre, São Paulo, Santos e Rio de Janeiro, ou mesmo Goa, Macau, Lisboa e Porto, entre outros. No jornal o Progressista de Pernambuco, em 24 janeiro de 1864, podemos ver que a Associação Commercial Beneficente de Recife fez a conversão das apólices da dívida pública, na caixa filial do Banco do Brasil como "resultado da subscrição agenciada para a construção de um Asylo de Mendicidade nesta cidade; instituição que a presidência da provinda aprovou ${ }^{119}$.

A maneira como a sociedade civil se implicava na articulação para a manutenção das instituições asilares pode ser vista na publicação do dia 18 de

\footnotetext{
${ }^{116}$ O Diário do Rio de Janeiro, 4 de janeiro de 1861 - Ano XLI n. 4, p 02.

${ }^{117}$ Ibidem, 20 fevereiro de 1861 - Ano XLI n. 50, pg. 3.

${ }^{118}$ Idem, 19 maio de 1861 - Ano XLI n. 136, pg. 1.

${ }^{119}$ Idem, 24 janeiro 1864 - Ano XLIV n. 24, pg. 1.
} 
novembro 1863 o Jornal o Diário de Rio de Janeiro, que demonstra tanto a existência do Asylo de Mendicidade em Coimbra como também confirma a maneira como se fazia doação do Brasil para tais instituições em Portugal. Esta edição informa sobre a portaria do conselheiro Antonio José Duarte Nazareth que avisa sua Majestade El-rei sobre

o ofício em que o governador civil do distrito de Coimbra participa o importante donativo de 4:500\$, que recebeu o asylo de mendicidade daquella cidade, provenientada subscripçao promovida no império do Brasil pelo conselheiro Antonio José Duarte Nazareth e pelos negociantes portnguezes, estabelecidos na cidade do Rio de Janeiro, Manoel Joaquim Mendes Monteiro e Joaquim José Duarte, que para esse meritório fim se constituíram em commissão ${ }^{120}$ :

Do mesmo modo havia no Rio uma comissão central, presidido pelo Visconde de Souto com a finalidade de enviar recursos financeiros para a "asylos de orphaos de infância desvalida de Portugal”. Na mesma portaria, o conselheiro afirma que "foram muito agradáveis para Sua Magestade as provas de philantropia e amor caritativo dos súbditos portuguezes, representados pela mencionada commissão central $^{121 "}$. Interessante observar que o Diário do Rio de Janeiro era um jornal dedicado as "notícias oficiais" do Império português e ao mesmo tempo em que suas posições eram claramente a favor da perpetuação deste Império, suas posições, no entanto, apesar de monárquicas eram de cunho liberal, como na crítica a escravidão.

A criação do Asylo de Mendicidade na cidade do Rio de Janeiro era um clamor antigo da sociedade e uma necessidade demonstrada pelos mais diferentes níveis de governo. O desenvolvimento de ações de assistência no império português se dava sempre a partir de uma relação íntima entre igreja, Estado e sociedade. Este aspecto fica evidenciado no processo de criação do Asylo de Mendicidade na cidade do Rio de Janeiro. A criação deste tipo de instituição asilar no Rio de Janeiro foi uma articulação da sociedade como, por exemplo, em 1860 quando a Caixa Municipal de Beneficência instaura comissões ${ }^{122}$ ligadas a diversas paróquias da cidade com apoio formal da Congregação de Santa Tereza de Jesus. A seção da Câmara Municipal da cidade do Rio de Janeiro, em reunião consagrada ao

\footnotetext{
${ }^{120}$ Ibidem,18 de novembro de 1863,pg. 1.

${ }^{121}$ Idem, 18 de novembro de 1863, p. 2.

122 Comissão de São Cristóvão, de São João Batista e a criada comissão do Espírito Santo para convergirem suas forças para a criação do Asylo de Mendicidade.
} 
aniversário da instalação da Caixa Municipal de Beneficência, "inaugurada em 29 de julho de 1860, na vista de soccorrer aos pobres recolhidos, de promover o consorcio das desvalidas orphãs de exemplar moralidade ${ }^{123}$ ", fica estabelecido que

estão no firme proposito de convergirem em todas as a suas forcas para o seguimento da fundação do asylo de mendicidade, destinando dóra avante para tal effeito todo o produto pecuniário (...) que a idea de fundação de um estabelecimento desse genero está consignada no estatuto da institução, idéia cuja realização nõa só a caridade a exige, como tambem a reuqer toda a população, e principalmente o commercio, que para animal-a promete, ao antes, assegura sua coadjuvação ${ }^{124}$.

A lógica asilar e o espirito humanitário, que substitui o religioso, tinha no Asylo de Mendicidade a experiência científica adequada e gestada pelo Estado para o controle da pobreza urbana. No entanto, é importante pensar que o Asylo de Mendicidade fazia parte de uma rede de instituições gestado pelo Estado e pela a sociedade civil - aqueles que possuíam direitos civis de poder agir sobre o Estado, geralmente os proprietários, os comerciantes, a Igreja e o próprio Estado. Buscavase tratar sob os auspícios da ciência a pobreza na cidade, com vistas à construção da nação pela "modernização" das relações sociais. O Asylo de Mendicidade era parte fundamental do projeto científico-político que fundamentou o sentido de Estado republicano e liberal, enquanto parte estatal das respostas necessárias a pobreza inválida. Se não na prática, no nível dos discursos, a direção era do "humanitarismo" e de agir estritamente pelos princípios da ciência, ainda que baseado no saber construído na prática cotidiana.

Tanto a Albergaria de Mendigos, quanto mais tarde o Asylo de Mendicidade, estavam diretamente ligados ao Ministério da Justiça e, gestado por subordinados diretos aos chefes de polícia. Sua relação com as implicações técnico-cientificas do século XIX evidenciava que a eficácia na construção da ordem urbana não bastava a punição, deveria também existir o tratamento e a cura, seja pela medicalização, seja pela regeneração pelo trabalho e práticas sociais de ajuda e apoio. Neste sentido, entender arquitetonicamente o projeto do Asylo de Mendicidade nos coloca diante da influência que tal instituição exerceu no conjunto das instituições e das práticas sociais destinadas a lidar com a problemática da pobreza urbana na cidade do Rio de Janeiro. Para Silva Júnior (2000, p. 44), o Asylo de Mendicidade

${ }^{123}$ O Diário do Rio de Janeiro, 30 julho de 1870, pg. 2.

${ }^{124}$ Ibidem, 30 julho de 1870 , pg. 2. 
constituía-se em um "instrumento de intervenção médica na sociedade do final do século XIX" (Silva Júnior, 2000, p. 44) e um "núcleo de implementação da Medicina Social na cidade do Rio de Janeiro" (Silva Junior, 2013, p. 25).

A construção do Asylo de Mendicidade foi envolta a polemicas, a começar pelo valor pago pelo terreno, ao mesmo tempo em que emprestou a fama aquele que o construíram e idealizaram. Segundo Aguinaga (1976), a ousadia de ter construído sobre o mangue edifício de proporções extraordinárias para época, conferiu notoriedade a seus idealizadores. Sua construção era clamor da sociedade dominante e fazia parte do projeto de modernização e civilização da cidade do Rio de Janeiro, integrante do plano elaborado pela comissão de Melhoramentos em 1876 (Amora \& Souza, 2014). Seu projeto arquitetônico foi elaborado pelo arquiteto Radmarker Grunewald, que recém-voltado da Europa atendeu ao pedido do ministro Dr. Diogo Velho Cavalcanti de Albuquerque. A construção do asylo era peça de muita importância política.

Além da polêmica que envolvia a compra do terreno, a construção do asilo se via em constante falta de recursos, mesmo com a lei orçamentária aprovada, tendo, os chefes de polícia, comissões e câmaras beneficentes de se mobilizaram diversas vezes durante as obras para angariar os recursos necessários, apelando para os nobres sentimentos humanitários e filantrópicos da classe dominante. Além disso, houve uma importante contribuição do diretor da casa de detenção, que disponibilizou mão de obra e também parte do material. Neste sentido, podemos observar no relatório do chefe de polícia referente ao ano de 1877 Dr. Tito Algusto Pereira de Matos que em relação ao "novo Asylo de Mendigos" que "acham-se promptos os dous raios deste edifício, e trata-se de concluir a parte destinada para a administração e Capella". Estas informações apareciam como uma prestação de contas, para mais adiante solicitar "o credito necessário para continuação das obras, havendo necessidade de se levantarem mais tres raios, e proporcionaremse accommodações para os mendigos loucos, que a Santa Casa de Misericórdia não pôde receber" ${ }^{225}$. Continuava o chefe de polícia informando que

actualmente as obras estão paralysadas, ficando adiada a inauguração do novo asylo para depois que me habilitardes com o credito necessário para as despezas

125 BRASIL. Ministério da Justiça. Relatório do ano de 1877. Rio de Janeiro. Typographia Perseverança, 1878 , p. 86. 
mais urgentes. Trata-se de organizar o regulamento recommendado pelo art. $16 \S$ $8^{\circ}$ da Lei n. 2670 de 20 de Outubro de $1875^{126}$.

Os esforços do chefe de polícia e comissões deram resultados e muitos foram as doações recebidas para finalizar a construção do abrigo, como, por exemplo, em 1877, do mosteiro de S. Bento e da sociedade dos Estudantes de Heidelberg ${ }^{127}$. A título de exemplificar um pouco mais como havia uma mobilização da classe dominante para construção, reforma e manutenção do asylo de mendicidade, podemos citar, no ano de 1887, a doação da "Fazenda do - Galeão -, na ilha do Governador, pelo barão e baroneza de Itacurussá, a quem Sua Alteza Imperial nomeou protectora dos asylos" ${ }^{128}$. A "Chácara no Engenho Novo (Caxamby), terrenos e casas vizinhas, no valor não inferior a 15:000\$000, pelo dr. Francisco de Salles Rosa" ${ }^{129}$. Recebeu, ainda, como doação expressiva um "cheque contra o banco rural e hypothecario a quantia de 2:000\$000, doada por Francisco Xavier da Silva Leitão" ${ }^{130}$. Com doações que variavam entre quinhentos e mil e quinhentos réis havia uma lista onde diversas pessoas e empresas que faziam doações para o Asylo de Mendicidade eram mencionadas, como, por exemplo, Conselheiro João Sertório, Directores e empregados do banco rural e hypothecario, Club dos Democráticos, J. Villeneuve \& C.", A empreza d'0 Pais, Commendador Bellarmino Braziliense Pessoa de Mello, Antonio Dias Ferreira e sua mulher e o $1^{\text {o }}$ "delegado de policia, dr. Silva Mattos, quantia que lhe foi entregue na corrida de touros em 29 de abril" 131. Contava também como "todo o pão necessário aos asylos, pela Illma. câmara municipal" ${ }^{132}$. Com as doações, entre outras coisas, autorizou o ministro da justiça Dr. Lafayette Rodrigues Pereira por aviso de 30 de abril de 1878 " a cocstrucção de um chalet para accommodações dos mendigos loucos, visto não haver para elles lugar apropriado no edificio do Asylo. A obra, que estará concluida em fins de Julho, não excederá de 6:0008000"133.

\footnotetext{
${ }^{126}$ Idem.

${ }^{127}$ Idem, p, A5-55.

${ }^{128}$ BRASIL. Ministério da Justiça. Relatório do ano de 1887. Rio de Janeiro. Imprensa Nacional, 1888, p. 143.

${ }^{129}$ Idem.

${ }^{130}$ Idem.

${ }^{131}$ Idem.

${ }^{132}$ Idem.

133 BRASIL. Ministério da Justiça. Relatório do ano de 1878. Rio de Janeiro. Typographia Perseverança, 1879 , p. 79.
} 
A pedra fundamental para o início da obra se deu no dia 06 de agosto de 1876 com pompas, cobertura de todos os importantes jornais da época e a presença da princesa Isabel, sendo inaugurado 3 anos mais tarde, ainda não concluído, pelo imperador D. Pedro II em 10 de julho de 1879. Foi construído na rua Visconde de Itaúna, na região da cidade chamada mangue, naquele momento já habitada por prostitutas, imigrantes, ex-escravos, entre outros personagens do mundanismo da cidade do Rio de Janeiro. Local de odores pestilentos, no dizer dos contemporâneos, já considerado como ponto de concentração de mendigos e vagabundos. Importante ressaltar que além desta área ser considerada na época como afastada do centro comercial, sem deixar de ser de fácil acesso, era localizada a poucos metros da Casa de Correção e Detenção, que funcionavam no mesmo prédio da Rua Frei Caneca. Este aspecto de afastado do centro mais movimentado da cidade, como víamos nos relatórios referente à década de 1870 , já não se verificava mais na década seguinte, como podemos ver no relatório referente ao ano de 1884, quando ponderava o chefe de polícia Dr. José Antonio Gomes que "sentia-se a necessidade (...) de um muro indispensável para a segurança dos asylados, e mesmo para evitar-lhes a vista e contacto de pessoas estranhas que devassam o estabelecimento, encravado no seio da cidade ${ }^{134}$.

A passagem da hospedaria dos mendigos da praia de Santa Luzia para o novo Asylo de Mendicidade se deu durante a gestão do chefe de polícia Dr. Tito Matos, como citato anteriormente. Tito Matos era um dos chefes de polícia que tinha preocupações e desenvolvia ações para o controle e disciplinamento da pobreza inválida e da válida não criminalizada. Em 1878 informava o referido chefe de polícia em seu relatório que "já se póde realisar a passagem dos mendigos para o novo Asylo do qual estão promptos a parte da administração, capella, dous raios, cosinha, latrinas, encanamento de gaz, agua, esgoto e tudo quanto é necessário a um edifício dessa ordem" ${ }^{135}$. No relatório do ano seguinte informava o chefe de polícia Titio Matos em relação ao novo Asylo de Mendicidade que "em 13 de março do corrente anno expediu-se ordem afim de serem transferidos para esse estabelecimento os velhos, vagabundos e alienados, que, sem mandado da

${ }^{134}$ BRASIL. Ministério da Justiça. Relatório do ano de 1884. Rio de Janeiro. Imprensa Nacional, 1885, p. 157.

${ }^{135}$ BRASIL. Ministério da Justiça. Relatório do ano de 1878. Rio de Janeiro. Typographia Perseverança, 1879 , p. 79. 
autoridade competente, estivessem na Casa de Detenção"136. Esta mudança foi bastante conflituosa. Inicialmente, o asylo havia sido pensado com capacidade de 600 vagas para ambos os sexos, mas foi inaugurado com menos da metade desta capacidade e com diversas áreas ainda por ser concluída. Como se não bastasse recebeu quase o dobro do que o número de vagas das pessoas removidas da Albergaria da praia de Santa Luzia. Apesar de incialmente ter sido concebido para a mendicância reconhecidamente exercida por aqueles que não podiam trabalhar, continuou como na albergaria a receber todo tipo de pobreza inválida, sendo ao mesmo tempo, um hospício, uma instituição orfanológica, um hospital para velhos pobres e doentes, depósito de mendigos e bêbados. A esse respeito podemos ler no relatório do ministério da justiça referente ao ano de 1888 que

apenas concluída essa parte do novo asylo, o corpo central e duas alas com a capacidade para 160 pessoas no máximo, para elle foram transferidos em 1879 todos os míseros hospedes da albergaria em numero muito superior a 267, homens e mulheres, velhos e crianças, quesi todos idiotas, ou affectados de moléstias incuráveis. O asylo continuou, pois, a ser um deposito geral de todas as misérias, que exigem aliás, conforme os preceitos da sciencia e da humanidade, remédio, tratamento, hygiene e regimens muito diversos ${ }^{137}$.

O fato da superlotação e de ter sido inaugurado sem a conclusão do projeto aprovado podia ser visto pela reclama do chefe de polícia Dr. Ovídeo Fernando Trigo de Loureiro, no relatório referente aos anos de 1880 e 1881, quando assenta que "convém que com a possível brevidade, se trate de continuar a construcção do edifício do asylo, cujas acommodações são actualmente insufficientes ao numero de indivíduos, que a elle são recolhidos"138. A este comentário junta-se o de um de seus sucessores, chefe de polícia Dr. Bellarmino Peregrino da Gama e Mello, quando afirmava em 1882 que

a parte já acabada do edifício está bem longe de satisfazer as necessidades de uma grande capital; e no futuro, com o prolongamento dos raios começados, se tornará

\footnotetext{
136 BRASIL. Ministério da Justiça. Relatório do ano de 1879. Rio de Janeiro. Typographia Perseverança, 1880, p. 99.

${ }^{137}$ BRASIL. Ministério da Justiça. Relatório do ano de 1888. Rio de Janeiro. Imprensa Nacional, 1889, p. 123.

${ }^{138}$ BRASIL. Ministério da Justiça. Relatório do ano de 1880 e 1881 . Rio de Janeiro. Typographia Nacional, 1882b, p. A-G-46.
} 
evidentíssima a estreiteza da área que ha de restar para plantação e outros serviços imprescindíveis espaço ${ }^{139}$.

Estes aspectos, as obras inconclusas, a superlotação e os diversos tipos de pobres inválidos misturados sem condições de separar por sexo e características, pode ser também verificada na recomendação do chefe de polícia Dr. Ovídeo Fernando Trigo de Loureiro, no relatório referente aos anos de 1880 e 1881, segundo o qual "torna-se urgente reparar o chalet, no qual são conservados os loucos, bem como murar e aterrar o terreno do asylo, sendo também de necessidade a construcção de uma lavanderia, para que o serviço do lavagem, não continue a ser feito ao tempo" ${ }^{140}$. Do mesmo modo, e com mais veemência, podemos ler no relatório referente ao ano de 1884 que era impossível "de serem devidamente alojados e tratados os alienados que a policia tinha de remover das ruas, e que a Santa Casa da Misericórdia não podia receber por insufficiencia de recursos"141. Estas críticas levaram a nova reorganização do asylo feita pelo decreto n. 9274, de 6 de setembro de $1884^{142}$, que deu novo regulamento para a instituição. No entanto a continuidade das críticas nos faz inferir que este regulamento não surtiu o efeito que se esperava.

A diversidade dos tipos de pobres que abrigava o asylo e a não definição de um público especifico, devido principalmente, a falta de outros locais que pudessem encaminhar, era parte constante das críticas feita por ministros da justiças e chefes de polícia. No relatório de 1883, o chefe de polícia Tito Mattos apresenta interessante análise sobre tema afirmando que há a necessidade

de punir-se ao mendigo-voluntario, ao homem valido que não se quer sujeitar ao trabalho; mas, o asylo de mendicidade não recolhe em seu seio só o mendigo; ahi vão ter, por centenas, homens e mulheres que soffrem de alienação mental, e outros que, por seu estado valetudinário, não podem prover a subsistência, e para os quaes o governo deve olhar com toda a solicitude ${ }^{143}$.

${ }^{139}$ BRASIL. Ministério da Justiça. Relatório do ano de 1882. Rio de Janeiro. Typographia Nacional, 1883, p. 130.

${ }^{140}$ BRASIL. Ministério da Justiça. Relatório do ano de 1880 e 1881. Rio de Janeiro. Typographia Nacional, 1882b, p. A-G-46.

${ }^{141}$ BRASIL. Ministério da Justiça. Relatório do ano de 1884. Rio de Janeiro. Imprensa Nacional, 1885 , p. 157.

${ }^{142}$ Idem, p. A-F-16.

${ }^{143}$ BRASIL. Ministério da Justiça. Relatório do ano de 1883. Rio de Janeiro. Typographia Nacional, 1884, p. A-G-42. 
Importante chamar a atenção para o aspecto relativo a classificação do "homem válido", o "mendigo voluntário" em oposição aos que não podem prover sua subsistência, como discutimos em pormenores no Capítulo 3. Cabe destacar também, que mesmo em relação ao "mendigo voluntário", este não estava sendo posto no lugar especifico da criminalização. No relatório de 1886 podemos ler que em uma das

visitas que os delegados da inspectoria geral de hygiene fizeram ao asylo, ponderaram que este era mais de alienados do que de mendigos, pois de 319, que na occasião existiam, só dez ou doze imploravam a caridade publica; e que o estabelecimento carecia de condições hygienicas ${ }^{144}$.

Era evidente e corrente nos relatórios a crítica de que não podia o asylo continuar a receber as "duas classes" que vieram desde o "primitivo albergue de Santa Luzia”, "os mentecaptos que o hospício de Pedro II não podia recolher, e os menores de 14 annos abandonados"145. E, que "emquanto não estiverem concluídas as obras dos tres raios e não forem retirados do estabelecimento os asylados que não pertencem propriamente á classe dos mendigos, elle não poderá ter a conveniente organização" ${ }^{146}$. Ainda mais contundente era a crítica expressa pelo chefe de polícia desembargador Monoel José Espínola, no relatório referente ao ano de 1888. Segundo o referido desembargador,

o estabelecimento que nesta corte tem esse nome, não é penal, não é correccional, e si for qualificado como de assistência publica - policial ou judiciaria - afim de permanecer justificadamente sob a direcção do ministério da justiça, precisa que se trate de sua organisação definitivo, que ainda não tem ${ }^{147}$.

A colocação acima colabora com nossa interpretação que havia uma clara diferenciação ao nível do discurso que buscava se reproduzir na prática cotidiana sobre os diferentes tipos de instituições adequadas aos diferentes tipos de problemática que suscitava a pobreza urbana.

\footnotetext{
144 BRASIL. Ministério da Justiça. Relatório do ano de 1886. Rio de Janeiro. Imprensa Nacional, 1887, p. 167.

145 Idem, p. 168.

${ }^{146}$ Idem.

${ }^{147}$ BRASIL. Ministério da Justiça. Relatório do ano de 1888. Rio de Janeiro. Imprensa Nacional, 1889, p. 122.
} 
Apesar das doações da beneficência privada e das subvenções do governo, segundo consta nos relatórios, era sobre a precariedade que vivia o Asylo. Como meio de buscar soluções para a deficiência de recursos orçamentários organizou-se em 1884 "uma associação protectora para angariar donativos, que se destinassem áquelle fim e á formação de um patrimônio" ${ }^{148}$. Esta associação teve seus estatutos aprovados no mesmo ano pelo decreto $\mathrm{n}$. 9317 de 11 novembro.

Entretanto logo no anno seguinte, 1885, o Poder Legislativo reconheceu que a mesma instituição não podia servir simultaneamente para hospício de alienados, collegio de menores, asylo de velhos e inválidos, recolhimento de todes os mendigos vagabundos; dispoz no art. $1^{\circ} \S 9^{\circ}$ da lei n. 3271: O actual asylo de mendicidade será destinado exclusivamente aos indigentes mendigos e vagabundos adultos ${ }^{149}$.

Podemos vera abaixo que a própria lei já legislava sobre o principal entrave para se ter um asilo voltado exclusivamente aos indigentes adultos, pois não havia instituições que pudessem suprir a necessidade de vagas para os alienados e menores. Em relação a este último aspecto afirmava a referida lei que na

falta de estabelecimento especial para menores fica o governo autorisado, dentro da verba consignada para aquelle serviço, a despender até a quantia de 10:000\$ como subvenção a um ou mais asylos que recebam menores indigentes, mendigos $e$ vagabundos dos dous sexos, sendo taes estabelecimentos organisados de modo que os menores possam nelles empregar-se, tanto quanto fòr possivel, em trabalhos de agricultura e outros que constituam educação profissional ${ }^{150}$.

No relatório referente ao ano de 1889 afirmava o chefe de polícia Dr. João Batista de Sampaio Ferraz que

um dos últimos ministros da monarchia reconheceu em 1888 os graves males resultantes dessa escola de perdição no seio da Capital, e removeu os meninos para a Casa de S. José, e uma parte dos mentecaptos para o Galeão, dous estabelecimentos que fundou; mas sahiu do ministério antes de realizar a reforma do Asylo ${ }^{151}$.

\footnotetext{
148 Idem, p. 124.

${ }^{149}$ Ibidem.

${ }^{150}$ Idem.

${ }^{151}$ BRASIL. Ministério da Justiça. Relatório do ano de 1889. Rio de Janeiro. Imprensa Nacional, 1891 b, p. 92.
} 
Segundo Sampaio Ferraz, o asylo continuo a ser o que era, aceitando "órfãos e quantos mentecaptos o hospício de alienados se recusava a receber" 152 . Informando que "depois que a Republica mudou a administração desse hospício [Pedro II] foram para elle transferidos do Asylo de Mendicidade 142 loucos. Foram remeltidos para a casa de S. José menores, e para diversos hospitaes outros asylados" 153 . Para o chefe de polícia perdeu-se a oportunidade naquele momento onde houve uma breve separação de classe, de reformar o regulamento do asylo " $e$ estabelecendo officinas, fazer do Asylo uma casa de trabalho para os mendigos, $e$ determinar as condições de entrada e sabida por forma a evitar que com elles se confundissem outras classes" ${ }^{154}$. No entanto, entende o chefe de polícia que uma instituição voltada para mendicidade não fosse atribuição do Ministério da Justiça. Segundo o chefe de polícia Dr. João Batista de Sampaio Ferraz

não parece que essa instituição, a não ser correccional, coubesse bem ao ministério da justiça, e que com o caracter de assistência publica seja urgente no Brazil, onde não falta o trabalho. Sob o aspecto de mera beneficência, fora mais acertado deixar o serviço a associações particulares, embora subvencionadas pelo Estado ${ }^{155}$.

Cabe aqui chamar a atenção para o fato de que as ações do asylo não eram correcionais, e que já começa a haver a grita que vai ganhar vulto nas primeiras décadas do seculo XX que não deve a assistência estar sob a alçada administrativa do Ministério da Justiça. Para o chefe de polícia, deveria os serviços de assistência deixar de ser executado por esta instituição e ser acertado para as associações particulares. Segundo o referido chefe, o edifício do asylo de mendicidade prestavase "bem a um estabelecimento disciplinar exclusivamente destinado a tres classes de menores" ${ }^{156}$, os que cometeram crime com discernimento antes dos 14 anos, os condenados a pena disciplinar e, por último, “áquelles que, a requerimento do pai ou tutor e a juizo da autoridade competente, precisarem de ser submettidos a um regimen disciplinar" ${ }^{157}$. Fica evidente na exposição do chefe de polícia que o asylo não era para punir ou corrigir, isto era a transformação que ele propunha. $\mathrm{O}$ Asylo de Mendicidade estava posto dentro das instituições estatais destinadas a proteger

\footnotetext{
152 Idem.

${ }^{153}$ Idem.

154 Ibidem

${ }^{155}$ Idem.

${ }^{156}$ Idem.

157 Idem.
} 
pelo controle a pobreza inválida. Dr. João Batista de Sampaio Ferraz, quando do exercício do cargo de chefe de polícia, era contundente ao falar do lugar em que o Asylo de Mendicidade é percebido no âmbito geral das instituições policiais, segundo ele;

ha tres estabelecimentos penaes sob a direcção deste Ministério: a Casa de Detenção e a de Correcção, nesta Capital, e o presidio de Fernando de Noronha. $O$ primeiro, por sua natureza, deveria ser destinado exclusivamente ás prisões preventivas, mas desde 1888 cumpre-se nella a pena de prisão simples. Além desses estabelecimentos ha um sobre a imprópria denominação de - Asylo de Mendicidade -, que é desde muitos annos um deposito de vagabundos, ébrios, alienados, de mistura com os menores abandonados, velhos e enfermos desvalidos, sem distincção de idade ou sexo, sem regimen de trabalho ou disciplina ${ }^{158}$.

O trecho do relatório transcrito acima deixa ainda mais exposto e transparente o fato de que o Asylo de Mendicidade não era classificado e, portanto, não se configurava em uma instituição penal. Não era punitivo, por mais que houvesse e não eram poucas as punições em suas metodologias e regulamentos. O que o chefe de polícia apalavra acima sobre a denominação impropria do asylo, diz respeito a ideia de mendicidade, pois não devia abrigar menores e nem alienados. Esta era uma questão que se buscava resolver desde quando o asylo funcionava na praia de Santa Luzia.

Para termos uma ideia ainda mais evidente de que o asylo não era instituição penal e que lidava prioritariamente com a pobreza inválida, podemos ver as tabelas (2 e 3) abaixo. A tabela (2) demonstra o movimento dos asilados no ano de 1890. Esta tabela reproduz exatamente o modo como era sistematizado as informações. Nela podemos perceber que o Asylo de Mendicidade também funcionava como um local provisório e, de certo modo, também de triagem. Na tabela (3) podemos vislumbrar o quantitativo de atendimento anual do asylo de mendicidade no período de 12 anos, parte ainda enquanto albergaria e após o ano de 1877, já funcionando no novo Asylo de Mendicidade.

${ }^{158}$ BRASIL. Ministério da Justiça. Relatório do ano de 1889. Rio de Janeiro. Imprensa Nacional, 1891b, p. 90-1. 
Tabela 7. Movimento do Asylo de Mendicidade no ano de $\mathbf{1 8 9 0}$

\begin{tabular}{l|r}
\hline Existiam em $1^{\circ}$ de janeiro de 1890 & 415 \\
Entraram até 12 de outubro & 591 \\
\cline { 2 - 2 } Total & 1.006 \\
\hline Foram removidos para o Hospício Nacional de Alienados & 142 \\
Tiveram alta & 339 \\
Removidos para a casa de S. José & 11 \\
Removidos para diversos hospitaes & 12 \\
Evadiram-se & 92 \\
Falleceram & 135 \\
Ficam existindo & 275 \\
Total & 1.006 \\
\hline
\end{tabular}

\begin{tabular}{lr}
\hline & \multicolumn{2}{r}{ Dos que existiam eram: } \\
\hline Homens & 222 \\
Mulheres & 193 \\
\cline { 2 - 2 } Total & 415 \\
\hline
\end{tabular}

Total

Dos que entraram eram:

\begin{tabular}{l|r}
\hline Homens & 392 \\
Mulheres & 199 \\
\cline { 2 - 2 } Total & 591 \\
\hline
\end{tabular}

Total

Dos que foram removidos para o Hospício eram:

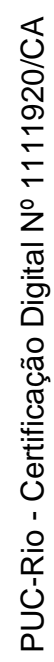

\begin{tabular}{l|r}
\hline Homens & 78 \\
Mulheres & 64 \\
\cline { 2 - 2 } Total & 142 \\
\hline
\end{tabular}

\begin{tabular}{l|r}
\hline & \multicolumn{2}{c}{ Dos que tiveram alta eram: } \\
\hline Homens & 210 \\
Mulheres & 129 \\
\cline { 2 - 2 } Total & 333 \\
\hline
\end{tabular}

\begin{tabular}{|c|c|}
\hline \multicolumn{2}{|r|}{ Dos que foram removidos para a Casa de S. José eram: } \\
\hline Menores & 11 \\
\hline \multicolumn{2}{|r|}{ Dos removidos para diversos hospitaes eram: } \\
\hline Homens & 9 \\
\hline Mulheres & 312 \\
\hline \multicolumn{2}{|r|}{ Dos que evadiram-se eram: } \\
\hline Homens & 85 \\
\hline Mulheres & 7 \\
\hline Total & 92 \\
\hline
\end{tabular}

Fonte: BRASIL. Ministério da Justiça. Relatório do ano de 1889. Rio de Janeiro. Imprensa Nacional, 1891b, p. 93. 
Tabela 8. Número asilados por ano na Albergaria de Mendigos / Asylo de Mendicidade

\begin{tabular}{cccc} 
Ano & Homens & Mulheres & Entrada \\
1870 & & & 232 \\
1871 & 204 & 98 & 302 \\
1872 & 280 & 104 & 384 \\
1873 & 316 & 180 & 496 \\
1874 & 323 & 163 & 486 \\
1875 & 311 & 123 & 434 \\
$1876 *$ & 98 & 44 & 142 \\
1877 & & & 566 \\
1878 & 319 & 196 & 515 \\
1879 & 408 & 223 & 631 \\
1880 & & & 892 \\
1881 & & & 834 \\
\hline Fonte: (BRASIL, 1871, 1872, $1873,1874,1875,1876,1877,1878,1879,1880,1881,1882)$
\end{tabular}

Mesmo já em pleno funcionamento, somente "em 1884 é que foi aprovado pelo decreto $n .9274$ de 6 de setembro" 159 o regulamento do asylo. Neste regulamento evidencia-se ainda mais seu caráter protetivo e de assistência a pobreza inválida. Segundo o regulamento aprovado o Asylo de Mendicidade se destina a receber

$1^{\circ}$ Os menores de 14 annos encontrados na rua em abandono ou ociosidade. $2^{\circ}$ Os que, por seu estado physico ou idade avançada, não podendo pelo trabalho prover ás primeiras necessidades da vida, tiverem o habito de esmolar. $3^{\circ}$ Os que solicitarem a entrada, provando a sua absoluta indigência. $4^{\circ}$ Os idiotas, imbecis e alienados que não forem recebidos no hospício de Pedro $\mathrm{II}^{160}$.

No artigo $4^{\text {a }}$ do regulamento do asylo vê-se a separação dos serviços prestados por classes, segundo o sexo e subdividida em válidos, inválidos, menores, imbecis, idiotas e alienados. Estas divisões em "classes" - termo usado no regulamento demonstram toda a discussão levantada no capítulo anterior sobre pobreza inválida

\footnotetext{
159 BRASIL. Ministério da Justiça. Relatório do ano de 1887. Rio de Janeiro. Imprensa Nacional, 1888 p. 141.

${ }^{160} \mathrm{Idem}$
} 
e pobreza válida. Confirmam ainda mais nossa interpretação que esta instituição policial de assistência, não era destinada a pobreza calcificada por criminosa. Cabia exatamente a ela tratar das expressões da questão social pelas práticas de assistência, no caso, social. Nossa interpretação fica ainda mais evidente ao olharmos para o quadro de pessoal do asylo; diretor, capelão, medico, porteiro, escrevente, enfermeiro, enfermeira, servente ordinário, cozinheiro e guarda de material. O chefe de polícia Dr. João Batista de Sampaio Ferraz, no relatório referente ao ano de 1889 , demonstra que as divisões por classe não ocorreram de fato. A esse respeito vale reproduzir o longo trecho do relatório de sua autoria.

\begin{abstract}
O nome do estabelecimento não diz o que elle é. Confundiu-se a infância desamparada, a decrepitude, a enfermidade e o idiotismo com a mendicidade; sem attender a que esta pôde ser o effeito do infortúnio ou do vicio, juntou-se o indigente que esmola o pão por falta de trabalho, com o vagabundo que explora a sensibilidade alheia; e porque havia urgência de recolher o ébrio, e de amparar o menor sem tutor, reuniu-se o orphão com o réo de policia. Assim, o Asylo converteuse no que era a albergaria de Santa Luzia, a que succedeu em 1879, um deposito de todas as misérias, alimentadas a custa do Estado. É impossível classifical-o. Não é de assistência publica, nem de correcção. Não dá educação aos orphãos, nem tratamento aos loucos, nem trabalho aos mendigos, nem conforto aos velhos. Outro motivo não se descobre para ter sido collocado sob a administração da justiça, senão o haver determinado o Regulamento que os mendigos permaneceriam á disposição do chefe de polícia, e os menores e mentecaptos passariam á do juiz de orphãos, ficando a entrada e a sahida ao prudente arbitrio dessas autoridades. Dispensa toda demonstração a impossibilidade de regimen para um estabelecimento que reúna e confunda instituições tão diversas: manicomio; instituto orphanologico; hospício de velhos; asylo de mendigos; hospital; deposito de vagabundos e ébrios. Fácil era prever a excessiva agglomeração, que não poderia permittir, como não tem permittido, as convenientes separações a bem dos costumes, e para evitar o contagio de vicios e enfermidades ${ }^{161}$
\end{abstract}

No entanto, mesmo o asylo não produzindo na prática o que era em ideias e regulamentos, fica evidente que havia um claro conceito sobre a pobreza criminalizada e a pobreza não criminalizada para a qual fora criado. Em relação ao pobre inválido é mais fácil perceber esta diferença entre criminalizar e não criminalizar a pobreza, mas ao levarmos em conta as ideias do chefe de polícia transcritas acima evidencia-se o que demonstramos no capítulo anterior que havia também um modo de classificar a pobreza válida em criminosa e não criminosa. Esta classificação da pobreza válida incorporava fatores morais e ao mesmo tempo de conjuntura social em suas análises. Tinha por finalidade identificar a diferença

${ }^{161}$ BRASIL. Ministério da Justiça. Relatório 1889. Rio de Janeiro. Imprensa Nacional, 1891b, p. 91. 
entre o "indigente que esmola o pão por falta de trabalho", portanto não criminalizável, e o "vagabundo que explora a sensibilidade alheia", portanto criminoso e, assim definir os destinos e os métodos empregados pelo Estado para cada um deles. Ora, para haver uma separação objetiva entre o indigente e o vagabundo, necessitava-se de conhecimentos sociológicos do significado destas situações no âmbito geral da sociedade, que apontasse os traços formadores estas diferenças. Havia de se ter construído um conhecimento embasado na teoria e na prática cotidiana que pudesse subsidiar tais classificações, pois, esta era fundamental para a eficácia das ações estatais. Este conhecimento sociológico que juntava análise social e perspetiva moral deveria também se embasar na perspetiva que fazia a leitura imediata dos comportamentos e de informações objetivas da história de vida destes pobres válidos. De modo que se construísse também certo perfil psicológico do pobre para determinar se este era indolente, incorrigível ou dócil e trabalhador, mas sem oportunidades. De certo modo, não muito diferente do modo como o senso comum classifica a pobreza em nossa atualidade.

Segundo o chefe de polícia desembargador Manoel José Espínola, apenas 21 dias mais tarde da aprovação do referido decreto de 1884 que dá regulamento ao asylo, foi empossado

\begin{abstract}
uma commissão composta do conde de S. Salvador de Mattosinhos, barão de Quartim, cónego Luiz Raymundo da Silva Brito, conselheiros Tito Augusto Pereira de Mattos e José Bento da Cunha Figueiredo Júnior, e do director da casa de correcção Bellarmino Brasiliense Pessoa de Mello para organizar os estatutos de uma associação protectora do mesmo asylo, e empregar os esforços necessários, afim de que ella se instituísse com o maior numero possível de contribuintes ${ }^{162}$.
\end{abstract}

Importante lembrar que o conselheiro Tito Augusto Pereira de Mattos, integrante desta comissão fora chefe de polícia em duas oportunidades. O chefe de polícia desembargador Manoel José Espínola destaca os bons serviços desta comissão, enfatizando seus "valiosos donativos com os quaes tem sido executada grande parte das obras do estabelecimento, e providas as despezas do custeio" ${ }^{163}$. Para o desembargador havia um "vício orgânico da instituição" acarretado por ter um "regime comum sem divisão de classe e sem organização de trabalho, da

\footnotetext{
${ }^{162}$ BRASIL. Ministério da Justiça. Relatório do ano de 1887. Rio de Janeiro. Imprensa Nacional, 1888 p. 141.

${ }^{163}$ Idem.
} 
educação e do tratamento"164. Misturava-se "meninos e velhos, válidos e inválidos, mendigos, idiotas, e toda a espécie de indigentes". Segundo o citado chefe de polícia, estes vícios orgânicos explicam o estado deplorável a que se encontrava o asylo "convertido num hospício de mentecaptos de todas as idades e de ambos os sexos" ${ }^{165}$. Segundo o chefe de polícia, desembargador Manoel José Espínola, suas análises confirmaram a "convicção de que carecemos de um systema de assistência pública" 166. Para o referido desembargador havia dois meios "de prover as necessidades dos infelizes" 167 , nos dois meios "só da sociedade podem esperar o remédio" ${ }^{168}$. Para o desembargador estes remédios consistiam em

ou o estado vota annualmente certa quantia para os estabelecimentos destinados a esse fim, como praticam a Inglaterra e os Estados Unidos, ou assegura um patrimônio ás associações que tomem a seu cargo a beneficência publica, reservando-se unicamente a fiscalisação, segundo o systema mais geralmente adoptado $^{169}$.

Segundo o referido desembargador o Estado não deveria se responsabilizar pelas instituições de assistência. Ao Estado caberia as instituições penais,

os estabelecimentos propriamente correccionaes ${ }^{170}$ (...) Os outros infortúnios particulares, salvo os casos extraordinários em que "tomam o caracter de calamidade publica, são mais eficazmente soccorridos por associações, protegidas e auxiliadas pelo estado, mas espontaneamente constituidas para o exercício dos deveres da caridade. ${ }^{171}$

Após as constantes reclamas dos chefes de polícia e ministro da justiça de que não cabia a este ministério, através da polícia, ser responsável por instituições e práticas de assistência, o Asylo de Mendicidade foi transferido para a esfera do Distrito Federal pela lei n. 85, de 20 de setembro de 1892. Em 1894 é feito a nova reforma regimental no asylo, de modo a retomar seu objetivo inicial, o acolhimento, apenas, dos pobres que mendigavam e esmolavam nas ruas. É nesta reforma que

\footnotetext{
164 Ibidem.

165 Idem.

166 Idem.

${ }^{167}$ Idem.

${ }^{168}$ Idem.

${ }^{169}$ Idem.

${ }^{170}$ Idem.

${ }^{171}$ Idem, p. 142.
} 
deixa de se chamar Asylo de Mendicidade e assume o nome de Asilo São Francisco de Assis.

Cabe ressaltar que tanto o regulamento do asylo em 1884 no Império, quanto o regulamento já na República sob a gestão da municipalidade do Distrito Federal, se constituíram em decretos e lei, respectivamente instrumentos de gestão jurídica, diretamente concebido como uma política de Estado. Quando se tratava de resoluções dos ministros ou de outros setores da alta administração pública, estes se davam através de avisos, ordens, requerimentos, ofícios, entre outros. Este fato em nosso ver escalasse que havia uma gestão e uma legislação pública sobre a assistência tanto no Império, quanto na primeira República.

Sob a gestão municipal e funcionando para o fim que foi concebido, abrigar os pobres urbanos adultos que vivem ou sobrevivem nas ruas da cidade do Rio de Janeiro, o Asilo São Francisco de Assis funcionou até dezembro de 1920, quando sai da municipalidade do Distrito Federal e retorna para a União. Da qual na verdade nunca saiu, pois ao ser o Rio o Distrito Federal, a municipalidade estava a cargo direto da União. Havia, é fato, uma separação jurídica que se dava ao nível administrativo. No campo político esta separação era nula. Com a reforma, a antiga instituição policial de assistência, o Asylo de Mendicidade torna-se pelo decreto ${ }^{\circ}$ 15719 de 10 de novembro de 1922 o Hospital Geral de Assistência do Departamento Nacional de Saúde Pública, batizado de Hospital Escola São Francisco Assis (HESFA). Esta última transformação do antigo asylo se deu durante a gestão de Carlos Chagas a frente do Departamento Nacional de Saúde Pública, durante o governo do presidente Epitácio Pessoa ${ }^{172}$.

A construção do Asylo de Mendicidade e suas posteriores transformações de finalidade e gestão, se configuram dentro de um quadro mais geral da formação do Estado através do ato de "civilizar" a cidade do Rio de Janeiro. Fazia parte do projeto de "aburguesamento" da cidade, integrava o plano urbanístico de 1876 e o Plano da Junta de Higiene de 1878, seu conjunto arquitetônico foi parte fundamental da construção da saúde pública no Brasil. O Asylo de Mendicidade era a expressão concreta da razão burguesa, da cientificidade, da racionalidade administrativa do Estado. Era parte dos planos urbanísticos enquanto ação de hygiene por parte do Estado, era indubitavelmente uma ação de assistência social

172 Para um entendimento do papel do Asylo de Mendicidade na formação saúde pública e da medicina social ver Silva Júnior (2000). 
pública, ou se quisermos nos restringir fielmente a denominação da época, era sem dúvida uma ação de assistência pública. Era parte do processo de modernização da cidade do Rio de Janeiro, espelhava não só a modernidade técnica pela engenharia empregada para construir no mangue, como também a modernidade pela técnica social empregada.

Por fim, como meio de deixar mais evidente que o Asylo de Mendicidade, apesar de ter sido um "pardieiro" - como era denominado por alguns chefes de polícia da época - deve ser classificado como uma instituição policial de assistência, transcrevemos as ideias do chefe de polícia Dr. João Coelho Bastos, segundo o qual:

a infância desamparada requer casas de educação. Por ora só temos na capital do império um asylo destinado a este fim; o qual é insufficiente. Os esylos de mendicidade não entram, por sua natureza, na espécie das instituições protectoras da infância ou da velhice, nem na dos hospitaes e enfermarias. Seu fim é soccorrer a indigência que obriga a esmolar para viver, e que pôde ser remediada pelo trabalho compativel com as forças e estado do mendigo. É este, pelo menos, o caracter dos que devem estar sob a direcção do estado, e que em vários paizes tem a denominação de cassa de trabalho, como na Inglaterra, de casas de industria, como na Allemanha. A assistência publica previne assim a extrema miséria, que conduz ao crime; separa os verdadeiros indigentes dos vadios e vagabundos, que devem estar sujeitos a acção correccional da policia. Si a indigência procede da idade, de moléstias curáveis, ou de defeitos e vícios orgânicos que exijam um tratamento ou regimen peculiar, outras são as instituições que devem prestar o soccorro necessário. Tudo isto reconheceu o governo desde a fundação, e esteve por algum tempo o estabelecimento sob a inspecção do chefe de policia, regido por suas instrucçoes; mas; a necessidade de não deixar em abandono aquelles outros infelizes determinou as disposições regulamentares em vigor que dão ao asylo um caracter mixto de assistência publica e de beneficência particular, e o subordinam a policia e ao juízo de orphãos, conforme as differentes classes dos asylados ${ }^{173}$.

\subsection{Escolas da Polícia}

Estamos chamando de escolas da polícia a Escola Quinze de Novembro e a Escola dos Menores Desvalidos, como meio de chamar a atenção para o fato de que a assistência se constituía em práticas de polícia, que somente começa a se descolar desta no final da década de 1920. Além do asylo de mendicidade, que era uma

173 BRASIL. Ministério da Justiça. Relatório do ano de 1886. Rio de Janeiro. Imprensa Nacional, 1887, p. 168. 
instituição de assistência criada e gerenciada pela polícia até o final do século XIX, quando passa para a municipalidade, havia a Escola Quinze de Novembro, fundada no último ano do século XIX pelo chefe de polícia João Batista de Sampaio Ferraz e a Escola dos Menores Desvalidos, fundada em 1907, também por um chefe de polícia, Dr. Alfredo Pinto Vieira de Melo. Estas duas escolas eram instituições policiais claramente de assistência, voltada para o pobre inválido, especificamente para a infância desvalida. As histórias destas instituições confirmam, ainda mais nossa interpretação de que as instituições policiais protagonizaram como representantes do Estado, e na mesma monta que a filantropia e a caridade, a construção da história da assistência social na cidade do Rio de Janeiro. Neste sentido passaremos a destacar alguns pontos que consideramos relevantes para desmontar com mais veemência que as práticas de polícia incluem a assistência social como meio de disciplinar a pobreza não criminalizada. Mais uma vez se faz necessário a ressalva de que não pretendemos aqui construir a histórias das instituições citadas, mas usar suas histórias para demonstrar as relações das ideias e práticas de polícia com a concepção do controle via práticas de assistência.

A Escola Quinze de Novembro era mais uma instituição policial de práticas de assistência pública, na categoria que hoje denominamos de "assistência social". Criada no dia 3 de dezembro de 1899, funcionou inicialmente na Rua de São Christovão n. 168. Neste início era recomendado "só mandar admittir menores viciosos ou vagabundos, exclusivamente do Districto Federal, orphãos de pai e mãe, e que em absoluto não disponham dos recursos para prover á sua honesta subsistência"174. Havia 25 vagas, 20 sob a ordens do chefe de polícia e as outras 05 a disposição do juiz criminal "para os menores condemnados, a que se refere o art, 30 do Código Penal, comtanto que o recolhimento destes não exceda á idade de 17 annos"175. A Escola Quinze de Novembro sofreu nova organização pelo decreto $\mathrm{n}$. 4730 de 2 de março de 1903, quando assume a direção o Dr. Franco Vaz, o qual permaneceu frente ao cargo por mais de 20 anos. A esse respeito escrevia o chefe de polícia no relatório referente ao ano de 1924, que "está ainda á frente deste util

\footnotetext{
${ }^{174}$ BRASIL. Ministério da Justiça e Negócio Interiores. Relatório dos anos de 1900 e 1901 . Rio de Janeiro. Imprensa Nacional, 1901, p. 158.

175 Idem.
} 
e importante estabelecimento o Sr. Mario Franco Vaz"176. No relatório referente aos anos de 1914 e 1915 o chefe de polícia Dr. Aurelino de Araujo Leal tecia grandes elogios a Franco Vaz registrando que "é de justiça pôr em relevo que o seu director, reconhecidamente um estudioso da especialidade e por ella apaixonado, tem, com o seu próprio esforço, attenuado as deficiências financeiras que hão difficultado o desenvolvimento da escola"177.

O decreto citado acima obrigava o diretor a Escola Quinze a enviar seu relatório direto para o ministro e não mais para o chefe de polícia como fazia. $\mathrm{O}$ decreto instituía a finalidade da Escola Quinze de Novembro, "que deveria recolher os menores entre 9 e 14 anos encontrados habitualmente sós na via pública, entregues a si mesmos e privados de educação". Para que através da educação pelo e para o trabalho pudesse transformar potenciais criminosos em trabalhadores dóceis. Este decreto continuava em vigor mesmo quando da mudança da Escola para a fazenda da Bica. Esta mudança era parte do clamor e recomendações dos diversos chefes de polícia como, por exemplo o desembargador Dr. Manoel José Espinola, em seu relatório referente aos anos de 1905 e 1906 clamando que "urge, portanto, dar nova organização a Escola Quinze de Novembro para que, pelo menos, esse asylo preste os serviços que pôde prestar e que até agora não

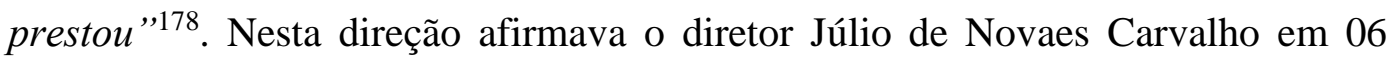
fevereiro de 1905 que "a Escola Correcional Quinze de Novembro está na adversidade e passando por uma grande crise; eu vol-o aviso em tempo" "179.

As inúmeras adversidades e a necessidade de um estabelecimento educacional agrícola gerenciado pela polícia levaram a mudança da Escola Quinze do meio urbano para o meio rural. Um mudança nitidamente inspirada nas experiencias francesas das escolas agrícolas para menores, decantadas e usadas como exemplo - de tratamento adequado, civilizado e cientificamente justificado por diversos chefes de polícia do século XIX na cidade do Rio de Janeiro. Esta inspiração pode ser verificada no relatório referente aos anos de 1919 e 1920,

176 BRASIL. Ministério da Justiça e Negócio Interiores. Relatório do ano de 1924. Rio de Janeiro. Imprensa Nacional, 1926, p. 220. Há uma controvérsia de datas para Vianna de 1903 a 1912, mas claramente em 1903 ele era assistente do diretor Júlio de Novaes Carvalho.

${ }^{177}$ BRASIL. Ministério da Justiça e Negócio Interiores. Relatório dos anos de 1914 e 1915 . Rio de Janeiro. Imprensa Nacional, 1915a, p. 125.

${ }^{178}$ BRASIL. Ministério da Justiça e Negócio Interiores. Relatório dos anos de 1905 e 1906 - Volume 01. Rio de Janeiro. Imprensa Nacional, 1906a, p. A-E-5.

${ }^{179}$ BRASIL. Ministério da Justiça e Negócio Interiores. Relatório dos anos de 1904 e 1905 - Volume

I. Rio de Janeiro. Imprensa Nacional, 1905a, p. A-F-13. 
quando afirmava o ministro da justiça Dr. Alfredo Pinto Vieira de Mello que a "Escola Quinze de Novembro é uma instituição que nos honra e nada tem que invejar ás escolas de Mettray e Saint Hilaire ${ }^{" 180}$. Sobre a mudança informava o chefe de polícia Dr. Alfredo Pinto Vieira de Mello, em seu relatório referente aos anos de 1906 e 1907.

Com a transferencia da sede desta instituição para a Fazenda da Bica, adquirida para esse fim, pensa o seu director, o Sr. Franco Vaz, que, dispondo a escola de uma administrarão esforçada e apta, poderá com os recursos do próprio solo da fazenda constituir umpatrimónio regular no fim de cinco a seis annos,que bastará, talvez,para custeal-a de então por diante, offerecendo-lhe uma vida inde-pendente, ideal este que parece perfeitamente attingivel ${ }^{181}$.

No relatório seguinte (1907-1908) informava, o referido chefe de polícia, que:

este estabelecimento, cujos serviços são superintendidos pelo chefe de policia, achase definitivamente instalado na fazenda da Bica, para esse fim expressamente adquirida. A sua remoção para a localidade em que se acha trouxe incontestavelmente as melhores condições de hygiene e conforto, qualidades essenciaes aos estabelecimentos de tal natureza ${ }^{182}$.

A Escola Premonitória Quinze de Novembro permaneceu como uma instituição de assistência configurada como práticas de polícia até 1922, quando ainda sob a direção de Franco Vaz "recebeu, por decreto n. 15.848, de 20 de novembro (...) uma organização independente do serviço policial" ${ }^{\text {"183 }}$. A Escola Quinze tinha a preocupação claramente enunciada em associar educação e trabalho. O trabalho como elemento regenerador que aparece pronunciado em todas as instituições, tinha clara diferenças entres as instituições consideradas punitivas e correcionais e as consideras premonitórias, chamadas por isto mesmo de escola. $\mathrm{O}$ contraponto que nos ajuda a perceber a diferença se dá ao olharmos comparativamente para a Colônia Correcional de Dois Rios, para onde a infância desvalida só era levada em caso de comportamento criminoso e comprovadamente incorrigível. Diferente da Escola Quinze que tinha por objetivo prevenir a infância

\footnotetext{
${ }^{180}$ BRASIL. Ministério da Justiça e Negócio Interiores. Relatório dos anos de 1919 e 1920 . Rio de Janeiro. Imprensa Nacional, 1920, p. XLVI.

${ }^{181}$ BRASIL. Ministério da Justiça e Negócio Interiores. Relatório dos anos de 1906 e 1907 - Volume 01. Rio de Janeiro. Imprensa Nacional, 1907a, p. 76.

${ }^{182}$ BRASIL. Ministério da Justiça e Negócio Interiores. Relatório dos anos de 1907 e 1908 - Volume 01. Rio de Janeiro. Imprensa Nacional, 1908a, p. 124.

${ }^{183}$ BRASIL. Ministério da Justiça e Negócio Interiores. Relatório dos anos de 1922 e 1923 . Rio de Janeiro. Imprensa Nacional. 1923, p. 227.
} 
desvalida de trilhar seu caminho "natural" de anteposto do comportamento criminoso. Enquanto que a Escola Quinze tinha a ênfase no trabalho na perspectiva da educação, a colônia correcional tinha o trabalho como punição. A história de inúmeras famílias pobres que por vontade própria colocavam seus filhos para serem instruídos profissionalmente não deve ser desconsiderada. As histórias destas famílias demonstram que a representação social da Escola Quinze para os contemporâneos não orbitava, somente, em torno da punição e do banimento, como era o caso dos comportamentos classificados como criminosos. Fica evidente que a Escola Quinze não era uma instituição punitiva e o fato de ser uma instituição da polícia não descredencia enquanto prática exclusivamente de assistência no aspecto preventivo e protetivo da infância desvalida. Guardada as devidas proporções do que significa prevenção e proteção para a época. A esse respeito podemos observar a descrição feita pelo chefe de polícia Dr. Aurelino de Araujo Leal, em seu relatório referente aos anos de 1914 e 1915, por ocasião da visita realizada na Escola Premonitória Quinze de Novembro. Após destacar a boa impressão despertada pela "ordem, limpeza e disciplina do pessoal", criticava: "sob o ponto de vista technico, a Escola Premunitoria reclama grandes reformas de ordem a approximal-a do ideal pedagógico e dos princípios firmados no domínio da prevenção" ${ }^{184}$.

Podemos categoricamente afirmar que a Escola Premonitória Quinze de Novembro era uma instituição policial de assistência, ou dito de outra maneira, que a assistência também era parte do cabedal de técnicas policias no controle e disciplinamento da administração da cidade. A descrição do chefe de polícia Dr. Belisario Fernandes da Silva Távora nos permite, entre outras, ajuizar a afirmação acima. Segundo o referido chefe

este departamento policial [Escola Premonitória Quinze de Novembro] caminha em uma serie progressiva de melhoramentos e se impõe como instituição de utilidade imprescindivel de interesse publico. Às oficinas funccionaram satisfactoriamente; a de alfaiate preparou 6.665 peças de vestuário; a de marceneiro fez 452 trabalhos diversos; a de sapateiro fabricou 3.055 pares de sapatos; a de ferreiro 1.954 peças diversas; a de vassoureiro 3.937 obras diversas; a de funileiro 689 trabalhos de sua especialidade: a de pintura executou 236 trabalhos $^{185}$

\footnotetext{
${ }^{184}$ BRASIL. Ministério da Justiça e Negócio Interiores. Relatório dos anos de 1914 e 1915. Rio de Janeiro. Imprensa Nacional, 1915a, p. 125.

185 BRASIL. Ministério da Justiça e Negócio Interiores. Relatório dos anos de 1910 e 1911 . Rio de Janeiro. Imprensa Nacional, 1911, p. 92.
} 
Além de toda esta produção, a Escola Quinze ainda fabricava tijolões que eram vendidos e usados na própria escola, da mesma forma, pedras extraídas da pedreira de seu próprio terreno, produtos resultantes da agricultura cultivada na escola e, ainda, vacas, bois, cavalos, muares e galinhas. Contava com uma produção de leite e ovos que supria as necessidades da escola. Havia também o ensino formal e disciplinas especiais, por exemplo, em 1912

foram submettidos a exames, nas duas series de ensino da escola, 448 alumnos, e no ensino especial de musica, gymnastica e esgrima, 128. Approvados em instrucção primaria, 365 e em disciplinas especiaes 124. Reprovados em instrucção primaria, 83 e em disciplinas especiaes quatro ${ }^{186}$.

Segundo Vianna (1997, p. 64), a Escola Quinze tinha "um caráter singular frente às demais instituições policiais, mais próximo de um outro circuito de intervenção (que estou denominando vagamente aqui de assistência)”. Interessante observar que autora vagamente interpõe a interpretação que para nós é a chave central de nossa tese, que a polícia produzia práticas e discurso de assistência. Percebemos que, como acontece com a maioria dos autores, qualquer ação que se associa as instituições policiais acaba-se "naturalizando" como da ordem estrita da repressão e criminalização. Esta interpretação das instituições policiais que naturaliza suas práticas de modo a torna-las "a-histórica", não considera, ou desconhece, a amplitude e complexidade do papel da polícia, enquanto instância política e administrativa na formação do Estado-nação no Brasil.

O olhar interpretativo hegemônico da formação histórica das instituições policiais naturalizou determinadas dinâmicas sociais a esse respeito que não considerou a complexidade e a amplitude do escopo de ação que as instituições policiais usavam na administração da cidade, no controle e disciplinamento da pobreza urbana. Por não podermos descolar a polícia da criação e gestão da Escola Quinze, sendo esta uma instituição policial, a interpretação usual ou falar desta escola, acaba por inferir a criminalização da infância desvalida materializada na representação social do "menor". Fato é que, quando o menor era classificado como incorrigível e criminoso seu destino certamente não era a Escola Quinze. Levavase a sério a denominação "premonitória". De modo que, se aceita, sem muitos

${ }^{186}$ Ibidem. 
questionamentos, uma interpretação que prescreve o sentido genealógico na criminalização da pobreza ao jugar o fato, de que, por analogia simples, se a Escola Quinze de Novembro e a Escola de Menores desvalidos são instituições pertencentes e gestadas pela polícia, logicamente são da ordem da punição, repressão e criminalização. Este modo de olhar a polícia, pela naturalização hegemônica que sofreu a interpretação de sua história, mesmo quando se identifica práticas alheias a criminalização é possível de ser identificado, por exemplo, quando afirma Vianna (1997, p. 72), em relação a Escola Quinze que, embora "procurasse construir para si uma imagem distinta e mesmo oposta das demais instituições policiais para menores, o seu pertencimento à organização polícia”, não permitia tecer outra interpretação, a não ser, pelos aspectos que levavam a criminalização da infância pobre desvalida. Mesmo reconhecendo que a Escola Quinze "legitimava uma determinada forma de intervenção policial, calcada não na punição a atos concretos mais na necessidade de "reformar" indivíduos" (Vianna, 1997, p. 72), o simples fato de estar associada a polícia não permite interpreta-la como instituição de assistência social, ou simplesmente, assistência como era o usual da época.

No entanto, mesmo não se desgarrando totalmente do pensamento hegemônico que enxerga as ações de polícia como única e exclusivamente pela lógica de controle pela repressão e criminalização. A autora reconhece que "não é possível compreender a ação da polícia, portanto, apenas com relação ao seu escopo usual de tarefas (vigilância, repressão e apuração de delitos, etc.), mas sim como parte de certa economia própria de Estado" (Vianna, 1997, p. 76). Neste sentido, Vianna nos inspira e antecipadamente aponta o que apropriadamente comprovamos aqui, de que nesta economia de Estado, da qual a polícia era parte, encontrava-se, entre outras práticas não criminalizantes, as ações e ideias de assistência social. Estas ideias eram materializadas nas práticas de polícia, onde vislumbramos as três instituições de assistência aqui tratadas. Através do estudo da infância desvalida nas primeiras décadas do século XX, Vianna (1997) acaba por concluir, tal qual o ponto de vista que defendemos, que a polícia exercia funções e práticas que não podem ser reduzidas ao escopo da mera repressão e criminalização, sob a pena de naturalização do processo histórico de formação desta instituição. Tanto no que diz respeito a história da polícia na sua dimensão do mundo ocidental judaico-cristão, quanto na particularidade referente a formação das instituições do Estado brasileiro. 
Como meio de aferir a veracidade da interpretação decantada acima, podemos citar as ideias do chefe de polícia Dr. Belisário Fernandes da Silva Távora expressas em seu relatório referente aos anos de 1911 e 1912. Segundo Dr. Belisário a Escola Premonitória Quinze de Novembro era um "Instituto de assistência á infância moralmente abandonada, tendo por escopo, nossa tarefa de protecção ás crianças desvalidas ou transviadas, o desempenho de uma funcção que é um dever da collectividade" ${ }^{187}$. No entanto, e apesar de ser um dever de toda a sociedade, segundo o referido chefe de polícia, não cabia a polícia da conta de tal demanda. Para o Dr. Belisário a "Escola Premunitoria Quinze de Novembro por sua natureza e por seu destino seria logicamente comprehendida na esphera da competência municipal" ${ }^{188}$. Como era a longa discussão que se dava, naquele momento, entre a polícia e a municipalidade abordada no capítulo anterior. Nesta colocação do Dr. Belisário Távora podemos identificar claramente que a Escola Quinze não se tratava de local do criminoso, mas de espaço para a proteção da infância desvalida. Exatamente por este raciocínio que o Dr. Belisário afirmava que a Escola Quinze devia ser uma atribuição da municipalidade, por não se tratar do local onde se lida com criminosos.

A outra escola da polícia, denominada Escola de Meninos Abandonados, também se configurava como um inciativa para dar respostas ao cotidiano da pobreza não criminalizada que "incomodava" a ordem urbana na parte burguesa da cidade. A Escola de Menores Abandonados era também chamada em alguns relatórios de Asylo de Menores Abandonados. A historiografia produzida até agora sobre esta instituição de assistência ligada diretamente a polícia concorrem em unânime para a fato de que sua fundação seu deu em 16 de fevereiro de 1907. Parece-nos, no entanto, que esta instituição é uma continuidade da ação de recolhimento que se fazia de menores não criminosos para local específico da Casa de Detenção. Neste sentido, podemos observar nos relatórios pesquisados que era constante a grita dos chefes de polícia denunciando o fato de que não correspondia aos preceitos da moderna ciência e do humanitarismo enviar menores para as dependências da Casa de Detenção. Ainda que separado em instalações próprias, eram acusadas pelos seus próprios gestores de serem improvisadas e inadequadas

\footnotetext{
${ }^{187}$ BRASIL. Ministério da Justiça e Negócio Interiores. Relatório dos anos de 1911 e 1912 . Rio de Janeiro. Imprensa Nacional, 1912, p 91.

188 Idem.
} 
ao desenvolvimento de oficinas e atividades educacionais. Outro indício de que a inauguração da Escola de Menores Abandonados é a reformulação, melhoramentos e adequando do tratamento dado a infância desvalida, em muito reivindicado e denunciados pelos diversos chefes de polícia, pode ser vislumbrada quando no relatório dos anos de 1906 e 1907 o chefe de polícia Dr. Augusto Tavares de Lyra descreve que "em logar de encarcerados como eram na Casa de Detenção, teem esses infelizes um abrigo protector, ali-mento e instrucção elementar durante a permanência no estabelecimento, onde ficam á disposição dos respectivos juizes de Orphãos" ${ }^{\prime 189}$.

Mesmo tendo sido separado da Casa de Detenção, fisicamente, a Escola de Menores Abandonados continuava administrativamente vinculada a esta, o que leva a interpretações de que este Escola era simplesmente uma prisão de menores de caráter meramente punitivo. Este aspecto pode ser vislumbrado no relatório referente aos anos de 1913 e 1914, quando lê-se, que "a chefia de policia confiou novamente a superintendência de ambas as secções da Escola - a do sexo masculino e a do sexo feminino - ao administrador da Casa de Detenção, coronel Arthur de Meira Lima ${ }^{190}$. No entanto, apesar de haver vagas aos incorrigíveis não era esse o seguimento da infância pobre prioritário para os anseios da Escola. Esta relação direta com a administração da Casa de Detenção permite a hegemonia das interpretações que a referida Escola era mais um elemento de criminalização da infância desvalida. Ao nosso modo de ver, ela se configura exatamente em um exemplo de que as instituições policiais buscavam respostas institucionais no controle da pobreza urbana, neste caso a inválida, distinta da mera criminalização.

No relatório referente aos anos de 1911 e 1912 podemos ler em relação a Escola de Menores Abandonados que "este instituto continua a funccionar no edifício á rua Francisco Eugênio, installação capaz de abrigar hygienicamente grande numero de menores, necessitando, porém, de pavilhões destinados á infermaria, pharmacia, aulas e alojamentos dos guardas" ${ }^{\prime 191}$. Neste relatório, podemos ainda ver a descrição das oficinas que eram realizadas e o resultado do

\footnotetext{
${ }^{189}$ BRASIL. Ministério da Justiça e Negócio Interiores. Relatório dos anos de 1906 e 1907 - Volume 01. Rio de Janeiro. Imprensa Nacional, 1907a, p. 82.

${ }^{190}$ BRASIL. Ministério da Justiça e Negócio Interiores. Relatório dos anos de 1913 e 1914. Rio de Janeiro. Imprensa Nacional, 1915b, p.108.

${ }^{191}$ BRASIL. Ministério da Justiça e Negócio Interiores. Relatório dos anos de 1911 e 1912 . Rio de Janeiro. Imprensa Nacional, 1912, p. 94.
} 
processo educacional desenvolvido nesta "escola da polícia". A esse respeito descrevia o chefe de polícia Dr. Belisario Fernandes da Silva Távora que "mais de 100 menores, que entraram completamente analphabetos, aprenderam a ler $e$ outros ampliaram os seus conhecimentos, notando-se o aproveitamento de todos os alumnos, em numero de 259"192. Ainda podemos ler no referido relatório sobre o modo de funcionamento da Escola de Menores Abandonados que "a aula de gymnastica sueca muito concorreu para o desenvolvimento physico e boa saúde dos menores, alliando a essas vantagens innegaveis a de poderem ser todos eles exercitados ao mesmo tempo" ${ }^{193}$. Aspectos do ensino educacional militarizado também compunham a metodologia empregada "os jogos de força e destreza ao ar livre, a marcha, a corrida e a natação completariam o systema de exercícios sem apparelhos, que é de todos o mais recommendavel na cultura physica dos menores" 194.

Havia também "aula de música, possuindo a escola uma excelente banda composta de 40 figuras" 195 no ano de 1912. Esta banda era contratada para tocar em diversas festas, no ano de 1913, por exemplo, recebeu "como resultado desses contractos, a quantia de 660\$700, que se acha em poder da administração" 196. Existia também outros meios que a Escola gerava renda através do produto dos trabalhos dos internos, como por exemplo, a carpintaria que produzia vários mobiliários para a própria escola e para a venda, como bancos, armários, entre outros, da mesma forma que a "industria de vassouras, escovas e espanadores produziu para o consumo geral da Escola, como também para o de algumas repartições publicas" ${ }^{197}$. Além destas oficinas havia serviços médicos e odontológicos que, por exemplo, ano de 1911, realizou diversas correções de anomalias dentárias, praticou 538 obturações, fez 106 extrações de dentes temporários e 157 de dentes permanentes ${ }^{198}$. Preocupações, todas, que se quer eram ventiladas quando de se tratava de Casa de Detenção ou da Escola Correcional de Dois Rios.

\footnotetext{
192 Ibidem.

193 Idem.

${ }^{194}$ Idem.

195 Idem, p. 95.

${ }^{196}$ Idem.

${ }^{197}$ Idem.

198 Idem.
} 
Nas circunstâncias acima, evidencia-se o envolvimento direto da polícia não pelo aspecto criminal mas pelo aspecto social do que significava este tipo de ação dentro do mais moderno pensamento científico da época. A esse respeito, afirmava o chefe de polícia Dr. Alfredo Pinto Vieira de Mello que a fundação da Escola de Menores Abandonados

é a demonstração viva do interesse que tem o Policia pela sorte de muitas infelizes creanças, que perambulam pelas ruas, sem educação, nem officio, destituídos de qualquer assistência natural, dormindo nas lages das calcadas de ruas escusas, servindo de auxiliares a gatunos audazes, alimentando-se das sobras dos hotéis e entregues aos vicios mais abjectos ${ }^{199}$.

A Escola de Menores Abandonados difere da prisão e da ideia de punição, pois a ela era reservado os menores passíveis de regeneração. Havia, é fato, um claro componente de afastar estes menores das ruas, de confina-los, mas no confinamento de instrui-los e, não simplesmente o banimento e a punição. Segundo Vianna (1997), a Escola de Menores Abandonados funcionava como um local de passagem ou mesmo de triagem para os outros diversos destinos que a polícia tinha para os menores abandonados. Segundo a autora, o fato de que havia um grande número de entradas e saídas e uma curta permanência, diferente do que acontecia na Escola Quinze indica tal interpretação. Podemos ter uma ideia deste movimento no relatório de 1913 através de uma sistematização, onde lê-se que em 1907 houveram 197 internos, em 1908 passaram 217, em 1910 um total de 213, no ano de 1911 foram 238, em 1912 tiveram 400, em 1913 a totalidade de $485^{200}$.

Além destes aspectos relativos a rotatividade havia também a questão da provisoriedade da própria Escola que aparecia em vários relatórios. Em alguns momentos não fica claro se esta provisoriedade era relacionada às instalações ou ao próprio fato de que não devia ser a polícia que devia dar respostas sociais para esta problemática. Vianna (1997) também chama a atenção para o aspecto da provisoriedade que aparecia nos relatórios em relação a Escola de Menores Abandonados. Neste sentido, podemos ler no relatório, referente aos anos de 1913 e 1914 que a escola mesmo com a

\footnotetext{
${ }^{199}$ BRASIL. Ministério da Justiça e Negócio Interiores. Relatório dos anos de 1906 e 1907 - Volume 01. Rio de Janeiro. Imprensa Nacional, 1907a, p. 82.

${ }^{200}$ BRASIL. Ministério da Justiça e Negócio Interiores. Relatório dos anos de 1912 e 1913. Rio de Janeiro. Imprensa Nacional, 1913, p. 93.
} 
organização provisória e deficiente, continua a prestar, entretanto, os mesmos serviços de assistência immediata, inadiável, não sendo outro o recurso de que se valem as autoridades policiaes e judiciarias em situações verdadeiramente penosas, creadas pelo abandono material e moral de centenas de menores, entregues a si próprios ou, melhor, a todas as influencias degradantes do vicio e do crime nas ruas desta capital $^{201}$.

Da mesma forma que o chefe de polícia Dr. Belisário Távora propunha no relatório referente aos anos de 1911 e 1912 que a Escola Quinze deveria ser parte da gestão municipal. Visto que estas são medidas que "cabe perfeitamente na orbita administrativa da cidade, escapando á acção preventiva e judiciaria da Policia que deveria limitar-se a exercer em primeiro caso a vigilância assecuratoria da ordem publica obstando a violação dos direitos individuais"202. O Ministro da Justiça Dr. Carlos Maximiliano Pereira dos Santos no relatório referente aos anos de 1914 e 1915 também expressava suas ideias no mesmo sentido de que instituições como a Escola de Menores Abandonados não deveriam ser parte da administração policial. No entanto, há uma diferença na proposta entre o chefe de polícia e o ministro. Enquanto que o Dr. Belisário Távora propunha que o município assumisse a Escola Quinze, Dr. Carlos Maximiliano propunha que a Escola de Menores fosse encampada pela filantropia privada, como podemos ver no trecho do relatório transcrito abaixo.

Quanto a Escola de Menores Abandonados, que figura na verba da Policia, seria preferivel confial-a ao Patronato de Menores, associação beneficente dirigida por cidadãos respeitáveis e dedicados á pratica do bem. Não se compara a solicitude de um philanthropo com a de um mercenário. Se a iniciativa particular toma a si uma obra de previdencia social, corra em seu auxilio o Governo, porém não dirigindo em pessoa os trabalhos e, sim, apenas cooperando para o equilíbrio do orçamento do instituto ${ }^{203}$.

Interessante observar a concretude do pensamento liberal nesta exposição de ideias. Apesar do chefe de polícia propor a gestão governamental direta e o ministro, a indireta, das ações de assistência social, os dois convergiam para a

\footnotetext{
${ }^{201}$ BRASIL. Ministério da Justiça e Negócio Interiores. Relatório dos anos de 1913 e 1914. Rio de Janeiro. Imprensa Nacional, 1915b, p.108.

${ }^{202}$ BRASIL. Ministério da Justiça e Negócio Interiores. Relatório dos anos de 1911 e 1912. Rio de Janeiro. Imprensa Nacional, 1912, p 92.

${ }^{203}$ BRASIL. Ministério da Justiça e Negócio Interiores. Relatório dos anos de 1914 e 1915 . Rio de Janeiro. Imprensa Nacional, 1915a, p. VII-VIII.
} 
concordância de que cabia ao governo financiar, fiscalizar e animar a inciativa privada nesta direção dos negócios do Estado. A ação do ministro Dr. Carlos Maximiliano Pereira dos Santos para viabilizar a transferência da Escola de Menores para filantropia privada não se limitou a exposição de ideias. "Pessoalmente propoz e obtive que o digno presidente do Patronato tomasse a seu cargo a Escola de Menores Abandonados; a Camara o approvou, mas o Senado manteve o instituto como dependência da Casa de Detenção!'”204. Parece-nos que seus esforços nesta direção não foram em vão, aproximadamente um ano após a articulação política descrita acima, foi aprovada a lei n. 3.089, de 8 de janeiro de 1916, transferindo "a direcção da Escola de Menores Abandonados, que até a quella data estava a cargo da Policia Civil para o Patronato de Menores"205.

No entanto, não fica evidente, pelos relatórios subsequentes, se esta transferência de fato se deu. Esta dúvida paira ao lermos o relatório do diretor do, agora denominado, Abrigo de Menores do Distrito Federal em anexo no relatório do Minério da Justiça e Negócios Interiores, referente aos anos de 1925 e 1926. Neste relatório, podemos ler que "abrigou este estabelecimento em 1925, 485 menores", destes 180 foram para "Patronatos por designação do Juiz de Menores" 206. Reclamava o diretor do abrigo que o pessoal administrativo era "insuficiente para poder preencher os grandes afazeres e trabalhos aqui existentes" ${ }^{207}$. Neste sentido, ponderava que "um estabelecimento com 485 meninos não póde ter o Medico do Juizado de Menores" ${ }^{208}$. Continuava o diretor com suas reivindicações afirmando que "Temos, portanto, dois professores para lecionarem a 485 meninos" ${ }^{209}$. Neste relatório aparece também a questão da transitoriedade deste abrigo, a esse respeito podemos ler que

alega o Juiz de Menores, Senhor Ministro, ser este estabelecimento apenas uma passagem transitória, porém, essa dura mais de um ano, a maior parte das vezes, devido a dificuldade que há em colocar os menores em Patronatos e Escolas Profissionaes. Ficam, portanto, Senhor Ministro, os menores aqui abrigados sem a

\footnotetext{
${ }^{204}$ BRASIL. Ministério da Justiça e Negócio Interiores. Relatório dos anos de 1914 e 1915. Rio de Janeiro. Imprensa Nacional, 1915a, p. VIII.

${ }^{205}$ BRASIL. Ministério da Justiça e Negócio Interiores. Relatório dos anos de 1915 e 1916. Rio de Janeiro. Imprensa Nacional, 1916, p. 104.

${ }^{206}$ BRASIL. Ministério da Justiça e Negócio Interiores. Relatório dos anos de 1925 e 1926. Rio de Janeiro. Imprensa Nacional, 1928, p. 138.

${ }^{207}$ Idem.

208 Idem

${ }^{209}$ Idem, p. 139.
} 
menor ocupação e por tempo indeterminado. (...) o maior numero d'elles é de 14 a 18 anos, crescendo na maior ociosidade ${ }^{210}$.

A lógica institucional da Escola de Meninos Abandonados nos permite inferir que seu intento era abrigar a infância desvalida não criminalizada, aquela abandonada e ainda não propriamente degenerada. Do mesmo modo como se dava a finalidade da Escola Quinze. Nenhuma destas duas Escolas eram os locais do incorrigível, pois para os "reincidentes cumpre que a lei seja mais severa”. E, os tipos de regime das "Escolas da Polícia" não se adequavam ao que deveria ser aplicado aos criminosos e incorrigíveis. A estes estavam reservados a Casa de Detenção e, mais tarde, já no início do século XX, também a Colônia Correcional de Dois Rios ${ }^{211}$ e o presídio de Fernando de Noronha. Para a pobreza criminalizada, era de banimento que se tratava, para a pobreza não criminosa era oportunizado transformá-la em força de trabalho dócil e subalterna. O que para nós ganha importância é demonstrar que nestas instituições predominava o aspecto da assistência e buscavam se distanciar dos aspectos criminais. De modo que podemos afirmar categoricamente que a polícia participou ativamente na construção do campo da assistência social na cidade do Rio de Janeiro.

${ }^{210}$ BRASIL. Ministério da Justiça e Negócio Interiores. Relatório dos anos de 1925 e 1926. Rio de Janeiro. Imprensa Nacional, 1928, p. 139.

${ }^{211}$ BRASIL. Ministério da Justiça. Relatório do ano de 1875. Rio de Janeiro. Instituto Typographico do Direito, 1877b, p. A-256. 


\title{
6. Para aqueles que necessitam: considerações finais
}

\begin{abstract}
Articular o passado historicamente não significa conhecê-lo "tal como ele propriamente foi". Significa apoderar-se de uma lembrança tal como ela lampeja num instante de perigo. Importa ao materialismo histórico capturar uma imagem do passado como ela inesperadamente se coloca para o sujeito histórico no instante do perigo. O perigo ameaça tanto o conteúdo dado da tradição quanto os seus destinatários. Para ambos o perigo é único e o mesmo: deixar-se transformar em instrumento da classe dominante.
\end{abstract}

(Tese VI. Walter Benjamin apud Löwy, 2005, p.: 65).

Era inverno, quarta, por volta das $22 \mathrm{~h}$, uma noite chuvosa e fria, antecedida por um dia cinzento e ameaçador, principalmente para os que vivem "sobre si"212. Era junho de 2013, eu, para complementar a renda e por expertise nesta área, coordenava a implantação de um projeto para crianças e adolescentes em situação de rua. Este projeto funcionava em um ônibus que ficava por tempo determinado em diversos locais da cidade realizando atividades de cultura digital e atendimento social para crianças e jovens em situação de rua. Funcionava de segunda a sexta das $18 \mathrm{~h}$ às $22 \mathrm{~h}$ e no momento do ocorrido encontrava-se estacionado no bairro de Botafogo. Naquela noite úmida, tinha aparecido para as atividades poucas crianças e jovens. Em torno de 5, o que geralmente orbitava perto dos 30. Os que apareceram, logo foram tratar de resolver como e onde passar aquela madrugada, que seria triste e longa para os desaquecidos. Quando já pela hora de encerrar as atividades, que não aconteceram pela falta de audiência, aparece, de maneira curta e rápida, um grupo de quatro adolescentes. O menor tinha 9 e o maior beirava seus 14 anos de idade. Já nos conhecíamos das atividades do projeto. Costumavam "parar" em Copacabana e, para dormir usavam como estratégias, entre outras, as "malocas" propiciadas pelas pedras, praias e parques, o que seria inviável naquela noite. As marquises mais protegidas do centro da cidade já é pecúlio de outros que as dominam. Não é simples chegar, parar e dormir. As ruas para quem vive nelas

${ }^{212}$ Expressão usada no século XIX na cidade do Rio de Janeiro para designar os escravos que moravam fora da casa do seu senhor, devido a esta não ter condições de acomodar sua família e mais seus empregados. Depois passou a ser usado também no século XIX para denominar as pessoas, livres e escravos que viviam pelas ruas ou sem endereço certo. 
ou delas tem regras rígidas de mobilidade, diferentes para quem somente passa. Os quatros jovens ao chegar apresentaram diretamente sua demanda: nos leva para dormir num abrigo. Já sabiam o que queriam e para chegar a tal solução é porque já haviam avaliados todas as outras possibilidades. A equipe usou todos os recursos que tinha para fazer contatos com os equipamentos de assistência para os receberem. Ou os telefones não atendiam pelo adiantado da hora ou não havia vaga. Ao mesmo tempo nós também não tínhamos recursos de deslocamento junto com os jovens para bater na porta de equipamentos da assistência social municipal e, "tentar a sorte". Foi quando um experiente educador ${ }^{213}$ ponderou que a possibilidade de maior chance de êxito para abrigá-los naquela noite, seria através da polícia. E assim procedemos. Acenamos para um carro da polícia que passava. Ficamos incialmente com medo, pois o imediatismo do julgamento e as representações sociais do "menor" fizeram a polícia chegar em atitude que ajuizava sermos vítimas. Confusão de percepção desfeita imediatamente. Fomos prontamente bem atendidos pela polícia que anotou nossos dados para compor a ocorrência e o sargento disponibilizou seu número de celular, bem como, foram todos os policiais identificado por nós. Também a nossa representação social da polícia nos fazia tomar algumas precauções. Os meninos entraram no carro da polícia sem nenhum tipo de coerção, enrolados em seus cobertores. Foram levados para $10^{\mathrm{a}}$ Delegacia de Polícia, de onde foram conduzidos para abrigos da prefeitura. Dormiram aquela noite fora do frio e da chuva. Todos os recursos da assistência social, particular e pública, mobilizados se mostraram impotentes para propiciar de maneira urgente uma noite fora da chuva e do frio para uma criança e três adolescentes.

Estava naquele momento em meio as pesquisas e já escrevendo a tese aqui materializada, não podia deixar de pensar, correlacionar, inferir, procurar a lógica, a representação social, o sentido sociológico do fato. Construir interpretações, falar de continuidades, emanar as rupturas. Buscar Foucault, lembrar de Donzelot, Goffmam, nos ancorar em Marx, pensar na danação da norma, na abolição inconclusa, na metamorfose das questões, no povo Cam, nas pesquisas de Rizzini e Del Priori, nas primeiras interpretações de Lígia Costa Leite sobre as "crianças de rua" nos anos 1980. Nenhum destes vigorosos mestres, presentes em minha

\footnotetext{
${ }^{213}$ Saúdo aqui Jô Ventura e Fábio Moraes que estavam comigo no fato narrado, arte educadores,
} profundos conhecedores da dinâmica da população pobre que vive e sobrevive das ruas. 
trajetória, entre outros, eram capazes naquela noite de me confortar ou de ensejar uma lógica que satisfizesse meus anseios humanisticamente acadêmicos. Revigorava em mim um conhecimento admitido fora de todo este circuito acadêmico, construído e cravado na prática cotidiana de mais de 20 anos trabalhando diretamente com os pobres que vivem ou sobrevivem das ruas na cidade do Rio de Janeiro. No entanto, da mesma forma que não me bastavam nenhum referencial teórico a priori, também não encontrava no conhecimento construído na prática ancoragem possível que me satisfizesse. Era algo simples que acontecia, se pensarmos comparativamente com a dinâmica das desgraças humanas que esta cidade sofre a séculos. Crianças dormindo na rua, algo que acontece a séculos no Rio de Janeiro, para o qual já perdemos nossa capacidade de se indignar. Já se "naturalizou". Era simples, mas subvertia a ordem das análises que até então me satisfaziam. Era "simplesmente", adolescentes e uma criança sem ter onde dormir numa noite fria, mas era exatamente a cena que estava lendo naquele momento nos relatórios dos chefes de polícia do século XIX, que me fazia ver a todo tempo continuidades, mas sem conseguir identificar onde e nem mesmo traduzir academicamente tal percepção. Crianças pobres, pelas ruas, sem adultos responsáveis e cuja intervenção da polícia não foi pautada pela repressão ou criminalização. A única instituição que conseguiu, naquele momento, responder a uma "urgência social".

Apesar de não haver aqui qualquer sentido de continuidade entre este relato e a discussão abordada nos capítulos anteriores sobre o papel da polícia na construção da assistência social, o sentido da ação supera os significados e lógicas de análises pré-concebidas. Ressaltando o fato de que a materialidade da dinâmica social dos pobres urbanos que vivem ou sobrevivem das ruas na cidade do Rio de Janeiro tem uma complexidade que não permitir enquadrar de maneira genérica qualquer característica. A polícia nem de longe, no acontecido acima, estava fazendo assistência como fizera no século XIX e início do XX. No entanto, há de se pensar que tal qual no século XIX, a assistência, pública e privada, não foram capazes de resolver um "simples" problema de encaminhamento da pobreza urbana inválida a não ser através da polícia. Na perspectiva de analisar os aspetos das práticas de polícia atualizada nas políticas de assistência social que desenvolveremos nossa derradeira análise, porém longe de ser conclusiva. 
Ambicionamos nesta análise, realizar em medida reduzida o que Paulo Prado confessara a Mário Guastini, através de carta publicada em "A hora futurista que passou". "Confesso a minha fraqueza pelas coisas do passado (...) Se eu tivesse, porém, o gênio e a arte do padre Antonio Vieira, em vez de história do passado, escreveria como ele a História do Futuro" (Prado, 1997, p. 7). É neste sentido que pretendemos nos recorrer ao passado para reificar o presente, sem qualquer pretensão de recontar a história, mas através dela propor interpretação particular ao que é silenciado por algumas hegemonias, acerca do modo como se deu a construção da assistência social no Brasil e sua relação como a questão social. A partir de perguntas novas intrínsecas ao posicionamento político do pesquisador, buscamos construir respostas no presente a partir do que no passado encontra-se silenciado. Antes de tudo, trata-se de uma narrativa que em nada busca um cientificismo pretensamente isento e neutro. Cabe aqui a pergunta inquietante de Walter Benjamim sobre que é a imagem verdadeira do passado. Não há aqui a pretensão do conhecimento objetivo acerca do passado, mas as interposições das subjetividades e representações do presente. O que almejamos, inspirados em Benjamin, é consagrar a unicidade entre política e teoria no domínio da subjetividade e excomungar qualquer intervenção estética que presume a linearidade vazia do tempo histórico. O que procuramos são as intermitências, os variados ritmos que compõe um mosaico messiânico de lógicas que a partir do passado reifica e se apodera da interpretação histórica-política para intervenção no presente. Não pretendemos olhar para traz, numa espécie de resignação hegeliana. Mas assentados na crítica de Marx a Hegel nos indignar com o passado para compreender os perigos e os panoramas atuais. De modo que, o pensamento dialético afugente o despertar histórico de certezas produzidas. E tanto pela realidade quanto pelo que há de onírico, se coloque como instrumento da intuição e da razão para interferir no presente, deixando de ser exclusivamente meio de construir e descontruir o passado.

Acreditamos que conseguimos de maneira bastante consistente responder a pergunta que fizemos no capítulo conclusivo de nossa dissertação de mestrado ${ }^{214} \mathrm{a}$ qual foi a gênese desta tese. A pergunta que encerra nossa dissertação apontou "novas questões acerca do papel da polícia enquanto formuladora e executora de

${ }^{214}$ Idem, op. cit, nota 2, p. 15. 
políticas de assistência" (Souza, 2010, p. 160). Finalizar a dissertação fazendo uso de uma pergunta, se deu devido à polícia ter aparecido com um decisivo papel no gerenciamento de instituições de assistência. Neste sentido afirmava em minha dissertação que "as evidencias surgidas no decorrer de nossa pesquisa documental confirmam a importância da reconstrução histórica e análise do papel da polícia na institucionalização de práticas e discursos" (Souza, 2010, p. 160) relacionados a assistência social. Confiamos que agora está posta a resposta da pergunta que eclodiu inesperada e intuitivamente. Um insight só possível de acontecer, em minha concepção, pois experiência nos documentos históricos o que vivi em mais de 20 trabalhando diretamente com a população pobre que usa as ruas para morar e sobreviver. Por aqui a história não se constitui em instrumento frio, documento empoeirado, a todo o momento a poeira era exatamente as lagrimas, os suores, os sorrisos, os desejos e o sangue diário que vivenciava trabalhando diretamente nas ruas. Não era somente um pesquisador diante de documentos históricos, era toda a carga de emoções e percepções de quem atuou a anos, e atua, junto a pobreza urbana visível nas ruas da cidade do Rio de Janeiro.

Ao aceitarmos que ficou demasiadamente comprovado que as instituições policiais têm o mesmo peso dramático e que protagonizaram, tal e qual, a filantropia e a caridade a cena da construção histórica da assistência social, temos que inevitavelmente rever nossas interpretações do presente que se sustentam em análises sobre o passado, adversa a que demonstramos. É aceito, sem nenhuma, ou praticamente nenhuma expressão em contrário, sem celeumas ou contradições aparentes, que podemos identificar claramente que a Igreja e o laicismo pela filantropia são os pilares históricos que se constituem nos propulsores e "protoformas" 215 do que hoje se nominou, em seu mais alto grau técnico, como política de assistência social. Mesmo considerados como "protoformas" - o que não concordamos - a caridade e a filantropia estão presentes em qualquer

\footnotetext{
${ }^{215}$ Segundo Rangel (2013, p. 19) a ideia de "protoforma" para se referir indiscriminadamente a toda e qualquer ação referente a assistência social anterior a 1930, deve-se ao processo de reconceituação, que buscou reconstituir a história profissional do Serviço Social. "Nessa reconstituição histórica prioriza-se a década de 1930, quando a profissão [Serviço Social] implanta suas primeiras instituições de formação. Nesse período, o Serviço Social é reconhecido na divisão sociotécnica do trabalho, situando-se no processo de reprodução das relações sociais na sociedade capitalista (Iamamoto \& Carvalho, 1986). Na leitura realizada pelo Serviço Social "reconceituado", o passado assistencial é considerado como uma pré-história profissional e suas concepções e práticas passam a ser conscienciosamente evitadas pela memória oficializada. Maiores informações consultar: Yazbek (1980); Backe (1994); Dahmer (2007).”
} 
reconstrução histórica que pretenda abordar a assistência social. Igreja e filantropia foram disto que sempre tratou a história da assistência social, em certa medida no mundo cristão ocidental com raras exceções, mas com toda a certeza, sem nenhuma exceção no caso da história da assistência social no Brasil e no Rio de Janeiro.

Ora, poderíamos de certo modo deduzir, sem prejuízo reducionista para nossos argumentos, que duas características sem impõe para a conclusão hegemônica de que caridade e filantropia estão nas bases históricas da construção da assistência social. Estas características consistem objetivamente em dois pontos; terem criados e gerenciados instituições de assistência social e médica e ao mesmo tempo serem os detentores dos discursos hegemônicos, baseados na ajuda, na técnica, no humanitarismo ou no paraíso sobre a pobreza urbana. Este protagonismo dotado de um discurso técnico e/ou messiânico sobre a pobreza, respaldado em práticas interventivas, fizeram estas duas instâncias a caridade e a filantropia privada serem interpretadas como gênese da "pré-história" das práticas atuais de assistência social.

De certo, se são estes os fatores que possibilitam imprimir a interpretação atual sobre o papel da caridade e da filantropia na construção histórica da assistência social, sem nenhum espaço para dúvida - por todos os aspectos apresentados nos capítulos anteriores -, devemos incluir a polícia na categórica histórica-sociológica da fundação da assistência. No modo como se expressaria Foucault, a polícia é parte da genealogia da assistência social. No entanto a polícia não é uma instituição isolada em si mesma, com autonomia própria, ela é parte direta e objetiva das forças administrativa do Estado e, a serviço deste senhor supremo que calcula suas ações. Como vimos, a polícia era o braço executor das ações do Ministério da Justiça, portanto se quisermos ampliar nossa proposição da inclusão da polícia como fundante das atuais políticas de assistência, basta olharmos para as ações de assistência da polícia como uma ação de Estado. De modo que devemos incluir a polícia enquanto representante do Estado, junto com a caridade e filantropia na construção da história da assistência social na cidade do Rio de Janeiro.

$\mathrm{Na}$ direção das ideias expostas no decorrer de nossa narrativa, como um demiurgo que busca sua própria hermenêutica, apontamos que determinadas práticas das instituições policiais de assistência se configuraram em superestrutura capaz de forjar a continuidade destas práticas nas políticas de assistência social atuais. Ficou evidente que a assistência social, médica e jurídica, já se configurava 
como ação de Estado desde a segunda metade do século XIX, cujas instituições policiais eram as principais executoras destas ações. Ficou demonstrado que a assistência é historicamente uma prática de polícia na administração das cidades e na regulação do trabalho, fora do mundo do trabalho. E, comprovou-se que havia claramente uma preocupação, nem sempre transformada em ações, no discurso policial em não criminalizar indistintamente a pobreza.

O discurso humanístico da assistência estatal, que visava não criminalizar, mas controlar e disciplinar, ao final é disso que se trata as práticas de polícia em relação a administração da pobreza inválida e da válida não criminalizada. A esse respeito manifestava-se o ministro da justiça J. J. Seabra que foi "ainda sobre a predisposição methodica da beneficência, nunca dispensada a intervenção do Estado"216. Além dos diversos aspectos da assistência pública, cuja a polícia era o principal executor, havia outras ações do Estado, também a cargo do Ministério da Justiça, que se configuravam intervenções sociais de assistência, como, por exemplo, o decreto n. 5.532, de 24 de janeiro de 1874 que cria "10 Escolas publicas de instrucção primaria, do primeiro gráo, no Municipio da Côrte”. Segundo o referido decreto, uma das escolas deveria ser destinada para execução das disposições dos arts. 62 e 63 do Regulamento aprovado pelo Decreto ${ }^{\circ} 1331$ A de 17 de Fevereiro de 1854, "sendo destinada a servir de Casa de Asylo para os meninos que se acharem nas circumstancias declaradas no primeiro dos ditos artigos, e regida pelo regulamento especial que o Governo Imperial expedirá".

Para ficar mais evidente a ação do Estado na formação da assistência social, vale reproduzir o decreto $\mathrm{n}^{\mathrm{o}} 1.331$-A, de 17 de fevereiro de 1854 . Neste decreto podemos ver outro aspecto da assistência estatal sob as ordens do Ministério da Justiça. Não mais gerenciado diretamente pela polícia, mas ligado a estrutura governamental do que na época se denominava instrução pública. No referido decreto podemos nitidamente enxergar, enquanto proposta, alguns programas, projetos e políticas públicas existentes em nossa contemporaneidade. O referido decreto que aprova o "regulamento para a reforma do ensino primário e secundário do Município da Côrte”, prevê no art. 62 que

se em qualquer dos districtos vagarem menores de 12 annos em tal estado de pobreza que, além da falta de roupa decente para frequentarem as escolas, vivão

${ }^{216}$ BRASIL. Ministério da Justiça e Negócio Interiores. Relatório dos anos de 1904 e 1905 - Volume II. Rio de Janeiro. Imprensa Nacional, 1905b, p. 231. 
em mendicidade, o Governo os fará recolher a huma das casas de asylo que devem ser creadas para este fim com hum Regulamento especial. Em quanto não forem estabelecidas estas casas, os meninos poderão ser entregues aos parochos ou coadjutores, ou mesmo aos professores dos districtos, com os quaes o Inspector Geral contractará, precedendo approvação do Governo, o pagamento mensal da somma precisa parar o supprimento dos mesmos meninos.

Podemos também perceber no referido decreto de 1854 que havia uma preocupação clara com o aspecto hoje denominado de "porta de saída" dos programas sociais, prevendo as etapas metodológicas que deveriam seguir. A este respeito podemos ler no art. Art. 63 que

os meninos, que estiverem nas circumstancias dos Artigos antecedentes, depois de receberem a instrucção do primeiro gráo, serão enviados para as companhias de aprendizes dos arsenaes, ou de Imperiaes Marinheiros, ou para as officinas publicas ou particulares, mediante hum contracto, neste ultimo caso, com os respectivos proprietarios, e sempre debaixo da fiscalisação do Juiz de Orphãos.

No entanto, apesar de serem gerenciados por outros setores do Ministério da Justiça que não a polícia, estes asilos sofriam influência direta das instituições e autoridades policiais. Estas influências se davam, entre outros, pelo aspecto do encaminhamento, pois quem destinava os que deviam ser asilados nas escolas era a polícia, depois de internos ficavam sob as ordens dos juízes de órfãos. O que demonstra mais uma vez a necessidade de estabelecer sofisticadas classificações sobre o tipo de pobreza. A polícia também influenciava, na própria dinâmica interna das instituições, pois cabiam aos chefes de polícia fiscalizá-las. A esse respeito é esclarecedor o relato do chefe de polícia Dr. Miguel Calmon du Pin e Almeida quando prescrevia que

não é fora de propósito lembrar também a salutar providencia de ser ampliado o número dos menores admissíveis no Asylo de Meninos Desvalidos, creado pelo decreto n. 5.532 de 24 de Janeiro de 1874. Tendo o governo a faculdade de fixar annualmente o numero de asylados (art. 7 do regulamento), poderia assim eleval-o de modo a serem nelle recolhidos os que a policia apprehende cada dia em abandono, e para os quaes não tem outro recurso senão o de remettel-os aos juizes de orphaos, que por sua vez veem-se em embaraços pela exigência da lei em nomearlhes tutor, não sendo fácil achar quem se queira a isso prestar, attentos os ônus a que ficam sujeitos os seus bens immoveis ${ }^{217}$.

${ }^{217}$ BRASIL. Ministério da Justiça. Relatório do ano de 1875. Rio de Janeiro. Instituto Typographico do Direito, 1877b, p. A-255-6. 
Os aspectos demonstrados acima, associados aos dados apresentados no decorrer da tese, se não nos permitem afirmar - para não sermos acusados de sacrilégio pelos "puristas" - de que havia, de certo modo, uma política de Estado voltada para assistência no século XIX, tão pouco, estes mesmo puristas podem negar a evidência de que o Estado, coordenava instituições, animava o debate, financiava iniciativas particulares, legislava e fiscalizava as práticas de assistência, entre elas a que hoje denominamos de social. Descrito assim de forma genérica nos parece às funções atual do Estado sobre a assistência social. A partir dos pressupostos acima que inferimos as continuidades e permanências - tal e qual Giuseppe Tomasi di Lampedusa no romance Il Gattopardo - das práticas e discursos policiais da virada do século XIX para XX, presentes por diversas expressões nas práticas e discursos contemporâneos das políticas de assistência social.

Um dos aspectos que inferimos enquanto permanência que nos remete a dinâmica como se dava a relação entre as instituições policiais de assistência, devese ao fato de que a assistência social só se configura enquanto direitos sociais se associada e, através da justiça e outras políticas públicas. Não bastam as instituições e políticas de assistência social para que esta se configure em direito, pois os direitos sociais somente se constituem enquanto tal, fora da assistência social, pois trata-se de uma questão do trabalho e consumo. A assistência social só se aquiesce enquanto direito pela justiça ou pelas outras políticas sociais, ela em si mesma não se configura em campo de direitos sociais. A assistência social em si se constitui unicamente em práticas de ajuda, apoio e compensações, não em direitos. Portanto, para nossa interpretação, a assistência social se configura no campo do controle e disciplinamento do mundo do trabalho, fora do mundo do trabalho, a partir de práticas de ajuda e apoio, no mesmo molde liberal, defendido pelos chefes de polícia estudados, principalmente se pensarmos em relação ao papel da assistência social no escopo geral da legitimação do Estado.

A assistência como "política estruturada e não como mediadora de acesso" (Mota, 2010, p. 138) é princípio que identificamos na lógica dos chefes de polícia do século XIX do mesmo modo como propõe a interpretação de Mota (2010), em relação a nossa contemporaneidade. Ao demonstrar que a polícia, enquanto instância executora do Ministério da Justiça (Estado), foi protagonista na formação do campo da assistência social na cidade do Rio de Janeiro, quiçá no Brasil, 
demonstramos a linha histórica de continuidade entre as ideias e práticas de uma assistência estatal construída, a partir da segunda metade do século XIX que dessegue hoje no modo em que o Estado continua gestando a assistência social, uma inciativa liberal, de legitimação do capital, sem a centralidade do trabalho. De modo que, fica evidente que as atuais políticas de assistência social têm sua genealogia composta muito mais por uma linha de continuidade das ações estatais no século XIX executadas pela polícia, do que propriamente por uma ruptura advinda da caridade e/ou da filantropia. Neste sentido, a assistência promovida pelo Estado no século XIX não permite conjecturar a aplicabilidade de conceitos como "protoformas" mas sim como um mesmo processo de continuidade de ação estatal que se moderniza a cada instante na busca soluções que permitam controlar e docilizar humanisticamente a pobreza urbana. Podemos claramente identificar que as ações de assistência social no século XIX e as atuais políticas sociais do século XXI se constituem como respostas em perspectiva liberal que busca interferir na questão do trabalho, alheio ao próprio trabalho, de modo a reeditar a cada dia a epifania republicana de fazer da não inclusão o meio eficaz de dominação. Mais uma vez a afirmação de Mota (2010, p. 137) de que o "grande capital utiliza o social como pretexto para ampliar seu espaço de acumulação" se aplica não só aos dias atuais, como é o intento de sua análise, mas também é perfeitamente compatível com a história da assistência contada aqui, bem como, com a interpretação de outros autores que estudam a assistência como, por exemplo, Sanglard (2003, 2005, 2008a) e Rangel (2013). A pobreza "como objeto do direito à assistência e não do trabalho" (Mota, 2010, p. 142) é uma continuidade possível de ser identificada literalmente nas falas dos chefes de polícia e nas políticas atuais de assistência parta os pobres válidos, o que persiste nos dois momentos a explícita desvinculação entre pobreza e acumulação da riqueza. A assistência em sua perspectiva social serviu de legitimação para o avanço do capital desde o século XIX, na cidade do Rio de Janeiro. Neste sentido afirma Mota (2010, p. 135) que "o processo histórico de desenvolvimento da Seguridade brasileira ampara a assertiva ao indicar como a burguesia brasileira, subordinando o Estado aos seus interesses, utilizou medidas relacionadas à proteção para legitimar-se".

A aliança estabelecida entre a justiça e assistência "que deu origem a ação tutelar do Estado" (Rizzini, 2008, p. 125) vai ser a base da criação do Juizado de 
Menores e o Código de Menores a partir da década de 1920, segundo a referida autora. As interpretações sobre este aspecto da relação da assistência com a justiça na formação das ações tutelares priorizam, de certo modo, um olhar para a assistência pública e privada exteriores aos domínios da justiça. Fica demonstrado pelos relatórios analisados que deveríamos incluir neste raciocino a assistência autóctone a própria justiça. Era da alçada do mesmo ministério a regulação e organização do funcionamento propriamente da justiça e das instituições de assistência social, médica e educacionais do Estado durante o período abordado por nossos estudos.

É evidente que se recorremos a Moncorvo Filho, Ataulpho de Paiva e Evaristo de Morais, entre outros, encontraremos o discurso jurídico do controle e da proteção pela assistência, da mesma forma que o encontramos em diversos chefes de polícia. Afirmava o chefe de polícia Dr. Belisario Fernandes da Silva Távora, em seu relatório referente aos anos de 1911 e 1912, que não bastava apenas a construção e o melhoramento de instituições, para ele "a solução do problema da assistência, um dos mais complexos dentre os nossos problemas sociaes, inclue as medidas de

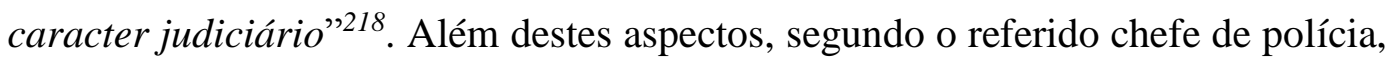
"deveria unificar os serviços autaes num systema efficiente e homogêneo, sob o ponto de vista administrativo" ${ }^{219}$. Em sua proposta de assistência continha ainda a ampliação de "duas secções da Escola de Menores Abandonados, convertidas, então, em verdadeiros núcleos profissionais, que se reforme a Escola Premunitoria Quinze de Novembro - sendo ella dotada de novas instalações capazes de abrigarem 800 ou mais crianças $^{220}$. Propunha ainda extinguir as albergarias e "promover a creação de albergues nocturnos e o desenvolvimento do Asylo de Mendicidade sob outro regímen" ${ }^{221}$. Ainda sugeria que o governo auxiliasse "as associações de iniciativa particular fundadas para soccorror a velhice ou a infância desamparada" ${ }^{222}$. Atentamos para o fato de que nesta época o asylo de mendicidade já estava sob a administração da municipalidade. As ideias do chefe de polícia citado acima demonstram outro aspecto de continuidade nas atuais

\footnotetext{
${ }^{218}$ BRASIL. Ministério da Justiça e Negócio Interiores. Relatório dos anos de 1911 e 1912. Rio de Janeiro. Imprensa Nacional, 1912, p 91.

${ }^{219}$ Idem.

${ }^{220} \mathrm{Idem}$.

${ }^{221}$ Idem

${ }^{222}$ Idem, p 92.
} 
políticas de assistência social, qual seja, a ideia de que o problema da pobreza se concentra na perspectiva da eficácia dos programas, projetos e instituições sociais.

Tal qual hoje, pelas forças das políticas de assistência social, também no Império e na primeira República a pobreza não era simplesmente criminalizada de maneira genérica pelas forças dominantes do Estado. Havia uma sutil e sofisticada classificação na construção de critérios objetivos, que separava a pobreza imposta pelas condições sociais, da pobreza adquirida pelas condições morais. Estes aspectos indicavam a pobreza que devia e a que não devia ser criminalizada. Esta lógica de classificação pode ser perfeitamente verificada no relatório de Franco Vaz, quando a pedido do ministro J. J. Seabra faz um minucioso estudo sobre as condições da infância na cidade do Rio de Janeiro. É fato, porém, como deixa transparecer o referido relatório, o aspecto moral era o que mais sobressaia e justificava as principais ações. $\mathrm{O}$ aspecto moral era o fio condutor que justificava a repressão e o banimento, mais comum do que o disciplinamento pelo trabalho e educação para o pobre não criminoso. Era longa a descrição das diversas nuances subjetivas que imperavam sob o que significava os aspectos morais na justificativa da punição. Talvez estes aspectos possam explicar o fato de ser uníssona e hegemônica a ideia de que a pobreza era indiscriminadamente criminalizada. Este tipo de pensamento expressa certo maniqueísmo e não deixa transparecer a complexidade e diversidade das relações sociais e das lutas de classes.

Fica evidente que havia uma diferença marcante nas instituições de polícia entre aquelas próprias para punir o criminoso e, aquelas que deviam controlar a pobreza pelo disciplinamento. Este controle pelo disciplinamento é próprio das instituições escolares, sejam elas policiais ou não. As próprias ações e políticas na esfera da assistência social na atualidade se dão em sua dinâmica diária pelo disciplinamento e condicionalidades. As instituições policiais de assistência não exerciam o controle simploriamente criminalizando, exclusiva e indiscriminadamente, mas disciplinando. A inda que ao olhar de hoje, por exemplo, encontremos nos métodos do asylo de mendicidade punições como a solitária, ali o regime não era penal. O disciplinamento não necessariamente passava pela criminalização, apesar de lidar com um personagem que vive neste limiar, o qual muitas vezes, como acontece hoje, passavas pelos dois sistemas, o punitivo e o disciplinador/regenerador. 
Tal qual a assistência social, as práticas de polícia foram instituídas pelo Estado para o enfrentamento dos problemas imediatos da pobreza urbana, as respostas necessitavam de ser cotidianas e resolutivas. "As coisas da polícia são coisas de cada instante, enquanto as coisas das leis são coisas definitivas e permanentes" (Foucault, 2001, p. 457). Além deste aspecto que nitidamente se constitui em características de longa duração das políticas de assistência social, encontramos outros dois que se colocam também nesta dimensão de continuidade, quais sejam; "congregar os interesses da assistência publica o da beneficencia privada" como aspectos complementares de uma única ação e ter o município, no caso a Prefeitura do Distrito Federal, desde a última década do século XIX, como o principal executor das ações de assistência social, tal qual propõe as diretrizes atuais das políticas sociais e; o fato da polícia também promover os fluxos e congregar uma rede de intuições e serviços sociais e filantrópicos, de maneira que a exercia, tal qual a assistência social hoje, um papel de articuladora das "políticas" e de instituições.

O aspecto de articulação do chefe de polícia que nos remete a mobilização de setores das classes dominantes na formulação de "políticas públicas” pode ser observado nas ideais do Dr. Antonio Algusto Cardoso de Castro, expressas em seu relatório referente aos anos de 1904 e 1905, nele podemos ler que,

appellando para a iniciativa privada, consegui fundar o conselho de Assistencia da Candelaria e tencionava obter a creação de outros, mas a situação de espectativa que nesse particular atravessamos, paralysou de alguma sorte aquella obra generosa e humnaitaria. Urge, porém, que melhoremos as cousas, e não descubro outro meio eifficaz sinão appellar para a Santa Casa da Misericórdia, que é quem no Rio de Janeiro exerce de facto a assistencia publica. O Governo póde perfeitamente augmentar as subvenções dadas á benemérita instituição, que é um titulo de honra e orgulho para a nossa cidade, e pedir-lhe que estabeleça e administre: a) creches onde possam ser acolhidos os filhos dos mendigos inválidos que o poder publico soccorrer; b) albergues nocturnos para indivíduos transitoriamente privados do trabalho; c) dispensários, onde os necessitados occasionaes encontrem alimento; d) novos hospitaes e asylos com os necessários pavilhões para moléstias chronicas; e etc. Os postos médicos municipaes para consultas aos pobres já vão dando bons resultados, e si a Prefeitura augmentar o Asylo de S. Francisco de Assis, estou que o mal ficará de alguma sorte remediado. Essas idéas já eu as expendi a um jornalista, que procurou conhecel-as e que assim as divulgou na folha em que trabalha. ${ }^{223}$

${ }^{223}$ BRASIL. Ministério da Justiça e Negócio Interiores. Relatório dos anos de 1904 e 1905 - Volume I. Rio de Janeiro. Imprensa Nacional, 1905a, p. A-G-191. 
A necessidade da transcrição deste longo trecho é para evidenciar que os chefes das instituições policiais pensavam as ações de assistência como forma de criar meios para dar respostas aquilo que eram suas incumbências; controlar a pobreza urbana, disciplinar os pobres não criminosos e punir os delinquentes. É, principalmente, deste aspecto descrito acima, que se trata nossa revisão interpretativa do papel da polícia na constituição do campo da assistência social. As práticas e discursos assistenciais relacionados à cientificidade estavam postos pelos chefes de polícia, ministros da justiça e filantropos já na segunda metade do século XIX e, com veemência. Estes eram os protagonistas das classes dominantes que discutiam a pobreza no Brasil na virada do século XIX e início do XX. No relatório referente aos anos de 1910 e 1911, o chefe de polícia Dr. Belisario Fernandes da Silva Távora nos brinca também com uma análise sobre a assistência e a polícia, que para nós se constitui em prova cabal da confirmação de nossa tese; a de que a polícia faz parte da construção histórica da assistência social. Afirmava o Dr.

Belisário que que,

outros encargos como os da assistencia, podem alargar o seu raio de influencia social e tornal-a uma instituição aparatosa, mas de certo embaraçam e complicam o funccionamonto do mecanismo policial. Constituindo especialidade techinicamente apparelhada para os seus fins não deve a policia dispersar allenção e esforço em outro domínio. Só por um desvio de bons princípios é que se mantêm a duplicidade administrativa em matéria de assistência. (...) A integração municipal dos serviços de assistência, mediante accôrdo entre o Governo da União e o do Município, cujas rendas foram accrescidas com a percepção do producto do imposto de transmissão de propriedade, contribuiria decisivamente para a solução do problema, lucrando com essa medida salutar o desenvolvimento das instituições já organizadas sobre as melhores bases e dirigidas com o mais louvável critério ${ }^{224}$.

Fica evidenciado que a polícia promovia práticas de assistência e tinha uma alocução, que em muito reproduzia ou influenciava no discurso oficial do Estado sobre a assistência e a pobreza. Deste modo, que podemos identificar as instituições policias como o local de produção simbólica sobre a pobreza e as técnicas de seu enfrentamento. Havia uma discussão entre os chefes de polícia, se era ou não função do Estado cuidar da "caridade". Cabe ressaltar que em todas as propostas o liberalismo imperava. De um lado, o "humanitarismo" positivista que defendia a perspectiva da assistência exclusivamente privada e o Estado como financiador,

${ }^{224}$ BRASIL. Ministério da Justiça e Negócio Interiores. Relatório dos anos de 1911 e 1912 . Rio de Janeiro. Imprensa Nacional, 1912, p. 92. 
regulador e fiscalizador. Contrapondo a este ponto de vista, havia a defesa de que o Estado também deveria ter suas próprias instituições e serviços, além de fiscalizar, regular e financiar as iniciativas privadas de assistência. Havia, ainda, a defesa de caridade legal e do regime de taxas. A esse respeito Dr. Antonio Algusto Cardoso de Castro, chefe de polícia, em seu relatório referente aos anos de 1904 e 1905, afirmava que

em toda parte do mundo civilizado, o auxilio do Estado, a beneficência privada, e a esmola das religiões, continuaram a ser as grandes formas do soccorro humano, mas tudo começou a identificar-se com os princípios e com os methodos rigorosos, sendo digno de registrar se o successo que semelhante resolução trouxe para o augmento da funcção normal da assistência, ao contrario do que previam e vaticinavam os adversários da caridade official ${ }^{225}$.

Estava posta a discução da seguridade social, bem como, estava também em pauta que modelo de assistencia deveria seguir, ou ainda, como adptar aspectos de diferentes modelos de assistência à realidade brasileira. Continuava o citado chefe de polícia a defender seu ponto de vista embasado nas últimas discussões internacionais sobre tema afirmando que

a transplantação necessária dos termos textuaes com que tem sido nos diversos congressos scientificos definido precisamente o papel do Estado em relação á obrigação da assistência, funcção que não pode ser illimitada e sem regras, porque importaria, de um modo implícito, na confusão manifesta dos seus intuitos, com patente prejuízo de sua execução ${ }^{226}$.

Dr. Antonio Algusto Cardoso de Castro, continuava defendendo seu ponto de vista sobre o papel do governo nas políticas de assistência afirmando que

um governo que aimunciasse que só elle concederia soccorros completos aos indigentes e em todas as idades da sua vida, carregaria com fardo enorme, anniqnüaria a industria, favoreceria a indolência do rico, do pobre mesmo, e quebraria a grande mola da sociabilidade - a beneficencia privada. Dous laços poderosos devem ser empregados para soccorrer a massa dos pobres - a beneficencia nacional e a beneficencia particular - uma deve ser limitada, variável e considerada, sob todos os pontos de vista, como um simples exemplo dado ás classes abastadas; a outra deve ser reputada - um dever ${ }^{227}$.

${ }^{225}$ BRASIL. Ministério da Justiça e Negócio Interiores. Relatório dos anos de 1904 e 1905 - Volume II. Rio de Janeiro. Imprensa Nacional, 1905b, p. 231.

${ }^{226}$ Idem, p. 234.

${ }^{227} \mathrm{Idem}$. 
Podemos destacar outros traços de continuidades que demonstram tanto a legitimidade que a assistência empresta as ações de repressão e controle, quanto os aspectos militarizantes presentes nas práticas e políticas de assistência. Entre estes traços de continuidades, destacamos a força legitimadora que as práticas de assistência imprimiam nas ações da polícia no ordenamento urbano no século XIX na cidade do Rio de Janeiro, tal qual a legitimidade emprestada hoje pela Secretaria Municipal de Assistência às operações de choque de ordem coordenadas pela Secretaria de Ordem Pública do município do Rio de Janeiro ${ }^{228}$. Outro fato que aponta um traço de continuidade na legitimação que a assistência social empresta ao ordenamento urbano via militarização é a necessidade de legitimar as ocupações militares do Estado nas favelas do Rio de Janeiro através de práticas sociais, as chamadas Unidades de Polícia Pacificadora Sociais - UPPs Sociais. Além destes aspectos poderíamos elencar a ideia da regeneração pelo trabalho e inclusão subalternizada pelos postos mais baixos da cadeia produtiva, com as inúmeras propostas dos Chefes de Polícia da cidade do Rio de Janeiro no século XIX. Tal qual no Império ou no momento fundante da República, a questão social continuou a "ser traduzida em termos políticos militares, pacificar e não de organizar, educar, mobilizar criar sujeitos potentes no mundo subalterno capazes de mobilizar seus direitos (Werneck Vianna, 2012b)". A esse respeito vale nos recorremos novamente aos nossos conhecimentos empíricos construídos em mais de 20 anos de atuação direta com pessoas pobres que vivem nas ruas e participando de fóruns e conselhos de direitos. Esta empiria nos remete as inúmeras vezes que escrevemos, discursamos, asseguramos, defendemos o ponto de vista em debates e em justificativas de projetos que o trabalho social realizado pela assistência privada, pois estávamos falando deste lugar, se constituía em um trabalho de segurança pública. De outro modo, estávamos usando a mesma lógica dos chefes de polícia do século XIX e, porque não pombalina, na medida em que se atua com intervenções sociais e com isto, também se contribui para a "tranquilidade pública".

\footnotetext{
${ }^{228}$ A esse respeito ver a dissertação de mestrado de Márcia Elizabeth Gatto Brito "O outro lado de uma política de governo na reprodução e perpetuação de desumanidades: o recolhimento de crianças e adolescentes em situação de rua na cidade do Rio de Janeiro" (Programa de Pós-Graduação em Políticas Públicas e Formação Humana, da Universidade do Estado do Rio de Janeiro. Rio de Janeiro, 2011).
} 
Ficou demonstrado que as instituições policiais se constituem parte da história da assistência social que se descortinam enquanto uma continuidade da Intendência de polícia do século XVIII em Portugal. Do mesmo modo que podemos vislumbrar determinados códigos das ordenações filipinas a imperar nas relações jurídicassociais na Primeira República. Estas relações jurídicas-sociais podem ser observadas nas "funções educativas, formativas, repressoras e regeneradoras" (Abreu, 2010, p. 367) das diversas instituições que surgiram em Portugal a partir das Casas Pia, fundadas pelo intendente de polícia Pina Manique. Decorrem da interseção da assistência com a justiça e do mesmo modo são identificáveis nas práticas e intenções dos chefes de polícia no período analisado por nós. Por esta interpretação devemos enxergar nos chefes de polícia da cidade do Rio de Janeiro, no Império e na Primeira República, como continuadores das "políticas sociais do Marques de Pombal e do intendente-geral da Polícia, Pina Manique” (Abreu, 2010, p. 367). A interpretação de Abreu (2010, p. 367), a qual nos associamos, aponta que "não se pode deixar de reconhecer a existência de projetos ambiciosos e, em alguns casos, revolucionários" nas políticas sociais pombalinas e de Pinas Manique.

Aqui reside em nosso ver a maior característica de permanência que identificamos entre as instituições policiais e as atuais políticas de assistência social a "grande capacidade de utilização do pragmatismo pombalino, que, segundo Raymundo Faoro, perpassa os processos de modernização conservadora presentes no mundo luso-brasileiro, desde as reformas empreendidas em Portugal pelo marquês de Pombal" (Neder \& Naro, 1997, p. 106). A matriz portuguesa presente na formação jurídica brasileira impedia que as inúmeras reformas e modernizações que houve ao longo da história das instituições policiais abandonassem as o "pensamento político e da afetividade portugueses, fortemente calcados na visão de mundo tomista e rigidamente hierarquizada" (Neder \& Naro, 1997, p. 134).

A assistência social é a secularização da teologia da caridade, de modo que modificou a prática sem alterar o seu sentido e significado; disciplinar a pobreza urbana na busca pelo ordenamento do mundo do trabalho, fora do mundo do trabalho. De maneira a incluir, desde o século XIX, nos postos mais subalternos da cadeia produtiva o pobre válido sem trabalho, transformado nas políticas atuais na categoria de "usuário". As oficinas de fazer vassoura, por exemplo, foram empregadas como meio de incluir subalternamente pelo trabalho desde os asylo de mendicidade e, permaneceram ativas em diversas instituições de assistência social 
pública e privada - se ainda não permanece - até a primeira década dos anos 2000. Este exemplo de continuidade, demonstrável objetivamente, traduz a lógica do controle e disciplinamento transvestido da ideia de inclusão e direito. Poderíamos aqui citar diversos outros exemplos desta continuidade das "oficinas de geração de renda" mantidas pelos serviços de assistência público e privado, como meio de resolver a questão do trabalho, fora do mundo do trabalho, por exemplo carpintaria que já existia no século XIX, entre outros. A “inclusão” pela assistência social no que significa hoje a cidadania continua a ser, como secularmente foi construído, sem nenhuma ruptura, uma inclusão que busca docilizar o lúmpen proletariado, ao mesmo tempo em que os direitos sociais só se realizam efetivamente fora do campo da assistência social. Toda a lógica armada pelas instituições preventivas e que permanece entranhada nas políticas de assistência social da atualidade é que o filho da classe proletária dever ser preparado (ajudado) para ser no máximo um proletário, ainda que seja livre para sonhar em ser proprietário "Numerosos, trabalhadores, dóceis, ou melhor, muitos trabalhadores dóceis - tudo isso vai assegurar a quantidade, de certo modo, eficaz de que se necessita para uma boa polícia" (Foucault, 2008, p. 463).

Por esta maneira de enxergar o papel da assistência na formação do Estadonação, percebemos que a regulação social não se deu pela via da cidadania. Esta tensão que passa pela formação da classe de trabalhadores livres, pelo desmonte do estatuto da escravidão e pelos incentivos a imigração branca, tem na assistência e no direito o princípio legitimador do Estado e da nação, "a transação entre a liberdade como condição da ordem e ordem como condição da liberdade, a que se referiu Justiniano José da Rocha” (Werneck Da Silva, 1981, p. 144).

Ao transformar o pobre válido na categoria de "usuário", a assistência social, por outro viés dá continuidade à política de não inclusão como meio de dominação sob o discurso vicário de direitos sociais. A regulação do mundo do trabalho fora do mundo do trabalho, as propostas pífias de geração de renda e a não inclusão "disfarçada" em inclusão subalterna, foi o modo pelo qual as instituições policiais estruturam a assistência, que hoje chamaríamos de social, na virada do século XIX para o XX.

É fato que as instituições policiais e seus "chefes" contribuíram de modo relevante para o processo de racionalização da assistência, bem como foram fundamentais para a organização de leis e políticas para este setor da administração 
pública, tal e qual os filantropos considerados reformadores (Viscardi, 2011). Os chefes de polícia continuavam influindo fortemente na determinação dos modos e meios de assistência, mesmo quando esta passa para a municipalidade. Como demonstramos anteriormente, polícia e assistência pertenciam ao mesmo ministério, mesmo quando parte da assistência vai para a municipalidade do Distrito federal, continuava sob as ordens e fiscalização direta do Ministério da Justiça, que para isto se valia da polícia. As instituições policiais de assistência e os discursos dos chefes de polícia na organização da assistência constituíram-se em representações sociais sobre a pobreza que contribuiu na formação da ordem burguesa e na estruturação de um discurso oficial do Estado liberal sobre a assistência e as desigualdades. As ações de assistência social da polícia eram parte do modo burguês de organização do Estado, onde não havia o interesse em incluir os subalternos, mas controlá-los e discipliná-los "humanisticamente". Neste sentido, buscava-se pela ideia de assistência, de algum modo, humanizar as práticas estatais de controle e disciplinamento da pobreza urbana. A partir de 1892, começa a acontecer uma gradativa e lenta perda de espaço das instituições policiais nas funções administrativas e de assistência, quando da criação da Intendência Municipal. No entanto, é somente a partir da década de 1920 que se aprofunda a distinção entre a polícia e a administração municipal na gestão da assistência.

A assistência social incorporou ao longo de sua história na cidade do Rio Janeiro, parte das funções e papeis que antes era da alçada das instituições policiais. As práticas de "ajuda e apoio", as ações de inclusão subalternizada e a necessidade de articular de outras instâncias para o controle e disciplinamento da pobreza urbana. A organização do mundo do trabalho era do que se tratava, na medida em que devia a polícia e deve hoje a assistência dar conta de conhecer, classificar e capacitar os pobres válidos, moralmente aptos, que estão fora do mundo do trabalho, de modo a não criminalizar os "que ainda fazem jus a proteção social". Atendendo aos interesses da reprodução do capital, da exploração do trabalho e do controle da circulação de pessoas e mercadorias.

Ao ter o pobre válido como parte de suas ações a assistência social nos permite tecer a afirmação acima. Ao tratar do pobre válido, aquele que precisa de trabalho, como instância de suas ações, políticas de transferência de renda e prestação de serviços, a assistência social admite aquilo que se caracterizava como parte do papel administrativo das instituições policiais no século XIX, na cidade do 
Rio de Janeiro. De certo modo, nossas afirmações apontam para permanências verificadas em práticas de polícia onde a assistência era um importante componente liberal da legitimação do Estado. É fato que a polícia enquanto formuladora e executora de práticas de assistência se dá tanto pela ausência, ou insuficiência, de instituições com estes fins na cidade do Rio de Janeiro, no período de nossa pesquisa, quanto pela tradição administrativa da polícia que remonta ao século XVII na Europa. De modo que, a polícia esta deve ser vista em sua história como residente na interseção das instancias políticas, administrativa e judiciais (Werneck da Silva, 1981).

Tal qual a assistência social na atualidade que é instrumento de legitimação da classe dominante, seja através do Estado, seja principalmente através da assistência privada, as instituições policiais eram parte direta da "construção da nação pela classe senhorial" (Werneck da Silva 1981, p. 70), onde nitidamente se incluía ações de assistência. A assistência social, segundo nossa interpretação, se constitui em aspecto da modernização administrativa do Estado de polícia. Segundo Foucault (2008, p. 433), o que interessa ao Estado de polícia é aquilo "que os homens fazem, é sua atividade, é sua ocupação". Para isto, as instituições policiais devem adotar instrumentos concretos que permitam ao Estado "estimular, determinar e orientar essa atividade de uma maneira que seja efetivamente útil ao Estado. Numa palavra, trata-se da criação da utilidade estatal, a partir de e através da atividade dos homens" (Foucault, 2008, p. 433). Em outra palavra, trata-se de formar cidadãos docilizados, capazes de contribuir com sua força de trabalho e de consumo "subalternos" para utilidade estatal, cujo mercado é o fim supremo de sua força. Papel hoje assumido no corpo estatal pelas políticas de assistência social, visto que são estas instituições que compõem a armadura material da cidadania falsificada pela ideia de constituição de direitos através de políticas de assistência social. É fato, que estava posto em todo período de nossa pesquisa a afirmação de Mota (2010, p. 141) que "as classes dominantes invocam a política de assistência social como solução para combater a pobreza relativa que imprimem o selo do enfrentamento da desigualdade", ao mesmo tempo em que institucionalizam estas desigualdades ou naturalizam-nas.

É neste sentido do "Estado de Polícia" que as ações de assistência estatais ligadas administrativamente a polícia não vão se configurar a partir da lógica da criminalização da pobreza, mas através da razão do disciplinamento pelo trabalho. 
Da maneira como preconizava o tratado de economia política de 1615, que "o homem mais entendido em matéria de polícia não é o que, por suplício rigoroso, extermina os bandidos e os ladrões, mas o que, pela ocupação que dá aos que são subordinados ao seu governo, impede que eles existam"229.

Embasado em nosso engajamento atrelado ao tema e, sobressaltado por inspirações bejaminianas, buscamos construir um pensamento eminentemente político e teórico, que não se furtou em correr riscos para traçar uma particular interpretação, do modo de compreender o papel da assistência social na longa revolução burguesa no país. Interpretação que vislumbra historicamente a assistência social como um mecanismo de poder estatal que atingiu certa eficiência no modo de incorporar de forma subalterna "aqueles que dela necessitam". Para além de toda ajuda, apoio e "diretos sociais", que se constituem hoje a políticas de assistência social, há a sofisticação e o aperfeiçoamento das práticas administrativas do "Estado de Polícia": conhecer, sistematizar, territorializar, para controlar e disciplinar as populações, nas epidemias, nas catástrofes, na pobreza e no cotidiano das relações sociais. Segundo Castel (2001, p. 49), “o social-assistencial também mantem uma relação estreita com a territorialização".

Não é por acaso que as políticas públicas atuais fundamentam-se em análise que privilegiam a razão direta entre território e população, e muito menos pode ser considerado uma formulação moderna de gestão do Estado a ideia de territorialização. O modo como se concebe a atual administração racional das práticas sociais do Estado relativa às políticas públicas de saúde, assistência social e educação tem na territorialização o conceito básico de sua estruturação. Este aspecto que hoje se coloca como moderno conceito da administração pública é facilmente localizado no princípio da racionalidade que estruturou a administração das cidades pelas instituições policiais nos principais centros urbanos da Alemanha, França, Inglaterra e Itália no século XVI. Os aspectos relativos a territorialização como meio da razão administrativa do Estado foram impostos pela necessidade de “conhecer" e possibilitado pelo desenvolvimento da ciência da estatística, ligadas estritamente a polícia, como demonstrado nos capítulos anteriores.

As práticas de assistência social da atualidade, tal qual as instituições policiais no período de nossos estudos, mais do que proteger funcionam como acionadores

\footnotetext{
${ }^{229}$ Idem, op. cit., nota 112 , p. 114 ,
} 
que legitimam a desigualdade e contribuem decisivamente para a construção de representações sociais que naturalizam o processo de produção e reprodução da pobreza no Brasil. Há certa convergência que enxerga a assistência social como uma política meramente de controle estatal sobre a pobreza e, neste aspecto, não há novidades. O ponto que, a nosso ver, conseguimos provar e introduz novidades, diz respeito ao fato de que este aspecto da assistência social se associa muito mais aos componentes históricos ligados às instituições policiais do que propriamente as filantrópicas ou caritativas. Tal qual a polícia, mas agora em lugar diferente, a assistência social faz parte da gestão da desigualdade social sem a busca de sua superação, talvez este seja esta a maior permanência do século XIX, atualizada nas politicas atuais de assistência social. 


\section{Bibliografia e fontes}

\subsection{Bibliografia}

ABREU, Laurinda de. Purgatório, Misericórdias e caridade: condições estruturantes da assistência em Portugal (séculos XV-XIX). Dynamis. Acta Hisp. Med. Sci. Hist. Illus. 2000, 20, 395-415. Disponível em: <http://www.raco.cat/index.php/Dynamis/article/viewFile/86639/111653>.

Acesso em: 05 jun. 2014.

Um Sistema Antigo num Regime Novo. Permanências e Mudanças nas Políticas de Assistência e Saúde. O Caso do Alentejo. In O Alentejo entre o Antigo Regime e a Regeneração. Mudanças e permanências. Teresa Fonseca, Jorge Fonseca (Ed.) Edições Colibri. CIDEHUS/Universidade de Évora. Lisboa, 2011.

Limites e fronteiras das políticas assistenciais entre os séculos XVI e XVIII continuidades e alteridades. Varia História, Belo Horizonte, vol. 26, $\mathrm{n}^{\circ}$ 44: p.347-371, jul/dez 2010.

Outra visão do purgatório. In Revista Portuguesa de História. Tomo XXXIII. Portugal e Brasil rotas de culturas. Volume II. Faculdade de Letras da Universidade de Coimbra. Instituto de História e Comunicação Social. Coimbra .1999.

ABREU, Maurício A. Evolução urbana do Rio de Janeiro. Rio de Janeiro: Jorge Zahar Editor, 1987.

ADORNO, Sergio. A Gestão Filantrópica da Pobreza Urbana In: São Paulo em Perspectiva, 4(2): 8-17, abril/junho 1990.

AgUINAGA. H. Hospital São Francisco de Assis: história. Centenário de lançamento da pedra fundamental 1876-1976. Rio de Janeiro: Companhia Brasileira de Artes Gráficas, 1976.

ALVAREZ, M. C.; SALLA, F.; SOUZA, L. A. F. A sociedade e a lei: o código penal de 1890 e as novas tendências penais na primeira república. 2003. Disponível em: <http://www.nevusp.org/downloads/down113.pdf> Acesso em: 08 jun. 2009.

ALVAREZ, Marcos César. Bacharéis, Criminologistas e Juristas: saber jurídico e a nova escola penal no Brasil. São Paulo: Método, 2003. 
AMORA, A. M. G. A.; SOUZA, E. B. O Asylo da Mendicidade e os Planos Urbanísticos do Século XIX no Rio de Janeiro. URBANA, V.6, nº 8, jun. 2014 Dossiê: Cidade e Habitação na América Latina - CIEC/UNICAMP.

ANDREATTA, V. Cidades quadradas, paraísos circulares: os planos urbanísticos do Rio de Janeiro no século XIX. Rio de Janeiro: Mauad X, 2006.

ARAÚJO, V. L. de. A Experiência do tempo: conceitos e narrativas na formação nacional brasileira (1813-1845). São Paulo: Editora HUCITEC, 2008.

ARANHA, Graça. A Esthetica da Vida. Garnier Livraria. Rio de Janeiro, Paris, s/d.

Machado de Assis e Joaquim Nabuco. Commentarios e notas á correspondência entre estes dous escriptores. Monteiro Lobato \& Cia Editores, S. Paulo 1923.

ARENDT, Hannah. A Condição Humana. Tradução de Roberto Raposo. 7. ed. Rio de Janeiro: Forense Universitária, 1981.

ASSISTENCIA PUBLICA E PRIVADA NO RIO DE JANEIRO (Brasil): história e estatística. Comemoração do Centenário da Independência Nacional. Rio de Janeiro: Prefeitura do Distrito Federal. 1922.

AZEVEDO, A. N. de. Da Monarquia à República: um estudo dos conceitos de civilização e progresso na cidade do Rio de Janeiro entre 1868 e 1906. Tese de Doutorado - Departamento de História. - Pontifícia Universidade Católica do Rio de Janeiro, Rio de Janeiro, 2003.

BANDEIRA, F. M. Fardados e disciplinados: recrutamento e enquadramento social na Armada Imperial e na Polícia da Corte (1870-1889). In: Anais do XIII Encontro de História Anphu Rio, 2008.

BARBOSA, J. L. Modernização Urbana e Movimento Operário. Rio de Janeiro: Programa de Pós-Graduação em Geografia. UFRJ, 1990.

BARBOSA, L. Serviços de Assistência no Rio de Janeiro. Rio de Janeiro: Typ. Ao Luzeiro, 1908.

BARRETO FILHO, M.; LIMA, H. História da polícia do Rio de Janeiro: aspectos da cidade e da vida carioca, 1565-1831. Rio de Janeiro: A Noite, 1939.

BARRETO, J. F. de B. Projeto de organização da policia do Distrito Federal, Rio de Janeiro, Leuzinger; Polícia Civil do Distrito Federal, 1895. 
BARRETO, Tobias. O fundamento do direito de punir, in Barreto, Menores e loucos, Obras Completas, vol. V, Edição do Estado de Sergipe, 1926.

BARROS, R. S. M. de. A ilustração brasileira e a idéia de universidade. São Paulo: Convívio; Edusp. 1986.

BATITUCCI, E. C. A evolução institucional da Polícia no século XIX: Inglaterra, Estados Unidos e Brasil em perspectiva comparada. Revista Brasileira de Segurança Pública. Ano 4 Edição 7 Ago/Set 2010.

BAYLEY, D. H. Padrões de Policiamento: Uma Análise Comparativa Internacional, São Paulo, Edusp, 2006.

; SKOLNICK, J. H. Nova Polícia: inovações nas polícias de seis cidades norte-americanas. São Paulo: Editora da USP, 2001.

BENCHIMOL, J. L. A Modernização do Rio de Janeiro. In O Rio de Janeiro de Pereira Passos. Rio de Janeiro: Index, 1985.

BENJAMIN, W. Magia e técnica, arte e política. Ensaios sobre literatura e história da cultura. Obras escolhidas. Vol. 1. São Paulo: Brasiliense, 1987.

BICALHO, M. F. A Cidade e o Império. Rio de Janeiro: Civilização Brasileira, 2003.

BILÉU, M. M. C. Diogo Inácio De Pina Manique, Intendente Geral da Polícia: inovações e persistências. História, Dissertação de mestrado. Lisboa, 1995

BLUTEAU, Raphael. Vocabulario portuguez \& latino: aulico, anatomico, architectonico. Coimbra: Collegio das Artes da Companhia de Jesus, 1712 - 1728. $8 \mathrm{v}$.

BONIFÁCIO, M. F. A Associação Comercial do Porto no contexto políticoeconómico nortenho e nacional. Análise Social. Vol. XXII, 92, 331-367, 1986.

Relações Externas e Revolução Liberal, Séculos XVII-XIX. In João Marques de Almeida e Rui Ramos (Eds.), Revoluções, Política Externa e Política de Defesa em Portugal, Séc. XIX-XX (pp. 13-24). Lisboa: Edições Cosmo e Instituto de Defesa Nacional, 2008.

BOTELHO, A.; SCHWARCZ, L. M. Um enigma chamado Brasil. Companhia das Letras. São Paulo, 2009. 
BRANDÃO. B. C.; MATTOS, I. R.; CARVALHO, M. A. R. Estudos das características histórico-sociais das instituições policiais brasileiras, militares e paramilitares, de suas origens até 1930. A polícia e força policial no Rio de Janeiro. Série Estudos - Pontifícia Universidade Católica do Rio de Janeiro, Rio de Janeiro, 1981.

BRAUDEL, F. Escritos sobre a história. 2.ed. São Paulo: Perspectiva. 2005.

BRESCIANNI. M. S. Londres e Paris no século XIX: O espetáculo da pobreza. (Tudo é história. 52). São Paulo: Brasiliense, 2004.

Lógica e dissonância: sociedade do trabalho - lei, ciência, disciplina e resistência operária, Revista Brasileira de História, 1986. nº 11, p. 7-44.

BRESSER-PEREIRA, L. C. As três interpretações da dependência. Perspectivas, São Paulo, v. 38, p. 17-48, jul./dez. 2010.

Do ISEB e da CEPAL à teoria da dependência. Mímeo.

BRETAS, M. L. A polícia carioca no Império. Estudos Históricos, Rio de Janeiro, v. 12, n. 22, p. 219-234, 1998.

A guerra das Ruas. Povo e polícia na cidade do Rio de Janeiro. Rio de Janeiro: Arquivo Nacional, 1997a.

Ordem na cidade: o exercício cotidiano da autoridade policial no Rio de Janeiro, 1907-1930. Rio de Janeiro: Editora Rocco, 1997b.

CALMON, P. História do Ministério da Justiça (1822-1972). Rio de Janeiro: Imprensa Nacional, 1972.

CÂNDIDO, A. Dialética da Malandragem. Revista do Instituto de Estudos Brasileiros. São Paulo. no 8. 1970. p. 67 a 89.

CARVALHO, A. da S., Pina Manique, o ditador sanitário. Lisboa: Imprensa Nacional, 1939.

CARVALHO, E. de. A polícia carioca e a criminalidade contemporânea. Rio de Janeiro: Imprensa Nacional, 1910.

CARVALHO, J. M. de. A Formação das Almas. O Imaginário da República no Brasil. São Paulo: Companhia das Letras, 2006. 
Os bestializados: o Rio de Janeiro e a República que não foi. 3. Ed.

São Paulo: Companhia das Letras, 1999.

CASTANHA, A. P. Edição crítica da legislação educacional primária do Brasil imperial: a legislação geral e complementar referente à Corte entre 1827 e 1889. Unioeste - Campus de Francisco Beltrão; Campinas: Navegando Publicações, 2013.

CASTEL, R. As metamorfoses da questão social: uma crônica do salário. Petrópolis: Vozes, 2001.

CASTRO A. O. V. de. Tratado de Sgiengia da Administração Direito Administrativo. Rio de Janeiro, Imprensa Nacional, 1906.

CERQUEIRA FILHO, G. A "questão social" no Brasil. Rio de Janeiro: Civilização Brasileira, 1982.

CHALHOUB, S. História, Literatura e Legados Historiográficos: Entrevista com Sidney Chalhoub Entrevistadores: Claudia Engler Cury, Elio Chaves Flores e Regina Maria Rodrigues Behar sÆculum - REVISTA DE HISTÓRIA [20]; João Pessoa, jan./ jun. 2009. 183-201

Cidade Febril. Cortiços e epidemias na corte imperial. São Paulo: Companhia das Letras, 1996.

Trabalho, lar e botequim: o cotidiano dos trabalhadores no Rio de Janeiro da Belle Époque. São Paulo: Brasiliense, 1986.

CHAUI, M. Cultura e Democracia - o discurso competente e outras falas. São Paulo: Cortez Editora, 2006.

COARACY, Vivaldo. Memórias da Cidade do Rio de Janeiro. Rio de Janeiro: Livraria José Olympiio, 1965. Coleção Rio 4 Séculos. Vol. 3.

COGGIOLA, Osvaldo. Origens do Movimento Operário e do Socialismo no Brasil. São Paulo: Mimeo, 2003.

Movimento e pensamento operários antes de Marx. São Paulo: Brasiliense. (Coleção Tudo é história, nº 139), 1991.

CONRAD, R. Os últimos anos de escravatura no Brasil. Rio de Janeiro: Civilização Brasileira, 1976. 
Os últimos anos da escravatura no Brasil: 1850-1888. Rio de Janeiro:

Civilização Brasileira, 1975.

COSTA, J. F. Ordem médica e norma familiar. Rio de Janeiro: Graal, 2004.

COTTA, F. A. Breve história da Polícia Militar de Minas Gerais. Belo Horizonte: Ed. Crisálida, 2006.

COUTINHO, C. N. O estruturalismo e a miséria da razão. Rio de Janeiro, Paz e Terra, 1971.

CRUZ, H. de F. Mercado e Polícia - São Paulo 1890-1915. In Revista Brasileira de História, São Paulo, v.7, n.14, pp.115-130, mar/ago, 1987.

CUNHA, O. M. G. da. Os Domínios da Experiência, da Ciência e da Lei: os Manuais da Polícia Civil do Distrito Federal, 1930-1942. Estudos históricos. $1998-22$.

DAMAZIO, S. F. Retrato Social do Rio de Janeiro na Virada do Século. Rio de Janeiro: Eduekj, 1996.

DANTES, M. A. Os positivistas brasileiros e as ciências no final do século XIX. In: Hambúrguer, Maria Amélia [et al.]. A ciência nas relações Brasil-França (18501950). São Paulo: EDUSP, 1996, pp.49-64.

DORIA, A. de S. A Questão Social. São Paulo: Monteiro Lobato \& C., 1922.

DURÃO, S. Patrulha e Proximidade. Uma Etnografia da Polícia em Lisboa, Dissertação de Doutoramento em Antropologia das Sociedades Complexas, Lisboa: ISCTE, 2006.

EMSLEY, C. The english police. 2a . ed. Harlow: Pearson Education, 1996.

ENGEL, M. G. Os delírios da razão: médicos, loucos e hospícios (Rio de Janeiro, 1830-1930). Rio de Janeiro: Editora Fiocruz, 2001.

ENGELS, F. Do socialismo utópico ao socialismo científico. 9.ed., São Paulo: Ed. Global, 1988.

FAORO, Raymundo. Existe um Pensamento Político Brasileiro? São Paulo: Ática, 1994.

FERNANDES, F. A revolução burguesa no Brasil. Rio de Janeiro: Zahar, 1974. 
FERREIRA, L. O.; SANGLARD, G. Médicos e filantropos: a institucionalização do ensino da pediatria e da assistência à infância no Rio de Janeiro da Primeira República. Varia hist. [online]. 2010, vol.26, n.44.

FILHO, G. C. A "questão social” no Brasil. Crítica do discurso político. Rio de Janeiro: Editora Civilização Brasileira, 1982.

FORATTINI, O. P. A ciência e a sociedade. Rev. Saúde Pública [online]. 1999, vol.33, n.1 ISSN 0034-8910.Similarity:0.315863

FOUCAULT, M. Os Anormais. Curso dado no Collège de France (1974-1975). São Paulo: Martins Fontes, 2002.

Segurança, Território, População. Curso dado no Collège de France (1977-1978). São Paulo: Martins Fontes, 2001.

FREIRE. M. M. de L.; Marília M. de L.; LEONY. V. da S. A caridade científica: Moncorvo Filho e o Instituto de Proteção e Assistência à Infância do Rio de Janeiro (1899-1930). História. Ciências, Saúde. Mangninhos. Rio de Janeiro. v. 8, p.199-225, dez. 2011.

FURTADO, C. O mito do desenvolvimento econômico. São Paulo: Paz e Terra, 1980.

GEBARA, A. O mercado de trabalho livre no Brasil (1871-1888). São Paulo: Brasiliense, 1986.

GEIGER. Pedro Pinchas. Evolução da rede urbana brasileira. Rio de Janeiro: instituto Nacinal de estudos Pedagógicos, minstério da Educação e Cultura 1963

GEREMEK, B. Os filhos de Caim: vagabundos e miseráveis na literatura européia: 1400-1700. São Paulo: Companhia das Letras, 1995.

GERSON, B. História das Ruas do Rio de Janeiro. Rio de Janeiro: Lacerda, 2000.

GINZBURG, C. Mitos, Emblemas e Sinais. Companhia das Letras, São Paulo, 1989a.

, et. Al. A micro-história e outros ensaios. Lisboa, DIFEL, 1989b.

GOMES, A. de C. A invenção do trabalhismo. $3^{\text {a }}$ ed. Rio de Janeiro: Editora FGV, 2006. 
(org.). Histórias de imigrantes e de imigração no Rio de Janeiro. Rio de Janeiro: 7 Letras, 2000, p. 164-182.

Burguesia e Trabalho: política e legislação social no Brasil, 19171937. Rio de Janeiro: Campus, 1979.

GOMES, F. S.; CUNHA, O. M. G. da (orgs). Quase-Cidadão. Histórias e antropologias da pós-emancipação no Brasil. São Paulo: Editora da Fundação Getúlio Vargas, 2005.

GONÇALVES. G. R. Modernização policial: as múltiplas dimensões de um objecto historiográfico. CIES e-Working Paper N.o 116/2011 Lisboa, Portugal. Centro de Investigação e Estudos de Sociologia. Instituo Universitário de Lisboa. 2011a.

(), “A transformação liberal do sistema policial português, 18611868", em José Murilo de Carvalho, e outros (orgs.), Linguagens e Fronteiras do Poder. Rio de Janeiro: Fundação Getúlio Vargas, 2011b [no prelo].

A construção de uma polícia urbana (Lisboa, 1890 - 1940) institucionalização, organização e práticas. Dissertação de mestrado em Sociologia. Instituto Superior de Ciências do Trabalho e da Empresa. Departamento de Sociologia. Lisboa, julho de 2007.

GOUVÊA, M. T. de. Hospital Escola São Francisco de Assis: um marco do neoclássico tardio. Dissertação de Mestrado apresentada à Faculdade de Arquitetura e Urbanismo da Universidade Federal do Estado do Rio de Janeiro, 1987.

GRAMSCI, A. Cadernos do Cárcere, Volume 2: os intelectuais, o princípio educativo. Edição e Tradução de Carlos Nelson Coutinho. 4. ed. Rio de Janeiro: Civilização Brasileira, 2006.

Cadernos do cárcere. Volume 1. Tradução Carlos Nelson Coutinho; coedição, Luiz Sérgio Henriques e Marco Aurélio Nogueira. $3^{\circ}$ ed. Rio de Janeiro: Civilização Brasileira, 2004.

Concepção dialética da história. Tradução de Carlos Nelson Coutinho. 8. ed. Rio de Janeiro: Civilização Brasileira, 1989.

GRINBERG, K. O fiador dos brasileiros: cidadania, escravidão e direito civil no tempo de Antonio Pereira Rebouças. Rio de Janeiro: Civilização brasileira, 2002. 
GURGEL, JB Serra e. Evolução Histórica da Previdência Social. Pesquisa cronológica de dispositivos constitucionais, Leis Complementares, Leis, Decretos, Decretos-Lei; Medidas Provisórias, Legislação Constitucional e Infraconstitucional. Brasília, FUNPREV, Fundação ANASPS, 2008.

HAHNER, J. E. Pobreza e Política: os pobres urbanos no Brasil - 1870: 1920. Brasília: EDUNB, 1993.

HARRING, S. Policing a Class Society: the experience of american cities (18651915). New Brunswick, N. J., Rutgers University Press, 1983.

HESPANHA, A. M.; SUBTIL, J. Corporativismo e Estado de Polícia como modelos de governo das sociedades euro-americanas do Antigo Regime, in $\mathrm{O}$ Brasil Colonial, F. GOUVÊA e J. FRAGOSO, (org.), Rio de Janeiro: Editora Civilização Brasileira (prelo).

HOBSBAWM, E. A Era dos Extremos - o Breve Século XX 1914-1991. São Paulo: Companhia das Letras, 1997.

A Era dos Impérios 1875-1914. Rio de Janeiro: Paz e Terra, 1988.

Os trabalhadores. Rio de Janeiro: Paz e Terra, 1981.

(org.) História do Marxismo. 2 ed., Rio de Janeiro: Paz e Terra, 1985.

HOLlOWAY, T. Polícia no Rio de Janeiro: repressão e resistência numa cidade do século XIX. Rio de Janeiro: Editora Fundação Getúlio Vargas, 1997.

IAMAMOTO. M. V.; CARVALHO. R. de. Relações Sociais e Serviço Social no Brasil. São Paulo: Cortez; 1986.

IANNI, O. A Questão Social. São Paulo em Perspectiva, n. 5 (1): 2-10. Janeiro/março, 1991.

Industrialização e desenvolvimento social no Brasil. Rio de Janeiro: Editora Civilização Brasileira, 1963.

JACQUES, L. M. da S. A Intendência de Polícia e vida cotidiana no Rio de Janeiro de inicio do século XIX. Niterói. Universidade Federal Fluminense (Dissertação de Mestrado) 2002.

JANCSÓ, I. (org), Independência: história e historiografia. São Paulo: Hucitec, 2005. 
PIMENTA, J.P.G. Peças de um mosaico (ou apontamentos para o estudo da emergência da identidade nacional brasileira). In: MOTTA, C.G. (org.). Viagem Incompleta. A experiência brasileira (1500-2000), pp. 127-176, São Paulo: Ed. SENAC, 2000.

KANT DE LIMA, R. A polícia na cidade do Rio de Janeiro: seus dilemas e paradoxos. Rio de Janeiro: Forense, 1995.

KONDER, Leandro. A derrota da dialética. Rio de Janeiro: Ed. Campus, 1988.

LACOMBE, L. L. Os chefes do executivo fluminense. Petrópolis: Vozes, 1973.

LANE, R. Polícia urbana e crime na América do século XIX. In TONRY, Michael \& MORRIS, Norval (orgs) Policiamento Moderno. São Paulo, Edusp, 2003, p. 47.

LAXE. J. B. C. Regimento das Câmaras Municipais ou lei de 19 de ouutbro de 1828, anotado e precedido de uma introdução histórica. Rio de Janeiro: 1868.

LEAL, Aurelino. Policia e poder de policia. Rio de Janeiro: Imprensa Nacional. 1918.

LEMOS, M. O pozitivismo e a escravidão modérna: trechos estraídos das obras de Augusto Comte, seguidos de documentos pozitivistas relativos à questão da escravatura no Brazil. 2. ed. Rio de Janeiro: Templo da Humanidade, 1934.

LIMA, M. M. Cálculo da Reserva de Benefícios Concedidos da Previdência Social. Dissertação de Mestrado. Programa de Pós-Graduação em Ciências Atuariais do Instituto de Gestão de Risco Financeiros e Atuariais da PUC-Rio. Rio de Janeiro, 2007.

LIMA, R. K. de, et al. Polícia e democracia: controle social e administração da Justiça. Revista da OAB, vol. 22, pp. 279-286, 1985.

LOBO, E. M. L. Imigração portuguesa no Brasil. São Paulo: Hucitec, 2001.

; et al. Evolução dos preços e do padrão de vida no Rio de Janeiro, 1820-1930 - Revista Brasileira de Economia 21 - outurbro dezebro de 1971

LOPES, M. A, da S. F. Pobreza, assistência e controlo social em Coimbra (1750-1850), Viseu, Palimage, 2000.

LOURENÇO FILHO, M. B. A Psicologia no Brasil. In: AZEVEDO, Fernando de (org.) [1955] As Ciências no Brasil. ${ }^{\circ}$ ed Rio de Janeiro: Ed. UFRJ, 1994 
LÖWY, M. A filosofia da história de Walter Benjamin. Estudos Avançados 16 (45), 2002. Disponível em: 〈http://www.scielo.br/pdf/ea/v16n45/v16n45a13.pdf> Acesso em: 06 jun. 2014

A contrapelo. A concepção dialética da cultura nas teses de Walter Benjamin (1940). Lutas Sociais, São Paulo, n.25/26, p.20-28, $2^{\circ}$ sem. de 2010 e $1^{\circ}$ sem. de 2011.

Walter Benjamin: Aviso de incêndio. Uma leitura das teses "Sobre o conceito de história". Boitempo Editorial, São Paulo, 2005.

As aventuras de Karl Marx contra o Barão de Munchhausen. São Paulo, Cortez, 1991.

LUKÁCS, G. História e Consciência de Classe. Estudos sobre a dialética marxista. São Paulo: Martins Fontes, 2003.

Ontologia do ser social. São Paulo: Ed. Ciências Humanas, 1979.

LYRA, R. Comentários ao código penal. Rio de janeiro: Forense, 1942. V.2

MACHADO, M. H. P. T. O plano e o pânico - os movimentos sociais na década da Abolição. Rio de Janeiro: Editora UFRJ/EDUSP, 1994.

MACHADO, Roberto, et al. A Danação da Norma. Medicina social e constituição da psiquiatria no Brasil. Rio de Janeiro: Graal, 1978.

MARAM, S. L. Arnaquistas, Imgrantes e o Movimento Operário Brasileiro, 1980 a 1920. Rio de Janeiro: Paz e Terra, 1979.

MARTINS, E. A invenção da vadiagem. Os termos de Bem Viver e a sociedade disciplinar no Império do Brasil. Curitiba: Editora CRV, 2011.

MARX, Karl. A produção de consciência. In: IANNI, Otávio, (org.). Marx. 4.ed. São Paulo: Atiça, 1984.

Glosas críticas marginais ao artigo "O Rei da Prússia e a reforma social”. De um prussiano. In: Praxis. Belo Horizonte, nº 5, 1995.

A Miséria da Filosofia. Tradução e introdução José Paulo Neto. São Paulo: Global, 1985 [1847]. 
MATTOS M. B. Trabalhadores escravizados e livres na cidade do Rio de Janeiro na segunda metade do século XIX. Revista Rio de Janeiro, $\mathrm{n}^{\circ} 12$, janabril. 2004.

MATTOS. H. M. Escravidão e Cidadania no Brasil Monárquico. Rio de Janeiro: Zahar. 2000.

MENEZES, L. M. de. Os indesejáveis: desclassificados da modernidade. Protesto, crime e expulsão na Capital Federal (1890-1930). Rio de Janeiro: EdUERJ, 1996.

MESTRINER, M. O Estado entre a filantropia e assistência social. São Paulo: Cortez, 2008.

MONKKONEN, E. H. História da Polícia Urbana, in TONRY, Michael; MORRIS, Norval (Orgs.). Policiamento Moderno. Edusp, São Paulo, 2003.

From cop history to social history: the significance of the police in american history. Journal of Social History, vol 15, 1982.

. Police in urban America, 1860-1920. Cambridge: Cambridge University Press, 1981.

MORAES FILHO, E. de. As idéias fundamentais de Tavares Bastos. Rio de Janeiro: DIFEL, 1978.

MOSCOVICI, S. A representação social da psicanálise. 1.ed. Rio de Janeiro: Zahar, 1978.

MOSCOVICI, S. Representações Sociais: investigação em psicologia social. Petrópolis, RJ: Vozes, 2003.

MOTA, A. E. (org.). O mito da assistência social. Ensaios sobre Estado, Política e Sociedade. São Paulo: Cortez, 2010.

MOURA, E. B. B. de. Meninos e meninas na rua: impasse e dissonância na construção da identidade da criança e do adolescente na República Velha. Revista Brasileira História, vol.19, n.37, São Paulo, 1999.

NEDER, G.; NARO, N. A Instituição Policial na cidade do Rio de Janeiro e a construção da ordem burguesa no Brasil. In Estudos das características históricosociais das instituições policiais brasileiras, militares e paramilitares, de suas origens até 1930. A Polícia na Corte e no Distrito Federal 1831-1930. NEDER, 
Gizlene; NARO, Nancy e WERNECK DA SILVA, J. L. Série Estudos - Pontifícia Universidade Católica do Rio de Janeiro, Rio de Janeiro, 1981.

n 3, 1997, pp. 106-134.

. Cidade, Identidade e Exclusão Social. Tempo, Rio de Janeiro, Vol. 2,

NETO, A. L. M. Estrutura social da República das letras (Sociologia da Vida Intelectual Brasileira-1870-1930). São Paulo: Editora da Universidade de São Paulo, Editorial Grijalbo Ltda, 1973.

NETTO, J. P. Capitalismo Monopolista e Serviço Social. São Paulo: Cortez, 1992, capítulo 1 .

NETTO, R. de S. O Império brasileiro e a Secretaria de Estado dos Negócios da Justiça (1821-1891). Cadernos Mapa n. 2. Memória da Administração Pública Brasileira. Rio de Janeiro, 2011.

NIETZSCHE, F. Da utilidade e desvantagem da história para a vida. Rio de Janeiro: Relume Dumará, 2003.

NOGUEIRA, J. F. O Município no Século XIX. Lisboa: Tipografia do Progresso, 1856.

OLIVEIRA, C. M. S. O Rio de Janeiro da Primeira República e a imigração portuguesa: panorama histórico. Revista do Arquivo Geral da cidade do Rio de Janeiro n.3, 2009, p.149-168.

OLIVEIRA, Francisco. O Estado e Urbano no Brasil. Revista Espaço \& Debates, n. $6,1982$.

PECHMAN, R. Cidade, Povo e Nação. Rio de Janeiro: Civilização Brasileira, 1996.

PÉRCHEIRO, D. A. G. Portugal e Brazil: emigração e colonização. Typ. Lusohespanhola, Lisboa, 1878.

PICCININI, W. J. História da Psiquiatria. Afrânio Peixoto (1876-1947). Psychiatry On-line Brazil. Vol. 7, nº 8, agosto, 2002. (5p.)

PINTO, L. M. da S. Diccionario da Lingua Brasileira. Na Typographia de Silva, 1832.

PINTO, W. de M. Hospital Escola São Francisco de Assis: características do conjunto arquitetônico. UFRJ, 1990 (mímeo) 
PLEKHÂNOV, G. A concepção materialista da História. 7. ed. Rio de Janeiro: Paz e Terra, 1987.

POCHMANN, M. Proteção social na periferia do capitalismo: considerações sobre o Brasil. São Paulo em Perspectiva, vol.18 nº 2, São Paulo, Apr/June 2004.

PRADO, P. Retratos do Brasil: ensaio sobre a tristeza brasileira. Org. Carlos Augusto Calil. São Paulo: Companhia das Letras, 1997.

QUIROGA. A. M. Assistência Social no Rio de Janeiro: experiências e permanências históricas. In: Anais do XII Encontro Nacional de Pesquisadores em Serviço Social (ENPESS). Rio de Janeiro, dezembro de 2010a.

Assistência Social no Rio de Janeiro Oitocentista: desqualificação dos atendidos, racismo científico e filantropia. In: Anais do XIV Encontro Regional da ANPUH-Rio. Rio de Janeiro, julho de $2010 \mathrm{~b}$.

A construção da Assistência Social no Rio de Janeiro: cenários da $1^{a}$ República. In: Em Debate, $n^{\circ}$ 08. Departamento de Serviço Social, PUC-Rio, Rio de Janeiro, 2009.

Assistência e Poder: revendo uma articulação histórica. Revista Praia Vermelha, n. 18. Rio de Janeiro. $1^{\circ}$ semestre. 2008

Caridade, Filantropia e Justiça e os Modelos de Ação Social. Revista Praia Vermelha, n. 5, $2^{\circ}$ semestre. Rio de Janeiro. 2001.

QUIROGA, C. Invasão positivista no marxismo: manifestações no ensino da metodologia no Serviço Social. Dissertação de Mestrado. Faculdade de Educação da Universidade Federal de Minas Gerais. Orientadora Marilda Vilella Iamamoto. Belo Horizonte, 1989.

RAGO, M. O efeito-Foucault na historiografia brasileira. Tempo Social. Rev.Sociol. USP, São Paulo, 7 (1-2): 67-82, outubro de 1995.

RANGEL R. F. Assistência no Rio de Janeiro: elite filantropia e poder na Primeira República. Tese de Doutorado. Programa de Pós-Graduação em Serviço Social. PUC-Rio. Rio de Janeiro, 2013.

RANGEL, M. de M. Reflexão e diálogo. Liberdade e responsabilidade em Gonçalves de Magalhães e a construção da Nação brasileira. Dissertação de Mestrado - Departamento de História, Pontifícia Universidade Católica do Rio de Janeiro, Rio de Janeiro, 2005 
REINER, R. The politics of the Police. $2^{\mathrm{a}}$ ed. Toronto: The University of Toronto Press, 1992.

REIS, J. de O. O Rio de Janeiro e seus Prefeitos. Rio de Janeiro: Prefeitura do Rio de Janeiro, 1977.

REIS, M. de F. A Intendência Geral da Polícia da Corte e do Estado do Brasil: os termos de bem viver e a ação de Paulo Fernandes Viana. In: REUNIÃO ANUAL DA SOCIEDADE BRASILEIRA DE PESQUISA HISTÓRICA, 2., Rio de Janeiro. Anais. São Paulo: Sociedade Brasileira de Pesquisa Histórica, 1983. p. 95-105.

RIZZINI. I. O Século Perdido. Raízes históricas das Políticas Públicas para a Infância no Brasil. São Paulo: Cortez, 2008.

RODRIGUES, A. E. M. João do Rio. A Cidade e o Poeta. Rio de Janeiro: Editora da FGV, 2000.

História da urbanização no Rio de Janeiro A cidade: capital do século XX no Brasil, p. 85 a 120 in Cidades; olhares, trajetórias. (Organizadoras). CARNEIRO, Sandra de Sá e SANT’ANNA Maria Josefina Gabriel. Garamond, Rio de Janeiro, 2009.

RODRIGUES, C. A Construção Social do Vadio e o Crime de Vadiagem (18861906). Rio de Janeiro: UFRJ/IFCS, 2006.

ROMERO, S. Introdução a Doutrina contra Doutrina. O evolucionismo e o positivismo no Brasil. in CANDIDO, Antonio (org.). Sílvio Romero, Teoria, Crítica e História Literária, São Paulo: EDUSP, 1978.

Machado de Assis. Estudo comparativo da literatura brasileira. Laemmert \& C. Editores, Rio de Janeiro, 1897

Doutrina contra doutrina. $O$ evolucionismo e o positivismo na Republica do Brasil. Editor, J. B. Nunes. Typografia da Empresa Democrática Editora, Rio de Janeiro, 1894.

RUONAVAARA, H. Moral regulation: a reformulation. Sociological Theory, 15(3):277-293. 1997.

SÁ, N. R. de. O Império brasileiro e a Secretaria de Estado dos Negócios da Justiça (1821-1891). Rio de Janeiro: Arquivo Nacional, 2011. 
SANGLARD, G. Assistência entre o liberalismo e o bem-estar social. Anais do XIII Encontro de História. ANPUH, 2008a.

Entre os salões e o laboratório: Guilherme Guinle, a saúde e a ciência no Rio de Janeiro, 1920-1940. Rio de Janeiro: Editora Fiocruz. 2008b.

Filantropia e assistencialismo no Brasil. Hist. cienc. saudeManguinhos [online]. 2003, vol.10, n.3.

SANTOS, M. J. M. A Real Casa Pia de Correcção e Educação do Porto, 1792-1804. Revista da Faculdade de Letras. História, Porto, III Série, vol. 2, 2001, pp. 129-144.

SANTOS, M. A. C. dos S. A polícia e a organização dos trabalhadores urbanos em São Paulo (1890-1920). Texto integrante dos Anais do XVIII Encontro Regional de História - O historiador e seu tempo. ANPUH/SP - UNESP/Assis, 24 a 28 de julho de 2006 .

SANTOS, W. G. dos. Cidadania e Justiça: a política social na ordem brasileira. Rio de Janeiro: Ed. Campus, 1979.

SARMENTO, S. N. A Raposa e a Águia J. J. Seabra e Rui Barbosa na Política Baiana da Primeira República. Dissertação apresentada ao Programa de PósGraduação em História da Faculdade de Filosofia e Ciências Humanas da Universidade Federal da Bahia, como requisito parcial para obtenção do título de Mestre em História. Salvador, 2009.

SCHETTINI C. Viver a tolerancia: policía, municipalidade e trabalho sexual no espaco urbano portenho (1870-1880). Anais do XXVI Simpósio Nacional de História - ANPUH • São Paulo, julho 2011

SCHWARCZ, L. M. O espetáculo das raças. Cientistas, instituições e questão racial no Brasil 1870-1930. São Paulo: Companhia das Letras, 1993.

SCHWARZ, R. Ao Vencedor As Batatas. Forma literária e processo social nos inícios do romance brasileiro. São Paulo: Editora 34, 1997.

Leituras em competição. Novos estud. - CEBRAP [online]. 2006, n.75, pp. 61-79. Disponível em: <http://www.scielo.br/pdf/nec/n75/a05n75.pdf>. Acesso em: 05 fev. 2014.

SEVCENKO, N. Literatura como missão: tensões sociais na Primeira República. 2a . ed. São Paulo: Companhia das Letras, 2003. 
Introdução: o prelúdio republicano, astúcias da ordem e ilusões do progresso. In: NOVAIS, Fernando A.; SEVCENKO, Nicolau (org.). História da Vida Privada no Brasil, vol.3. República: da Belle Époque à Era do Rádio. São Paulo: Companhia das Letras, 1998.

SILVA JUNIOR, O. C. Do Asylo da Mendicidade ao Hospital Escola São Francisco de Assis: A Mansão dos Pobres. Rio de Janeiro: Papel Virtual, 2000.

SILVA, A. M. Diccionario da lingua portugueza - recompilado dos vocabularios impressos ate agora, e nesta segunda edição novamente emendado e muito acrescentado, por Antonio de Moraes Silva. Lisboa: Typographia Lacerdina, 1813.

SILVA, A. de A. O capitalismo tardio e sua crise: estudo das interpretações de Ernest Mandel e a de Jürgen Habermas. Dissertação (mestrado) - Universidade Estadual de Campinas, Instituto de Filosofia e Ciências Humanas. Campinas, SP, 2012

SILVA, A. M. da. Portugal e Brasil: dos fluxos migratórios às interacções ideológico-políticas (1889-1918). $1990 . \quad$ Disponível em: <http://www.realgabinete.com.br/geadmedia/mediapackages/giadrgpl_rgpl/docum entsmain/20101005134151264b_armandomalheirodoriginal.pdf >. Acesso em: 08 mai. 2014.

SILVA, E. As queixas do povo. Rio de Janeiro: Paz e Terra, 1988

SILVA, M. B. Dicionário da História da Colonização Portuguesa no Brasil. Nizza da (org.) São Paulo/Lisboa, Verbo.1994

SODRÉ, N. W. História militar do Brasil. Rio de Janeiro: Ed. Civilização Brasileira, 1965.

SOUZA, A. R. M. de. Da Desumanização e da Norma: A construção social das noções de vadio e vagabundo em meio as atribulações da fabricação do EstadoNação no Brasil (1870-1900). Orientadora Irene Rizzini. Programa de Pósgraduação em Serviço Social, Pontifícia Universidade Católica do Rio de Janeiro PUC-RIO, Rio de Janeiro, 2010.

SPOSATI, A.; BONETTI. D. A.; YASBEK. M. C.; FALÇÃO. M. do C. B. C. Assistência na trajetória das políticas sociais brasileiras: uma questão em análise. São Paulo: Cortez, 1995.

SUBTIL, J. O Governo da Real Casa Pia de Lisboa (1780-1807). Conceito n. ${ }^{\circ} 1$ (Loucura \& Desrazão), 2005, pp. 181-202. 
TAVARES, A.; PINTO, J. dos S. Pina Manique: Um homem entre duas épocas. Lisboa: Casa Pia, 1990.

THEOPHILO, R. Hitória da sêcca no Ceará, 1877-1880. Rio de Janeiro: Imprensa Ingleza, 1922.

THOMPSON, E. P. A miséria da teoria ou um planetário de erros. Rio de Janeiro: Zahar, 1981.

THOMPSON, E. P. Costumes em comum: estudos sobre cultura popular tradicional. São Paulo: Cia das Letras, 1998.

TONRY, M.; MORRIS, N. (Orgs.). Modern policing. Chicago: The University of Chicago, Press, 1992.

TOPALOV, C. Da questão social aos problemas urbanos: os reformadores e a população das metrópoles em princípios do século XX. In: RIBEIRO, L. C. e PECHMAN, R. Cidade, Povo e Nação. Rio de Janeiro: Civilização Brasileira. 1996

VALE, M. M. de M. Considerações sobre a mendicidade do Rio de Janeiro. Tese à Faculdade de Medicina do Rio dc Janeiro, 1846.

VARELLA, C. A. B. Da instrução ao vagabundo, ao engeitado, ao filho do proletário e ao jovem delinquente: meios de jazê-la efetiva. Tese à Faculdade de Medicina do Rio de Janeiro, 1874.

VELLASCO, I. de A. Policiais, pedestres e inspetores de quarteirão: algumas questões sobre as vicissitudes do policiamento na Província de Minas Gerais (1831-1850). In: CARVALHO, J. M. (Org.). Nação e cidadania no Império: novos horizontes. Rio de Janeiro: Ed. Civilização Brasileira, 2007.

As seduções da ordem: violência, criminalidade e administração da justiça, Minas Gerais, séc. XIX. Bauru: Edusc, 2004.

VENÂNCIO, R. P. Famílias abandonadas: assistência à criança de camadas populares no Rio de Janeiro em Salvador - século XVII e XIX. Campinas, SP: Papirus, 1999.

VIANNA, A. de R. B. O mal que se adivinha: Polícia e Menoridade no Rio de Janeiro 1910-1920. Rio de Janeiro: Arquivo Nacional, 1999.

VIANNA, P. F. Abreviada Demonstração dos Trabalhos da Policia. Revista do Instituto Histórico e Geográfico Brasileiro, 55, parte I (1892); 373-380. 
VIDAL, L. M. Manual prático das Câmaras Municipais (contendo a lei dc 1828, leis e avisos expedidos até o presente). Rio de Janeiro, 1878.

VILLAS BÔAS, G. Evaristo de Moraes Filho e a maioridade dos trabalhadores brasileiros. Rev. bras. Ci. Soc. [online]. 2004, vol.19, n.55.

VISCARDI, C. M. R. Pobreza e assistência no Rio de Janeiro na Primeira República. História, Ciências, Saúde - Manguinhos, Rio de Janeiro, v.18, supl.1, dez. 2011, p.179-197.

WERNECK DA SILVA, J. L. A polícia no Município da Corte: 1831-1866. In Estudos das características histórico-sociais das instituições policiais brasileiras, militares e paramilitares, de suas origens até 1930. A Polícia na Corte e no Distrito Federal 1831-1930. NEDER, Gizlene; NARO, Nancy e WERNECK DA SILVA, J. L. Série Estudos - Pontifícia Universidade Católica do Rio de Janeiro, Rio de Janeiro, 1981

WERNECK VIANNA, L. Modernização, questão agrária e República. Disponível em: <http://www.acessa.com/gramsci/?page=visualizar\&id=1436>. Acesso em: 05 jun. 2012. (2012)

O fim da história do Brasil ou um novo começo para ela. Disponível em: <http://www.acessa.com/gramsci/?page=visualizar\&id=1216>. Acesso em: 05 jun. 2012. (2010)

Americanistas e Iberistas: A Polêmica de Oliveira Vianna com Tavares Bastos. Revista de Ciências Sociais, Vol. 34,n² 2. 1991. Rio de Janeiro: pp: $145-189$

WILKIS, Ariel. Os usos sociais do dinheiro em circuitos filantrópicos: o caso das "publicações de rua". Mana [online]. 2008, vol.14, n.1 


\section{2. Fontes}

\section{Documentos consultados.}

\section{Relatórios do Ministério da Justiça}

1. BRASIL. Ministério da Justiça e Negócio Interiores. Ministro Augusto de Víanna do Castello. Relatório dos anos de 1927 e 1928. Apresentado ao Presidente da República dos Estados Unidos do Brasil em 1928. Rio de Janeiro. Imprensa Nacional, 1930.

2. BRASIL. Ministério da Justiça e Negócio Interiores. Ministro Affonso Penna Júnior. Relatório dos anos de 1925 e 1926. Apresentado ao Presidente da República dos Estados Unidos do Brasil em 1926. Rio de Janeiro. Imprensa Nacional, 1928.

3. BRASIL. Ministério da Justiça e Negócio Interiores. Ministro Affonso Penna Júnior. Relatório do ano de 1924. Apresentado ao Presidente da República dos Estados Unidos do Brasil em 1925. Rio de Janeiro. Imprensa Nacional, 1926.

4. BRASIL. Ministério da Justiça e Negócio Interiores. Ministro Dr. João Luiz Alves. Relatório do ano de 1923. Apresentado ao Presidente da República dos Estados Unidos do Brasil em 1924. Rio de Janeiro. Imprensa Nacional, 1924.

5. BRASIL. Ministério da Justiça e Negócio Interiores. Dr. João Luiz Alves. Relatório dos anos de 1922 e 1923. Apresentado ao Presidente da República dos Estados Unidos do Brasil em 1923. Rio de Janeiro. Imprensa Nacional. Rio de Janeiro. Imprensa Nacional, 1923.

6. BRASIL. Ministério da Justiça e Negócio Interiores. Ministro Dr.Joaquim Ferreira Chaves. Relatório dos anos de 1921 e 1922. Apresentado ao Presidente da República dos Estados Unidos do Brasil em 1922. Rio de Janeiro. Imprensa Nacional, 1922.

7. BRASIL. Ministério da Justiça e Negócio Interiores. Ministro Dr. Alfredo Pinto Vieira de Mello. Relatório dos anos de 1919 e 1920. Apresentado ao Presidente da República dos Estados Unidos do Brasil em 1920. Rio de Janeiro. Imprensa Nacional, 1920.

8. BRASIL. Ministério da Justiça e Negócio Interiores. Ministro Dr. Urbano Santos da Costa Araújo. Relatório dos anos de 1918 e 1919. Apresentado ao Presidente da República dos Estados Unidos do Brasil em 1919. Rio de Janeiro. Imprensa Nacional, 1919.

9. BRASIL. Ministério da Justiça e Negócio Interiores. Ministro Dr. Carlos Maximiliano Pereira dos Santos. Relatório dos anos de 1917 e 1918. Apresentado ao Presidente da República dos Estados Unidos do Brasil em 1918. Rio de Janeiro. Imprensa Nacional, 1918. 
10. BRASIL. Ministério da Justiça e Negócio Interiores. Ministro Dr. Carlos Maximiliano Pereira dos Santos. Relatório dos anos de 1916 e 1917. Apresentado ao Presidente da República dos Estados Unidos do Brasil em 1917. Rio de Janeiro. Imprensa Nacional, 1917.

11. BRASIL. Ministério da Justiça e Negócio Interiores. Ministro Dr. Carlos Maximiliano Pereira dos Santos. Relatório dos anos de 1915 e 1916. Apresentado ao Presidente da República dos Estados Unidos do Brasil em 1916. Rio de Janeiro. Imprensa Nacional, 1916.

12. BRASIL. Ministério da Justiça e Negócio Interiores. Ministro Dr. Carlos Maximiliano Pereira dos Santos. Relatório dos anos de 1914 e 1915. Apresentado ao Presidente da República dos Estados Unidos do Brasil em 1915. Rio de Janeiro. Imprensa Nacional, 1915a.

13. BRASIL. Ministério da Justiça e Negócio Interiores. Ministro Dr. Uladislau Herculano de Freitas. Relatório dos anos de 1913 e 1914. Apresentado ao Presidente da República dos Estados Unidos do Brasil em 1914. Rio de Janeiro. Imprensa Nacional, 1915b.

14. BRASIL. Ministério da Justiça e Negócio Interiores. Ministro Dr. Rivadavia da Cunha Corrêa. Relatório dos anos de 1912 e 1913. Apresentado ao Presidente da República dos Estados Unidos do Brasil em 1913. Rio de Janeiro. Imprensa Nacional, 1913.

15. BRASIL. Ministério da Justiça e Negócio Interiores. Ministro Dr. Rivadavia da Cunha Corrêa. Relatório dos anos de 1911 e 1912. Apresentado ao Presidente da República dos Estados Unidos do Brasil em 1912. Rio de Janeiro. Imprensa Nacional, 1912.

16. BRASIL. Ministério da Justiça e Negócio Interiores. Ministro Dr. Rivadavia da Cunha Corrêa. Relatório dos anos de 1910 e 1911. Apresentado ao Presidente da República dos Estados Unidos do Brasil em 1911. Rio de Janeiro. Imprensa Nacional, 1911.

17. BRASIL. Ministério da Justiça e Negócio Interiores. Ministro Dr. Esmeraldino Olympio de Torres Bandeira. Relatório dos anos de 1909 e 1910. Apresentado ao Presidente da República dos Estados Unidos do Brasil em 1910. Rio de Janeiro. Imprensa Nacional, 1910.

18. BRASIL. Ministério da Justiça e Negócio Interiores. Ministro Dr. Augusto Tavares de Lyra. Relatório dos anos de 1908 e 1909. Apresentado ao Presidente da República dos Estados Unidos do Brasil em 1909. Rio de Janeiro. Imprensa Nacional, 1909.

19. BRASIL. Ministério da Justiça e Negócio Interiores. Ministro Dr. Augusto Tavares de Lyra. Relatório dos anos de 1907 e 1908 - Volume I. Justiça, Interior e Contabilidade. Apresentado ao Presidente da República dos Estados Unidos do Brasil em 1908. Rio de Janeiro. Imprensa Nacional, 1908a. 
20. BRASIL. Ministério da Justiça e Negócio Interiores. Ministro Dr. Augusto Tavares de Lyra. Relatório dos anos de 1907 e 1908 - Volume II. Saúde Pública. Apresentado ao Presidente da República dos Estados Unidos do Brasil em 1908. Rio de Janeiro. Imprensa Nacional, 1908b.

21. BRASIL. Ministério da Justiça e Negócio Interiores. Ministro Dr. Augusto Tavares de Lyra. Relatório dos anos de 1906 e 1907 - Volume I. Justiça, Interior e Contabilidade. Apresentado ao Presidente da República dos Estados Unidos do Brasil em 1907. Rio de Janeiro. Imprensa Nacional, 1907a.

22. BRASIL. Ministério da Justiça e Negócio Interiores. Ministro Dr. Augusto Tavares de Lyra. Relatório dos anos de 1906 e 1907 - Volume II. Saúde Pública. Apresentado ao Presidente da República dos Estados Unidos do Brasil em 1907. Rio de Janeiro. Imprensa Nacional, 1907b.

23. BRASIL. Ministério da Justiça e Negócio Interiores. Ministro Dr. José Joaquim Seabra. Relatório dos anos de 1905 e 1906 - Volume I. Diretoria da Justiça. Apresentado ao Presidente da República dos Estados Unidos do Brasil em 1906. Rio de Janeiro. Imprensa Nacional, 1906a.

24. BRASIL. Ministério da Justiça e Negócio Interiores. Ministro Dr. José Joaquim Seabra. Relatório dos anos de 1905 e 1906 - Volume II. Diretoria do Interior. Apresentado ao Presidente da República dos Estados Unidos do Brasil em 1906. Rio de Janeiro. Imprensa Nacional, 1906b.

25. BRASIL. Ministério da Justiça e Negócio Interiores. Ministro Dr. José Joaquim Seabra. Relatório dos anos de 1905 e 1906 - Volume V. Diretoria de Saúde Pública. Apresentado ao Presidente da República dos Estados Unidos do Brasil em 1906. Rio de Janeiro. Imprensa Nacional, 1906c.

26. BRASIL. Ministério da Justiça e Negócio Interiores. Ministro Dr. José Joaquim Seabra. Relatório dos anos de 1905 e 1906 - Volume VI. Diretoria de Contabilidade. Apresentado ao Presidente da República dos Estados Unidos do Brasil em 1906. Rio de Janeiro. Imprensa Nacional, 1906d.

27. BRASIL. Ministério da Justiça e Negócio Interiores. Ministro Dr. José Joaquim Seabra. Relatório dos anos de 1904 e 1905 - Volume I. Diretoria da Justiça. Apresentado ao Presidente da República dos Estados Unidos do Brasil em 1905. Rio de Janeiro. Imprensa Nacional, 1905a.

28. BRASIL. Ministério da Justiça e Negócio Interiores. Ministro Dr. José Joaquim Seabra. Relatório dos anos de 1904 e 1905 - Volume II. Diretoria do Interior Apresentado ao Presidente da República dos Estados Unidos do Brasil em 1905. Rio de Janeiro. Imprensa Nacional, 1905b.

29. BRASIL. Ministério da Justiça e Negócio Interiores. Ministro Dr. José Joaquim Seabra. Relatório dos anos de 1904 e 1905 - Volume III. Diretoria de Saúde Pública. Apresentado ao Presidente da República dos Estados Unidos do Brasil em 1905. Rio de Janeiro. Imprensa Nacional, 1905c. 
30. BRASIL. Ministério da Justiça e Negócio Interiores. Ministro Dr. José Joaquim Seabra. Relatório dos anos de 1904 e 1905 - Volume IV. Diretoria de Contabilidade.Apresentado ao Presidente da República dos Estados Unidos do Brasil em 1905. Rio de Janeiro. Imprensa Nacional, 1905d.

31. BRASIL. Ministério da Justiça e Negócio Interiores. Ministro Dr. José Joaquim Seabra. Relatório dos anos de 1903 e 1904. Apresentado ao Presidente da República dos Estados Unidos do Brasil em 1904. Rio de Janeiro. Imprensa Nacional, 1904.

32. BRASIL. Ministério da Justiça e Negócio Interiores. Ministro Dr. José Joaquim Seabra. Relatório dos anos de 1902 e 1903. Apresentado ao Presidente da República dos Estados Unidos do Brasil em 1903. Rio de Janeiro. Imprensa Nacional, 1903.

33. BRASIL. Ministério da Justiça e Negócio Interiores. Ministro Dr. Sabino Barroso Júnior. Relatório dos anos de 1901 e 1902. Apresentado ao Presidente da República dos Estados Unidos do Brasil em 1902. Rio de Janeiro. Imprensa Nacional, 1902.

34. BRASIL. Ministério da Justiça e Negócio Interiores. Ministro Dr. Epitácio Pessôa. Relatório dos anos de 1900 e 1901. Apresentado ao Presidente da República dos Estados Unidos do Brasil em 1901. Rio de Janeiro. Imprensa Nacional, 1901.

35. BRASIL. Ministério da Justiça e Negócio Interiores. Ministro Dr. Epitácio Pessôa. Relatório dos anos de 1899 e 1900. Apresentado ao Presidente da República dos Estados Unidos do Brasil em 1899. Rio de Janeiro. Imprensa Nacional, 1900.

36. BRASIL. Ministério da Justiça e Negócio Interiores. Ministro Dr. Epitácio Pessôa. Relatório dos anos de 1898 e 1899. Apresentado ao Presidente da República dos Estados Unidos do Brasil em 1890. Rio de Janeiro. Imprensa Nacional, 1899.

37. BRASIL. Ministério da Justiça e Negócio Interiores. Ministro Dr. Amaro Cavalcanti. Relatório dos anos de 1897 e 1898. Apresentado ao Presidente da República dos Estados Unidos do Brasil em 1898. Rio de Janeiro. Imprensa Nacional, 1898.

38. BRASIL. Ministério da Justiça e Negócio Interiores. Ministro Dr. Amaro Cavalcanti. Relatório dos anos de 1896 e 1897. Apresentado ao Presidente da República dos Estados Unidos do Brasil em 1897. Rio de Janeiro. Imprensa Nacional, 1897.

39. BRASIL. Ministério da Justiça e Negócio Interiores. Ministro Dr. Antonio Gonçalves Ferreira. Relatório dos anos de 1895 e 1896. Apresentado ao Presidente da República dos Estados Unidos do Brasil em 1896. Rio de Janeiro. Imprensa Nacional, 1896.

40. BRASIL. Ministério da Justiça e Negócio Interiores. Ministro Dr. Antonio Gonçalves Ferreira. Relatório dos anos de 1894 e 1895. Apresentado ao 
Presidente da República dos Estados Unidos do Brasil em 1895. Rio de Janeiro. Imprensa Nacional, 1895.

41. BRASIL. Ministério da Justiça e Negócio Interiores. Ministro Dr. Alexandre Cassiano do Nascimento. Relatório dos anos de 1893 e 1894. Apresentado ao Presidente da República dos Estados Unidos do Brasil em 1894. Rio de Janeiro. Imprensa Nacional, 1894.

42. BRASIL. Ministério da Justiça e Negócio Interiores. Ministro Dr. Fernando Lobo. Relatório dos anos de 1892 e 1893. Apresentado ao Presidente da República dos Estados Unidos do Brasil em 1893. Rio de Janeiro. Imprensa Nacional, 1893.

43. BRASIL. Ministério da Justiça e Negócio Interiores. Ministro Dr. Antonio Luiz Affonso de Carvalho. Relatório dos anos de 1890 e 1891. Apresentado ao Presidente da República dos Estados Unidos do Brasil em 1891. Rio de Janeiro. Imprensa Nacional, 1891a.

44. BRASIL. Ministério dos Negócios da Justiça. Ministro Dr. Manoel Ferraz de Campos Salles. Relatório do ano de 1889. Apresentado Chefe do Governo Provisório da República dos Estados Unidos do Brasil em 1891. Rio de Janeiro. Imprensa Nacional, 1891b.

45. BRASIL. Ministério da Justiça. Ministro Francisco D’Assis Rosa e Silva. Relatório do ano de 1888. Apresentado a Assembléia Geral Legislativa na $4^{\mathrm{a}}$ Sessão da $20^{\mathrm{a}}$ Legislatura. Rio de Janeiro. Imprensa Nacional, 1889.

46. BRASIL. Ministério da Justiça. Ministro Antonio Ferreira Vianna. Relatório do ano de 1887. Apresentado a Assembléia Geral Legislativa na $3^{\text {a }}$ Sessão da $20^{\text {a }}$ Legislatura. Rio de Janeiro. Imprensa Nacional, 1888.

47. BRASIL. Ministério da Justiça. Ministro Samuel Wallace Mac-Dowell. Relatório do ano de 1886. Apresentado a Assembléia Geral Legislativa na $2^{a}$ Sessão da $20^{a}$ Legislatura. Rio de Janeiro. Imprensa Nacional, 1887.

48. BRASIL. Ministério da Justiça. Ministro Joaquim Delfino Ribeiro da Luz. Relatório do ano de 1885. Apresentado a Assembléia Geral Legislativa na $1^{\text {a }}$ Sessão da $20^{\text {a }}$ Legislatura. Rio de Janeiro. Imprensa Nacional, 1886.

49. BRASIL. Ministério da Justiça. Ministro Affonso Algusto Moreira Penna. Relatório do ano de 1884. Apresentado a Assembléia Geral Legislativa na $1^{\text {a }}$ Sessão da $19^{\mathrm{a}}$ Legislatura. Rio de Janeiro. Imprensa Nacional, 1885.

50. BRASIL. Ministério da Justiça. Ministro Francisco Prisco de Souza Paraizo. Relatório do ano de 1883. Apresentado a Assembléia Geral Legislativa na $4^{\text {a }}$ Sessão da $18^{\text {a }}$ Legislatura. Rio de Janeiro. Typographia Nacional, 1884.

51. BRASIL. Ministério da Justiça. Ministro João Frreira de Moura. Relatório do ano de 1882. Apresentado a Assembléia Geral Legislativa na $3^{\text {a }}$ Sessão da $18^{a}$ Legislatura. Rio de Janeiro. Typographia Nacional, 1883. 
52. BRASIL. Ministério da Justiça. Ministro Manoel da Silva Mafra. Relatório do ano de 1881. Apresentado a Assembléia Geral Legislativa na $2^{a}$ Sessão da $18^{a}$ Legislatura. Rio de Janeiro. Typographia Nacional, 1882a.

53. BRASIL. Ministério da Justiça. Ministro Manoel Pinto de Souza Dantas. Relatório do ano de 1880 e 1881. Apresentado a Assembléia Geral Legislativa na $1^{a}$ Sessão da $18^{a}$ Legislatura. Rio de Janeiro. Typographia Nacional, 1882b.

54. BRASIL. Ministério da Justiça. Ministro Manoel Pinto de Souza Dantas. Relatório do ano de 1879. Apresentado a Assembléia Geral Legislativa na $3^{\mathrm{a}}$ Sessão da $17^{\mathrm{a}}$ Legislatura. Rio de Janeiro. Typographia Nacional, 1880.

55. BRASIL. Ministério da Justiça. Ministro Lafayette Rodrigues Pereira. Relatório do ano de 1878. Apresentado a Assembléia Geral Legislativa na $2^{a}$ Sessão da $17^{\text {a }}$ Legislatura. Rio de Janeiro. Typographia Perseverança, 1879.

56. BRASIL. Ministério da Justiça. Ministro Lafayette Rodrigues Pereira. Relatório do ano de 1877. Apresentado a Assembléia Geral Legislativa na $1^{a}$ Sessão da $17^{a}$ Legislatura. Rio de Janeiro. Typographia Perseverança, 1878.

57. BRASIL. Ministério da Justiça. Ministro Francisco Januario da Gama Cerqueira. Relatório do ano de 1876. Apresentado a Assembléia Geral Legislativa na $2^{a}$ Sessão da $16^{a}$ Legislatura. Rio de Janeiro. Instituto Typographico do Direito, 1877a.

58. BRASIL. Ministério da Justiça. Ministro Diogo Vilho Cavalcanti de Albuquerque. Relatório do ano de 1875. Apresentado a Assembléia Geral Legislativa na $1^{\mathrm{a}}$ Sessão da $16^{\mathrm{a}}$ Legislatura. Rio de Janeiro. Instituto Typographico do Direito, 1877b.

59. BRASIL. Ministério da Justiça. Ministro Manoel Antonio Duarte de Azevedo. Relatório do ano de 1874. Apresentado a Assembléia Geral Legislativa na $4^{\mathrm{a}}$ Sessão da $15^{\mathrm{a}}$ Legislatura. Rio de Janeiro. Typographia Americana, 1875.

60. BRASIL. Ministério da Justiça. Ministro Manoel Antonio Duarte de Azevedo. Relatório do ano de 1873. Apresentado a Assembléia Geral Legislativa na $3^{a}$ Sessão da $15^{a}$ Legislatura. Rio de Janeiro. Typographia Americana, 1874.

61. BRASIL. Ministério da Justiça. Ministro Manoel Antonio Duarte de Azevedo. Relatório do ano de 1872. Apresentado a Assembléia Geral Legislativa na $2^{\text {a }}$ Sessão da $15^{a}$ Legislatura. Rio de Janeiro. Typographia Americana, 1873.

62. BRASIL. Ministério da Justiça. Ministro Manoel Antonio Duarte de Azevedo. Relatório do ano de 1871. Apresentado a Assembléia Geral Legislativa na $1^{a}$ Sessão da $15^{a}$ Legislatura. Rio de Janeiro. Typographia Americana, 1872a. 
63. BRASIL. Ministério da Justiça. Ministro Manoel Antonio Duarte de Azevedo. Relatório do ano de 1871. Apresentado a Assembléia Geral Legislativa na $4^{a}$ Sessão da $14^{a}$ Legislatura. Rio de Janeiro. Typographia Nacional, 1872b.

64. BRASIL. Ministério da Justiça. Ministro Francisco de Paula de Negreiros Sayão Lobato. Relatório do ano de 1870. Apresentado a Assembléia Geral Legislativa na $3^{\mathrm{a}}$ Sessão da $14^{\mathrm{a}}$ Legislatura. Rio de Janeiro. Typographia Nacional, 1871.

\section{Jornais}

Diário do Rio de Janeiro - 1860 a 1878

O Apostolo - 1866 a 1901

D. Pedro II - 1870 a 1874

\section{Outros documentos}

Annuario de Estatística da Cidade do Rio de Janeiro. Volume V. 1923 1924. Cardinale e Cia. Rio de Janeiro.

Arquivo Nacional. BR AN, RIO 4T - Ministério da Justiça e Negócios Interiores - BR AN, RIO DE - Polícia da Corte

Arquivo Público do Estado do Rio de Janeiro (APERJ). Livro de registro da entrada de presos na Casa de Detenção da cidade do Rio de Janeiro. Fundo/Coleção - Casa de Detenção do Rio de Janeiro - CDRJ. Notações 06 e 08 .

Torre do Tombo. Portugal, Leis, decretos etc. [Alvará com força de Lei da criação da Intendência Geral da Polícia e seu Regulamento, de 25 de Junho de 1760]. - [Lisboa] : reimpresso na Officina de Miguel Rodrigues, [1760]. 11 p. ; $2^{\circ}(31 \mathrm{~cm})$ - http://purl.pt/17387 


\section{Anexos}

\subsection{Anexo 01 - Leis, decretos e regulamentos.}

\section{Tabela 9. Leis, decretos, alvarás e regulamentos que incidem diretamente} sobre as instituições policiais no período estudado.
Alvará de 25 de Junho de 1760
Decreto de 18 junho de 1780
Decreto de 10 de Dezembro de 1801
Alvará Régio de 10 de maio de 1808
Lei de 13 de maio de 1809
Constituição de 1824
Lei de 1 de outubro de 1828
Lei de 16 de Dezembro de 1830
Lei de 6 de Junho de 1831

Lei de 18 agosto de 1831

Lei de 29 de Novembro de 1832.

Lei de 3 de dezembro de 1841

Regulamento 120 de 31 de janeiro de 1842

Decreto n 190 de 1 julho de 1842

Decreto n 678 de 6 julho de 1850

Lei de 19 de setembro de 1850

Decreto $n 3598$ de 27 de janeiro de 1858

Decreto n 2.081 de 16 de janeiro de 1858

\section{Portugal.}

Portugal.

Regulariza a Guarda Real da Polícia.

Cria o Intendente Geral da Polícia do Brasil.

Regula a divisão Militar da Guarda Real de Polícia.

Institui câmaras municipais e juízes de paz

Código Criminal do Império do Brasil.

Administração da Justiça e punição dos criminosos.

Cria as Guardas Nacionais e extingue os corpos de milícias, guardas municipais e ordenanças.

Código do Processo Criminal de Primeira Instância.

Reforma o Código do Processo Criminal.

Regulamenta da lei de reforma do código de processo criminal.

Reformando o Código de Processo Criminal.

Regulamenta a Casa de Correção do Rio de Janeiro.

Dá nova organização a Guarda Nacional do Império.

Regulamenta o corpo policial da corte.

Regula a organização e disciplina o Corpo policial da Corte. 
Decreto n 3572 de 30 de dezembro 1865

Decreto n 3598 de 27 de janeiro de 1866

Decreto n 3.609 de 17 de fevereiro de 1866

Decreto 3.598 de 27 de janeiro de 1866

Decreto n 4824 de 22 de novembro 1870

Lei n 2033 de setembro 1871

Lei de n 2033 de 20 setembro de 1871

Decreto 4.824 de 22 de dezembro de 1871

Decreto n. 9274 de 6 de setembro de 1884

Decreto n 9.395 de 07 março de 1885

Decreto n. 847 de 11 de outubro de 1890

Decreto n 958 de 6 de novembro de 1890

Constituição 1891

Lei n. 947, de 20 de dezembro do 1892 ,

Decreto n. 3640, de 14 de abril de 1900

Decreto n. 4272, de 11 de dezembro de 1901

Lei n. 947, de 29 de dezembro de 1902

Decretos de 5 de fevereiro de 1903 n. 4762 , n. 4763 , n. 4764

Decreto n. "328 de 2 de Janeiro de 1905

Lei n. 1.338, de 9 de janeiro de 1905

Lei n. 1631, de 3 de janeiro 1907

Decreto n 6.440, de 30 de março de 1907
Manda executar o Regulamento da Estatística Policial e Judiciaria.

Reorganiza a força da polícia da corte em dois corpos um militar e outro civil.

Regulamenta o serviço da Guarda Urbana.

Cria um corpo de Policiais Civis uniformizados.

Regula a execução da Lei no 2033 de 24 de Setembro de 1870, que alterou diferentes disposições da Legislação Judiciaria.

Altera diferentes disposições da Legislação Judiciaria.

Reforma o código de processo criminal.

Regulamentada a reforma de 1871 desvinculando justiça de polícia civil.

Regulamenta o asilo de mendicidade

Dá novo regulamento para o corpo militar de polícia da corte.

Código Penal dos Estados Unidos do Brasil.

Organizava a polícia militar através de hierarquias.

\section{Autoriza o poder Executivo a} reorganizar a polícia do Distrito Federal.

Nova organização da polícia.

Regulamenta o funcionamento da Brigada Policial e Guarda Civil.

Reforma o serviço policial no Distrito Federal.

Regulamenta o funcionamento da Guarda Civil e dá novo regulamento á Secretaria de Polícia.

Autoriza o poder Executivo a reorganizar a Brigada Policial e a Guarda Civil.

Reorganiza a justiça local do Distrito Federal.

Reorganiza o serviço de polícia do Distrito Federal regulamentada pelo decreto n 6.440 .

Reforma a polícia. 
Decreto n. 8.332, de 3 de novembro de 1910

Decreto n. 9.263, de 28 de dezembro de 1911

Decreto n. 13.8781919

Decreto n. 14.079, de 25 de fevereiro 1920

Decreto n. 1.543, de Decreto $\mathrm{n}^{\circ} 15.848$, de 20 de Novembro de 1922

Emenda Constitucional de 3 de setembro de 1926
Aprova o Código do Processo Civil e Comercial do Distrito Federal.

Reorganiza a Justiça do Distrito Federal.

Regula a guarda civil

Organiza o Corpo de Segurança Pública

Reorganiza a Escola XV de Novembro

Legisla sobre a organização municipal do

Distrito Federal, bem como sobre a polícia, o ensino superior e os demais serviços que na capital forem reservados para o Governo da União.

\subsection{Anexo 02 - Documentos de gestão policial.}

Destacamos abaixo alguns exemplos de documentos produzidos pela polícia na sistematização de suas práticas. De modo que, permitiam conhecer a população de maneira científica, administrar nos preceitos da ideia de eficiência da gestão e produzir conhecimentos que influenciavam na criação de leis e instituições. 
$-52-$

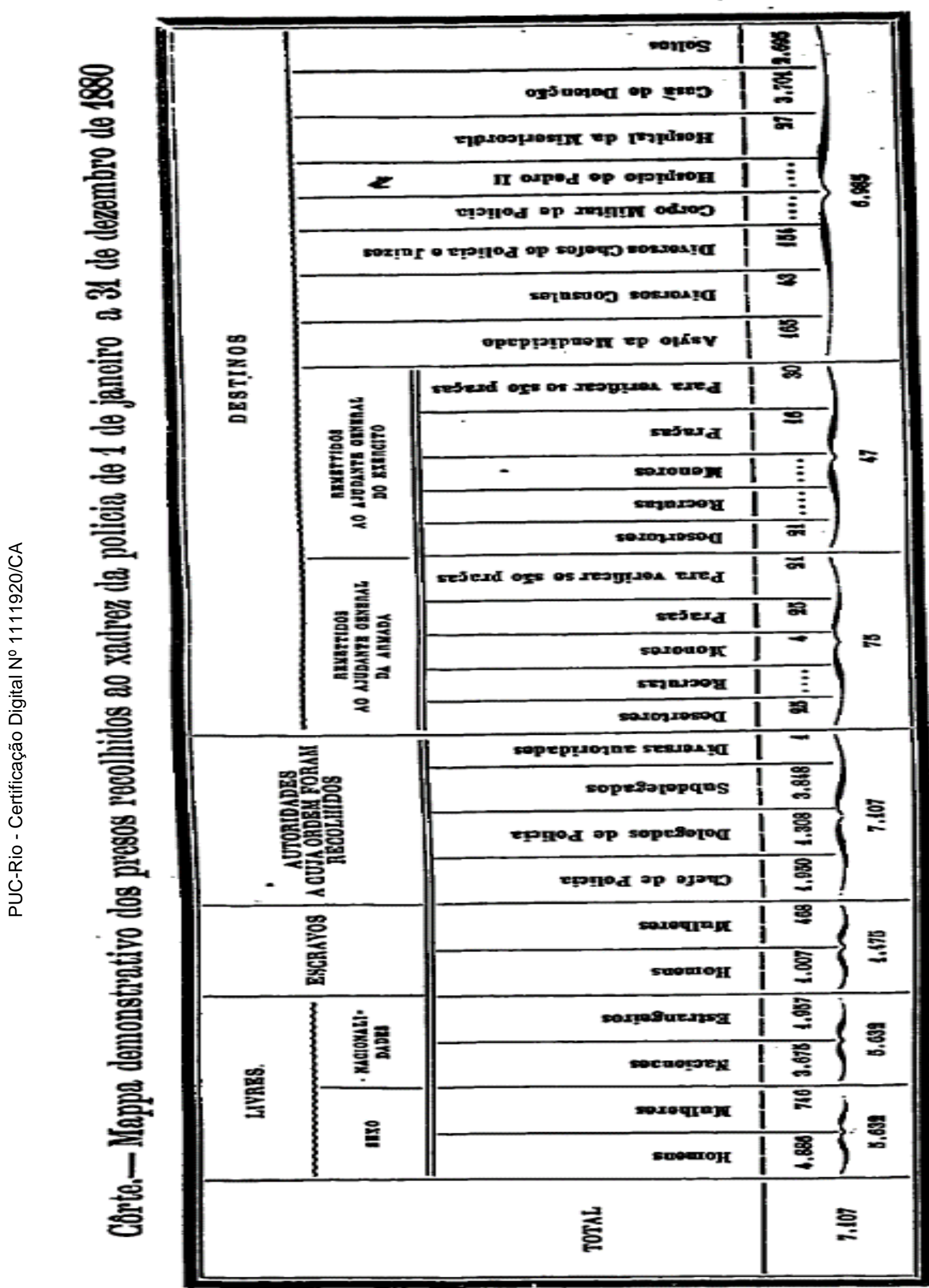

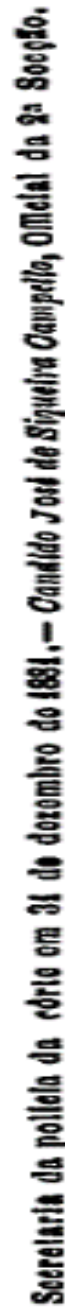

BRASIL. Ministério da Justiça. Relatório do ano de 1880 e 1881. Typographia Nacional, 1882b, p. A-G-52 


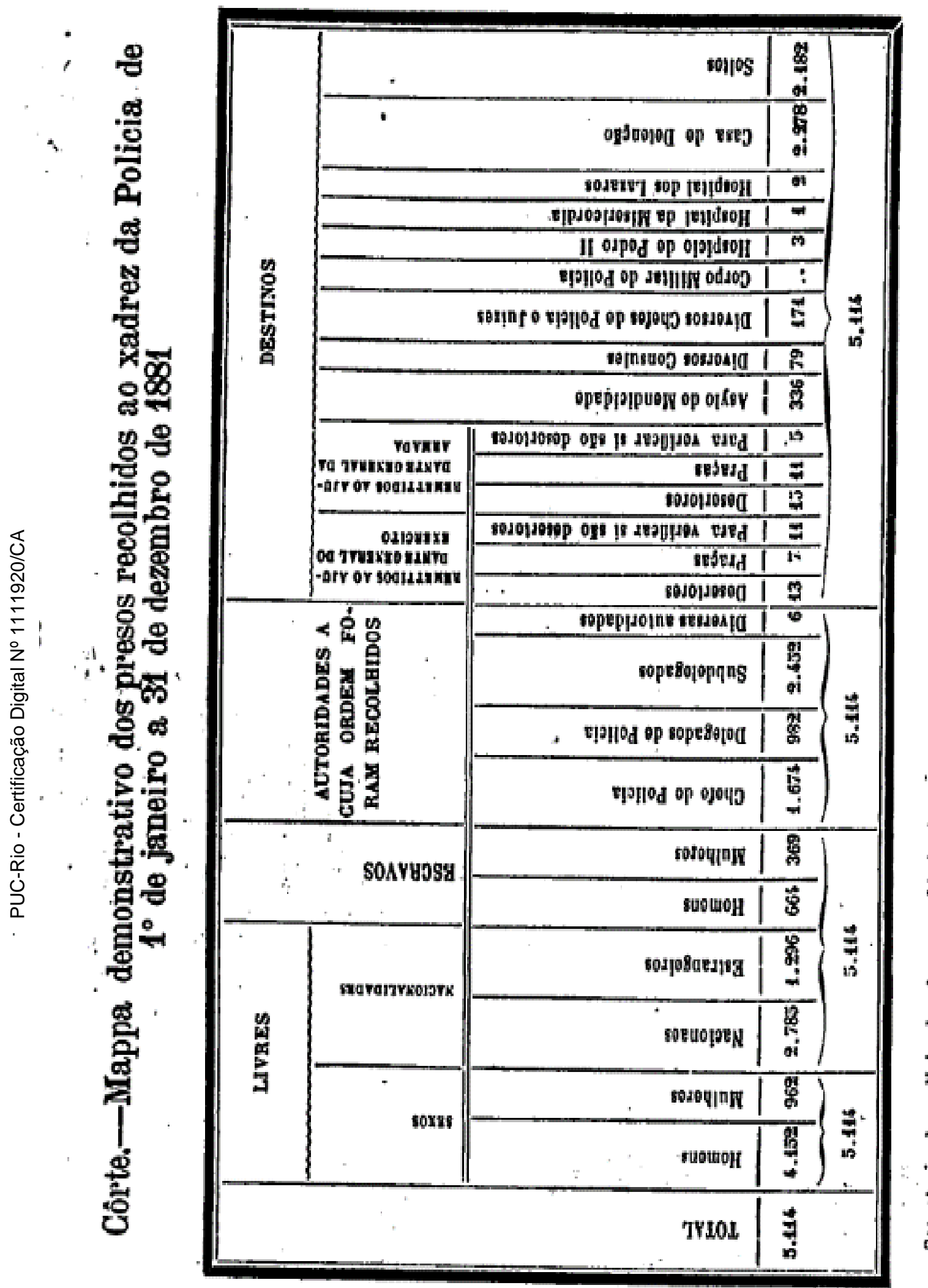

BRASIL. Ministério da Justiça. Relatório do ano de 1880 e 1881. Typographia Nacional, 1882b, p. A-G-53 


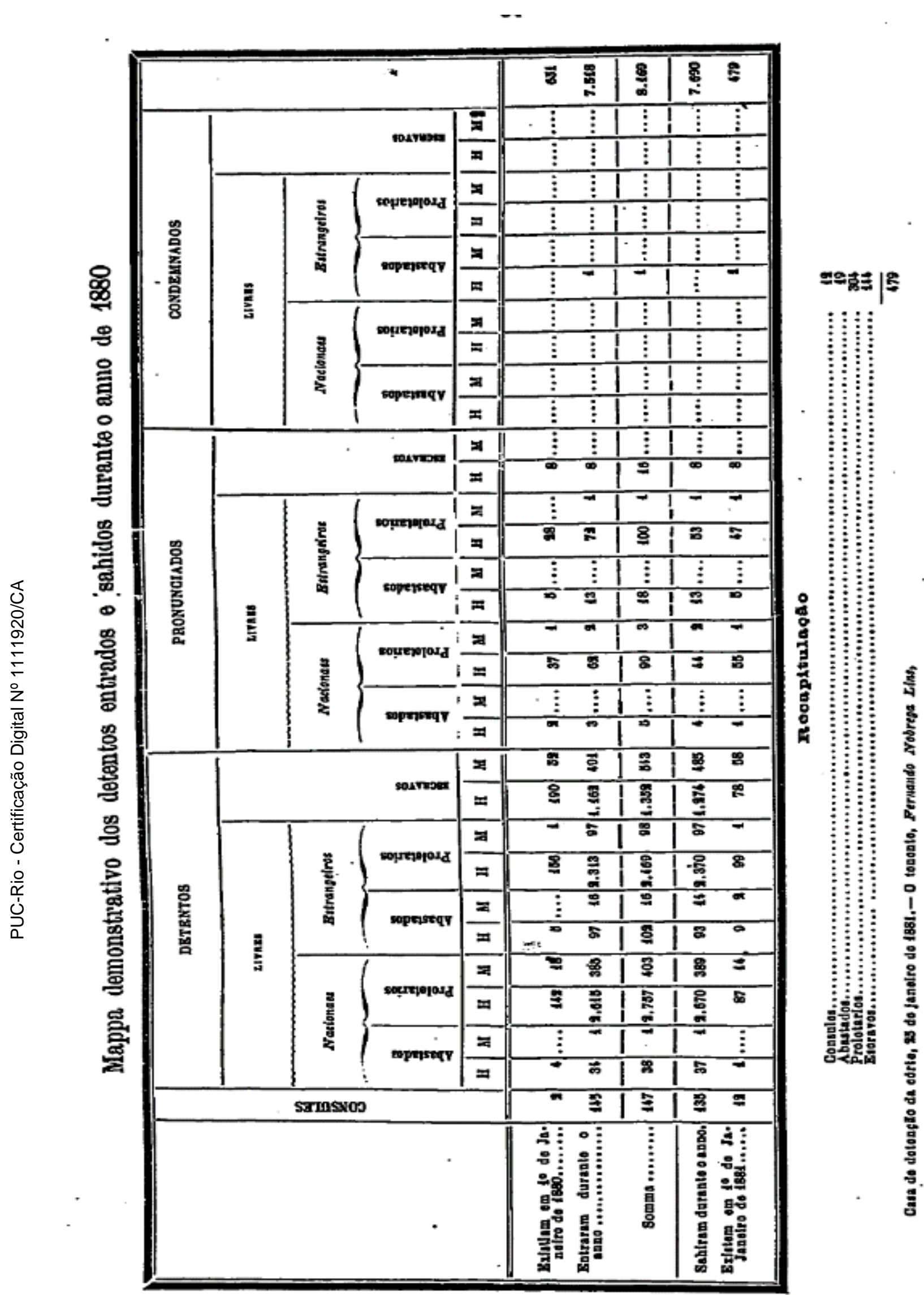

BRASIL. Ministério da Justiça. Relatório do ano de 1880 e 1881. Typographia Nacional, 1882b, p. A-G-54 


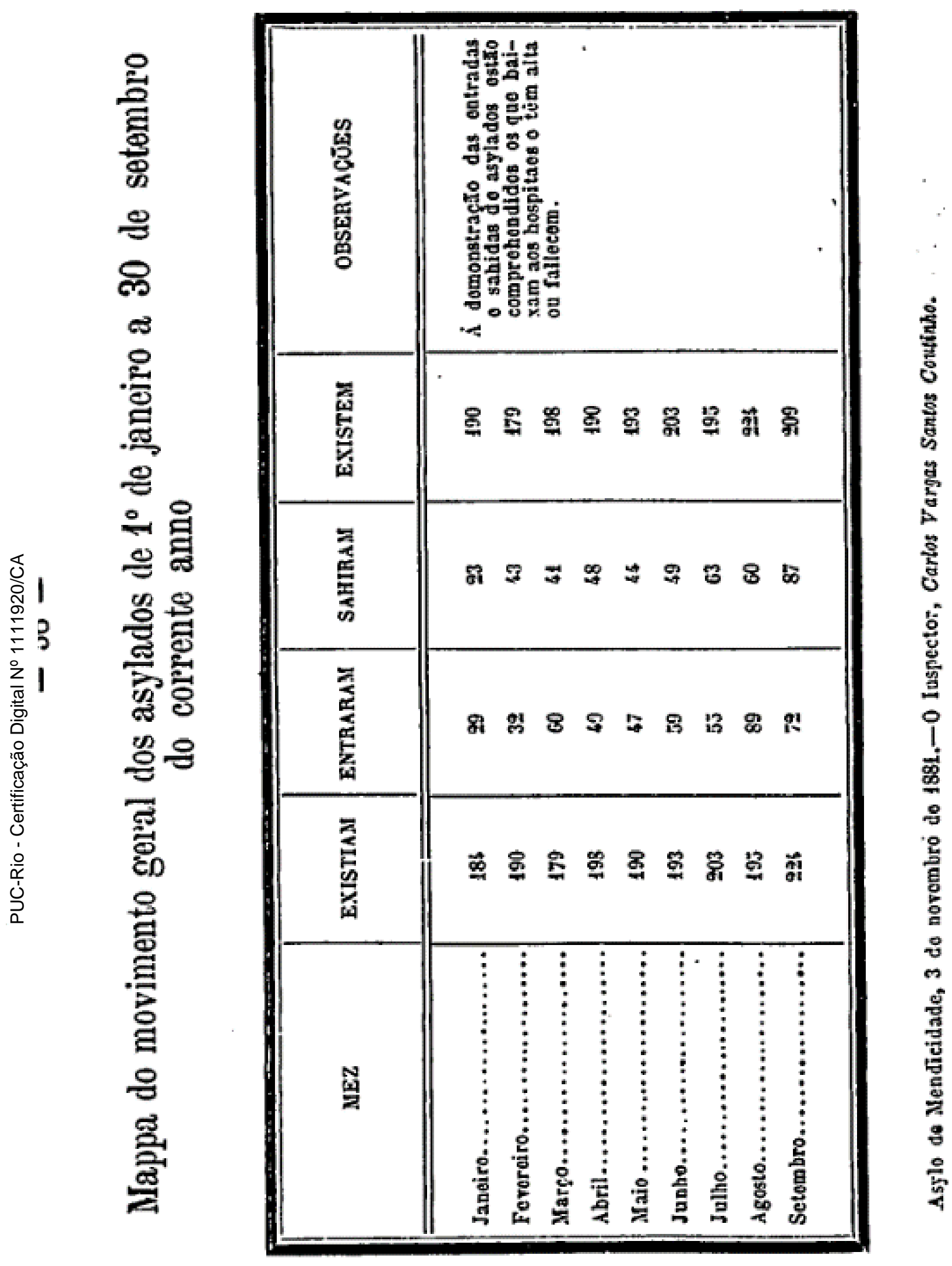

ASIL. Ministério da Justiça. Relatório do ano de 1880 e 1881. Typographia Nacional, 1882b, p. AG-56 


\subsection{Anexo 03 - Matérias de Jornais sobre o Asylo de Mendicidade}

História da construção do Asylo de Mendicidade, contada em recortes jornais.

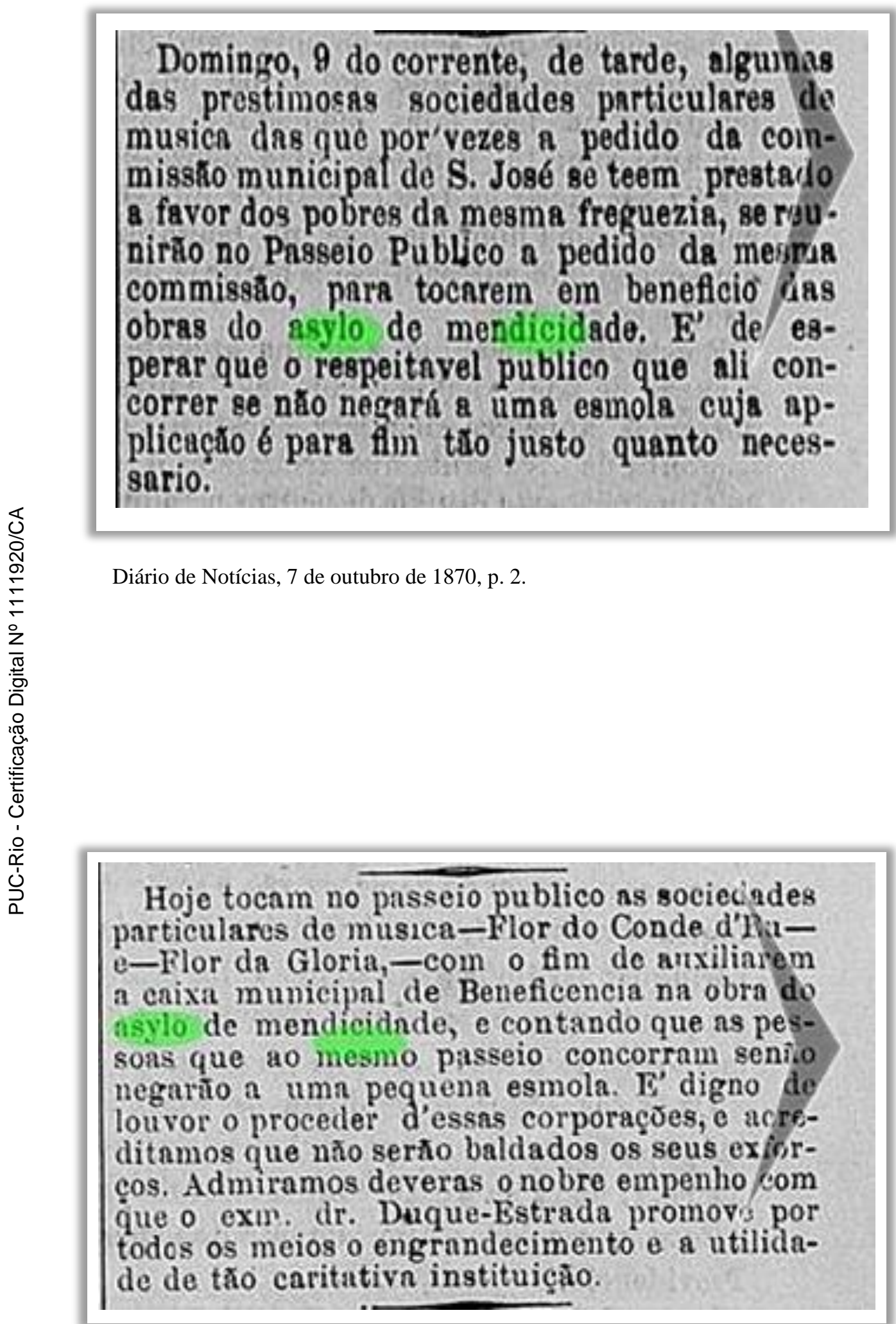

Diário de Notícias, 9 de outubro de 1870, p. 2. 
Amnihn tera lugar, na Phonix Dramatica, um beneficio, promovido pela commissno mudicipal da freguezia de-s. José, para a fun. nagjo do Aaylo de Mendiciclade; subindo á seena o wireito por linhas tortasn e uDefuito Ao Ramiliay comedins do distincto eseriptor dx Rrança Junior. O publico desta corte deve concorrer generosamente para uma obra tio pia, tăo phylantropica e tắo necessaria á infeliz pobreza, como á nossa civilisaçăo; contiumos, Pois, que havera uma enchente real.

Diário de Notícias, 22 de novembro de 1870, p. 1.

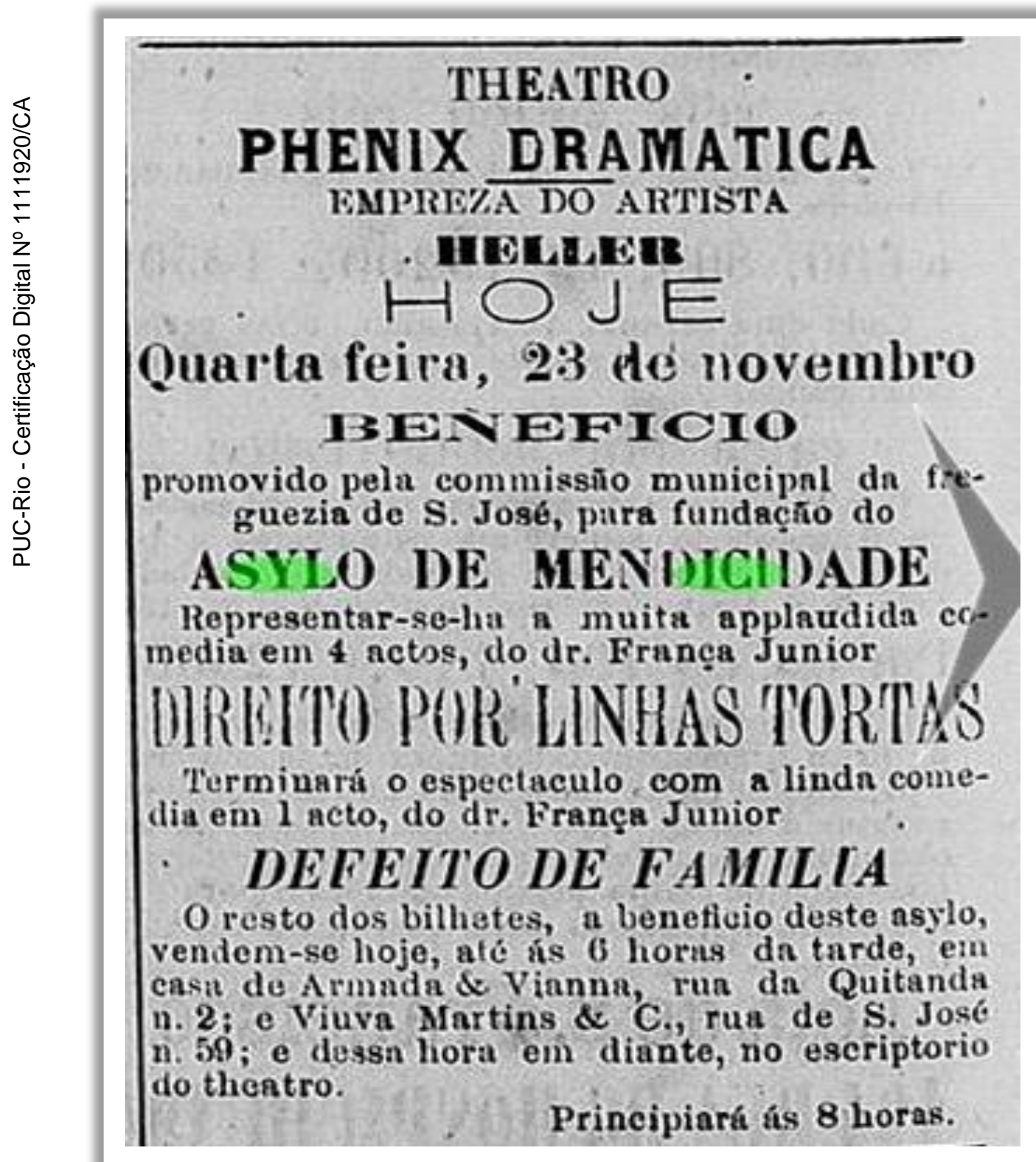

Diário de Notícias, 23 de novembro de 1870, p. 4. 
Apezar do mal que se tem dito da maçonaria, continúa ellá por toda a parte, e principalmente nesta corte, a trabalhar comafinco em prol do progresso da humanidade,e do desenvolvimento ios principios pregados pelo martyr do Golgotha. Somos informados de que $\mathrm{n}$ Inj, 18 de. Julbo que funeciona ao Vulle dos Benedictinos propóe-so a empozsar a directorin que tem de servireste anno, sem a menor poinpa, distinando a quantin de 500gosi, que devêra gastar nisto á fundação do Asylo de Menticidade.

Estia propnsta que se acha affecta á commissro central da mesma loja, ha de ser, necessariamente, adoptada e fazemos votos para que ns demais oftleinns sigam o exemplo de sua nobre eo-irmat.

Diário de Notícias, 9 de fevereiro de 1871, p. 1.

\section{DECLAARAÇÕES}

\section{Asylo de Mendieldade.}

O sr. dr. provedor municipal, manda convidar a todos os senhores, que por parte das freguezias do municipio da corte compঠem o centro, encarregado pela Caixa Municipal de Benittcencio, da edificaçăo do Asvlo de Mendicidade, para so reunirem hoje 2 de marca ás 5 horas da tarde, na casa n. 1 a rua da Constituiçito, sfim do lies ser apresente o relntorio da commissío sobre o oresamento e planta do referido asylo, o resolverem diversos assumptos concernentes ao mesmo. $-\mathrm{AN}$ rosio Vicests DA Costa, 10.eceretario de centro.

Diário de Notícias, 9 de fevereiro de 1871, p. 3. 


\section{Um sorriso da patria}

AO VENERANDO CONDE DO BOM-FIM

Por occasiño de concorrer para a fundação do asylo de mendicidade do Rio de Janeiro.

Nĩo é debalde que appe lan Para o vosso coração, Em vós a pobreza encontra A mais santa protecção.

Nas conquistas sacrosantas

Parra bem da humanidade 0 vosso nome fulgurn Ante a luz da immensidade.

0 seu fulgor é suave E encerra um doce encanto Ao pobres, tristes, coitados, Enxuga o tristonho pranto. $E$ nesse asylo que aos pobres A caridade fundou, Na fachada desse templo 0 vesso nome estampou. A. C. Azevedo Coimbra. 


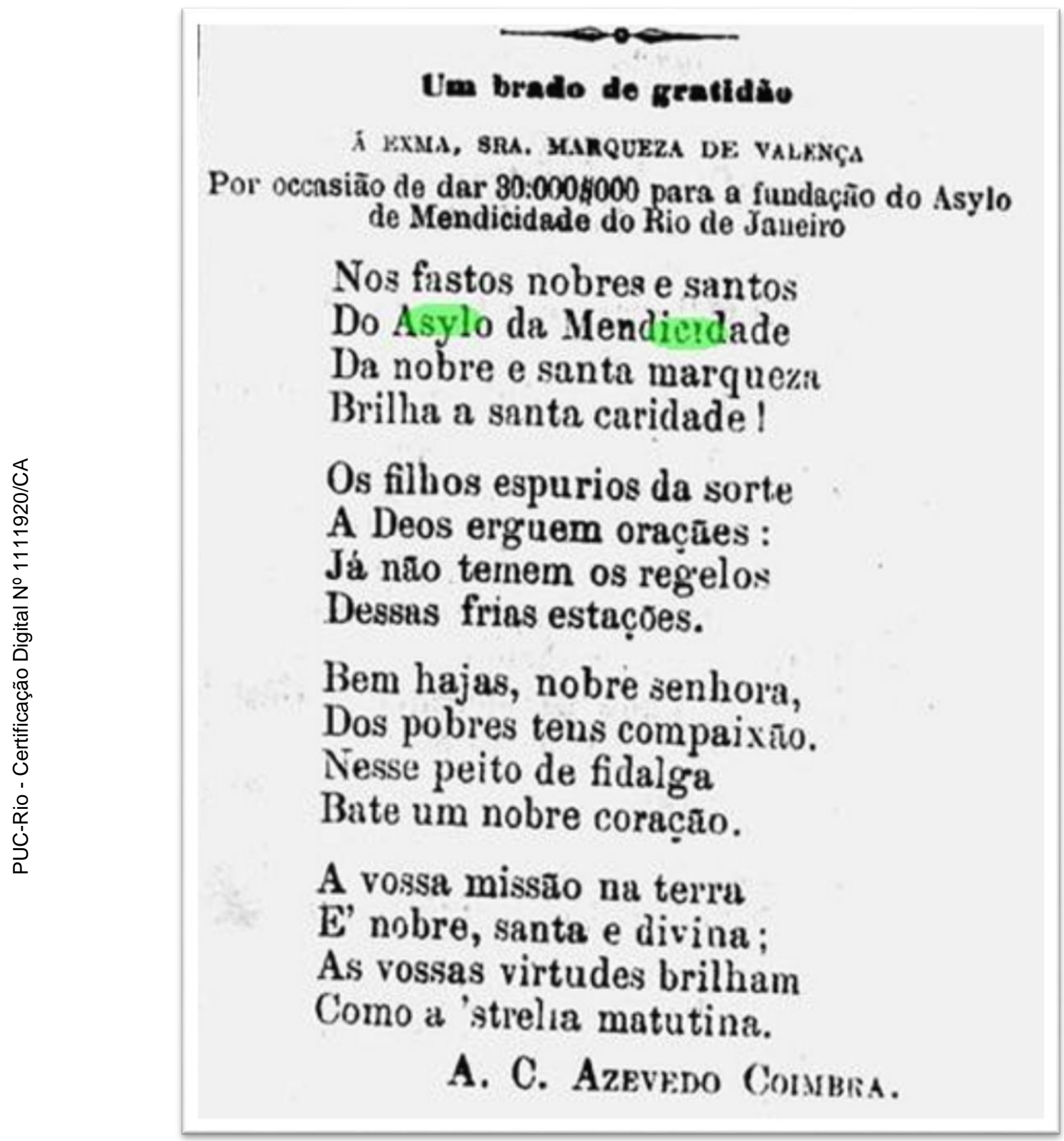

Jornal D. Pedro II, janeiro de 1872, Anno V, n. 50, p. 2. 


\section{Festejos 'publicos}

Pela provedoria municipal foi dirigida a seguinte circular:

"Aos Illustres Srs. memhros das commissỏes de festejos. - Náo está no espirito dos abaixos assignados a intençáo de desviar por qualquer modo a idéa de festejos em honra de Suas Magestades Imperiaes, a quem tudo é devido, e para quenı nunca serào de mais as demonstraçòes de nosso amor e de nosso respeito; a publicacảo, porén, do Jornal do Commercio do dia 24 do corrente -de que os srs. corretores de nossa praça concertando sobre o modo de festejar o regresso de Suas Magestades, resolvêráo abrir uma subscripçío e applicar seu producto em favor da instrucçáo publica-suscitou aos mesmos abaixo assignados a lembrança de pedirem aos srs. das commissóes encarregadas dos festejos-quequando entendáo dever dar applicaçào differente da dos ditos festejos aos dinheiros para os mesmos subscriptos-se sirvào de destinal-os á edificaçào do asylo de mendicidade de S. Pedro de Alcantara, para o qual já se achafeita a acquisiçào de excellente $e$ vasto terreno, á beiramar, na rua do Imperador, em S. Christovào, onde Sua Alteza Imperial Regente, se dignou collocar a primeira pedra no dia 13 de dezembro do anno lindo,

Rio 29 de fevereiro de 1872.- Dr. Domingos de Azeredo Coutinho de Duque Estrada, provedor da Caixa Municipal de Iseneficencia. Commendador José Rodrigues dos Santos, thesoureiro. 
A sociedade hespanhola de beneficencia, tendo promovido uma subseripgào entre seus membros, rosolreu applicar o respectivo producto em beneflcio do asylo de mendicidade de S. Pedro de Aleantara, como demonstraçào de seu regosijo pelo proximo regresso de Suas Magestados Imperiaes a esta corte.

Movidos de iguaes sentimentos, os Srs. Manoel Goulart Raposo \& C., estabelecidos á rua do Ouvidor $\mathrm{n} .120$, entregaram ao $\mathrm{Sr}$. Joso Rodrigues dos Santos, thesoursiro da provedoria municipal, a quantia de 508, para ser applicada em partes iguaes a Caixa Municipal de Beneficencia e ao Asylo de Mendicidade

\section{pelatorió dia Connpaninia de seguros sir. Conntariea.}

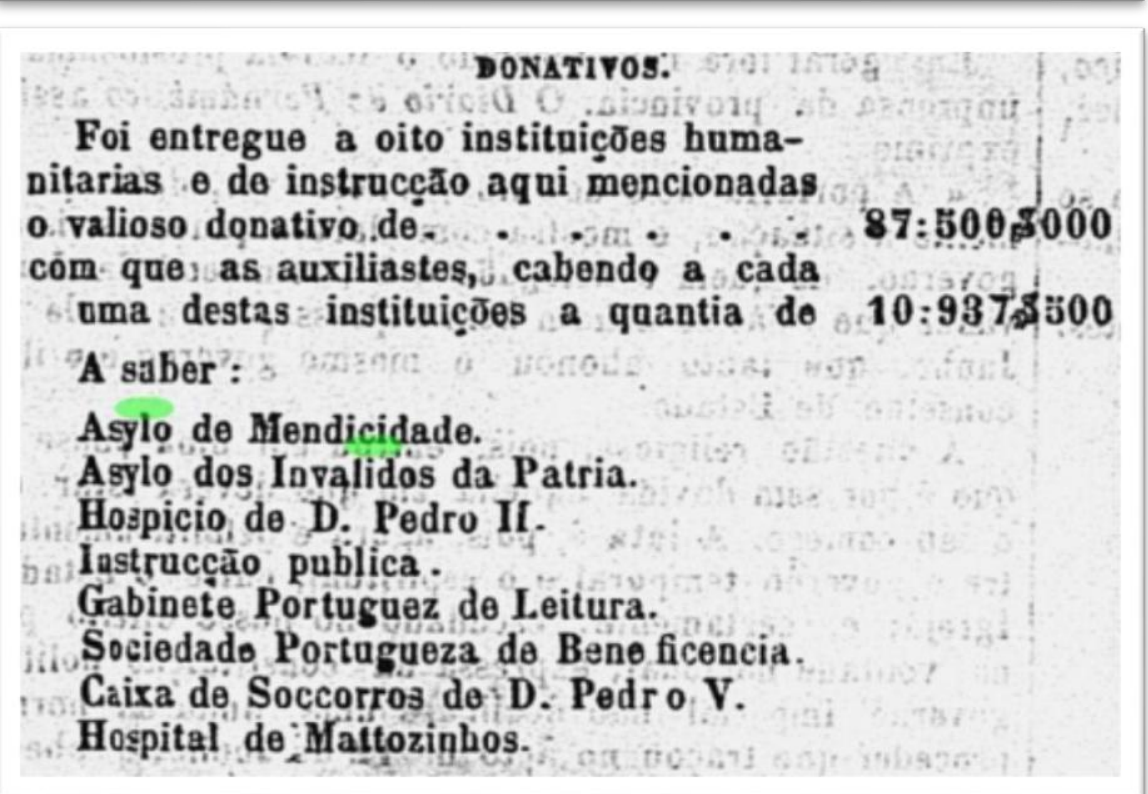


Ministerio da justica. - Lai n. 2670 de 20 de outubro le 1876, art. 16, \$ $S^{\circ}$ :

Acquisiģão on construccẫn de um esliflcio para asylo to mendiciriado; flcando auctorisado 0 govergn a fazer operações de credito atcé 100:0003, no cano de quo não bastem as sobras da reala goral.

A Gazeta de Notícias, 13 de maio de 1878, p. 2.

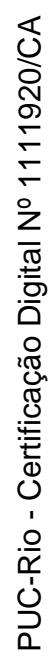

\section{$O$ QUE POR AHI VAI}

- Começamos por agradecer a promp. tidào com quo a pessoa competente attendeu á nossa ultima noticia, mandando concertar' o calçamento da rua da Prainha.

- Ha um nsylo do mendicidade, ediflcio vellio; ha outro novo e os pobres filsos on verdadoiros continuam a incommodar os transeuntes pela rta dos nurrives.

A Gazeta de Notícias, 13 de maio de 1878, p. 2. 


\section{Arylo de Mlemalletilade}

Illm. Si. rodactor. -Diz V. S., om o no. tleiario do sua concoltuada folha do hoje, quo S. Ex. o Sr. Dr. choto do polloia dou algumas providencias no sontido de melhorar as condiçðos dos asylados, man. dando croar no novo Asylo do Mendíldade cluas oflleinas, ofliclar ao governo pedindo mais agua, pois a que ha no odiflcio $\delta$ pouca, ordonando tambem a construçấo do mais banheiros e de tanques para lavagam.

Podo-so suppor, pelo modo por que o dada a noticia, quo certas condişos os. scaciaes năo foram tomalive am consideracĩo a bem dos mondigon.

$O$ que $\$$. Ex. fez, scm duvida, fol man-dar nontar as ollicinas nas ealas dest. nadas para essa flm; reclamar das obras publicas a agan quo dovería corrar uos oncanamontos com capacidade nocovsarin para abastecimonto alundanto, como ja foi experimontado; sendo certo que ro. clamoi diversas veres, antes do ontrogar. - ediflcio, para quo olla nũo faltasso, o mandar comprar dez banheiras, aflm do completar as doze que comportam as respectivas salas, onde js existem os competentes registros para agua quanto e iria.

Essa falta de banheiras, a de tanques para lavagom o a do outros minteres, săo devidas a năo estar ainda concluidó o edificio, por falta do verba.

Rogo, pois, a v. S. de publicar esta minha carts, rectificando a noticla que den a semelhante respeito.

Sou com muits contideraç̃o

Do V. S. venerador o criado, O director, B. B. Prssod de Melio. 


\section{Asylo de mendicidado.-}

0 Sr. Dr. chefe de policia, nao perdendo Io vista 0 seu lonvavel empenho de me. lhorur cousideruvelmente este estubelecimento, $\theta$ us condiço dos individuos alli reculhidos, ขূo se tem pouprdo aos muiores esf rços; ussim, uchn-se prompto nu f eute do edificio $n \mathrm{~m}$ jurdim, que foi feito pelo iuspr-ctor do mesmo anylo, de accôrdo com o carereiro da casa de detenção, formecendo este algumas plantrs, $* 0$ Dr. Jorqnim Pinto Netto Machado diversos arvuredos importantes, que obtivera do Sr. engenheiro Gluzion.

O Apostolo, 1 de agosto de1879, p. 2.

As usheinas de alfaiate $\theta$ suputeiro $j h$ estio trabulliando; a capella foi guarnecilin com os moveis a utensilios indispensaveis. An S. ministro da justiç reclumou o - Dr. chefe de policis autorisuçă para for necer ceira aos asylidos, que ató sgura só tên almoço e jantar.

O Apostolo, 1 de agosto de1879, p. 2. 
Sabernos tambem que no saguão do edificio foi collocnda uma elegante lapide de pedra mermore, com a seguinte inscripçao: " Asylo de Mendicidade, inangurado em 10 de Julho de 1879, por S. M o Imperador - Sr. D. Pedro II, sendo ministro du justiça - conselheiro Laffayette Rodrigues Pereira e chefe de policia o Dr. Tito Augusto Prsreira de Mattos. - Assentada a pedra fundumental em 6 de Agosto de 1876. na preseriç de S. A. Imperial a Renie, sendo ministro da justiça o conselheiro Dirgo Velho. Cavalcanti de Albuquerque e chefe de policia o Dr. Mriguel Calmon du Pin Almeida, "

O Apostolo, 1 de agosto de1879, p. 2. 
Tosplolo do alionados mondigos. - Le-se no Jornal do Comi mercio:

« O Sr. director da casa de correçaio que tem prestado relevantes serviços, quel na edificaça do Asylo de Mendicidade, que va do hospicio que, debsixo de suas vistas foi construido nos terrenos do mesmo asylk para os mendigos loucos, entregou hontem no Sr. desembargador chefe de policia chave do referido hospicio, que se acha prompto.

I. esse hospicio construido de ricas madeiras de lei, sobre embasumento de pilares rectangulares, sendo as paredes de taboado 1uplo e cheias do areía para evitar o éco.

O estylo do edificio é em fórma de chalet, com escadas, que dao accesso ás varandss transversaes e longitudinaes.

Tem quatorze cellulas para loucos sgita. dos e duss para empregados, e nos fundos do todas ellas, ha mezaninus com grades de ferro, que dao para as varandas e aer. vem, nao só para a entrada de abundante luz $e$ ar, como tambem para a facil inspec. ino dos loucos.

O Apostolo, 26 de outubro de 1879, p. 2.

Sua Magestado o Imperador visitou houtem o hovo Asylo to Mondieidade, percorrendo todo o cuillcio e examinando com minucia todas - as dependencias daquello estabolecimento. 
OSr. ministro da justica visithu hontem o novo Asylo de Ilendicidade.

A Gazeta de Notícias, 28 de outubro de 1879 p. 1

Apylo de Mendicidade. - $0 \mathrm{Sr}$. Dr chefe te policis expedio, em data de 28 de mez passado,aos Sts. delegados e subdelegados a seguinte circular :

Sendo destinado o Asylo de Mendicidade somente aos individuos que, pelo seu estadc de invalidez e complets ausencia de meios, sũo incapazes do prover á propria subsistencia, ou aos alienados que nÆ̃o possam ser adwritidos no Hospicio de D. Pedro II, recommeado a V.S. que remetta os mendigos enonntrados na via publica a esta repartiçăo, efim de serem $s 6$ alli recolhidos, depois do competente exame medico, os que se acharem 9m taes circumstancias. Deus guarde a V. S. -O chefe de policia, Luiz Barrelo Correa de Menezes.

- Na mesma data o Sr. Dr. chefo de po. licis expedio terminantes ordens ao inspector do Asylo de Mendicidade, recommendando-lhe que so deve receber alli os individuos que forem directamente remettillos pels repartiçáo da policia ; e tambem que com urgencis deve enviar a essa repartiçăo uma relação nominal de todos os asylados que nťo se acharem nas circumstancias acima especificadas. 
Em um dos diss da semana passada, un moşo residente na rua do Conde d'Ea n. 79 solicitou do respoctlvo inspector de quarteirão auxilio para proteger sua mâi c ntra os accensos de loueura do que padece um outio sou irmũo, 0 inspector foj solicito em at onder a tico justa reclamaçio, e foz condiazir o mos para a policia no sabbado pela manhí.

A mùi d'esso infeliz, supp nilo quo ello estivesse no Asylo do Mendicidado, dirtgiu-se alli pars o visitar.

Näo o en rontrou, mas, liontem á tardo, tevo occasiăo do vel-o no xadrcz da policla Dosde sabbado, pois, quo se conservavo no xadroz um moço que somio, segunds diz a famillia, de allenaç̧o mental.

0 logar pareco-nos incontestavelmence Improprito, pois um nenhium caso se póte domorar um individuo, por lantos dins, n'uma enxovis d'nquol a ordem. So - o mogo soffro offectivamento do allenacăo montal, nato ha de ser o Sr. carcerciro quem lho lis do applicar a sub theuripeutea policial; so nite soffre, nâo ha razáo para ser alli detido por tanto teinpo.

Ousumos esperar quo o $\mathrm{Sr}$. desembargador chefe de policis tomo conhecimento to caso o proviliencio como melhor enreniler. 


\section{o vintem}

Na rua do Visconde de Itauna estabeleccu o governo um asylo de mendicidade para serem recolhidos os pobres que pedian um vintem pelo amor de Deus, agora vai o governo cobrar o imposto de vintem; qual será mais moral ? pedir o pobre pelo amor de Deus ou a força armada cobrav o governo um vintem por passagem ? devem ou ñ̃ ser lecolhidos todos prira esto asylo ?

Responda

$$
\text { o senso. commum. }
$$

A Gazeta de Notícias, 31 de dezembro de 1879, p. 2.

\section{Asylo da mendioldade.-} 0 Sr. Barao de Sants Justs, pels casa commercial Mothias \& Gonçalves Roqua, offere cen ao Sr. desambargador chefo de policis 50 saccas de farinhs para slimentuça dos individuos recolhidos áquelle estabelecimento.

O Apostolo, 1 de setembro de 1880, p. 1.

Asylo de mendicidade.-Realizou-se ante-hontem com toda solemnidade, . na presenca de S. M. o Imperador, a benção e lançamento da primeira pedra para 0 asylo de mendicidade. Observando-se o ceremonial p:escripto para taes occasiões, foi officiante o Exm. e Rvm Sr. Vigario Geral, Conego Luiz Raymundo da Silva Brito.

O Apostolo, 19 outubro de 1884, p. 2. 
Asylo de mendicidade.- Reuniramse, ante hontem, á 1 hora da tarde, no asylo de mendicidade, com assistencia do Sr. ministro da justiça, conselheiro Sodré, os Srs.: conde de S. Salvador de Maftozinhos, barão de Quartim, Conego Luiz Rayrnundo da Silva Brito. conselheiros Tito Augusto Pereira de Mattos e José Bento da Cunha Figueiredo Junior, e Belarmino Braziliense Pessoa de Mello, membros da commis. são nomeada pelo governo para promover a creação da associação protectora do mesmo asylo.

Por accôrdo unanime, foram nomeados: presidente da mesma commissão, o Sr. conselheiro Sodré ; vice-presidente, o Sr. conselheiro Tito de Mattos; 1. secretario, o $\mathrm{Sr}$. conselheiro Figueiredo Junior ; $2^{\circ}$ dito, o Si. Belarmino ; thesoureiro, o Sr. barão de Quartim; e membros da commissão de estatutos da associacão protectora, os Srs. : conde de S. Salvador de Mattozinhos, conse-

- Iheiro Cunha Figueiredo Junior e Conego Brito.

Tendo alguns socios concorrido com importantes quantias, e todos se compromettido a etapregarem todos os meios possiveis para o começo das obras, se esforçarâo para que o mais breve possivel seja lançada a primeira pedra. 
Asylo de mendicidade.- Reuniramse, ante hontem, á 1 hora da tarde, no asylo de mendicidade, com assistencia do Sr. ministro da justiça, conselheiro Sodré, os Srs.: conde de S. Salvador de Maftozinhos. barão de Quartim, Conego Luiz Raymundo da Silva Brito. conselheiros Tito Augusto Pereira de Mattos e José Bento da Cunha Figueiredo Junior, e Belarmino Braziliense Pessoa de Mello, membros da commis. são nomeada pelo governo para promover a creação da associação protectora do mesmo asylo.

Por accôrdo unanime, foram nomeados: presidente da mesma commissão, o Sr. conselheiro Sodré; vice-presidente, o Sr. conselheiro Tito de Mattos; 1. secretario, o Sr. conselheiro Figueiredo Junior ; $2^{\circ}$ dito, o Si. Belarmino ; thesoureiro, o Sr. barão de Quartim; e membros da commissão de estatutos da associacão protectora, os Srs. : conde de S. Salvador de Mattozinhos, conselheiro Cunha Figueiredo Junior e Conego Brito.

Tendo alguns socios concorrido com importantes quantias, e todos se compromettido a etnpregarem todos os meios possiveis para o começo das obras, se esforçarâo para que o mais breve possivel seja lancada a primeira pedra. 
Ifendizos. - Aos subiclegados di rigio o St. Dr. Bernartina da Silva, ch fe de policiu, a seguinte circular:

a Convindo evitur a continusçóo do espectaculo com que a miseri, re l ou simulada, estende a máo á caridade publica, nas ruas e praças desta gran. de capital, recommendo-vos que com o msior empenho, fiçais apprehender tod is os mendigos encontrados a va. zar cm vosso diste cto, enviando a esta repartiçáo os reconhecidamente invalidos, afi $n$ de serem,soscorritos no asylo e menticidade, remettendo pura a cisa de Detencio os que nio se ach irem impossibilitados de pr curar no trabilho honesto os meios de subsistencia ; e contrs estes livrareis auto de prisio em fi grante, conforme as hyp th:ses em que incorrerem, dos art. $39 t$ e seguintes do codigo pensl, auto que será assigna do por vius tes. temunh is, pilo menos, passando-os com estes elementos á disposição do respectivo pretor, pars os effcitos do art. 59 de decreto n. 1, 3 s de 14 de Novembro de 189 ,: 
Asylo de mendicidade.-Keuniram- I se, ante hontem. á 1 hora da tarde, no asylo de mendicidade, com assistencia do Sr. ministro da justiç, conselheiro Sodre, os Srs.: conde de S. Salvador de Maftozinlıos. barīo de Quartim, Conego Luiz Raymundo da Silva Brito. conselheiros Tito Augusto Pereira de Mattos e José Bento da Cunha Figueirndo Junior, e Belarmino Braziliense Pessoa de Mello. membros da cornmis. saio nomeada pelo governo para promover a creaçào da associaçio protectora do mesmo asylo.

Por accórdo unauime, foram nomeados: presidente da mesma commisstio, - Sr. conselheiro Sodré: vice-presidente, o Sr. conselheiro Tito de Mattos; 1* secretario, o $\mathrm{Sr}$. conselheiro Figueiredo Junior; $2^{\circ}$ dito, o Sr. Belarmino; thesoureiro, o Sr. bar:io de Quartim; e mernbros da commissio de estatutos da - jassociacito protectora, os Srs. : conde de S. Salvador de Mattoxinhos, conse-

theiro Cunha Figueiredo Junior e $\mathrm{Co}$. - nego Brito.

a Tendo alguns socios concorrido $\mathrm{com}$ - importantes quantias. e todos se compromettido a etapregarem todos 05 - taejos possiveis para o comego das - obras, se esforcario para que o mais breve possivel seja lancada a primeira Dedira.

O Apóstolo, 10 de outubro de 1884, p. 2. 